ESCOLA POLITÉCNICA DA UNIVERSIDADE DE SÄO PAULO DEPARTAMENTO DE ENGENHARIA DE CONSTRUCAOO CIVIL Área de Concentraçảo: Engenharia de Construção Civil e Urbana

Mercia Maria Bottura de Barros

\title{
METODOLOGIA PARA IMPLANTAÇÃO DE TECNOLOGIAS CONSTRUTIVAS RACIONALIZADAS NA PRODUÇÃO DE EDIFÍCIOS
}

Tese apresentada à

Escola Politécnica da Universidade de São Paulo para obtenção do título de Doutor em Engenharia

Orientador: Prof. Dr. FERNANDO H. SABBATINI 


\section{Ficha Catalográfica}

Barros, Mercia Maria Bottura de Metodologia para implantação de tecnologias construtivas racionalizadas na produção de edifícios. São Paulo, 1996.

$422 \mathrm{p}$.

Tese (doutorado) - Escola Politécnica da Universidade de São Paulo. Departamento de Engenharia de Construção Civil.

1. Construção Civil - Inovação tecnológica 2. Racionalização construtiva I. Universidade de São Paulo. Escola Politécnica. Departamento de Engenharia de Construção Civil II. $t$ 
Ao Marcelo, meu esposo, aos meus filhos Ana Carolina e Guilherme José e aos meus pais, João Aristides e Maria Valentina. 


\section{AGRADECIMENTOS}

Esta Tese é um resultado de intensas pesquisas desenvolvidas ao longo dos últimos dez anos em conjunto com o Grupo de Pesquisa em Tecnologia de Processos Construtivos da EPUSP e em parceria com diversas empresas construtoras que vêm acreditando na mudança tecnológica como uma estratégia de ação. Por isso, são tantos os responsáveis pela concretização do trabalho aqui apresentado que citar todos seria muito difícil.

Por isso, gostaria de agradecer àqueles que, ao longo de todos esses anos, vêm integrando esse Grupo de Pesquisa. Aos bolsistas de iniciação científica, aos colegas do curso de pós-graduação e aos professores, obrigada pela ajuda na realização deste trabalho.

Além disso, quero agradecer, ainda, o apoio e incentivo dos professores e colegas do Departamento de Engenharia de Construção Civil, que me auxiliaram na troca de experiências, na indicação de referências bibliográficas, nas discussões, na leitura e comentário dos textos. $E$ também, aos funcionários desse Departamento, por sua dedicação e eficiência no apoio às atividades docentes e discentes.

A participação de todos no meu dia-a-dia foi fundamental para que eu pudesse desenvolver os meus estudos e realizasse este trabalho. A todos esses colegas, muito obrigada.

Entretanto, não posso deixar de mencionar nominalmente aqueles cuja contribuição foi inestimável e decisiva para a efetivação da Tese. Assim, mesmo correndo o risco de injustamente esquecer-me de alguém, quero registrar meu agradecimento especial.

Ao professor Fernando Henrique Sabbatini, que me proporcionou a oportunidade de integrar o Grupo de Pesquisa em Tecnologia de Processos Construtivos, pela confiança depositada em mim desde as primeiras pesquisas e pela orientação firme e segura ao longo desses dez anos e, em particular, durante o desenvolvimento deste trabalho.

Ao professor Luiz Sérgio Franco, por ter me proporcionado melhores condições para a realização deste trabalho e, também, pelo seu apoio, incentivo e dedicação constantes, num intenso trabalho de co-orientação. 
Ao professor Sílvio Burrattino Melhado, por ter acompanhado de perto o desenvolvimento deste trabalho, contribuindo com suas opiniōes valiosas nas discussões sobre o tema e analisando criticamente os originais.

Aos professores Racine Tadeu de Araújo Prado e Francisco Ferreira Cardoso que colaboraram com a revisão crítica do trabalho final.

À amiga Ana Lúcia Rocha de Souza, engenheira e pós-graduanda, que compartilhou a realização do trabalho de pesquisa junto às empresas construtoras, pela sua contribuiçăo nos trabalhos de campo e na análise dos resultados e, principalmente, pelas constantes demonstrações de amizade.

À amiga Adriana Terumi Yoshida, estudante de engenharia e bolsista de iniciação científica, com quem tive grande prazer de trabalhar durante mais de dois anos, pelo que me ensinou com sua dedicação, paciência e profissionalismo na realização das pesquisas de laboratório e de campo, que muito auxiliaram o desenvolvimento deste trabalho.

Quero agradecer, de modo especial, ao meu esposo Marcelo, pelo seu apoio irrestrito, pela sua paciência, dedicação e compreensāo que foram fundamentais para a realização deste trabalho.

Preciso agradecer, também, aos meus filhos Ana Carolina e Guilherme José por terem compreendido a importância deste trabalho, cedendo-me parte de nosso tempo de convivência para a sua realização.

Por último, não poderia deixar de citar as empresas construtoras que viabilizaram o desenvolvimento e a implantação de novas tecnologias e aquelas que se dispuseram a participar da pesquisa realizada especificamente para o desenvolvimento da Tese. A todas meu muito obrigada. 
Empresas que participaram das pesquisas para o trabalho de tese:

Andrade Gutierrez;

Barbara Engenharia e Construtora;

Barros Pimentel Engenharia e Comércio;

BHM Empreendimentos e Construções;

BKO Engenharia e Comércio;

Construtora Alves Dinis;

Construtora Consaj;

Construtora Concima;

Construtora Gafisa;

Construtora Noroeste;

Construtora Simão;

DP Engenharia e Empreendimentos;

Encol, Engenharia, Comércio e Indústria;

Grotta Consultoria de Engenharia;

Hernandez Construtora e incorporadora;

Pinto de Almeida Engenharia São Paulo;

Schahin Cury Engenharia e Comércio;

Sinco Sociedade Incorporadora e Construtora;

Soedil-Soteco Edificações;

Tecnisa Engenharia e Comércio; e

Unitec Sociedade Construtora. 
Lista de Figuras, i

Lista de Tabelas, iv

Lista de Abreviaturas e Siglas, v

RESUMO

"ABSTRACT"

CAPITULO 1 - INTRODUÇÃO 1

1.1 Justificativa para o Desenvolvimento do Tema 1

1.2 Formulação da Tese e dos Objetivos 10

$\begin{array}{ll}1.3 \text { Metodologia } & 11\end{array}$

1.4 Estruturação do Trabalho 13

CAPÍTULO 2 - CONCEITOS BÁSICOS RELACIONADOS COM A IMPLANTAÇÃO DE TECNOLOGIAS CONSTRUTIVAS RACIONALIZADAS NO PROCESSO DE PRODUÇĀO DE EDIFÍCIOS

2.1 Processo de Produção e Processo Construtivo Tradicional 17

2.1.1 Processo e sistema de produção 17

2.1.2 Técnica, método, processo e sistema construtivo 20

2.1.3 Processo construtivo tradicional 23

2.2 Tecnologia e Tecnologia Construtiva 28

2.3 Racionalização Construtiva e Tecnologia Construtiva Racionalizada 31

2.4 Qualidade e Melhoria Contínua 36

2.4.1 Os conceitos atribuídos à qualidade 37

2.4.2 Evolução histórica do conceito de qualidade 40

2.4.2.1 A era da inspeção $\quad 41$

2.4.2.2 A era do controle estatístico da qualidade 42

2.4.2.3 A era da garantia da qualidade 43

2.4.2.4 A era da gestão estratégica da qualidade 46

2.4.3 A busca da melhoria continua $\quad 48$

2.5 Inovação Tecnológica $\quad 50$ 
CAPÍTULO 3 - A INDÚSTRIA DA CONSTRUÇÃO CIVIL NO BRASIL E AS ESTRATÉGIAS DO SUBSETOR EDIFICAÇÕES NA BUSCA DA COMPETITIVIDADE

3.1 A Estruturação da Indústria da Construção Civil 62

3.1.1 Setor que dá suporte às atividades produtivas 63

3.1.2 Setor de projeto, produção e montagem de produtos finais 65

3.1.2.1 Subsetor Construção Pesada 66

3.1.2.2 Subsetor Montagem Industrial $\quad 67$

3.1.2.3 Subsetor Edificações $\quad 67$

3.1.3 Análise da Estruturação da Indústria da Construção Civil 68

3.2 A Evolução Tecnológica do Setor Edificações 70

$\begin{array}{ll}\text { 3.2.1 Primeiro estágio de desenvolvimento } & 71\end{array}$

3.2.2 Segundo estágio de desenvolvimento $\quad 72$

3.2.3 Terceiro estágio de desenvolvimento 74

3.3 As Estratégias de Ação das Empresas do Subsetor Edificações $\quad 79$

3.3.1 A implantação de programas de Gestão da Qualidade 84

3.3.2 Implantação da racionalização construtiva 98

3.3.3 A implantação de TCR's e a evolução do processo de produção 101

CAPITULO 4 - O PROCESSO DE INOVAÇÃO TECNOLÓGICA NA INDÚSTRIA SERIADA E NA INDÚSTRIA DA CONSTRUÇÃO DE EDIFÍCIOS

4.1 A Inovação Tecnológica na Indústria Seriada 106

4.1.1 Modelos com enfoque para o mercado 108

4.1.2 Modelos que envolvem a integraçāo entre os departamentos funcionais da empresa

4.1.3 Modelos que envolvem a gestão do processo de inovação $\quad 115$

4.1.4 Outras diretrizes para a condução do processo de implantação 116

4.1.5 Análise das propostas voitadas à indústria seriada 
4.2.1 Modelo que envolve o processo de desenvolvimento tecnológico

4.2.2 Modelos específicos para a implantação de inovações tecnológicas

4.2.3 Análise das diretrizes para implantação de inovações tecnológicas

4.2.3.1 Reconhecer as forças e oportunidades para inovação

4.2.3.2 O comprometimento e desenvolvimento dos recursos

4.2.3.3 Busca de novas tecnologias construtivas

4.2.3.4 A experimentação e o refino de novas tecnologias

4.2.3.5 Avaliação e disseminação da tecnologia na empresa

4.2.4 Elementos que se constituem em dificuldades à inovação

4.2.5 Análise das propostas voltadas à indústria da Construção

4.3 Análise das Experiências de Implantação de TCR's

4.4 Conclusões sobre o Processo de Implantação de Novas Tecnologias 161

4.4.1 Etapas do processo de inovação

4.4.2 Elementos de ordem estratégica

4.4.2 Elementos de ordem tática

\section{CAPÍTULO 5 - METODOLOGIA PARA IMPLANTAÇÃO DE} TECNOLOGIAS CONSTRUTIVAS RACIONALIZADAS NA PRODUÇÃO DE EDIFÍCIOS

5.1 Premissas para Aplicação da Metodologia

5.1.1 Estabelecimento de um sistema de decisões e de informações 166

5.1.1.1 A relação entre o sistema de decisões e o de informações

5.1.1.2 O sistema de informações e a comunicação interna na empresa 173

5.1.2 Identificação da situação tecnológica da empresa

5.1.3 Disposição e motivação para o aprendizado

5.1.4 Disponibilidade dos recursos

5.2 Fundamentos da Metodologia 
5.4 Diretrizes Balizadoras da Metodologia

5.4.1 Desenvolvimento da atividade de projeto

5.4.1.1 O projeto e o projeto para produção

5.4.1.2 O desenvolvimento do projeto na implantação de TCR's

5.4.1.3 O processo de projeto na implantação de TCR's

5.4.1.3 O desenvolvimento do projeto para produção

5.4.2 Desenvolvimento da documentação

5.4.2.1 Conteúdo e desenvolvimento da documentação

5.4.2.2 O desenvolvimento dos procedimentos de produção

5.4.3 Desenvolvimento dos recursos humanos

5.4.3.1 As estratégias de contrataçăo e o desenvolvimento de recursos humanos

5.4.3.2 Elementos constituintes do processo de desenvolvimento dos recursos humanos

5.4.3.3. Motivaçăo e treinamento dos recursos humanos

5.4.4 Desenvolvimento do setor de suprimentos

5.4.4.1 Atendimento às especificações

5.4.4.2 Atendimento ao planejamento

246

5.4.4.3 Suporte aos projetistas

5.4.5 Desenvolvimento do controle do processo de produção

5.4.5.1 O controle na indústria da Construção Civil

5.4.5.2 As orientações para o controle de processos

5.4.5.3 Diretrizes para o controle do processo de execução na indústria da Construção de Edifícios

5.5 A Estratégia para a Implantação de TCR's na Produção de Edifícios

5.5.1 O modelo do plano de ação

5.5.2 Detalhamento do plano de ação

5.5.2.1 1 $1^{\mathrm{a}}$ FASE - A organização da implantação

5.5.2.2 2 ${ }^{\mathrm{a}}$ FASE - Estudo de viabilidade

292

5.5.2.3 $3^{\mathrm{a}}$ FASE - Consolidação da tecnologia

314

5.5.2.4 4 ${ }^{\mathrm{a}}$ FASE - Disseminação e consolidação das TCR's

323

\section{CAPITTULO 6 - ANÁLISE DA METODOLOGIA DE IMPLANTAÇĀO DE TECNOLOGIAS CONSTRUTIVAS RACIONALIZADAS}

6.1 Caracterização das Empresas Participantes da Pesquisa

6.1.1 Porte e a área de atuação das empresas

6.1.2 A motivação para a introdução de mudanças tecnológicas 
6.2 Principais Alterações Tecnológicas Introduzidas pelas Empresas

6.2.1 Alteraçōes na produção da estrutura

6.2.2 Alterações na produção das alvenarias

6.2.3 Alterações na produção das instalações

6.2.4 Alterações na produção das esquadrias

6.2.5 Alterações na produção dos revestimentos

6.2.6 Alterações na produção das impermeabilizações

6.3 Análise das Ações das Empresas e a Importância da Metodologia para Implantação de TCR's

6.3.1 Organizaçāo da empresa voltada ao processo de implantação

6.3.1.1 Existência de um líder

6.3.1.2 Identificação de novas tecnologias

6.3.2 Aplicação da nova tecnologia aos projetos do edifícios

6.3.2.1 O processo de desenvolvimento dos projetos

6.3.2.2 A aplicação do projeto nas obras das empresas

6.3.3 A organizaçāo da documentação

6.3.4 O desenvolvimento dos recursos humanos

6.3.4.1 A forma de contratação

6.3.4.2 Capacitação tecnológica e organização das equipes de trabalho

6.3.4.3 Programas de motivação dos recursos humanos

6.3.5 A organização do setor de suprimentos

6.3.6 A implantação de um sistema de controle

6.3.7 A retroalimentação das ações nos canteiros de obras

6.4 Considerações Finais sobre a Importância da Metodologia

\section{CAPÍTULO 7 - CONCLUSÕES}

7.1 A necessidade e a proposiçāo da metodologia

7.2 A Contribuição da Metodologia para a Evolução da Indústria da Construção de Edifícios

7.3 A Continuidade dos Trabalhos e as Necessidades de Pesquisa para a Evolução da Indústria da Construção de Edifícios 


\section{LISTA DE FIGURAS}

FIGURA 1.1

Formulação do preço numa economia competitiva [CTE, 1994]

FIGURA 2.1

Representação esquemática dos conceitos de processo de produção e sistema de produção [adaptada de CARDOSO, 1996]

FIGURA 2.2

Representação do conceito da qualidade ampliado [PICCHI, 1993]

FIGURA 2.3

A espiral do progresso da qualidade numa empresa [JURAN; GRYNA, 1991]

FIGURA 2.4

Ilustração do Ciclo de DEMING voltado à integração das áreas

de pesquisa, projeto, produção e vendas [IMAI, 1992]

FIGURA 2.5

llustração do "Ciclo PDCA" [BURATI JR. et al., 1992]

FIGURA 2.6

llustraçāo do progresso que deve haver no processo de produção da empresa pela associação conjunta de esforços de inovação e de melhoria contínua [IMAI, 1992]

\section{FIGURA 3.1}

Representaçăo das inter-relaçōes entre os elementos do sistema da qualidade [adaptado de PICCHI, 1993; CTE, 1994]

FIGURA 4.1

Inovação tecnológica como um processo de conversão orientado

pela relação "tecnologia/mercado" [adaptado de TWISS, 1974]

FIGURA 4.2

Processo multiestágio da inovação [BARATELLI JR. et al., 1994]

\section{FIGURA 4.3}

Modelo simplificado das relações entre a firma inovadora e o seu ambiente externo [COOMBS; et al. 1987] 
FIGURA 4.4

Estrutura da Função Tecnológica ("FT") utilizada no estudo de KRUGLIANSKAS; SBRAGIA [1995]

FIGURA 4.5

llustração das fases e etapas da metodologia para o

desenvolvimento de MPSConst. [SABBATINI, 1989]

FIGURA 4.6

Fluxograma das etapas iniciais da transferência de tecnologias ao mercado [adaptado de SABBATINI, 1989]

FIGURA 4.7

Processo de inovação em empresas de construção [TATUM, 1987]

FIGURA 4.8

Relação entre os fatores que afetam a transferência de tecnologia de sistemas especialistas [DE LA GARZA; MITROPOULOS, 1992]

FIGURA 5.1

Hierarquia do sistema de decisões [ROCHA LIMA JR., 1990a]

\section{FIGURA 5.2}

Capacidade de influenciar o custo final de um empreendimento de edifício ao longo de suas fases [CII, 1987]

FIGURA 5.3

llustração dos fundamentos da metodologia de implantação de TCR's

FIGURA 5.4

Proposta de um processo de projeto para empresas construtoras e incorporadoras [adaptado de MELHADO, BARROS, SOUZA, 1996]

FIGURA 5.5

Proposta de fluxo do processo de projeto a ser implantado pelas empresas construtoras

FIGURA 5.6

A alça de feedback para o controle do processo [JURAN, 1992]

\section{FIGURA 5.7}

llustração das fases e etapas do processo de implantação de TCR's no processo de produção de edifícios 


\section{FIGURA 5.8}

Simbologia adotada nas representações gráficas do plano de ação [adaptada de SABBATINI, 1989]

\section{FIGURA 5.9}

Fluxograma da etapa 1 - criação de um ambiente favorável

FIGURA 5.10

Fluxograma da etapa 2 - estudos iniciais

\section{FIGURA 5.11}

Fluxograma da etapa 3 - investigação preliminar

FIGURA 5.12

Fluxograma da etapa 4 - estudo em protótipos

FIGURA 5.13

Fluxograma da etapa 5 - aplicação em escala piloto

\section{FIGURA 5.14}

Fluxograma da etapa 7 - Disseminação da tecnologia

na cultura da empresa

FIGURA 6.1

Processo de análise de projeto adotado pela empresa "l"

\section{FIGURA 6.2}

Processo de desenvolvimento de projeto mais comum entre as empresas construtoras e incorporadoras

\section{FIGURA 6.3}

Processo de projeto desenvolvido pela empresa "A" 


\section{LISTA DE TABELAS}

\section{TABELA 2.1}

Diferenças mais expressivas entre melhoria de processo

e inovação de processo [DAVENPORT, 1993]

TABELA 2.2

Diferenças mais expressivas entre o Kaizen e inovação [IMAI, 1992]

\section{TABELA 3.1}

Proposta de itemização de Sistemas da Qualidade para

empresas construtoras, segundo PICCHI [1993] e CTE [1994]

\section{TABELA 4.1}

Despesas com C\&T/P\&D por fonte de financiamento (governo e indústria) e relação DNTC/PIB [ZAWISLAK, 1995]

\section{TABELA 4.2}

Influência do tamanho da empresa no processo de inovação

tecnológica [LABORDE; SANVIDO, 1994].

TABELA 5.1

Distribuição de normas técnicas, por assunto [PICCHI, 1993]

TABELA 5.2

Comparação entre o controle informal e o controle formalizado

[PICCHI, 1993]

\section{TABELA 6.1}

Caracterização das empresas que participaram da pesquisa

\section{TABELA 6.2}

Atividades do processo de produção que vêm sendo alvo de ações de racionalização por parte das empresas construtoras

TABELA 6.3

Opinião das empresas quanto à relação projeto-produção, expressa em porcentagem do total de empresas pesquisadas 


\section{LISTA DE ABREVIATURAS E SIGLAS}

AACE

ABNT

ASCE

ASQC

$\mathrm{BNH}$

CTE

CPqDCC

CII

EPUSP

ENTAC

FVS

IPT

ISO

MERCOSUL

NBR

PATI

PBQP

PCC

P\&D

PRONATH

PIB

PIS

SEBRAE

SENAI

SECOVI

SFH

SINDUSCON

TCR

TQC
American Association Civil Engineering

Associação Brasileira de Normas Técnicas

American Society of Civil Engineers

American Society of Quality Control

Banco Nacional da Habitação

Centro Tecnológico de Edificações

Centro de Pesquisa e Desenvolvimento em Construção Civil da EPUSP

Construction Industry Institute

Escola Politécnica da Universidade de São Paulo

Encontro Nacional do Ambiente Construído

Fichas de Verificação de Serviços

Instituto de Pesquisas Tecnológicas

International Organization for Standardization

Mercado Comum dos Países da América do Sul

Norma Brasileira

Plano de Atualização Tecnológica e Industrial

Programa Brasileiro da Qualidade e Produtividade

Departamento de Engenharia de Construção Civil da Escola Politécnica da Universidade de São Paulo

Pesquisa e Desenvolvimento

Programa Nacional de Tecnologia de Habitação

Produto Interno Bruto

Procedimentos de Inspeção de Serviços

Serviço de Apoio às Micro e Pequenas Empresas

Serviço Nacional de Aprendizagem Industrial

Sindicato das Empresas de Compra, Venda, Locação e Administração de Imóveis Ltda.

Sistema Financeiro da Habitação

Sindicato da Indústria da Construção Civil de Grandes

Estruturas

Tecnologia Construtiva Racionalizada

Total Quality Control 


\section{METODOLOGIA PARA IMPLANTAÇÃO DE TECNOLOGIA CONSTRUTIVA RACIONALIZADA NA PRODUÇÃO DE EDIFÍCIOS}

Mercia M. S. Bottura de Barros Agosto de 1996

\section{RESUMO}

O trabalho propõe uma metodologia para a implantação de Tecnologias Construtivas Racionalizadas na produção de edifícios pelo processo construtivo tradicional, objetivando a evolução tecnológica do processo de produção. Inicialmente, os conceitos relacionados ao desenvolvimento e à implantação de Tecnologias Construtivas Racionalizadas são apresentados e discutidos. Na sequência, discutem-se as estratégias que as empresas têm utilizado para atuarem num mercado altamente competitivo. E, completando os fundamentos do trabalho, apresentam-se e analisam-se os modelos para a implantação de inovações tecnológicas na indústria seriada e da Construção Civil.

A partir desse quadro referencial, propõe-se uma metodologia para implantaçāo de Tecnologias Construtivas Racionalizadas, fundamentada em um conjunto de diretrizes balizadoras e numa estratégia de ação. As diretrizes contemplam a organizaçāo da empresa, o processo de projeto, a documentação, os recursos humanos e o controle do processo de produção; enquanto a estratégia de ação contém uma sugestão de como conduzir o processo de implantação no interior da organização.

Finalmente, realiza-se uma análise das ações de empresas de construção ao introduzirem mudanças tecnológicas na construção de edifícios, concluindo-se pela importância de se empregar uma adequada metodologia para a condução do processo de implantação de Tecnologias Construtivas Racionalizadas. 


\title{
A MODEL TO INTRODUCE INNOVATIVE TECHNOLOGIES \\ INTO THE BUILDING CONSTRUCTION
}

\author{
Mercia M. S. Bottura de Barros \\ August de 1996
}

\section{ABSTRACT}

This thesis proposes a model to introduce innovative technologies into the traditional building construction with the purpose of achieving the continuous improvement in building construction.

Firstly, the main concepts related to development and introduction of innovative technologies are presented and discussed. Then, the building construction companies organization and the majors strategies to increase their effectiveness are presented and analysed.

The work discusses available models used for introducing innovation processes in the manufacturing and the construction industries in order to identify the barriers and key factors to introduce the innovative technologies.

Based on this framework, it is proposed a model including guidelines related to companies organization, design process, process of documentation, human resources development and the control of production process.

Finally, the companies actions about the introduction of innovative technologies are analysed. This shows that the correct development and use of a capable formal approach does help introducing innovative technologies into the building construction. 


\section{CAPÍTULO 1}

\section{INTRODUÇÃO}

\subsection{Justificativa para o Desenvo/vimento do Tema}

Juntamente com as diretrizes políticas recém-instaladas no país, está-se consolidando uma nova fase de crescimento industrial voltada à modernização das relações de produção.

A indústria da Construção Civil, caracterizada, por diversos autores, por desperdícios de diversas naturezas, por altos custos de produção e pela manutenção e emprego de mão-de-obra desqualificada, devida a importância econômica e social que representa no conjunto produtivo, não poderia deixar de participar do processo de modernização do país. Além de ser responsável por expressiva parcela do Produto Interno Bruto (PIB) nacional, está intimamente relacionada a inúmeras outras atividades, que não apenas a específica de construção.

Acredita-se que a situação social, política e econômica, pela qual o Brasil vem passando atualmente, seja propícia para alterações de algumas posturas do setor da construção civil e, em particular, do subsetor de construção de edifícios.

Novos referenciais estão presentes no mercado de produção e comercialização de edifícios. VARGAS [1993] ${ }^{1}$ destaca como fatores que têm resultado em um mercado cada vez mais exigente e competitivo: o fim da ciranda financeira e do processo inflacionário; a abertura do mercado nacional e a integração da América Latina com a criação do MERCOSUL; a falência do Estado e a eliminação de seu intervencionismo; a queda de renda do mercado consumidor,

\footnotetext{
${ }^{1}$ As referências bibliográficas utilizadas neste trabalho serão apresentadas entre colchetes, através da indicação do sobrenome do(s) autor(es) e da data de publicação da obra (ou somente a data, quando o(s) autor(es) estiver(em) sendo nominalmente citados(s) no texto. A referência completa poderá ser encontrada no final do trabalho.
} 
com conseqüente redução dos preços de obras públicas, habitacionais, comerciais e industriais; a privatização de empresas estatais; a nova Lei de Licitações e Contratos; a exigência de qualidade por parte dos clientes privados; o código de defesa do consumidor.

Em função desses novos parâmetros de mercado, muitos empresários do setor têm voltado a atenção à necessidade de repensarem as antigas formas de produção.

Nesse aspecto, Ricardo Yazbek, presidente do SECOVI-SP, afirma que "a mentalidade do empreendedor da indústria imobiliária está evoluindo em vários aspectos, pois rompeu a dependência crônica com o Sistema Financeiro da Habitação (SFH), superou o fantasma da falta de financiamento, buscou e encontrou fórmulas alternativas de agilizar a produção e a comercialização de imóveis, (...) estabeleceu parcerias e criou sistemas de autofinanciamento" [NUNCA, 1994].

Um exemplo dessa nova postura foi expressa pelo presidente de uma importante construtora e incorporadora de edifícios, que afirma ter como objetivo reduzir $7 \%$ no custo de incorporação e $20 \%$ no custo de construção, a serem repassados aos clientes e à própria empresa [HOMEM, 1994].

Por essas colocações, que de certa maneira expressam o pensamento dos empresários do setor, é possivel perceber que as empresas estão inseridas num mercado altamente competitivo, estimulado pelo desafio de se oferecer um produto economicamente acessível e que satisfaça às exigências dos clientes.

Esse contexto deixa evidente que as relações entre preço e custo dos edifícios precisam tomar novos rumos. Segundo o CTE [1994], a antiga equação em que o preço do produto era o resultado do custo acrescido do lucro que se pretendia auferir, está dando lugar a uma nova expressão em que o lucro é o resultado do preço definido pelo mercado, subtraídos os custos, como ilustra a figura 1.1. 


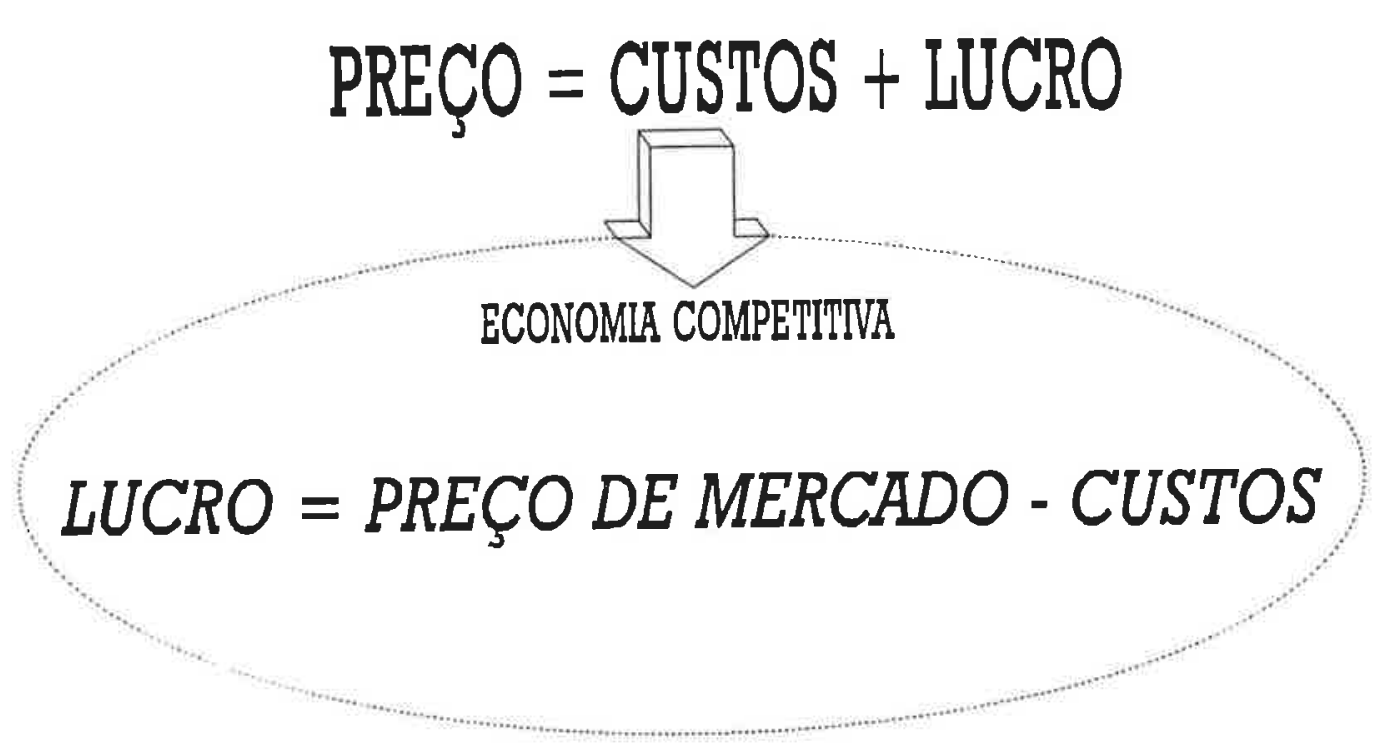

FIGURA 1.1: Formulação do preço numa economia competitiva [CTE, 1994]

Numa economia competitiva, como a que atualmente está se configurando, a redução dos custos de produção dos empreendimentos é um fator decisivo para a sobrevivência das empresas.

Considerando-se as características intrínsecas da indústria da Construção de Edifícios, pode-se dizer que a competitividade hoje estabelecida é o grande estímulo para que as empresas invistam na modernização de suas formas de produção, de maneira a obterem o aumento da produtividade dos serviços, a diminuição da rotatividade da mão-de-obra, a redução do retrabalho e a eliminação de falhas pós-entrega $e$, por conseqüência, a redução dos custos de produção.

ROCHA LIMA JR. [1993], de certa maneira, confirma essa idéia ao afirmar que "os que pretendem se perpetuar no setor necessitam trilhar rotinas de ação empresarial orientadas por um competente vetor de modernidade (...) definido pela adequação dos métodos de administração e gerenciamento; capacidade de entender o relacionamento empreendedor-mercado em toda a sua amplitude e o condicionamento dos processos de produção a técnicas que resultem numa melhoria no nivel de perdas, através da sua racionalização". 
Esse autor destaca, ainda, que todas essas ações podem ser reunidas na palavra qualidade, ou seja, para o setor da construção civil, o vetor da modernidade está vinculado à busca de ganhos de qualidade.

É certo que, procurando responder às exigências de mercado, através de uma maior eficiência do processo de produção, muitas empresas têm buscado empreender ações que visam a organização e a gestão do processo de produção.

No entanto, alterar as caracteristicas do atual processo de produção de edifícios, tem sido um desafio de grande envergadura para a maioria das empresas construtoras.

Existem muitos obstáculos a serem transpostos para se promover alteraçōes nos processos produtivos, dentre os quais pode-se destacar aqueles que se originam num ambiente externo ao processo de produção e os que têm origem internamente a esse processo, como por exemplo os apresentados a seguir:

\section{a) obstáculos devidos ao ambiente externo ao processo de produção}

- a falta de investimentos institucionais e as incertezas do mercado de construção de edifícios provocadas sobretudo pela instabilidade econômica vivida pelo pais, mesmo nos dias atuais;

- a falta de uma organização institucional do segmento da Construção de Edifícios, que leve a melhores condições de atuação para a indústria como um todo, como por exemplo uma política de normalização que subsidie as ações do setor;

- a falta de uma política institucional que envolva o setor de suprimentos de materiais e componentes, de maneira a que venha a atender melhor as atividades de projeto e as que se desenvolvem no canteiro de obras;

- a falta de uma política de desenvolvimento de equipamentos e ferramentas específico para a Indústria da Construção de Edifícios;

- a falta de uma política de educação básica voltada aos excluídos da escola, que constituem a mão-de-obra potencialmente empregada pela indústria da Construção. 


\section{b) obstáculos devidos ao ambiente interno ao processo de produção}

- a administração do conflito: período de tempo demandado para a implantação de ações visando as alterações do processo de produção e a ansiedade pelos resultados (reflexo do ambiente externo);

- o difícil equacionamento entre as distintas necessidades dos setores que compõem a empresa, como por exemplo, comercial e produção; projetos, suprimentos e execução das obras;

- as falhas nos fluxos de informações e decisōes internos à empresa;

- o trabalho não sistematizado e descoordenado dos diversos agentes participantes de um empreendimento;

- os problemas decorrentes do difícil relacionamento entre as empresas construtoras e os fornecedores de materiais e equipamentos que, muitas vezes, enxergam apenas os seus interesses particulares;

- o difícil relacionamento com os recursos humanos, em que ganha importância a complexa forma de contratação de mão-de-obra, hoje caracterizada pelas empreitadas de serviços e alta rotatividade;

- as dificuldades de implantação de um mecanismo de controle das ações implantadas, visando a realimentação do processo e a sua evolução contínua.

Com isso, fica evidente a premência de se criarem condições para que a empresa seja capaz de entender o complexo processo de produção que a envolve, de modo a organizar e gerenciar o seu todo e não apenas partes dele.

A definição de uma estratégia de atuação das empresas, voltada à racionalização do processo produtivo, constitui um o ponto fundamental para que o setor da construção evolua, tornando-se mais competitivo.

Entretanto, a indústria da Construção Civil apresenta um conjunto particular de características, tanto de natureza do processo de produção, como do próprio mercado em que se insere, em que os conceitos e os procedimentos trazidos pelas modernas teorias de organização e gestão, aplicados à indústria de bens 
de consumo, encontram uma série de dificuldades para serem utilizados, devendo sofrer adaptações, para permitir sua implantação [MELHADO, 1994].

Muitas empresas construtoras vêm encontrando sérias dificuldades para racionalizar o seu processo de produção. As intenções relativas ao incremento da competitividade empresarial acabam não se tornando realidade na execução das tarefas diárias, fazendo com que as ações práticas pareçam estar longe de chegar aos canteiros de obras ou aos escritórios de projeto [FRANCO, 1992].

Buscando minimizar as dificuldades de implantação de ações voltadas à evolução tecnológica do processo de produção, acredita-se que os esforços das empresas devem ser dirigidos no sentido de conciliar a introdução de mudanças tecnológicas no processo construtivo tradicional ${ }^{2}$ com a organização e a gestão do processo de produção empregado pela empresa, de forma a permitir a evolução contínua das mudanças inicialmente propostas.

A componente tecnológica dessa proposta entra como uma forma de proporcionar a evolução do processo construtivo e de exigir, desde o primeiro momento, o envolvimento da produção propriamente dita, a fim de se obter, em um período de tempo não muito longo, retornos positivos que servirão de motivação para a continuidade da implantação das ações. Os aspectos organizacionais e de gestão do processo de produção, por sua vez, são essenciais para sedimentar e fazer evoluir os resultados inicialmente obtidos.

A necessidade de um rápido envolvimento da produção, como motivação para manter ativo o processo de busca da melhoria, é destacada em alguns depoimentos obtidos em uma pesquisa ${ }^{3}$ realizada junto a empresas de construção, tais como os apresentados na seqüência:

\footnotetext{
${ }^{2}$ O processo construtivo tradicional é entendido, neste trabalho, como "um específico modo de se produzir um edifício e que se fundamenta em métodos construtivos tradicionalmente empregados em uma certa regiäo" [SABBATINI, 1989].

${ }^{3}$ Essa pesquisa foi realizada pela autora, em conjunto com Ana Lúcia Rocha de Souza, pesquisadora em nivel de Mestrado, objetivando subsidiar o desenvolvimento deste trabalho de Tese. Os resultados obtidos serão utilizados principalmente no capítulo 6 , ao se realizar a análise da viabilidade de aplicação da metodologia proposta.
} 
Ao Marcelo, meu esposo, aos meus filhos Ana Carolina e Guilherme José e aos meus pais, João Aristides e Maria Valentina. 


\section{AGRADECIMENTOS}

Esta Tese é um resultado de intensas pesquisas desenvolvidas ao longo dos últimos dez anos em conjunto com o Grupo de Pesquisa em Tecnologia de Processos Construtivos da EPUSP e em parceria com diversas empresas construtoras que vêm acreditando na mudança tecnológica como uma estratégia de ação. Por isso, são tantos os responsáveis pela concretização do trabalho aqui apresentado que citar todos seria muito difícil.

Por isso, gostaria de agradecer àqueles que, ao longo de todos esses anos, vêm integrando esse Grupo de Pesquisa. Aos bolsistas de iniciação científica, aos colegas do curso de pós-graduação e aos professores, obrigada pela ajuda na realização deste trabalho.

Além disso, quero agradecer, ainda, o apoio e incentivo dos professores e colegas do Departamento de Engenharia de Construção Civil, que me auxiliaram na troca de experiências, na indicação de referências bibliográficas, nas discussões, na leitura e comentário dos textos. E também, aos funcionários desse Departamento, por sua dedicação e eficiência no apoio às atividades docentes e discentes.

A participação de todos no meu dia-a-dia foi fundamental para que eu pudesse desenvolver os meus estudos e realizasse este trabalho. A todos esses colegas, muito obrigada.

Entretanto, não posso deixar de mencionar nominalmente aqueles cuja contribuição foi inestimável e decisiva para a efetivação da Tese. Assim, mesmo correndo o risco de injustamente esquecer-me de alguém, quero registrar meu agradecimento especial.

Ao professor Fernando Henrique Sabbatini, que me proporcionou a oportunidade de integrar o Grupo de Pesquisa em Tecnologia de Processos Construtivos, pela confiança depositada em mim desde as primeiras pesquisas e pela orientação firme e segura ao longo desses dez anos e, em particular, durante o desenvolvimento deste trabalho.

Ao professor Luiz Sérgio Franco, por ter me proporcionado melhores condições para a realização deste trabalho e, também, pelo seu apoio, incentivo e dedicação constantes, num intenso trabalho de co-orientação. 
Ao professor Sílvio Burrattino Melhado, por ter acompanhado de perto o desenvolvimento deste trabalho, contribuindo com suas opiniōes valiosas nas discussões sobre o tema e analisando criticamente os originais.

Aos professores Racine Tadeu de Araújo Prado e Francisco Ferreira Cardoso que colaboraram com a revisão crítica do trabalho final.

À amiga Ana Lúcia Rocha de Souza, engenheira e pós-graduanda, que compartilhou a realização do trabalho de pesquisa junto às empresas construtoras, pela sua contribuição nos trabalhos de campo e na análise dos resultados e, principalmente, pelas constantes demonstrações de amizade.

À amiga Adriana Terumi Yoshida, estudante de engenharia e bolsista de iniciação cientifica, com quem tive grande prazer de trabalhar durante mais de dois anos, pelo que me ensinou com sua dedicação, paciência e profissionalismo na realização das pesquisas de laboratório e de campo, que muito auxiliaram o desenvolvimento deste trabalho.

Quero agradecer, de modo especial, ao meu esposo Marcelo, pelo seu apoio irrestrito, pela sua paciência, dedicação e compreensão que foram fundamentais para a realização deste trabalho.

Preciso agradecer, também, aos meus filhos Ana Carolina e Guilherme José por terem compreendido a importância deste trabalho, cedendo-me parte de nosso tempo de convivência para a sua realização.

Por último, não poderia deixar de citar as empresas construtoras que viabilizaram o desenvolvimento e a implantação de novas tecnologias e aquelas que se dispuseram a participar da pesquisa realizada especificamente para o desenvolvimento da Tese. A todas meu muito obrigada. 
Empresas que participaram das pesquisas para o trabalho de tese:

Andrade Gutierrez;

Barbara Engenharia e Construtora;

Barros Pimentel Engenharia e Comércio;

BHM Empreendimentos e Construções;

BKO Engenharia e Comércio;

Construtora Alves Dinis;

Construtora Consaj;

Construtora Concima;

Construtora Gafisa;

Construtora Noroeste;

Construtora Simão;

DP Engenharia e Empreendimentos;

Encol, Engenharia, Comércio e Indústria;

Grotta Consultoria de Engenharia;

Hernandez Construtora e Incorporadora;

Pinto de Almeida Engenharia São Paulo;

Schahin Cury Engenharia e Comércio;

Sinco Sociedade Incorporadora e Construtora;

Soedil-Soteco Edificações;

Tecnisa Engenharia e Comércio; e

Unitec Sociedade Construtora. 


\section{SUMÁRIO}

Lista de Figuras, $\mathbf{i}$

Lista de Tabelas, iv

Lista de Abreviaturas e Siglas, v

RESUMO

"ABSTRACT"

CAPÍTULO 1 - INTRODUÇÃO

1.1 Justificativa para o Desenvolvimento do Tema

1.2 Formulação da Tese e dos Objetivos

1.3 Metodologia

1.4 Estruturação do Trabalho

CAPÍTULO 2 - CONCEITOS BÁSICOS RELACIONADOS COM A IMPLANTAÇÃO DE TECNOLOGIAS CONSTRUTIVAS RACIONALIZADAS NO PROCESSO DE PRODUÇÄO DE EDIFICIOS

2.1 Processo de Produção e Processo Construtivo Tradicional

2.1.1 Processo e sistema de produção

2.1.2 Técnica, método, processo e sistema construtivo

2.1.3 Processo construtivo tradicional

2.2 Tecnologia e Tecnologia Construtiva

2.3 Racionalização Construtiva e Tecnologia Construtiva Racionalizada

2.4 Qualidade e Melhoria Contínua

2.4.1 Os conceitos atribuídos à qualidade

2.4.2 Evolução histórica do conceito de qualidade

2.4.2.1 A era da inspeção

2.4.2.2 A era do controle estatístico da qualidade

2.4.2.3 A era da garantia da qualidade

2.4.2.4 A era da gestão estratégica da qualidade

2.4.3 $\mathrm{A}$ busca da melhoria contínua 
CAPÍTULO 3 - A INDÚSTRIA DA CONSTRUÇÃO CIVIL NO BRASIL E AS ESTRATÉGIAS DO SUBSETOR EDIFICAÇÕES NA BUSCA DA COMPETITIVIDADE

3.1 A Estruturação da Indústria da Construção Civil

3.1.1 Setor que dá suporte às atividades produtivas

3.1.2 Setor de projeto, produção e montagem de produtos finais

3.1.2.1 Subsetor Construção Pesada

3.1.2.2 Subsetor Montagem Industrial

3.1.2.3 Subsetor Edificaçōes

3.1.3 Análise da Estruturação da Indústria da Construção Civil

3.2 A Evolução Tecnológica do Setor Edificações

3.2.1 Primeiro estágio de desenvolvimento

3.2.2 Segundo estágio de desenvolvimento

3.2.3 Terceiro estágio de desenvolvimento

3.3 As Estratégias de Ação das Empresas do Subsetor Edificações

3.3.1 A implantação de programas de Gestão da Qualidade

3.3.2 Implantação da racionalização construtiva

3.3.3 A implantação de TCR's e a evolução do processo de produção

\section{CAPÍTULO 4 - O PROCESSO DE INOVAÇĀO TECNOLÓGICA NA INDÚSTRIA SERIADA E NA INDÚSTRIA DA CONSTRUÇÃO DE EDIFÍCIOS}

4.1 A Inovação Tecnológica na Indústria Seriada

4.1.1 Modelos com enfoque para o mercado

4.1.2 Modelos que envolvem a integração entre os departamentos funcionais da empresa

4.1.3 Modelos que envolvem a gestão do processo de inovação

4.1.4 Outras diretrizes para a condução do processo de implantação 
- 4.2 A Inovação Tecnológica na Indústria da Construção Civil

4.2.1 Modelo que envolve o processo de desenvolvimento tecnológico

4.2.2 Modelos específicos para a implantação de inovações tecnológicas

-4.2.3 Análise das diretrizes para implantação de inovações tecnológicas

4.2.3.1 Reconhecer as forças e oportunidades para inovação

4.2.3.2 O comprometimento e desenvolvimento dos recursos

4.2.3.3 Busca de novas tecnologias construtivas

4.2.3.4 A experimentação $e o$ refino de novas tecnologias

4.2.3.5 Avaliação e disseminação da tecnologia na empresa

4.2.4 Elementos que se constituem em dificuldades à inovação

4.2.5 Análise das propostas voltadas à indústria da Construção

4.3 Análise das Experiências de Implantação de TCR's

4.4 Conclusões sobre o Processo de Implantação de Novas Tecnologias

4.4.1 Etapas do processo de inovação

4.4.2 Elementos de ordem estratégica

4.4.2 Elementos de ordem tática

\section{CAPÍTULO 5 - METODOLOGIA PARA IMPLANTAÇÃO DE TECNOLOGIAS CONSTRUTIVAS RACIONALIZADAS NA PRODUÇÃO DE EDIFICIOS}

5.1 Premissas para Aplicação da Metodologia

5.1.1 Estabelecimento de um sistema de decisões e de informações

5.1.1.1 A relação entre o sistema de decisões e o de informações

5.1.1.2 O sistema de informaçōes e a comunicaçăo interna na empresa 173

5.1.2 Identificação da situação tecnológica da empresa

5.1.3 Disposição e motivação para o aprendizado

5.1.4 Disponibilidade dos recursos

5.2 Fundamentos da Metodologia 
5.4 Diretrizes Balizadoras da Metodologia

5.4.1 Desenvolvimento da atividade de projeto

5.4.1.1 0 projeto e o projeto para produção

5.4.1.2 O desenvolvimento do projeto na implantação de TCR's

5.4.1.3 O processo de projeto na implantação de TCR's

5.4.1.3 O desenvolvimento do projeto para produção

5.4.2 Desenvolvimento da documentação

5.4.2.1 Conteúdo e desenvolvimento da documentação

5.4.2.2 O desenvolvimento dos procedimentos de produção

5.4.3 Desenvolvimento dos recursos humanos

5.4.3.1 As estratégias de contratação e o desenvolvimento de recursos humanos

5.4.3.2 Elementos constituintes do processo de desenvolvimento dos recursos humanos

5.4.3.3. Motivação e treinamento dos recursos humanos

5.4.4 Desenvolvimento do setor de suprimentos

5.4.4.1 Atendimento às especificações

5.4.4.2 Atendimento ao planejamento

5.4.4.3 Suporte aos projetistas

5.4.5 Desenvolvimento do controle do processo de produção

5.4.5.1 O controle na indústria da Construção Civil

5.4.5.2 As orientações para o controle de processos

5.4.5.3 Diretrizes para o controle do processo de execução na indústria da Construção de Edifícios

5.5 A Estratégia para a Implantação de TCR's na Produção de Edifícios

5.5.1 O modelo do plano de ação

5.5.2 Detalhamento do plano de ação

5.5.2.1 1 ${ }^{\mathrm{a}}$ FASE - A organização da implantação

5.5.2.2 $2^{\mathrm{a}}$ FASE - Estudo de viabilidade

5.5.2.3 $3^{\mathrm{a}}$ FASE - Consolidação da tecnologia

5.5.2.4 4 ${ }^{\mathrm{a}}$ FASE - Disseminação e consolidação das TCR's

\section{CAPÍTULO 6 - ANÁLISE DA METODOLOGIA DE IMPLANTAÇÃO DE TECNOLOGIAS CONSTRUTIVAS RACIONALIZADAS}

6.1 Caracterização das Empresas Participantes da Pesquisa

6.1.1 Porte e a área de atuação das empresas 
6.2 Principais Alteraçōes Tecnológicas Introduzidas pelas Empresas

6.2.1 Alterações na produção da estrutura

6.2.2 Alterações na produção das alvenarias

6.2.3 Alterações na produção das instalações

6.2.4 Alterações na produção das esquadrias

6.2.5 Alterações na produção dos revestimentos

6.2.6 Alterações na produção das impermeabilizações

6.3 Análise das Ações das Empresas e a Importância da Metodologia para Implantação de TCR's

6.3.1 Organização da empresa voltada ao processo de implantação

6.3.1.1 Existência de um líder

6.3.1.2 Identificação de novas tecnologias

6.3.2 Aplicação da nova tecnologia aos projetos do edifícios

6.3.2.1 O processo de desenvolvimento dos projetos

6.3.2.2 A aplicação do projeto nas obras das empresas

6.3.3 A organização da documentação

6.3.4 O desenvolvimento dos recursos humanos

6.3.4.1 A forma de contratação

6.3.4.2 Capacitação tecnológica e organização das equipes de trabalho

6.3.4.3 Programas de motivaçăo dos recursos humanos

6.3.5 A organização do setor de suprimentos

6.3.6 A implantação de um sistema de controle

6.3.7 A retroalimentação das ações nos canteiros de obras

6.4 Consideraçōes Finais sobre a Importância da Metodologia

\section{CAPÍTULO 7 - CONCLUSÕES}

7.1 A necessidade e a proposição da metodologia

ơ 7.2 A Contribuição da Metodologia para a Evolução da Indústria da Construção de Edifícios

7.3 A Continuidade dos Trabalhos e as Necessidades de Pesquisa para a Evolução da Indústria da Construção de Edifícios 


\section{LISTA DE FIGURAS}

FIGURA 1.1

Formulação do preço numa economia competitiva [CTE, 1994]

FIGURA 2.1

Representação esquemática dos conceitos de processo de produção e sistema de produção [adaptada de CARDOSO, 1996]

FIGURA 2.2

Representação do conceito da qualidade ampliado [PICCHI, 1993]

FIGURA 2.3

A espiral do progresso da qualidade numa empresa

[JURAN; GRYNA, 1991]

FIGURA 2.4

Ilustração do Ciclo de DEMING voltado à integração das áreas

de pesquisa, projeto, produção e vendas [IMAI, 1992]

FIGURA 2.5

Ilustração do "Ciclo PDCA" [BURATI JR. et al., 1992]

\section{FIGURA 2.6}

llustração do progresso que deve havier no processo de produção da empresa pela associação conjunta de esforços de inovação e de melhoria contínua [IMAl, 1992]

FIGURA 3.1

Representação das inter-relações entre os elementos do sistema da qualidade [adaptado de PICCHI, 1993; CTE, 1994]

\section{FIGURA 4.1}

Inovaçăo tecnológica como um processo de conversão orientado pela relação "tecnologia/mercado" [adaptado de TWISS, 1974]

FIGURA 4.2

Processo multiestágio da inovação [BARATELLI JR. et al., 1994]

FIGURA 4.3

Modelo simplificado das relaçōes entre a firma inovadora e o seu ambiente externo [COOMBS; et al. 1987] 
FIGURA 4.4

Estrutura da Função Tecnológica ("FT") utilizada no estudo de KRUGLIANSKAS; SBRAGIA [1995]

FIGURA 4.5

llustração das fases e etapas da metodologia para o desenvolvimento de MPSConst. [SABBATINI, 1989]

FIGURA 4.6

Fluxograma das etapas iniciais da transferência de tecnologias ao mercado [adaptado de SABBATINI, 1989]

FIGURA 4.7

Processo de inovação em empresas de construção [TATUM, 1987]

\section{FIGURA 4.8}

Relação entre os fatores que afetam a transferência de tecnologia de sistemas especialistas [DE LA GARZA; MITROPOULOS, 1992]

FIGURA 5.1

Hierarquia do sistema de decisões [ROCHA LIMA JR., 1990a]

FIGURA 5.2

Capacidade de influenciar o custo final de um empreendimento de edifício ao longo de suas fases [CII, 1987]

FIGURA 5.3

llustração dos fundamentos da metodologia de implantação de TCR's

FIGURA 5.4

Proposta de um processo de projeto para empresas construtoras e incorporadoras [adaptado de MELHADO, BARROS, SOUZA, 1996]

FIGURA 5.5

Proposta de fluxo do processo de projeto a ser implantado pelas empresas construtoras

FIGURA 5.6

A alça de feedback para o controle do processo [JURAN, 1992]

FIGURA 5.7

llustração das fases e etapas do processo de implantação de TCR's no processo de produção de edifícios 


\section{FIGURA 5.8}

Simbologia adotada nas representações gráficas do plano de ação [adaptada de SABBATINI, 1989]

FIGURA 5.9

Fluxograma da etapa 1 - criação de um ambiente favorável

FIGURA 5.10

Fluxograma da etapa 2 - estudos iniciais

FIGURA 5.11

Fluxograma da etapa 3 - investigação preliminar

FIGURA 5.12

Fluxograma da etapa 4 - estudo em protótipos

FIGURA 5.13

Fluxograma da etapa 5 - aplicação em escala piloto

\section{FIGURA 5.14}

Fluxograma da etapa 7 - Disseminação da tecnologia na cultura da empresa

FIGURA 6.1

Processo de análise de projeto adotado pela empresa "I"

FIGURA 6.2

Processo de desenvolvimento de projeto mais comum entre as empresas construtoras e incorporadoras

FIGURA 6.3

Processo de projeto desenvolvido pela empresa " $A$ " 


\section{LISTA DE TABELAS}

\section{TABELA 2.1}

Diferenças mais expressivas entre melhoria de processo

e inovação de processo [DAVENPORT, 1993]

TABELA 2.2

Diferenças mais expressivas entre o Kaizen e inovação [IMAI, 1992]

\section{TABELA 3.1}

Proposta de itemização de Sistemas da Qualidade para

empresas construtoras, segundo PICCHI [1993] e CTE [1994]

\section{TABELA 4.1}

Despesas com C\&T/P\&D por fonte de financiamento (governo e indústria) e relação DNTC/PIB [ZAWISLAK, 1995]

\section{TABELA 4.2}

Influência do tamanho da empresa no processo de inovação tecnológica [LABORDE; SANVIDO, 1994].

\section{TABELA 5.1}

Distribuição de normas técnicas, por assunto [PICCHI, 1993]

\section{TABELA 5.2}

Comparação entre o controle informal e o controle formalizado [PICCHI, 1993]

TABELA 6.1

Caracterização das empresas que participaram da pesquisa

TABELA 6.2

Atividades do processo de produção que vêm sendo alvo de ações de racionalização por parte das empresas construtoras

\section{TABELA 6.3}

Opinião das empresas quanto à relação projeto-produção, expressa em porcentagem do total de empresas pesquisadas 


\section{LISTA DE ABREVIATURAS E SIGLAS}

AACE

ABNT

ASCE

ASQC

BNH

CTE

CPqDCC

CII

EPUSP

ENTAC

FVS

IPT

ISO

MERCOSUL

NBR

PATI

PBQP

$P C C$

P\&D

PRONATH

PIB

PIS

SEBRAE

SENAI

SECOVI

SFH

SINDUSCON

TCR

TQC
American Association Civil Engineering

Associação Brasileira de Normas Técnicas

American Society of Civil Engineers

American Society of Quality Control

Banco Nacional da Habitação

Centro Tecnológico de Edificaçōes

Centro de Pesquisa e Desenvolvimento em Construção

Civil da EPUSP

Construction Industry Institute

Escola Politécnica da Universidade de São Paulo

Encontro Nacional do Ambiente Construído

Fichas de Verificação de Serviços

Instituto de Pesquisas Tecnológicas

International Organization for Standardization

Mercado Comum dos Países da América do Sul

Norma Brasileira

Plano de Atualização Tecnológica e Industrial

Programa Brasileiro da Qualidade e Produtividade

Departamento de Engenharia de Construção Civil da Escola

Politécnica da Universidade de São Paulo

Pesquisa e Desenvolvimento

Programa Nacional de Tecnologia de Habitação

Produto Interno Bruto

Procedimentos de Inspeção de Serviços

Serviço de Apoio às Micro e Pequenas Empresas

Serviço Nacional de Aprendizagem Industrial

Sindicato das Empresas de Compra, Venda, Locação e Administraçăo de Imóveis Ltda.

Sistema Financeiro da Habitação

Sindicato da Indústria da Construção Civil de Grandes

Estruturas

Tecnologia Construtiva Racionalizada

Total Quality Control 
"O inicio do processo pela obra motiva a continuidade das ações e o envolvimento de todas as demais pessoas. Não adianta 'fazer qualidade' apenas no escritório, esquecendo-se da obra, pois se é uma empresa construtora, o que lhe dá vida, o que a movimenta é a obra" (empresa "I");

"Os resultados obtidos nas obras são mais rápidos, mais motivantes. Na área administrativa os resultados não são visiveis; portanto, não motiva" (empresa "A").

Uma maneira eficiente de envolver desde o início a etapa de produção é através da implantação de Tecnologias Construtivas Racionalizadas (TCR's), termo que neste trabalho é entendido como sendo "um conjunto sistematizado de conhecimentos científicos e empíricos, empregados na criação, produção e difusão de um modo específico de se construir um edifício ou uma sua parte e orientado pela otimização do emprego dos recursos envolvidos em todas as fases da construção".

O emprego de TCR's pode ser feito por qualquer empresa, para quaisquer subsistemas do edifício, à medida em que "alguém", que tenha o poder de decidir acerca da condução de um determinado processo produtivo, possui a informação de como alterá-lo racionalmente.

Alguns resultados positivos dessa prática podem ser verificados na reportagem: "Parceria incentiva pesquisas técnicas" [PARCERIA, 1995], que relata a experiência extremamente positiva de cinco empresários da construção de edifícios ao implantarem diversas mudanças tecnológicas em suas obras, como por exemplo, o contrapiso racionalizado e a laje nivelada.

No entanto, aplicar TCR's em uma determinada obra, não implica que as novas tecnologias tenham sido implantadas na empresa. A implantação de $T C R$ 's, objeto do desenvolvimento do presente trabalho, envolve mais do que a simples aplicação de uma dada tecnologia, em um dos canteiros de obras da empresa. "Implantar" significa, no contexto deste trabalho, consolidar a nova tecnologia no sistema produtivo da empresa e no processo de produção de edifícios, através de princípios que permitam a sua constante evolução. 
Essa consolidação não é fácil de ser realizada. Para a empresa desfrutar de resultados positivos através da implantação de TCR's na produção de edifícios pelo processo construtivo tradicional, precisará adotar uma adequada metodologia de ação, que contemple os aspectos tecnológicos, organizacionais e de gestão do processo de produção, os quais permitirão que as TCR's venham a ser incorporadas à cultura da empresa.

A situação, apresentada a seguir, vivida pela autora algumas vezes ao tentar implantar TCR's em empresas construtoras, ilustra bem as colocações anteriores.

Se a partir dos procedimentos para a produção racionalizada de contrapisos, divulgados ao meio técnico através de diversas publicações, como por exemplo, BARROS [1993], BARROS [1994] e BARROS; SABBATINI [1995], o gerente de uma obra decidir aplicar os procedimentos de execução ali contidos, poderá obter um ganho localizado de racionalização em sua obra, pois esses procedimentos, se corretamente utilizados, possibilitam a redução no consumo de aglomerante da argamassa de contrapiso, maior produtividade e obtenção de um produto final com características mecânicas e de textura superficial adequadas às necessidades de uso.

Entretanto, por se tratar de uma ação implementada apenas na fase de execução de uma obra específica, limita o potencial de racionalização da tecnologia envolvida. Por outro lado, se essa ação estiver inserida numa filosofia de trabalho voltada à evolução do processo de produção da empresa, iniciando-se, portanto, na fase de projeto, possibilitará obter uma significativa redução dos recursos envolvidos.

Pensar a produção do contrapiso como uma atividade do projeto de piso, realizado no início do empreendimento, permitirá a compatibilização dos subsistemas estrutura, instalações, impermeabilização e revestimentos, levando à racionalização tanto da argamassa a ser utilizada no momento da execução, como também, e principalmente, das espessuras empregadas. Isso resulta na otimização de todos os recursos envolvidos, como mostram claramente as publicações anteriormente citadas. 
Considerar a racionalização de qualquer parte do edifício como uma atividade inserida no processo global de produção, significa alterar as atuais formas de organização e de gestão desse processo e da empresa como um todo.

Além disso, à medida em que a empresa evolui continuamente nessa forma de racionalização da produção, proporciona condições para que outras formas de racionalização possam ser empreendidas mais facilmente, como por exemplo, a implantação de programas de Gestão da Qualidade.

Acredita-se e pretende-se confirmar no decorrer do desenvolvimento deste trabalho de tese, que o aumento da competitividade da empresa construtora de edifícios, através da implantação de TCR's, seja possível uma vez que a introdução de novas tecnologia na empresa:

- requer o desenvolvimento de projetos voltados à produção e exige um planejamento prévio de todas as atividades envolvidas, alterando, desta forma, a postura atual das empresas que permitem o "improviso", fazendo com que se perca todo o potencial de racionalização da produção;

- permite que o corpo técnico da empresa tenha domínio sobre o processo de produção do edifício, podendo empregar com mais propriedade as ferramentas do planejamento e da tecnologia para a solução de problemas;

- exige o desenvolvimento dos recursos humanos, através do treinamento e da motivação pessoal, o que leva à valorização profissional e à adoção de novas posturas para a realização do trabalho;

- exige a implantação de procedimentos de controle do processo de produção e aceitação do produto, em geral inexistentes, mas que permitem estabelecer um maior nível de confiança no produto final e a realimentação do processo de implantação.

Procurando contribuir para que as empresas construtoras possam vir a ser tecnologicamente mais competitivas é que se está propondo o presente trabaIho, cuja formulação da tese e os objetivos principais são apresentados na seqüência. 


\subsection{Formulação da Tese e dos Objetivos}

Neste trabalho tem-se como premissa que um dos caminhos profícuos a serem percorridos, com vistas à evolução tecnológica do processo construtivo tradicional, é o da implantação de TCR's no processo de produção do edifício, para o quê, faz-se necessária a aplicação de uma metodologia adequada.

Desta maneira, o trabalho de tese está vinculado à proposição de uma metodologia para a implantação de TCR's que possa ser aplicada por empresas construtoras que adotem o processo construtivo tradicional para a produção de edifícios.

Neste sentido, a tese pode ser assim formulada:

"A implantação de tecnologias construtivas racionalizadas (TCR's) na produção de edifícios pelo processo construtivo tradicional pode se consubstanciar num importante instrumento para a evolução do processo de produção, se estiver orientada por uma metodologia que permita incorporar as ações de racionalização à cultura da empresa".

Com isto, o principal objetivo que se pretende alcançar é:

- a proposição e a discussão de uma metodologia para a implantação de TCR's, disponiveis no mercado, contribuindo para que as empresas de Construção de Edifícios possam aumentar sua capacidade competitiva.

A metodologia será proposta tendo como objeto de estudo a construção de edifícios de múltiplos pavimentos pelo processo construtivo tradicional, que no caso de São Paulo, e da maioria das cidades brasileiras, é caracterizado por: uma estrutura reticulada de concreto armado, moldado no local com fôrmas de madeira; vedação de alvenaria; e revestimentos argamassados.

O trabalho de tese apresenta uma metodologia genérica para a implantação de TCR's, passivel de ser aplicada à produção do edifício como um todo ou de alguma sua parte. 
Para que implantação de TCR's no processo construtivo tradicional leve a empresa a alcançar uma maior capacidade competitiva, a metodologia envolve todos os elementos presentes no processo de produção do edifício e suas relações, ou seja: os projetos; a documentação; os recursos humanos; os recursos de tempo, materiais, equipamentos; o controle do processo de produção; e a realimentação do processo de implantação.

Com esse enfoque, espera-se contribuir para: a redução de retrabalhos e desperdícios, tanto de materiais como de natureza humana; o aumento da produtividade e competência da mão-de-obra; a diminuição de problemas patológicos; e, por conseqüência, a diminuiçăo dos custos de produção, aumentando, dessa maneira, a competitividade da empresa.

\subsection{Metodologia}

A definição do tema da tese e a proposição de seu objetivo foi uma decorrência natural do trabalho realizado por ocasião da elaboração da dissertação de mestrado da autora: "Tecnologia de Produção de Contrapisos para Edifícios Habitacionais e Comerciais" [BARROS, 1991]. Nesse trabalho, no seu capítulo de Considerações Finais, expressava-se a preocupação com o repasse da tecnologia proposta às empresas construtoras de edifícios e a necessidade de se ter uma adequada metodologia para concretizar a nova tecnologia no sistema de produção das empresas.

Para que se tivesse elementos que permitissem consolidar uma metodologia, passivel de ser empregada pela maioria das empresas atuantes no mercado de construção de edifícios e sobretudo pelas de pequeno e médio porte, inicialmente foi proposta a implantação da tecnologia racionalizada de produção de contrapisos, junto a duas empresas construtoras, que objetivavam a racionalização de seus métodos construtivos.

Apesar da implantação ter sido interrompida, antes da sua consolidação nas empresas, a experiência decorrente do contato com os profissionais, tanto da área de projeto, como de produção (em todos os seus níveis), proporcionou a oportunidade de aperfeiçoar as idéias que se alimentava naquele momento 
quanto à forma de implantação das TCR's em empresas construtoras de edifícios.

A partir dessa primeira experiência, seguiram-se contatos com outras empresas, por meio de trabalhos desenvolvidos no âmbito do grupo de pesquisa do qual a autora faz parte, no Centro de Pesquisa e Desenvolvimento em Construção Civil, da Escola Politécnica da USP (CPqDCC-EPUSP).

Esses trabalhos foram realizados através de projetos de pesquisa e debates internos às empresas, sempre no sentido de se implantar as TCR's desenvolvidas no CPqDCC no sistema de produção dessas empresas.

Os resultados advindos dessas experiências permitiram reunir importantes informações relacionadas com os fatores intervenientes (facilitadores e dificultantes) no processo de Implantação de Tecnologias Construtivas Racionalizadas.

Além dessas informaçōes, coletadas a partir de experiências em campo, utilizou-se também, como uma importante fonte de dados, uma pesquisa realizada junto a um conjunto de empresas que constrói pelo processo construtivo tradicional.

As empresas pesquisadas, de alguma maneira, estão buscando alterar suas relações de produção, seja pela introdução de mudanças tecnológicas, seja através de programas de Gestão da Qualidade, ou ainda, através das duas formas conjuntas.

Durante a pesquisa, buscou-se conhecer as principais características de organizaçăo das empresas e como estas afetam o desenvolvimento do projeto; como ocorre o repasse das TCR's à etapa de obra, quais as formas de controle utilizadas em cada etapa do processo de produção e como se dá o retorno dos resultados obtidos nas obras aos projetos futuros.

Além das atividades envolvendo diretamente as empresas construtoras, o trabalho de tese tem sua parte conceitual fundamentada em uma revisão bibliográfica realizada de maneira crítica, abordando os temas relacionados aos conceitos envolvidos no trabalho, à organização das empresas de construção 
de edifícios e as estratégias empregadas na busca da sua competência tecnológica e ainda, aos modelos de implantação de novas tecnologias, tanto na indústria de bens de consumo, como em empresas de Construção Civil.

As experiências vividas através da implantação de TCR's em empresas construtoras, somadas à pesquisa bibliográfica realizada e à pesquisa junto às empresas construtoras foram de grande valia para a formulação e a análise da viabilidade da proposta, uma vez que possibilitaram identificar: o ambiente e o momento mais adequados à implantaçăo das TCR's; a importância da existência de um projeto voltado à produção; a importância da parceria com os subempreiteiros e a necessidade de treinamento da mão-de-obra, a partir de procedimentos racionalizados de produção; a relevância das atividades relacionadas ao setor de suprimentos; e a necessidade de estabelecimento de mecanismos de controle.

\subsection{Estruturação do Trabalho}

Buscando atingir o objetivo anteriormente proposto, o trabalho de tese é desenvolvido ao longo de cinco capítulos, além deste relativo à introdução ao tema e do capitulo destinado às conclusões.

Os conceitos fundamentais envolvidos com o tema da tese são apresentados no segundo capítulo, "Conceitos Básicos Relacionados com a Implantação de Tecnologias Construtivas Racionalizadas no Processo de Produção de Edifícios", procurando-se estabelecer uma linguagem única para a condução do trabalho.

No terceiro capítulo, "A indústria da Construção Civil no Brasil e as Estratégias do Subsetor Edificações na Busca da Competitividade", apresentam-se as características principais desse setor industrial, com enfoque para a empresa de Construção de Edifícios e para a sua organização frente ao processo de produção. Além disso, nesse capítulo discutem-se, ainda, as principais estratégias que vêm sendo implementadas pelas empresas construtoras para se manterem ou mesmo para se tornarem competitivas no mercado, com destaque para 
a implantação de programas de Gestão da Qualidade e para a implantação de mudanças tecnológicas no processo de produção.

Fundamentando-se na estrutura teórica montada nos dois capítulos precedentes, no quarto capítulo, "O Processo de Inovação Tecnológica na Indústria Seriada e na Indústria da Construção de Edifícios", apresenta-se inicialmente uma revisão bibliográfica sobre os modelos propostos para a introdução de mudanças e inovações tecnológicas, tanto nas indústrias de bens de consumo, quanto na indústria da Construção de Edifícios, destacando-se os elementos fundamentais que contribuem para a fixação de novas tecnologias na cultura das empresas; além disso, apresentam-se, ainda, duas tentativas de implantação de TCR's em empresas construtoras, realizadas pela autora, das quais foram destacados elementos importantes que auxiliaram na proposição da metodologia.

A partir dos subsídios reunidos no quarto capítulo, passa-se ao desenvolvimento da proposta metodológica, a qual é apresentada no quinto capitulo: "Metodologia para Implantação de Tecnologias Construtivas Racionalizadas na Produção de Edifícios". Nesse capítulo, propõem-se as premissas, as diretrizes balizadoras e a estratégia de ação que deverão ser adotadas pelas empresas construtoras, para a implantação de TCR's no processo de produção de edifícios construídos pelo processo construtivo tradicional.

No sexto capítulo, faz-se uma análise da metodologia, procurando-se mostrar a validade das premissas, das diretrizes balizadoras e do plano de ação propostos. Essa análise é realizada a partir da consideração das ações que um conjunto de empresas vem adotando para alcançar a sua competência tecnológica e organizacional.

No sétimo e último capítulo, reservado às conclusões, discutem-se a necessidade e a contribuição da metodologia, para a evolução da indústria da Construção de Edifícios, bem como, a necessidade da continuidade dos trabalhos e das pesquisas visando a evolução tecnológica e organizacional da indústria da Construção de Edifícios. 


\section{CAPITULO 2}

\section{CONCEITOS BÁSICOS RELACIONADOS COM A IMPLANTAÇÃO DE TECNOLOGIAS CONSTRUTIVAS RACIONALIZADAS NO PROCESSO DE PRODUÇÃO DE EDIFICIOS}

O desenvolvimento de métodos, processos e sistemas construtivos tem sido objeto de trabalho constante do grupo de pesquisa do qual a autora participa, tendo sido tema da Tese de Doutorado apresentada por SABATTINI [1989]. Entretanto, a existência e a disponibilidade de uma dada tecnologia construtiva, seja ela racionalizada ou mesmo inovadora, por si só, não garante a meIhoria do processo de produção de edifícios ou o incremento da qualidade, tão almejados pelo setor produtivo.

As açōes visando o repasse ou a transferência das novas tecnologias às empresas construtoras têm sido tema pouco discutido e não sistematizado pelos pesquisadores da área, sobretudo no Brasil.

Essa ausência de informações sistematizadas sobre o assunto, somada às dificuldades de repasse dessas tecnologias aos canteiros de obras, motivaram a realização do presente trabalho. No entanto, durante o seu desenvolvimento, percebeu-se a falta de consenso acerca dos conceitos envolvidos pelo o tema.

Ao se falar em introdução de "novas tecnologias no canteiro de obras", comumente aparecem três enfoques distintos para a questão, quais sejam:

- pode-se fazer um paralelo com os demais setores industriais e se falar em implantação de inovações tecnológicas;

- às vezes, empregam-se os termos consagrados pelos Programas da Qualidade, falando-se em melhoria contínua das atividades e serviços;

- há ainda quem defenda o termo racionalização da produção ou, como se pretende abordar neste trabalho, em implantação de tecnologias construtivas racionalizadas. 
De fato, na literatura consultada, não há definição clara para cada um desses significados. Diversos pesquisadores utilizam indistintamente as palavras "alteração", "inovação", "melhoria", "novas tecnologias". Assim, neste capítulo, busca-se analisar e discutir esses conceitos que fundamentam a tese, definindo-se o sentido com os quais os mesmos serão entendidos ao longo do trabalho, procurando, desta maneira, contribuir para a consolidação de uma terminologia junto ao meio técnico.

Considerando-se que a tese tem como objeto de análise o processo construtivo tradicional, cabe explicitar inicialmente o que se entende por esse termo, deixando claro o escopo do presente trabalho.

Ainda que os termos tecnologia e racionalização pareçam ter aceitação generalizada no meio técnico, é importante que antes de se discutir o que se entende por implantação de tecnologia construtiva racionalizada, seja explicitado o significado de tecnologia, de tecnologia construtiva e de racionalização para o presente trabalho.

Os termos inovação tecnológica e transferência de tecnologia serão também discutidos, por estarem presentes na linguagem comumente empregada pelo meio técnico, quando se deseja fazer referência a novos materiais e componentes, ou mesmo novos métodos construtivos empregados na produção de edifícios. Procura-se, desta maneira, delimitar o alcance destes termos, mostrando sua relação com o conceito adotado para implantação de tecnologias construtivas racionalizadas.

E, finalmente, apresenta-se como será entendido, neste trabalho, o conceito de melhoria contínua, dentro do enfoque da qualidade, uma vez que a implantação de tecnologias construtivas racionalizadas tem forte relação com a busca da qualidade pelas empresas construtoras. 


\subsection{Processo de Produção e Processo Construtivo Tradicional}

\subsubsection{Processo e sistema de produção}

Antes de se definir o que se entende por "processo construtivo tradicional" cabe explicitar como estarão sendo utilizados os termos "processo", "processo de produção" e "sistema de produção".

O termo processo pode ser definido com diferentes amplitudes. Consultando um dos grandes dicionários da língua portuguesa [FERREIRA, 1986], é possível encontrar pelo menos seis diferentes significados, sendo que um deles atende melhor às necessidades do presente trabalho, sendo assim colocado: "processo é a maneira pela qual se realiza uma operação, segundo determinadas normas".

JURAN [1992] também propõe uma definição genérica, afirmando que "processo é uma série sistemática de ações dirigidas à realização de uma meta". Em função disso, esse autor destaca que o processo deverá satisfazer os seguintes critérios:

- ser orientado por metas, pois não se pode planejar no abstrato;

- ser sistemático, ou seja, as atividades que compõem um processo devem ser todas interligadas através de um conceito coerente;

- ser capaz de atingir as metas preestabelecidas, em condições operacionais;

- ser legítimo, ou seja, deve poder evoluir através de canais autorizados; deve ter a aprovação daqueles a quem foram delegadas as responsabilidades associadas.

Das colocações de JURAN [1992], observa-se que o processo é caracterizado por envolver atividades factíveis, dentro de um determinado ambiente, devidamente organizadas e empregadas para se atingir um determinado fim. Além disso, apresenta ainda a necessidade de se ter responsáveis legítimos pela condução desse processo dentro da organizaçăo.

DAVENPORT [1993], por sua vez, enfoca o "processo" a partir de uma visão de negócios (business). Para esse autor, um processo pode ser entendido 
como sendo "um conjunto estruturado e organizado de atividades destinadas a produzir um específico 'resultado' para um determinado cliente ou mercado (...) é uma ordenação específica das atividades de trabalho no tempo e no espaço, com um início e um fim e com entradas e saídas claramente identificadas, ou seja, uma estrutura para ação".

É, pois, com esse sentido, de atividades devidamente estruturadas e organizadas no tempo e no espaço, que será entendido o termo "processo", agregandose a essa visão, a necessidade constante de existirem responsáveis pela condução do "processo", seja qual for a sua natureza.

O termo "processo", isoladamente, é pouco utilizado, sendo mais comum o emprego do termo composto: "processo de produção"; "processo de inovação"; "processo de fabricação", entre outros.

Aqui, há o interesse particular de se conceituar o "processo de produção de edificios" e, para isso, emprega-se a definição proposta por CARDOSO [1996], que define "processo de produção", como sendo:

"o conjunto das etapas físicas, organizadas de forma coerente no tempo, que dizem respeito à construção de uma obra; essas etapas concentramse sobre a execução, mas vão desde os 'estudos comerciais', até a utilização da obra, e são asseguradas por diferentes agentes".

CARDOSO [1996] distingue o "processo de produção" do "sistema de produção", definindo "sistema de produção" como sendo:

"o modo de articulação entre um sistema de operações físicas de produção (inserido em suas dimensões técnico-sociais) e um sistema de operações de gestão, de condução, controle e avaliação dos resultados (inserido em suas dimensōes técnico-organizacionais)".

Segundo esse autor, o "sistema de produção" é característico da empresa envolvida com a construção do edifício, incluindo todas as etapas funcionais dos estudos necessários, que precedem a realização da obra, os quais denomina de "estudos de execução" e "estudos de preparação" e ainda as operações físicas envolvidas com a produção propriamente dita. 
O que CARDOSO [1996] denomina "estudos de execução" poderia ser aproximado ao que vem sendo denominado, no Brasil, de "projeto para produção" (discutido e proposto no capítulo 5); enquanto os "estudos de preparação" poderiam ser comparados ao planejamento operacional do empreendimento.

A representaçăo esquemática dos conceitos de "processo de produção" e "sistema de produção" voltados à construção de edifícios, propostos por CARDOSO [1996], é apresentada na figura 2.1.

\section{EMPREENDIMENTO}

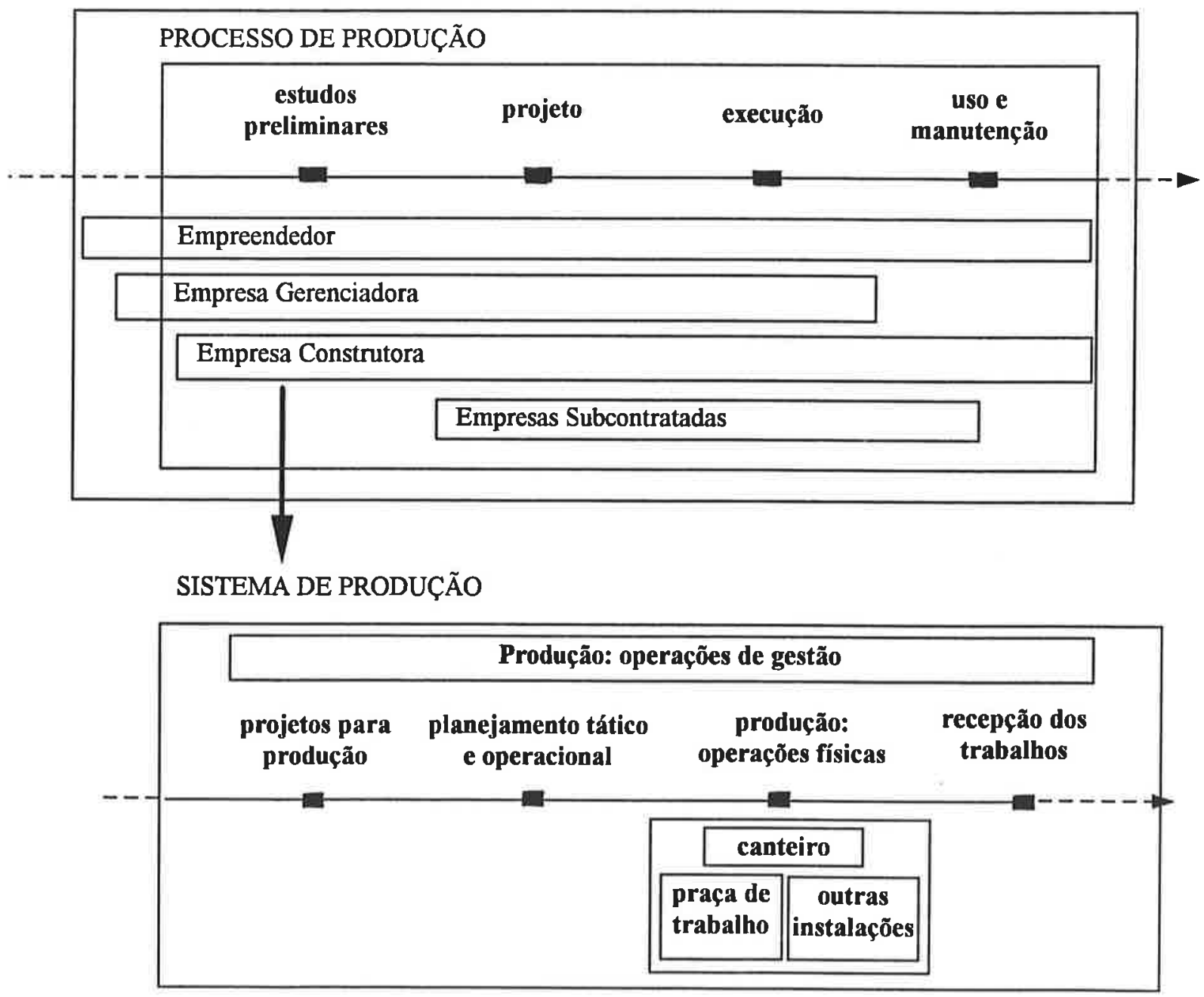

FIGURA 2.1: Representação esquemática dos conceitos de processo de produção e sistema de produção [adaptada de CARDOSO, 1996] 


\subsubsection{Técnica, método, processo e sistema construtivo}

O conceito de processo construtivo tradicional, apresentado no item 2.1.3, é definido a partir da discussão dos termos técnica, método, processo e sistema construtivo, os quais na linguagem comum da Construção Civil sempre foram utilizados com o mesmo significado, ou seja, "o modo ou a maneira de construir um edifício ou uma sua parte".

A partir dos anos 70 , com as primeiras tentativas de industrialização do processo de Construção de Edifícios, esses termos passaram a ser empregados com mais freqüência. Por essa época falava-se em "sistemas construtivos industrializados", em contraposição aos "sistemas construtivos tradicionais", sendo estes últimos considerados como o modo de construção vigente até o momento.

Outras expressões como, por exemplo, "técnica de construção de uma parede de alvenaria", ou ainda, "método de construção de uma parede de alvenaria", são utilizadas, muitas vezes, com o mesmo significado.

Ainda hoje não se tem consenso sobre o significado preciso de cada um desses termos, daí a importância de se deixar claro como serão empregados ao longo do trabalho e sobretudo o significado de processo construtivo tradicional, objeto de referência para o desenvolvimento da tese.

VARGAS [1994], ao discutir o desenvolvimento da Ciência, apresenta o que se entende por técnica. Segundo este professor, na Grécia surgiu um tipo de conhecimento que não a ciência. Esse conhecimento era denominado 'techné' e não se limitava à pura contemplação da realidade. "Era uma atividade cujo interesse estava em resolver problemas práticos, guiar os homens em suas questōes vitais, curar doenças, construir instrumentos e edifícios, etc.". Esse autor salienta ainda: "as 'techné' gregas eram, em princípio, constituídas por conjuntos de conhecimentos e habilidades profissionais transmissiveis de geração a geraçāo".

GAMA [1986] conceitua técnica como sendo: "um conjunto de regras práticas para fazer coisas determinadas, envolvendo habilidade do executor e transmi- 
tidas, verbalmente, pelo exemplo, no uso das mãos, dos instrumentos e ferramentas e das máquinas. Alarga-se freqüentemente o conceito para nele incluir o conjunto dos processos de uma ciência, arte ou ofício, para obtenção de um resultado determinado com o melhor rendimento possivel".

As duas conceituações são convergentes e levam a que "técnica" seja entendida como o conjunto das habilidades de um determinado profissional, no caso presente, operário da construção, para realizar uma determinada operação.

Acrescentando o vocábulo "construtivo", SABBATINI [1989] restringe o conceito ao campo da construção e, em particular, à construção de edifícios, e propõe: "Técnica Construtiva é um conjunto de operações empregadas por um particular ofício para produzir parte de uma construção".

Esse autor salienta que o conjunto de todas as técnicas pode ser entendido como "a técnica construtiva de um edifício", mas que nesse conceito "não estão implicitas noções de seqüência, precedência, organização, mas tão somente a noção de coleção".

As noções de seqüência, precedência, organização aparecem quando se fala em métodos e processos construtivos, em que a idéia de movimento, de seqüência de procedimentos ou operações para se atingir um determinado objetivo está presente.

Essas duas expressões, na linguagem técnica corrente, na maioria das vezes, são utilizadas como sinônimos. Entretanto, SABBATINI [1989], depois de realizar uma análise minuciosa, emprega-as com diferentes sentidos. Não cabe repetir aqui a análise realizada por esse autor, apenas serão adotados os significados por ele propostos, discutindo-os no contexto deste trabalho.

"Método construtivo é um conjunto de técnicas construtivas interdependentes e adequadamente organizadas, empregado na construção de uma parte (subsistema ou elemento) de uma edificação".

"Processo Construtivo: é um organizado e bem definido modo de se construir um edifício. Um específico processo construtivo caracteriza-se 
pelo seu particular conjunto de métodos utilizado na construção da estrutura e das vedações do edifício (invólucro)".

Com a proposição desses conceitos, SABBATINI [1989] diferencia método e processo construtivo em função de sua complexidade, ou seja, o método refere-se apenas à construção de uma parte de um edifício, enquanto o processo relaciona-se às características de produção do edifício como um todo, estando relacionado particularmente à natureza e à seqüência de operações empregadas no invólucro do edifício, ou seja, sua estrutura e suas vedações, por serem estas as partes mais expressivas da produção do conjunto.

Conceito semelhante é proposto por MARTUCCI [1990], ainda que utilize caminhos distintos para propô-lo.

Segundo esse autor, o processo construtivo "viabiliza, através da tecnologia e da técnica, a materialização das unidades habitacionais, ou seja, o processo construtivo é o responsável por definir as formas e as capacidades técnicas e econômicas de se construir".

O processo construtivo envolve, segundo MARTUCCI, "um determinado estágio tecnológico, indutor da forma de se executar os edifícios, ou seja, sintetiza o conjunto de conhecimentos técnicos e organizacionais passíveis de serem combinados, em função do grau de desenvolvimento tecnológico em que se encontram a indústria de materiais de construção e a indústria de máquinas, equipamentos e ferramentas para a Construção Civil, (...) bem como os processos de trabalho, incorporados nas técnicas construtivas".

Observa-se nas definições dos dois autores que a organização do processo de produção, além do conjunto de técnicas específicas, aparece explicitamente, para com isso caracterizar o processo construtivo.

Para completar a idéia apresentada inicialmente neste item, cabe conceituar o termo sistema construtivo, o qual, mais que os anteriores, gera grande polêmica ao ser empregado pelo meio técnico. Como não se trata de termo amplamente utilizado neste trabalho, apenas será registrado o conceito proposto por SABBATINI [1989] e que vem sendo empregado nos trabalhos desenvolvi- 
dos pelo Grupo de Ensino, Pesquisa e Extensão em Tecnologia de Processos Construtivos da EPUSP:

"SISTEMA CONSTRUTIVO é um processo construtivo de elevados níveis de industrialização e de organização, constituído por um conjunto de elementos e componentes inter-relacionados e completamente integrados pelo processo."

A partir dessa definição, pode-se dizer que "um sistema construtivo é um processo construtivo de superior complexidade, muito bem definido e tecnologicamente mais avançado" [SABBATINI, 1989].

\subsubsection{Processo construtivo tradicional}

Considerando-se o grau de desenvolvimento tecnológico, ou seja as características específicas da tecnologia construtiva empregada, bem como as características organizacionais implementadas para a produção de edifícios, é possivel propor uma classificação para os diversos processos construtivos comumente empregados.

Considerando-se esses dois aspectos, são diversas as classificações propostas pelos pesquisadores da área, não havendo, ainda, um consenso.

SABBATINI [1989] propõe uma classificação que prevê três níveis distintos para o caso da produção de edifícios: os processos construtivos tradicionais, racionalizados e industrializados; enquanto MARTUCCI [1990] propõe uma classificação com cinco níveis diferentes: os processos construtivos "artesanais"; "tradicionais"; "tradicionais racionalizados"; "pré-fabricados"; e "industrializados".

Para MARTUCCI [1990], "artesanais" são os processos construtivos que carregam um forte traço regional, cultural e histórico. São transmitidos de uma geração para outra como um patrimônio. Como exemplo, cita as habitações indigenas e as habitações rurais de taipa de pilão. 
SABBATINI [1989], por estar mais voltado à produção de edifícios de múltiplos pavimentos, os quais não poderiam ser produzidos a partir desse tipo de organização da produção, não considera tal classificação.

Para SABBATINI [1989], os processos construtivos tradicionais são aqueles "baseados na produção artesanal, com uso intensivo de mão-de-obra, baixa mecanização (produção essencialmente manual), com elevados desperdícios de mão-de-obra, material e tempo, dispersão e subjetividade nas decisões, descontinuidade e fragmentação da obra".

Esses processos fundamentam-se em métodos construtivos tradicionalmente empregados em uma certa região. SABBATINI [1989] exemplifica com o processo construtivo tradicional para se construir edifícios de múltiplos pavimentos na cidade de São Paulo, que emprega estrutura reticulada de concreto armado moldada no local com fôrmas de madeira e vedações de blocos cerâmicos ou de concreto.

O INSTITUTO DE PESQUISAS TECNOLÓGICAS [IPT, 1988] denomina esse processo construtivo de "processo convencional", salientando que "na construção convencional, os elementos do edifício são produzidos no próprio canteiro - via de regra no seu local definitivo de emprego - através da reunião de materiais e componentes fornecidos pela indústria de materiais e componentes."

MARTUCCI [1990] propõe conceito semelhante ao de SABBATINI [1989]. Segundo esse autor, "processos construtivos tradicionais são aqueles que vêm se mantendo, na prática, através de longos anos. Estão incorporados culturalmente na história da construção de edificações (...) esses processos estão amplamente disseminados e arraigados na prática construtiva de pessoas, empresas e instituições em geral (...) mantêm técnicas que guardam muito das relações estabelecidas pelas corporações artesanais", que na realidade são as corporações de ofício, constituídas por pedreiros, carpinteiros, eletricistas, entre outras.

Para MARTUCCI [1990], no caso da produção de edifícios de múltiplos pavimentos, esse processo construtivo caracteriza-se pela produção de unidades 
constituídas por estrutura de concreto armado moldada no local, vedações de componentes cerâmicos, esquadrias metálicas, revestimentos de argamassa e azulejos (para áreas molhadas).

Além de empregar técnicas e métodos construtivos tradicionais (de domínio da mão-de-obra local), deve-se acrescentar que esse processo construtivo é caracterizado, ainda, por uma atividade de projeto também tradicional; isto é, o projeto é voltado apenas ao produto e não à produção; na maioria das vezes, não há a coordenação de projetos ou, quando existe, não passa de compatibilização.

Por exemplo, existe o projeto de instalaçōes enquanto dimensionamento das tubulações, dos eletrodutos e aparelhos; porém, neste projeto não se define como as instalações serão efetivamente executadas. Além disso, é comum existirem prumadas cortando elementos estruturais, caracterizando que neste caso não houve nem mesmo uma compatibilização entre projetos. Outras vezes, as instalaçōes previstas para serem passadas pela laje do edifício não cabem na espessura disponivel.

Seria possivel listar uma série de situaçōes típicas da falta de integração entre projetos e da ausência de um projeto verdadeiramente voltado à produção. $O$ que ocorre nesses casos é que decisões de grande repercussão técnica e econômica são tomadas quase sempre de maneira subjetiva, no momento da produção, perdendo-se praticamente todo o potencial de racionalização que poderia ser imprimido à produção do edifício.

Atualmente, o processo construtivo tradicional é, com certeza, o mais empregado na cidade de São Paulo. O trabalho de pesquisa realizado junto a diversas empresas, para subsidiar o desenvolvimento da tese, mostrou claramente que a grande maioria vem empregando esse processo construtivo para a produção de seus edifícios de múltiplos pavimentos.

O que se pretende propor com o presente trabalho, através da implantação de tecnologias construtivas racionalizadas, é incrementar o grau de organização do processo construtivo tradicional objetivando atingir um patamar tecnológico 
mais elevado, a fim de que possa ser considerado como um processo construtivo racionalizado, como definido na seqüência.

Os processos construtivos denominados "racionalizados" por SABBATINI [1989] são denominados, por MARTUCCI [1990], "tradicionais racionalizados". Exceto pela diferenciação na denominação, apresentam as mesmas características.

Neste trabalho, será adotada a terminologia proposta por SABBATINI [1989], sobretudo por ser a comumente adotada no âmbito do grupo de pesquisa do CPqDCC-EPUSP.

"Processos construtivos racionalizados são aqueles nos quais as técnicas organizacionais utilizadas nas indústrias manufatureiras são empregadas na construção sem que disto resultem mudanças radicais nos métodos de produção".

Essas técnicas organizacionais devem ser introduzidas tanto na etapa de projeto como na de produção. Nesses processos construtivos, os projetos passam a ser elaborados com maiores definiçōes técnicas, voltando-se mais à produção e não se restringindo apenas ao produto. Há efetivamente a coordenação de projetos, buscando a otimização de todos os recursos que estarão envolvidos com a produção, desde o início do empreendimento, levando o conhecimento das tecnologias construtivas utilizadas no canteiro à fase de projeto.

Nos processos construtivos racionalizados, todas as disciplinas de projeto (arquitetura, estruturas, instalações, alvenarias, esquadrias, impermeabilização, revestimentos, etc.) são desenvolvidas em conjunto, interagindo e convergindo para o projeto voltado à produção, que deve conter informações necessárias e suficientes para que o edifício seja produzido sem a necessidade de tomada de decisões subjetivas e no momento da produção.

O canteiro passa a ser organizado, buscando-se maior racionalidade das atividades. Introduz-se o conceito de centralização da produção, montando-se unidades produtoras tais como de argamassas, fôrmas, armaduras, "kits" hidráulicos e elétricos. 
MARTUCCI [1990] salienta que esses processos construtivos, do ponto de vista do produto, permanecem quase que inalterados quando comparados ao processo construtivo tradicional; entretanto, do ponto de vista organizacional, expressam um verdadeiro avanço no desenvolvimento tecnológico do setor da Construção de Edifícios.

O principal objetivo desses processos construtivos é, pois, eliminar desperdícios de mão-de-obra e de materiais; aumentar a produtividade; planejar o fluxo de produção e centralizar e programar as decisões [SABBATINI, 1989].

É portanto, nesse estágio tecnológico que se deseja chegar com o desenvolvimento deste trabalho, aplicado aos processos construtivos tradicionais.

O processo construtivo denominado industrializado por SABBATINI [1989] é subdividido por MARTUCCI [1990] em processo construtivo pré-fabricado e industrializado.

Acredita-se que do ponto de vista da tecnologia incorporada e dos processos organizacionais estabelecidos, a subdivisão proposta pelo segundo autor trata de um rigor conceitual que não cabe aqui ser discutido. Desta forma, neste trabalho adota-se a conceituação proposta por SABBATINI [1989], entendendo-se por processo construtivo industrializado: "aquele baseado no uso intensivo de componentes e elementos produzidos em instalações fixas e acoplados no canteiro. Utiliza preponderantemente as técnicas industriais de produção, transporte e montagem. A integração do todo submete-se aos principios organizacionais da indústria estacionária".

Pela classificação adotada, fica evidente a evolução que os processos construtivos vão alcançando à medida em que se incorpora os princípios de organização e tecnologias construtivas que buscam a racionalização do processo, ou seja, que procuram diminuir os desperdícios gerados pelo emprego inadequado de materiais, pelo retrabalho, pela baixa produtividade, entre outros.

Por isso, o que se busca ao propor uma metodologia para a implantação de tecnologias construtivas racionalizadas aplicada ao processo construtivo tradicional é a evolução do atual processo tradicional a tal ponto que possa ser 
considerado num patamar de desenvolvimento tecnológico equivalente aos processos construtivos racionalizados.

Isto significa que, ainda que năo rompam com os processos de trabalho vigentes, os processos construtivos tradicionais precisam ser organizados a partir de: projeto e planejamento voltados à produção; incorporação de tecnologias racionalizadas; adequado controle de produção; e mecanismos de realimentação do processo.

\subsection{Tecnologia e Tecnologia Construtiva}

Diversos estudiosos da área discutiram amplamente o conceito de tecnologia, buscando elucidar 0 seu significado. Dentre esses pesquisadores cabe destacar os trabalhos de VARGAS, [1994], e o de [GAMA, 1986].

Além desses trabalhos, tem sido de grande importância para o meio técnico e acadêmico a discussão e síntese dos conceitos realizadas no trabalho de SABBATINI [1989], que procurou definir o que se entende por tecnologia e, em particular, o que se entende por tecnologia construtiva.

Por serem termos amplamente discutidos nesses e em outros trabalhos, não cabe aqui uma longa explanação sobre os mesmos, mas tão somente o registro das definições propostas por esses autores.

Para GAMA [1986], tecnologia é "o estudo e o conhecimento científico das operações técnicas ou da técnica. Compreende o estudo sistemático: dos instrumentos, das ferramentas e das máquinas, empregados nos diversos ramos da técnica; dos gestos e dos tempos de trabalho; dos custos; dos materiais; e da energia empregada".

SABBATINI [1989] propōe: "tecnologia é um conjunto sistematizado de conhecimentos empregados na criação, produção e difusão de bens e serviços".

VARGAS [1994], por sua vez, define tecnologia como sendo "a simbiose da técnica com a ciência moderna, consistindo também num conjunto de atividades humanas associado a um sistema de símbolos, instrumentos e máquinas 
visando a construção de obras e a fabricação de produtos, segundo teorias, métodos e processos da ciência moderna".

Pode-se concluir, então que a "tecnologia" envolve: "conhecimentos científicos e técnicos, bem como uma série de instrumentos e máquinas, os quais são utilizados em conjunto, objetivando a produção de bens".

A tecnologia caracteriza um determinado estágio de conhecimento em uma determinada cultura; desta maneira, é passivel de evolução à medida em que os conhecimentos científicos avançam e podem ser agregados às técnicas anteriormente estabelecidas.

E, nesse contexto, VARGAS [1994] salienta que: "tecnologia não é algo que se importe ou exporte, ou que se compre ou venda, como são seus instrumentos e máquinas. Ela é algo que, quando não se tem, deve-se aprender (...) exige condiçōes de possibilidade de existência dentro de determinada contextura social".

A colocação de VARGAS [1994] deixa clara a importância de se ter mecanismos sistematizados, ou seja, metodologias, que auxiliem as empresas a "aprenderem as tecnologias disponiveis", ou seja, que thes permitam "implantarem efetivamente, em seu sistema de produção, as tecnologias, que não são de seu domínio".

O termo tecnologia construtiva é menos discutido pelo meio técnico. Numa abordagem ampla do processo de produção, TATUM [1986] conceitua tecnologia construtiva como sendo "o estado da arte dos métodos e processos construtivos e dos equipamentos e materiais de construção".

Essa visão ampla está presente também no trabalho de MARTUCCI [1990] ao afirmar que "a tecnologia para a construção está embutida nos processos construtivos, através dos projetos".

A visāo proposta por MARTUCCI [1990], de que a tecnologia construtiva esteja incorporada ao projeto, vem ao encontro das idéias aqui defendidas, uma vez que é na fase de projeto que se tem a oportunidade de atingir o maior 
potencial de racionalização através da proposição de tecnologias construtivas racionalizadas e da organização da produção.

Entretanto, a realidade vivenciada pela indústria da Construção Civil tem mostrado que nem sempre o projeto incorpora a tecnologia construtiva efetivamente empregada no canteiro de obras. Ainda hoje, na maioria das vezes, o projeto limita-se à definiçāo do produto sem incorporar-lhe os métodos e processos construtivos, os materiais e equipamentos. Nesse sentido, a tecnologia será incorporada apenas na etapa de execução, ou seja, na etapa de obra.

Com um enfoque para o sistema de produção da empresa, TATUM [1987] apresenta uma definição mais precisa do que entende por tecnologia construtiva, como sendo: "a combinação da influência das técnicas e métodos construtivos, dos recursos disponiveis e do projeto, os quais definem a maneira de realizar as operações construtivas.

SABBATINI [1989] também propõe uma definição considerando o sistema de produção, ou seja, parte do princípio que são muitas as tecnologias construtivas e cada uma delas é relativa a um determinado modo de se construir, que leva em conta um específico conjunto de conhecimentos. A partir dessa idéia, limitando o conceito à construção de edifícios, estabelece:

"tecnologia construtiva é um conjunto sistematizado de conhecimentos científicos e empíricos, pertinentes a um modo específico de se construir um edificio (ou uma sua parte) e empregado na criação, produção e difusão deste modo de construir".

O conceito formulado por SABBATINI [1989], assim como o proposto por TATUM [1987], não vincula a tecnologia construtiva a uma etapa específica do processo de produção do edifício, ainda que se defenda que ela seja incorporada na fase de projeto. Desta maneira, no presente trabalho será adotado o conceito proposto por SABBATINI [1989]. 


\subsection{Racionalização Construtiva e Tecnologia Construtiva Racionalizada}

O conceito de racionalização não é recente; há muito fala-se em "racionalizar" uma determinada coisa ou atividade. É um termo que parece ter significado bem entendido, tanto coloquialmente, como no meio técnico. Segundo um dos mais utilizados dicionários da língua portuguesa, o termo racionalização pode ser entendido como o ato ou efeito de racionalizar alguma coisa, ou seja, tornar racional, tornar mais eficientes os processos de trabalho ou a organização de empreendimentos [FERREIRA, 1986].

Transferindo esse conceito para a área específica de construção, pode-se entender a racionalização como o esforço para tornar mais eficiente a atividade de construir, o esforço para se buscar a solução ótima para os problemas da construção.

ROSSO [1980] conceitua racionalização com esse sentido. Para esse autor, "a racionalização é o processo mental que governa a ação contra os desperdícios temporais e materiais dos processos produtivos, aplicando o raciocínio sistemático, lógico e resolutivo, isento do influxo emocional; é um conjunto de ações reformadoras que se propõe substituir as práticas rotineiras convencionais por recursos e métodos baseados em raciocínio sistemático, visando eliminar a casualidade nas decisões."

As colocações de ROSSO [1980] levam a concluir que a substituição de práticas tradicionais por métodos fundamentados em principios de organização e predefinição das atividades, resgatando para o início do processo de produção as decisōes que se fazem necessárias, caracteriza a racionalização de uma determinada atividade ou processo.

É com esse sentido que ROSSO [1980] salienta que os princípios da racionalização devem ser aplicados ao edifício tanto como produto quanto como processo, ou seja, o edifício precisa começar a ser racionalizado na sua fase de concepção. É nesse momento que se consegue auferir os maiores ganhos com as ações de racionalização, estendendo, então, essas açōes para a etapa de 
produção, a fim de que possam ser efetivamente implementadas, obtendo-se os ganhos previamente definidos.

SABBATINI [1989], analisando as definições de racionalização propostas por diversos autores, conclui que: "o objetivo, claramente definido, é a otimização do uso dos recursos disponíveis em um dado instante e em um certo local". Com isso, esse autor propõe uma definição para o termo racionalização construtiva, com um enfoque microeconômico, ou seja, restrito às atividades de produção de um empreendimento:

"Racionalização Construtiva é um processo composto pelo conjunto de todas as ações que tenham por objetivo otimizar o uso dos recursos materiais, humanos, organizacionais, energéticos, tecnológicos, temporais e/ financeiros disponiveis na construção em todas as suas fases."

O conceito formulado por SABBATINI [1989] será o adotado no presente trabalho.

O conceito de racionalização construtiva e definição discutida e adotada para tecnologia construtiva permitem formular o conceito proposto por este trabalho para TECNOLOGIA CONSTRUTIVA RACIONALIZADA, o qual será entendido como sendo:

"um conjunto sistematizado de conhecimentos científicos e empíricos, empregados na criação, produção e difusão de um modo específico de se construir um edifício ou uma sua parte, orientado pela otimização do emprego dos recursos materiais, humanos, organizacionais, energéticos, tecnológicos, temporais e financeiros envolvidos em todas as fases da construção".

Incentivando o emprego de Tecnologias Construtivas Racionalizadas (TCR's), busca-se alterar a atual forma de produção, concentrada sobretudo no uso de "tecnologias construtivas tradicionais", sobre as quais SABBATINI [1989] afirma: "são tecnologias sedimentadas, desenvolvidas ao longo do tempo e de forma quase sempre empírica; variam de um local para outro, sendo o resultado de tradições construtivas regionalizadas e portanto, restritas a um dado 
local (...) Essas tecnologias caracterizam-se por terem condições de produção amplamente insatisfatórias que se traduzem normalmente por uma baixa produtividade (de todos os recursos envolvidos) e baixo nível de produção".

SABBATINI [1989] salienta ainda que "existe a necessidade de tecnologias alternativas que apresentem condições de produção mais adequadas que as tecnologias em uso, aquelas que incorporando um maior cabedal de conhecimentos técnico-científicos, em substituição aos empíricos, possibilitem o incremento do nivel de produção e da produtividade, ou seja, tecnologias que promovam uma otimização dos recursos existentes naquela sociedade, naquele momento; e, por conseqüência, reduzam o custo, os prazos e melhorem o desempenho do produto."

Dentro desse contexto, a implantação de TCR's no âmbito do processo construtivo tradicional na produção de edifícios é um instrumento poderoso para se chegar ao aperfeiçoamento e evolução da atividade construtiva, buscando sempre a solução ótima para os problemas da construção, portanto a sua racionalização.

FARAH [1988] é defensora da aplicação de ações de racionalização ao processo de produção, afirmando que essas ações permitem ganhos de produtividade e minimização de custos e prazos, sem implicar numa ruptura da base produtiva que caracteriza o setor.

Para FARAH [1988], a tendência atual da construção de edifícios é de orientação para a racionalização da construção, pois os altos lucros que caracterizavam esse subsetor, comumente decorrentes de atividades improdutivas, foram ameaçados sobretudo pela expressiva retração da promoção estatal.

Para essa pesquisadora, a crise que se aprofundou nos últimos anos atribuiu uma importância maior à atividade produtiva, sinalizando com novas estratégias empresariais que incluem a busca da minimização dos custos de produção através da racionalização.

Ainda que a pesquisa realizada por FARAH [1988] tenha se realizado há mais de 10 anos, essa tendência continua direcionando as ações de diversas em- 
presas construtoras de edifícios, pois a implementação de ações visando a racionalização da produção foi um aspecto destacado como fundamental para a sobrevivência empresarial por praticamente todas as empresas do setor que participaram da pesquisa realizada para subsidiar a elaboração deste trabalho.

Segundo PICCHI [1993], a aplicaçăo de ações de racionalização é a tendência que se observa no mercado, por "permitir às empresas do setor menores investimentos, possibilidade de atuar em pequena escala, eliminaçăo da dependência de grandes concentrações de unidades e maior flexibilidade.

Este movimento tende a ter conseqüências mais benéficas, do ponto de vista da qualidade do produto, que os anteriores, pois exige ações tais como coordenação de projetos, planejamento, controle de materiais e serviços".

É uma decorrência natural das relações de mercado que a empresa construtora de edifícios, para sobreviver, precise entregar um produto competitivo. Ainda que influenciem os custos devidos à imobilização do capital de giro, de comercialização e para obtenção de recursos financeiros em empresas de crédito, é a atividade de produção que caracteriza a empresa. Portanto, é nessa atividade que a mesma tem chances de diminuição de custos, independentemente do retorno que da atividade de incorporação, principalmente porque muitas empresas nem mesmo atuam expressivamente como incorporadoras.

Essa posição, de certa maneira foi ratificada por pesquisadores do IPT, quando propuseram o Plano de Atualização Tecnológica e Industrial - PATI [IPT, 1988], afirmando que: "diante da crise que atingiu o setor desde o início da década de 80 , a atividade produtiva acabou por assumir uma importância maior na composição de custos da construção. Alguns riscos presentes na atividade de construção, no âmbito da promoção privada, foram potencializados com a crise; (...) houve uma diminuição da participação do Estado no financiamento do consumo, através da contenção do limite de financiamento e da exigência de pagamento do saldo devedor, ao final do prazo de financiamento (...) portanto, o incorporador tem sido obrigado a financiar uma parcela do valor dos imóveis, diminuindo sua lucratividade pela imobilização do capital de giro (...) e, diante desse quadro, há sinais de estabelecimento de novas estra- 
tégias empresariais, que incluem uma orientação à minimização dos custos de produção através da racionalização".

Esses fatores que vêm caracterizando a economia atual devem permanecer e, se a implantação de tecnologias construtivas racionalizadas é a resposta aos problemas atualmente enfrentados pelas empresas construtoras de edifícios, pode-se questionar: por que essas empresas não racionalizam todo o processo de produção?

Na realidade, a dificuldade de ser mais eficiente na atividade de construir está em que não é simples encontrar-se soluções ótimas para os problemas, quando se tem um grande número de variáveis ou fatores intervenientes.

Esse é o caso da construção de edifícios, em cujo ciclo de produção aparecem inúmeros agentes, como, por exemplo, os empreendedores, os projetistas, os fornecedores de materiais e componentes, os fornecedores de mão-de-obra, as características da própria força de trabalho, os usuários, entre tantos outros. Além da presença de inúmeras outras variáveis, como, por exemplo: os projetos únicos, que não se repetem; a interferência dos fatores ambientais, como o solo e fatores climáticos; a subjetividade dos anseios dos clientes; a falta de domínio do sistema de produção da própria empresa, entre outros.

Em função dessa dificuldade, SABBATINI [1989] salienta que "racionalização da construção é concebida como um processo complexo, de fundamental importância para a atividade construtiva e com reflexos sociais e econômicos importantíssimos na sociedade como um todo".

Na pesquisa realizada junto às empresas, foi possível observar que, em função das dificuldades de se promover a racionalização no processo construtivo tradicional como um todo, algumas empresas, preocupadas em serem competitivas, através da redução de desperdícios e aumento da qualidade e da produtividade, têm buscado implementar ações de racionalização em atividades de grande repercussão na produção de edifícios, como são os casos de:

- melhoria do sistema de fôrmas, através da racionalização do projeto, que passa a incluir aspectos relativos ao controle da montagem e desforma; 
- proposição de projeto de revestimento de piso, objetivando a produção da "laje racionalizada", com o emprego de contrapiso mínimo ou até mesmo a sua eliminação;

- proposição de nova metodologia de projeto e procedimentos de produção e controle, objetivando a racionalização das alvenarias de vedação, das instalações e dos revestimentos.

Com relação a essa prática das empresas, é oportuno citar as palavras de FRANCO [1992], ao afirmar que: "a racionalização construtiva não pode ser encarada unicamente como a melhoria ou alteração de determinados procedimentos construtivos, sob pena de se ter anulado ou diminuído os seus efeitos em termos de redução de custos e benefícios".

ROSSO [1980] também expressa a necessidade de se pensar a racionalização globalmente, afirmando que as ações de racionalização, no canteiro de obras, "são fadadas ao insucesso quando resultam de intervenções isoladas".

A racionalização deve ser aplicada de forma ampla ao processo de produção (ilustrado na figura 2.1). Deve abranger todas as etapas do empreendimento, ou seja, desde a sua concepção, passando pelas etapas de planejamento e execução e chegando até a manutenção do edifício entregue.

É nesse sentido que a implantação de TCR's, como um importante ferramental para evolução tecnológica do processo de produção, necessita efetivamente de uma metodologia específica, que conduza a sua implantação, a fim de que os esforços empreendidos possam ser fixados na cultura da empresa, fazendoa ganhar competitividade por poder oferecer ao mercado um produto diferenciado, tanto no custo, como no desempenho.

\subsection{Qualidade e Melhoria Continua}

A implantação de TCR's no processo de produção de edifícios, assim como a implantação de programas ou sistemas de Gestão da Qualidade, têm como objetivo central a melhoria dos processos empregados pelas empresas. 
Essas duas "estratégias de ação empresarial", aplicadas na indústria da Construção de Edifícios como importantes "ferramentas" de racionalização da produção, serão discutidas no âmbito do capítulo 3. Para isso, busca-se, neste item, entender os conceitos atribuídos à qualidade e a sua evolução ao longo do tempo, até configurar-se como uma função gerencial na empresa. Além disso, procura-se entender também o papel das ações de melhoria contínua, nesse contexto.

\subsubsection{Os conceitos atribuídos à qualidade}

Segundo GARVIN [1992] "a qualidade é um conceito notavelmente escorregadio, de fácil visualizaçăo, mas exasperadoramente difícil de se definir. Continua sendo motivo de grande confusão para os gerentes, levando à alegação freqüente, mas vazia: sei o que ela é quando a vejo".

Segundo esse mesmo autor, "a melhoria da qualidade é improvável em tais circunstâncias"; daí, a necessidade de se explicitar e empregar adequadamente este conceito.

JURAN; GRYNA [1991] destacam que o termo qualidade tem assumido distintos significados na linguagem corrente, dando destaque para dois deles:

- a qualidade consiste nas características do produto que vão ao encontro das necessidades dos clientes e dessa forma proporcionam a satisfação em relação ao produto; e

- a qualidade é ausência de falhas.

A ISO 8401 [ISO, 1986] define qualidade como sendo: "a totalidade das propriedades e características de um produto ou serviço, que the conferem capacidade de satisfazer necessidades explícitas ou implícitas", o que coincide com o primeiro significado proposto por JURAN; GRYNA [1991] e que, de certa maneira, embute o segundo significado proposto por esses autores.

PICCHI [1993] afirma que o conceito de qualidade tem sofrido uma rápida evolução e vem sendo cada vez mais ampliado, incorporando novos elementos e mantendo os anteriores. 
Os conceitos atribuídos por diferentes autores ao termo qualidade, discutidos, um a um, por PICCHI [1993], estão ilustrados na figura 2.2.

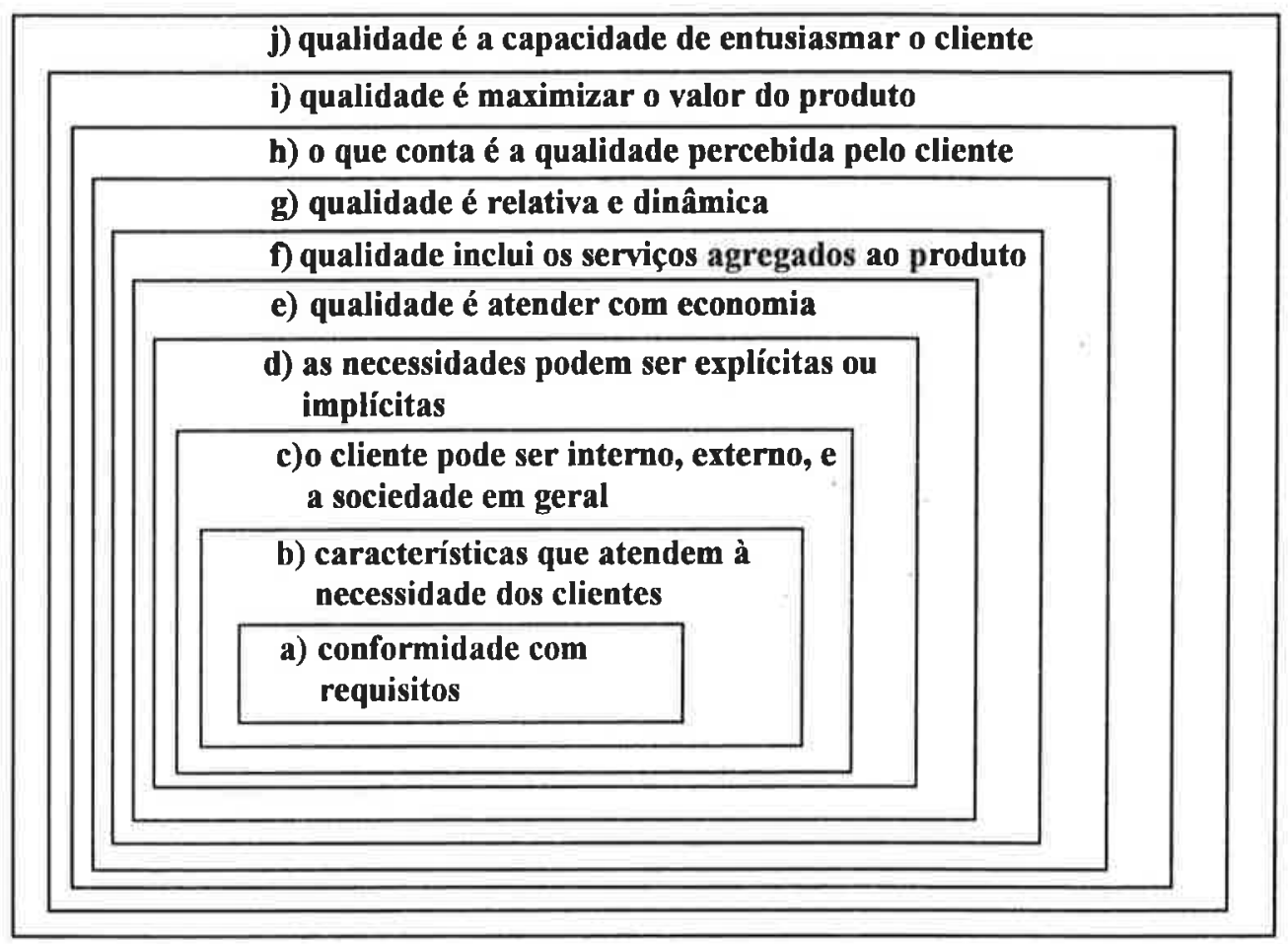

FIGURA 2.2: Representação do conceito da qualidade ampliado [PICCHI, 1993]

A diversidade de conceitos atribuídos à qualidade resulta de como a mesma é enfocada, o que, segundo GARVIN [1992], pode ocorrer a partir de cinco abordagens distintas, aqui apresentadas:

filosófica (enfoque "transcendente"): neste caso, a qualidade é sinônimo de "excelência inata", não é definida com precisão, aprende-se a reconhecer pela experiência - "qualidade é atingir ou buscar o padrão mais alto em vez de se contentar com o mal feito ou fraudulento";

enfoque no produto: considera-se que a qualidade é uma variável precisa e mensurável; as diferenças de qualidade de um produto referem-se a diferenças em quantidade de algum ingrediente ou atributo desejado. Segundo esse enfoque, uma melhor qualidade só pode ser obtida a um custo mais alto;

enfoque no usuário: neste caso, a qualidade significa a capacidade de satis- 
fazer os diferentes desejos e necessidades dos consumidores; assim, os produtos que atendem melhor às preferências dos consumidores são os que eles acham de melhor qualidade;

enfoque na produção: qualidade é a conformidade com as exigências; uma vez estabelecidas no projeto, qualquer desvio implica uma queda da qualidade. A excelência significa fazer certo da primeira vez. Este é um enfoque interno, que valoriza pouco o que os consumidores consideram como qualidade. Nesta abordagem a melhoria da qualidade leva a menores custos, pois impedir defeitos é considerado mais barato que corrigir ou refazer o trabalho.

enfoque no valor: qualidade é definida em termos de preços e custos. Um produto de qualidade é aquele que oferece um desempenho ou conformidade a um preço ou custo aceitável.

GARVIN [1992] salienta a necessidade de enfocar a qualidade com mais de uma das abordagens anteriores. Para ele, "as abordagens centradas no usuário, no produto e na produção podem ser combinadas e coordenadas".

Além do enfoque com que se enxerga a qualidade, os seus elementos constituintes também são essenciais para a sua correta definição. Segundo PICCHI [1993], a qualidade do produto recebido pelo cliente é a resultante de diversos elementos componentes, que atuam ao longo do processo de produção, com destaque para o projeto, a conformação e os serviços.

Segundo esse autor, a qualidade de projeto refere-se ao grau em que o produto, através de sua concepção e especificações, atende às necessidades do cliente. A qualidade de conformação abrange os aspectos de atendimento às especificações e ao projeto, bem como, aspectos de eficiência do processo, como por exemplo reduzido número de defeitos e de desperdícios. A qualidade de serviços, por sua vez, envolve atendimento e informação ao consumidor, bem como a assistência técnica.

No caso específico da indústria da Construção Civil, e em particular seu subsetor de edifícios, esses três elementos são de fundamental importância no contexto da busca da qualidade e racionalização do processo de produção. 
Com um conceito tão ampliado, a qualidade deixa de ser utilizada apenas como um adjetivo e passa a ser vista como uma "função gerencial", com grande potencial de provocar mudanças nas organizações, uma vez que traspassa todos os departamentos da empresa. Segundo JURAN; GRYNA [1991], todos devem realizar as suas atividades objetivando a qualidade, resultando, coletivamente, a qualidade do produto.

A esse processo de obtenção da qualidade, JURAN; GRYNA [1991] denomina "função qualidade", representada por uma espiral que vai integrando todas as atividades na empresa, ilustrada na figura 2.3.

A idéia de se ter uma espiral representando a "função qualidade", deixa claro que a busca da qualidade em uma empresa é um processo contínuo e progressivo, exigindo constante realimentação das ações em função dos resultados obtidos em um momento anterior.

GARVIN [1992] salienta que apenas mais recentemente a qualidade surge como função gerencial, afirmando que "na sua forma original, era relativa e voltada para a inspeção; hoje as atividades relacionadas com a qualidade se ampliaram e são consideradas essenciais para o sucesso estratégico da empresa".

Ao passar da 'inspeção' para a 'função gerencial', GARVIN [1992] e outros pesquisadores, como ISHIKAWA [1993]; GITLOW [1993]; DALE; PLUNKETT [1995], por exemplo, identificam, comumente, quatro "eras da qualidade" distintas: inspeçăo, controle estatístico da qualidade, garantia da qualidade e gestão estratégica da qualidade, as quais foram sintetizadas na seqüência, buscandose mostrar a evolução histórica do conceito.

\subsubsection{Evolução histórica do conceito de qualidade}

Segundo GITLOW [1993], "as questões da qualidade têm existido desde a época em que chefes tribais, reis e faraós governavam". Esse autor cita que "o código de Hammurabi, datado de 2150 a.C., estabelece que "se um construtor 
erguer uma casa para alguém e seu trabalho nāo for sólido, e a casa desabar e matar o morador, o construtor deverá ser imolado".

Além desse exemplo, esse autor apresenta outras situações que caracterizam a existência de princípios de busca da qualidade, muito antes da revolução industrial, mas enfatiza que foi a partir dela, com a necessidade de produção em massa de bens manufaturados, que as indústrias voltaram-se mais globalmente às questões da qualidade dos produtos fabricados, caracterizando a primeira era da qualidade: a era da inspeção.

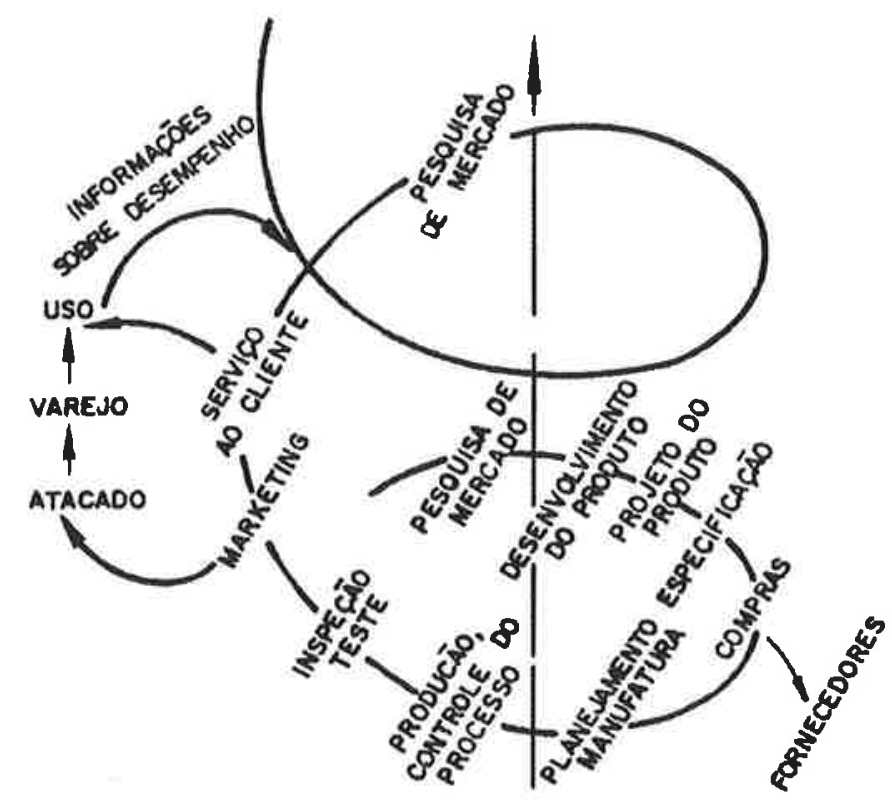

FIGURA 2.3: A espiral do progresso da qualidade numa empresa [JURAN; GRYNA, 1991]

\subsubsection{A era da inspeção}

Nos séculos 18 e 19, a produção de bens ocorria em pequena escala e era realizada por artesãos e artífices. Por essa época, as peças eram ajustadas umas às outras manualmente $e$ a inspeção era informal, quando feita.

A necessidade de produção em massa, visando a diminuição dos custos dos produtos, trouxe a necessidade de peças intercambiáveis e por conseqüência, a necessidade de se formalizar a inspeção. 
Assim, a inspeção, que no princípio era feita em função do sentimento das pessoas envolvidas, passou a ser realizada através de um sistema de medidas específico, apoiado em instrumentos de medição e gabaritos-padrão, utilizados por inspetores.

No início do século 20 a inspeção ganha mais força. Na década de 20 , passa a ser relacionada mais fortemente com o controle da qualidade, que podia ser feito para $100 \%$ da produção ou mesmo através de amostragens aleatórias, porém sem nenhum fundamento estatístico.

Essa fase é caracterizada pelo controle de conformidade no recebimento, ou seja, o produto deveria atender às especificações estabelecidas. Existe nessa era da qualidade um enfoque 'a posteriori', isto é, a partir do produto acabado.

\subsubsection{A era do controle estatístico da qualidade}

A segunda era da qualidade ocorreu durante os anos 30 e 40 . Teve o seu marco inicial estabelecido pela publicação da obra "Economic Control of Quality of Manufactured Products, de W. A Shewhart, do "Bell Laboratories", em $1931^{1}$.

A aplicação industrial do gráfico de controle proposto por W. A. Shewhart, e das técnicas de amostragem desenvolvidas por Harold Dodge e Harry Roming, também pesquisadores do "Bell Laboratories", deu continuidade a essa era, cujo apogeu ocorreu durante a Segunda Guerra Mundial.

O período da Segunda Guerra motivou a aplicação do gráfico de controle e das técnicas de amostragem em diversas indústrias dos Estados Unidos, em função da grande demanda que se tinha, sobretudo na indústria de material e equipamento bélico. Nessa época eram utilizados os Padrōes Normativos Z-1.

O controle estatístico desenvolveu-se também na Inglaterra com os estudos de E. S. Pearson. Segundo ISHIKAWA [1993], "a produção na Inglaterra, pós Segunda Guerra, foi satisfatória, em parte devido ao controle estatístico". O

\footnotetext{
${ }^{1}$ Segundo GARVIN [1992], essa publicação envolvia "uma definição precisa e mensurável de controle de fabricação, criou poderosas técnicas de acompanhamento e avaliação da produção diária e propôs diversas maneiras de se melhorar a qualidade."
} 
controle estabelecido pelas empresas inglesas baseava-se nos Padrões Normativos Britânicos 600 , que mais tarde seriam substituídos pelos Padrões Normativos 1008, de mesmo conteúdo que os utilizados nos Estados Unidos.

A fundação, em 1946, da Sociedade Americana de Controle da Qualidade (ASQC) consolida as idéias da época, estabelecendo o controle da qualidade como importante ferramenta do controle de produção.

O enfoque da qualidade, nesta era, está na necessidade de manter os padrões de atendimento às especificações dos produtos seriados, buscando-se reduzir a possibilidade de colocação de produtos defeituosos no mercado [MELHADO, 1994].

Naquela época, o Japão ainda utilizava o denominado "método Taylor", que exigia que os trabalhadores seguissem as especificações determinadas por especialistas. O controle de qualidade dependia totalmente da inspeção, mas nem todos os produtos eram suficientemente inspecionados. "O Japão estava literalmente na era dos produtos 'baratos e ruins'" [ISHIKAWA, 1993].

\subsubsection{A era da garantia da qualidade}

Esse periodo, que envolveu uma forte evolução dos conceitos anteriores, foi introduzido com a publicação de diversas obras durante as décadas de 50 e 60 , que propunham que a qualidade deveria deixar de ser restrita e baseada na produçăo fabril, transformando-se numa disciplina voltada ao gerenciamento do processo de produção.

Nessa era, segundo GARVIN [1992], a prevenção de problemas continuou sendo o objetivo fundamental da Garantia da Qualidade, mas os instrumentos utilizados foram ampliados para além do controle estatístico. Quatro elementos caracterizaram essa era da qualidade: quantificação dos custos da qualidade, controle total da qualidade, engenharia de confiabilidade e "zero defeito".

Os custos da qualidade foram abordados por Joseph Juran em sua obra "Quality Control Handbook", publicada em 1951. Nessa obra, Juran discute os custos inevitáveis, associados a medidas decorrentes do controle da qualidade (inspeção, amostragem, classificação) e os custos evitáveis, gerados por fa- 
Ihas no processo de produção, que poderiam ser minimizadas ao se investir na melhoria da qualidade.

Segundo GARVIN [1992], a publicação da obra de Armand Feigenbaum, em 1956, acrescenta mais um elemento a esse processo de evolução, pois propõe - Controle Total da Qualidade, fundamentado em que: "para se conseguir uma verdadeira eficácia, o controle precisa começar pelo projeto do produto e só terminar quando o produto chegar às mãos de um cliente que fique satisfeito". Sua obra destaca que "qualidade é um trabalho de todos".

Essa era da qualidade foi caracterizada, ainda, por uma distinção entre o enfoque ocidental e o enfoque japonês.

Considerando-se o enfoque ocidental, GARVIN [1992], em sua retrospectiva histórica, salienta que "nessa época, o controle estatístico ainda era importante (...) mas o sistema da qualidade passara a incluir agora o desenvolvimento de novos produtos, a seleção de fornecedores e o atendimento aos clientes, além do controle de fabricação".

Desenvolve-se, ainda nessa época, a engenharia da confiabilidade, cujo objetivo era garantir um desempenho aceitável do produto ao longo do tempo. Salientava a necessidade de atenção para a qualidade durante todo o processo de projeto.

No enfoque ocidental, segundo PICCHI [1993], a garantia da qualidade tem como principais ações:

- a priori: a organização de medidas visando o planejamento e a prevençăo;

- durante a implementação: a adoção de procedimentos para garantir que os conceitos planejados estão sendo realizados: "controle do controle";

- a posteriori: o estabelecimento de documentação, através da qual pode-se demonstrar que todos os procedimentos planejados foram postos em prática.

O último elemento dessa era da qualidade concentrou-se no gerenciamento da produção e nas relações humanas. Essa etapa foi denominada "zero defeito", 
que passou a atuar junto às pessoas, ressaltando a filosofia, a motivação e a conscientização, enfatizando menos as propostas específicas e técnicas de solução de problemas.

A garantia da qualidade sob o enfoque japonês diferenciou-se muito dos conceitos praticados no ocidente. Segundo ISHIKAWA [1993], a indústria japonesa começou a alterar seu enfoque para a qualidade, a partir do esforço de reconstrução do pós-guerra, sendo um marco importante a criação da Associação japonesa de padrōes Normativos, em 1945, seguida pelo Comitê de Padrões Normativos Japoneses para a indústria (PNJI), em 1946.

O sistema de padronização industrial instituído por essa época foi importante para a introdução e popularização do controle de qualidade estatístico nas indústrias japonesas. Era um sistema que envolvia as empresas, de maneira voluntária. Uma empresa podia solicitar inspeçāo de seus produtos ou recusar essa inspeção. $E$, passando pela inspeção, podia decidir se queria ou não que seu produto levasse a marca "PIJ" ("padrão industrial japonês") [ISHIKAWA, 1993].

ISHIKAWA [1993] salienta, ainda, que em 1946 houve a formação do Sindicato dos Cientistas e Engenheiros Japoneses - SCEJ (Japanese Union of Scientists and Engineers - JUSE) que procurava meios de racionalizar as indústrias japonesas, exportar produtos de alta qualidade para o estrangeiro e ainda, melhorar os padrōes de vida do povo japonês. A partir daí, começaram a ser exercidas atividades no sentido de trazer para o Japão os conhecimentos já desenvolvidos no ocidente. Em 1954 esse grupo trouxe o Dr. Juran para o Japão, cuja visita e trabalhos desenvolvidos marcaram uma transição nas atividades de controle de qualidade no Japão. A partir dessa época, o controle de qualidade passou a ser encarado como uma ferramenta de administração que envolveria toda a empresa.

O início dessa nova visăo ainda tinha como forte aliado o controle de qualidade, mas logo foi percebido que: "se produtos defeituosos são fabricados em diferentes estágios do processo de fabricação, mesmo a inspeção mais rigorosa não conseguirá eliminá-los. (...) Se fossem controlados os fatores em um 
processo determinado que origina produtos defeituosos, poderiam poupar o dinheiro gasto em inspeção" [ISHIKAWA, 1993].

Passou-se, assim, a enfocar a garantia da qualidade que enfatizasse o controle do processo de fabricação: " (...) as questões de confiabilidade dos produtos, segurança e economia não podem ser resolvidas se o projeto tiver faIhas ou se o material for de qualidade inferior. Para resolver estes problemas, todos os processos envolvidos no desenvolvimento, no planejamento e na elaboração de um novo produto precisam ser colocados sob controle" [ISHIKAWA, 1993].

Um importante elemento introduzido nesta era da qualidade no Japão foi a necessidade de envolvimento e participação de todas as divisões da empresa e todos os seus empregados no controle de qualidade.

Segundo ISHIKAWA [1993], o controle de qualidade total (TQC) por toda a empresa tem sido o aspecto mais importante do controle de qualidade no Japão.

Ishikawa, apud IMAI [1992], resumiu as principais características do controle total da qualidade no Japão, como sendo:

- TQC na empresa inteira, com a participação de todos os empregados;

- ênfase no ensino e no treinamento;

- atividades de círculo de controle da qualidade, com a participação dos operários responsáveis pelas atividades;

- realização de auditorias de TQC, exemplificadas pela auditoria do prêmio Deming e pela auditoria do presidente;

- aplicação de métodos estatísticos;

- promoção de TQC na nação inteira.

\subsubsection{A era da gestão estratégica da qualidade}

A quarta era da qualidade teve início aproximadamente a partir da década de 70-80, com enfoque organizacional, ênfase na política de recursos humanos e no relacionamento intra e inter-empresas. 
Nessa era, segundo PICCHI [1993], o enfoque ocidental buscou se aproximar do enfoque japonês.

Segundo GARVIN [1992], "num processo de contínua evolução, entra-se nos anos 80 com uma nova perspectiva da qualidade. A alta gerência das empresas começam a associá-la à lucratividade, definindo-a de acordo com o ponto de vista do cliente e exigindo sua inclusão no processo de planejamento estratégico".

Segundo esse mesmo autor, a abertura dos mercados para a entrada de produtos estrangeiros, principalmente a concorrência com os produtos japoneses, foi a mola propulsora da preocupação da qualidade ligada à estratégia.

Nessa era apareceu um novo conceito de qualidade, relacionado com essa dimensão estratégica. Segundo GARVIN [1992], num relatório da Sociedade Americana de Controle da Qualidade (ASQC), surgiu a essência dessa nova abordagem voltada ao cliente, refletida na afirmação de que: "não são os fornecedores do produto, mas aqueles para quem eles servem - os clientes, usuários e aqueles que os influenciam ou representam - que têm a última palavra quanto e até que ponto um produto atende às suas necessidades e satisfaz suas expectativas", e ainda: "a satisfaçāo relaciona-se com o que a concorrência oferece e é conseguida durante a vida útil do produto e não apenas na ocasião da compra".

Esse conceito de qualidade voltada ao cliente já estava presente no TQC, do enfoque japonês, como pode ser ilustrado pelas palavras de IMAI [1992]: "quando o conceito de TQC é aplicado nos vários estágios de produção, no final ele chega aos seus beneficiários finais - os consumidores que compram o produto. Assim, dizem que o TQC é orientado para o consumidor".

Segundo GARVIN [1992], quando a indústria produzia pequenos volumes, a inspeção formal era suficiente para garantir uma alta qualidade. Com o aumento de produção foi necessário um controle mais rígido.

O crescimento da demanda e da exigência de qualidade dos produtos originou a era da garantia da qualidade, que trouxe um projeto do produto mais exato, 
dando origem à engenharia da confiabilidade e à necessidade de melhor coordenação entre os departamentos. Novas idéias de gerenciamento dos recursos humanos foram incorporadas, chegando-se finalmente à gestão estratégica, encarando a qualidade como uma possível base de concorrência.

A qualidade como estratégia de mercado prevê o estabelecimento de metas móveis, a serem revistas sempre que o concorrente chegar ao mesmo patamar. O objetivo passa a ser sempre a melhoria contínua e não, atingir niveis de qualidade aceitáveis.

\subsubsection{A busca da melhoria contínua}

A melhoria contínua, elemento essencial da Gestão Estratégica da Qualidade, exige o comprometimento de toda a empresa, com a participação da alta gerência no processo, a fim de que se possa estabelecer seriedade de propósitos e dedicação a longo prazo à qualidade.

A melhoria contínua a ser buscada no processo de produção deve ser uma premissa que conduz todas as atividades produtivas, de todos os setores da empresa. Essa premissa de melhoria contínua em todos os segmentos produtivos e da própria humanidade é que tem impulsionado o processo de produção oriental.

Esse conceito recebeu o nome de "kaizen", que significa, segundo IMAI [1992]: "contínuo melhoramento, envolvendo todos, inclusive gerentes e operários (...). A filosofia do "kaizen afirma que o nosso modo de vida, seja no trabalho, na sociedade ou em casa, merece ser constantemente melhorado".

IMAI [1992] é enfático ao afirmar que "... a qualidade e a produtividade podem ter diferentes interpretaçōes (...) mas ninguém pode questionar o valor do meIhoramento, já que ele é genérico e bom por si só. Ele é bom por definição. Sempre e onde quer que sejam feitos melhoramentos na empresa, eles levarão, posteriormente, a melhoramentos em áreas como a qualidade e produtividade". 
Segundo IMAI [1992], podem existir empresas que não adotam o "kaizen" em seu dia-a-dia, existindo apenas ações voltadas às inovações radicais (discutidas no item 2.5) e à manutenção. Essas empresas nascem correndo, crescem rapidamente e desaparecem com a mesma rapidez, quando o seu sucesso inicial diminui ou os mercados mudam. Mas, segundo 0 autor, as piores empresas são aquelas que não fazem nada a não ser manutenção, significando que não há nenhum direcionamento interno para o kaizen ou à inovação, não há direcionamento estratégico da empresa, ficando à mercê das oscilações do mercado.

Uma das ferramentas destacadas por IMAI [1992] e por BURATI JR. et al. [1992] como de grande importância para se alcançar a melhoria contínua dos produtos e processos é o ciclo de "Deming", o qual foi pensado originalmente como sendo a interação constante entre pesquisa, projeto, produção e vendas na administração de uma empresa, como ilustra a figura 2.4.

Segundo IMAI [1992], a concepção do ciclo de "Deming" estava fundamentada no princípio de que "para se chegar à qualidade que satisfaz os consumidores, os quatro estágios devem ser "girados" constantemente, sendo a qualidade o critério prioritário.

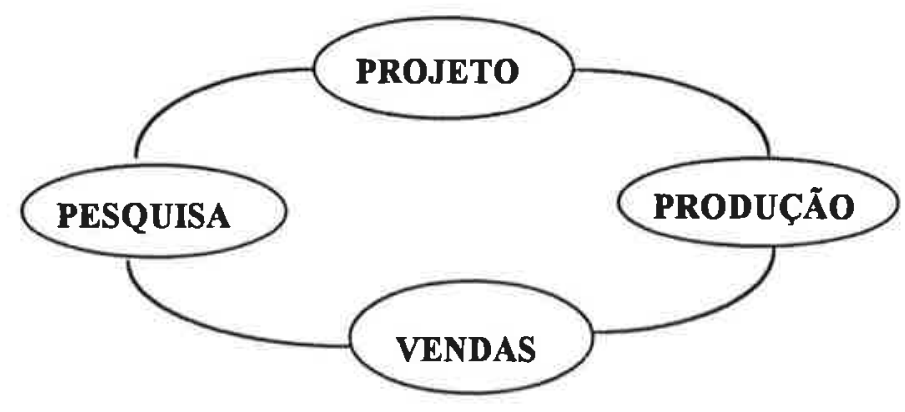

FIGURA 2.4: Ilustração do Ciclo de DEMING voltado à integração das áreas de pesquisa, projeto, produção e vendas [IMAI, 1992]

Posteriormente, esse conceito de girar o "círculo de Deming" constantemente, para melhorar o estágio em que uma empresa se encontra, foi estendido a todas as fases da organização e descobriu-se que os quatro estágios do círculo correspondem a ações administrativas específicas, originando, então, o que atualmente é chamado de ciclo "PDCA", ilustrado na figura 2.5. 
Esse ciclo contempla atividades voltadas ao planejamento das açōes de melhoria em qualquer setor da empresa ("P"); à sua execução ("D") ${ }^{2}$ e verificação (" $C$ ") $)^{3}$ e, finalmente, a ação ("A"), no sentido de correção dos problemas identificados ou de implementar novos esforços para se atingir um novo patamar na busca da melhoria contínua.

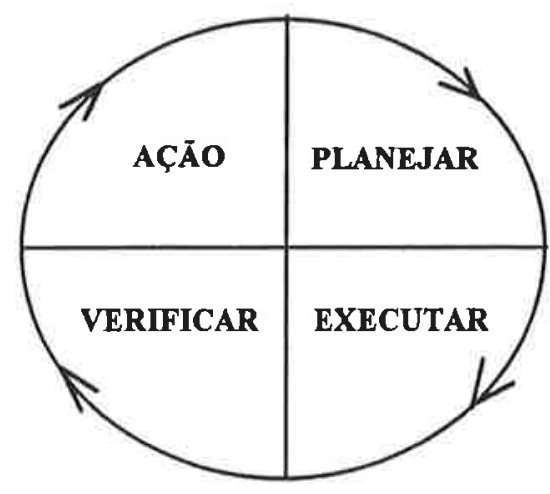

FIGURA 2.5: Ilustração do "Ciclo PDCA" [BURATI JR. et al., 1992]

Segundo DEMING [1986], o ciclo possibilita a melhoria contínua a cada estágio; orienta para o estudo dos resultados da mudança, para tentar aprender como melhorar o produto ou o processo de amanhã, ou do próximo ano.

Para DEMING [1986], planejar requer previsão. A avaliação dos resultados da mudança ou da experimentação pode melhorar o grau de credibilidade na previsão que irá subsidiar o planejamento.

Segundo o autor, a avaliação dos resultados pode indicar que nenhuma mudança precisa ser estabelecida, pelo menos por aquele momento, mas podese decidir girar o ciclo novamente, sob diferentes condiçōes, para aprender mais um pouco sobre o processo em andamento.

\subsection{Inovação Tecnológica}

No presente item, tem-se como objetivo, conceituar o termo inovação tecnológica, procurando mostrar a sua relação com a busca de melhoria contínua,

\footnotetext{
${ }^{2}$ Sigla proveniente da palavra em inglês "do", que significa fazer, executar, realizar.

${ }^{3}$ Sigla proveniente da palavra em inglês "check", que significa verificar
} 
bem como a relação entre esses dois conceitos, e a implantação de TCR's no processo de produção de edifícios.

A inovação tecnológica é questão antiga nos setores industriais de produção em massa. Segundo PICCINA [1991], a inovação tecnológica, desde o século XVIII, tem sido tema amplamente discutido, tanto sob o aspecto da influência de seus resultados de pesquisa e desenvolvimento (P\&D) na sociedade, quanto sob uma ótica mais restrita de aplicação do processo de inovação tecnológica pelas empresas, individualmente.

Segundo esse autor, Adam Smith, em sua obra "A riqueza das nações", foi o primeiro pesquisador a dar ênfase à "importância das invenções e da ciência para o crescimento econômico, através de suas idéias sobre mudança técnica".

A importância da inovação tecnológica no processo de desenvolvimento das nações é defendida por outros autores. Segundo ALMEIDA [1981], em 1911, Schumpeter, um dos grandes estudiosos do tema, falava em 'mudança' e 'nova combinação' de materiais e forças, como sendo fundamental no processo de desenvolvimento econômico.

HILL [1983] também defende essa idéia ao enfatizar a importância da inovação tecnológica afirmando que "é o maior agente de crescimento e mudanças de uma sociedade" e acrescenta ainda: "é uma força significativa para alterações sociais porque altera valores humanos e também as características das relações humanas (...) é o principal recurso pelo qual os avanços científicos são adaptados para satisfazer as necessidades e expandir as oportunidades humanas".

Trabalhos mais recentes, tais como o de RODRIGUES et al. [1994]; SBRAGIA e BARRA [1994]; e BARATELLI JR. et al. [1994], também destacam a capacidade de inovar como fator de sobrevivência das empresas.

Diversos trabalhos deixam evidente a participação da inovação tecnológica como agente indutor do desenvolvimento econômico e social do setor produtivo e conseqüentemente das nações. E se assim o é, a inovação tecnológica 
deve estar presente também na indústria da Construção Civil, ainda que este setor seja considerado, por alguns autores, como tecnologicamente atrasado, quando comparado aos demais setores industriais.

$\mathrm{Na}$ linguagem coloquial, inovação significa "ato ou efeito de inovar", isto é, "tornar novo, introduzir novidade em" [FERREIRA, 1986]. No entanto, inovação tecnológica é definida com mais precisão por diversos autores.

Segundo ALMEIDA [1981], o conceito de inovação tecnológica formulado por Schumpeter (1959) engloba cinco casos:

a) introdução de um novo bem, isto é, que os consumidores não conheçam, ou de uma qualidade nova de um bem;

b) introdução de um novo método de produção, ainda não testado no ramo de manufatura em questão, que tenha se lastreado sobre uma nova descoberta científica e que possa se constituir em um novo modo de manusear comercialmente um bem;

c) abertura de um novo mercado, onde o ramo de manufatura em questão não tenha penetrado, mercado este previamente existente ou não;

d) conquista de uma nova fonte de suprimentos já existente, ou tendo que ser criada;

e) levar a cabo uma nova organização, uma indústria, tal como criar ou romper uma posição de monopólio.

ALMEIDA [1981] destaca, ainda, que o pesquisador sueco Janssen afirma que "inovação tecnológica é um longo e complexo processo que torna possivel colocar um produto vendável no mercado, o qual é novo ou manufaturado por um novo processo". Além disso, salienta que: "sem comercialização autêntica e 'consumo' final, inovação não passa de imaginação".

Para HILL [1983], "o processo de inovação tecnológica envolve a criação, o projeto, a produção, o primeiro uso e a difusão de um novo produto, processo ou sistema tecnológico".

UTTERBACK [1983] salienta que diferentes definições e conceitos são propostos nos estudos sobre inovação. Segundo esse autor, alguns estudos apresen- 
tam a inovação como criação, originalidade, uma novidade; outros apresentam como sendo algo tangível, possível de ser aplicado no mercado ou num processo de produção; e outros, ainda, apresentam uma abordagem mercadológica para diferentes classes de usuários.

Procurando incorporar essas diferentes visões, UTTERBACK [1983] propõe que inovação tecnológica seja entendida como: "um processo que envolve a criação, o desenvolvimento, o uso e a difusão de um novo produto ou idéia".

TATUM [1986], a partir dos trabalhos de Meyers e Marquis, propõe uma classificação para a inovação tecnológica, segundo o seu impacto sobre o sistema econômico. Classificação semelhante é proposta pelo Banco Nacional de Desenvolvimento Social (BNDES) e adotada por CASTRO [1993] em seu trabalho.

Para esses autores, são três os tipos de inovação:

- aquela decorrente de sistemas complexos, que envolvem muitos elementos, como as redes de comunicação; são inovações tecnológicas sistêmicas que têm efeitos tão amplos que afetam a economia como um todo.

- aquela decorrente de uma alteração radical da tecnologia que muda as características de uma indústria, como a locomotiva a vapor; constituem-se de eventos descontínuos, resultado de trabalhos dirigidos e de pesquisa e desenvolvimento; e

- a inovação corriqueira ("nuts and bolts"), que ocorre internamente à empresa. Decorre de aperfeiçoamentos tecnológicos que acontecem continuamente, resultado de atividades induzidas de $P \& D$, produto do trabalho dos departamentos de engenharia das empresas e sugestōes dos usuários.

Segundo ALMEIDA [1981], o primeiro tipo de inovação implica em investimentos significativos, necessitando um planejamento que assegure a disponibilidade da tecnologia adequada no momento certo. O segundo tipo trata-se de "casos raros e imprevisíveis, com predominância de inventores independentes ou de firmas de fora da indústria que receberá o impacto da mudança". O terceiro tipo trata da inovação que busca a melhoria do produto, a redução de custo, o controle de qualidade, a expansão da linha de produtos. Para esse 
autor, esta forma de inovação, tão modesta quanto possa parecer, é essencial à sobrevivência das empresas.

Para ALMEIDA [1981], o terceiro tipo trata do caso mais freqüente, e consiste na aplicação da capacitação técnica do pessoal da empresa no desenvolvimento de um projeto de um produto novo ou modificado, ou de qualidade mais controlada, ou de um processo mais barato de execução, transformado depois em realidade pela implantação na produção propriamente dita.

UTTERBACK [1983] apresenta uma classificação cujo conteúdo coincide com a análise realizada anteriormente por ALMEIDA [1981]. Na sua proposição, distingue três tipos de inovações: as grandes inovações de produto; as grandes inovaçōes de processo e as inovações incrementais de produtos e processos.

Segundo esse autor, a inovação incremental pode ser definida como: "um avanço da tecnologia existente que melhora o desempenho do produto, meIhora o custo ou a qualidade passo a passo". UTTERBACK [1983] salienta que esse pode ser o tipo mais importante de inovação por causa do seu rápido impacto econômico e competitivo.

RATTNER [1989] também destaca a importância das inovações incrementais na economia, ao analisar o crescimento da indústria japonesa. Na sua análise, destaca a nova forma de organização empresarial e de coordenação do pessoal e da produção, que contém como elementos básicos: "uma visão e abordagem de integração sistêmica; a flexibilidade (...); e a busca incansável de inovações secundárias e incrementais, produzindo novos designs e melhoria de processos e produtos, o que gera um processo de inovação contínuo, envolvendo os trabalhadores". E conclui: "Não são, portanto, os baixos custos da mão-de-obra que conferem vantagens decisivas nos mercados externos mas, as inovações na produção baseadas em pequenos e sucessivos avanços tecnológicos, imaginação e criatividade organizacional".

O que alguns autores denominam de "inovação incremental" é denominado por outros de "melhoria". DAVENPORT [1993], por exemplo, distingue a "inovação 
de processo" da "melhoria de processo". Para esse autor, o termo inovação de processo envolve a visão de uma nova estratégia de trabalho, o conhecimento das atuais atividades do processo de projeto e a implementação de mudanças em todas as suas complexas dimensões tecnológicas, humanas e organizacionais.

Segundo esse autor, a melhoria de processo envolve um nivel menor de alterações, afirmando que: "se inovação de processo significa realizar uma atividade através de uma alteração radical, a melhoria de processo significa realizar o mesmo processo melhorando a eficiência e a eficácia".

DAVENPORT [1993] salienta que há importantes diferenças entre melhoria e inovação de processo, sendo destacadas as principais na tabela 2.1.

TABELA 2.1: Diferenças mais expressivas entre melhoria de processo e inovação de processo [DAVENPORT, 1993]

\begin{tabular}{|l|l|l|}
\hline & \multicolumn{1}{|c|}{ MELHORIA } & \multicolumn{1}{c|}{ INOVAÇÃO } \\
\hline nível de mudança & incremental & radical \\
\hline ponto de partida & processo existente & novo processo \\
\hline freqüência da mudança & uma vez ou contínua & uma vez \\
\hline tempo necessário & curto & longo \\
\hline participação & de baixo para cima & de cima para baixo \\
\hline escopo típico & $\begin{array}{l}\text { estreito, interno às } \\
\text { funções }\end{array}$ & $\begin{array}{l}\text { extenso, através das } \\
\text { funções }\end{array}$ \\
\hline risco & moderado & elevado \\
\hline agente ativador primário & controle estatístico & tecnologia da informação \\
\hline tipo de mudança & cultural & cultural e estrutural \\
\hline
\end{tabular}

GITLOW [1993] também defende a diferenciação entre a melhoria e a inovação. Para esse autor, "a melhoria dos processos modifica produtos e processos existentes, para reduzir continuamente a diferença entre as necessidades do cliente e o desempenho do processo; enquanto o propósito da inovação é duplo: (1) criar uma profunda melhoria pela redução da diferença entre as necessidades do cliente e o desempenho do processo e (2) 
descobrir as necessidades futuras do cliente". Para esse autor, tanto a melhoria como a inovação são necessárias se uma empresa pretende ser competitiva no futuro.

IMAI [1992] tem uma posição semelhante à de DAVENPORT [1993], diferenciando a filosofia de trabalho voltada para o Kaizen (que significa melhoria contínua segundo o enfoque oriental), da filosofia voltada para a inovação (enfoque ocidental), apresentando-os como dois enfoques voltados para o progresso.

Para IMAI [1992], "a inovação é empolgante e geralmente atrai a atenção. O Kaizen, por outro lado, freqüentemente é monótono e sutil e raramente os seus resultados são visíveis de imediato. O Kaizen é um processo contínuo. A inovação é, geralmente, um fenômeno momentâneo".

As características que diferenciam a filosofia do Kaizen, da filosofia da inovação, segundo IMAI [1992], são apresentadas na tabela 2.2.

IMAI [1992] defende que a estratégia de inovação seja utilizada em conjunto com a estratégia de Kaizen para que o sucesso obtido seja mantido.

HILL [1983] não fala em melhoria, mas sim em "mudança tecnológica. Esse autor delimita as fronteiras entre a inovação e a mudança tecnológica pela condição de uso pioneira no mercado.

Para HILL [1983], a mudança tecnológica envolve alguma troca em um produto ou processo, como por exemplo a adoção de um método existente, porém meIhor, para ser incorporado num processo de produção. Enquanto isso, defende que a inovação tecnológica ocorre apenas quando o produto, processo ou sistema incorpora um novo método ou uma nova idéia e acrescenta que "não é um requisito que o produto ou processo seja tecnologicamente novo para constituir-se numa inovação, ele apenas precisa ser o primeiro a ser utilizado comercialmente com sucesso".

O estabelecimento de limites entre a inovação e a mudança tecnológica, a partir de seu primeiro emprego no mercado, é bastante antigo. 
TABELA 2.2: Diferenças mais expressivas entre o Kaizen e inovação [IMAI, 1992]

\begin{tabular}{|c|c|c|}
\hline CARACTERISTICAS & KAIZEN & INOVAÇÃO \\
\hline Efeito & $\begin{array}{l}\text { longo prazo e } \\
\text { duradouro; monótono }\end{array}$ & curto prazo; empolgante \\
\hline Ritmo & pequenos progressos & grandes progressos \\
\hline Estrutura de tempo & contínua e incremental & $\begin{array}{l}\text { intermitente e não } \\
\text { incremental }\end{array}$ \\
\hline Mudança & gradual e constante & repentina e passageira \\
\hline Envolvimento & todos & $\begin{array}{l}\text { poucos "defensores" } \\
\text { selecionados }\end{array}$ \\
\hline Enfoque & $\begin{array}{l}\text { coletivismo, esforços em } \\
\text { grupo, enfoque } \\
\text { sistêmico }\end{array}$ & $\begin{array}{l}\text { forte individualismo, idéias } \\
\text { e esforços individuais }\end{array}$ \\
\hline Método & $\begin{array}{l}\text { manutenção e } \\
\text { melhoramento }\end{array}$ & Refugo e retrabalho \\
\hline Estímulo & $\begin{array}{l}\text { "Know-how" e atua- } \\
\text { lizações convencionais }\end{array}$ & $\begin{array}{l}\text { avanços tecnológicos, } \\
\text { novas invençōes e novas } \\
\text { teorias }\end{array}$ \\
\hline Exigências práticas & $\begin{array}{l}\text { exige pouco investimen- } \\
\text { to, porém grande esforço } \\
\text { para mantê-lo }\end{array}$ & $\begin{array}{l}\text { exige grande investimento, } \\
\text { porém pouco esforço para } \\
\text { mantê-la }\end{array}$ \\
\hline Orientação do esforço & pessoas & tecnologia \\
\hline Critérios de avaliação & $\begin{array}{l}\text { Processo e esforços por } \\
\text { melhores resultados }\end{array}$ & Resultados por lucros \\
\hline Vantagem & $\begin{array}{l}\text { é útil na economia de } \\
\text { crescimento lento }\end{array}$ & $\begin{array}{l}\text { adapta-se melhor à econo- } \\
\text { mia de crescimento rápido }\end{array}$ \\
\hline
\end{tabular}

Segundo ALMEIDA [1981], Marquis (s.d.) cita os conceitos de Schmookler (1966), que afirma: "Quando uma empresa produz um bem ou serviço, ou usa um método ou insumo que é novo para ela, está produzindo uma mudança tecnológica. A primeira empresa a fazer uma certa mudança tecnológica é uma inovadora. Sua ação é uma inovação. Se outra empresa faz a mesma mudança é, provavelmente, uma imitadora, e sua ação, uma imitação". Entretanto, ALMEIDA [1981] salienta que Marquis (s.d.) faz uma ressalva a 
essa definição. Para esse autor, a imitação é uma inovação que não deve ser distinguida da "inovação verdadeira". $\mathrm{Na}$ imitação a inovação existe para a empresa imitadora, do mesmo modo que na outra, só não é nova na economia. A defesa desse argumento, segundo ALMEIDA [1981], procura caracterizar a inovação pela mudança que ela acarreta na empresa; o conhecimento em si, invenção ou não, pode ser escolhido do estoque corrente de conhecimento técnico difundido pela economia.

Nas colocações defendidas por ALMEIDA [1981], por IMAI [1992], por DAVENPORT [1993], e por GITLOW [1993], fica claro que melhoria ou mudança tecnológica são termos que podem ser considerados como sinônimos. Entretanto, os limites entre a melhoria (ou mudança) e a inovação tecnológica devem ser estabelecidos pelo impacto da alteração no processo de produção da empresa, independente das condições de mercado. Observando-se que o impacto causado na produção através de uma melhoria é muito menor que o causado através da inovação.

A figura 2.6 procura ilustrar a relação existente entre a busca da melhoria contínua, através da melhoria incremental de processos ou mesmo nos produtos e a prática da inovação.

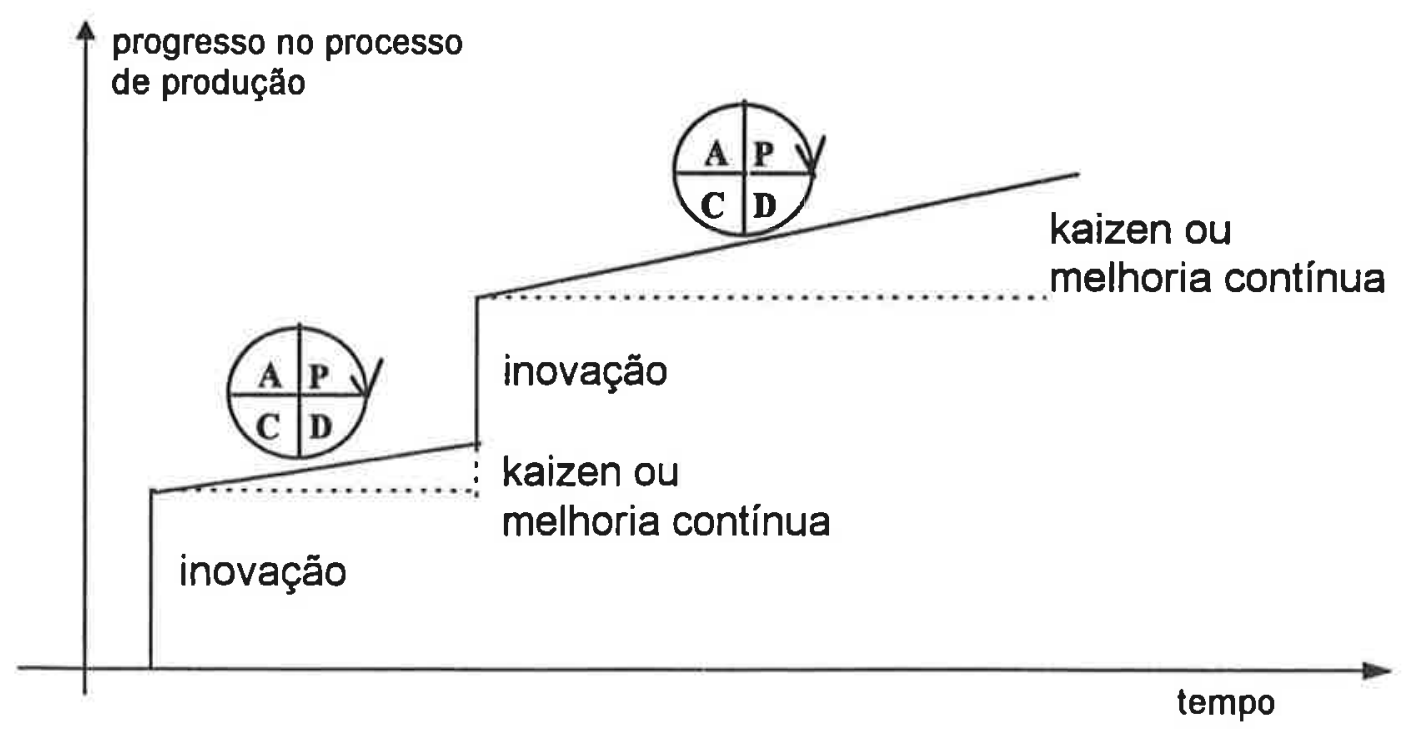

FIGURA 2.6: Ilustração do progresso que deve haver no processo de produção da empresa pela associação conjunta de esforços de inovação e de melhoria contínua [IMAI, 1992] 
Analisando-se a conceituação anteriormente apresentada, pode-se dizer que o significado dos termos "mudança tecnológica" ou "melhoria de processo" defendidos por alguns autores coincide com o que outros definem como sendo "inovação tecnológica incremental".

Ao se analisar a produção de edifícios pelo processo construtivo tradicional, fica clara a importância da introdução das inovações tecnológicas incrementais ou de mudanças tecnológicas visando a melhoria do processo e, por conseqüência, do próprio produto oferecido ao mercado.

O conceito de inovação, melhoria ou mudança tecnológica não é claramente definido no âmbito da indústria da Construção Civil.

Segundo TATUM [1986], "a inovação de processo geralmente envolve um novo método de produçāo ou um novo equipamento. Isto é, pode produzir um produto existente mais eficiente ou, ainda, pode ser necessária para produzir novos produtos".

Para LABORDE; SANVIDO [1994], "uma nova tecnologia é um produto ou processo que a companhia ainda não utilizou em suas operações de construção; enquanto a inovação é enxergar, reconhecer e implementar uma nova tecnologia para melhorar o desempenho funcional da empresa. $O$ que pode ser considerado uma nova tecnologia para uma empresa, pode não ser necessariamente para outra".

Para SERPELL [1995], "inovação significa introduzir algo novo em uma organização ou mudar a forma com que se fazem as coisas. A inovação pode ser definida de forma ampla como a introdução de novas idéias, conhecimentos, métodos, tecnologias e equipamentos à forma em que uma organização desenvolve seu negócio ou realiza uma tarefa".

SABBATINI [1989] particulariza o termo "inovação tecnológica" para o campo da tecnologia de construção de edifícios, adotando a seguinte definição: "um novo produto, método processo ou sistema construtivo introduzido no mercado, constitui-se em uma inovação tecnológica na construção de edifícios quando incorporar uma nova idéia e representar um sensível avanço na tecno- 
logia existente em termos de: desempenho, qualidade ou custo do edifício, ou de uma sua parte".

Resgatando-se a proposta de SABBATINI [1989] e particularizando-a para o caso específico do processo construtivo tradicional, pode-se apresentar, então, - que se entende, neste trabalho, por "inovação tecnológica no processo de produção de edifícios":

"é um aperfeiçoamento tecnológico, resultado de atividades de pesquisa e desenvolvimento internas ou externas à empresa, aplicado ao processo de produção do edifício objetivando a melhoria de desempenho, qualidade ou custo do edifício ou de uma parte do mesmo".

Analisando-se o que se entende neste trabalho por "tecnologia construtiva racionalizada", termo anteriormente apresentado, e comparando com o significado proposto para "inovação tecnológica aplicada ao processo construtivo tradicional" pode-se dizer que:

"uma Tecnologia Construtiva Racionalizada configura-se numa Inovação Tecnológica desde que seja incorporada ao sistema produtivo da empresa, sendo efetivamente aplicada ao processo de produção do edifício".

É, pois, com esse sentido que se busca desenvolver uma metodologia para a implantação de TCR's nas empresas de construção de edifícios, objetivando a sua incorporação na cultura da empresa e conseqüente avanço do setor.

Para finalizar, cabe salientar que a conceituação aqui proposta e utilizada no presente trabalho não se confronta com a proposição mais contemporânea que diferencia a inovação da melhoria de processo.

As alterações tecnológicas que se pretende realizar ao se introduzir TCR's no processo de produção de edifícios construidos pelo processo construtivo tradicional, de fato, apresentam um nivel incremental; têm como ponto de partida o processo existente; e devem ser realizadas de maneira contínua, o que caracteriza uma mudança tecnológica e não uma inovação. 
No entanto, pelas próprias características do setor, irão exigir uma série de outras ações que são características típicas do processo de inovação tecnológica, tais como:

- alterações iniciais radicais na gestão e na organização do processo de produção;

- trabalho de longo prazo para que a organização como um todo possa assimilar as alterações;

- a participação e o comprometimento da alta direção, pois as mudanças empreendidas de baixo para cima têm pouca influência no produto final, o que não alteraria o atual processo de gestāo e organização;

- a necessidade de integração das atividades funcionais internas e externas à empresa;

- agente ativador através da incorporação de novas tecnologias;

- uma mudança cultural e organizacional, objetivando manter as alterações introduzidas. 


\section{CAPÍTULO 3}

\section{A INDÚSTRIA DA CONSTRUÇÃO CIVIL NO BRASIL E AS ESTRATÉGIAS DO SUBSETOR EDIFICAÇÕES NA BUSCA DA COMPETITIVIDADE}

Neste capítulo, apresenta-se de maneira sucinta a estruturação da indústria da Construção, como um importante segmento da economia nacional, destacando-se as principais características dos subsetores que a constituem.

Dá-se destaque às características do subsetor edificações, apresentando-se a evolução tecnológica e organizacional ocorrida. Essa evolução é enfocada desde que a produção de edifícios deixou de ser uma atividade de autoconstrução e passou a ser uma prática voltada ao mercado, ate os dias atuais com uma acirrada disputa por um mercado cada vez mais estreito, enquanto demanda solvável, levando as empresas a uma constante busca de melhoria nos processos de produção.

Frente a esse contexto, o capítulo trata ainda das estratégias que as empresas vêm adotando para fazer frente a esse mercado cada vez mais competitivo, com ênfase para a introdução dos programas de Gestão da Qualidade e da adoção dos princípios da racionalização construtiva.

\subsection{A Estruturação da Indústria da Construção Civil}

É indiscutivel a participação da indústria da Construção Civil na economia nacional. Segundo dados do SINDUSCON [1991], "o peso do setor da Construção Civil no PIB, nos países industrializados, situa-se em torno de 5\%, enquanto que nos países de industrialização recente, como é o caso do Brasil, chega a atingir a participação de $7 \% "$.

Segundo o SENAI [1995], "Para o ano de 1992, os dados do relatório 1993 Banco de Dados da Câmara Brasileira da Indústria da Construção - apontam para uma taxa de $6 \%$ de participação da Construção Civil no PIB total". 
Além do que representa diretamente a sua atividade econômica, destaca-se pelo seu papel social, pois é um setor que dá suporte a todas as demais atividades industriais, através da edificação e montagem das unidades produtivas; materialização da infra-estrutura para o desenvolvimento urbano e regional do país, por meio da construção de estradas, ferrovias, obras de saneamento, linhas de transmissāo de energia, construçăo de escolas, hospitais, habitações, entre outros.

Segundo a revista Dirigente Construtor [ALTOS, 1990] em seu artigo especial "Altos e baixos da construção", considerando-se o macrocomplexo da indústria da Construção, onde está incluída a indústria de materiais e componentes, a participação do setor no PIB nacional chega a ser de $36 \%$.

Esse macrocomplexo pode ser subdividido segundo ramos de atividade específica. Neste trabalho, adotou-se a classificação proposta por MARTUCCl [1990] que divide inicialmente o macrocomplexo em dois grandes setores:

- o que dá suporte às atividades produtivas do setor da Construção Civil; e

- o de projeto, produção e montagem de produtos finais do setor Construção Civil.

\subsubsection{Setor que dá suporte às atividades produtivas}

O setor de suporte às atividades produtivas é subdividido em dois outros subsetores: o de produção de materiais e componentes de construção; e o de produção de máquinas, equipamentos, ferramentas e instrumentos.

O subsetor de produção de materiais e componentes é um segmento industrial que influencia fortemente o subsetor de Construção de Edifícios, tratado adiante.

Segundo o IPT [1988] esse segmento industrial é bastante diversificado, sendo possível constatar a convivência de um grande número de pequenas empresas, juntamente com grandes empresas de estrutura oligopolista.

Ainda que seja um subsetor que apresente expressiva heterogeneidade quanto às características industriais das atividades que envolve, de certa maneira, 
mostra um acentuado desenvolvimento tecnológico, o qual tem sido intensificado nos últimos anos, tanto pela abertura de mercado, como também por exigência dos próprios consumidores.

Para o IPT [1988], "É a partir deste segmento, no qual a pesquisa e desenvolvimento e a divulgação técnica têm lugar de destaque, que se assiste à introdução e à difusão de inovações tecnológicas no campo da construção".

Apesar da relevância desse segmento industrial no desenvolvimento tecnológico da Construção de Edifícios, deve-se destacar que muitas vezes a introdução desses materiais no canteiro ocorre completamente dissociada do processo de produção, o que tem levado à ocorrência de sérios problemas patológicos.

Esse subsetor do macrocomplexo da Construção não é o foco do presente trabalho; mas, pela sua participação no processo de modernização do subsetor da Construção de Edificios, estará sempre presente nas análises e reflexões se irão fazer ao longo do texto, buscando-se mostrar, com isso, que é premente um estreito relacionamento entre esses dois segmentos industriais.

O subsetor de produção de máquinas, componentes e equipamentos é o setor mais avançado do ponto de vista tecnológico, com uma estrutura produtiva fortemente calcada em empresas multinacionais [MARTUCCI, 1990].

Esse setor, no Brasil, não produz exclusivamente para o setor da Construção Civil; inclusive, não tem havido uma preocupação técnica direcionada ao projeto e produção de máquinas, ferramentas, equipamentos e instrumentos que venham a cooperar fortemente com a racionalização do processo de produção na Construção Civil.

Enquanto nos países mais avançados são encontrados equipamentos e ferramentas específicas que efetivamente proporcionam melhores condições de trabalho e maior racionalidade para a realização das atividades de produção, no Brasil, encontra-se uma reduzida gama de equipamentos e ferramentas para esse fim.

Antes da abertura de mercado para as importações, era maior ainda a dificul- 
dade de se obter ferramentas ou equipamentos específicos. Quando essenciais, os equipamentos eram construídos com o auxílio de técnicos especializados. São exemplos disto o desenvolvimento de diversos instrumentos e ferramentas realizado no Centro de Pesquisas e Desenvolvimento em Construção Civil da Escola Politécnica da USP (CPqDCC-EPUSP) em especial os equipamentos para avaliação da resistência mecânica de contrapisos e revestimentos de piso, os quais são apresentados nos trabalhos de BARROS [1991] e EISINGER; BARROS [1993(a),(b)].

Hoje, com as importaçöes crescentes, começam a aparecer diversas ferramentas, tais como: o nivel a "laser"; réguas com bolhas de nível acopladas; ferramentas de menor porte, tais como desempenadeiras para trabalhos específicos de arremates em cantos, entre tantos outros. Porém, a falta de divulgação para o setor produtivo e a não conscientização sobre as vantagens de utilização fazem com que poucas empresas empreguem esses equipamentos e ferramentas, considerando-as como "custo" e não como investimento.

O que se tem observado, a partir do trabalho realizado junto às construtoras, é que a dificuldade ainda existente para importação, somada aos elevados impostos e às incertezas de comportamento do mercado, têm restringido os investimentos em ferramentas, equipamentos e instrumentos de controle.

Frente a essa situação, há que se concordar com MARTUCCI [1990] quando afirma que a ausência de um mercado específico de ferramentas, equipamentos e instrumentos voltados à indústria da Construção Civil prejudica o desenvolvimento tecnológico do setor no Brasil.

\subsubsection{Setor de projeto, produção e montagem de produtos finais}

O subsetor de projeto, produção e montagem de produtos finais do setor Construção Civil é, segundo MARTUCCI [1990], onde estão alocadas todas as atividades fins das empresas de projeto e construção, órgãos públicos e privados, que direta ou indiretamente estão envolvidos com a construção. É nesse setor que se dá a sintese e a integração dos conhecimentos gerados nos dois subsetores anteriormente destacados. 
Em função das características específicas dos produtos gerados por esse subsetor, é possivel subdividi-lo mais uma vez. A FUNDAÇÃO JOÃO PINHEIRO [1992] destaca três subsetores principais - Construção Pesada, Montagem Industrial e Edificações. Além deles, salienta que existe um quarto - o subsetor de serviços especiais ou auxiliares - que envolve atividades de diferentes naturezas, dentre as quais a de projetos.

Para TRYLINSKI [1987] esse último subsetor dedica-se à concepção de projetos e serviços de engenharia que são materializados nos outros três segmentos da indústria; é, portanto, intrínseco aos demais, na medida em que as atividades que compreende são essenciais para o funcionamento daqueles.

Assim sendo, neste trabalho serão apresentadas as principais características dos três principais subsetores adotando-se a subdivisão proposta pela FUNDAÇÃO JOÃO PINHEIRO [1992] e também empregada por FARAH [1992] e TRYLINSKI [1987].

\subsubsection{Subsetor Construção Pesada}

Esse subsetor abrange principalmente as atividades de construção de infraestrutura viária, urbana e industrial, envolvendo, entre outros, os serviços ligados à construção de rodovias, de aeroportos e de ferrovias; a construção de vias urbanas; os serviços ligados a obras estruturais e de arte (como por exemplo, contençōes de encostas, pontes e viadutos); construção de barragens, de hidroelétricas, entre outras.

Segundo MARTUCCI [1990] esse subsetor caracteriza-se por obras que ocupam grandes áreas, constituindo-se em infra-estrutura básica para todos os outros setores produtivos do país; além disso, são obras que requerem elevados investimentos públicos por longos períodos de tempo. É um segmento em que comumente participam empresas de grande porte.

De modo geral, os processos produtivos empregados por esse segmento caracterizam-se por prazos extensos para a elaboração dos projetos, com emprego de tecnologias comumente sofisticadas que fazem uso intenso de equipamentos pesados. 
É um segmento que tem uma expressiva participação setorial na indústria da construção. Segundo dados do Centro de Análise Econômica da $\mathrm{DCl}$ Editora Civil [VAI SER, 1992], esse setor participou com $72,6 \%$ do patrimônio líquido total da amostragem envolvendo todo o setor da Construção Civil.

\subsubsection{Subsetor Montagem Industrial}

As empresas desse subsetor atuam, principalmente, na montagem de estruturas para instalação de indústrias, de sistemas de geração, transmissão e distribuição de energia elétrica e de sistemas de telecomunicações, entre outros.

Segundo a FUNDAÇĀO JOÃO PINHEIRO [1992], esse subsetor é representado por um número reduzido de empresas, sendo elas comumente de grande e médio porte, em que a especialização não segue uma tendência bem definida, principalmente no caso das empresas de maior porte que têm condições técnicas e organizacionais para realizar qualquer atividade típica deste subsetor, adentrando, inclusive na construção dos edifícios industriais.

É um subsetor de reduzida participação na composição do patrimônio líquido total do setor. Segundo dados do Centro de Análise Econômica da DCl Editora, representou apenas 4,3\% do total [VAI SER, 1992].

\subsubsection{Subsetor Edificações}

Neste subsetor, encontram-se as empresas que atuam principalmente na construção de edifícios residenciais, comerciais, institucionais ou industriais, seja no seu todo ou em partes dele, especializando-se em algumas atividades, como por exemplo, na execução de fundações, estruturas, instalações, ou serviços diversos, como é o caso das reformas.

Em relação aos demais subsetores, este é o que apresenta maior heterogeneidade interna. É caracterizado pela participação de empresas de grande, médio e pequeno porte, com predominância dessas duas últimas.

É o segmento que apresenta o maior número de empresas. Apesar disso, sua participação no patrimônio líquido total, segundo dados do Centro de Análise Econômica da DCl Editora, chegou apenas a $17,6 \%$ do patrimônio total [VAI SER, 1992]. 


\subsubsection{Análise da Estruturação da Indústria da Construção Civil}

Segundo FARAH [1992], as empresas não restringem sua atuação apenas a um dos subsetores, havendo uma tendência de diversificação de atividades, em particular por parte das grandes empresas. Mas, sempre é possível identificar a área principal na qual a construtora atua.

Para FARAH [1992], "a diferenciação dos subsetores quanto ao porte das empresas está associada a características de suas atividades típicas, tais como porte da obra e tecnologia requerida".

As grandes obras, como pontes, barragens, hidrelétricas requerem tecnologias mais complexas, exigindo grande aporte de capital, o que exclui as pequenas empresas desse mercado, que ficam restritas às obras de pequeno porte.

Por outro lado, a grande empresa possui maior mobilidade intersetorial. Desta forma, em época de crise, como a que vem se caracterizando desde os anos 80 , em que as obras públicas de infra-estrutura praticamente inexistem, vê-se muitas empresas de grande porte atuando na área de edificações, disputando, com as empresas de menor porte, as poucas obras existentes [FARAH, 1992].

Segundo MARTUCCI [1990], é no subsetor de projeto, produção e montagem de produtos finais do setor Construção Civil, que foi introduzido o menor número de inovações tecnológicas nos seus processos construtivos. Esse autor afirma, ainda, que ao se analisar detalhadamente os espaços físicos dos canteiros de obras, considerando-se as atividades de construção, verifica-se que o desenvolvimento tecnológico e industrial obtido pelos subsetores de materiais e equipamentos desaparece como em um "passe de mágica".

Reunindo as idéias apresentadas por FARAH [1992] e MARTUCCI [1990] é possivel concluir que a maior defasagem tecnológica do setor de projetos, produção e montagem dos produtos finais, quando comparado aos demais subsetores que compōem o macrocomplexo da indústria da Construção Civil, concentra-se principalmente no setor edificações, em especial nas obras de menor porte que, segundo FARAH [1992], não requerem grande complexidade tecnológica e organizacional para se concretizarem. 
A premência do desenvolvimento tecnológico do subsetor edificações está expressa também no PROGRAMA NACIONAL DE TECNOLOGIA DE HABITAÇÃO (PRONATH) [BRASIL, 1991]. Nesse programa, reconhece-se que a implantação de ações visando a "inovação tecnológica" do subsetor é imprescindivel, sendo destacado que é preciso:

- fortalecer a estrutura produtiva do setor no que diz respeito à sua capacidade tecnológica e gerencial;

- implementar políticas de capacitação da mão-de-obra favorecendo a introdução de inovações tecnológicas;

- incentivar o emprego de novas tecnologias para a produção habitacional;

- fortalecer a infra-estrutura laboratorial e de pesquisa para o desenvolvimento tecnológico e prestação de serviços;

- fomentar a criação de novas unidades laboratoriais e grupos de pesquisa, assessoria e consultoria tecnológica;

- desenvolvimento de cursos de formação em inovação tecnológica;

- desenvolver mecanismos de transferência de tecnologia.

A respeito do subprograma Inovação Tecnológica, o PRONATH [BRASIL, 1991] apresenta o seguinte objetivo central: "ampliar a gama de conhecimento e tecnologias disponiveis no país, nas áreas de projeto, fabricação de materiais e componentes, execução de obras e operação e manutenção de edificações habitacionais".

Com esse objetivo, propōe-se a minimizar os "gargalos" tecnológicos hoje presentes no subsetor, alcançando as seguintes metas:

- desenvolvimento de inovações tecnológicas nas áreas de projeto, materiais, componentes e sistemas construtivos ;

- capacitação do parque produtivo nacional para o emprego de novas tecnologias de projeto, fabricação, construção, operação e manutenção;

- promoção e aplicação em larga escala de novas tecnologias na construçãc de habitações no Brasil. 
Entretanto, ainda que careça de grande desenvolvimento tecnológico, o setor de produção de edifícios não tem se mantido estático; pelo contrário, como afirma FARAH [1992], é um setor em constante movimento, que vem sofrendo constantes evoluções com o passar dos anos.

Diversos pesquisadores apresentam e analisam a evolução tecnológica e organizacional do setor. Os principais momentos dessa evolução, de interesse para este trabalho, serão apresentados na seqüência.

\subsection{A Evolução Tecnológica do Setor Edificações}

A atual configuração da indústria da Construção Civil, anteriormente apresentada, não se estabeleceu em um curto espaço de tempo. Houve um longo período de desenvolvimento. Como bem destaca VARGAS [1994], "o aparecimento de uma engenharia, radicada num determinado meio e baseada numa tecnologia autêntica - que é a condição necessária para a industrialização não é um processo de geração espontânea e imediata. É um processo cultural que exige uma preparação prolongada, através de estágios sucessivos."

Assim, para o melhor entendimento da situação que atualmente vive o subsetor de edificações quanto às tecnologias construtivas empregadas, deve-se realizar um breve retrospecto do caminho percorrido desde a sua formação.

Segundo VARGAS [1994], a indústria da Construção Civil passou por pelo menos três estágios sucessivos.

O primeiro estágio é puramente técnico, com ausência de qualquer ciência aplicada, limitando-se à adaptação de técnicas externas às condições locais. O Brasil passa por esse estágio desde a sua descoberta até o início do século 19, incorporando a técnica medieval e renascentista.

' O segundo estágio refere-se à aplicação de teorias e métodos científicos aos problemas da técnica anteriormente estabelecida, o que ocorreu no Brasil a partir da criação das escolas militares e de engenharia, quando chegou ao Brasil a corte portuguesa. 
O terceiro estágio tem início quando aparecem, no começo desse século, em São Paulo e no Rio de Janeiro, os institutos de pesquisas tecnológicas.

Considerando-se esses três estágios, propostos no trabalho de VARGAS [1994], a seguir será feita uma breve apresentação e análise dos mesmos, considerando-se o desenvolvimento tecnológico ocorrido.

\subsubsection{Primeiro estágio de desenvolvimento}

No primeiro estágio de desenvolvimento da Construção Civil, na época do Brasil colônia, as técnicas utilizadas na construção de fortalezas, igrejas e mosteiros, edifícios, aquedutos eram as mesmas que os europeus utilizavam, adaptadas ao meio e às condiçōes de trabalho coloniais. Não envolviam nenhum conhecimento teórico ou de pesquisa. As obras eram 'riscadas' e construídas por mestres portugueses ou por militares 'oficiais de engenharia' ou ainda por padres instruídos em questōes de arquitetura para a construção de mosteiros e igrejas [VARGAS, 1994].

Segundo TELLES [1984], "a partir do primeiro quartel do século 17, tornam-se cada vez mais numerosas as construções de pedra e cal, inclusive casas particulares". Segundo esse pesquisador, ainda, essas casas eram feitas artesanalmente, sem nenhum plano formal, às vezes pelo próprio morador ou seus vizinhos e amigos.

Quanto às edificações não militares ou religiosas, segundo FARAH [1992], "no período colonial, a atividade construtiva consistiu principalmente na execução de edificações residenciais, nas propriedades rurais e nas cidades, as quais se caracterizavam pela uniformidade de plantas e técnicas construtivas".

As técnicas comumente empregadas nesse periodo eram, no caso de moradias mais simples, o pau-a-pique, adobe ou taipa de pilão e, nas habitações mais sofisticadas, a pedra, o barro e, às vezes, o tijolo e a cal [TELLES, 1984]. VARGAS [1994] destaca que nessa época "o trabalho manual era desenvolvido por serventes ou escravos, a princípio índios e depois negros".

TELLES [1984] afirma que "O desenvolvimento tecnológico (e portanto da en- 
genharia) no Brasil-Colônia foi drasticamente atrasado e entravado por dois fatores: a proibição à instalação de indústrias e a economia baseada na escravidão, que tornava o trabalho uma atividade desprezivel e desestimulava qualquer inovação técnica, devido à mão-de-obra abundante e aparentemente gratuita.

\subsubsection{Segundo estágio de desenvolvimento}

Uma das primeiras alteraçōes significativas no setor ocorre em meados do século 19, caracterizando o início do segundo estágio de desenvolvimento. Nessa época, a produção deixou de ser realizada exclusivamente para uso próprio e passou a atender ao mercado. Em função da expansão da atividade cafeeira, houve um adensamento dos centros urbanos, exigindo-se a construção de moradias, de obras de infra-estrutura urbana, ainda que em pequena escala, e também a abertura de caminhos para o escoamento da produção [FARAH, 1992].

Segundo FARAH [1988], a construção ocorria como autoprodução, tanto por iniciativa do governo, como de particulares, utilizando-se mão-de-obra escrava e também trabalhadores livres, cuja função era dirigir o trabalho pesado realizado pelos escravos. Aos poucos o trabalho escravo foi sendo substituído por mão-de-obra assalariada.

Houve uma forte imigração européia, aumentando a demanda por construçōes, principalmente em decorrência das atividades industriais. Nesse período, a construção deixou de se organizar como autoconstrução e passou a se organizar como atividade independente, distinguindo-se dois ramos de atividades: o subsetor de construções pesadas e de edificações.

Segundo FARAH [1988] no setor de edificações houve grande diversificação da demanda, tanto para edifícios industriais, comerciais e também para diferentes modalidades de habitação, destacando-se a proliferação dos cortiços e vilas operárias com vistas à locação.

No que se refere ao conhecimento embutido na atividade produtiva VARGAS [1994] salienta que nesse periodo o ensino de engenharia era apenas 
baseado em tratados, a maioria dos quais franceses, com predominância dos cálculos matemáticos. Os conhecimentos tecnológicos dos materiais e processos construtivos eram limitados; as propriedades dos materiais empregados eram muito mal conhecidas. Além disso, os processos e operações de construção eram deixados à prática empírica dos mestres de obra.

À medida em que os edifícios passavam a ser produzidos como mercadoria, a produção de seus insumos também se convertia em produção para o mercado. Por essa época, apesar das pesadas importações decorrentes de especificações de projetos, quase sempre elaborados por técnicos estrangeiros, houve uma expansão lenta e gradual da indústria nacional de materiais e componentes [FARAH, 1992].

Segundo VARGAS [1994], "os primeiros materiais de construção industrializados, precariamente, foram os tijolos, os quais começaram a substituir o processo artesanal da taipa nas construçōes das paredes de edifícios".

Em fins do século passado, com a multiplicação das olarias em torno de São Paulo, começou a se difundir uma nova tecnologia: a alvenaria de tijolos.

Segundo CASTRO [1986], "a nova maneira de construir adotava estrutura metálica pré-fabricada, pisos de madeira apoiados sobre vigas metálicas, componentes hidráulicos para as áreas molhadas, telhados com telhas cerâmicas, com chapas de cobre ou de aço galvanizado, sendo tudo isso importado".

Segundo o IPT [1988] "nas construções de pequeno porte passaram a predominar as alvenarias portantes de tijolos, às vezes complementadas por peças estruturais de aço ou de concreto armado, as fundações diretas e as coberturas com o uso de telhas cerâmicas do tipo 'Marselha'".

VARGAS [1994] salienta que: "foi a construção dos edifícios das nossas duas principais capitais que, a partir da Proclamação da República em 1889, com a utilização ampla do ferro, vidro, madeiras aparelhadas e dos materiais cerâmicos, tornou necessária a organização da construção civil em bases industriais". 
Apareceram, então, as primeiras empresas de construção, cuja origem provável, segundo FARAH [1992] pode ser: "oficinas independentes de pequeno porte ligadas às corporações de ofício" ou "engenheiros ligados à construção de ferrovias que teriam se associado, criando empresas de construção que, inicialmente, atuavam como subempreiteiras na construção de infra-estrutura, sob controle de grandes empresas estrangeiras. Num segundo momento, teriam diversificado sua atuação passando a atuar também na construção de edificações".

Para a FUNDAÇĀO JOÃO PINHEIRO [1992], "a convivência entre empreiteiras estrangeiras, que empregavam engenheiros brasileiros e subempreiteiras nacionais possibilitou a absorção e difusão de novas tecnologias que vieram a ser integradas, através de adaptações, à engenharia nacional, sofisticando-a e fortalecendo-a em termos de elaboração de projetos e execuçăo de obras".

Houve também alteraçōes quanto à mão-de-obra empregada. Surgiu, nessa época, a classe operária da construção, que segundo FARAH [1992] "destacava-se por seu padrão cultural, por seu caráter combativo e por sua capacidade de mobilização".

Essas características do operariado da construção são atribuidas a um conjunto de fatores, dentre os quais FARAH [1992] e a FUNDAÇÃO JOÃO PINHEIRO [1992] destacam: o elevado número de estrangeiros e as características sócio-culturais e econômicas dessa força de trabalho; o controle exercido pelo trabalhador sobre o processo de trabalho, no qual predominavam tarefas que requeriam grande habilidade e destreza e ainda, as próprias características de organização das empresas construtoras".

\subsubsection{Terceiro estágio de desenvolvimento}

Como VARGAS [1994] propõe a classificação dos períodos segundo o envolvimento com a pesquisa tecnológica, para esse pesquisador, o terceiro período compreende 0 final da década de 30 até os dias atuais. Entretanto, nos trabaIhos de FARAH [1992] e da FUNDAÇÃO JOÃO PINHEIRO [1992], o terceiro período termina na década de 60 , com a criação do Banco Nacional de 
Habitação. E, a partir de fins da década de 60 , esses pesquisadores encaram como um novo período no desenvolvimento do setor.

Como essa divisão não é relevante no presente trabalho, será mantida a proposiçāo feita por VARGAS [1994].

Nesse terceiro período, segundo os trabalhos de FARAH, [1988], da FUNDAÇÃO JOÃO PINHEIRO, [1992] e de VARGAS [1994], ocorreram grandes mudanças estruturais em toda a sociedade brasileira, com significativas repercussões sobre a indústria da Construção.

Houve uma reorientação da economia para o setor industrial, propiciando condições para a criação de um subsetor de montagem industrial; ocorreu a implantação de infra-estrutura para viabilizar a industrialização, fortalecendo o subsetor de Construção Pesada; e, ainda, deu-se a intensificação do processo de urbanização levando ao desenvolvimento do subsetor edificações, particularmente, em função da intervenção do Estado, através dos Institutos de Previdência e da Fundação da Casa Popular

FARAH [1992] afirma que conhecimentos com base cientifica começaram a ser introduzidos na construção de edificações nas décadas de 20 e 30, passando a serem incorporados tanto no projeto como na produção de materiais e componentes.

O suporte tecnológico para este estágio de desenvolvimento foi prestado pelo "Laboratório de Ensaios de Materiais (LEM), ligado à Escola Politécnica de São Paulo, pelo Instituto Nacional de Tecnologia (INT), no Rio de Janeiro e também pela Associação Brasileira de Cimento Portland (ABCP) e Associação Brasileira de Normas Técnicas (ABNT) [CASTRO, 1986; VARGAS 1994].

As alterações tecnológicas atingiram os canteiros de obras sobretudo através da incorporação de novos materiais, componentes e ferramentas.

Segundo CASTRO [1986], "a indústria nacional abarcava a produção de novos materiais e componentes que permitiam pequenas transformações na produção de edifícios, tais como: tijolos cerâmicos de oito furos (1935); lajes mistas (1935), louça sanitária (1936); telhas de fibrocimento (1937), bacias sifonadas 
(1943); blocos de concreto celular autoclavados (1948); fios revestidos com material termoplástico; esquadrias de alumínio; tubulaçōes e eletrodutos rígidos de P.V.C. e materiais para revestimentos, como pastilhas cerâmicas e vitrificadas, pisos plásticos e novas tintas".

Por essa época houve também a introdução de novos equipamentos e ferramentas que visavam o aumento da produtividade do setor, destacando-se o emprego de betoneiras, elevadores de obra e vibradores de concreto.

A incorporação da ciência ocorreu principalmente em áreas que exigiam o desenvolvimento de novos conhecimentos, dando resposta aos desafios colocados principalmente no campo das construções pesadas e da verticalização das edificações, em função do adensamento urbano.

Para FARAH [1992], a incorporação da ciência ao processo de produção deslocou o "domínio do saber", que era do trabalhador, para a engenharia. No entanto, ela acrescenta, que a cientifização não atingiu o modo de executar as atividades no canteiro de obras, que continuou sob o controle dos operários.

Surgiram nesse período as empresas especializadas em partes da obra. FARAH [1988] afirma: "o projeto completo de um edifício fora se decompondo, passando a constituir-se de um conjunto de partes desenvolvidas por diversas empresas ou profissionais".

Houve também reflexos na mão-de-obra. Segundo FARAH [1988] "os operários estrangeiros aos poucos foram sendo substituídos por migrantes oriundos da zona rural, sem tradição anterior nessa atividade. Como contrapartida, ganhou importância o profissional de engenharia e arquitetura".

Com a mudança de regime de governo em 1964 teve início uma nova etapa de desenvolvimento da indústria da Construção Civil. Intensificou-se o desenvolvimento dos subsetores construções pesadas e montagem industrial, especialmente, devido à implantação de grandes projetos na área de transportes, energia, mineração e siderurgia.

Quanto à produção de edificaçōes habitacionais, o mercado estava praticamente paralisado, ainda que a demanda tivesse crescido vertiginosa- 
mente. $\mathrm{Na}$ realidade, as políticas governamentais implementadas até então, voltadas aos programas habitacionais, haviam fracassado.

A resposta à grande demanda foi a criação do Banco Nacional de Habitação $(\mathrm{BNH})$, que buscava a produção em massa de unidades habitacionais, proporcionando, desta maneira, condições para a expansão do subsetor edificações e do próprio setor de materiais e componentes [FARAH, 1988].

O setor teve, assim, grande expansão até início da década de 70 , começando a dar sinais de queda gradual a partir do seu final, intensificando-se a recessão em meados da década de 80.

Durante a segunda metade da década de 70 e início da década de 80 , a construção de grandes conjuntos habitacionais marcou uma etapa importante da história da Construção de Edifícios no Brasil, introduzindo alterações tecnológicas rumo à industrialização da construção.

Por essa época, incentivado pela elevada demanda proporcionada pela liberação de recursos governamentais, o setor de Construção de Edifícios foi motivado à obtenção do incremento da produtividade e à redução de custos de produção, a fim de que se pudesse produzir um grande número de unidades habitacionais.

Teve início o processo de questionamento sobre a competência da indústria da Construção nacional em atender à demanda por unidades habitacionais. Surgiram, então, discussōes quanto ao "atraso tecnológico" do setor, uma vez que, segundo FARAH [1992], "o progresso técnico é visto como um dos elementos centrais do processo histórico que possibilitou, em outros ramos industriais, o aumento da produtividade e a redução de custos, elementos característicos da produção de bens de consumo de massa".

A introdução de "sistemas construtivos inovadores" ou ainda "sistemas industrializados", baseados principalmente na pré-fabricação, na sua maioria trazidos de outros paises, foi a resposta dada pelas empresas construtoras de edifícios à demanda estabelecida.

Essa modernização, segundo FARAH [1992], tinha por "paradigma a produção 
fabril seriada, propondo a transformação dos métodos de trabalho prevalecentes no setor", ou seja, uma modernização embasada na introdução de alterações tecnológicas e organizacionais na produção.

Observa-se, assim, que é recente a preocupação do setor de Construção de Edifícios em alterar as suas características de produção, com a implantação de novas tecnologias nos seus empreendimentos.

FARAH [1988] lembra que datam dessa época os canteiros experimentais instalados em Naramdiba (BA), em 1978 e no Jardim São Paulo (SP), em 1981. Nesses canteiros eram testadas "novas tecnologias" objetivando alcançar a modernização do setor, através da "diminuição dos prazos de execução e da redução de custos, atendendo aos 'novos' objetivos da ação estatal, de barateamento e de produção em escala, para 0 atendimento da população de baixa renda".

Segundo CASTRO [1986], mais de $50 \%$ da tecnologia dos processos construtivos utilizada nesses canteiros foi importada e, para a sua adaptação às condições nacionais foram exigidos investimentos em pesquisa tecnológica. Segundo essa autora, quando tais investimentos não eram feitos por iniciativa dos fabricantes, fatalmente cabia às construtoras fazê-lo.

Os processos não estavam resolvidos em sua totalidade. Eram processos mistos que incorporavam muitas partes típicas do processo construtivo tradicional. As soluções limitavam-se a resolver o subsistema vedação, utilizando-se blocos ou painéis; a cobertura, as fundaçōes e a estrutura.

A mão-de-obra também passou por transformações. Para CASTRO [1986], houve uma certa perda da qualificação profissional, na medida em que eram eliminados alguns acabamentos que exigiam mão-de-obra mais qualificada para a sua execução e na medida em que as fôrmas de madeira eram substituídas por fôrmas metálicas.

FARAH [1988] salienta que essa experiência de introdução de inovações tecnológicas acabou por se caracterizar como um evento pontual e localizado, pois à medida em que as condições favoráveis à utilização das inovações, 
proporcionadas pelo governo, deixaram de existir, houve uma retração em seu uso por parte das empresas. Permaneceram apenas os processos construtivos em alvenaria estrutural que, por não implicarem em grandes investimentos de capital, acabaram se difundindo pelo mercado.

A partir dessa época, o desenvolvimento do subsetor edificações, em particular, tem passado por sucessivos periodos de altos e baixos até os dias atuais, como bem demostra a colocação de artigo da revista Dirigente Construtor [ALTOS, 1990]: "A afirmação de Euclides da Cunha de que o sertanejo é antes de tudo um forte, pode ser aplicada à Construção Civil brasileira: subindo e descendo à mercê dos ventos soprados pelos sucessivos planos de estabilização que atormentam o país (...)."

Com a retração do mercado, existe uma tendência atual do setor em buscar a racionalização da produção de edifícios, que segundo FARAH [1988] "permite ganhos de produtividade e minimização de custos e prazos, sem implicar em uma ruptura da base produtiva que caracteriza o setor".

A racionalização da produção como uma das estratégias de ação adotadas pelas empresas construtoras para enfrentar a concorrência de mercado será discutida na seqüência.

\subsection{As Estratégias de Ação das Empresas do Subsetor Edificações}

O PRONATH [BRASIL, 1991], ainda que tenha detectado com propriedade os atuais problemas do subsetor edificações e, de modo particular, os do subsetor de habitação, propondo ações específicas para minimizá-los, não foi levado adiante pelo Governo Federal.

A expectativa criada no setor em 1991, com o lançamento do Programa, hoje não existe mais; pelo contrário, os recursos financeiros para esse segmento estão cada dia mais escassos; conseqüentemente, a demanda não é solvável, restando um reduzido mercado, fortemente disputado pelas empresas que atuam nesse segmento.

Em um país marcado por incertezas, descontinuidade de ações governamen- 
tais e, por conseqüência, pela impossibilidade de se realizar um planejamento de longo prazo para investimentos no setor, as ações visando a eficiência e a competitividade das empresas passam a ser essenciais para a sua sobrevivência no mercado. $E$ isto é o que vem se observando, cada vez mais claramente, nas estratégias das empresas.

SOARES [1992], referindo-se à competitividade do setor industrial como um todo, afirma que a presença de algumas características estratégicas são essenciais para conferir a modernização às empresas, dentre as quais destaca:

- adoção de uma nova postura em relação ao mercado e ao cliente;

- busca da flexibilidade da produção e de novas soluções organizacionais;

- maior inter-relação das atividades de produção, manutenção, serviços e fornecedores; e

- novo relacionamento entre os agentes do processo de produção, com a adoção de sistemas participativos.

FLEURY; FLEURY [1995] também destacam que é preciso uma nova organização empresarial para fazer frente à competitividade presente no mercado. Para esses autores as estratégias das empresas devem contemplar, entre outros, os seguintes elementos:

- reposicionamento em termos de mercado, através de processos de terceirização e de um forte esforço de racionalização das atividades produtivas;

- introdução de novos métodos de gestão da produção, tais como o TQC Total Quality Control, o JIT - Just in Time e o TPM - Total Productivity Maintenance;

- redefinição do processo de trabalho; e

- reorganização da empresa como um todo.

O direcionamento dos esforços das empresas no sentido de fazer evoluir seu processo de produção, como uma forma de alcançar um melhor posicionamento no mercado, está presente também em outros trabalhos especificamente voltados à indústria da Construção Civil. 
CARDOSO [1993] afirma, para esse segmento industrial, que: "se num passado não muito distante, privilegiava-se os aspectos não produtivos das operações, e 'ser eficiente' significava fundamentalmente bem gerir a carteira comercial e os recursos financeiros, a atual realidade de mercado traz um novo quadro: para um construtor, ser eficiente significa agora construir melhor, da maneira mais econômica e o mais rapidamente possivel".

KOSKELA [1992] também defende, para a indústria da Construção Civil, uma "nova filosofia de produção", fundamentada no gerenciamento do processo de execução, com vistas à racionalização de suas atividades.

Para esse pesquisador, todos os processos envolvidos na construção de um edifício estão embasados em "atividades de conversão" e em "atividades de fluxo"1. KOSKELA [1992] defende que apenas as atividades de conversão agregam valor ao produto e, por isso, precisam ser eficientes; enquanto as atividades de fluxo não agregam valor e, por isso, devem ser eliminadas do processo.

Segundo KOSKELA [1992], a "nova filosofia de produção" deve estar alicerçada nas seguintes diretrizes:

- aumento do valor do produto final através da consideração sistemática das exigências e dos desejos dos usuários;

- redução das atividades que não agregam valor ao produto ou ao processo de produção;

- redução da variabilidade do processo produtivo;

- redução do tempo de produção;

- simplificação da produção pela redução do número de passos, partes e ligaçōes;

- aumento da flexibilidade de produção;

1 São exemplos de atividades de produção, a execução de uma parede de alvenaria, a execução de um revestimento de argamassa; enquanto as atividades de fluxo referem-se à inspeção dos materiais, o transporte, as esperas que existem no sistema de produção. 
- aumento da transparência do processo;

- foco no controle no processo como um todo;

- desenvolvimento da melhoria contínua dos processos;

- equilíbrio entre a melhoria dos fluxos e a melhoria dos processos de conversão;

- desenvolvimento de ações objetivando o "benchmarking".

Pelas colocações anteriores, observa-se que o foco estratégico das empresas de construção deve estar claramente voltado à reorganização do processo de produçăo, objetivando a racionalização das atividades produtivas.

O trabalho de CARDOSO [1996], no qual é apresentado um panorama atual da indústria da Construção de Edifícios no Brasil e na França, mostra que realmente existe um mercado crescente voltado à busca da competência empresarial, seja motivado pelas exigências dos clientes, seja pela competitividade das próprias empresas.

A eficiência dos processos produtivos está sendo exigida e as empresas, para a sua própria sobrevivência, vêem-se motivadas a alcançá-la utilizando diferentes caminhos.

CARDOSO [1996] afirma que as estratégias de ação das empresas na busca da competitividade devem estar voltadas ao que denomina "novas formas de racionalização da produção". Para o caso do Brasil, esse pesquisador identificou que estăo presentes nas estratégias das empresas de construção as seguintes formas de racionalização:

- engenharia simultânea - centrada no relacionamento empresa-empreendedor, que pressupõe uma forte capacidade daquela em propor inovações durante a fase de concepção do empreendimento. A base dessa estratégia são os ganhos de custo que a engenharia simultânea permite, ao fazer a prévia integração das necessidades da produção na fase de concepção;

- sócio-técnica - é uma forma de racionalização que envolve o sistema de produção da empresa construtora e permite ganhos de custo através do 
emprego de técnicas e procedimentos de produção, com um cuidado particular com a mão-de-obra de produção;

- gerencial - envolve a gestão da produção através dos fluxos de informação e estabelecimento de parcerias. É uma forma de racionalização centrada no sistema de produção da empresa construtora, envolvendo também as suas subcontratadas. Ela permite ganhos de custo não mais devido a técnicas e procedimentos de produção, mas graças a uma capacidade de gestão através dos fluxos de operação e de informação que circulam no canteiro;

- técnico-comercial - é uma forma de racionalização da produção fruto da falta de recursos financeiros 'oficiais'. A empresa construtora e incorporadora brasileira trabalha com formas de autofinanciamento que exige, em contrapartida, uma organização minuciosa do desenvolvimento das obras e organização do canteiro;

- qualidade total - é uma forma de racionalização da produção cujo objetivo maior é fornecer aos clientes um produto que apresente ao mesmo tempo a qualidade que representa as exigências e os anseios dos clientes e da sociedade em geral e também a qualidade intrínseca do produto construído;

- compressão global dos prazos - é uma forma de racionalização cujo objetivo maior é atrair os clientes graças à capacidade de organização e condução dos processos de produção que permite ganhos de tempo através da redução global dos tempos das operações;

- oferecimento de serviços - é uma forma de racionalizaçāo cujo objetivo maior é atrair os clientes pelo oferecimento de diferentes tipos de serviços, ao longo de todo o processo de produçăo. $O$ oferecimento de serviços comumente ocorre em conjunto com as demais formas de racionalização;

- financeira-comercial - e uma forma de racionalização não ligada diretamente ao sistema de produção da empresa, mas à sua capacidade de atrair os clientes através do oferecimento de um financiamento que lhe permita adquirir a unidade. 
A pesquisa realizada junto às empresas construtoras para a realização deste trabalho de tese permitiu confirmar as colocações de CARDOSO [1996]; entretanto, duas dessas "novas formas de racionalização" aparecem mais fortemente nas estratégias das empresas pesquisadas e, muitas vezes, agregam algumas das demais.

As principais formas de racionalização identificadas foram a implantação de sistemas de Gestão da Qualidade e a implantação de ações, em canteiro, objetivando a racionalização da produção.

Inseridas nessas duas "estratégias maiores", encontrou-se também intervençōes com enfoque para:

- a "qualidade do projeto" como um subsídio à produção;

- o desenvolvimento de parcerias com fornecedores de materiais, de componentes e de mão-de-obra (subempreiteiros); e

- a organização e a gestão das atividades nos canteiros de obras.

As duas principais formas de racionalização que vêm sendo adotadas pelas empresas para incrementar a competitividade e a eficiência tecnológica serão apresentadas e analisadas na seqüência.

Para se proceder a essa análise, esse item está subdividido em três partes. $\mathrm{Na}$ primeira apresentam-se os programas de Gestão da Qualidade que vêm sendo empregados em empresas do setor da Construção de Edificios. Na segunda parte, discutem-se as ações de racionalização construtiva comumente implantadas nos canteiros de obras. E, finalmente, na terceira parte, frente a essas duas "novas formas de racionalização", faz-se uma análise do papel da implantação de TCR's, conduzida por uma adequada metodologia, como um eficiente elemento na busca da modernização empresarial.

\subsubsection{A implantação de programas de Gestão da Qualidade}

Diversos pesquisadores da área manifestam a opinião que os princípios que norteiam a filosofia da qualidade total, aplicados à indústria da Construção Civil, ainda estão distantes dos canteiros de obras. 
GARCIA MESEGUER [1989a], árduo defensor da aplicação dos princípios da qualidade à construção, afirma: "no que diz respeito à construção, é opinião generalizada em todos os paises, que a qualidade apresenta-se, em termos médios, abaixo do que corresponderia a uma indústria da sua importância e do que desejariam seus usuários. Têm-se que admitir, por isso, que o controle da qualidade que atualmente é realizado na construção é insatisfatório".

FRANCO [1992], analisando especificamente a indústria da Construção Civil no Brasil, destaca que: "esta se encontra, ainda, nos estágios primitivos da evolução da qualidade; excetuando-se alguns projetos especiais (...) praticase, quase que exclusivamente, o controle de qualidade sobre alguns insumos, mesmo assim, de forma incipiente e, em alguns poucos casos, o controle sobre produtos ou serviços acabados".

Esse autor destaca que apenas recentemente tem-se procurado "incorporar os conceitos de qualidade, utilizados pelos demais setores da indústria de transformação, com o objetivo de atingir melhores niveis de produção, produtividade e desempenho, aprimorando os processos construtivos e produtos".

Para FRANCO [1992] a gestão da qualidade, apesar de atualmente ser tema amplamente discutido para o setor da Construção Civil, parece algo ainda teórico, longe da realidade do canteiro de obras e dos escritórios de projeto. "Está longe de se consubstanciar em uma realidade tecnológica".

SIQUEIRA; BEVERINOTTI; SOUZA [1991] afirmam que embora a implantação de sistemas da qualidade na Construção Civil sejam incipientes tanto no Brasil quanto no exterior, no caso internacional o assunto é mais difundido que no Brasil devido às exigências de maior competitividade no mercado, especialmente no caso europeu, americano e japonês.

As dificuldades encontradas pelo setor da Construção Civil ao buscar introduzir uma nova mentalidade voltada à "qualidade total", predominante em outros setores, decorrem das características intrínsecas da construção que dificultam a utilização prática das teorias modernas de Gestão da Qualidade [GARCIA MESEGUER, 1989b]. 
Tais características são apresentadas também por outros autores, entre eles VARGAS [1981], FARAH [1988] e MARTUCCI [1990]. Apesar dos trabalhos desses pesquisadores guardarem entre si um intervalo de até 10 anos, as principais características citadas continuam inalteradas e manifestam-se, ainda hoje, no setor produtivo.

Dentre as características comumente destacadas, são listadas, a seguir, aquelas de interesse para este trabalho e que mais interferem no processo produtivo:

- caráter não estacionário da indústria da Construção, que implica em grandes dificuldades para a obtenção de constância das matérias primas e dos processos de produção empregados, pois, de modo geral, devido à impossibilidade de se estabelecer um fluxo contínuo de produção, a empresa é obrigada a mobilizar e desmobilizar toda uma estrutura a cada início e término de obra;

- poder de decisões pulverizado entre inúmeros agentes que participam do processo produtivo, podendo-se destacar entre outros: o usuário; o empreendedor; os projetistas; os agentes financeiros; a indústria de materiais e componentes; e o construtor, pesando aqui ainda, toda a hierarquia e forma de organização existente no canteiro de obras, onde no processo construtivo tradicional imperam, quase sempre, as tomadas de decisões subjetivas;

- ciclo longo de produção e produto de elevado custo, o que, muitas vezes, resulta numa produção não seriada que gera produtos não padronizados. Este fato tem obscurecido a possibilidade da indústria voltar-se ao processo de produção como algo passivel de ser padronizado, ainda que a sua aplicação resulte em produtos diferenciados. Assim, tem-se, na maioria das vezes, produtos e processos únicos que dificultam a implantação de princípios de racionalização;

- emprego de especificações complexas, muitas vezes contraditórias e confusas, e até mesmo inexistência das especificações voltadas à produção, o que dificulta a definição da qualidade; 
- elevada rotatividade, acrescida de emprego de mão-de-obra pouco qualificada e, na maioria das vezes, completa ausência de investimentos em treinamento, uma vez que no pensamento geral dos empresários tratam-se de investimentos que se perdem num curto espaço de tempo;

- o grau de precisão com que se trabalha é muito flexível, para qualquer parâmetro que se analise: orçamento; prazo; dimensões; etc.

Frente à complexidade do processo produtivo e às suas características que dificultam o processo de implantação de ações voltadas à qualidade, naturalmente, deve existir uma adaptação das teorias comumente empregadas para a indústria estacionária.

Essa idéia também é apresentada por GRAZIA [1988], salientando que os princípios da qualidade total, ainda que tenham de ser adaptados às circunstâncias da Construção Civil, poderăo ter importante contribuição a dar ao setor, pois as características de suas atividades requerem uma condução contínua da qualidade durante todo o processo através de um amplo gerenciamento do empreendimento.

Antes mesmo da edição das normas da série NBR-ISO 9000 [ABNT, $1994 a, b, c]$, buscava-se adaptar à Construção Civil os principios da qualidade implantados em outros setores industriais.

Pode-se dizer que um dos primeiros pesquisadores a propor um modelo visando a garantia da qualidade na Construção Civil, com repercussões no Brasil, foi GARCIA MESEGUER [1980; 1989a,b]. De lá para cá, outros modelos de Gestão da Qualidade vêm sendo formulados e aplicados às empresas de construção, fundamentados, em particular, na proposição das normas NBRISO 9000 [ABNT, 1994a,b,c].

PICCHI [1993] relacionou quatro propostas de sistemas da qualidade específicos para a construção, apresentados pelas seguintes entidades:

- Associacion Española para el Controle de la Calidad (AECC) - Comite de Construcción (1985); 
- American Society for Quality Control (ASQC) - Construction Technical Committee (1987);

- Comitê Euro-international Du Beton (CEB) (1988); e

- Norwegian Building Research Institute (1989).

Essas propostas, ainda que apresentem diferenças quanto ao detalhamento dos itens, abordam praticamente os mesmos temas, passando pelos seguintes aspectos:

- organização da empresa para a qualidade;

- controle de documentação;

- projeto;

- produção;

- controle de materiais, componentes e de processos;

- entrega do produto.

O sistema da qualidade proposto pelo Norwegian Building Research Institute vem sendo amplamente difundido e implantado na Noruega e, segundo FORMOSO e SJOHOLT [1994], consiste em uma das mais expressivas experiências de desenvolvimento cooperativo da Gestăo da Qualidade no setor Construção Civil, adotado, inclusive por vários grupos de empresas em países como Finlândia, Islândia e Holanda.

Segundo esses autores, o sucesso do programa de gestão empregado na Noruega vem sendo favorecido por um conjunto de características intrínsecas à indústria da Construção Civil norueguesa, as quais diferem sobremaneira das características da indústria da Construção no Brasil.

FORMOSO e SJOHOLT [1994], destacam como principais características da indústria de Construção norueguesa, as seguintes:

- avanço tecnológico decorrente de obras pesadas e das condições climáticas adversas;

- o envolvimento das empresas de construção pesada com o programa; 
- a cultura empresarial que favorece as associaçōes de empresas, parcerias e trabalhos de desenvolvimento cooperativo, inclusive na área de Gestão da Qualidade;

- a tradição em se ter poucos niveis hierárquicos nas organizações e a preocupação com o bem estar dos operários;

- o elevado nível de treinamento da mão-de-obra; e

- a existência de um sistema de normalização e de informações técnicas bastante eficientes, tanto com relação ao controle de insumos, como ao projeto e ao processo.

Segundo FORMOSO e SJOHOLT [1994], a implantação do programa leva, em geral, entre 24 e 36 meses, com grupos que têm variado de três a nove empresas, com perfil heterogêneo, ou seja, participam empresas projetistas, subempreiteiras, fabricantes de materiais, construtoras.

No Brasil, são diversos os sistemas da qualidade objetivando especificamente a indústria da Construção Civil, os quais vêm sendo propostos e aplicados desde a década de 80 .

PICCOLI [1988] propöe um modelo de sistema de garantia da qualidade aplicado à Construção Civil no Brasil, o qual, segundo o autor, foi adaptado da indústria nuclear e de outros setores industriais.

Na sua proposição defende que a qualidade é relativa, sendo fixada através de uma série de características predeterminadas que poderão ser mais ou menos exigentes e mais ou menos abrangentes.

Assim, esse autor defende que "ter qualidade é estar conforme os padrões preestabelecidos e o controle da qualidade compara esses padrōes com as características do produto".

A metodologia proposta por PICCOLI [1988] prevê o estabelecimento de um plano da qualidade para a Construção Civil, não rígido, mas que deve ter alguns elementos básicos, cujos principais são listados a seguir: 
- dados de entrada: documentos que incluem projeto básico e especificações da construção; projeto executivo das etapas iniciais da obra; normas técnicas para os materiais, equipamentos e métodos executivos a serem empregados; contrato da construção; cronograma da obra.

- procedimentos executivos dos serviços (PES): documentos que detaIham como o "órgão de produção" pretende executar cada etapa do serviço";

- matriz de atribuiçōes e responsabilidades: documento que contém as atribuições e responsabilidades dos departamentos envolvidos na produção;

- planos de arquivamento das informações coletadas: documentos que definem como os dados coletados em campo deverão ser arquivados;

- relação dos procedimentos de inspeção de materiais $(\mathrm{PI})$ e folhas de verificação dos serviços (FV).

Mais recentemente, após a publicação do modelo proposto pela série NBRISO 9000, tanto PICCHI [1993] como o CTE [1994] particularizam o modelo de gestão proposto pela NBR-ISO 9004-1 [ABNT, 1994c], adaptando-o às empresas de Construção Civil.

Essas duas metodologias incorporam praticamente os mesmos elementos, havendo alguma diferenciação quanto à terminologia que empregam e o aprofundamento que propõem para alguns dos itens.

Para esses autores, um sistema da qualidade objetivando o ciclo da qualidade da construção deve conter os seguintes elementos:

- política e organização da empresa voltadas à qualidade;

- qualidade em recursos humanos;

- qualidade em planejamento do empreendimento e vendas (qualidade em "marketing");

- qualidade no projeto;

- qualidade em suprimentos (na aquisição);

- qualidade no gerenciamento e execução de obras;

- qualidade na operaçăo e assistência técnica pós-ocupação. 
As inter-relações entre os elementos desse sistema da qualidade estão ilustradas na figura 3.1; enquanto um detalhamento dos itens propostos por PICCHI [1993] e pelo CTE [1994] é apresentado na tabela 3.1.

Comentando o conteúdo da figura 3.1, PICCHI [1993] salienta que os elementos "planejamento do empreendimento e vendas", "projeto", "suprimentos", "execução", "serviços ao cliente e assistência técnica" sucedem-se no processo de produção e mantêm interfaces através de retroalimentações; o elemento "recursos humanos" interage com todos os elementos anteriores, enquanto os aspectos de "política e organização" permeiam todos os demais.

Programas de Gestão da Qualidade, baseados nos modelos propostos pelos diversos institutos de pesquisa e pesquisadores citados, vêm sendo difundidos e aplicados em diversas empresas de Construção Civil em todo o Brasil.

Entre outras iniciativas, vale destacar o esforço que tem sido feito pelo SINDUSCON-SP no sentido de atingir o maior número de empresas possível, através do "Programa de Capacitação Gerencial de Empresas Construtoras para Desenvolvimento e Implantação de Sistemas de Gestão da Qualidade", com o apoio do SEBRAE-SP (Serviço de Apoio às Micro e Pequenas Empresas do Estado de São Paulo) e do CTE (Centro de Tecnologia de Edificações) [SINDUSCON, 1995].

O programa liderado pelo SINDUSCON-SP prevê a formação de grupos de empresas, que irão, passo a passo, implementar os módulos previstos na tabela 3.1. São formados grupos em torno de 12 empresas que trabalham durante 11 meses, as quais são representadas por dois elementos, um deles deve ser, de preferência, membro da diretoria [SINDUSCON, 1995]. Atualmente (julho de 1996) o programa está iniciando a formação da sexta turma.

Os resultados alcançados até o momento pelas empresas que já participaram não foram objeto de sistematização. Entretanto, num dos seminários patrocinados pelo SINDUSCON-SP [1995], o representante do SEBRAE-SP, entidade que também participa do programa, salientou que: "de cada 10 empresas, uma apresenta resultados acima do esperado". 


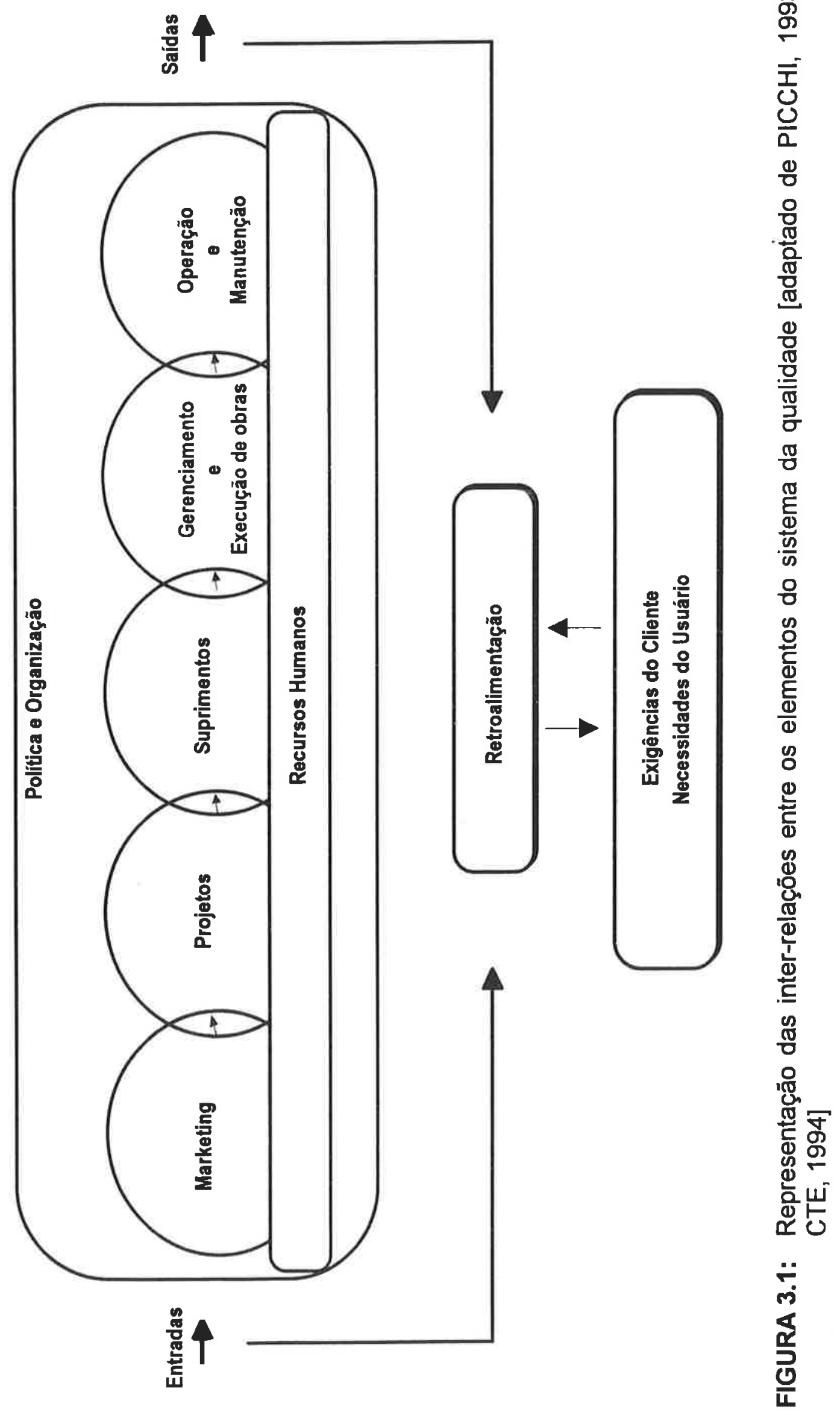


TABELA 3.1: Proposta de itemização de Sistemas da Qualidade para empresas construtoras, segundo PICCHI [1993] e CTE [1994]

\begin{tabular}{|c|}
\hline 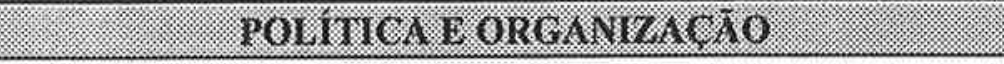 \\
\hline $\begin{array}{c}\text { Política da Qualidade } \\
\text { Responsabilidade e Organização da Empresa para a Qualidade } \\
\text { Documentação do Sistema e Controle de Documentos } \\
\text { Arquivo Técnico } \\
\text { Custos e Indicadores da Qualidade } \\
\text { Tratamento de Não-conformidades e Açôs Corretivas } \\
\text { Auditorias Internas } \\
\text { Avaliação do Sistema }\end{array}$ \\
\hline
\end{tabular}

\begin{tabular}{|c|}
\hline 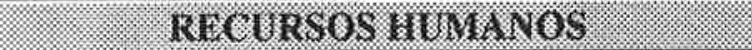 \\
\hline $\begin{array}{c}\text { Integração dos Recursos Humanos na Empresa } \\
\text { Fixação dos Recursos Humanos na Empresa } \\
\text { Treinamento } \\
\text { Motivação e Participação } \\
\text { Segurança do Trabalho }\end{array}$ \\
\hline
\end{tabular}

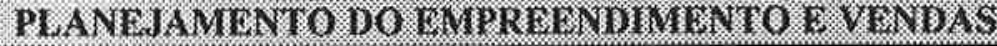

Análise do Mercado

Estudo de Viabilidade do Empreendimento

Programa do Produto

Documentação para Lançamento

Vendas e Retroalimentação

\section{गROJIT TO}

Qualificação de Produto e Processos

Coordenação de Projetos

Análise Crítica de Projetos

Qualificação de Projetistas

Projetos de Produção

Planejamento de Projetos

Controle de Qualidade e de Projetos

Controle de Revisões

Controle de Modificações Durante a Execução

Projetos em Computador (CAD)

\section{SUPRIMUNTOS}

Critérios para Especificações de Materiais

Qualificação de Fornecedores e Produtos

Controle de Documentos de Compra

Planejamento e Controle do Suprimento

Controle da Qualidade do Material Recebido

Recursos para Realizações de Medições e Ensaios

Controle de Manuseio e Armazenamento 
TABELA 3.1: Continuação. Proposta de itemização de Sistemas da Qualidade para empresas construtoras, segundo PICCHI [1993] e CTE [1994]

\begin{tabular}{|c|}
\hline Qualificação de Procedimentos de Execução \\
Planejamento e Controle de Obra \\
Análise de Unidade-Protótipo \\
Controle de Pré-montagem \\
Procedimentos de Execuça e Programaço de Serviços \\
Controle da Qualidade dos Serviços \\
Qualificação de Subempreiteiros \\
Planejamento e Controle de Equipamentos \\
Controle da Qualidade do Produto Final e da Manutenção da Qualidade até \\
a Entrega ao Cliente
\end{tabular}

\section{SERVICOS AO CI IENTE E ASSISTENCIA TECNICA}

Atendimento ao Cliente

Vistoria de Entrega da Unidade

Manual do Proprietário e do Condomínio

Setor de Assistência Técnica

Retroalimentação

A avaliação de quatro empresas que participaram do segundo grupo formado pelo SINDUSCON-SP, em um depoimento feito à autora, deixa claro que o programa de Gestão da Qualidade "é uma ferramenta fundamental na busca da excelência dentro do setor em que atuam". Salientam, porém, que a maior dificuldade de implantação do programa está em "transferir para o canteiro de obras todos os conceitos desenvolvidos durante o programa".

Apesar de todas essas dificuldades, os esforços na busca da implantação de sistemas de Gestão da Qualidade continuam e não se restringem a São Paulo. Outras cidades e outros estados participam igualmente dessa tarefa.

No último Encontro Nacional de Tecnologia do Ambiente Construído, realizado em 1995, no Rio de Janeiro, [ENTAC, 1995] foram apresentados trinta e nove trabalhos cujo tema era a qualidade na indústria da Construção.

Dentre esses trabalhos, destacam-se os realizados por NEVES [1995], em 
Salvador (BA); O de HEINECK; TRISTÃO; NEVES [1995], em Florianópolis (SC); o de FREITAS [1995], no Rio de Janeiro (RJ); o de FABRÍCIO; MARTUCCI [1995], em São Carlos (SP) e os que vêm sendo desenvolvidos pela Universidade Federal do Rio Grande do Sul (RS), sendo que pela amplitude desse último trabalho e pela sua repercussão no setor, serão apresentados alguns de seus principais resultados.

Desde abril de 1992, a Universidade Federal do Rio Grande do Sul (UFRGS), - SEBRAE-RS, o SINDUSCON-RS e a Fundação de Ciência e Tecnologia (CIENTEC) assinaram um convênio para a realização do "Projeto de Apoio Tecnológico e Gerencial a Empresas de Construção Civil de Pequeno Porte".

Segundo FORMOSO; LIMA [1995], um dos objetivos desse Programa foi a implantação de sistemas de Gestão da Qualidade nas empresas participantes.

O programa envolveu, ao todo, quarenta e oito empresas, tendo sido desenvolvido em três etapas distintas, quais sejam: preparação da empresa para o desenvolvimento do programa de Gestão da Qualidade; disseminação do programa pela empresa e consolidação do mesmo; desenvolvimento de estudos e projetos de melhorias específicas.

Com a realização desse programa, os pesquisadores envolvidos puderam reunir uma série de pontos positivos e negativos.

A análise do trabalho de FORMOSO; LIMA [1995] mostra que os pontos positivos foram muito expressivos, valendo destacar que o programa levou à criação de um "fórum para o aprofundamento do estudo de problemas que afetam o subsetor de edificações".

Esses pontos favoráveis permitiram a continuidade do programa, ainda em andamento naquele Estado. Nāo obstante, foram expressivos os pontos negativos, os quais serviram para redirecionar as ações inicialmente previstas.

Dentre as dificuldades identificadas por esses pesquisadores, cabe registrar as seguintes:

- dificuldades na assimilação das ferramentas da qualidade pelos membros dos comitês; 
- falta de continuidade na participação de algumas empresas, tanto nas reuniōes de grupo, quanto na realização das atividades propostas, motivadas, em geral, por fatores externos ao projeto, tais como início de obras novas, participação em licitações, etc.

- dispersão de esforços do grupo de empresas em decorrência da amplitude do campo de ação e da inexistência de limites para suas atividades.

FORMOSO e SJOHOLT [1994] também deixam claro que há uma série de dificuldades a serem vencidas para a implantação e manutenção de um programa de Gestão da Qualidade, observando que geralmente há uma grande mobilização das empresas nas etapas iniciais, as quais envolvem sensibilização e conscientização; no entanto, existem maiores dificuldades quando se inicia a etapa de implantação do programa propriamente dito.

Esses pesquisadores salientam que "é comum uma certa dificuldade por parte dos gerentes em visualizar os objetivos no início do processo, principalmente por ser este de longo prazo".

Os pesquisadores do CTE, que vêm participando ativamente do programa desenvolvido pelo SINDUSCON-SP, também apontam dificuldades na condução do programa.

Esses pesquisadores registraram no trabalho de SOUZA; MEKBEKIAN [1995] que as dificuldades encontradas na aplicação da proposta são de ordem comportamental das empresas e não de origem técnica e apontaram como sendo as principais:

- não comprometimento prático da alta administração, com a implantação do programa de Gestão da Qualidade e com sua avaliação sistemática;

- postura pouco colaborativa dos gerentes, sendo que muitos vêem o programa da qualidade como inimigo e não como aliado;

- falta de atenção para o planejamento do processo de implantação, resultando em incoerências ao longo da implantação;

- ausência de um sistema de informações e comunicação entre a diretoria da empresa e seus gerentes e colaboradores; 
- a ausência de investimentos em recursos humanos e nas condições de trabalho;

- ansiedade por resultados;

- falta de liderança do processo.

Esses autores afirmam, ainda, que: "Estabelecer tecnicamente as especificaçōes e os procedimentos de projeto, planejamento, suprimentos e execução de obras, nem sempre garante o êxito do sistema de Gestão da Qualidade".

PICOLI [1991] também detecta uma série de dificuldades na implantação de sistemas da qualidade na indústria da Construção Civil. E, dentre elas, cabe destacar:

- utilizaçăo dos sistemas da qualidade como um fim e não como um meio, ou seja: um excessivo valor dado à documentação em detrimento do verdadeiro objetivo do sistema, que é a qualidade da obra;

- dificuldade de cultura para a qualidade ao nivel de gerência da construtora;

- intervenção de agentes diferentes nas diversas etapas do processo de produção;

- ausência de investimentos em recursos humanos; e

- projetos incompletos com incorreções e acompanhados de especificações também incompletas.

Pelas colocações anteriores, observa-se que os programas de Gestão da Qualidade, enquanto "ferramental" a ser utilizado pelas empresas para a busca de competitividade, já é uma realidade no Brasil. Entretanto, são muitas as dificuldades que têm sido encontradas para a efetivação desses programas nos canteiros de obras.

Como bem afirma PICCHI [1993], "os resultados, considerando-se algumas empresas isoladamente, já são bastante promissores, mas na média geral do pais os esforços ainda são modestos e, embora a melhoria da qualidade dos produtos e processos já esteja no discurso dos empresários, ainda tem um longo percurso até chegar ao chão de fábrica". 


\subsubsection{Implantação da racionalização construtiva}

A racionalização construtiva é apontada por FARAH [1988] como uma forte tendência da indústria da construção de edifícios, para fazer frente à crise que atingiu o setor desde o início da década de 80 , permanecendo, de certa maneira, até os dias atuais.

Segundo o IPT [1988], "Através do processo de racionalização, as empresas procuram obter ganhos de produtividade e minimizar custos e prazos, sem uma ruptura da base produtiva que caracteriza o setor. Procura-se reduzir o desperdício de tempo e de materiais, atacando alguns dos principais pontos de estrangulamento da construção convencional, tais como: desarticulação entre os diversos projetos e entre o projeto e obra; ausência de controle de qualidade; más condições de trabalho como fator de baixa produtividade; desorganização do canteiro, etc.".

O desenvolvimento tecnológico e a aplicação de métodos e processos construtivos que objetivam a racionalização da construção sempre foi a tônica das pesquisas desenvolvidas pelo grupo no qual a autora participa, no CPqDCCEPUSP.

Fazem parte do conjunto de pesquisas realizadas, as apresentadas por SABBATINI, BARROS [1988]; SABBATINI, BARROS, SILVA [1988]; SABBATINI, SELMO [1989a]; SABBATINI, SELMO [1989b]; SABBATINI; BARROS [1989]; SABBATINI [1989]; BARROS [1991]; FRANCO [1992], entre outros.

Além dessas, há uma série de outros trabalhos desenvolvidos por pesquisadores de diversas partes do pais, podendo-se destacar o de SALDANHA [1995] e SCARDOELLI [1995].

SALDANHA [1995] apresenta um estudo de caso envolvendo a "implantação de um programa de racionalização parcial do processo construtivo", em uma empresa de Juazeiro do Norte, no Ceará.

Esse programa envolveu diversos aspectos do processo de produção, dentre eles: a integração dos projetos do edifício, inclusive com a elaboração do pro- 
jeto de montagem das fôrmas; a elaboração do planejamento considerando as reais necessidades da produção e o planejamento do canteiro de obras, considerando-se os conhecimentos de engenharia de métodos, ergonomia, arranjo físico e segurança do trabalho.

O foco desse trabalho de intervenção foi a investigação dos reflexos da racionalização no comportamento da mão-de-obra, buscando-se identificar a redução dos custos envolvidos e o aumento da produtividade.

SALDANHA [1995] conclui que a "Racionalização do Trabalho na construção de edificações é favorável, visto que atua na redução dos desperdícios de mão-de-obra (...). No entanto, resultados melhores poderiam ter sido obtidos se a racionalização tivesse sido abordada de maneira sistêmica".

SCARDOELLI et al. [1994] registram uma pesquisa realizada junto a empresas construtoras, de várias regiões do país. Nesse trabalho, realizou-se um inventário sobre as melhorias voltadas à produtividade e à qualidade desenvolvidas por essas empresas.

A listagem das melhorias identificadas por esses pesquisadores é expressiva, tendo-se identificado cinco categorias de melhorias, assim agrupadas:

- aspectos organizacionais e de gestão: houve a melhoria de aspectos relacionadas à cultura, estratégia, implantação de sistemas de Gestão da Qualidade e implantação de mecanismos internos de comunicação;

- recursos humanos: ocorreram melhorias nas condições de trabalho, através de educação e treinamento da mão-de-obra, motivação, participação e diminuição de riscos de acidente no canteiro;

- desenvolvimento e integração de projetos: ocorreram melhorias que buscaram implementar a forma de expressão e comunicação das soluções e especificações; melhoria da objetividade, clareza e interpretação e facilidade de sua utilização correta na etapa de construção;

- programação, planejamento e venda do empreendimento: envolveu melhorias relativas à forma de promover as vendas e à forma de se avaliar a sua viabilidade econômica; e 
- organização do canteiro e da produção: envolveram melhorias no gerenciamento dos materiais; controle de qualidade e produtividade no canteiro; organização do canteiro; planejamento e organização da produção; equipamentos, máquinas e ferramentas.

SCARDOELLI [1995], ao analisar as iniciativas de melhorias, realizadas em trinta e oito empresas, identifica que:

- $87 \%$ das empresas buscaram a melhoria da qualidade pela introdução de novos equipamentos nos canteiros, melhoria das instalações, racionalização de processos, redução de esforço físico e utilização de novos materiais e componentes; e

- $13 \%$ das empresas aliaram às melhorias anteriores um grande investimento em recursos humanos.

Essa pesquisadora salienta, ainda, que as empresas que não investiram em recursos humanos tiveram resultados das ações de racionalização significativamente inferiores àquelas que realizaram algum tipo de investimento.

SCARDOELLI [1995] continua a sua análise afirmando que: "as empresas que avançaram pela linha da racionalização dos processos parecem ter obtido um ganho bastante significativo de qualidade e produtividade, mas atingiram um ponto no qual inovaçōes incrementais parecem não surtir mais efeito (...) em algumas empresas observou-se um retrocesso do processo de inovaçāo, com o retorno da utilização de técnicas tradicionais (...)".

Essa pesquisadora afirma, também, que foi observado nas empresas a adoção de iniciativas isoladas e pontuais, sem avaliação rigorosa quanto à sua efetividade, viabilidade de implantação e adequação da solução para a empresa. "De uma maneira geral, percebe-se em todas as empresas uma defasagem entre o que a empresa alardeia e o que realmente realiza".

Ao se analisar as conclusões de SCARDOELLI [1995] e também as de SALDANHA [1995], fica claro que as ações de racionalização, na sua maioria, foram inseridas num contexto de organização tradicional da empresa. $E$, nesse ambiente, por mais simples que sejam, essas ações não são facilmente im- 
plantadas, isto é, não são fáceis de serem incorporadas ao sistema de produção da empresa, de modo que seus efeitos benéficos sejam perenizados e possam ser reproduzidos em empreendimentos futuros.

Apesar dessas ações demonstrarem um esforço das empresas em buscar um caminho que as leve à evolução tecnológica, a experiência da autora mostra que acabam resultando em esforços localizados em um determinado canteiro, além de, muitas vezes, terem um período curto de aplicação.

E ainda, tais ações dependem da voluntariedade e entusiasmo das pessoas diretamente envolvidas que, por razões pessoais, tentam fazer com que as pequenas mudanças aconteçam.

Para minimizar as dificuldades encontradas para a implantação de programas de Gestão da Qualidade ou mesmo para a aplicação de ações de racionalização, neste trabalho, defende-se a implantação de TCR's, balizada por uma adequada metodologia, sendo que a contribuição do processo de implantação de TCR's, na evolução tecnológica do setor da Construção de Edifícios, será discutido a seguir.

\subsubsection{A implantação de TCR's e a evolução do processo de produção}

É certo que as empresas de construção de edifícios têm buscado "novas estratégias de ação", objetivando ganhar espaço num mercado cada vez mais competitivo.

A implantação de programas de Gestão da Qualidade, assim como as técnicas e métodos racionalizados aplicados diretamente na produção têm sido estratégias adotadas pelas empresas.

Entretanto, a implantação dos programas de Gestão da Qualidade não tem conseguido alcançar plenamente os seus objetivos. Muitas empresas, ansiosas por resultados, acabam perdendo o estímulo inicial, sendo difícil fazer a "qualidade" chegar aos canteiros de obras.

As açōes de racionalização, da maneira como vêm sendo empregadas, são de escopo restrito; não têm a abrangência requerida para modificar o atual pro- 
cesso de produção, sendo difícil a sua fixação à cultura da empresa. Os ganhos localizados, advindos dessas ações, perdem-se rapidamente, não sendo possível, na maioria dos casos, repetir o seu efeito nos empreendimentos subseqüentes

As dificuldades encontradas para fazer evoluir o processo de produção dos edifícios têm sido intensas e extensas e estão expressas em trabalhos de diversos pesquisadores da área.

O trabalho de TATUM [1986], no qual o pesquisador estuda o comportamento de empresas de Construção Civil nos Estados Unidos sob o aspecto das inovações introduzidas, conclui que a fragmentação desse setor industrial torna a inovação um processo mais difícil de ocorrer do que em outras indústrias de menor complexidade organizacional, exigindo um controle efetivo dos diversos agentes envolvidos, dentre eles, clientes, usuários, projetistas e construtores.

SANDERS; ESKRIDGE [1993], por sua vez, afirmam que o desenvo/vimento da cultura da empresa é imprescindível para que ocorra a implantação de inovações. Segundo esses pesquisadores, é preciso haver compromisso com as mudanças, destinando os recursos econômicos, de tempo e de pessoas e compreendendo que não há soluções prontas.

Esses pesquisadores destacam que muitas empresas "pensam" que podem implantar novas idéias e resolver seus problemas em curto espaço de tempo, mas isso não ocorre, pois a mudança deve ser vista como um caminho para a melhoria constante dos processos.

SOUZA; BARROS; MELHADO [1995] também deixam claro que não é fácil fazer evoluir o processo construtivo tradicional de construção de edifícios e evidenciam a relevância de se alterar as características gerenciais e organizacionais da empresa, para o sucesso da implantação de inovações tecnológicas.

Esse trabalho apresenta estudos de casos, envolvendo cinco empresas construtoras que, de alguma maneira, buscaram alterar a tecnologia construtiva 
empregada no processo de produção de edifícios. Dessas, três empresas empreenderam alterações tecnológicas localizadas, visando a racionalização da execução de partes do edifício construído pelo processo construtivo tradicional, ou seja, buscaram empregar métodos construtivos racionalizados; enquanto duas delas empreenderam mudanças mais "radicais" em seu processo de produção, alterando o processo construtivo utilizado.

Uma das conclusōes principais que se pôde chegar, a partir da análise desse trabalho, foi que as empresas que seguiram o caminho das "inovações radicais", por terem rompido fortemente com os métodos construtivos tradicionais, conduzindo "passo-a-passo" a implantação das inovações, obtiveram resultados positivos que aos poucos foram se consolidando nas empresas.

Por outro lado, aquelas empresas que se propuseram a implantar ações localizadas, objetivando a racionalização construtiva, perderam grande parte do esforço empreendido, sobretudo porque não conseguiram alterar a forma tradicional de organização e gestão do processo de produção.

Frente à premência de se fazer com que o segmento de construção de edifícios evolua tecnologicamente e altere o processo tradicional de gestão e organização da produção para que as inovações possam ser fixadas à cultura da empresa, defende-se, neste trabalho, a implantação de TCR's, como sendo um recurso valioso para o processo de evolução tecnológica e organizacional das empresas.

O processo de evolução tecnológica do processo construtivo tradicional iniciado pela introdução de TCR's diretamente no processo de produção, na maioria das vezes, traz resultados rápidos, ainda que inicialmente localizados. Esses resultados motivam a continuidade das ações, principalmente as gerenciais e organizacionais, abrindo caminho, inclusive, para a implantação dos programas de gestão, como mais uma "nova forma de racionalização".

Essa posição é confirmada por PICCHI [1993], que apresenta a evolução da qualidade em uma grande empresa construtora que iniciou suas atividades de melhoria em 1987, através da produção. Essa empresa, teve como primeira 
açăo "o questionamento das técnicas construtivas tradicionalmente utilizadas, através de convênios e projetos de pesquisa (...). A partir das conclusões destes convênios foram elaboradas disversas normas internas, uma série de treinamentos foram realizados e procedimentos de controle da qualidade implantados". Esse autor acrescenta que, até fins de 1992, a empresa não possuía um Sistema da Qualidade formalizado e que as ações de melhoria em todas as áreas estavam sendo implantadas gradativamente $e$ iriam compor o sistema de Gestão da Qualidade, que estava em desenvolvimento.

A implantação de TCR's não é uma ação localizada como as ações de racionalização que vêm sendo empreendidas pelas empresas. A implantação de TCR's envolve uma visão sistêmica de todo o processo de produção, interferindo na sua forma de organização e de gestão desde a etapa de projeto, até a conclusão do produto e sua entrega ao cliente.

Por outro lado, a implantação de TCR's não incorre nas dificuldades comumente apresentadas pelos programas de Gestão da Qualidade, que custam a penetrar nos canteiros de obras, desmotivando as pessoas envolvidas. A implantação de TCR's permite um completo envolvimento das atividades ligadas à execuçăo da obra, logo no início do processo de desenvolvimento de um empreendimento, motivando a continuidade das ações.

Entretanto, a implantação de TCR's não se faz de uma hora para outra. Para que apresente resultados positivos, exige uma alteração do atual sistema de organização e de gestão do processo construtivo tradicional, caracterizado por:

- descontinuidade e ausência de definições do processo de produção;

- inúmeros agentes interferindo no processo de produção e, na maioria das vezes, trabalhando de maneira descoordenada e desvinculados de um objetivo comum;

- despreparo técnico-organizacional de muitos destes agentes;

- pulverização do poder de decisões, com grande número de níveis hierárqui$\cos ; \mathrm{e}$ 
- ausência ou ineficiência de canais formalizados de comunicação que conduzam adequadamente o sistema de decisões e de informações.

Para fazer evoluir esse processo de organizaçăo, será fundamental um firme propósito da empresa construtora e também dos demais agentes que interferem na produção.

A implantação de TCR's exige que a empresa esteja comprometida com a mudança, proporcionando os recursos para que a evolução se estabeleça no sistema produtivo da empresa. E, além disso, todas as ações empreendidas deverão ser devidamente coordenadas para que se a evolução gradual e contínua do processo de produção.

Para isto, as empresas precisarão estar orientadas por uma adequada metodologia de ação, sem a qual, acredita-se que as açōes que visam a racionalização do processo de produção não terão condições de se fixarem à cultura da empresa, recaindo nos programas de racionalização atualmente desenvolvidos.

Essa metodologia deverá conter os elementos fundamentais para que a empresa, ao adotar a implantação das TCR's como uma estratégia para a racionalização da produção, possa evoluir continuamente.

A proposição de uma metodologia que possa conduzir as empresas ao longo do processo de implantação de TCR's para a produção de edifícios pelo processo construtivo tradicional constitui a grande contribuição do presente trabalho de tese.

Acredita-se e espera-se confirmar que, utilizando-se da metodologia proposta, as empresas consigam efetivamente evoluir o seu processo de produção, alcançando a sua competência tecnológica e empresarial.

Essa metodologia será desenvolvida ao longo dos capítulos quatro e cinco, sendo que a importância de sua aplicação é analisada no sexto capitulo. 
fenômeno novo, nem o desenvolvimento de um novo produto ou procedimento de fabricação, nem a criação de um novo mercado. É, sobretudo, a conjugação estreita de todo um conjunto integrado de açōes dirigidas para um objetivo industrial comum".

Além de ser um processo de dificil condução, não tem um tempo previsto para a sua completa ocorrência, pois, seja proveniente de um avanço científico ou de uma demanda de mercado, ocorrendo em uma grande, média ou pequena organização, a inovação tecnológica é um processo que segundo HILL [1983] pode ocorrer rapidamente ou pode requerer um extenso período de tempo.

A partir de uma pesquisa realizada por QUINN [1986], com amplitude mundial, tendo como amostra grandes companhias européias, japonesas e americanas e também pequenos empreendimentos bem documentados, esse pesquisador conclui que "o tempo entre a invenção e a produção comercial variou entre três e vinte e cinco anos".

Segundo RATTNER [1988], entretanto, há uma forte tendência de diminuição desse periodo, sobretudo no caso das indústrias de tecnologia de ponta.

Seja de longo ou curto prazo, a inovaçāo é um processo, e como tal envolve diversas etapas e atividades, cuja implantação pode variar em função de diferentes características, tanto internas, como externas à empresa, como por exemplo: os objetivos que a empresa pretende atingir; as suas especificidades organizacionais e os recursos disponiveis; e as oscilações de mercado.

Assim sendo, o que se pretende neste item é identificar as diretrizes contidas nos principais modelos para a implantação de inovações tecnológicas em empresas da indústria seriada, propostos na bibliografia disponivel.

A bibliografia analisada neste item concentra sobretudo os estudos realizados por pesquisadores das áreas de economia e administração industrial, os quais vêm șe preocupando com o processo de inovação tecnológica nas empresas, praticamente desde a revolução industrial. Os livros mais antigos que se teve acesso datam da década de 50 [BARNETT, 1953; HAGERSTRAND, 1953]. Essas publicações fazem referência a trabalhos mais antigos ainda e procuram 


\section{CAPITULO 4}

\section{O PROCESSO DE INOVAÇÃO TECNOLÓGICA NA INDÚSTRIA SERIADA E NA INDÚSTRIA DA CONSTRUÇĀO DE EDIFÍCIOS}

A partir do quadro conceitual montado no capítulo 2, entende-se que um aperfeiçoamento tecnológico ou uma TCR, efetivamente incorporado ao processo de produção de edifícios, possa ser considerado uma "inovação tecnológica na indústria da Construção Civil", caracterizando-se por ser uma inovação incremental.

Portanto, considera-se que a "inovação tecnológica no processo de produção de edifícios", seja o resultado positivo de um processo de implantação de TCR's no sistema produtivo de uma empresa construtora atuante no mercado.

Para que tenha maiores chances de sucesso, esse processo de implantação deverá ser adequadamente conduzido no interior da empresa construtora. Por isso, busca-se, neste capítulo, identificar as diretrizes fundamentais que devem nortear a implantação de uma inovação tecnológica, a fim de que se possa propor uma metodologia adequada para a condução desse processo.

Essa identificação será realizada através de dois mecanismos: pela análise e compreensăo dos modelos propostos na literatura, para se concretizar uma inovação tecnológica, tanto na indústria seriada como na indústria da Construção e pela análise de experiências pessoais na condução de implantações de TCR's em empresas construtoras.

\subsection{A Inovação Tecnológica na Indústria Seriada}

O processo de inovação tecnológica não é algo de simples ocorrência, o que é confirmado por ALMEIDA [1981], ao citar as palavras de Morton (1966) descrevendo o sistema de desenvolvimento tecnológico utilizado pela Bell Telephone Co.: "a inovação não é uma açăo simples, mas um processo global composto de partes ligadas entre elas. Não é somente a descoberta de um 
caracterizar o que é a inovação tecnológica e o que significa para a economia de um país e para a sobrevivência das empresas.

Os modelos estudados têm diversas características em comum. Entretanto, por uma questão didática, procurou-se agrupar a apresentação desses modelos segundo suas características principais. Assim, foram agrupados em quatro conjuntos, assim identificados:

- modelos que enfocam a solicitação de mercado como diretriz para a inovação;

- modelos que destacam a integração dos diversos departamentos funcionais como diretriz para a implantação;

- modelos que enfocam a gestão da inovação; e

- modelos que apresentam algumas outras diretrizes mais genéricas, porém, fundamentais para a condução do processo.

Ao final desse item, faz-se uma análise crítica acerca dos modelos propostos procurando identificar os pontos fundamentais de cada um, e que poderão contribuir para a proposição da metodologia para implantação de TCR's em empresas construtoras de edifícios.

\subsubsection{Modelos com enfoque para o mercado}

TWISS [1974] defende a inovação tecnológica como sendo um processo de conversão, não apenas orientado ao produto simplesmente, mas sim, orientado ao mercado, ou seja, deve haver a preocupação em se produzir de modo a satisfazer as exigências e desejos dos clientes. Assim, o processo de inovação deverá considerar esses elementos desde o inicio, o que fica bem ilustrado pela figura 4.1, proposta por esse autor.

BARATELLI JR. et al. [1994] também deixam clara a interferência das condicionantes de mercado no processo de inovação ao utilizarem a proposição de Ed Roberts (1988) como um modelo de processo inovatório multiestágio, aplicado às indústrias de bens de consumo, ilustrado na figura 4.2. 


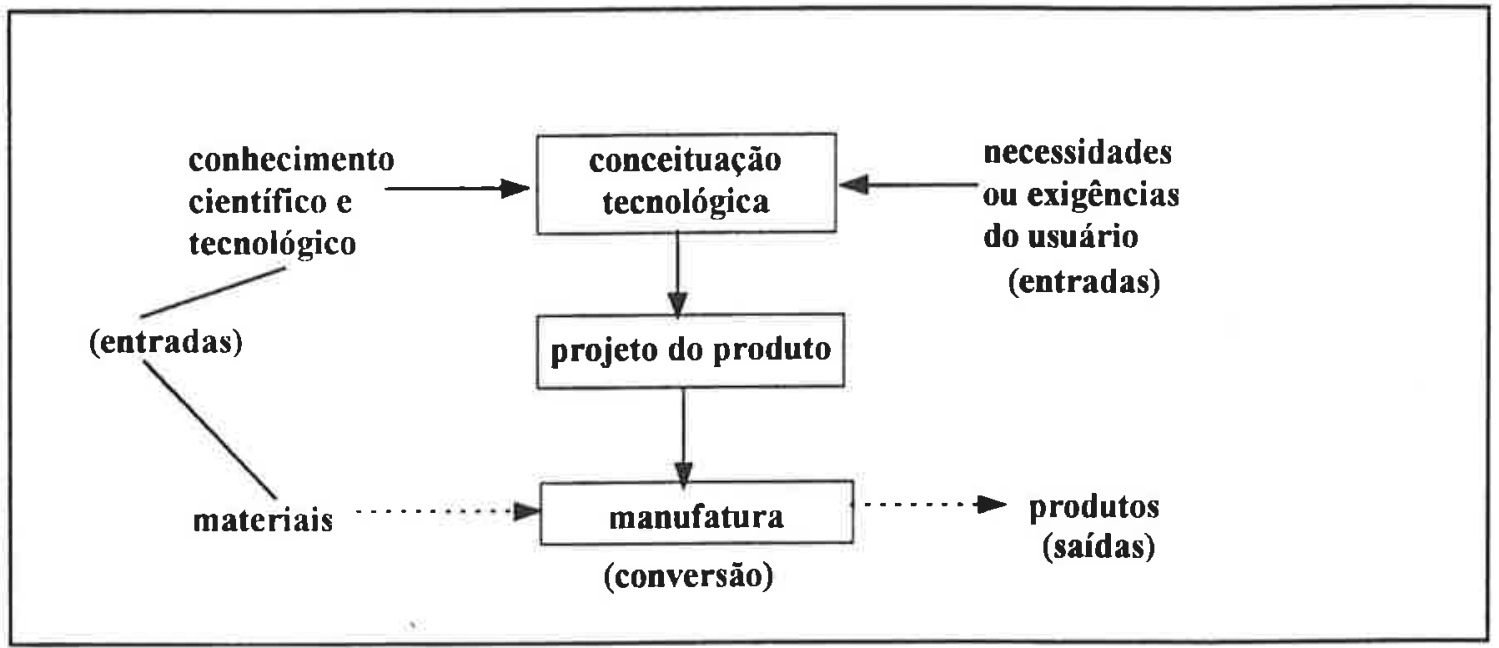

FIGURA 4.1: Inovação tecnológica como um processo de conversão orientado pela relação "tecnologia/mercado" [adaptado de TWISS, 1974]

BARATELLI JR. et al. [1994] salientam que embora o processo de inovação seja conduzido comumente dentro de uma organização de pesquisa, ele tem grande interação com o mercado, e com o sistema tecnológico fora da organização. Nesse modelo, fica explícita, ainda, a idéia de que a inovação pode ter início ou com uma demanda de mercado ou com uma oportunidade tecnológica, mas, em ambos os casos, o objetivo final é atingir o mercado, dando destaque às etapas de desenvolvimento comercial e fabricação.

SBRAGIA; BARRA [1994] analisando o esforço de inovação de nove empresas latino-americanas, de diferentes tamanhos e setores industriais, os quais incluiam indústrias do setores químico, metalúrgico e óptico, destacam que o papel do avanço tecnológico e das forças de mercado podem ter pesos distintos em função do porte das empresas.

Segundo esses pesquisadores, o que estimula a inovação nas pequenas empresas são as solicitações dos clientes, a globalização de mercado e os fatores ecológicos.

Nas empresas de médio porte, a competitividade no mercado mundial, aliada aos padrões internacionais de qualidade são os principais fatores responsáveis pelos investimentos em inovações tecnológicas. Para as organizações inovadoras de grande porte o que tem grande peso é o fator 
evolução tecnológica, que leva a "investimentos crescentes em modernização, objetivando-se alcançar estágios mais avançados de desenvolvimento".

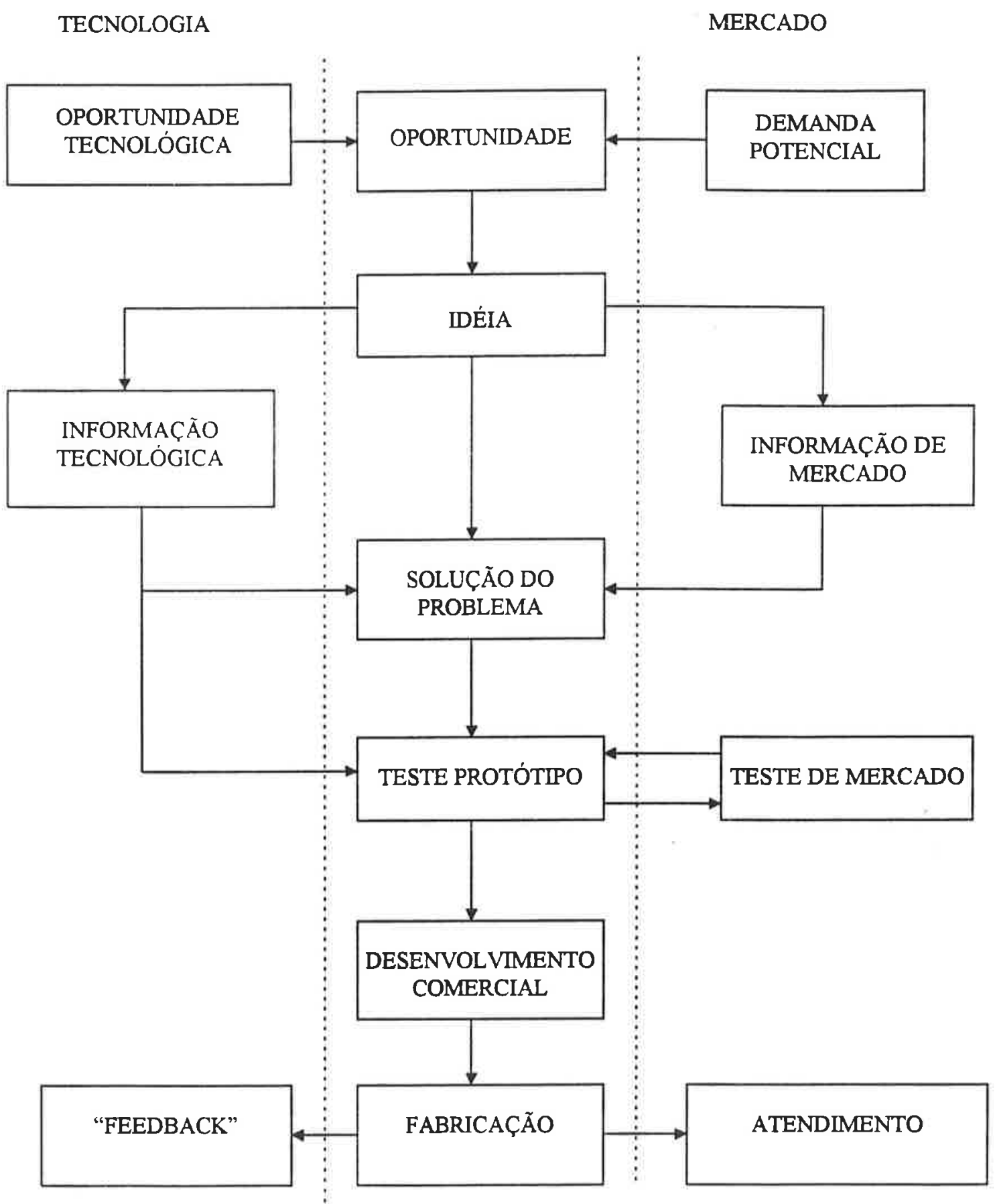

FIGURA 4.2: Processo multiestágio da inovação [BARATELLI JR. et al., 1994] 
SBRAGIA; BARRA [1994] identificaram que as pequenas empresas, comumente, não possuem pessoal próprio para realizar o desenvolvimento tecnológico, organizando-se mais na forma de parcerias com universidades e com outros centros de pesquisa; enquanto nas grandes organizações, apesar de também haver forte parceria com universidades, no mínimo $50 \%$ do pessoal destinado à pesquisa pertence à empresa.

\subsubsection{Modelos que envolvem a integraçāo entre os departamentos funcionais da empresa}

EDOSOMWAN [1989] afirma que a inovação pode ser vista como um processo "interfuncional", que consiste na forte relação de três áreas funcionais fundamentais na empresa:

- pesquisa e desenvolvimento - a área que cria;

- manufatura - a área que produz;

- "marketing" - a área que vende

O modelo do processo de inovação proposto por esse pesquisador tem como princípio que: "a inovaçăo inicia por uma idéia nova que é influenciada por algum evento decorrente de condições internas ou externas e, a operação das condições ambientes estimulam a memória, inteligência e experiência do inovador".

O departamento de pesquisa e desenvolvimento (P\&D) que aparece na proposição de EDOSOMWAN [1989] também está presente na proposição de COOMBS et al. [1987]. No entanto, esses últimos autores afirmam que: "estabelecer as atividades e os departamentos voltados à pesquisa, ao desenvolvimento (P\&D) e ao planejamento pode criar mais problemas do que resolvê-los, pois geralmente confronta-se com uma série de indefinições e falta de objetivos da empresa".

Para COOMBS et al. [1987], o departamento de P\&D deve funcionar coordenado com os demais departamentos da empresa, considerando-se as mudanças no ambiente externo, como ilustra a figura 4.3. 


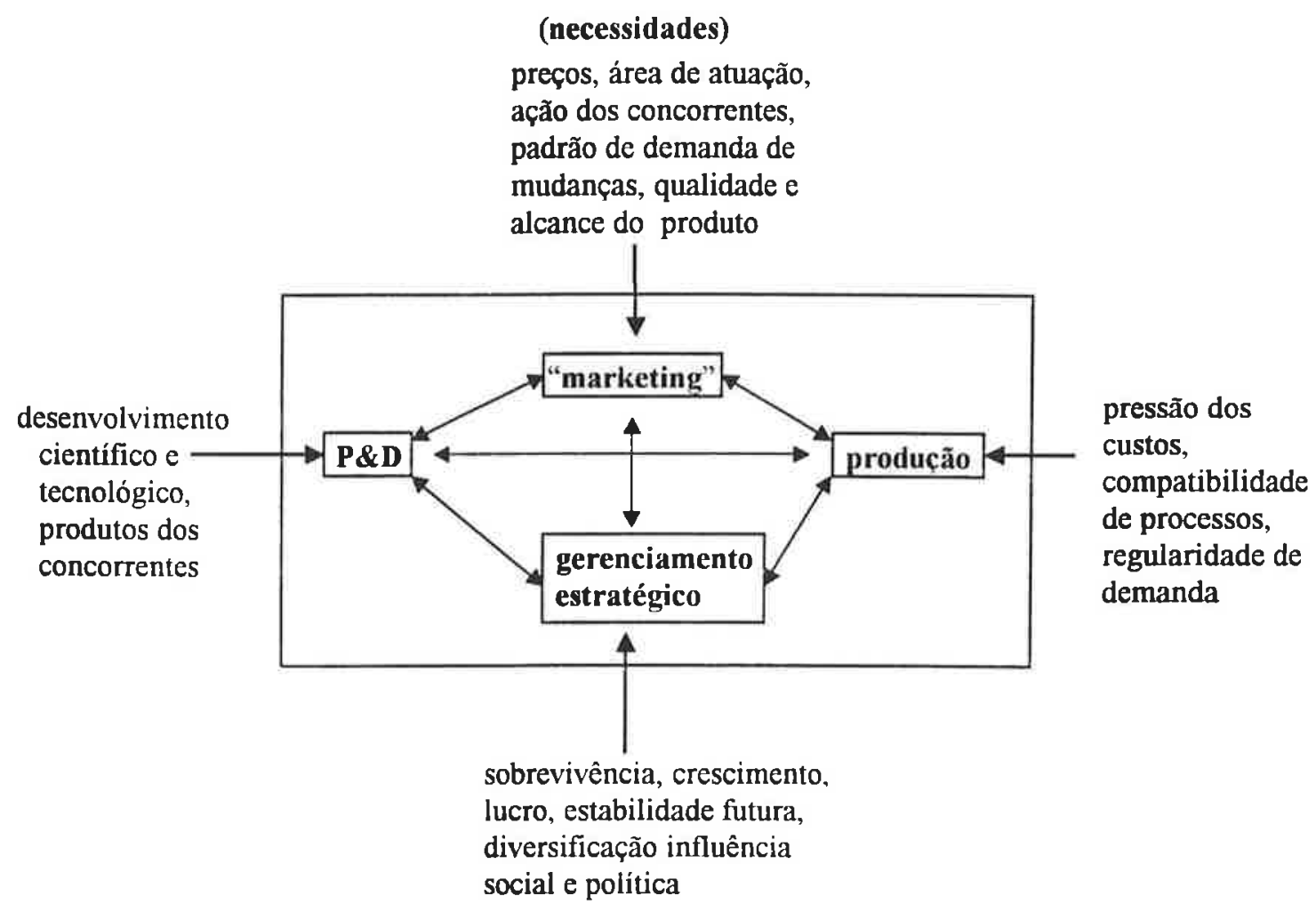

FIGURA 4.3: Modelo simplificado das relações entre a firma inovadora e o seu ambiente externo [COOMBS; et al. 1987]

A integração entre as diversas áreas da empresa com o seu entorno é explicitamente colocada por esses autores, como uma forma de viabilizar o desenvolvimento e a implantação de novas tecnologias.

SBRAGIA; BARRA [1994] também defendem a integração forte entre as funções "marketing", engenharia e P\&D, como uma forma de facilitar a troca de idéias e proporcionar um esforço simultâneo dos diferentes envolvidos em direção à inovação.

KRUGLIANSKAS; SBRAGIA [1995] destacam, de certa maneira, a integração departamental, aọ tratarem a inovação tecnológica em pequenas empresas brasileiras de diversos setores da indústria seriada.

Esses autores colocam como questão central, a dificuldade que se tem em assegurar um ritmo sustentado de inovações tecnológicas que permitam às pequenas empresas, especialmente aquelas dos setores mais tradicionais, manterem-se competitivas. Segundo os autores, "as grandes empresas, entre 
outras estratégias, têm implantado unidades dedicadas à Pesquisa e Desenvolvimento - P\&D (...) porém, as Pequenas e Micro Empresas Industriais PMEl's - não possuem, por via de regra, condições para manterem este tipo de unidade organizacional".

Para essas empresas os autores propõem uma alternativa organizacional denominada Função Tecnológica - "FT", a qual "consiste em superpor, à estrutura organizacional da empresa, uma estrutura transdepartamental que permite uma alta interação e integração voltada, de forma seletiva, às atividades relacionadas com a inovação tecnológica". Essa forma de organização é ilustrada na figura 4.4

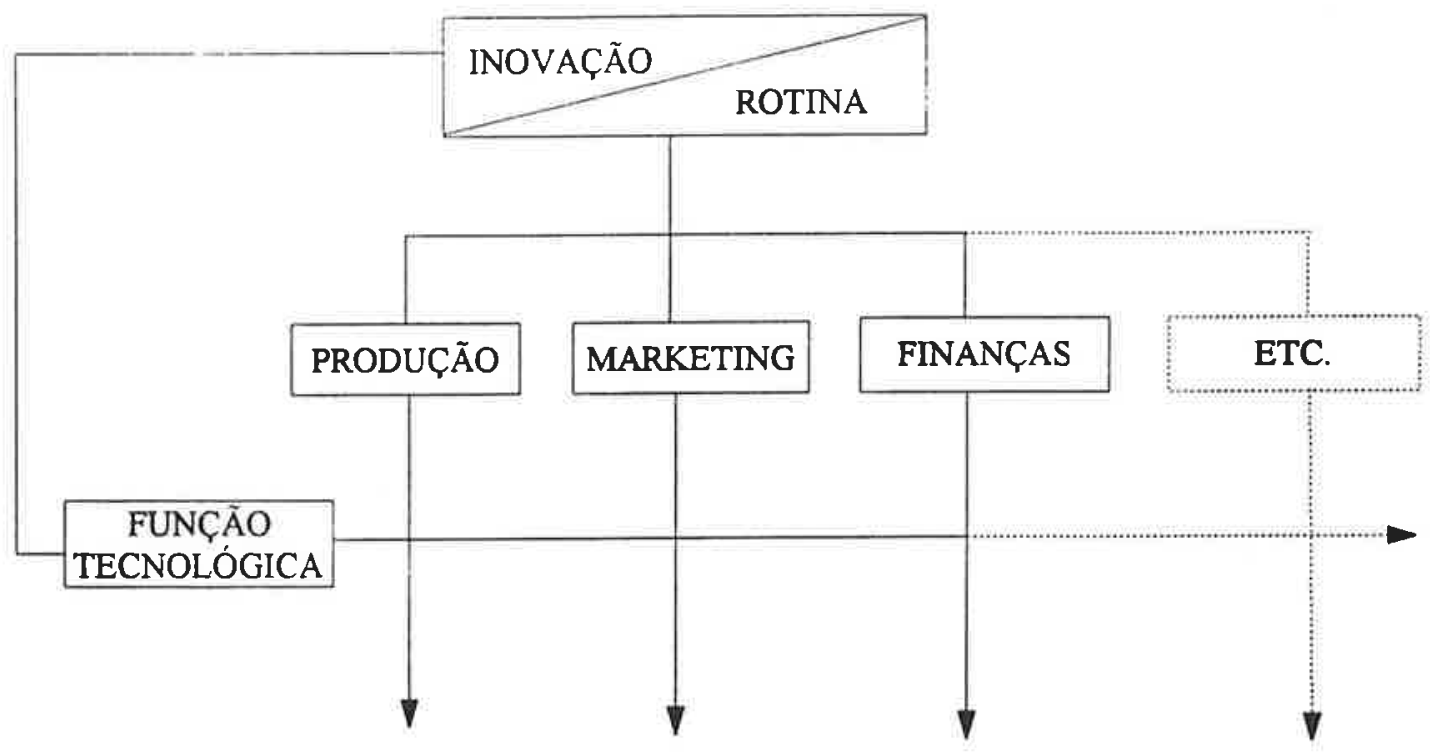

FIGURA 4.4: Estrutura da Função Tecnológica ("FT") utilizada no estudo de KRUGLIANSKAS; SBRAGIA [1995]

A aplicação desse mecanismo organizacional foi analisada para dez empresas do setor da indústria seriada, as quais haviam recebido algum tipo de capacitação prévia sobre o conceito e a operação da FT.

KRUGLIANSKAS; SBRAGIA [1995] estudaram a forma de operação da FT nessas empresas, os impactos que produz na organizaçāo e os fatores condicionantes à sua eficácia. Desse estudo, pôde-se identificar alguns elementos fundamentais, aqui destacados: 
- a necessidade de existirem responsáveis pela condução da FT, em todos os setores da empresa, sendo que essas pessoas devem estar constantemente motivadas à continuidade do processo;

- a exigência de apoio constante da direção da empresa, sendo ainda desejável que a alta administração adote um estilo mais informal e descentralizado, quando atuando no âmbito da FT;

- a dificuldade de retroalimentação dos resultados, aos funcionários da empresa. Essa condicionante da FT, segundo os autores, mostrou ser um grande desafio a ser superado: "para que a FT seja implantada na empresa, é fundamental que haja comunicação interna sobre as atividades e resultados alcançados";

- a visão da FT como elemento complementar, e às vezes facilitador, para a introdução de outros aprimoramentos organizacionais que estavam sendo desenvolvidos pela empresa;

- o maior aproveitamento das idéias mais simples. As sugestōes envolvendo gastos mais significativos, em geral, não foram implantadas.

Concluindo, os autores destacam que: "a FT, do modo como é concebida, tem se mostrado um instrumento que facilita a implantação de inovaçōes nas PMEl's, na medida em que propicia condições favoráveis para divulgar novos conceitós e conhecimentos, bem como reduz as resistências a mudanças".

KRUGLIANSKAS; SBRAGIA [1995] ressaltam, que "as pequenas empresas, ao se concentrarem na implantação de outras inovações, especialmente as de caráter gerencial, podem ser levadas a reduzir ou até mesmo a abandonar as atividades relacionadas com a $\mathrm{FT}$, o que pode constituir um equivoco, pois, se adequadamente operada, a FT produzirá sinergia para a implantação de inovações na empresa".

Um outro aspecto relevante apontado pelos autores é que "depois de certo período de funcionamento regular da $\mathrm{FT}$, ela tende a se tornar mais informal e a se desestruturar, não funcionando mais com a regularidade inicialmente estabelecida. Esse efeito, segundo os autores, pode ser causado pelo fato de que as atribuições da FT são muito restritas e abstratas, na medida em que se 
limitam a estimular e registrar sugestōes para inovações. Para reverter isso, os autores sugerem que se ampliem suas atribuições, de modo que ela possa criar metas e objetivos que se integrem melhor com a estratégia da empresa.

\subsubsection{Modelos que envolvem a gestão do processo de inovação}

Do trabalho de ZAWISLAK [1995], pôde-se depreender que o processo de implantação de inovações tecnológicas está intimamente relacionado ao processo de "gestão tecnológica da empresa". Esse autor propōe que toda e qualquer empresa, com maior ou menor capacitação tecnológica, deverá gerenciar o conteúdo tecnológico, mais ou menos complexo, de seu processo produtivo a fim de:

- manter o bom funcionamento dos processos de inovação tecnológica já estabelecidos;

- levar empresas, cujos processos de inovação tecnológica parecem estar aquém de suas necessidades, a patamares superiores de organização; e

- adequar cada tipo de empresa e de processo produtivo a um tipo específico de organização da atividade produtiva.

Segundo ZAWISLAK [1995], "a gestão tecnológica deverá lidar com as maneiras de se realizar o próprio processo de inovação, com a estratégia envolvida nesse processo, com a possibilidade de transferir tecnologias, com a gestão da qualidade, com a longevidade dos processos e dos produtos, com as oportunidades tecnológicas que se abrem às empresas, com o estado-da-arte, etc."

Dentro desse processo de gestão tecnológica, ZAWISLAK [1995] destaca a atividade de documentação e registro das experiências da empresa, como uma forma efetiva de se chegar a uma independência gradativa das fontes externas de tecnologia, sendo que, segundo esse autor, o balanceamento entre fontes externas e internas tende a pender para o lado interno, quanto mais uma empresa se organizar.

SBRAGIA; BARRA [1994], por sua vez, identificaram que a participaçāo efetiva da alta administração e a existência de um sistema eficaz de informações ge- 
renciais e técnicas, que garanta a tomada de decisões com maior nivel de segurança, são condições essenciais para que ocorra o processo de inovação.

\subsubsection{Outras diretrizes para a condução do processo de implantação}

\section{- diretrizes estratégicas}

Muitos autores vinculam a implantação de inovaçōes tecnológicas à definição estratégica da empresa. Um desses autores é TWISS [1974], que tem por princípio que os investimentos destinados à inovação tecnológica somente podem ser justificados se a exigência de inovação estiver presente na estratégia da empresa.

Analisando o sucesso ou o fracasso de diversas situações envolvendo a implantação de novas tecnologias, esse autor conclui que a inovação tecnológica decorre de uma complexa interação de uma série de elementos essenciais, apontando como principais:

- a orientação para o mercado;

- a relevância nos objetivos da empresa;

- uma empresa receptiva a inovaçōes;

- uma efetiva seleção de tecnologias e avaliação dos sistemas;

- uma fonte de idéias criativas;

- comprometimento de uma pessoa ou um grupo de pessoas;

- um efetivo gerenciamento e controle do projeto.

PARKER [1985] também destaca as diretrizes estratégicas como fortes aliadas para remover as barreiras que comumente existem ao se tentar implantar novas tecnologias. Segundo esse autor, "as barreiras deverão ser transpostas por quem detém o poder dentro da empresa, usando a sua autoridade dentro da organização, para levar adiante uma idéia nova".

Os resultados de KRUGLIANSKAS; SBRAGIA [1995], anteriormente apresentados, também demonstram que para conduzir o processo de implantação de novas tecnologias com sucesso é imprescindível a participação da alta gestão e uma definição estratégica da empresa. 
- diretrizes que visam a informação e a comunicação interna da empresa

PARKER [1985] enfatiza a dependência do crescimento da empresa em relação a informação. Segundo esse autor, para o estabelecimento de suas diretrizes estratégicas, a empresa deverá considerar tanto os seus competidores como os fatores ambientais. $E$, neste contexto, a informação é o pré-requisito básico no processo de crescimento.

KRUGLIANSKAS; SBRAGIA [1995] também destacam a comunicação interna na empresa, como um importante elemento para a inovação, ou seja, o sistema de comunicação da empresa precisa ser pensado para trabalhar a favor da implantação, permitindo que todos os níveis hierárquicos da empresa possam trocar informaçōes.

- diretrizes que visam a motivação pessoal e o treinamento

Outros autores colocam a questão da motivação das pessoas como uma diretriz fundamental para o processo de implantação, como é o caso de CRESSEY; MARTINO [1991], que vêem a tecnologia como uma ferramenta que tem forte relacionamento com diferentes agentes de mercado e dentro da própria empresa. E, dentre essas diferentes relações, destacam a questão da "participação individual" ou de "grupo", como elemento essencial para o sucesso da implantação de novas tecnologias.

DAVIS [1986] também defende a motivação ao afirmar que: "é extremamente difícil obter sucesso em P\&D quando os indicadores de qualidade de vida no trabalho, na organização, não são considerados". Em seu trabalho, esse autor destaca algumas práticas estratégicas voltadas à melhoria das condiçōes de vida dos recursos humanos na empresa.

A motivação está expressa também no modelo de KRUGLIANSKAS; SBRAGIA [1995], ao proporem a implantação de novas tecnologias, via a Função Tecnológica.

RODRIGUES et al. [1994], por sua vez, trabalhando com inovaçōes tecnológicas em quatro setores industriais: têxtil, de alimentos, de confecçōes e eletroeletrônico num total de trinta empresas identificaram que: "com exceção de 
quatro empresas, todas as outras oferecem alguma forma de treinamento para o seu pessoal; o treinamento de operários é quase sempre dado dentro da empresa, enquanto o treinamento de gerentes e supervisores, geralmente, acontece fora; apenas $10 \%$ das empresas não oferecem programa de beneficios para seus empregados".

Esses pesquisadores afirmam, ainda, que: "a pouca valorização para o desenvolvimento e o treinamento de pessoal é uma condiçāo desfavorável para o processo de inovação".

BURATI JR. et al. [1992] também destacam que o treinamento no processo de implantação de inovações tecnológicas é imprescindivel e propōem alguns elementos importantes no esforço para a sua realização:

- o treinamento não deve se limitar aos aspectos técnicos, mas deve se estender ao comportamento humano;

- o treinamento é um trabalho essencial e todos devem estar envolvidos nesse esforço;

- deve ser realizado pelos gerentes e acompanhados cuidadosamente por aqueles que estão sendo treinados;

- o esforço do treinamento deve ser medido pelo grupo que está sendo treinado. Os objetos de estudo e exemplos devem ser relevantes ao seu particular trabalho;

- o treinamento deve ser complementado com material escrito ou visitas;

- a gerência deve mostrar o seu compromisso com o programa de treinamento através de sua participação ativa e suporte;

- o esforço de treinamento não deve decair durante uma situação de crise;

- métodos e técnicas desenvolvidos através do esforço do treinamento deveriam ser aplicados ao trabalho o mais rápido possivel

- o treinamento deve seguir um planejamento especifico e sua implementação e efetividade devem ser cuidadosamente verificados.

- deve ser iniciado com um limitado número de grupos piloto, os quais foram cuidadosamente selecionado pelo grupo de planejamento; 
- as ações de sucesso do grupo piloto devem ser utilizadas para alimentar o próximo esforço de treinamento.

\subsubsection{Análise das propostas voltadas à indústria seriada}

Os modelos propostos para a implantação de inovações tecnológicas na indústria seriada, ainda que fossem completamente detalhados, dificilmente poderiam ser aplicados diretamente à indústria da Construção Civil, sobretudo pelas particularidades dessa frente àquela indústria.

A maioria dos modelos apresentados pressupõe a existência de um departamento de pesquisa e desenvolvimento.

Segundo SBRAGIA; BARRA [1994] esse departamento não precisa ser interno à empresa, pois nos casos em que as empresas não podem arcar com a montagem do seu próprio departamento, acabam por desenvolver parcerias junto às universidades e aos centros de pesquisa.

Seja através de desenvolvimento interno ou através de parcerias, a indústria seriada realiza investimentos em atividades voltadas à $P \& D$, ainda que estes sejam pouco expressivos, se comparados aos realizados por outros paises, como ilustra a tabela 4.1 .

TABELA 4.1: Despesas com C\&T/P\&D por fonte de financiamento (governo e indústria) e relação DNTC/PIB. [ZAWISLAK, 1995].

\begin{tabular}{|l|c|c|c|}
\hline \multicolumn{1}{|c|}{ PAÍS } & GOVERNO (\%) & INDÚSTRIA (\%) $^{\text {DNCT/PIB (\%) }}$ \\
\hline Coréia do Sul & 19,0 & 81,0 & 1,8 \\
\hline Japão & 21,3 & 78,7 & 2,8 \\
\hline Alemanha & 35,3 & 64,2 & 2,7 \\
\hline Inglaterra & 39,8 & 60,2 & 2,4 \\
\hline Canadá & 44,7 & 55,3 & 1,3 \\
\hline Estados Unidos & 50,5 & 49,5 & 2,7 \\
\hline França & 52,9 & 47,1 & 2,3 \\
\hline Itália & 54,9 & 45,1 & 1,3 \\
\hline Brasil & $\mathbf{8 3 , 8}$ & $\mathbf{1 6 , 2}$ & $\mathbf{0 , 5}$ \\
\hline
\end{tabular}

(*) DNCT: Despesa Nacional com Ciência e Tecnologia

PIB: Produto Interno Bruto 
A análise dos dados apresentados na tabela 4.1 , deixa claro que, além do Brasil investir pouco em P\&D, frente aos demais paises, o investimento que é feito, na sua maioria, não provém do setor industrial, mas sim de incentivos governamentais. Isto contrasta significativamente com os demais paises, que além de terem um maior investimento em $P \& D$, esses são provenientes, em grande parte, do próprio setor industrial.

Se os investimentos na indústria de bens de consumo são considerados reduzidos, é pior a situação na indústria da Construção de Edifícios, no Brasil. Tal setor industrial opera quase que exclusivamente com empresas de médio e pequeno porte, com capital exclusivamente nacional e com pouquissimos recursos destinados ao desenvolvimento tecnológico.

Há, além disso, uma pulverização das atividades entre um grande número de pequenas empresas, especializadas por serviços e, também, um grande número de participantes no processo de produção, havendo, por conseqüência, maior limitação de recursos individuais, para investimentos específicos em P\&D.

Além de partirem de um pressuposto ainda distante da indústria da Construção de Edifícios, os modelos estudados no item 4.2 contêm diretrizes genéricas, enfocando, na maioria das vezes, questões conceituais envolvendo o processo de implantação e não aquelas de ordem estratégica e tática, que permitiriam conduzir efetivamente a implantação no interior de uma empresa.

TWISS [1973], em seu modelo, por exemplo, deixa expressa a necessidade de um projeto que incorpore o desenvolvimento tecnológico, a fim de se dar entrada ao processo de manufatura; n, entanto, o autor trata o assunto segundo uma abordagem conceitual e não apresenta os passos operacionais para a viabilização da entrada desse novo projeto no processo de manufatura e sabese que este é o momento mais difícil não apenas no caso da Construção de Edifícios, mas para uma expressiva parcela dos setores industriais.

O modelo proposto por BARATELLI JR. et al. [1994] está mais afeito à inovação de produto e não se encontra detalhado. Os autores apresentam como 
etapa operacional, apenas o teste em protótipo, que eventualmente poderá ocorrer num ambiente de mercado. No entanto, não enfatizam sob quais condiçōes este teste deverá ser realizado e como os resultados obtidos poderão realimentar o processo de inovação.

Vale destacar, ainda, que a participação e o comprometimento da alta gerência no processo de implantação aparece explícita ou implicitamente em todas as colocações anteriormente apresentadas. Com isto, pode-se concluir que nas empresas da indústria seriada, assim como na indústria da Construção de Edifícios, a função tecnológica não pode estar desvinculada da estratégia da empresa, senão, tende a desaparecer.

Finalmente, dos estudos realizados anteriormente, pode-se concluir que o processo de inovação tecnológica no contexto de uma indústria, deverá ser conduzido pelas seguintes diretrizes:

de ordem estratégica: participação e comprometimento da alta administração e, o desenvolvimento ou a busca de novas tecnologias, voltadas ao mercado;

de ordem operacional: incorporação das novas tecnologias ao "projeto que subsidia a produção" e, a execução e avaliação de protótipos.

\subsection{A Inovação Tecnológica na Indústria da Construção Civil}

A bibliografia que trata da inovação ou mudança tecnológica na indústria da Construção Civil não é tão extensa como a que se refere aos outros setores industriais; no entanto, existem pesquisadores que vêm estudando essa questão de maneira sistemática.

Ainda que pareça um assunto recente nesse setor industrial, não o é, como pode ser identificado pelo prefácio do Segundo Congresso do $\mathrm{CIB}$, realizado em Amsterdam, em 1962, assinado pelo presidente do Congresso, que afirma: "as construções de edifícios têm passado por um período de mudanças mais rápidas do que vinha ocorrendo em tempos anteriores. Novos materiais, novos 
sistemas estruturais e novos métodos de construção têm surgido a partir do avanço em ciência e tecnologia. Sua adoção tem sido, e está sendo, estimulada por pressões econômicas na indústria, para incrementar sua produtividade e ter a mesma velocidade de avanço dos outros setores industriais. crescimento gradual, que todas as nações almejam, no padrão de vida e os novos requisitos de desempenho exigidos pelos usuários estão incrementando e alterando a demanda na indústria da Construção." [LEA, 1962].

Nesse mesmo prefácio, o presidente do CIB destaca alguns elementos de reflexão para o processo de inovação na indústria da Construção Civil, os quais estão reproduzidos na seqüência:

- "se o caminho da inovação está sendo aplainado, precisamos entender as forças que a induzem e os obstáculos que podem impedir a aplicação de novos conceitos: os edifícios são construídos pelo trabalho individual de homens, treinados em diferentes ofícios e por um trabalho coletivo de uma organização empresarial. Nós precisamos conhecer as mudanças que as inovações trazem no modelo de trabalho e na sua forma de organização e perceber como estes podem ser trazidos mais suavemente para uma aplicação efetiva";

- "o projetista tem estado atento tanto para as novas demandas dos seus clientes quanto para os novos meios disponiveis para satisfazê-las. As exigências e os anseios dos usuários devem ser identificadas e expressas de modo que sejam significativas para o projetista; novos desenvolvimentos devem ser avaliados em relação à sua qualidade, adequação ao propósito e validade econômica";

- "o conhecimento de novos desenvolvimentos deve ser transferido àqueles que se relacionam com a construção para que a sua adoção seja assegurada".

As colocações anteriores mostram que é preciso ter um completo entendimento das forças que induzem e que inibem a inovação tecnológica no setor. De modo geral, são destacados como elementos imprescindiveis à inovação: a completa integração entre a organização empresarial e aqueles que 
concretizam essa inovação no canteiro de obras; as responsabilidades do projeto e do projetista ao procurarem integrar as necessidades dos clientes com as disponibilidades tecnológicas; e a transferência das novas tecnologias para toda a empresa, como uma forma de assegurar a efetivação da inovação.

Apesar de terem se passado mais de três décadas, esses temas continuam vivos e presentes nos dias atuais, deixando transparecer que não se caminhou muito no processo de desenvolvimento tecnológico, ao menos no Brasil; pois, junto a um cenário de grandes modificações pelas quais o setor vem passando, as preocupações européias, da década de 60 , voltam a ser discutidas, no Brasil, no fim da década de 90.

E hoje, tem-se presente na economia e na sociedade, tanto no Brasil, como em outros países, elementos propícios à introdução de inovações que levem à evolução do processo de produção de edifícios.

Segundo os pesquisadores chilenos, GHIO; BASCUÑÁN [1995] as principais condições, favoráveis à introdução de mudanças tecnológicas, são:

- estabilidade de mercado, por favorecer o crescimento industrial;

- fácil acesso à informação, tanto através dos fabricantes de materiais, componentes, equipamentos e ferramentas, como através da área científica, citando o fácil acesso à Internet;

- maior competitividade, em função da abertura de mercados;

- demanda por menores prazos e custos;

- demanda por qualidade, fazendo com que se busque incorporar novas tecnologias e melhorar a efetividade dos métodos construtivos;

- demanda por redução do impacto ao meio ambiente, imposta pela legislação.

É preciso possibilitar uma evolução tecnológica na produção dos edifícios; e, para isso, é preciso criar uma sistemática de trabalho que auxilie as empresas nessa "empreitada".

Para que se possa propor uma metodologia que seja eficiente às empresas que procuram essa evolução, busca-se apresentar e discutir, na seqüência, 
alguns dos modelos propostos por outros pesquisadores objetivando a implantação de novas tecnologias na Construção Civil.

\subsubsection{Modelo que envolve o processo de desenvolvimento tecnológico}

SABBATINI [1989] apresenta uma metodologia para o desenvolvimento de métodos, processos e sistemas construtivos (MPSConst.), na qual fica demonstrada que a fase de implantação é fundamental para a concretização do processo de desenvolvimento.

A sua proposta, ilustrada na figura 4.5, mostra que o resultado do desenvolvimento, para ser considerado uma inovação tecnológica, deve ser efetivamente implantado no mercado, o que significa existirem as etapas 9 a 12 da proposta, ou seja: as etapas de divulgação; construção em escala piloto; aperfeiçoamento da tecnologia e construção em escala de mercado.

Essas etapas, nesse modelo de desenvolvimento são agrupadas numa fase denominada pelo autor de ciclo de aperfeiçoamento da tecnologia.

O ciclo de aperfeiçoamento, melhor detalhado na figura 4.6, é constituido por um fluxo interativo, que se inicia logo após a etapa de consolidação da tecnologia (etapa 8), através da sua divulgaçăo ao mercado (etapa 9), envolvendo tanto a parte técnica, como a parte comercial. Segundo SABBATINI [1989], nessa fase, a participação dos pesquisadores envolvidos com o desenvolvimento é muito relevante, para que possam, a partir dos retornos obtidos, aperfeiçoar a tecnologia proposta.

Assim que a tecnologia esteja disponivel ao mercado, após a etapa de divulgação, SABBATINI [1989] propõe que a mesma seja empregada de maneira controlada, "em uma escala experimental, em condições de trabalho e em um ritmo de produçăo diferente da construção em escala industrial (...) para que a detecção das deficiências não causem problemas em niveis elevados e para que haja a possibilidade de efetivar as correções em tempo hábil". 


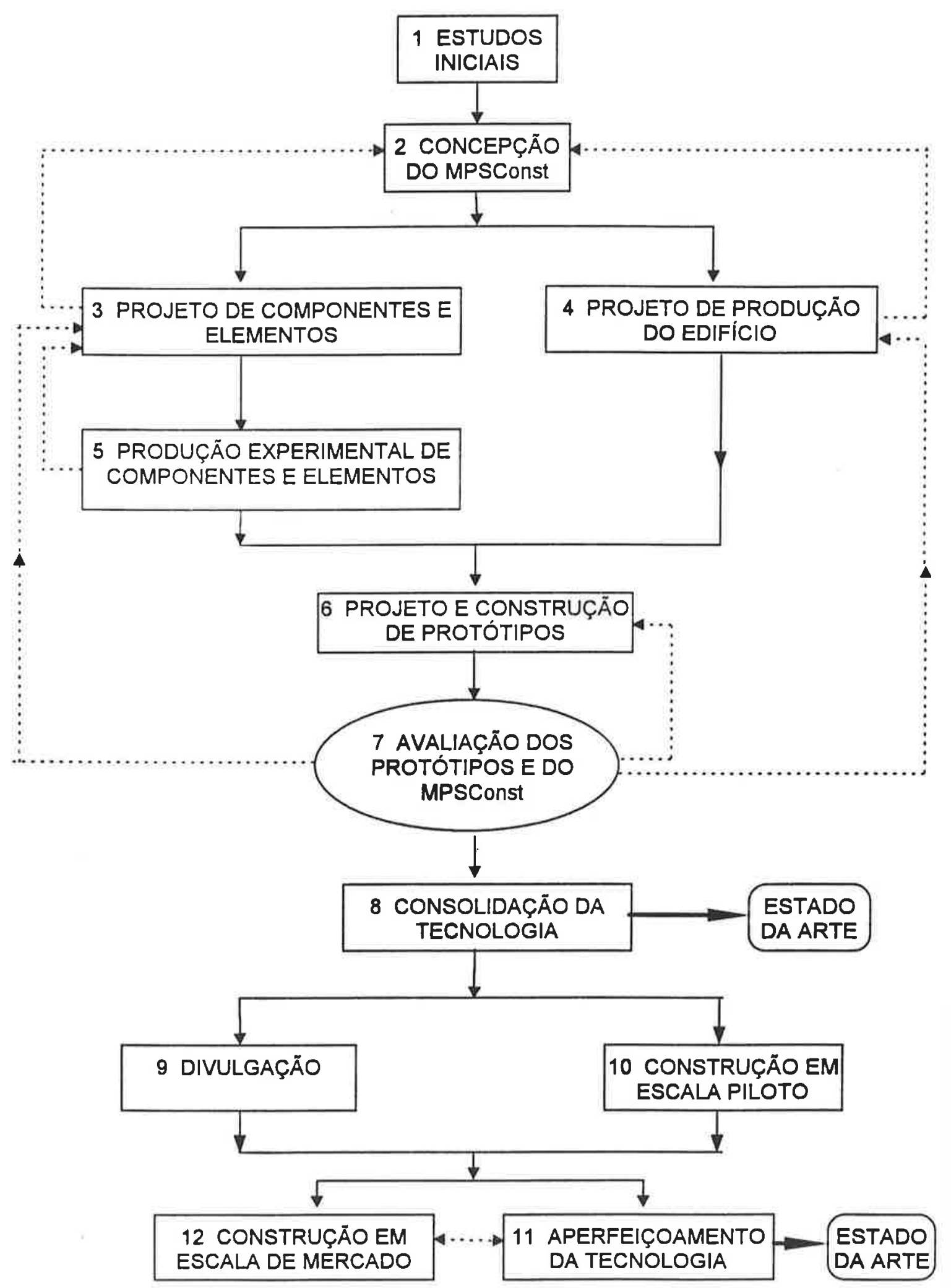

FIGURA 4.5: Ilustração das fases e etapas da metodologia para o desenvolvimento de MPSConst. proposta por SABBATINI [1989] 


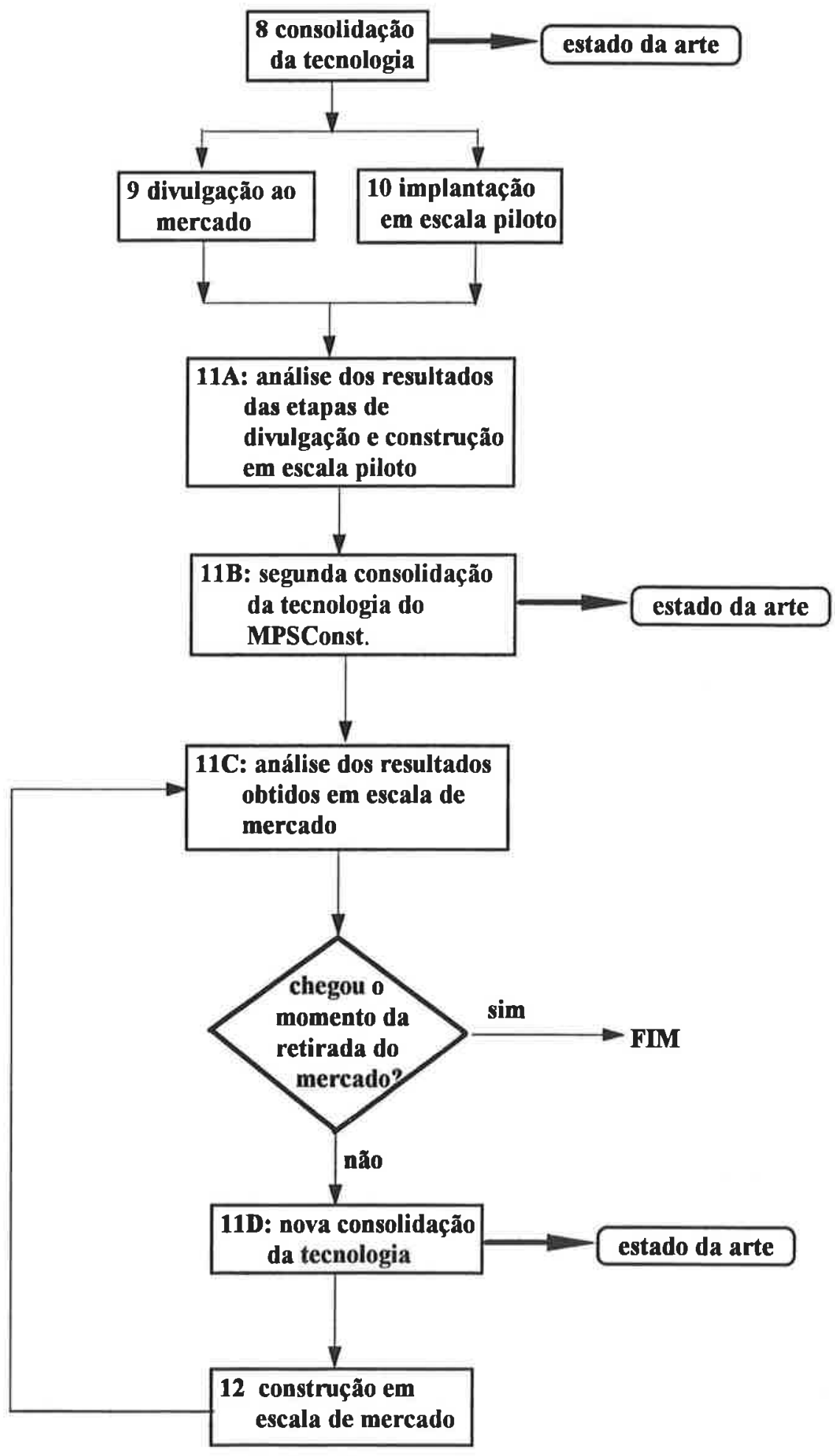

FIGURA 4.6: Fluxograma das etapas iniciais da transferência de tecnologias ao mercado adaptado de SABBATINI [1989] 
A etapa de implantação em escala piloto (etapa 10) gera as informações para que ocorra a etapa 11, de aperfeiçoamento da tecnologia, cujo objetivo é fazer a manutenção da tecnologia e promover a sua evolução. Essa é uma etapa que deve ser realimentada continuamente pelas avaliaçōes realizadas para cada aplicação, a fim de não deixar que a tecnologia torne-se obsoleta.

A fase final da proposta de SABBATINI [1989] constitui-se na disseminação da tecnologia para todo o mercado que, segundo o autor, justifica-se enquanto etapa do processo de desenvolvimento, na medida em que existe a etapa 11 para fazer a sua realimentação.

Dessa maneira, o ciclo de aperfeiçoamento contém, no seu interior, um outro ciclo fechado, constituído pela etapa de construção em escala de mercado (etapa 12) e subetapas $11 \mathrm{c}$ e $11 \mathrm{~d}$, o qual, segundo esse mesmo autor, é responsável pela contínua evolução da tecnologia e também, pela maximização da racionalização construtiva e alimentação do 'estado-da-arte' da tecnologia, até a sua retirada do mercado.

Uma análise cuidadosa da proposição de SABBATINI [1989] permite identificar que o processo de desenvolvimento pode ser associado ao processo de inovação tecnológica a ser empreendido por uma empresa construtora.

As etapas específicas de desenvolvimento da nova tecnologia não precisam ocorrer no âmbito da empresa. Elas podem se dar em um ambiente diferente, como por exemplo, em universidades, em institutos de pesquisa e desenvolvimento, em empresas de materiais, componentes e de equipamentos, a partir do que, as tecnologias estariam disponiveis.

No entanto, a partir do momento que a empresa passa a ter a informação sobre a existência das novas tecnologias, para evoluir tecnologicamente, deverá conseguir implantá-las em seu sistema produtivo. Deverá dar início a um processo de implantação, o qual, assim como o de desenvolvimento tecnológico, deverá envolver diversas etapas que permitam à empresa ir "aprendendo as novas tecnologias", conhecendo as suas características e efetivamente utilizando-as em seus canteiros de obras. 
Dessa maneira, fazendo-se uma analogia entre a proposiçāo de SABBATINI [1989], e o processo de implantação de TCR's em empresas construtoras, este último deverá envolver etapas e atividades que permitam:

- identificação da viabilidade de implantação de TCR's;

- planejamento do processo de implantação de TCR's;

- realização do projeto das TCR's visando a sua implantaçāo;

- aplicação experimental das TCR's, avaliando seus resultados;

- aplicação das TCR's em protótipos, avaliando seus resultados;

- consolidação e divulgação das TCR's na empresa.

Constitui-se num processo evolutivo pelo qual a empresa deverá passar, até que as inovaçōes tecnológicas sejam realmente incorporadas ao seu dia-a-dia.

O processo de implantação deverá envolver efetivamente a participação das empresas de construção de edificios, as quais deverão estar devidamente organizadas para a recepção das novas tecnologias.

\subsubsection{Modelos especificos para a implantação de inovações tecnológicas}

Os modelos para implantaçāo de inovaçōes tecnológicas, apresentados neste item, são constituídos, fundamentalmente, por diretrizes que deverão conduzir o processo de implantação, as quais estão presentes numa série de trabalhos, de diversos pesquisadores envolvidos com o tema.

Um estudo que deve ser destacado é o que vem sendo realizado por Clyde Tatum, um dos pesquisadores da Stanford University e membro da American Society of Civil Engineers (ASCE).

Esse pesquisador, a partir do estudo de inovações tecnológicas ocorridas em diversas empresas de construção civil, sobretudo de obras pesadas, afirma que as mudanças quanto às exigências dos usuários e a competição estrangeira no mercado de construção dos Estados Unidos vêm demandando a implantação de inovações tecnológicas [TATUM, 1984]. E, em um outro trabalho [TATUM, 1987], esse pesquisador propōe algumas diretrizes que devem conduzir o processo de inovação, as quais são ilustradas na figura 4.7. 


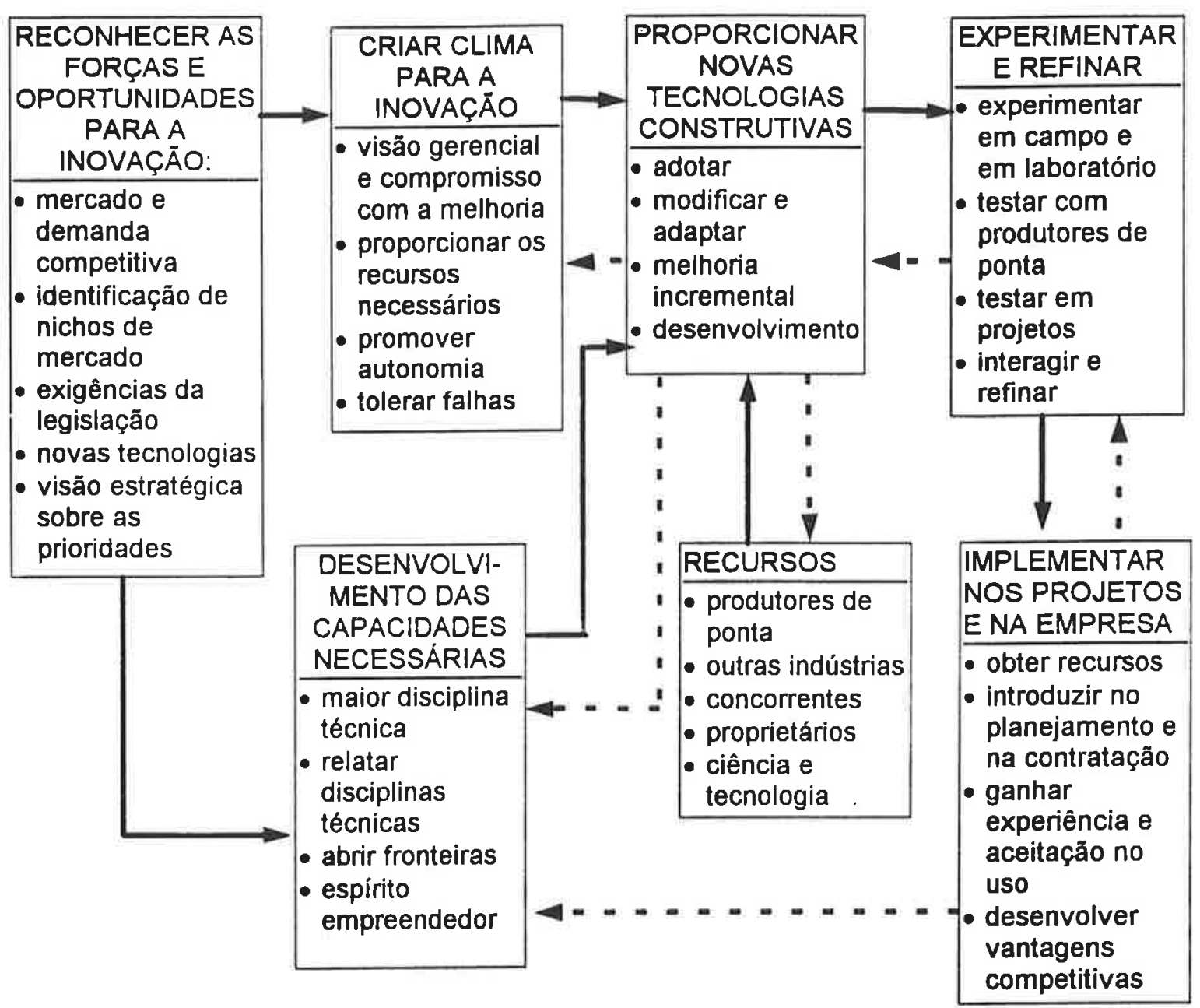

FIGURA 4.7: Processo de inovação em empresas de construção [TATUM, 1987]

LABORDE; SANVIDO [1994], por sua vez, fazem uma crítica ao modelo de implantação de inovações tecnológicas proposto por TATUM [1987]. Segundo esses autores, o modelo de TATUM [1987], devido à sua complexidade e ao número de papéis que é designado à pessoa chave, não deve ser utilizado para pequenas empresas.

E, a partir do estudo de seis casos bem sucedidos de inovação tecnológica aplicada à melhoria dos processos de produção, LABORDE; SANVIDO [1994], propõem algumas diretrizes para a implantação de inovaçōes tecnológicas em empresas de pequeno porte.

Os casos estudados pelos pesquisadores envolveram a implantação de sistemas de 3DCAD ("three dimensional computer-aided design"); um novo sistema 
de fôrmas trepantes; um método construtivo de estrutura do tipo "up-down" e o controle geométrico através de nivel "laser".

A maioria dos casos enfocados por LABORDE; SANVIDO [1994] tratam de inovações que rompem mais abruptamente com 0 antigo processo de construção, exceto no caso do controle geométrico por nivel "laser". Essa modificação, apesar de romper com a antiga forma de controle, trata-se de uma inovação restrita à algumas atividades no canteiro de obras, sendo, assim, uma de pequena amplitude e de mais fácil gerenciamento.

Segundo LABORDE; SANVIDO [1994], o que mais afeta o processo de inovação é o tamanho da empresa e o tipo de amplitude da inovação.

Quanto ao tamanho da empresa, segundo os autores, apesar de não ser uma barreira à inovação, há uma variação no processo de implantação, pelas implicaçōes na dinâmica da empresa, como ilustra a tabela 4.2.

TABELA 4.2: Influência do tamanho da empresa no processo de inovação tecnológica [LABORDE; SANVIDO, 1994].

\begin{tabular}{|c|c|c|}
\hline $\begin{array}{l}\text { fator } \\
\text { analisado }\end{array}$ & $\begin{array}{l}\text { pequena empresa } \\
\text { (empresa local) }\end{array}$ & $\begin{array}{l}\text { empresa de grande porte } \\
\text { (empresa nacional) }\end{array}$ \\
\hline $\begin{array}{l}\text { Risco } \\
\text { financeiro }\end{array}$ & $\begin{array}{l}\text { Elevado risco; desproporcional } \\
\text { porque não pode ser } \\
\text { amortizado no conjunto de } \\
\text { projetos. }\end{array}$ & $\begin{array}{l}\text { É possivel amortizar o risco em } \\
\text { um grande número de projetos. } \\
\text { Maior capacidade de encontrar } \\
\text { novas tecnologias. }\end{array}$ \\
\hline $\begin{array}{l}\text { Recursos } \\
\text { para P\&D }\end{array}$ & $\begin{array}{l}\text { Freqüentemente carecem de } \\
\text { técnicos qualificados e } \\
\text { recursos para suportar um } \\
\text { esforço formal de P\&D. }\end{array}$ & $\begin{array}{l}\text { Capaz de atrair equipes de } \\
\text { técnicos qualificados e podem } \\
\text { suportar departamentos de } \\
\text { P\&D. }\end{array}$ \\
\hline $\begin{array}{l}\text { Velocidade } \\
\text { de comuni- } \\
\text { cação inter- } \\
\text { na }\end{array}$ & $\begin{array}{l}\text { Rede de comunicação eficiente } \\
\text { e informal; rápida resposta a } \\
\text { problemas; fácil adaptação a } \\
\text { mudanças. }\end{array}$ & $\begin{array}{l}\text { Canais de comunicação } \\
\text { congestionados; vagarosa } \\
\text { reação a problemas; } \\
\text { implementação de mudanças } \\
\text { difícil e vagarosa }\end{array}$ \\
\hline $\begin{array}{l}\text { Estilo de } \\
\text { gerência }\end{array}$ & $\begin{array}{l}\text { Ausência de burocracia; } \\
\text { gerentes inovadores que } \\
\text { podem rapidamente tirar } \\
\text { vantagens de novas } \\
\text { oportunidades }\end{array}$ & $\begin{array}{l}\text { Processo de decisão } \\
\text { centralizado e aumento dos } \\
\text { níveis gerenciais; dificuldade } \\
\text { de comunicação; oculta } \\
\text { problemas e inibe mudanças. }\end{array}$ \\
\hline
\end{tabular}


No que se refere ao tipo e amplitude da inovação, os autores afirmam que, quando a inovação é aplicada a um particular empreendimento, fica restrita ao grupo, que, na maioria das vezes, deverá trabalhar com os recursos de orçamento afeitos a ele. Neste caso, são implementadas tecnologias que melhoram aquele empreendimento, esperando-se dele o retorno da implantação.

Nos casos em que a empresa tem por filosofia estar permanentemente inserida num ambiente inovador, é comum haver um departamento especifico, envolvido com as inovações; neste caso, os recursos e a equipe não são ligados a um particular empreendimento, aceitando-se retornos de mais longo prazo, que poderão se concretizar em obras futuras.

As diretrizes para implantação de inovações tecnológicas em empresas construtoras, propostas por LABORDE; SANVIDO [1994] são muito semelhantes às propostas por TATUM [1987]. Aqueles autores salientam, porém, que as suas diretrizes podem ser adaptadas ao emprego de uma situação específica, quando se deseja a resolução imediata de um problema particular, ou podem ser aplicadas num contexto maior, como ao direcionamento das ações de uma empresa que busque melhorar as práticas de negócios e manter-se competitiva no mercado.

DE LA GARZA; MITROPOULOS [1992], pesquisadores do Virginia Tech, Blacksburg, também associados do ASCE, propõem um modelo de transferência de tecnologia voltado à introdução de tecnologia de sistemas especialistas ("expert systems technology's"), o qual passa por três estágios distintos: identificação; avaliação e implementação, caracterizados a seguir e ilustrados na figura 4.8 .

IDENTIFICAÇÃO - é a fase que envolve o reconhecimento das oportunidades para explorar novas tecnologias e a identificação das tecnologias de sistemas especialistas por um membro da empresa.

AVALIAÇÃO - é a fase que envolve as etapas de comprometimento de recursos iniciais, desenvolvimento das capacidades dos sistemas especialistas e avaliação técnico-organizacional. 


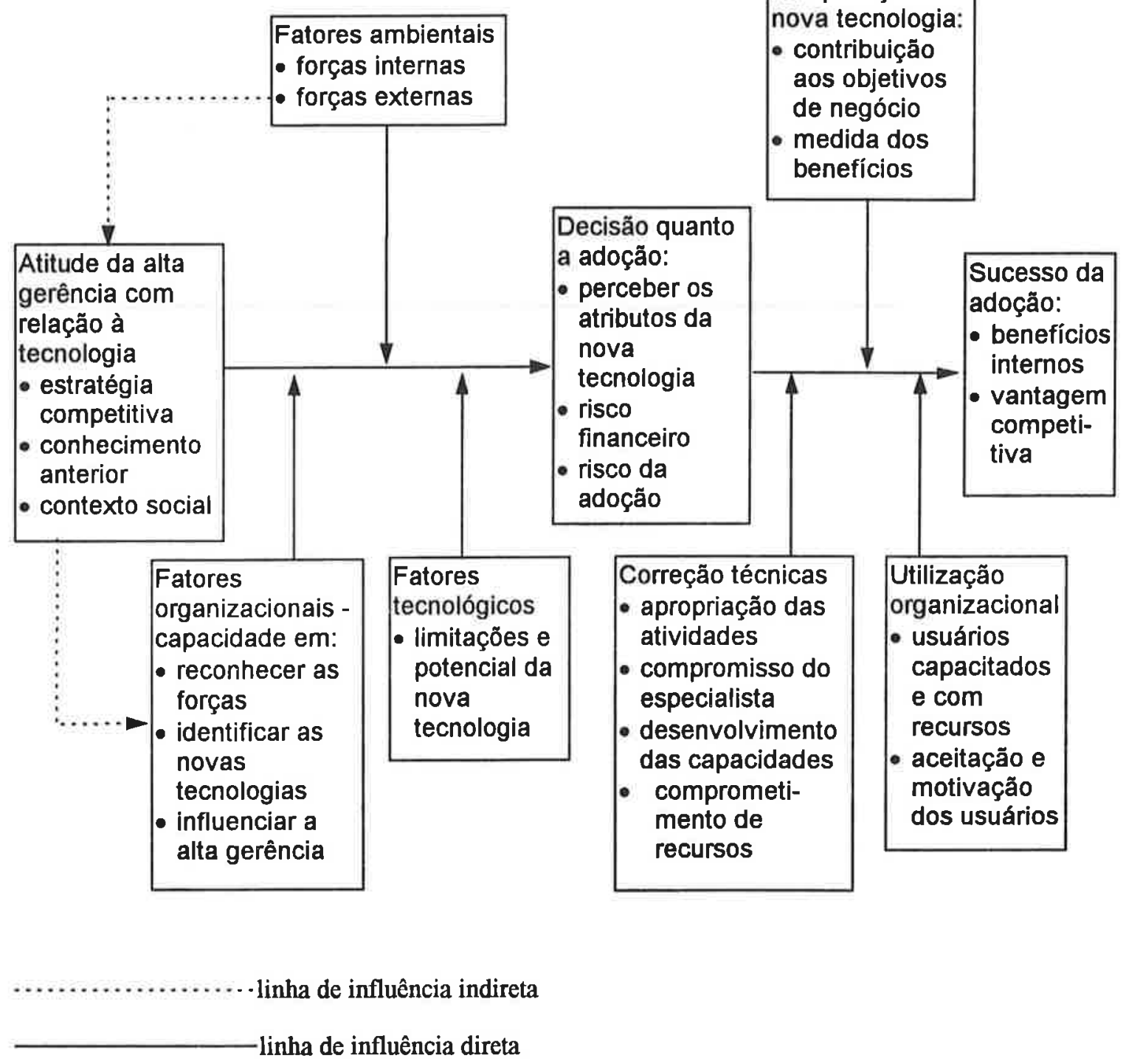

FIGURA 4.8: Relação entre os fatores que afetam a transferência de tecnologia de sistemas especialistas [DE LA GARZA; MITROPOULOS, 1992]

IMPLEMENTAÇÃO - fase que envolve: a decisão quanto a adoção pela alta gerência e o comprometimento dos recursos; desenvolvimento e implantação da tecnologia de sistemas especialistas; avaliação do retorno do emprego da nova tecnologia e confirmação da relevância dos sistemas especialistas.

Os modelos para o processo de inovação propostos por TATUM [1987]; por DE LA GARZA; MITROPOULOS [1992] e por LABORDE; SANVIDO [1994], 
contêm uma série de passos e ações que devem ser considerados no desenvolvimento de uma metodologia para implantação de TCR's. Por isso, a seguir, essas propostas serão analisadas, juntando-se, às mesmas, proposiçōes de outros autores, também envolvidos com o tema.

\subsubsection{Análise das diretrizes para implantação de inovações tecnológicas}

A análise feita neste item tomará como parâmetro o modelo proposto por TATUM [1987], apresentado na figura 4.7, considerando-se cada um dos elementos do seu plano de ação, quais sejam:

- reconhecer as forças e oportunidades para inovação;

- criar um clima para inovação;

- desenvolver as capacidades necessárias;

- busca de novas tecnologias construtivas;

- experimentar em campo ou em laboratório e refinar;

- implementar em empreendimentos e na empresa.

\subsubsection{Reconhecer as forças e oportunidades para inovação}

Analisando-se a proposição de TATUM [1987], ilustrada na figura 4.7, anteriormente apresentada, fica claro que o processo de inovação tecnológica na indústria da Construção é iniciado à medida em que existe algum tipo de impulso para a mudança, ou seja, "as forças e oportunidades para inovação".

TATUM [1987] salienta, ainda, que as principais forças e oportunidades para inovação são: demanda de mercado; identificação de novos "nicho" de mercado; exigências da legislação; novas tecnologias e visāo estratégica sobre as prioridades.

Reconhecer as forças e as oportunidades para explorar novas tecnologias está também presente no trabalho de DE LA GARZA; MITROPOULOS [1992], na etapa que denominam de identificação, anteriormente salientada. $E$, pela figura 4.8 , fica claro que essas forças podem ter origem interna ou externa à empresa. 
O papel das forças de mercado (demand-pull) e do "avanço tecnológico" (technology-push) como incentivos para a mudança é destacado, ainda, nos trabalhos de TATUM [1986] e de NAM; TATUM [1989], no qual afirmam que algumas vezes é a velocidade do avanço científico e o tamanho do grupo de pesquisa que determinam o nivel de inovação, enquanto outras vezes são as forças de mercado que provocam a inovação.

NAM; TATUM [1992], após uma extensa pesquisa, na qual analisam diferentes empresas que tiveram sucesso ao implantar inovações tecnológicas em seu processo de produção, são enfáticos ao afirmar que o principal elemento que leva à inovação é o desenvolvimento tecnológico.

Salientam ainda que o resultado desse desenvolvimento é comumente implantado a partir de melhorias incrementais, através de um esforço persistente em todos os níveis organizacionais da empresa.

Esses pesquisadores afirmam também que a demanda de mercado e a disponibilidade de tecnologia, por si só, não deflagram o processo de inovação na empresa. Há forças internas que podem conduzir ao processo de mudança ou mesmo obstruí-lo, destacando-se o foco estratégico da empresa, ou seja, o entendimento de para onde deseja prosseguir e como quer conduzir seus próximos passos. Nesse sentido, o posicionamento da alta administração, reconhecendo a necessidade de inovação, é apresentado como sendo um elemento de destaque.

O envolvimento da alta administração está presente também no trabalho de TATUM [1984] ao afirmar que uma condição fundamental para a inovação é "o compromisso gerencial forte e imparcial para selecionar as tecnologias que melhor suportem os objetivos do empreendimento".

Essa posição é confirmada por GHIO; BASCUÑÁN [1995], ao afirmarem que deve haver "a decisão expressa da empresa pelo caminho da inovação, entendendo claramente quais são os seus benefícios".

Além disso, esses pesquisadores destacam, ainda, que devem estar presentes: "a motivação e o comprometimento de pelo menos um executivo 
que participe da direção da empresa, disposto a promover o desenvolvimento". Quanto à participação gerencial, DE LA GARZA; MITROPOULOS [1992] salientam que a introdução de uma inovação tecnológica pode seguir dois caminhos distintos na empresa, em função da posição que o introdutor da nova tecnologia ("gatekeeper") ocupa na mesma.

Pode-se ter uma tecnologia vinda de cima para baixo ("top-down") ou de baixo para cima ("botton-up"). No primeiro caso, a nova tecnologia é introduzida e sustentada pela alta gerência. Numa abordagem de baixo para cima, a nova tecnologia é introduzida e conduzida por um membro da empresa que não pertence ao grupo da alta gerência.

DE LA GARZA; MITROPOULOS [1992] destacam que existem outros fatores que podem influenciar o processo de implantação de novas tecnologias, além da posição daquele que introduz a inovação ("gatekeeper"), destacando:

- atitude da alta gerência com relação à tecnologia;

- condições organizacionais da empresa;

- capacidades tecnológicas organizacionais;

- maturidade da tecnologia de sistemas especialistas.

No trabalho de DE LA GARZA; MITROPOULOS [1992], fica expresso que a atitude gerencial é um dos principais fatores que afetam todas as demais fases do processo de inovação. Salientam que o posicionamento da gerência frente à estratégia tecnológica da empresa direciona todas as açōes empresariais.

Uma atitude positiva da alta administraçāo leva a uma estratégia ativa; enquanto uma atitude negativa ou indiferente leva à perda da estratégia tecnológica. Neste caso, a tecnologia somente será aplicada se outros fatores criarem forças suficientes para sobrepor a esta atitude.

SERPEL [1995], analisando o comportamento de empresas chilenas frente ao processo de inovação tecnológica, afirma que existem forças, dentre as quais destaca a inércia, o hábito e a comodidade com o conhecido, que procuram manter a situação inalterada, sem a introdução de mudanças. 
Esse autor salienta que "as reações são mais devidas ao medo da perda de controle do que à mudança propriamente dita". Por essa razão, destaca que as empresas devem criar um ambiente de trabalho favorável às trocas e à introdução de inovações e de novas tecnologias.

A partir de um estudo realizado junto a cinco casos de implantação de algum tipo de inovação em empresas construtoras envolvendo melhoria nos sistemas administrativos e dos processos de construção, SERPEL [1995] identifica os elementos estratégicos que devem estar presentes no ambiente da empresa para facilitar o processo de implantação de inovações, dentre os quais, destaca:

- compromisso da alta administração, com uma organização de grupo;

- a inovação deve ser parte do plano estratégico da empresa;

- devem existir: uma perspectiva de longo prazo; programas de incentivos; difusão ampla dos objetivos e dos resultados esperados e alcançados.

SERPEL [1995] conclui que: "para que a inovação possa ser um processo mais difundido na Construção Civil, é clara a necessidade de controle nas relações entre os diversos envolvidos no processo de produção de edifícios, como por exemplo os empreendedores, projetistas, fornecedores de materiais, construtores, etc.".

SANDERS; ESKRIDGE [1993] destacam, ainda, como elementos estratégicos fundamentais para a condução do processo de inovação: o alinhamento dos interesses entre as diretrizes estabelecidas e os trabalhadores em todos os níveis; e também, a adaptação das inovações às características da empresa.

Das colocações anteriores fica claro que a estrutura organizacional e a cultura da empresa são fatores que influenciam a implantação de novas tecnologias, porque elas afetam a capacidade gerencial de conduzir esse processo. Por isso, o grau de compatibilidade entre a tecnologia e os valores organizacionais irão influenciar a capacidade de aceitação do processo de inovação.

\subsubsection{O comprometimento e desenvolvimento dos recursos}

A partir do momento que o foco estratégico da empresa passa a ser a implan- 
tação de melhorias e inovações, estabelece-se a necessidade de viabilizar essa estratégia.

Segundo TATUM [1987], essa etapa deve envolver atividades que resultem num ambiente propício à receptividade das inovações e que permitam o desenvolvimento das capacidades exigidas.

Os recursos para o processo de inovação dizem respeito, sobretudo, às pessoas com capacidade de condução do processo e à infra-estrutura exigida para a condução desse processo, abordados na seqüência.

\section{a) os líderes do processo de inovação}

O envolvimento daqueles que formam a empresa, na sua estratégia, é condição básica para que se alcance os objetivos estabelecidos. Assim, o início do processo de mudança e de evolução deve encontrar um ambiente favorável, no qual as pessoas estejam dispostas a participar e a se envolver com os objetivos estabelecidos.

GHIO; BASCUÑÁN [1995] apontam a necessidade de uma pessoa responsável pela condução do processo de mudança tecnológica, ainda que a pessoa não seja membro da empresa, como é o caso do uso de consultores. Esses pesquisadores destacam, também, a exigência de investimentos em algum tipo de capacitaçāo daqueles que irão participar do processo de implantação de inovações.

SANDERS; ESKRIDGE [1993], por sua vez, enfatizam que os líderes devem ser identificados desde cedo no processo de inovação. Segundo esses autores, os líderes não podem ser apontados; devem surgir. Devem ser pessoas que tenham seu próprio interesse na nova idéia e assim, devem ter desejo e determinaçāo de ver sua idéia completamente implementada com sucesso. Devem ter um papel de condutor do processo de inovaçăo.

Além disso, uma forte competência técnica nas disciplinas relativas aos requisitos de projeto e operações de produção usados pela empresa é a chave para a capacidade de inovar. Ou seja, devem existir pessoas que tenham o domínio tecnológico dos processos de produção em utilização na empresa, e também 
um lider ("champion") com competência para a condução da inovação, junto a todos os envolvidos no processo de produção: proprietários, projetistas, fornecedores, usuários [TATUM, 1987].

A existência de líderes conduzindo o processo de implantação de novas tecnologias é defendida também nos trabalhos de QUINN [1986]; TATUM [1989]; NAM; TATUM [1989], sendo que esses últimos identificam três tipos de líderes que trabalham juntos:

- o "líder técnico": é aquele que a partir de um conceito inicial, desenvolve-o até chegar a um produto ou processo viável;

- o "líder de negócio": é aquele que viabiliza a estrutura de negócio para a aplicação de uma idéia técnica;

- o "líder executivo": é aquele que sustenta a idéia junto à alta gerência.

Além desses "líderes", TATUM [1989] salienta que também devem estar presentes nas empresas:

- pessoas com visão de futuro, que acreditam no potencial da inovação;

- pessoas insatisfeitas com o patamar alcançado, ou seja, que acreditam que "deve haver um modo melhor";

- pessoas dispostas a buscar tecnologias externas à empresa, que tenham potencial para avaliá-las e percepção de onde utilizá-las.

Esse autor afirma que não há na empresa pessoas específicas para essas funções, sendo comum que isso parta dos gerentes, num primeiro momento, e depois, com o crescimento da idéia, essas funções sejam exercidas por pessoas que ocupam um plano secundário na empresa.

- O líder, como um elemento do processo de inovaçāo, é destacado também por SERPEL [1995]. Segundo esse autor, o líder deverá ter visão e disposição para assumir riscos e para superar obstáculos; ser capaz de se educar e de identificar oportunidades de inovação e, ainda, ser capaz de passar a inovação para os demais e educá-los, tanto formal como informalmente. $\vee$

DE LA GARZA; MITROPOULOS [1992], por sua vez, defendem que, além da firme disposição de buscar a inovação tecnológica, a gerência deve ser capaz 
de entender o potencial da nova tecnologia e para isto, precisa ter um embasamento tecnológico

Segundo esses autores, a alta posição dos "captadores de tecnologias" ("gatekeepers") na hierarquia organizacional capacita-os a entender o potencial da tecnologia e como pode servir para se chegar aos objetivos estratégicos da empresa. Por isso, a gerência deve assegurar que as aplicações escolhidas sejam relevantes para a organização e deve selecionar aquelas que sirvam melhor aos seus objetivos.s

Pela tabela 4.2, anteriormente apresentada, de autoria de LABORDE; SANVIDO [1994], fica claro que o "estilo de gerência" influencia no processo de implantação e que as caracteristicas da gerência são distintas nos casos das pequenas e grandes empresas. Segundo os autores, no caso das pequenas empresas, a ausência de burocracia e a conseqüente agilidade das açōes podem resultar em vantagens ao processo de implantação; enquanto o processo de decisão centralizado e o aumento dos niveis gerenciais, comum das grandes organizações, dificultam o processo de comunicação e podem favorecer e ocultar problemas, inibindo o processo de mudança.

\section{b) o sistema de comunicação favorecendo o processo de implantação}

Um ambiente favorável ao processo de inovação, segundo TATUM [1984], deverá permitir a "fluência efetiva de informações dentro da equipe para identificar e resolver problemas resultantes da nova tecnologia".

A existência de linhas de comunicação eficientes é destacada também por SERPEL [1995], para que se tenha sucesso na implantação de inovações.

SANDERS; ESKRIDGE [1993] também apontam o estabelecimento de comunicação formal e um sistema de retorno como elementos do processo de implantação de novas tecnologias.

Para que esses elementos estejam presente, os autores salientam que deverá existir canais de comunicaçāo internos à empresa de forma que idéias de mudanças (que venham dos empregados de todos os niveis da empresa) possam ser coletadas e implementadas. 
LABORDE; SANVIDO [1994] também destacam a relevância do sistema de comunicação nas empresas. Esses pesquisadores afirmam que as pequenas empresas tendem a ter uma rede de comunicação eficiente e informal, que proporciona rápida resposta a problemas, sendo mais fácil a adaptação a mudanças; enquanto as grandes empresas possuem, na maioria das vezes, canais de comunicação congestionados, com uma vagarosa reação a problemas e, com isto, a implementação de mudanças torna-se mais dificil e vagarosa.

$\rightarrow$ c) os recursos financeiros para a viabilização da implantação

O custo da tecnologia é um outro fator que afeta a probabilidade de sua adoção. O custo inclui todas as despesas com o desenvolvimento e o próprio uso da tecnologia e depende, preliminarmente, do estágio de desenvolvimento da tecnologia e, em segundo plano, das capacidades tecnológicas existentes na empresa. Então, para minimizar o custo e conseqüentemente o risco financeiro, a empresa pode desenvolver aplicações de pequena amplitude e relativamente simples, que requerem menos recursos [DE LA GARZA; MITROPOULOS, 1992].

O risco financeiro é destacado também por LABORDE; SANVIDO [1994], como uma das principais variáveis do processo de implantação. Esses autores afirmam que, para as pequenas empresas, é mais difícil assumir o risco envolvido na implantação de uma nova tecnologia, uma vez que os investimentos dificilmente poderão ser amortizados no seu conjunto de projetos. No que se refere aos riscos, a empresa de grande porte leva vantagens, uma vez que podem amortizá-los num grande número de projetos.

\subsubsection{Busca de novas tecnologias construtivas}

A busca de novas tecnologias é um aspecto destacado pela maioria dos pesquisadores.

TATUM [1987] salienta que as tecnologia podem ter diferentes origens, dentre as quais, destaca: a adoção de tecnologias provenientes de fontes externas à empresa; a modificação e adaptação de tecnologias disponíveis na empresa; a 
promoção de melhorias incrementais provocadas nas tecnologias em uso; o desenvolvimento de novas tecnologias.

DE LA GARZA; MITROPOULOS [1992], em sua metodologia voltada a aplicação de tecnologias de sistemas especialistas ("expert systems technology's") destacam as fases de "identificação", "avaliação" e "decisão sobre a adoção", como fundamentais para o inicio do processo de implantaçāo.

Segundo LABORDE; SANVIDO [1994], a etapa de identificaçăo refere-se à busca de tecnologias "candidatas" à implantação. Esses autores apresentam como fontes chaves para a busca de tecnologias: fornecedores de materiais e componentes; subcontratados; competição entre as empresas; universidades e institutos de pesquisa: operários; esforço formal de desenvolvimento interno.

Não basta, apenas, identificar as novas tecnologias disponiveis. Uma vez identificadas, deve-se passar à etapa de avaliação das mesmas, cujo primeiro passo consiste na análise da relação custo/benefício de cada alternativa.

Para LABORDE; SANVIDO [1994], esta análise pode ser realizada pelo diretor de desenvolvimento ou pelo gerente do empreendimento, segundo os seguintes critérios:

- grau com que a inovação atende aos objetivos da empresa ou a estratégia do empreendimento;

- primeiro custo do novo produto (inovação de produto) ou equipamento ou "software" (inovação de processo);

- tempo disponivel para a implantação das mudanças;

- impacto das mudanças nos diferentes departamentos da empresa;

- periodo de retorno;

- economia nos custos frente aos métodos convencionais;

- dificuldade de implementação;

- impacto sobre a moral, qualidade e segurança.

SANDERS; ESKRIDGE [1993] defendem a prática do "benchmarking" antes de se lançar a novas idéias, verificando-se o estágio das empresas concorrentes 
ou mesmo através da literatura, para identificar o estado-da-arte de uma determinada tecnologia dentro da indústria.

GHIO; BASCUÑÁN [1995] defendem a idéia de que, no princípio, deve-se optar por inovações que ofereçam retorno mais rápido, as quais, geralmente, referem-se a inovações que requerem menores investimentos, sendo mais tangíveis e mais fáceis de quantificar.

\subsubsection{A experimentação e o refino de novas tecnologias}

"Experimentar e refinar" as novas tecnologias é um aspecto destacado por diversos autores.

Tendo-se decidido sobre qual tecnologia empregar, deve-se passar a elaborar um planejamento para a utilização e o refino da nova tecnologia.

O planejamento dessa etapa é destacado como fundamental por muitos pesquisadores, dentre eles, SANDERS; ESKRIDGE [1993] e LABORDE; SANVIDO [1994].

TATUM [1987] salienta que muitas iterações poderāo ser realizadas para satisfazer as condições da inovação e encontrar todo o seu potencial. Dessa forma, é preciso experimentar, testar e refinar.

A experimentação não precisa ser realizada em um laboratório; pode-se experimentar em campo, sob condições controladas. A experimentação possibilita controlar variáveis específicas e identificar as mudanças exigidas para encontrar os requisitos ou as restrições impostas por outras variáveis durante o processo de inovação.

TATUM [1987] afirma que: "essa etapa pode trazer resultados imprevisiveis, podendo ser extremamente frustrante e altamente iterativa".

A etapa de teste, proposta por TATUM [1987], ainda dentro da fase de experimentação e refino, envolve a aplicação da nova tecnologia em protótipos objetivando o refinamento da mesma. O emprego em protótipos pode levar a alterações em critérios de projeto, materiais, configurações, técnicas de execução ou aplicaçōes específicas. 
A extensiva iteração e o refinamento, para a completa adequação da nova tecnologia, são elementos apresentados por diversos autores como sendo de grande dificuldade no processo de implantação. O longo período demandado para esta atividade pode criar sérios problemas para a empresa, quando 0 objetivo principal é a obtenção de resultados imediatos.

GHIO; BASCUÑÁN [1995] destacam que a equipe envolvida com o processo de implantação deverá ser responsável pela compatibilização das diversas disciplinas de projetos e pela montagem de um arquivo que resuma os procedimentos, alterações e inovações implementadas de modo a poder "aparar qualquer aresta" e passar a informação a futuros projetos.

Esses pesquisadores sugerem que essa equipe seja constituída: pelo proprietário; pelos representantes das empresas construtoras, das empresas de projeto e dos fornecedores; e também, pelos consultores especializados nos processos de mudança.

DE LA GARZA; MITROPOULOS [1992] também apresentam a etapa de implementação da nova tecnologia e afirmam que a capacidade de medir 0 retorno é crítica para a confirmação da relevância da tecnologia e para a continuidade de suporte da alta gerència.

SANDERS; ESKRIDGE [1993] salientam que devem ser estabelecidos meios de medição formal e procedimentos de avaliação. Segundo esses autores, essa é a maneira de avaliar se o programa de implantação está ocorrendo como planejado. Para eles, as táticas de avaliação variam de empresa para outra, conforme o número pessoas envolvidas, o número de melhorias implementadas e a economia esperada.

Durante o desenvolvimento da etapa de implementação, LABORDE; SANVIDO [1994] apresentam alguns elementos que devem estar presentes, a fim de favorecerem a efetivação da nova tecnologia.

- escolher um projeto pequeno, pois para uma primeira implantação de uma nova tecnologia, este tipo de projeto apresenta maior facilidade de gerenciamento, apresentando menores riscos para a empresa; 
- escolher uma equipe de projeto competente, possuindo capacidade técnica e uma atitude positiva frente às inovações e mudanças;

- envolver o arquiteto e o proprietário tanto quanto possivel, pois se eles participarem do desenvolvimento e planejamento dos estágios da nova tecnologia, estarão mais dispostos a cooperar;

- providenciar os recursos, tanto econômicos como humanos, aliviando-se o grupo de projeto de outras atividades que nāo dizem respeito à inovação;

- treinar os membros do grupo;

- investir tempo no planejamento, mais do que em um projeto convencional;

- assegurar encontros para revisões regulares, pois a comunicação é essencial neste tipo de proposta inovadora;

- registrar os acontecimentos sobre a nova tecnologia, seja o impacto sobre o planejamento, orçamento, produtividade, qualidade e segurança; o registro auxilia decisões futuras.

Nessa fase de implantação das novas tecnologias, SANDERS; ESKRIDGE [1993] destacam a contribuição do treinamento para a efetivação da nova tecnologia. Esses autores salientam que este é um recurso subutilizado na indústria da Construção Civil. Defendem que sejam utilizados treinamentos em todas as instâncias da empresa, de forma contínua e constante.

SANDERS; ESKRIDGE [1993] afirmam, ainda, que a empresa tem algumas opções para a implantação de mudanças, destacando-se a implantação por estágios incrementais e através de projetos piloto. Implantar por estágios significa que o esforço é quebrado em vários estágios e implementados um por vez. Segundo esses autores, essa situação facilita o controle gerencial, podendo-se implantar uma pequena parte, monitorar os resultados e então determinar o que se deve fazer em seguida. Trata-se de um processo de longo prazo e onde o retorno não vem tão cedo.

Esses autores propõem, ainda, que a implantação seja feita utilizando-se um projeto piloto, ao invés de se implantar a nova idéia em toda a empresa. Ao se selecionar um projeto para testar a implantação, tem um escopo mais estreito 
para ser monitorado. Além disso, destacam, que a empresa não deve tentar mudar muitas coisas de uma só vez, pois o sentimento de estabilidade deve estar presente nos operários.

\subsubsection{Avaliação e disseminação da tecnologia na empresa}

Após a fase de implantação, LABORDE; SANVIDO [1994] definem, ainda, uma etapa de retorno, que está implícita também na proposta de TATUM [1987], ao propor a fase de "refino". Esta etapa permite uma análise dos resultados da inovação implementada, assim que o empreendimento estiver completo.

Segundo LABORDE; SANVIDO [1994], essa etapa deve envolver os seguintes passos:

- $s$ compilação de toda a documentação produzida ao longo do desenvolvimento do empreendimento e análise do resultado final; ،

- * elaboração de recomendações para empreendimentos futuros, identificando-se como a tecnologia poderá ser modificada para melhor servir à empresa e, ainda, quais as características que o empreendimento deve apresentar para absorver a nova tecnologia e como poderá ser implantada em larga escala;

- recompensa dos membros do grupo, independente do sucesso ou fracasso da experiência. Essa recompensa poderá ser reconhecimento pessoal ou em dinheiro. Observam que, no caso de insucesso, o grupo não deverá ser punido, devendo-se dar uma chance para que aprenda a partir da falha, podendo corrigir num próximo trabalho;

- disseminação das informações para outros empreendimentos.

Para LABORDE; SANVIDO [1994], a disseminação pode ser viabilizada através do diretor de desenvolvimento, ou por meio da equipe que participou da primeira implantação. Para os autores, essa forma de disseminação diminui drasticamente o impacto da nova tecnologia na empresa.

Além disso, os autores propõem que seja criado um banco de dados contendo as lições aprendidas, o qual poderá subsidiar a elaboração de novos projetos e a realização de novos empreendimentos. 
rGHIO; BASCUÑÁN [1995] destacam, que uma base de dados com experiências passadas é fundamental para dar início ao processo de implantação. Para eles, se essa base não existir, deverá ser formada previamente à implantação.

SANDERS; ESKRIDGE [1993] também destacam que o estabelecimento de recompensas e reconhecimentos na fase de avaliação da implantação é um elemento relevante para o sucesso do processo de inovação. Segundo esses autores, "é melhor reconhecer um pouco de muitos do que muito de poucos". Acrescentam, ainda, que e a recompensa pode ser na forma de dinheiro ou prêmios ou simples reconhecimento e destacam que, às vezes, o reconhecimento público tem mais efeito que a recompensa financeira.

Além disso, SANDERS; ESKRIDGE [1993] colocam a documentação como mais um instrumento do processo de implantação, uma vez que os esforços para a implementação das novas tecnologias, os sucessos e as falhas precisam ser documentados, para auxiliar novos esforços.

Segundo DE LA GARZA; MITROPOULOS [1992], essa última etapa, de confirmação, possibilita o retorno dos resultados à gerência, a qual compromete novos recursos para a continuidade da implantação ou rejeita a tecnologia. Esse estágio resulta em três possibilidades de retorno:

- a empresa aprecia ou rejeita as novas tecnologias como forma de atingir os objetivos do negócio;

- a alta gerência continua ou não a comprometer recursos para a tecnologia;

- a estratégia de implementaçăo é reavaliada e uma diferente estratégia pode ser adotada.

Para TATUM [1987], a última etapa consiste na difusão das novas tecnologias na empresa como um todo. Para esse autor, assim como na indústria de bens de consumo, essa é uma etapa não totalmente equacionada. Coloca como passos principais para a sua concretização: prover os recursos de pessoal, de tecnologia, e os financeiros; alimentar o planejamento e orçamento, em função das implicações técnicas e comerciais; ganhar experiência e aceitação no uso e desenvolver a vantagem competitiva. 


\subsubsection{Elementos que se constituem em dificuldades à inovação}

Além de todas as diretrizes anteriormente apresentadas, cabe destacar, ainda, alguns elementos comumente destacados como barreiras ao processo de inovação, os quais devem ser evitados ao se definir a organização e estratégia das empresas.

$\downarrow$ Segundo SERPEL [1995], as principais barreiras são:

- a grande maioria das empresas construtoras são de propriedade de empresários individuais ou familiares que tendem a nāo valorizar adequadamente a contratação de pessoal qualificado para funções relevantes dentro da empresa; além disso, é comum haver um estilo personalista de administração, reduzindo a criatividade e inibindo a motivação das pessoas pelas idéias inovadoras;

- flutuações de mercado da indústria da Construção, uma vez que criam periodos de menor atividade relativa;

- falta de padronização dos produtos da construção (materiais e componentes) e de normalização adequada. Muitas idéias de inovações são deixadas de lado, por năo se ter fornecedores e produtos no mercado capazes de atender aos requisitos que as mesmas impõem;

- falta de incentivo a inovação por parte dos clientes;

- falta de integração entre os diferentes agentes que participam de um empreendimento de construção, em particular: clientes, projetistas, construtora,

- fornecedores e subcontratados.

NEVES [1995], a partir de uma análise junto a empresas construtoras da cidade de Salvador (BA), identifica aspectos que interferem negativamente na implantação de melhorias e de inovações tecnológicas na produção de edifícios, destacando:

- os materiais, quando fora das especificações ou inadequados ou, ainda, cuja oferta não atende a demanda;

- a mão-de-obra de terceiros, sem a devida especialização;

- a ausência de investimentos em equipamentos mais sofisticados; 
- equipe de engenharia pouco experiente para a construção de edifícios.

Segundo a autora, "as empresas que trabalham com estruturas pré-fabricadas de concreto ou metálicas têm mais facilidade de incorporar práticas racionalizadas ao processo construtivo, provavelmente transmitidas desta atividade para as demais".

\subsubsection{Análise das propostas voltadas à indústria da Construção}

Os modelos propostos para implantação de inovações tecnológicas na indústria da Construção Civil, assim como os propostos para a indústria seriada, também enfocam diretrizes globais, não chegando a orientar a condução estratégica do trabalho na empresa.

A metodologia proposta por SABBATINI [1989] foi criada objetivando o desenvolvimento tecnológico de MPSConst.. Nesse contexto, a implantação do "produto" do desenvolvimento (a tecnologia construtiva), no mercado, é apenas uma das etapas da metodologia. E, essa etapa contém apenas diretrizes amplas para a sua efetivação. Desta maneira, da proposição de SABBATINI [1989], é possivel aproveitar as idéias fundamentais, enquanto encadeamento global das atividades que deverão estar presentes.

Os modelos propostos por TATUM [1987] e por LABORDE; SANVIDO [1994] são os que mais se aproximam do objetivo do presente trabalho; no entanto, são muito genéricos, pois não enfatizam a operacionalizaçăo das diretrizes propostas.

Entretanto, acredita-se que, no Brasil, para se levar as TCR's ao canteiro de obras, é preciso mais que diretrizes genéricas. É preciso um plano de ação que permita às empresas visualizar e conduzir "passo-a-passo" o processo de implantação e que lhes permita definir com maior clareza os recursos envolvidos. $O$ que se propõe no capítulo 5 é uma metodologia que procura contemplar esses aspectos.

Ainda que tratem de diretrizes globais, o estudo dos modelos e diretrizes anteriormente apresentados permitiram reunir os principais elementos que deverão 
estar presentes numa metodologia de implantação, a fim de que tenha um maior potencial para a efetivação das TCR's na cultura da empresa.

Esses elementos serão sintetizados e discutidos na seqüência.

A análise das propostas deixa claro que o processo de implantação de inovações tecnológicas na indústria da Construção Civil ocorre, na maioria das vezes, a partir de incentivos provenientes do mercado que, de alguma maneira, reivindica as alteraçōes tecnológicas.

As novas tecnologias, raras vezes, são desenvolvidas pelas próprias empresas construtoras. No caso da indústria da Construção, a fonte de tecnologia é diversa, destacando-se a forte atuação das universidades e centros de pesquisa, bem como, a participação da indústria de materiais e componentes.

Além disso, ficou claro, também, que, para ocorrer a interação entre as necessidades de mercado e a mudança tecnológica, deverá haver uma "vontade" da organização, expressa em suas diretrizes estratégicas. Destaca-se, com isso, a participação da alta direção, envolvendo-se e comprometendo-se com o processo de implantação; agindo como elemento facilitador e tendo uma "visão de longo prazo" para a obtenção dos retornos pretendidos.

Não adianta existir demanda de mercado, sem a tecnologia ou, vice-versa, a tecnologia, sem uma demanda de mercado. E, além disso, o processo de inovação não será efetivado se as diretrizes estratégicas da empresa não contemplarem ações que facilitem a condução desse processo.

Assim, o foco estratégico e a definição de prioridades da empresa passam a ser um elemento motivador interno essencial para a aplicação de uma determinada inovação, em uma organização. Se a empresa não contemplar em sua estratégia de ação a busca da competência, através da introdução de novas tecnologias, pouco poderá ser feito.

Por isso, destaca-se a exigência de esforços persistentes em todos os níveis organizacionais da empresa, com o posicionamento da alta administração que tanto pode constituir-se num elemento motivador do processo de implantação, como pode obstruí-lo. 
A existência de elementos que impulsionem o processo de inovação não é uma característica apenas da indústria da Construção Civil, mas de todo o setor industrial. No trabalho de FLEURY; FLEURY [1995], em que analisam o processo de aprendizagem e inovaçāo nos setores automobilístico e de telecomunicações em três diferentes países - Japão, Coréia e Brasil - os autores salientam que "introduzir e cultivar a noção de mudança e inovação deixou de ser apenas um modismo para se tornar uma questão de sobrevivência e sucesso (...) Durante muito tempo a Função Tecnologia foi muito pouco importante na estratégia competitiva das empresas. Foi um tempo durante o qual produzir certo e de maneira ótima não resultava em vantagem competitiva para a empresa".

Para esses autores, "esse quadro começa a reverter com a mudança nas regras de competição, resultantes de um mercado que hoje é comprador, ou seja, a oferta é maior que a demanda e com isso é o cliente quem determina as regras de um mercado em que competiçāo é a palavra de ordem".

O ambiente em que a indústria da Construção Civil atua também tem passado por mudanças nos últimos tempos.

Atualmente, pode-se dizer que, enquanto demanda solvável, o mercado brasileiro é recessivo. Inúmeras empresas construtoras disputam um restrito número de empreendedores e de financiamentos disponíveis. Com isso, apenas as empresas de maior competência tendem a permanecer no mercado e há consenso entre os pesquisadores que a inovação tecnológica é uma das formas de desenvolvimento dessa competência.

No mercado brasileiro de Construção de Edifícios, algumas grandes empresas construtoras têm contribuído para que as demais, para não perder o seu mercado, realizem modificaçōes em seu processo de produção, com vistas a torná-lo mais competitivo.

Mas, para que essas mudanças efetivem-se na cultura da empresa, os trabaIhos estudados destacam, ainda, como sendo fundamentais os seguintes elementos: 
- a presença de "líderes" com competência tecnológica para a condução do processo de implantação;

- um sistema de comunicação, que permita a troca de informações e a integração entre todos os níveis hierárquicos da empresa e também de todos os participantes do processo de produção, tais como os proprietários, os usuários, os projetistas, os fornecedores de materiais e mão-de-obra e a própria empresa é fundamental para o processo de inovação; e

- a disponibilidade de recursos de tempo e financeiros, que permitam viabilizar os recursos humanos, materiais e de equipamentos.

Além disso, a bibliografia destaca, ainda, que caberá à alta gestão assumir os riscos naturais do processo de implantação de inovaçōes tecnológicas. Sem recursos e sem assumir riscos, não existe a implantação de novas tecnologias.

Além disso, alguns autores destacam o desenvolvimento do projeto como mais um elemento que deve estar presente na condução da implantação. Para isso, - projeto deverá incorporar a nova tecnologia e permitir que seja acessível aos canteiros de obras.

As proposiçōes que contém algumas diretrizes de ordem tática, destacam a importância de um cuidadoso planejamento da implantação, que deverá prever todas as etapas e ações a serem empreendidas. E, dentre as muitas etapas que o processo de implantação envolve, pôde-se identificar que há uma orientação geral no sentido de:

- realizar a implantação de novas tecnologias através de ações incrementais, que não alterem significativamente a dinâmica da empresa;

- envolver todos os participantes através de treinamentos, o qual deverá ser específico para cada fim que se deseja alcançar e, além disso, deverá ser permanente e contínuo;

- realizar experimentações sobre o uso da nova tecnologia, tanto em laboratório, como em campo;

- avaliar os resultados obtidos das experimentações, corrigir os eventuais problemas e retomar o processo de implantação; 
- realizar a anotação e o registro de todas as atividades desenvolvidas, como uma forma de subsidiar etapas futuras.

\subsection{Análise das Experiências de Implantação de TCR's}

O estudo da bibliografia disponível sobre o processo de inovação nas empresas da indústria seriada e da Construção Civil é fundamental para os objetivos do presente trabalho, mas não é suficiente. Por se tratarem de experiências advindas de outros setores industriais e da indústria da Construção de outros países, muitas vezes nem todos os elementos que interferem no processo de implantação estão presentes.

Por isso, acredita-se que a experiência pessoal da autora, fruto de diversas tentativas em se implantar TCR's em empresas construtoras, possa ser de grande valia para completar os elementos que deverão integrar a proposição da metodologia, no capítulo 5 .

Com esse objetivo, duas das principais experiências vivenciadas pela autora serão apresentadas e discutidas nesse item.

O envolvimento da autora com trabalhos objetivando o desenvolvimento e a implantaçăo de TCR's teve início em 1988, com a assinatura de um convênio entre a Escola Politécnica e uma grande empresa construtora de edifícios, atuante em todo o território nacional.

Nessa época, iniciou-se o desenvolvimento de TCR's visando a produção de alvenarias de vedação e de revestimentos, tanto, os verticais argamassados e cerâmicos, como os de piso, incluindo os contrapisos.

O desenvolvimento e a sistematização de métodos construtivos visando a produção de alvenarias e de revestimentos foram colocados completamente à disposição da empresa contratante do convênio de pesquisa. Além disso, os principais resultados foram amplamente divulgados ao meio técnico através de textos e boletins técnicos, trabalhos em congressos científicos, proposição de projeto de norma (caso específico da tecnologia de produção de contrapisos) e cursos treinamento para empresas construtoras. 
No entanto, apesar da premência em se promover o avanço tecnológico na construção, sentiu-se grande dificuldade para transferir a tecnologia disponivel ao setor. E apesar do relevante conteúdo tecnológico do material produzido, desde cedo pôde-se perceber que a disponibilidade da tecnologia não bastava para que se concretizasse uma evolução no processo de produção dos edifícios, sobretudo pelas características intrínsecas desse processo de produção, discutidas no capítulo 3 .

Os estudos de caso apresentados na seqüência demonstram as dificuldades de se fazer chegar a todos os canteiros de obras de uma empresa construtora as ações de racionalização, ainda que sejam relativas a um só serviço. Através desses estudos procura-se, ainda, reunir elementos que possam ser utilizados na metodologia, proposta no capítulo 5 .

Dentre os diversos trabalhos realizados, e utilizados para subsidiar a proposição da metodologia, destacam-se os relativos à "implantação da tecnologia de produção de contrapisos para edifícios habitacionais e comerciais".

Essa tecnologia foi apresentada por ocasião da dissertação de mestrado da autora [BARROS, 1991a]. Entretanto, apesar de estar disponível ao meio técnico, desde essa época, não vinha sendo aplicada nos canteiros de obras.

Essa tecnologia prevê todas as etapas para a produção racionalizada de contrapisos internos de edifícios, quais sejam:

- diretrizes para o projeto de contrapiso - as quais permitem definir as espessuras mínimas para o contrapiso, em função dos revestimentos de piso a serem empregados e dos fatores condicionantes do projeto de arquitetura, de estrutura, de instalaçōes e de impermeabilização. Permitem, ainda, a definição racional da composição e dosagem da argamassa a ser utilizada, em função das características de execução e do nivel de controle estabelecidos;

- diretrizes para o treinamento da mão-de-obra - as quais contêm a definição, explicitação e ilustração de todas as etapas de execução propostas para a racionalização da atividade; e

- diretrizes para o controle - as quais estabelecem os procedimentos para 
acompanhamento da produção e aceitação do produto executado, bem como as responsabilidades dos envolvidos no processo de implantação.

A produção de contrapisos é uma atividade considerada simples frente à complexidade de produção de um edifício. Por isso mesmo, imaginou-se que a implantação da TCR proposta também seria simples; no entanto, esse processo mostrou-se de grande complexidade.

O trabalho de implantação da tecnologia racionalizada de produção de contrapisos foi realizado, inicialmente, em duas empresas de construção, as quais não participaram do processo de desenvolvimento da nova tecnologia. Uma das empresas tem sua sede na cidade de Campinas e a outra, em São Paulo. Ambas atuam no mercado de construção e incorporação de edifícios, na maioria dos casos, produzidos segundo o processo construtivo tradicional.

Motivadas a diminuírem seus custos de produção para permanecerem no mercado cada vez mais competitivo, ambas partiram para contratação da consultoria de técnicos especializados em desenvolvimento tecnológico, com o objetivo de conhecer as tecnologias disponíveis e incorporá-las aos seus empreendimentos, daí para frente.

As duas empresas definiram o contrapiso racionalizado como a primeira tecnologia construtiva a ser implantada, pois seria o procedimento de mais rápida aplicação e de retorno imediato quanto a custos de produção, o que geralmente causa um impacto benéfico na empresa, motivando a continuidade dos trabalhos.

Para que se proceda a análise dos efeitos da introduçāo dessa TCR nas empresas, inicialmente será apresentada a maneira que foi utilizada para conduzir essa implantação e, também, o contexto em se deu e a sua evolução.

No caso da empresa de Campinas, pouco antes do início do trabalho, a equipe de projetos da empresa havia sido extinta. Permaneceu apenas uma pessoa com a função de coordenar as atividades dos projetos, que seriam contratados junto a empresas especificas. Além dessa pessoa, a empresa contava com um setor de engenharia, junto ao qual iniciou-se o processo de implantação. 
Inicialmente foi montada uma equipe com a participação dos engenheiros e de alguns mestres de obras, objetivando resgatar o conhecimento tecnológico no que se referia à produção de contrapisos. Nesta ocasião, identificou-se uma dispersão acentuada das tecnologias construtivas aplicadas nas obras em andamento, originada não apenas a partir das experiências distintas de cada técnico, mas sobretudo do fato da empresa organizar-se sob a coordenação de dois gerentes de obras, com "filosofias" de trabalho bastante diferentes.

A partir de então, procurou-se realizar não apenas uma padronização do procedimento de execução, mas também a promoção de um avanço tecnológico, ainda que incremental, padronizando-se o procedimento racionalizado.

Desta maneira, foram elaborados os procedimentos para projeto, execução e controle, incorporando os princípios de racionalização construtiva. Em paralelo, foi realizada uma experimentação da tecnologia proposta.

Com essa experimentação, pôde-se produzir um filme para vídeo, utilizando-se os operários da própria empresa; portanto, numa situação real de produção, mas em condições completamente controladas.

Tendo-se os procedimentos e o filme prontos, foi realizada uma implantação em dois níveis: formação da equipe de engenharia e treinamento dos mestres de obra. $O$ treinamento da equipe técnica foi feito pelos consultores, enquanto que o dos mestres foi realizado por um engenheiro da empresa, o qual seria responsável pela área de desenvolvimento tecnológico a ser implantada ${ }^{1}$.

Com isso, a tecnologia de produção do contrapiso racionalizado passou a ser utilizada pela empresa, mas tão somente no que se refere à técnica de execução.

Ainda que a tecnologia tenha sido parcialmente implantada, obteve-se uma economia significativa no consumo de aglomerante da argamassa. Passou-se de um consumo médio de $450 \mathrm{~kg}$ de cimento por $\mathrm{m}^{3}$ de argamassa para $250 \mathrm{~kg}$.

\footnotetext{
1 Até o momento em que a autora atuou como consultora da empresa, objetivando a implantação de TCR's, o departamento de desenvolvimento tecnológico não havia sido montado.
} 
Essa economia foi sentida de modo significativo na produção do contrapiso de um "shopping center" em Campinas. Essa obra resultou num contrapiso com uma espessura média de $11,0 \mathrm{~cm}$, tendo sido feito com a argamassa e a técnica de execução racionalizados.

A técnica racionalizada de execução foi utilizada, ainda, em dois edifícios de múltiplos pavimentos, construídos pela empresa.

Em um empreendimento, cujo projeto estava no início quando da realização do trabalho, foi possivel a elaboração do projeto de revestimento de piso, juntamente com os projetos tradicionalmente elaborados. Nesse empreendimento a economia de material e de mão-de-obra também foi significativa, uma vez que foi possivel compatibilizar os diversos revestimentos utilizados, reduzindo-se, com isso, as espessuras da camada de contrapiso nos diversos ambientes. A espessura média inicialmente estimada em $6,2 \mathrm{~cm}$, com uma sobrecarga de $126 \mathrm{~kg} / \mathrm{m}^{2}$, após o desenvolvimento do projeto, passou para $3,2 \mathrm{~cm}$, reduzindo a sobrecarga para $68 \mathrm{~kg} / \mathrm{m}^{2}$, o que viabilizou o sistema estrutural utilizado para o edifício.

No entanto, apenas esse projeto foi realizado pela empresa. Ainda que a metodologia de projeto existisse, a empresa não tinha uma estrutura organizacional adequada para a sua implantação.

Além disso, não foi implantada também a fase de treinamento para os operários, ainda que a mão-de-obra fosse própria, e nem a de controle formal da produção, também prevista.

Da experiência decorrente da implantação nessa empresa, pôde-se registrar algumas reflexões importantes, aqui destacadas:

- a tecnologia de produção de contrapiso racionalizado estava desenvolvida; precisava apenas ser introduzida no sistema produtivo da empresa;

- além da existência da tecnologia, ela foi adaptada à linguagem da empresa, enquanto procedimento; no entanto, percebeu-se logo que a existência desses procedimentos não bastava; não assegurava que a produção em canteiro seria efetivada de maneira racionalizada; 
- a implantação das etapas de projeto para produção, de treinamento da mãode-obra e de controle de produção e do produto executado, fundamentais para a completa racionalização dessa atividade, não foram implantadas completamente nessa empresa.

Com tudo isso, a tecnologia perdeu significativamente sua eficiência, pois, apesar de incorporar o "acervo tecnológico" da empresa, através da existência de procedimentos escritos, não conseguiu fazer com que esses procedimentos atingissem a produção propriamente dita.

A empresa não conseguiu organizar-se para consolidar o conhecimento adquirido e poder repassá-lo aos novos engenheiros e técnicos que futuramente viessem a integrar o seu corpo técnico.

A tecnologia ficou registrada apenas "na cabeça" das pessoas participantes do processo inicial e na forma de procedimentos que hoje fazem parte do "arquivo técnico" da empresa, mas não do seu dia-a-dia.

Se à época, os investimentos tivessem sido voltados à implantação da metodologia de projeto e no treinamento dos operários, os benefícios poderiam ter sido melhores, na medida em que seriam multiplicados por todos os demais empreendimentos que a empresa viesse a desenvolver.

Na empresa com sede em São Paulo, o processo de implantação deu-se de maneira diferente. A implantação do contrapiso racionalizado foi realizada apenas em uma obra, buscando-se aliar a racionalização do contrapiso à racionalização da produção da laje, a fim de que se obtivesse a menor espessura possível para o contrapiso. Portanto, a intervenção teve início pelo desenvolvimento do "projeto de piso".

A partir da análise dos projetos de estrutura, instalações e impermeabilização, foram estabelecidos os desniveis da laje para a obtenção de reduzidas espessuras do contrapiso e até mesmo a sua eliminação em algumas áreas, como por exemplo, cozinhas e banheiros, onde foi prevista a aplicação de revestimentos cerâmicos diretamente sobre a laje estrutural. 
Com isso, pôde-se desenvolver todo o "projeto de piso" e o edifício foi executado com o principio de se ter a laje produzida tal qual especificada no projeto. Contudo, pela estrutura organizacional da empresa, não foi possivel implantar o procedimento de controle das atividades de produção das lajes, que pudesse subsidiar um eventual "reprojeto" do contrapiso, em função das reais condiçōes de produção das lajes.

Desta maneira, quando a obra atingiu o momento de execução do contrapiso, verificou-se que nem sempre a laje estava nas condições previstas no projeto; daí, na maioria das vezes, não era possivel executar-se os revestimentos cerâmicos diretamente sobre as lajes, exigindo-se, nas áreas molhadas, a execução do contrapiso e, como decorrência, o aumento da sua espessura nas áreas secas.

Nesse caso, a racionalização potencial proporcionada pelo projeto foi perdida, devido a problemas de execução da estrutura, não identificados a tempo de se realizar um "reprojeto" do contrapiso.

Apesar disso, buscou-se ainda a execução racionalizada dessa camada, com treinamento para a dosagem da argamassa e para a execução.

Tal treinamento foi realizado com operários de uma subempreiteira e um encarregado pertencente ao quadro de funcionários da empresa, na própria obra. Esse treinamento foi conduzido enfatizando o preparo da base, a compactação da camada e a correta execução acabamento superficial, o qual previa um reforço com polvilhamento de pó de cimento.

Participaram do treinamento, além dos operários, o engenheiro e o mestre da obra e também o próprio empreiteiro.

Decorrida uma semana do treinamento, voltou-se para avaliar as condições da produção do contrapiso e identificou-se, entre outros aspectos, os seguintes:

- as equipes de produção não eram as mesmas;

- o encarregado da obra tinha sido afastado, por falta de liderança; e o mesmo não havia sido substituido, em função de contenção de despesas com mão-de-obra; 
- das três equipes que executavam o contrapiso, apenas uma preparava a base como havia sido estabelecido, mas não realizava o acabamento superficial especificado;

- nenhuma das equipes estava utilizando o soquete estabelecido para a compactação, a qual era feita com a própria enxada;

- o engenheiro e o mestre não tinham conhecimento do que estava realmente ocorrendo na obra, cujo controle estava nas mãos do estagiário que, por sua vez, não tinha participado do processo de treinamento e não havia recebido as instruções para o controle da execução.

Tendo em vista a exposição anterior, vê-se que essa experiência foi também de grande valia para o aprendizado quanto à condução do processo de implantação, podendo-se destacar algumas questões de maior relevância:

- a incorporação das TCR's ainda na fase de projeto permite obter um grande nivel de racionalização, desde que as etapas que antecedem o serviço a ser racionalizado sejam produzidas dentro das especificações estabelecidas;

- o controle de todas as etapas de execução é fundamental para que se possa ter uma etapa de reprojeto que considere as verdadeiras condições de execução da obra, e que direcione as próximas ações de racionalização;

- a organização da mão-de-obra na empresa e os investimentos na sua fixação, procurando diminuir a rotatividade, é essencial para que os esforços realizados com o treinamento não sejam perdidos em pouco tempo;

- o controle do serviço objeto da racionalização é fundamental; não se implanta uma nova tecnologia da noite para o dia, é preciso estabelecer uma sistemática de controle para se identificar os potenciais problemas e corrigilos, realimentando, dessa maneira, o processo de implantação.

Pode-se dizer que grande parte dos pontos de reflexão, destacados para as duas empresas, tem sua natureza ligada ao sistema de gestão e organização das mesmas, e essas experiências mostraram que os entraves para alterar tal sistema não são poucos.

Esses entraves aparecem logo no início, com a dificuldade de se alterar o 
processo de projeto. As dificuldades incluem desde a ausência de profissionais internos às empresas dedicados a esta atividade, até as precárias condições de contratação das equipes de projetistas externas às empresas.

Por outro lado, a complexa forma de contratação da mão-de-obra, em que se sobressaem os contratos por empreitada de serviços, sem critério técnico, aparece sempre como uma dificuldade à evolução desse processo de produção. Ao contratar subempreiteiras, não há motivação por parte da construtora em assumir o treinamento dos operários, uma vez que essa mão-de-obra permanecerá na empresa, no máximo, apenas durante a execução desse serviço específico.

- Os investimentos para a montagem de uma estrutura mínima de controle também aparecem como fatores dificultadores da implantação da proposta de racionalização. No entanto, sem controle não se pode ter retroalimentação da implantação e, portanto, não se consegue avaliar os seus resultados. .

Nessas duas oportunidades em que se buscou implantar essa TCR, os resultados finais foram praticamente os mesmos: a manutenção do sistema de gestão tradicional da empresa, ou seja não foi possivel alterar a organização do processo de produção, havendo, como conseqüência, a perda do potencial de racionalização embutida na tecnologia.

A redução do consumo de materiais proporcionada pela TCR para produção de contrapisos motiva qualquer profissional da área a experimentar sua implantação; entretanto, parece não ficar claro para esses profissionais que tal redução somente será possivel se um conjunto de fatores organizacionais e gerenciais forem agregados aos tecnológicos.

O consumo de aglomerante na produção da argamassa é reduzido significativamente com relação aos traços usualmente empregados em obra. Porém, para que isso ocorra, é preciso que seja adotada uma técnica de execução correta e de se estabelecer procedimentos de controle na produção das argamassas e do próprio contrapiso. Essas atividades, não são fáceis de serem implantadas. 
Além disso, essa economia não é mais significativa do que a obtida pela racionalização das espessuras comumente praticadas para os contrapisos, o que somente é possivel com a implantação de mudanças durante a fase de projeto e de produção da estrutura. É na fase de projeto que as espessuras do contrapiso podem ser otimizadas em função das demais disciplinas de projeto e, é na fase de produção da estrutura que se pode obter uma laje com os niveis especificados no respectivo projeto.

Com essas experiências, pôde-se compreender que mesmo a tecnologia estando disponivel, sem uma específica metodologia para a implantação, as TCR's não se fixam ao processo construtivo empregado pela construtora, ainda que esta se empenhe em padronizar seus próprios procedimentos.

Para que os resultados positivos, obtidos numa obra, possam ser fixados ao sistema de produção da empresa e venham a ser transferidos a outros empreendimentos, é imprescindivel um adequado equacionamento de todos os fatores intervenientes no processo de produção. $E$ isto não é fácil de ser realizado. Exige, dedicação e voluntariedade das pessoas envolvidas e, principalmente, uma adequada forma de condução do processo de implantação.

\subsection{Conclusões sobre o Processo de Implantação de Novas Tecnologias}

A apresentação e análise dos diversos modelos para a inovação tecnológica disponiveis na bibliografia e dos dois estudos de caso procuraram consolidar o conhecimento até então disponivel sobre o assunto e, principalmente, identificar as diretrizes principais que devem conduzir um processo de inovação.

Com isso, pretende-se, neste item, realizar uma síntese dos elementos identificados como fundamentais para o processo de implantação de novas tecnologias, distinguindo-se, inicialmente, as etapas que o processo de implantação

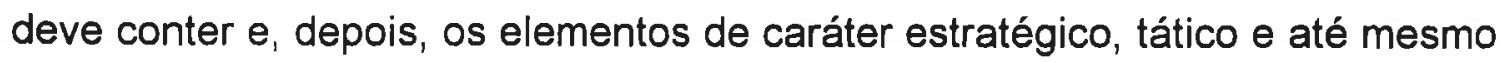
operacional. 


\subsubsection{Etapas do processo de inovação}

A inovação tecnológica ocorre a partir de um processo constituído de diversas etapas e subetapas. No entanto, antes de se propor a implantar uma nova tecnologia, a empresa deverá observar duas premissas fundamentais:

- a existência de motivação para a implantaçăo

- a preparação da organização para empreender a mudança, "criando um clima organizacional favorável e disponibilizando os recursos".

Dentro deste contexto empresarial, as principais etapas que deverão constituir o processo de inovação são:

- planejamento da implantação

- inserção da mudança no processo construtivo da empresa;

- avaliação dos primeiros resultados e correção dos problemas identificados;

- retomada das etapas anteriores até a consolidação da tecnologia.

\subsubsection{Elementos de ordem estratégica}

Os principais elementos de ordem estratégica que deverão ser contemplados pela metodologia são:

- visão de longo prazo;

- inovação tecnológica presente na definição estratégica da empresa e orientada para o mercado;

- desenvolvimento da capacidade técnico-organizacional da empresa;

- desenvolvimento das capacidades técnicas da empresa: deve existir um elemento com o domínio do processo de produção

- comprometimento da alta administração com o processo de implantação;

- presença de um elemento humano que lidere o processo de inovação na empresa;

- comprometimento de recursos humanos e financeiros;

- existência de um sistema de informações técnicas e gerenciais;

- adoção de coordenação de projetos; 
- implementação de atividades de treinamento;

- busca da padronização e normalização

\subsubsection{Elementos de ordem tática}

Os principais elementos de ordem tática que deverão ser contemplados pela metodologia são:

- identificação e avaliação das tecnologias disponíveis: parcerias com as universidades e centros de pesquisa; prática do 'benchmarking';

- motivação do pessoal envolvido, através de reconhecimento e recompensas;

- existência de um processo de documentação e registro;

- análise dos resultados obtidos;

- gerenciamento e controle dos resultados da implantação: permitir a retomada de direção em função dos resultados obtidos;

- implantação de açōes simples, de menor amplitude, como uma forma de possibilitar o controle e menores custos envolvidos;

- não implantar várias tecnologias de uma só vez, proporcionando maior segurança aos envolvidos com o processo de inovação;

- implantação das novas tecnologias por estágios incrementais;

- emprego de etapas experimentais, com o uso de protótipos;

- planejamento da implantação;

- envolvimentos dos agentes que participam do processo de produção, com o controle das relações entre eles;

- elaboração de recomendações para projetos futuros;

Considerando-se esses elementos, no capítulo 5, a seguir, apresenta-se a metodologia defendida neste trabalho como sendo um caminho adequado e propício para a implantação de TCR's em empresas construtoras de edifícios pelo processo construtivo tradicional. 


\section{CAPÍtULO 5}

\section{METODOLOGIA PARA IMPLANTAÇÃO DE TECNOLOGIAS CONSTRUTIVAS RACIONALIZADAS NA PRODUÇÃO DE EDIFİCIOS}

Propor a aplicação de uma metodologia para a condução de um determinado processo é uma forma de proporcionar uma orientação efetiva aos responsáveis pela implantação, permitindo-lhes selecionar as hipóteses, as técnicas, os dados mais adequados e adotar as decisões mais acertadas.

Entretanto, é preciso enfatizar que a aplicação da metodologia proposta não resultará no sucesso automático da implantação de TCR's em empresas construtoras.

O processo de implantação de novas tecnologias é complexo e dependente das características das organizações; assim, não se pode esperar uma "fórmula milagrosa", que resolva o problema de todos, indistintamente.

Como bem destacam PINTO; PINTO [1995]: "Para a melhoria da qualidade, baseada na redução do desperdício e no aumento da produtividade, é imprescindivel que se compreenda a impossibilidade de uma única solução mágica". Afirmam ainda: "se há na empresa a intenção de se apropriar de novos procedimentos e buscar melhores resultados, duas linhas de conduta são inevitáveis: uma delas é repensar toda sua estrutura, reexaminando e modificando sistemáticas de trabalho e tecnologias; a outra se expressa em uma única palavra - persistência, que deverá ser mantida pelo corpo dirigente da empresa".

DAVENPORT [1993] deixa expresso que "tanto a melhoria dos processos como a inovação dos processos exigem uma mudança cultural da empresa" e esse autor afirma ainda: "não conhecemos nenhuma organização de grande porte que tenha identificado e implementado uma importante inovação de processos em menos de dois anos".

Por ser imprescindivel que: se repense a estrutura organizacional da empresa; se empreenda uma mudança cultural; se tenha um firme propósito 
e persistência no objetivo, defende-se a utilização de uma adequada metodologia para a introdução de TCR's nos processos construtivos empregados pelas empresas. Pretende-se, com isso, que os condutores da implantação não se percam e não se desviem do caminho, pois essa metodologia permitirá minimizar as dificuldades comumente encontradas durante a implantação de novas tecnologias, as quais podem levar ao desânimo e ao abandono das ações que visam a melhoria.

Deve-se destacar que a metodologia deverá ser encarada como uma orientação ao processo de implantação e não o processo em si, à medida em que os seus principios e diretrizes deverão auxiliar e condicionar a tomada de de.cisões, enquanto os seus elementos estratégicos deverão ajudar no estabelecimento de um planejamento racional para a condução do processo no interior de cada empresa construtora.

O que se quer dizer com isso é que o sucesso potencial da implantação, empregando-se a metodologia proposta, dependerá não somente da metodologia em si, mas sobretudo do envolvimento da empresa, no sentido de estar motivada a evoluir através da realização efetiva de mudanças tecnológicas e gerenciais em seu processo de produção.

Esse envolvimento da organização deverá ser traduzido pela adoção de uma estratégia empresarial favorável à implantação de TCR's, a qual deverá conter uma série de elementos básicos, para que se tenha uma maior probabilidade de sucesso com a aplicação da metodologia.

Esses elementos são aqui identificados como premissas para a aplicação da metodologia.

\subsection{Premissas para Aplicação da Metodologia}

A implantação de TCR's não é de fácil condução, não se faz a partir da vontade de uma única pessoa. Ela exige uma mudança de postura; uma alteração na gestāo do processo de produção do edifício, desde a fase de concepção do empreendimento até o acompanhamento de seu desempenho após a entrega. 
Além disso, há consenso quanto ao longo período demandado para a implantação de novas tecnologias em qualquer setor industrial.

Portanto, a implantação de TCR's é uma atividade que, para ser levada adiante, precisa, em primeiro lugar de uma organização da empresa, voltada para $\circ$ aprendizado e com uma visão de longo prazo, pois não se pode exigir resultados perenes imediatos; necessita, além disso, de açōes de grande amplitude, isto é, que repercutam na empresa como um todo, o que exige um eficiente sistema de decisōes e informaçōes, além de recursos de diversas naturezas, para a implementação das ações.

Pode-se estabelecer, com isso, os elementos que devem estar presentes na organização para favorecer a introdução de mudanças, quais sejam:

- estabelecimento de um sistema de decisões e de informação;

- identificação da situação tecnológica da empresa;

- disposição e a motivação para o aprendizado;

- disponibilidade dos recursos.

\subsubsection{Estabelecimento de um sistema de decisões e de informações}

Segundo ROCHA LIMA JR. [1990a] o sistema de decisōes de uma empresa, funciona em três escalas hierárquicas diferentes, ilustradas na figura 5.1.

Para esse autor, a decisão tomada num determinado patamar na organização apresenta um determinado nível de abrangência, o que induz uma diretriz para as decisões de patamares inferiores. Nesses patamares intermediários, a decisão que chegou deverá ser complementada com novas informações próprias a esses patamares, e assim, sucessivamente, até que se atinja o nível de ação direta ou da produção do bem ou serviço.

Esse modelo de tomada de decisões ocorre também nas empresas de construção de edifícios. Há decisões que têm grande abrangência na empresa, por terem sido tomadas nos patamares hierárquicos mais elevados; enquanto outras são localizadas, porque ocorreram nos patamares inferiores. 


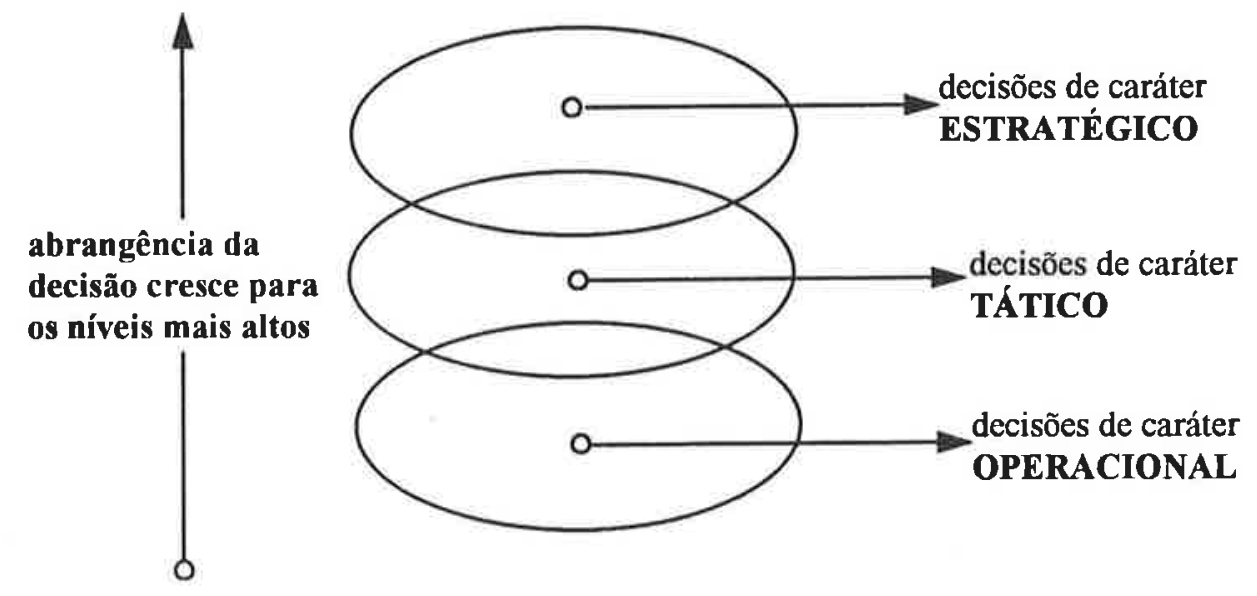

FIGURA 5.1: Hierarquia do sistema de decisões [ROCHA LIMA JR., 1990a]

Por exemplo, uma política de investimentos em equipamentos de grande porte somente poderá ter origem no nível estratégico da empresa. É o que ocorre quando a diretoria decide equipar todas as suas obras com gruas.

Por outro lado, o gerente de uma das obras dessa empresa, independentemente de uma política mais ampla, pode solicitar um equipamento desse porte. Essa decisão, de ordem tática, terá uma abrangência mais restrita que a primeira. Nem todas as obras da empresa serão beneficiadas.

Há, por outro lado, decisões de caráter operacional, as quais tem abrangência ainda mais limitada. Por exemplo, um prestador de serviço emprega um determinado equipamento para a realização de uma certa atividade, com vistas à elevação da produtividade.

O sistema de decisões, assim estruturado, reflete no processo de implantação de mudanças tecnológicas na empresa.

A decisão de se empregar uma nova tecnologia poderá ser tomada em qualquer um desses niveis decisórios, à medida em que exista alguém que detenha a informação de como alterar racionalmente um determinado serviço ou processo. Ou seja, a mudança tecnológica nos métodos construtivos adotados pela empresa poderá ocorrer tanto a partir de um processo que nasce de uma decisão no nível estratégico ("top-down"), como de uma decisão que ocorre no nivel tático ou mesmo operacional ("bottom-up"). 
Entretanto, se a mudança for proposta no nivel operacional, certamente a abrangência dessa ação estará limitada, pelo menos num primeiro momento, pelos recursos disponíveis nesse nível e às pessoas ou ao setor que promoveram a alteração, não influenciando em outras atividades da empresa, ainda que correlatas. Essa alteração tem, portanto, um poder de ação e uma amplitude reduzidos.

Ou seja, a decisão de se implantar TCR's, tomada nos niveis decisórios inferiores, tende a ser uma ação localizada e com menores chances de se fixar na cultura da empresa. Além disso, se a racionalização decorrer de uma atitude tomada em etapas mais adiantadas do processo de produção, o resultado poderá ser pouco expressivo, considerandos o conjunto de atividades produtivas. LAUFER [1985] deixa claro que "a introdução de mudanças durante a construção, depois que as principais decisões de projeto já tenham sido tomadas são, necessariamente, de escopo limitado. Apesar de exigirem recursos relativamente modestos, sua influência no processo de produção é limitada e tem curta duração".

Essa situação pode ser ilustrada, por exemplo, pela atitude de um operário treinado no uso da "bisnaga" para o assentamento de componentes de alvenaria. Ao empregar essa ferramenta, é possivel, ao operário, obter maior produtividade que com o emprego da colher e, além disso, essa ação resultará num menor consumo de argamassa de assentamento. No entanto, uma atitude desse tipo, isolada do contexto das demais ações empreendidas pela empresa, não fará com que esta venha a ter um método construtivo racionalizado de produção de alvenarias.

Por outro lado, se a decisão quanto à racionalização da produção das alvenarias for tomada nos niveis decisórios estratégicos da empresa, deverão ser providenciados os meios para que o conjunto das atividades de produção das alvenarias seja racionalizado. Neste caso, precisarão ocorrer, entre outras ações, o desenvolvimento do projeto voltado à produção, a revisāo do planejamento e, inclusive, o treinamento de todos os operários para o uso da técnica racionalizada. 
Observa-se pois, que a decisão vinda do nível estratégico, tenderá a influenciar os níveis inferiores como um todo, ampliando a sua ação.

Segundo DAVENPORT [1993], a inovação de processos faz-se muito mais de cima para baixo, exigindo uma administração forte por parte da alta gerência. Esse autor afirma: "como as estruturas das grandes empresas não refletem seus processos interfuncionais, apenas os que estão em posição que controlam funções múltiplas podem ser capazes de reconhecer as oportunidades de inovação." Essa afirmação tem uma aderência muito forte com o que realmente ocorre no processo de produção de edifícios, em que, aqueles que realizam as atividades praticamente ignoram a complexidade do processo como um todo.

Ou seja, o operário da construção que conhece a técnica de assentamento de alvenaria com o uso da bisnaga, pela sua formação, não tem condiçōes de imaginar a reformulação do método construtivo de produção de alvenarias e talvez não conheça a possibilidade de emprego de outros componentes para a execuçāo das vedações, visando a sua racionalização.

Não se quer dizer com isso que as contribuições vindas "de baixo para cima" não devam ser consideradas. Muito pelo contrário, a empresa deve desenvolver um sistema de comunicação que permita detectar com eficiência uma melhoria ocorrida em um determinado serviço, numa certa obra. Com isso, poderá utilizar a informação para ampliar essa ação para outros empreendimentos. Essas melhorias incrementais, quando bem conduzidas, possibilitam a sobrevivência e atualização das TCR's inicialmente implantadas.

Além de maior influência na organização da empresa, as decisões quanto a implantação de novas tecnologias, tomadas no nível estratégico, poderão ocorrer num momento que favoreça mais a realização da implantação.

Segundo o CII [1987], a capacidade de uma determinada ação de racionalização influenciar o custo final de um empreendimento de edifícios vai sendo reduzida com o avanço de suas fases, o que é ilustrado pelo gráfico apresentado na figura 5.2 . 


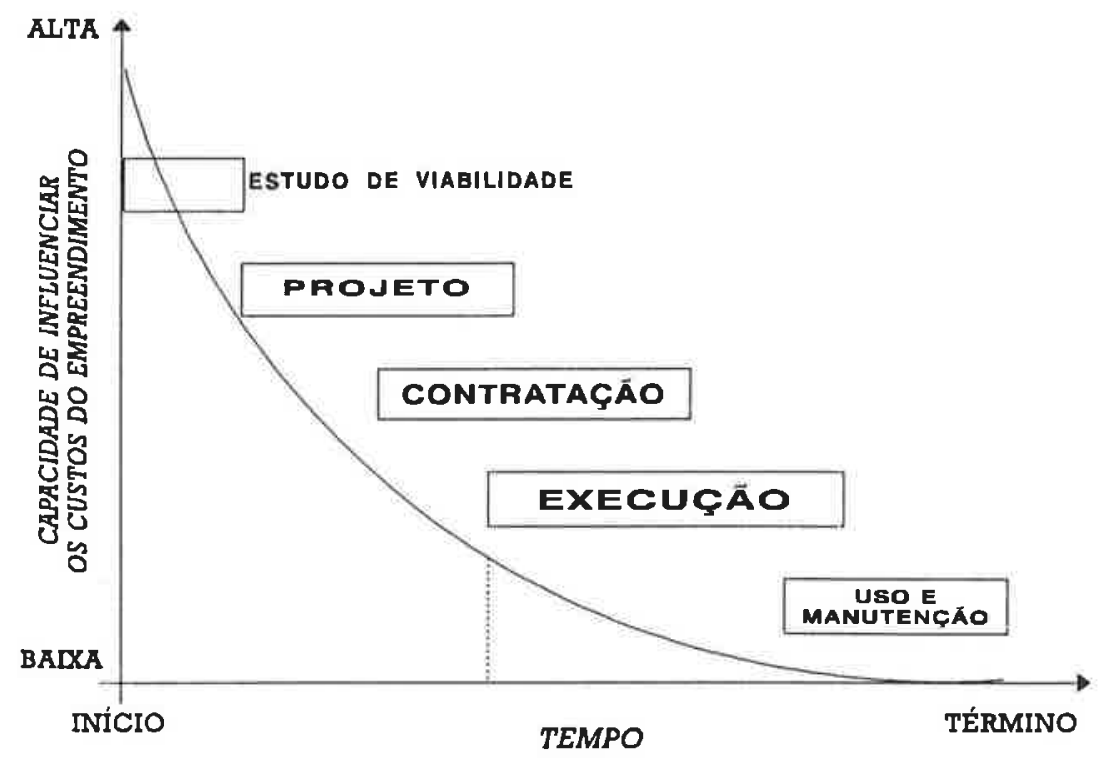

FIGURA 5.2: Capacidade de influenciar o custo final de um empreendimento de edifício ao longo de suas fases [CII, 1987]

Por esse gráfico fica claro que as decisões de mudança tecnológica incorporadas no momento da produção (de ordem operacional) têm pouca influência sobre o custo total do empreendimento; enquanto aquelas tomadas durante a fase de concepção (de ordem estratégica), podem ser decisivas para a viabilização de um empreendimento.

Ou seja, para que as TCR's tenham uma maior probabilidade de sucesso, isto é, para que venham a ser efetivamente implantadas no canteiro de obras, é preciso que a motivação para a implantação tenha origem em quem detém um certo "poder de decisão", ou seja, deve vir de cima para baixo, pois, pela abrangência de suas ações, serão maiores as chances de se conseguir incorporar as novas tecnologias à cultura da empresa.

\subsubsection{A relação entre o sistema de decisões e o de informações}

ROCHA LIMA JR. [1990b] salienta que as decisões não são tomadas por qualquer sistema, mas sim por indivíduos que cumprem funções dentro do sistema organizacional, dentro de um determinado patamar de risco, o qual deverá ser avaliado em função de um conjunto de informações disponíveis. 
Segundo esse autor, o sistema de informações deverá balizar o sistema de decisões e deverá "ser capaz de gerar informação com a velocidade compatível com a exigência da decisão; e ser eficiente no conteúdo da informação, que deverá responder às críticas quanto ao risco contido na decisão a tomar."

Observa-se, assim, que o sistema de informações alimenta o sistema de decisões, de maneira que juntos constituem o aprendizado da empresa, a sua cultura. E esse sistema de informaçōes, segundo ROCHA LIMA JR. [1990a], deverá ser dinâmico, incorporando a evolução do conhecimento dos indivíduos que formam a empresa e da própria sociedade.

Não resta dúvida que para os sistemas de decisões e de informações funcionarem, isto é, subsidiarem aqueles que precisam decidir e aqueles que precisam realizar as decisões, é importante que a empresa tenha uma organização voltada para esse fim.

Segundo FRANCO [1992], é difícil encontrar empresas que apresentem uma organização "formal" bem definida, que tenham o entendimento claro de seus objetivos, que estabeleçam os responsáveis pelo processo de implantação. $E$, isso tem dificultado a implantação das mudanças que permitam alcançar um maior nível de desenvolvimento tecnológico dos processos e dos produtos.

Em uma atividade prática, de análise da organização funcional de empresas de construção de edifícios na cidade de São Paulo, que vem sendo sistematicamente realizada pela autora juntamente com alunos do $3^{\circ}$ ano da graduação em Engenharia Civil da EPUSP, no escopo da disciplina "PCC 233 O Processo da Construção Civil", tem-se identificado que, atualmente, a maioria dessas empresas é de porte médio e pequeno, sem uma estrutura organizacional completamente definida.

É comum que essas empresas apresentem um organograma funcional definido apenas formalmente, não sendo utilizado na prática de suas atividades. Observa-se, ainda, um grande número de empresas com uma administração centralizada na pessoa do "proprietário" e com uma organização familiar, sem que haja a preocupação de existirem pessoas capacitadas a conduzir 0 
processo de mudança tecnológica dentro da empresa; características que SERPEL [1995] destaca como sendo barreiras ao processo de inovação.

A estrutura organizacional da empresa, refletindo a sua estratégia voltada ao processo de implantação de novas tecnologias, é fator fundamental para que a tomada de decisões se faça na direção do processo de mudança. $E$, além disso, um adequado sistema de informações, subsidiando as questōes que envolvem a nova tecnologia, é essencial para que as decisões atinjam a produção e sejam corretamente cumpridas.

O repasse tecnológico que vem sendo realizado junto às empresas construtoras tem mostrado claramente que esses dois fatores - organização para a tomada de decisão e características do sistema de informações - interferem significativamente no resultado esperado da implantação.

As decisões, que carregam consigo um certo grau de informação tecnológica, tomadas num determinado nível hierárquico, influenciam todos os niveis subseqüentes e, dependendo da posição hierárquica em que ocorreu e da maneira que atingiu a etapa de produção, pode comprometer totalmente a condução da implantação de uma nova tecnologia.

Durante o processo de implantação é comum ocorrerem as seguintes posturas por parte da alta gerência das empresas: "não investimos em projetos porque não são utilizados", "não realizamos treinamento porque a rotatividade é elevada"; "não alteramos os procedimentos porque o cronograma estava 'apertado'"; "não montamos um sistema de controle, pois representa um custo elevado"; "não alteramos o procedimento porque achamos que não dá certo".

Essas posturas, na maioria das vezes, individuais e subjetivas, ilustram como as decisões tomadas sem parâmetros completamente definidos e a falta de informações podem comprometer o processo de implantação. A decisão, vinda de cima para baixo, desprovida de uma informação correta, pode inviabilizar qualquer princípio de racionalização a ser implantado, inviabilizando, muitas vezes, o processo de mudança tecnológica. 
Assim como para a implantação de sistemas de Gestão da Qualidade, para a implantação de TCR's o processo deve começar igualmente pela conscientização e comprometimento da alta gerência. A decisão tomada nos níveis hierárquicos mais elevados tem maior potencial de proporcionar resultados positivos, desde que alicerçada por um adequado sistema de informações, em que o sistema de comunicação da empresa tem grande peso.

\subsubsection{O sistema de informações e a comunicação interna na empresa}

Um dos principais entraves, apontados por praticamente todas as bibliografias analisadas no âmbito do capítulo 4 e identificados durante a pesquisa de campo, é a ausência de um sistema de comunicação interno à empresa que permita que o fluxo de informações e de decisōes ocorra sem ruídos e de maneira eficiente.

GOMES; SALDANHA [1995] destacam que: "freqüentemente, as informações de cima para baixo na via hierárquica chegam ao operário deturpadas ou sem as explicações necessárias. As de sentido contrário, de operário para engenheiro, não chegam ao destino final. Tais desencontros geram insatisfações às equipes de trabalho, resultando em prejuizo para o andamento da obra".

Para que essa situação seja revertida e, ainda, conscientes de que é preciso realizar uma mudança tecnológica e motivadas a isso, as empresas deverão criar, inicialmente, um ambiente organizacional favorável ao aprendizado de novas tecnologias e formas de gestão, de maneira que as pessoas envolvidas estejam motivadas a contribuírem com a evolução pretendida.

Nesse aspecto, a informação é vital para a motivação dos envolvidos com o processo de mudança da organizaçāo. E, para que a flua adequadamente pela empresa, é preciso o estabelecimento de um sistema de comunicação eficiente entre todos os niveis hierárquicos, de modo que as decisões e as informações estratégicas e táticas cheguem às áreas operacionais. Além disso, os resultados obtidos nas atividades operacionais, sejam eles positivos ou negativos, devem retornar aos niveis estratégicos da empresa, subsidiando a definição de novos rumos para o processo de implantação das TCR's. 
Segundo CHIAVENATO [1992], "o processo de comunicação funciona como um sistema aberto em que certa quantidade de ruído tende a deturpar, distorcer e alterar, de maneira imprevisivel, as mensagens transmitidas. Ocorrem, então, interferências que tendem a provocar alterações no funcionamento desse processo de comunicação".

Por isso a organização deverá estar atenta às barreiras ao processo de comunicação, sendo as mais comuns: idéias preconcebidas; recusa de informação contrária; significados personalizados; motivação, interesse; credibilidade da fonte; habilidade de comunicação; clima organizacional; e complexidade dos canais [CHIAVENATO, 1992].

O sistema de comunicações a ser estabelecido pela empresa deverá permitir que o fluxo de decisões e o de informações ocorra com um mínimo de interferências e ruídos, subsidiando as atividades do processo de implantação.

Segundo AMORIM [1995] é "(..) necessário aperfeiçoar o tratamento das informaçōes e homogeneizar suas terminologias e os objetivos de cada participante para que todos 'falem a mesma língua' ao longo da cadeia de produção, evitando-se as rupturas a cada 'passagem do bastão', a cada vez que um ator transfere tarefas para o seguinte".

A esse sistema de comunicação deverão estar relacionados diversos elementos tais como os projetos e a documentação dos processos de produção utilizados pela empresa, os quais são fontes essenciais de informações para a realização do produto edifício.

Esses dois elementos de informação do processo, projeto e documentação, serão amplamente discutidos quando apresentadas as diretrizes balizadoras da metodologia.

A seguir, discutem-se dois outros aspectos que também interferem no sistema de decisão da empresa: o conhecimento da situação tecnológica em que a empresa se encontra e a obtenção de novas tecnologias. 


\subsubsection{Identificação da situação tecnológica da empresa}

A identificação da situação real da empresa quanto aos métodos e processos construtivos praticados, antecedendo o processo de implantação, é imprescindivel, pois, a implantação de TCR's exige investimentos em uma série de recursos tais como: temporais; financeiros; tecnológicos, materiais; humanos e organizacionais. Assim sendo, deverá haver consciência por parte da alta administração de que esse é o caminho mais adequado a ser percorrido para atingir as suas metas.

Se não houver o firme propósito de se realizar a implantação, entendendo que esta estratégia contribuirá para o desenvolvimento da empresa, o processo acabará sendo truncado, seja por não se destinar os recursos a serem empregados, seja pelas pressões impostas pelo próprio processo de implantação.

Ao interromper a implantação, a empresa perderá os recursos investidos e frustará aqueles que acreditaram na idéia, dificultando qualquer outra iniciativa de melhoria das características de produção.

Essa identificação da situação tecnológica deverá ser realizada frente a algum parâmetro que reflita os objetivos da empresa.

Esses parâmetros podem ser de diversas naturezas, mas apenas a título de exemplo, citam-se alguns comumente empregados: a relação entre os custos globais de produção e os preços pagos pelo mercado a que a empresa se propõe atender; os custos originados de manutenções posteriores à entrega do edifício e as reclamações recebidas após a entrega.

Apesar de se tratarem de parâmetros globais, poderão indicar se o caminho a ser seguido é o de implantação de alterações no processo construtivo, ou não. Além de um diagnóstico global, enfocando parâmetros mais amplos, relacionados ao mercado que se deseja atingir e à satisfação dos clientes, a empresa deverá realizar um diagnóstico que envolva a produção propriamente dita, analisando os seus métodos construtivos, questionando, por exemplo:

- "qual a tecnologia construtiva empregada pela empresa para a realização dos principais serviços em seus diversos canteiros de obras?"; 
- "quem conhece os métodos e técnicas construtivas empregados nos canteiros de obras?";

- "não haveria uma forma mais racional de se executar os serviços?";

- "por que se gasta tantos recursos para a retirada de entulho das obras?";

- "por que o orçamento sempre é superado?";

- "os projetos realizados atendem às necessidades da produção?";

- "onde estão os erros dos projetos?"

E, considerando-se a atual competitividade de mercado deve-se perguntar ainda: "como estão os nossos concorrentes frente às questões anteriormente colocadas?"

Utilizar os resultados dos concorrente como parâmetro de comparação tem sido denominado de "processo de benchmarking".

Segundo CAMP [1993] o "benchmarking" pode ser entendido como: "a busca pelas melhores práticas que conduzem uma empresa à maximização do desempenho empresarial". Segundo esse autor, ainda, "o "benchmarking" é um processo positivo, pró-ativo e estruturado que conduz a mudanças nas operações e, finalmente, ao desempenho superior e a uma vantagem competitiva".

A prática do "benchmarking" tem sido comum para as indústrias seriadas, proporcionando referenciais para que as empresas possam estabelecer suas metas segundo parâmetros do mercado.

Segundo DAVENPORT [1993], o 'benchmarking' ajuda as empresas a formularem suas metas para os programas de melhoria contínua. Mas, pode ser, além disso, um instrumento para se determinar os objetivos e os atributos de um processo inovador.

Esse autor salienta que o mais apropriado para os propósitos do processo de inovação é o "benchmarking da "melhor prática" ou da "inovação", que seleciona empresas com base no desempenho de um processo em particular, direcionando a atenção para as inovações e as mudanças mensuráveis nesse processo. 
DAVENPORT [1993] salienta ainda, que o "benchmarking" pode identificar metas de desempenho realísticas e caracteristicas objetivas para as empresas tentarem atingir ou superar. Segundo o autor, essa informação poderá ser utilizada durante as atividades de "brainstorming", visando estimular o reprojeto do processo em discussão.

A prática do "benchmarking" não é comum entre as empresas de construção de edifícios. São poucas as empresas que se lançam a observar e entender o que outras estão desenvolvendo e praticando em seus canteiros de obras, com a finalidade de estabelecer suas próprias metas.

Na realidade, há uma escassez de empresas que podem ser consideradas como parâmetro para as demais. São poucas as empresas que, tecnologicamente, destacam-se no mercado. $O$ que comumente se observa na organização das empresas construtoras, no Brasil, é um acentuado conservadorismo quanto às suas práticas de produção.

Além disso, a maioria das empresas não é aberta ao mercado concorrente. As que não têm domínio sobre o processo de produção, possivelmente, não querem se expor às prováveis críticas dos concorrentes e do próprio mercado; enquanto uma parte expressiva das poucas que vêm procurando evoluir, guarda somente para si os avanços conseguidos, como uma maneira de se defender da concorrência, acreditando que, com isso, irá se manter à frente das demais.

Há empresas bem organizadas para realizar o diagnóstico inicial, enquanto outras estão longe de se preocuparem com as questōes tecnológicas, as quais comumente são resolvidas nos canteiros de obras.

O que se tem observado, ao se trabalhar com diversas empresas atuantes no mercado, é que, na maioria dos casos, não há domínio sobre os processos construtivos empregados. Não se domina o "como" e o "porquê" as atividades são executadas de determinada maneira e não de outra; não se conhece realmente os custos de produção, porque não se conhece o processo de produção; os desperdícios não são objeto de controle nos canteiros de obras, mesmo sabendo-se que constituem grande volume de recursos perdidos. 
As empresas não sabem o quê e como controlar, porque não conhecem como os serviços e atividades devem ser realizados racionalmente. Do ponto de vista tecnológico, as organizações continuam a depender do conhecimento embutido no "saber-fazer" do operário, cuja qualificação, por outro lado, não tem sido objeto de preocupação das empresas.

Por esse não envolvimento com os fatores intervenientes na produção, podese afirmar que as empresas que optarem por alterar o seu atual processo de gestão e de organização, com vistas a aumentar a sua competitividade no mercado através da redução dos custos de produção, deverão realizar, em conjunto, uma mudança tecnológica que Ihes permita alcançar um patamar mais elevado de racionalização do processo de produção.

Há muito o que fazer evoluir no processo construtivo tradicional de produção de edifícios; no entanto, essa evolução dificilmente poderá ser empreendida de uma única vez. Caberá à direção da empresa priorizar as mudanças tecnológicas a serem realizadas primeiro.

DAVENPORT [1993], referindo-se à implantação de inovação de processos na indústria seriada, afirma que "a maioria das empresas prefere ocupar-se de um pequeno número de processos para adquirir experiência com iniciativas de inovação, e concentram seus recursos nos processos mais críticos". $E$, acrescenta: "cada iniciativa bem sucedida torna-se um modelo para esforços futuros".

Segundo esse autor, um dos critérios que podem auxiliar na definição dos processos críticos é a verificação das "condições reais do processo", para identificar e reconfigurar processos que são problemáticos e mostram evidente necessidade de melhoria.

O processo de produção de edifícios não é um processo simples. Ele é, na verdade, constituído por inúmeros outros processos de maior ou menor complexidade. Desta forma, caberá a quem tem o poder de decisão na empresa identificar por onde o processo de alteração tecnológica deverá ter início, sem 
perder de vista que essa decisão precisará chegar à produção, exigindo recursos de diferentes naturezas e uma forte disposição para o aprendizado.

\subsubsection{Disposição e motivação para o aprendizado}

Acerca do processo de aprendizagem de uma organização, do qual o elemento informação é básico, FLEURY; FLEURY [1995] afirmam que esse processo "não só envolve a elaboração de novos mapas cognitivos, que possibilitem compreender melhor o que está ocorrendo em seu ambiente externo e interno, como também a definição de novos comportamentos que comprovam a efetividade do aprendizado".

Portanto, a empresa disposta a aprender deve estar capacitada a criar, adquirir e transferir conhecimentos e a modificar seus comportamentos para refletir estes novos conhecimentos.

GARVIN (1993), apud FLEURY; FLEURY [1995], apresenta os cinco caminhos através dos quais a aprendizagem organizacional pode ocorrer:

- resolução sistêmica de prob/emas: ocorre através de diagnóstico feito com métodos científicos, uso de dados para a tomada de decisões e uso de métodos estatísticos para organizar as informações e proceder inferências;

- experimentação: envolve a pesquisa sistemática e o teste de novos conhecimentos, utilizando-se sempre de métodos científicos; é usualmente motivada pelas oportunidades de expandir horizontes e não pela resolução de problemas correntes;

- experiências passadas: as organizações precisam rever seus sucessos e fracassos, avaliá-los sistematicamente e gravar as liçōes de forma acessivel a todos os membros;

- circulação de conhecimento: o conhecimento precisa circular rápida e eficientemente por toda a organização; novas idéias têm maior impacto quando são compartilhadas coletivamente do que quando são propriedade de uns poucos;

- experiências realizadas por outros: a observação das experiências 
realizadas por outras organizações pode constituir um caminho para a aprendizagem (o "benchmarking" tem sido utilizado como uma estratégia para se repensar a própria organização).

Essas formas de aprendizado não têm sido observadas pela indústria da Construção de Edifícios. A "resolução de problemas", a "experimentação" e o "aproveitamento de experiências passadas" são, sem dúvida, formas relevantes de aprendizado; mas, para serem efetivas é preciso estarem sistematizadas; é preciso que sejam realizados registros precisos do seu processo de condução, o que não é uma realidade da indústria da Construção de Edifícios.

O mecanismo de "benchmarking", atualmente empregado pela indústria de bens de consumo, não é comum no setor da Construção, seja pela falta de entendimento do que seja essa modalidade de aprendizado, seja pelas reduzidas diferenças tecnológicas existentes entre as empresas que disputam um mesmo segmento de mercado.

A troca de "conhecimento" ocorre, de modo geral, por vias informais, através de um mecanismo que se acostumou denominar "rádio-peão".

Fruto da constante mobilidade da mão-de-obra do setor, as informaçōes sobre as novas tecnologias vão sendo passadas informalmente de um canteiro para outro, na maioria das vezes, sem que se conheçam os seus fundamentos.

Em SCARDOELLI; SILVA; FORMOSO [1994] pode-se perceber essa maneira informal de transferência de tecnologia. Os autores, referindo-se a uma série de melhorias observadas em canteiros de obras localizados em diferentes regiōes do país, afirmam: "foram identificadas duas mudanças bastante significativas na produção de alvenarias. A primeira delas foi a eliminação da junta vertical (...) uma outra (...) é a eliminação do encunhamento tradicional com tijolos inclinados, que tem sido substituído por preenchimento com argamassa expansiva ou de assentamento".

Essas mudanças tecnológicas são, na verdade, resultado de extensas pesquisas e investigações conduzidas no CPqDCC-EPUSP [SABBATINI; BARROS; SILVA, 1989] e propostas para serem empregadas dentro de um contexto ade- 
quado para a produção de edifícios. Fora desse contexto, o seu emprego pode trazer sérias conseqüências ao comportamento das alvenarias; entretanto, essa informação não é veiculada pelos canais informais, que se estabelecem entre os diversos canteiros de obras e as diferentes construtoras no país.

Mas, os problemas de aprendizado das empresas vão além da troca informal de conhecimento. $O$ conhecimento que poderia ser acumulado a partir da realização de um determinado empreendimento não se efetiva na empresa.

FLEURY, FLEURY [1995] salientam que no processo de aprendizagem "o mais importante é a integração dos conhecimentos, não apenas em nível de indivíduos, mas em nivel organizacional e em certos casos, interorganizacional". Para esses pesquisadores, "não basta integrar o conhecimento; é preciso conhecer uma dinâmica de contínua aprendizagem, uma postura de aprender a aprender, para mudar sempre".

A disposição para esse aprendizado contínuo deve estar presente para que se possa ter a constante evolução tecnológica da empresa. Não basta aprender $e$ incorporar uma nova tecnologia; a empresa precisa ser capaz de acompanhar os desenvolvimentos que ocorrem no setor, a fim de evoluir sempre.

Além disso, esse processo de contínua aprendizagem é um elemento de motivação das pessoas envolvidas com a mudança tecnológica na empresa. Por isso, é preciso criar o espírito de que se deve aprender sempre e isso somente é possivel a partir das informações que são recebidas, absorvidas e transmitidas pelos indivíduos que fazem parte da empresa, em todos os seus niveis hierárquicos.

Uma das formas de motivar aqueles que devem participar do processo de mudança na empresa, segundo DAVENPORT [1993] e FLEURY; FLEURY [1995], é favorecer o desenvolvimento da responsabilidade conjunta em torno de objetivos comuns; criando vínculos de interação e de comunicação entre as diversas áreas e competências.

FLEURY; FLEURY [1995] salientam ainda que: "permitir que os trabalhadores invistam em projetos de melhoria permanente, de tal modo que eles conside- 
rem o seu conhecimento não como um estoque a ser preservado, mas como uma competência-ação, ao mesmo tempo pessoal e engajada num projeto coletivo é um elemento motivador para que as mudanças tecnológicas se efetivem na empresa".

Esses pesquisadores destacam, ainda, que no processo de aprendizagem da empresa é imprescindivel uma maior comunicação entre os diversos setores que a compõem e um investimento nas pessoas que integram tais setores.

Assim, no caso da Construção de Edificios, para haver uma real evolução tecnológica dos processos de produção, deve-se favorecer a comunicação e a responsabilidade conjunta entre as áreas responsáveis pela definição do produto "edifício" e pela definição do sistema de produção da empresa construtora. Ou seja, as áreas de comercialização, desenvolvimento ou análise de projetos e definição do planejamento e orçamento do empreendimento devem ter uma estreita ligação com as áreas responsáveis pelos projetos voltados à produção, execução de obras, suprimentos e recursos humanos.

Além de uma iteração entre os principais setores de uma empresa construtora, deve ocorrer, ainda, uma estreita ligação entre as áreas envolvidas com a produção propriamente dita, para que uma certa ação, empreendida por uma delas, tenha ressonância nas demais, estimulando o processo de evolução.

No que se refere à motivação e ao treinamento dos envolvidos com a implantação de novas tecnologias, o que se tem observado na Construção de Edifícios é que os investimentos destinados tanto à formação, quanto à reciclagem do conhecimento de todos os profissionais que participam do processo de produção, são ainda muito reduzidos e, para que se possa contar efetivamente com uma evolução tecnológica do setor, esses investimentos deverão ser ampliados.

Portanto, não basta a empresa ter o firme propósito de querer "aprender". Além disso, ela deverá viabilizar esse aprendizado através de investimentos que deverão ser feitos para a obtenção de novas tecnologias, para a incorporação dessas tecnologias nos projetos da empresa, para o repasse das tecnologias a 
todos os envolvidos com a produção e para o controle do processo de implantação.

O desenvolvimento desses, entre outros recursos, constituem as diretrizes balizadoras que orientam o plano de ação proposto pela metodologia, as quais são apresentadas e discutidas no item 5.4 .

\subsubsection{Disponibilidade dos recursos}

A decisão estratégica de se implantar novas tecnologias no processo de produção exige a participação e empenho pessoal da alta administração da empresa e, ainda, o comprometimento e a disponibilidade dos recursos para viabilizar essa implantação.

Os recursos ao processo de implantação dizem respeito sobretudo ao tempo demandado, às pessoas que conduzem o processo dentro da empresa, à disponibilidade dos materiais, componentes e equipamentos envolvidos e, evidentemente, aos recursos financeiros para a viabilização dos demais.

Sem que haja um comprometimento, desde o início, em disponibilizar esses recursos, não convém que se deflagre o processo de implantação, uma vez que será grande a probabilidade de insucesso, frustrando outras possíveis açōes.

É preciso que a empresa tenha consciência de que a disponibilidade de tempo compativel com as ações a serem empreendidas é imprescindível para 0 sucesso da implantação. A incompatibilidade do planejamento de uma obra com o tempo demandado pelo processo de implantação podem comprometer seriamente esse processo.

Durante a pesquisa realizada junto às empresas foi comum, entre tantos outros, os seguintes depoimentos: "no primeiro edifício a implantação foi bem; mas no segundo tivemos de colocar mais gente, sem treinamento, para atendermos aos prazos previstos e não saiu como no projeto"; ou ainda, "o prazo do empreendimento era muito curto e não foi possivel a realização do projeto e o treinamento do pessoal; assim, a produção ficou comprometida". 
Tais depoimentos deixam claro que as empresas têm demonstrado interesse em evoluir o seu sistema de produção; entretanto, nem sempre estão completamente preparadas e orientadas para esse processo.

SALDANHA [1995], ao relatar um estudo de caso de implantação de ações de racionalização, destaca as etapas de planejamento, projeto, introdução de novas ferramentas e controle, como elementos que podem definir o sucesso ou fracasso da implantação.

Essa pesquisadora salienta que, em particular, com relação ao planejamento, a imposição de um cronograma físico-financeiro incompatível com as melhorias propostas dificultou, em alguns momentos, uma melhor utilização da mão-deobra, que, segundo ela, "se adequadamente motivada, traz excelentes contribuições à racionalização de métodos de trabalho".

O completo envolvimento da alta direção da empresa no processo de implantação deve ser buscado sempre, pois é somente neste nivel organizacional que os prazos podem ser discutidos e adaptados ao processo de implantação das novas tecnologias. Definido o planejamento global do empreendimento, a obra dificilmente terá autonomia para reprogramar os prazos estabelecidos.

A implantação de novas tecnologias envolve uma etapa de aprendizado e de absorção do conhecimento; envolve ainda o repasse da tecnologia aos funcionários de um modo geral, o que irá exigir atividades de motivação e de treinamento em todas os níveis hierárquicos. É preciso que fique claro que tudo isso, além de envolver recursos financeiros, envolve tempo, que precisará ser bem dimensionado para não interferir negativamente no processo.

Um outro recurso essencial, logo no início do processo de implantação, referese à pessoa ou ao grupo de pessoas que irão conduzir esse processo dentro da empresa. A essa pessoa, a bibliografia internacional, por exemplo, chama de "champion", que poderia ser traduzido como o líder da implantação.

Esse líder, deverá estar completamente motivado a conduzir o processo de implantação, e deverá ter, ainda, um certo poder de decisão dentro da empresa, além de capacitação técnica para conduzir a implantação. É preciso 
que ele domine, não apenas o sistema de produção da empresa, mas a tecnologia a ser implantada.

Quando o líder não tiver o domínio da nova tecnologia, pode-se recorrer à ajuda externa, tanto através de consultorias, quanto sob a forma de parcerias com aqueles que detém o conhecimento tecnológico. Mas, deve-se lembrar que para isso, serão indispensáveis os recursos de tempo e os financeiros.

Não é comum que as empresas tenham esse líder dedicado exclusivamente à função de implantação de novas tecnologias. Como salientado no item anterior, apenas duas das empresas pesquisadas tinham alguma estrutura que previa essa pessoa ou grupo. Todas as outras conduziam o processo de implantação de novas tecnologias, exclusivamente, através de seus diretores técnicos, muitas vezes com algum tipo de suporte externo (cursos de atualização, consultorias, parcerias com outras empresas) e às vezes, contando com a disposiçāo e empenho de alguns gerentes.

No entanto, o diretor técnico não está apenas preocupado com as novas tecnologias. Ele se envolve com uma série de outros problemas, tais como os novos lançamentos, a aquisição de novos terrenos, os prazos de entrega, as solicitações de manutenção, etc. e, nesse contexto, é comum a implantação ficar "sem uma liderança", sendo postergada.

Quando se fala em organizações de pequeno e médio porte é difícil exigir grandes investimentos em uma infra-estrutura voltada à gestão da tecnologia. Entretanto, uma infra-estrutura mínima é inevitável, de maneira que o processo de implantação não fique sem um referencial interno, que seja responsável pelas decisões, pela passagem das informações e pela coleta e avaliação dos resultados para a revisão do processo.

Desta maneira, uma organização que preveja pelo menos uma pessoa com qualificação e capacidade de conduzir o processo de implantação terá um maior potencial de chegar ao completo sucesso dessa atividade, do que aquela que não se dispuser a criar essa função na empresa.

Os materiais, componentes e equipamentos envolvidos com a nova tecnologia 
também deverão ser previstos, o que exige, em última instância, recursos financeiros para a sua aquisição ou mesmo locação, mas não só. Exige, além disso, uma disposição de se trabalhar em conjunto com o departamento de suprimentos, o qual deverá estar disposto, muitas vezes, a alterar sua rotina administrativa a fim de atender ao processo de implantação de TCR's.

Observa-se, assim, que a introdução de TCR's no processo de produção das empresas, para que tenha um maior potencial de sucesso, somente deverá ser iniciada a partir do momento em que as premissas básicas, aqui discutidas, fizerem parte da definição estratégica da empresa.

Existindo um ambiente que favoreça a implantação de TCR's é possivel passar à aplicação da metodologia propriamente dita, apresentada e discutida a partir do próximo item.

\subsection{Fundamentos da Metodologia}

Adaptando-se o conceito formulado por SABBATINI [1989], pode-se dizer que: uma metodologia para implantação de TCR's significa "um conjunto de preceitos que estabelece uma orientação para o direcionamento e a condução da implantação de tecnologias construtivas racionalizadas".

Para que seja efetiva, a metodologia deverá estar fundamentada em principios que sustentem o processo decisório e em um plano de ação que permita a operacionalização da implantação, os quais SABBATINI [1989] denomina, respectivamente, "doutrina" e "estratégia" da metodologia.

Segundo esse autor, a doutrina da metodologia é constituída por dois elementos, quais sejam:

- a filosofia - formada por um conjunto de princípios que direcionam o estabelecimento das diretrizes, norteando a metodologia; e

- as diretrizes balizadoras - que fundamentam a tomada de decisões, para a seleção e escolha do caminho a ser seguido pela empresa. Têm por função direcionar as ações para que o resultado tenha maiores possibilidades de atender aos pressupostos implícitos na metodologia adotada. 
Tanto a filosofia, como as diretrizes balizadoras, deverão estar compreendidas num contexto local e temporal, considerando-se entre outros, os aspectos técnicos, sócio-econômicos, culturais e legais nos quais a empresa está inserida.

A estratégia da metodologia, por sua vez, deve envolver o plano de ação, ou seja, deve conter o modelo para a operacionalização da implantação de TCR's. Sua função principal é fixar os passos que deverão ser cumpridos para que se atinja o sucesso da implantação.

A partir da estratégia estabelecida pela metodologia, cada empresa poderá montar o seu planejamento, o seu "plano de ataque", adaptando as ações que deverão ser empreendidas, segundo a sua realidade e particularidades (características internas) e as condições externas que direcionam a tomada de decisões.

Para uma compreensão clara desses conceitos que embasam a metodologia, os mesmos estão sintetizados e ilustrados na figura 5.3.

\subsection{Filosofia da Metodologia}

Estabelecidos os fundamentos da metodologia, a filosofia que irá conduzir o seu desenvolvimento pode ser assim enunciada:

"possibilitar a aplicação de TCR's como uma forma de impulsionar a melhoria contínua dos recursos tecnológicos e organizacionais empregados no processo construtivo tradicional de produção de edifícios com vistas à sua máxima racionalização e conseqüente evolução tecnológica e organizacional".

Ao se aplicar uma metodologia para implantação de TCR's no processo construtivo de uma empresa construtora, espera-se obter uma melhoria tecnológica nesse processo, suficiente para que o retorno obtido sirva de motivação para que novas melhorias sejam implantadas e esse processo ocorra continuamente, procurando-se atingir sempre um patamar mais elevado de racionalização do processo de produção. 


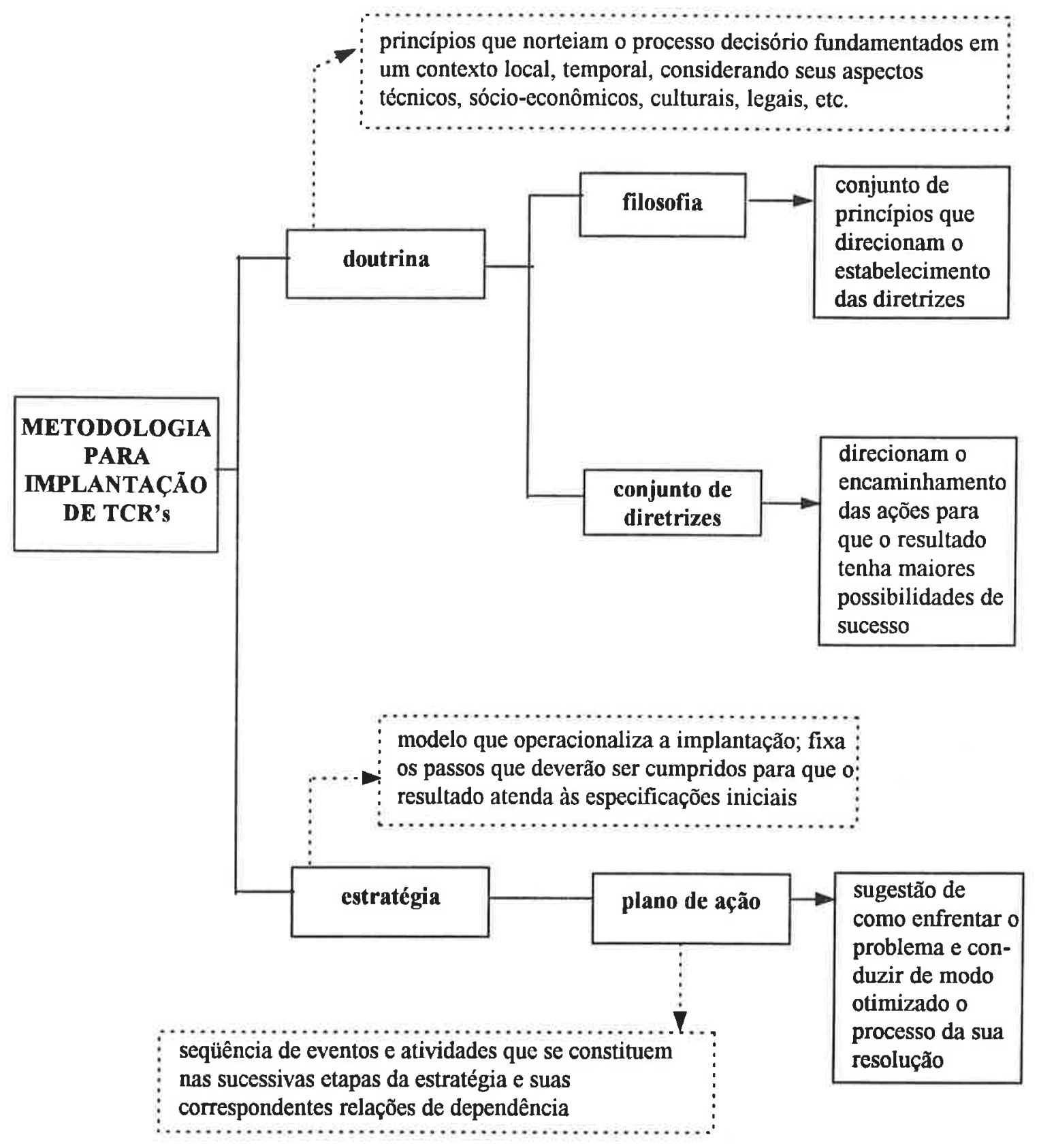

FIGURA 5.3: Ilustração dos fundamentos da metodologia de implantação de TCR's

O "kaizen" do povo japonês ou a melhoria contínua do ocidente, enquanto premissa aplicada à realização do produção, tem forte relação com a implantação de TCR's na produção de edifícios. Sem romper drasticamente com a base produtiva, que continua sendo o processo construtivo tradicional, busca-se, com ações de racionalização da produção, melhorar as condições de trabalho, 
o uso de equipamentos, o emprego da tecnologia disponível e assim, melhorar a produtividade, reduzir desperdícios e melhorar a qualidade do produto final.

Mas, como bem afirma SABBATINI [1989], "a filosofia de uma determinada metodologia não é a sua ferramenta operacional. A metodologia precisa ser operacionalizada através de ações efetivas".

Portanto, ter a melhoria contínua como filosofia implica em "fazer funcionar" o ciclo de "PDCA" (apresentado e discutido no item 2.3, do capítulo 2), em ações efetivas dentro da metodologia, as quais deverão envolver o planejamento, a implantação e a verificação das ações e a retomada do processo, após a avaliação dos resultados. Essas ações efetivas deverão ser traduzidas por um conjunto de diretrizes, estratégias e táticas a serem empregadas na condução do processo de implantação.

\subsection{Diretrizes Balizadoras da Metodologia}

As diretrizes que irão balizar o plano de açāo da metodologia deverão refletir a filosofia que a norteia, ou seja, devem permitir, inicialmente, um avanço tecnológico e, na seqüência, a evolução contínua do processo construtivo tradicional de produção de edifícios.

Para isso, o plano de ação deverá ser conduzido por diretrizes que permitam aumentar o nivel de racionalização e diminuir o grau de variabilidade do processo de produção, o que pode ser traduzido por diretrizes que envolvam uma maior interação entre os setores responsáveis pela produção, quais sejam: projeto; suprimentos; recursos humanos e execução de obras. $E$, neste sentido, as diretrizes que irão conduzir o desenvolvimento do plano de ação, discutidas a seguir, são aqui apresentadas:

-

desenvolvimento da atividade de projeto: diretriz que deve ser entendida como um instrumento para a informação e fixação das TCR's no sistema produtivo da empresa, proporcionando condições para o avanço tecnológico, à medida em que incorpore as definições para a completa realização da produção, inclusive as relativas ao planejamento do empreendimento; 
- desenvolvimento da documentação: diretriz que deve ser entendida como um instrumento de informação e fixação das novas tecnologias na empresa. Para isso, ela deve ser compatível com o processo de implantação das TCR's e deve proporcionar meios para o repasse uniforme dessas tecnologias a todos os empreendimentos. Além disso, essa documentação deverá servir como subsídio para o treinamento de todo o pessoal envolvido com a implantação;

- desenvolvimento dos recursos humanos: diretriz que deve permitir a capacitação tecnológica e organizacional da empresa, através da motivação e do treinamento que envolva todos níveis hierárquicos. Através dessa diretriz deve-se conseguir, ainda, uma menor variabilidade do processo de produção e a possibilidade de sua evolução contínua;

- desenvolvimento do setor de suprimentos voltado à produção: diretriz que pretende facilitar e viabilizar a implantação das TCR's, através do envolvimento e de um melhor relacionamento entre as equipes de projeto, produção e suprimentos, para que sejam adquiridos materiais, componentes e equipamentos que atendam à produçăo;

- desenvolvimento do controle do processo de produção: diretriz que possibilita o acompanhamento de todo o processo de produção, visando a sua qualidade, bem como, a do produto final; permite, ainda, a realimentação do processo de implantação e a evolução das ações que visam a melhoria.

\subsubsection{Desenvolvimento da atividade de projeto}

Como discutido no capítulo 4, as ações de racionalização dificilmente são fixadas ao sistema produtivo da empresa se não integrarem os projetos que irão dar origem ao edifício. Por isso, a proposição dessa diretriz balizadora para que ocorra a implantação das TCR's.

O projeto deve ser parte constituinte do sistema de informação da empresa, responsável pela transmissão do conteúdo tecnológico a ser incorporado no processo de produção. 
Por serem básicos no processo de implantação, neste item discutem-se alguns aspectos que deverão direcionar as ações das empresas, no que se refere ao desenvolvimento do projeto do edifício, no sentido de facilitar a implantação de TCR's no processo construtivo tradicional.

Antes disso, porém, será apresentado como estão sendo entendidos os termos projeto e projeto para produção.

\subsubsection{O projeto e o projeto para produção}

Para que se compreenda a importância do PROJETO como uma diretriz balizadora do processo de implantação de TCR's, cabe explicitar o que se entende por projeto e em especial por projeto para produção, pois este último é um elemento essencial ao processo de implantação.

\section{a) O conceito de projeto}

$\mathrm{Na}$ indústria da Construção Civil, muitas vezes, as atividades relacionadas à elaboração dos projetos terminam com a definição do produto edifício. De forma geral, o projeto do processo produtivo inexiste.

Essa constatação é confirmada por FARAH [1992] ao afirmar que: "como tendência geral, os projetos, na construção tradicional, indicam apenas a forma final do edifício (projeto arquitetônico) ou as características técnicas de elementos da edificação (projeto estrutural, de fundações, de instalaçōes, etc.), não descendo a detalhes da execução, nem estabelecendo prescrições relativas ao modo de executar e à sucessão de etapas de trabalho. 0 projeto é antes de mais nada, um projeto de produto, que não se traduz em especificações relativas ao 'como produzir'. O próprio projeto do produto é, por outro lado, pouco preciso, deixando à etapa da execução a definição final das características que o produto deve ter, inclusive quanto ao tipo de material ou componente a ser utilizado em cada etapa."

NAN; TATUM [1989], por sua vez, afirmam que há uma tendência de, na indústria da Construção, haver uma dissociação entre o projeto do produto e a produção. Esses autores salientam: "enquanto na indústria seriada, o projeto do produto ("product design") está se tornando uma parte conjunta do gerenci- 
amento da produção; na construção, a função projeto do produto é normalmente separada da produção". Segundo esses pesquisadores, isto pode levar a diferenças significativas na natureza do processo de inovação.

Se a indústria da Construção Civil deseja alcançar um patamar mais elevado no seu desenvolvimento tecnológico, é premente que o projeto, além de enfocar o produto, esteja voltado, de maneira especial, à produção.

Essa visão mais moderna e mais abrangente do significado do projeto é proposta por MELHADO [1994] que salienta que quando o tema é o Projeto de Edifícios, a visão do produto deve ser extrapolada, devendo-se encarar 0 projeto com o enfoque do processo de construção e, neste aspecto, defende que o projeto seja encarado como informação de natureza tecnológica e gerencial, cabendo a ele "o encargo fundamental de agregar eficiência e qualidade ao produto e ao processo construtivo (...)".

MELHADO [1994] apresenta seu entendimento quanto ao papel do projeto propondo uma definição para o termo, a qual passará a ser adotada no presente trabalho. Assim, o PROJETO será entendido como:

"uma atividade ou serviço integrante do processo de construção, responsável pelo desenvolvimento, organização, registro e transmissão das características físicas e tecnológicas especificadas para uma obra, a serem consideradas na fase de execução."

No entanto, no processo de elaboração tradicional do projeto, como destacam BARROS; MELHADO [1993], a grande dificuldade reside em harmonizar no projeto a visão do produto com a visão das condicionantes de produção, principalmente no processo construtivo tradicional em que, muitas vezes, o projeto é entendido como um ônus para o empreendedor no início da obra, sendo encarado como uma despesa a ser minimizada.

A dificuldade destacada por esses autores fica expressa em MARTUCCI [1990], ao afirmar: "há um distanciamento considerável entre o projeto da habitação e o processo construtivo: os profissionais, engenheiro e arquiteto, a 
quem cabe a concepção científica do produto, não têm, de um modo geral, domínio sobre $\dot{a}$ atividade concreta, sobre cada atividade realizada no canteiro de obras".

Além disso, MARTUCCI [1990] afirma: "o retrabalho, as paradas e esperas, elementos constantes na construção habitacional, não resultam apenas de uma frágil coordenação entre atividades. Outros fatores intervêm, tais como a incipiente coordenação entre projetos, a ausência de coordenação entre projeto e execução e o limitado grau de desenvolvimento do planejamento do processo produtivo e, ainda contribuem, as más condições de trabalho".

"O projeto, para qualquer subsistema do edifício, é um instrumento importante para que a inércia do processo construtivo tradicional seja vencida, pois somente a partir da sua elaboração será possivel definir adequadamente a produção na fase de concepção do produto, não permitindo que decisões subjetivas sejam tomadas durante a etapa de execução" [BARROS, 1991].

O papel do projeto como elemento de informação é destacado por outros pesquisadores. ROCH; COLAS [1993], por exemplo, salientam que um dos principais fatores que contribuem para a elevação dos custos da não qualidade é a má circulação de informações que pode ocorrer através do projeto. Segundo eles, "o projeto tem sido encarado apenas como um elemento subjetivo em que diferentes leituras são possiveis com diferentes interpretações, não permitindo um completo entendimento da informação".

Além disso, o projeto constitui a "porta de entrada" para que as novas tecnologias sejam efetivadas nos canteiros de obras, pois é através dessa atividade que se tem um grande potencial de avanço em termos tecnológicos, uma vez que permite incorporar, logo no início do processo de produção, as inovações oriundas dos setores de materiais e componentes, de equipamentos e de desenvolvimento tecnológico.

Essa posição é apresentada por DAVENPORT [1993] ao enfocar a inovação de processos na indústria seriada, de uma maneira geral. Segundo esse autor: 
"O projeto parece ser a melhor maneira de se introduzir e adquirir experiência com a reflexão e a inovação de processos dentro de uma organização".

Além disso, DAVENPORT [1993] salienta que: "apenas as equipes interfuncionais podem ser capazes de inovar processos que ultrapassam limites organizacionais e áreas de responsabilidade administrativa".

Pode-se dizer que a interfuncionalidade, assim como é um elemento essencial para a inovação de processos na indústria seriada, deve estar presente, da mesma forma, no processo de inovação na Construção de Edifícios.

O processo de produção de edifícios é uma atividade que envolve a participação de diferentes agentes; portanto, é uma atividade que deve ser tipicamente desenvolvida por equipes interfuncionais e multidisciplinares o que significa a exigência de uma maior integração entre as diversas disciplinas de projeto (arquitetura, estrutura, instalações, impermeabilização, etc.), bem como, entre essas disciplinas e as atividades da produção.

Assim, para que realmente o projeto possa ser a "porta de entrada das novas tecnologias", cumprindo o seu papel de indutor da modernização do setor, deverão ocorrer mudanças expressivas nas características atuais do processo de projeto. É preciso que realmente existam as equipes multidisciplinares, a fim de atender sempre a todos os envolvidos no processo de produção, representados pelo empreendedor, projetista, construtor e usuário.

\section{b) $O$ conceito de projeto para produção}

Para a implantação de TCR's na empresa construtora, o projeto do edifício deverá ser entendido como uma atividade ou serviço inerente ao processo de produção e, portanto, deverá extrapolar as características do produto, envolvendo as características do processo e dando suporte aos envolvidos com a construção.

O projeto que envolve as características da produção é denominado por JURAN [1992] de "projeto do processo", e é definido como sendo:

"a atividade de definição dos meios específicos a serem usados pelas forças operacionais para atingir as metas de qualidade do produto e deverá incluir: 
- as características do processo que, em conjunto, compõem os meios para se atingir as metas de qualidade do produto;

- os equipamentos físicos a serem providenciados;

- o "software" associado (métodos, procedimentos, cuidados, etc.),

- as informações a respeito de como operar, controlar e manter os equipamentos".

SABBATINI [1989] ressalta a relevância da elaboração do projeto de produção do edifício (ou de suas partes), no qual "(...) são definidas as técnicas construtivas (e os métodos, no caso do objeto do desenvolvimento ser um processo ou um sistema construtivo) e projetados os detalhes de execução (...) que irão permitir a construção do edifício ou de suas partes em acordo com o prescrito na concepção geral". Segundo esse mesmo autor, "o projeto de produção do edifício evolui em ciclos iterativos, iniciando-se por um projeto preliminar e avançando progressivamente até a solução consolidada".

BARROS; DORNELES [1991] concluem sua pesquisa salientando a necessidade de desenvolvimento do projeto construtivo visando atingir um patamar mais elevado na qualidade de um método ou processo construtivo. Colocam que o projeto construtivo "deve conter todos os aspectos essenciais à produção do edifício ou de uma sua parte".

MELHADO [1994] ressalta que a empresa deve estar estruturada para "(...) orientar e subsidiar a elaboração do projeto levando em conta os aspectos do produto e o do processo" e, esse autor defende a existência de um "projeto para produção", definindo-o como sendo: "um conjunto de elementos de projeto elaborados de forma simultânea ao detalhamento do projeto executivo, para utilização no âmbito das atividades de produção em obra, contendo as definições de: disposição e seqüência das atividades e frentes de serviço; uso de equipamentos; arranjo e evolução do canteiro; dentre outros itens vinculados às características e recursos próprios da empresa construtora".

Ao se analisar as colocações anteriores fica expresso que o projeto voltado à produção é indispensável, para auxiliar a implantação das TCR's nas 
empresas. E, aqui, essa etapa do projeto será denominada de projeto para produção, a qual será entendida como sendo;

"um conjunto de elementos de projeto elaborado segundo características e recursos próprios da empresa construtora, para utilização no âmbito das atividades de produção em obra, contendo as definições dos itens essenciais à realização de uma atividade ou serviço e, em particular: especificações dos detalhes e técnicas construtivas a serem empregados, disposição e seqüência de atividades de obra e frentes de serviço e uso e características de equipamentos".

Ao se propor esse entendimento para o projeto para produção procura-se deixar claro que para se ter um avanço efetivo no processo construtivo tradicional, o projeto deve conter especificações claras sobre o produto e sobre 0 processo de produção. Ou seja, ele deve proporcionar mecanismos eficientes para que a produção ocorra de maneira planejada e que suas atividades sejam devidamente acompanhadas possibilitando verificar a adequação dos procedimentos de execução ao projeto e a obtenção de um produto cuja qualidade seja compativel com a especificada.

\subsubsection{O desenvolvimento do projeto na implantação de TCR's}

O atual processo de projeto, que enfatiza a definição do produto sem levar em conta a produçăo, pouco contribui para o avanço tecnológico nos canteiros de obras.

Os projetos que chegam aos canteiros de obras são, muitas vezes, denominados "conceituais", os quais contêm, na maioria dos casos, apenas a definição do produto, os dimensionamentos; mas, não revelam como a produção deve ocorrer.

Além da ausência de informações relevantes ao desenvolvimento das atividades em obra, ocorre, muitas vezes, que as diversas disciplinas de projeto não são objeto de nenhum tipo de compatibilização, resultando em intensos e 
extensos problemas que o pessoal da obra deverá solucionar, no momento da realização das atividades.

Essa posição está expressa em outras publicações, como por exemplo no de PICCHI [1993]. Esse autor afirma: "na construção de edifícios brasileira, é comum o desenvolvimento dos projetos sem a devida coordenação. Os projetos de arquitetura, geotécnico e estruturas, e instalações, que são os que dão a configuração básica ao edifício, sāo muitas vezes desenvolvidos um em seqüência do outro, por projetistas diferentes, com muito poucas interações entre os mesmos. Isto gera uma série de incompatibilidades, que muitas vezes são detectadas somente em estágios avançados da obra”.

Para que o projeto possa viabilizar a entrada das novas tecnologias na empresa e possa servir como instrumento de informação para a produção, o atual processo de projeto deverá ser alterado e o novo processo deverá incorporar importantes características conceituais. Nesse sentido, interpretando-se a proposição de MELHADO [1995], o projeto deverá ser entendido como:

- parte integrante do processo de produção: ou seja, não se deve encarar o processo de projeto como algo isolado do conjunto das atividades que envolvem a produção de edifícios. As exigências e os anseios dos usuários e dos empreendedores deverão estar sendo representadas nesse contexto, assim como, as dos projetistas, as dos responsáveis pelas atividades de campo e as do setor de suprimentos;

- atividade multidisciplinar: em que, para atender a todos os envolvidos, o projeto deverá ser encarado como um elemento de ligação entre os agentes do processo de produção, em todas as suas fases, ou seja, não poderá ser apenas um produto da arquitetura ou da estrutura, mas sim um serviço que envolva análise de "marketing", análise de custos e até decisões acerca da tecnologia e do processo de produção;

- antecipação da produção: ou seja, o projeto deverá incorporar efetivamente a tecnologia construtiva a ser empregada no canteiro de obras, envolvendo as informações sobre os métodos construtivos adotados, a organização da produção e do seu controle, para antecipar e solucionar os 
problemas básicos da atividade de produção em canteiro. Com isso, será possível conciliar as características do produto (o edifício) com as da produção (o processo);

- serviço ativo do processo de produção: o projeto não deve se resumir em desenhos e detalhes genéricos e em documentos descritivos. Ele deve ser uma atividade dinâmica que acompanha todo o processo de produção, auxiliando constantemente na resolução de possíveis problemas; deve ser encarado como um serviço que permanecerá ativo até a entrega da obra e, mesmo depois, na assistência ao usuário.

Para que o projeto, visando as TCR's a serem implantadas, possa ser desenvolvido de maneira a conter os parâmetros para a sua adequada realização, propõe-se como diretriz que a empresa construtora reorganize o seu atual processo de projeto contemplando a produção, pois o projeto, enquanto elemento do sistema de informação da empresa, deve constituir o suporte para a materialização do produto edifício.

O desenvolvimento dos projetos de um empreendimento não é uma atividade simples de se realizar, pois não deve ser genérico. Tal desenvolvimento deve considerar o sistema de produção que será adotado pela empresa ao implantar as TCR's.

Para isso, a empresa precisará estar organizada para repassar esse "conhecimento tecnológico" aos que participam do processo de elaboração do projeto, a fim de que a nova tecnologia possa ser incorporada ao projeto, desde o seu início, tendo-se, assim, um maior potencial de racionalização das atividades de produção.

Uma das maneiras de se repassar esse conhecimento é através do desenvolvimento dos procedimentos de projeto que expressem claramente o sistema de produção da empresa, cuja elaboração será discutida no item 5.4.2, e através da qualificação de projetistas.

Essa qualificação significa encontrar projetistas dispostos a estabelecer uma parceria com a empresa, de maneira que os mesmos entendam os princípios 
embutidos na nova tecnologia proposta e venham realmente a incorporá-los nos seus projetos.

Em contrapartida a empresa deverá estar preparada para remunerar adequadamente um projeto com nível maior de qualidade, evitando a "concorrência por preço".

O desenvolvimento do projeto incorporando as novas tecnologias, como uma diretriz balizadora da implantação de TCR's no processo de produção de edifícios, deverá ser traduzido por uma estratégia da empresa para a realização do seu processo de projeto.

A definição dessa estratégia não deveria ser um enfoque a ser dado no presente trabalho; entretanto, pela relevância do projeto para a modernização do processo de produção e pelo envolvimento da autora com o tema, propõese uma alternativa para a condução desse processo de projeto no interior das organizaçōes.

Por isso, na seqüência, apresenta-se uma proposição para a organização do processo de projeto da empresa, na qual se insere o desenvolvimento do projeto para produção, cujas diretrizes são apresentadas no item 5.4.1.4.

5.4.1.3 O processo de projeto na implantação de TCR's

O processo de projeto aqui apresentado é baseado numa proposição feita para a empresa construtora " $D$ ", quando do desenvolvimento de uma pesquisa cujo tema foi a "qualidade de projeto", na qual a autora teve oportunidade de participar juntamente com outros pesquisadores do CPqDCC.

As diretrizes completas para a reorganização do processo de projeto, propostas para essa empresa, estão apresentadas em MELHADO; BARROS; SOUZA [1996].

Esse processo de projeto deve ser encarado como uma contribuiçăo desta pesquisa ao meio técnico. Trata-se, portanto, de uma das muitas possibilidades que as empresas poderão vir a adotar para realizar o desenvolvimento da sua atividade de projeto. 
O fluxo de projeto, ilustrado pela figura 5.4, contém os elementos principais para que o processo de projeto de um empreendimento de edifício possa ser conduzido de maneira a atender tanto o produto como a produção.

A figura 5.4 está estruturada em três colunas. Na coluna central aparece o fluxo propriamente dito; enquanto na primeira são apresentados os documentos utilizados no desenvolvimento de cada uma das etapas do fluxo e na última coluna apresentam-se os profissionais envolvidos com cada uma das atividades ou etapas do fluxo.

Dentre esses profissionais, cabe explicitar o que se entende por "grupo do projeto para produção". Esses são os profissionais que têm o domínio da produção, ou seja, conhecem o sistema de produção da empresa e têm forte ligação com as atividades de obra.

Em função das características organizacionais de cada empresa, esse "grupo" poderá ser constituído de maneira distinta. A empresa pode ter uma organização tal que esse "grupo" seja constituido por uma única pessoa, por exemplo, o engenheiro ou gerente do empreendimento. Entretanto, pode haver organizações que, pela sua complexidade, exija um maior número de pessoas na formaçāo desse "grupo".

O fluxo proposto está organizado em sete estágios de desenvolvimento.

O primeiro estágio é caracterizado pela elaboração da proposta arquitetônica, a qual é desenvolvida pelo arquiteto do empreendimento, orientado pelos documentos de referência. Eventualmente, para a elaboração dessa proposta pode-se ter subsídios de consultores ou outros projetistas.

Dentre os documentos de referência merecem destaque os procedimentos para elaboração de projeto e os dados do Banco de Tecnologia da empresa.

Esses dois documentos devem retratar o sistema de produção da empresa. Por isso, como discutido anteriormente, a empresa deverá estar organizada para a elaboração dos mesmos, a fim de que possa conduzir o processo de projeto (essa elaboração será discutida no item 5.4.2). 


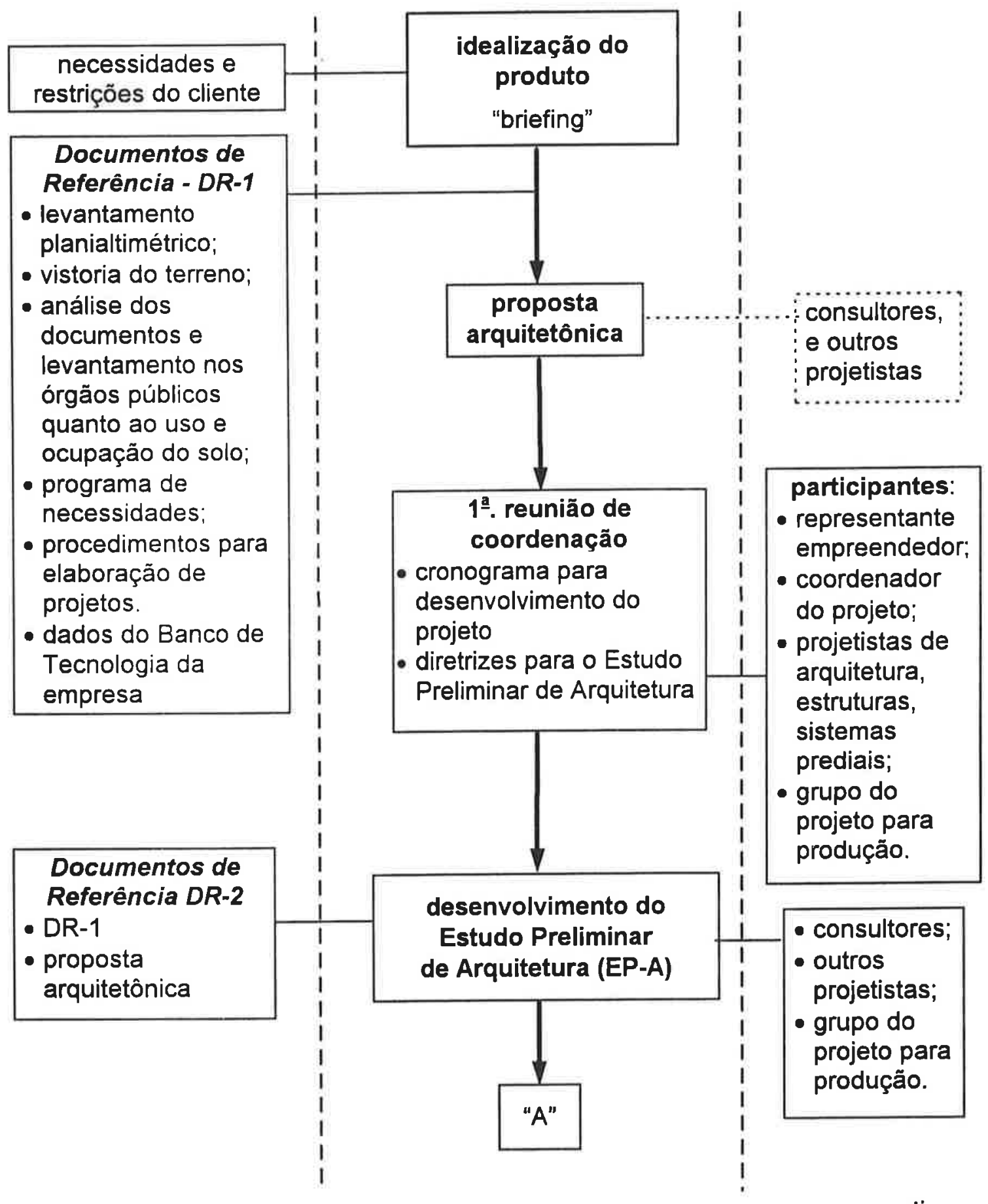

...continua

FIGURA 5.4: Proposta de um processo de projeto para empresas construtoras e incorporadoras [adaptado de MELHADO, BARROS, SOUZA, 1996] 


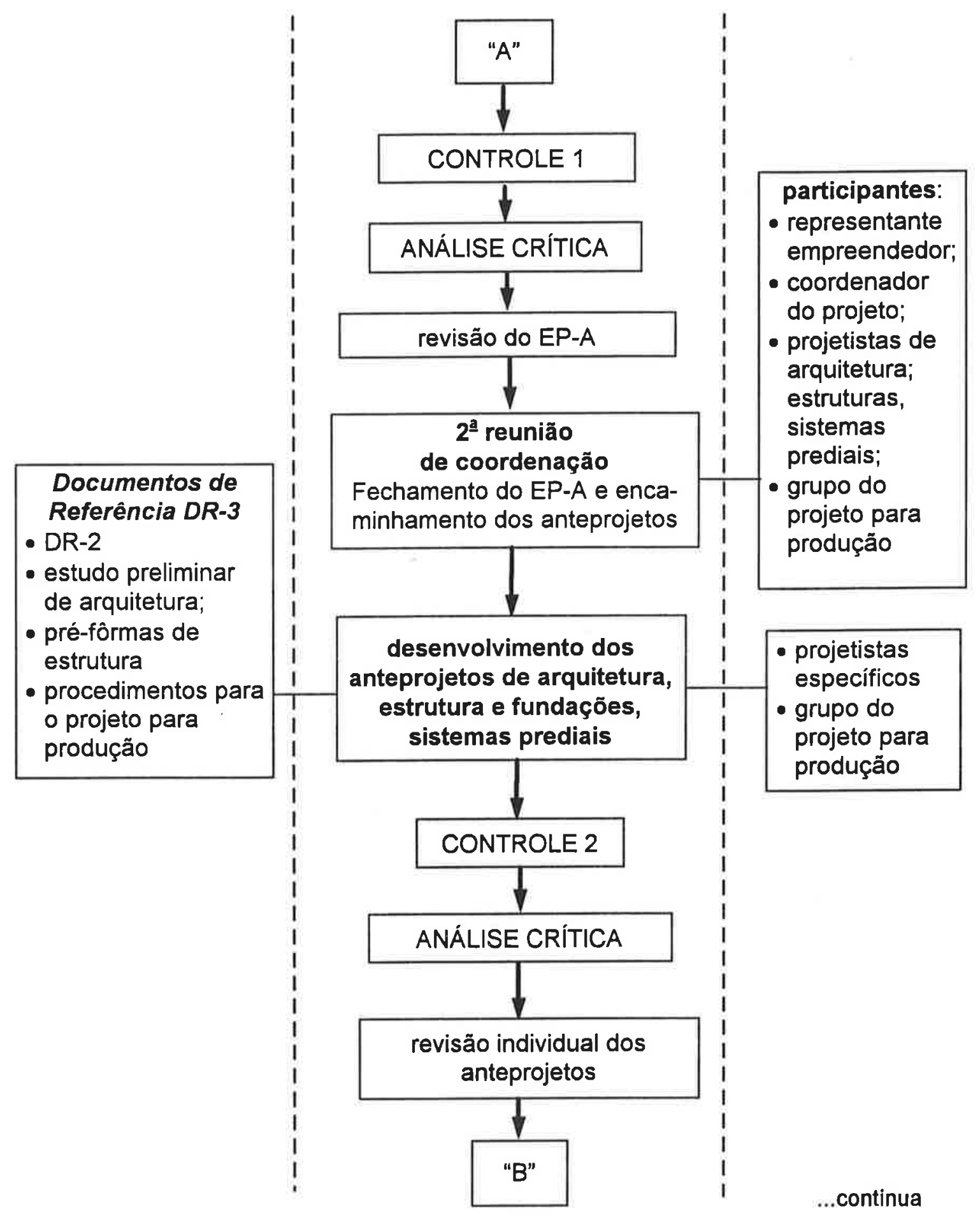

FIGURA 5.4: (continuação): Proposta de um processo de projeto para empresas construtoras e incorporadoras [adaptado de MELHADO, BARROS, SOUZA, 1996] 
Documentos de Referência $D R-4$

- DR-3

- anteprojetos de estruturas, sistemas hidráulicos, elétricos e mecânicos

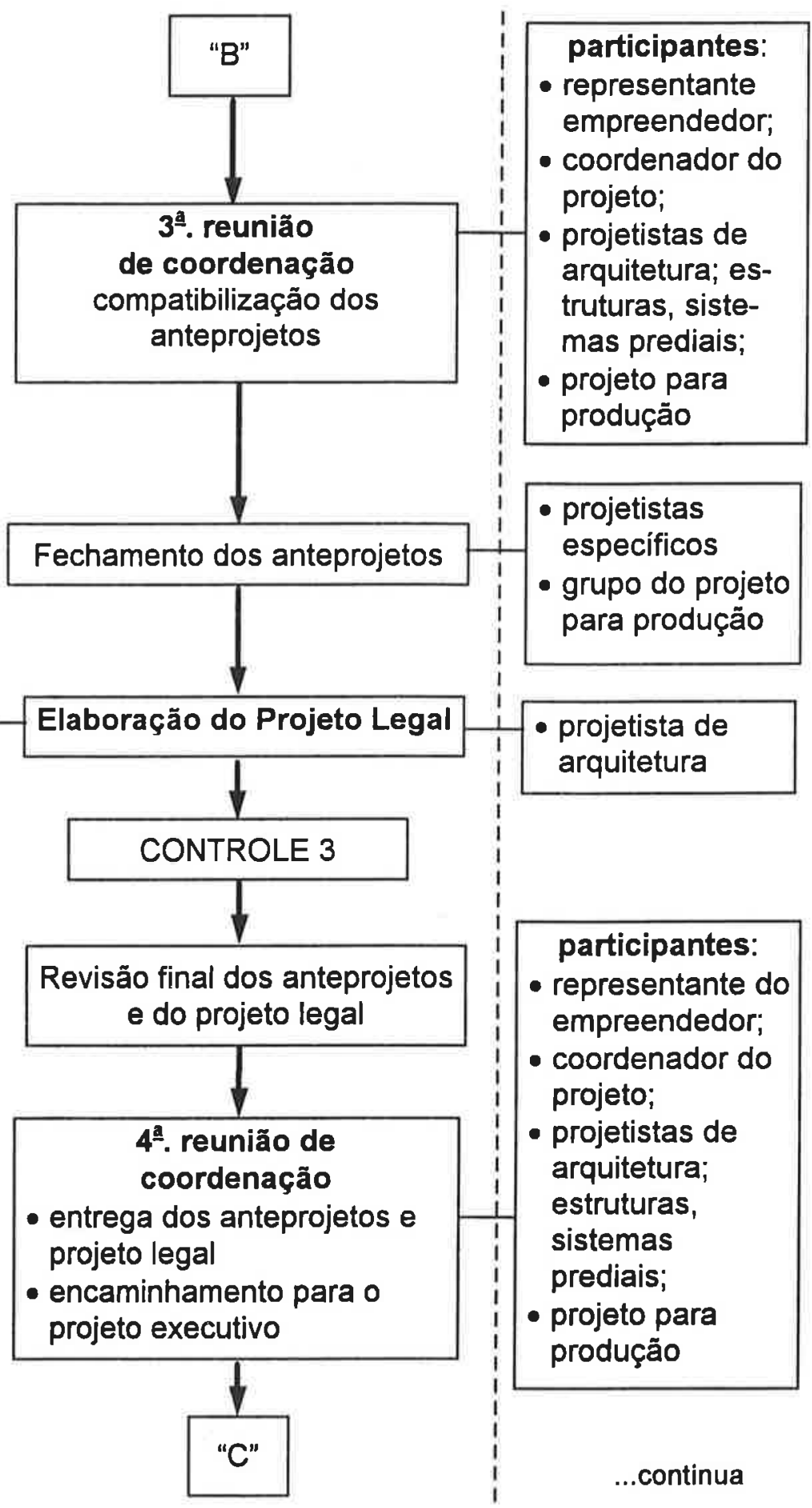

FIGURA 5.4: (continuação): Proposta de um processo de projeto para empresas construtoras e incorporadoras [adaptado de MELHADO, BARROS, SOUZA, 1996] 


\begin{tabular}{|l|}
\hline Documentos de \\
Referência DR-5 \\
- DR-4 \\
- informações \\
geradas pelo grupo \\
do projeto para \\
produção, por \\
consultores, \\
empresas especiali- \\
zadas em serviços, \\
fabricantes de \\
materiais e \\
componentes e \\
outros \\
\hline
\end{tabular}

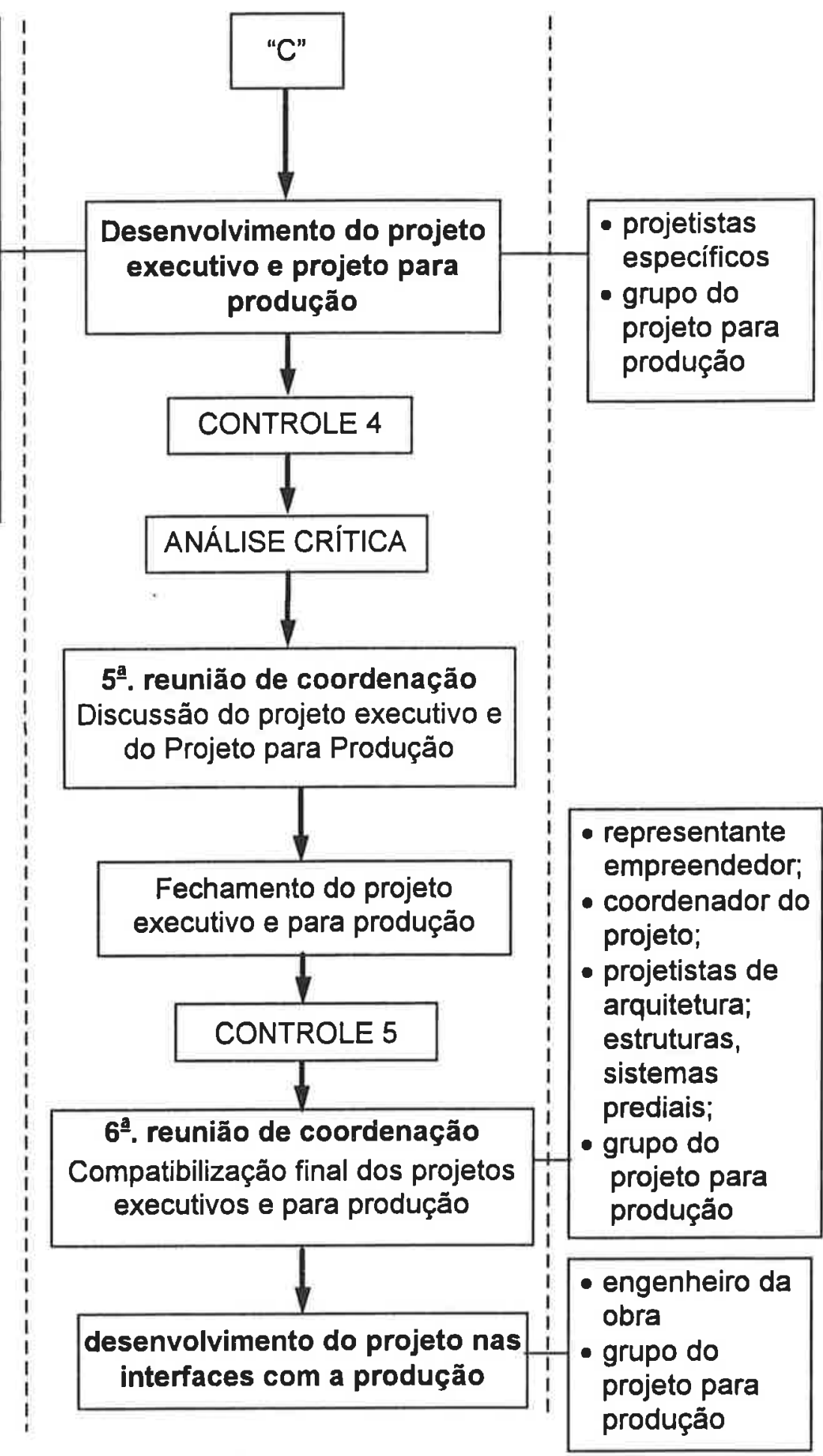

FIGURA 5.4: (continuação): Proposta de um processo de projeto para empresas construtoras e incorporadoras [adaptado de MELHADO, BARROS, SOUZA, 1996] 
A partir do desenvolvimento da proposta arquitetônica, realiza-se a primeira reunião de coordenação, a fim de se analisar a proposta frente aos fatores condicionantes preestabelecidos. Nessa reunião participa toda a equipe envolvida com o projeto, inclusive o representante do empreendedor. Por isso, essa análise é realizada por diversos profissionais de projeto, inclusive pelo grupo dedicado ao projeto para produção.

O resultado dessa reunião deve ser o cronograma de desenvolvimento do projeto e o estabelecimento de diretrizes para a realização do estudo preliminar de arquitetura.

O desenvolvimento do estudo preliminar de arquitetura caracteriza o inicio do segundo estágio de desenvolvimento que finalizará com a realização da segunda reunião de coordenação. Entretanto, antes dessa reunião, o estudo preliminar entregue pelo projetista de arquitetura deverá passar por uma etapa de controle e de análise crítica.

A etapa de controle tem por objetivo determinar se o material entregue está completo, evitando-se a convocação de uma reunião sem que todo o material esteja disponivel para análise. Essa etapa pode ser feita pelo próprio coordenador de projeto, ou mesmo por um outro profissional devidamente treinado para essa atividade. É uma atividade que pode ser auxiliada por um "checklist" de verificação que contenha todos os elementos comumente presentes num estudo preliminar.

Tendo-se o estudo preliminar completo, pode-se passar à etapa de análise crítica do projeto, a qual tem caracteristicas distintas da etapa de controle. 0 objetivo da análise crítica do estudo preliminar é verificar a compatibilidade da proposta com as diretrizes previamente estabelecidas $e$ as possiveis interferências que poderão vir a existir com os demais projetos. Ela deve ser feita previamente à reunião, otimizando o tempo de duração desta.

Essa etapa deverá estar a cargo de um profissional com larga experiência, tanto na elaboração de projetos, como nas atividades ligadas à produção propriamente dita, podendo ser o próprio coordenador do projeto. 
Após a análise crítica, o estudo preliminar poderá passar por uma etapa de revisão, antes de se realizar a reunião de coordenação, que caracteriza o final do segundo estágio.

Com a mesma filosofia de desenvolvimento, anteriormente apresentada, ocorre - terceiro estágio, no qual deve-se realizar o desenvolvimento dos anteprojetos. O final desse estágio é caracterizado pela terceira reunião de coordenação.

No quarto estágio, os anteprojetos deverão ser completamente definidos e o projeto legal deverá ser elaborado. Este estágio é finalizado com a quarta reunião de coordenação.

O quinto estágio do fluxo diz respeito ao desenvolvimento do projeto executivo e do projeto para produção. Esse estágio, assim como os anteriores, deve passar pelas atividades de controle e análise crítica, antes da realização da quinta reunião. Nessa reunião os projetos deverão ser discutidos à luz da análise realizada.

O sexto estágio do fluxo de projeto refere-se à finalização do projeto executivo e do projeto para produção, com a sua entrega na sexta e última reunião, após o controle de toda a documentação.

Após a realização do projeto executivo, resta ainda o sétimo estágio do processo de projeto que diz respeito ao desenvolvimento do projeto nas interfaces com a produção. Esse projeto, na maioria das vezes, é realizado com a obra em andamento, de modo a preceder a atividade a que se refere. Será discutido no item seguinte, relativo ao desenvolvimento do projeto para produção.

A forma de organização do processo de projeto, anteriormente apresentada, poderá ser utilizada por qualquer empresa incorporadora e construtora, independentemente de seu porte. Essas empresas poderão realizar as adaptações necessárias à sua forma de organização, ou mesmo, poderão vir a adotar qualquer outro modelo, desde que o processo de projeto esteja voltado não apenas ao produto, mas igualmente à produção.

Entretanto, esse processo de projeto não é adequado para as situações em 
que o projeto executivo chega pronto para a construtora, ou seja, quando ela constrói para terceiros. Nesse caso, para que as TCR's sejam introduzidas no canteiro, os projetos para produção deverão ser elaborados, posteriormente à realização dos projetos executivos, tradicionalmente realizados.

Um fluxo de análise e desenvolvimento dos projeto para produção, que pode ser adotado para o caso das empresas construtoras é proposto na figura 5.5 .

Nesse fluxo, após o recebimento dos projetos executivos, a empresa realiza uma análise crítica, identificando as possiveis interferências entre os projetos, bem como o seu potencial de racionalização.

Essa análise deverá estar embasada no conhecimento tecnológico da empresa que poderá estar registrado nos seus procedimentos de produção e até mesmo num Banco de Tecnologia.

Devem participar dessa análise pessoas que tenham o domínio do sistema de produção da empresa. Por isso, propōe-se a participação do gerente do empreendimento e do grupo do projeto para produção. Para determinadas situações, a empresa poderá ser auxiliada por consultores.

Após a identificação e registro das modificaçōes a serem realizadas, as mesmas devem ser discutidas com o cliente, a fim de que se possa obter a autorização para interferir no projeto recebido.

Nesse momento, deve-se mostrar ao cliente os ganhos potencialmente atingiveis ao serem introduzidas as modificações nos projetos. Esses ganhos podem decorrer de uma economia financeira devida à racionalização das atividades ou mesmo de um melhor desempenho do produto final.

A partir do momento que as alteraçōes forem autorizadas, devem ser incluídas no projeto executivo, iniciando-se o desenvolvimento do projeto para produção.

\subsubsection{O desenvolvimento do projeto para produção}

Neste item, é feita uma proposta de como desenvolver o projeto para produção visando a implantação de TCR's no sistema de produção da empresa. 


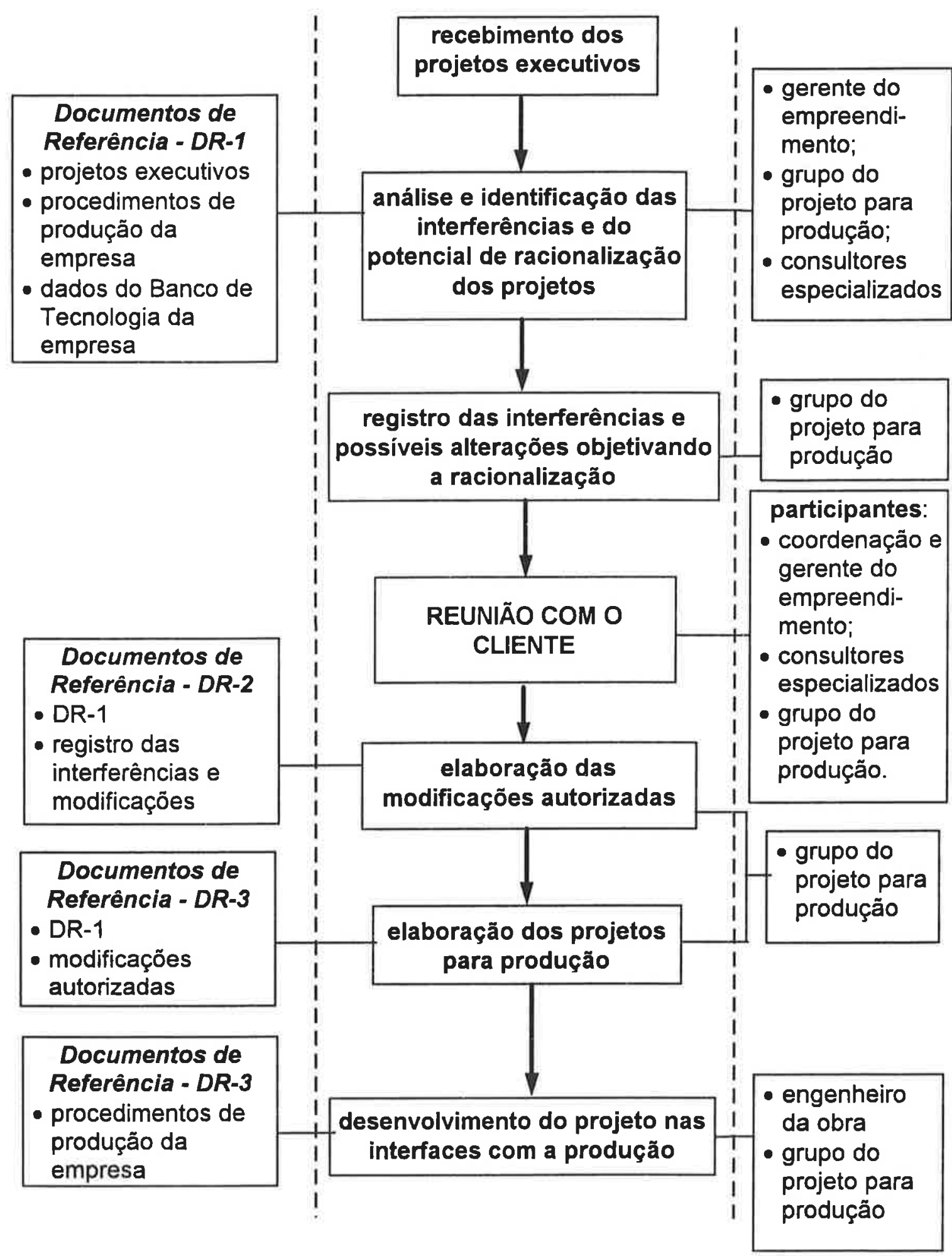

FIGURA 5.5: Proposta de fluxo do processo de projeto a ser implantado pelas empresas construtoras 
O desenvolvimento do projeto para produção é fortemente influenciado pelo estágio em que se encontra a realização do projeto como um todo, quando o aquele é iniciado.

O projeto visando a implantação de uma determinada TCR poderá vir a ser desenvolvido em pelo menos duas situações distintas: em conjunto com os demais projetos do edifício, desde o seu início ou posteriormente à elaboração destes. Por isso, as implicações dessas duas situações serão analisadas e discutidas antes de se apresentar o processo de elaboração propriamente dito.

\section{a) Quando realizar o projeto para produção}

A primeira situação, e a mais desejável, ocorre quando existe a possibilidade de compatibilização desse projeto com os demais, na fase de anteprojeto.

A segunda situação, passivel de ser encontrada, ainda que não ideal, ocorre quando o desenvolvimento do projeto visando a introdução de uma determinada TCR dá-se numa fase posterior à elaboração dos demais projetos do edifício, ou seja, depois do desenvolvimento dos projetos executivos.

Essa segunda situação pode limitar o potencial de racionalização da produção do edifício ou mesmo de suas partes, uma vez que, estando os projetos em fase adiantada de desenvolvimento, é possivel que algumas alterações, que visem a racionalização, não possam ser realizadas.

A elaboração do projeto para produção posteriormente aos demais projetos, ainda que não desejável, é uma situação bastante comum de ocorrer, tanto nos casos de empresas construtoras e incorporadoras, como principalmente no caso daquelas que realizam obras para terceiros, sejam clientes públicos ou privados.

Entretanto, mesmo nessa situação, a elaboração do projeto para produção não é inviável; muito pelo contrário, deverá ser levada adiante, pois através da elaboração desse projeto será possivel identificar as principais interferências que irão ocorrer, podendo-se, inclusive, minimizá-las através de alterações nos subsistemas que ainda permitem alguma modificação. 
Na seqüência, ilustra-se, através de exemplos, a diferença do potencial de racionalização do processo construtivo, em função do momento em que se realiza o projeto para produção.

Tomando-se como referência o projeto de alvenaria, tem-se que: se o mesmo começar a ser realizado em conjunto com os de arquitetura, estrutura e instalações, antes que estes estejam em fase adiantada de desenvolvimento, será possivel imprimir um elevado grau de racionalização ao processo construtivo.

Nessa situaçāo, as interferências entre os diversos subsistemas, tais como modulação, passagens de instalações, posicionamento de "shafts", detalhes para impermeabilização, entre outras, poderão ser identificadas e, portanto, poderão ser minimizadas.

Por outro lado, para um edifício que tenha o conjunto de projetos executivos prontos, reduz-se esse potencial de racionalização, pois se perde, por exemplo, a oportunidade de compatibilizar:

- os vāos da estrutura com a modulação da alvenaria, exigindo-se, em decorrência, o corte de blocos;

- a modulação da alvenaria com as aberturas para as esquadrias de portas e janelas; e

- o posicionamento das instalações com as características da alvenaria, inviabilizando, muitas vezes, a proposição de "shafts", ou mesmo a passagens dos condutos pelos componentes.

Entretanto, nessa situação, ainda que se tenha um menor potencial de racionalização, é desejável a realização do projeto de alvenaria de vedação, pois o seu desenvolvimento permitirá identificar, entre outros itens, os seguintes:

- quais blocos deverão ser cortados para compatibilizar a alvenaria com a modulação da estrutura;

- de que forma a alvenaria deverá estar ligada à estrutura;

- como será a relação alvenaria-esquadria, definindo-se, então como deverão ser realizadas as vergas e contravergas; 
- como será a relação alvenaria-instalações;

- a definição de detalhes construtivos, como cintas e outros tipos de reforços;

- a especificação de materiais, componentes e técnicas construtivas.

\section{b) Como realizar o projeto para produção}

Assim como o fluxo de projeto apresentado na figura 5.4, algumas diretrizes para o desenvolvimento do projeto para produção foram propostas para a empresa " $D$ ". Essas diretrizes envolveram três atividades, em particular, quais sejam: a produção da "laje nivelada e acabada"; a produção da alvenaria de vedação e a produção dos revestimentos argamassados e cerâmicos.

As diretrizes para a realização do projeto para produção, para essas atividades estão registradas por MELHADO; BARROS; SOUZA [1995,a,b,c].

Tomando-se por base tais diretrizes, e considerando-se o fluxo do processo de projeto proposto no item 5.4.1.2, estabeleceu-se um processo de elaboração do projeto para produção, o qual é proposto na seqüência.

As diretrizes aqui propostas são genéricas, isto é, podem vir a ser aplicadas para a elaboração do projeto para produção de qualquer subsistema ou atividade do edifício, desde que a sua tecnologia de produção esteja completamente e adequadamente definida.

Além disso, essas diretrizes poderão ser adotadas por qualquer empresa construtora de edifícios, independente de seu porte, desde que se façam as adaptações à sua forma de organização.

Ao se propor tais diretrizes, procurou-se envolver o caso mais complexo que é a realização do projeto para produção, desde o início do processo de projeto. No caso desses projetos virem a ser elaborados após os projetos executivos tradicionais estarem prontos, os princípios propostos poderão ser adaptados, procurando-se atingir o máximo grau de racionalização possivel, dentro das restrições impostas pelos demais projetos, já finalizados.

Para que seja possivel introduzir a TCR na cultura da empresa, propõe-se que o projeto para produção seja realizado em duas partes distintas. 
A primeira parte refere-se à interface do projeto para produção de uma determinada atividade, com as demais disciplinas de projeto.

Nessa parte, devem ser realizados os detalhes construtivos compativeis com as características de produção, considerando-se o domínio tecnológico da empresa construtora, bem como, a tecnologia disponivel.

A segunda parte refere-se à interface do projeto para produção de uma determinada atividade, com a produção propriamente dita.

Nessa parte, devem ser realizadas as atividades que se referem à preparação e execução da atividade, antecedendo a produção propriamente dita.

As diretrizes para a realização de cada uma dessas partes serão apresentadas e discutidas a seguir.

PRIMEIRA PARTE: interface do projeto para produção com as demais disciplinas de projeto

Essa primeira parte ocorre durante todo o desenvolvimento do processo de projeto, cujo fluxo proposto foi apresentado na figura 5.4. Para a sua realização, ou seja, para a elaboração dos detalhes construtivos referentes a uma determinada TCR, o projetista deverá conhecer as características intrinsecas da tecnologia de produção empregada pela empresa, para que possa considerar os principais parâmetros de produção.

Para isto, cada empresa deverá ter as suas diretrizes para o projeto, repassando-as aos projetistas, sejam eles internos ou mesmo externos à empresa.

Essas diretrizes servirăo tanto para orientar os projetistas na realização do detalhamento construtivo como para que a empresa proceda ao controle do projeto.

O desenvolvimento dessa primeira parte deverá compreender duas fases distintas, estabelecidas na seqüência.

- primeira fase: suporte aos projetistas

Essa fase ocorre a partir do desenvolvimento do estudo preliminar, ou seja, a partir do primeiro estágio proposto no fluxo de projeto apresentado na figura 
5.4, através dos subsídios que o "grupo do projeto para produção" fornece ao projetista de arquitetura.

Essa primeira fase terá continuidade ao longo do segundo, terceiro e quarto estágios do fluxo de projeto (figura 5.4).

Durante o segundo estágio, especialmente na segunda reunião de coordenação, o "grupo do projeto para produção" deve analisar criticamente o estudo preliminar de arquitetura, fazendo sugestōes que aproximem as especificações de projeto, das características de produção, facilitando, dessa maneira, a etapa seguinte, de elaboração dos anteprojetos.

Durante a elaboração dos anteprojetos, que caracteriza o início do terceiro estágio do fluxo, o "grupo do projeto para produção" deverá assistir aos projetistas das diversas disciplinas, fornecendo-lhes subsidios para que os anteprojetos reflitam as necessidades da produção.

Essa primeira fase deverá ser finalizada com a realização da quarta reunião de coordenação, quando os projetos para produção poderão começar a ser materializados, dando início à segunda fase de seu desenvolvimento, que consiste na elaboração do projeto para produção.

\section{- segunda fase: elaboração do projeto para produção}

Essa segunda fase ocorre durante o quinto e sexto estágios do fluxo de projeto (figura 5.4), ou seja, tem início imediatamente após a finalização dos anteprojetos das demais disciplinas e termina com a realização da sexta reunião de coordenação, com a compatibilização final dos projetos executivos e para produção.

Durante $\circ$ quinto estágio realiza-se $\circ$ que se denominou anteprojeto do projeto para produção.

Esse anteprojeto deve ser realizado considerando-se os demais anteprojetos do edifício e deverá conter os principais detalhes construtivos que subsidiem a produção.

A compatibilização do anteprojeto do projeto para produção com os demais 
projetos do edifício deve ser realizada durante a quinta reunião de coordenação, a partir da qual, deve ter início o detalhamento do projeto para produção.

Essa fase deve terminar com a realização da sexta reunião, quando se verifica se todos os projetos são compativeis, estando prontos para subsidiar a produção.

Nos casos em que a realização do projeto para produção somente possa ser iniciada com a completa definição dos demais projetos, esta primeira parte ficará prejudicada. Entretanto, é ainda possível realizar uma análise crítica do projeto executivo, para que sejam identificadas as principais interferências entre os mesmos e as possibilidades que ainda existem para a racionalização do processo, como salientado no item 5.4.1.2.

\section{SEGUNDA PARTE: interface do projeto para produção com a produção}

O desenvolvimento da segunda parte deve ocorrer durante a realização da obra, antecedendo a atividade a que se refere o projeto. Para a sua elaboração deve-se contar com o "grupo do projeto para produção" e com o gerente da obra (quando este não integrar o grupo).

Essa parte deverá conter: os procedimentos para preparação da execução da atividade no canteiro de obras, ou seja, o planejamento do canteiro (por exemplo, áreas de estoques e maneira de transporte de componentes, área para estoque e preparo de materiais, disposição e tipos de equipamentos utilizados); a preparação da execução propriamente dita, com as características das ferramentas a serem utilizadas; o estabelecimento das frentes de trabalho; e a seqüência de execução.

\subsubsection{Desenvolvimento da documentação}

Em praticamente todos as bibliografias analisadas no capítulo 4, em particular em TWISS [1974], SABBATINI [1989], DE LA GARZA; MITROPOULOS [1992], SANDERS; ESKRIDGE [1993], LABORDE; SANVIDO [1994], GHIO; BASCUÑAN [1995] e ZAWISLAK [1995], está expresso que, para que tenha 
um maior potencial de sucesso na implantação de inovações tecnológicas, a empresa deverá realizar o desenvolvimento da documentação das ações praticadas.

Segundo SBRAGIA; BARRA [1994], essa documentação é um dos aspectos centrais dos sistemas de administração utilizados pelas grandes empresas.

Nas normas da série NBR ISO 9000 [ABNT, 1994b,c], afeitas aos sistemas da qualidade, está registrado que a existência de "procedimentos documentados definindo o método de produção, instalação e serviços associados, onde a ausência de tais procedimentos possa afetar adversamente a qualidade" é essencial para o controle do processo.

PICCHI [1993], por sua vez, enfocando a indústria da Construção de Edifícios, afirma que os "planos da qualidade de obras" são elementos imprescindiveis ao sistema da qualidade. Segundo esse autor, esses planos deverão considerar as características de projeto, as especificações, os processos construtivos e a organização da empresa e deverão conter, entre outros itens:

- as especificações de materiais e serviços;

- os pontos de controle;

- os critérios de amostragem;

- os métodos de inspeção e ensaios;

- os critérios de aceitação e rejeição e os procedimentos de execução; e

- as listas de verificação.

BOGGIO [1995], cuja pesquisa é voltada à Construção de Edifícios, afirma que a documentação "é um instrumento fundamental para a padronização e o controle de processos e procedimentos de produçāo, visando aumentar o domínio tecnológico, elevar a produtividade e permitir que a empresa adapte-se com maior eficácia às mudanças exigidas pelas demandas dos clientes e as alteraçōes produzidas com a incorporação de novos materiais e tecnologias".

Esse autor acrescenta, ainda: "O processo de estabelecimento de uma documentação interna permite o desenvolvimento de uma tecnologia própria. 
Resultados imediatos podem ser obtidos na medida em que os procedimentos existentes são analisados, aplicados e questionados. Além disso, a padronização interna permite diminuir a variabilidade dos processos técnicos e administrativos e possibilita registrar a capacitação tecnológica da empresa, libertando-a da dependência exclusiva da experiência individual de seus técnicos".

Ou seja, quando se quer aumentar o potencial de racionalização do processo de produção de edifícios, seja através da implantação de inovações tecnológicas, ou mesmo por meio de sistemas de Gestão da Qualidade, precisa-se de uma documentação que explicite o sistema de produção da empresa.

Somente é possivel "cobrar" aquilo que foi previamente e devidamente "combinado". Portanto, para que se contrate um determinado tipo de serviço, a parte contratada deverá estar consciente de como o serviço deverá ser realizado e com base em que parâmetros ele será recebido.

Através do desenvolvimento dos procedimentos de produção é que se pode estabelecer as condições de contratação dos projetistas e fornecedores, bem como, definir os elementos para o treinamento de pessoal e as condições de controle dos serviços executados, podendo-se, desta maneira, fazer evoluir o processo produtivo.

Apesar da documentaçăo referente aos sistemas de produção das empresas ser essencial, MAIA [1995] salienta que, em uma pesquisa realizada recentemente em Porto Alegre, envolvendo 45 gerentes técnicos de empresas de pequeno porte do setor da Construção Civil, identificou-se que $71 \%$ dessas empresas não tinham nenhum tipo de documentação referente a procedimentos de execução.

A ausência de procedimentos de execução nas empresas, à primeira vista, poderia levar a pensar que as normas nacionais, voltadas à tecnologia de produção de edifícios, sustentam as atividades de produção. No entanto, este não é o caso do Brasil.

Segundo FARAH [1992] "constata-se uma reduzida influência da normalizaçāo técnica sobre o processo produtivo. Por um lado, pelo desenvolvimento ainda 
hoje relativamente incipiente de normas técnicas de construção, sobretudo de normas de execução. Em segundo lugar, pela tendência generalizada de não incorporação das normas existentes pela atividade produtiva".

Realmente, a normalização nacional voltada à construção de edifícios é deficiente em praticamente todas as áreas como ilustram os dados apresentados por PICCHI [1993], reunidos na tabela 5.1.

TABELA 5.1: Distribuição de normas técnicas, por assunto [PICCHI, 1993]

\begin{tabular}{|l|c|}
\hline \multicolumn{1}{|c|}{ Assunto } & Quantidade \\
\hline planejamento & nenhuma norma \\
\hline projeto & $33^{()^{()}}$ \\
\hline materiais e componentes & 160 \\
\hline execução e controle & 19 \\
\hline uso e manutenção & 2 \\
\hline
\end{tabular}

${ }^{(*)}$ dentre essas, 25 referem-se à coordenação modular.

Por esses dados, observa-se que, além de se ter uma quantidade reduzida de normas, as que existem estão voltadas, em sua maioria, aos materiais, as quais, segundo FARAH [1992], "são desenvolvidas a partir dos interesses dos fabricantes de materiais industrializados".

Nesse contexto, PICCHI [1993] destaca que: "a realidade é que as empresas de construção de edifícios terão um esforço adicional para suprir as deficiências das normas brasileiras no que diz respeito a procedimentos de projeto e execução", podendo-se acrescentar, que o mesmo poderia ser dito com relação aos procedimentos de controle da produçăo.

A empresa, para empreender mudanças no sentido de diminuir a variabilidade do seu processo de produção, precisa dominá-lo. Ou seja, deve conhecer: como cada serviço deve ser executado; como devem ser os seus projetos, para que possa realmente utilizá-los na produção; como deve controlar 0 processo de produção, identificando onde estão localizados os possiveis problemas e quais as prováveis soluções. 
Reduzir a variabilidade do processo, passa pela sua padronização. Para isso, deverão existir os documentos que se referem aos seguintes procedimentos de produção:

- procedimentos de projeto: os quais irão orientar os projetistas no desenvolvimento dos projetos para produção da empresa e, da mesma forma, o coordenador do projeto, ao realizar o controle e a análise crítica;

- procedimentos para execução de serviços: os quais servirão de referência para a contratação de serviços de terceiros; para o treinamento da mãode-obra; e como de referencial para o controle das atividades de produçăo;

- procedimentos de controle: os quais servirăo tanto para a realização do controle da produção, desde a elaboração dos projetos até a entrega da obra, como para identificar as possibilidades de melhoria que poderão vir a ser incorporadas em empreendimentos futuros. É esse tipo de procedimento que fornece subsídios para a avaliação da própria atividade de implantação, realimentando-a.

Tendo-se a disponibilidade da tecnologia, para que os procedimentos de produção sejam elaborados e possam ser incorporados à cultura da empresa, deverão passar por um processo adequadamente conduzido, de modo que não se tenham apenas "pilhas de papel" tomando espaço nos escritórios das empresas, sem atingir os canteiros de obras.

\subsubsection{Conteúdo e desenvolvimento da documentação}

A pesquisa junto às empresas permitiu identificar claramente que os procedimentos de produção são essenciais. Por outro lado, deixou claro que é preciso compatibilizá-los com as características de cada usuário, como bem demonstram os depoimentos a seguir:

"É preciso ter procedimentos de produção claros, com linguagem compativel com a de quem vai utilizar o procedimento. O procedimento de produção não pode apenas existir, ele deve ser pactuado com as partes envolvidas, para que seja colocado em prática" (empresa "A"). 
"Os procedimentos são básicos; no entanto, a introdução dos procedimentos é dificultada por existir, na obra, muitos encarregados analfabetos. Neste sentido, o procedimento de execução da alvenaria na forma de um 'gibi' facilitou a comunicação" (empresa "H").

Por outro lado, a pesquisa permitiu identificar, ainda, a dificuldade de se estabelecer um programa de controle das atividades de execução, como bem demonstram os depoimentos seguintes:

"Atualmente, como os serviços são executados sem um procedimento claro de controle, é preciso ter mestres de obras e engenheiros bons para exercer o controle; o problema é que esses profissionais não existem no mercado (...). Os procedimentos de controle ainda não são claros o suficiente. Às vezes dizem o que deve ser feito, mas não "como deve ser", dificultando essa atividade na obra" (empresa " $A$ ").

"Não existe procedimento de controle. Esta é uma das principais falhas da empresa. Sem os procedimentos de controle, o caderno de procedimentos perde muito a força. $A$ falta de controle traz maior dificuldade em se obter qualidade e prazo, ou conduz a um resultado negativo e irreparável, quando esse controle é deixado somente para o final dos serviços. O início de cada serviço deve passar por um controle muito rígido" (empresa "E").

Por todas as colocações anteriores, fica expressa a importância de se ter procedimentos de produção que envolvam o processo como um todo. E, são diversos os métodos que podem ser adotados visando a elaboração dos mesmos. $O$ método a ser utilizado pelas empresas para a elaboração da documentação deverá levar em consideração as particularidades de cada uma.

MAIA [1995] propõe um método para a padronização dos procedimentos de execução, o qual envolve:

especificação do produto: o qual é considerado como o resultado de um serviço executado (por exemplo, uma parede pintada é considerada um produto). Nesse caso, a empresa deverá definir quais produtos deverão ter a sua produção padronizada;

padrão técnico do processo: o qual envolve todo o processo de fabricação 
de um produto, em linguagem técnica, incluindo as características de qualidade e os parâmetros de controle;

procedimento operacional: são as informações que chegam ao operador, retiradas do padrão técnico do processo;

treinamento nas padronizações: é baseado no procedimento operacional, mas deve conter o "como fazer", o "porque fazer" e os riscos que podem decorrer, caso o procedimento descrito não seja seguido; e ainda, as formas de correção, caso existam resultados indesejáveis;

implementação da padronização: ocorre somente após a elaboração do procedimento, com participação, discussão da força tarefa, homologação da diretoria técnica e treinamento de gerentes e operários.

MAIA [1995] salienta que para o desenvolvimento dessa "metodologia" de elaboração dos procedimentos, é preciso que exista um lider que coordene a elaboração e a implementação da padronização.

PICCHI [1993], por sua vez, apresenta o método utilizado pela empresa de seu estudo de caso, para a elaboração dos procedimentos de produção. Segundo esse autor, "o primeiro passo foi o questionamento das práticas correntes, através de convênios e projetos de pesquisa (...). Os resultados dessa pesquisa foram registrados na forma de normas da empresa, servindo como instrumento de padronização, difusão e treinamento".

Ou seja, as normas eram produzidas a partir do questionamento das práticas correntes, visando a racionalização das mesmas através do desenvolvimento dos projetos de pesquisa e de experiências piloto realizadas em obras.

Segundo PICCHI [1993], o acervo de normas da empresa é representativo, contando com 160 textos técnicos, os quais abordam os vários subsistemas do edifício, com enfoque para projeto, materiais, execução e controle.

Nessa empresa, em conjunto com os textos técnicos, foram elaborados diversos documentos de treinamento, tais como textos de formação, para engenheiros e videos de treinamento, inclusive para o treinamento do operário. 
A proposição de MAIA [1995] e o método apresentado por PICCHI [1993] parecem não estar muito distantes um do outro, embora tenham sido pouco detalhados pelos autores.

A partir dessas duas proposições, pode-se dizer que os seguintes elementos são básicos para o processo de documentação e efetivação das novas tecnologias:

- estabelecimento dos serviços que deverăo ser padronizados;

- questionamento das práticas correntes e não apenas a padronização do que a empresa vem produzindo;

- experimentação das novas tecnologias em obra piloto; e

- treinamento para a implantação.

A etapa denominada por MAIA [1995] de "implementação da padronização", ou seja, colocá-la em prática, não é simples de se realizar, quando está relacionada à implantação de uma nova tecnologia, pois esta não se fixa na cultura da empresa pela simples existência dos procedimentos.

Por isso, defende-se que a elaboração dos procedimentos de produção esteja intimamente relacionada à estratégia adotada pela empresa para a implantação das novas tecnologias. O desenvolvimento desses procedimentos será discutido no item que segue, sendo complementado pelas discussões apresentadas no plano de ação, no item 5.5 .

\subsubsection{O desenvolvimento dos procedimentos de produção}

A partir da disponibilidade da tecnologia, a qual deverá estar documentada de alguma maneira, ela poderá ser testada na empresa, observando-se sempre a presença de um líder para a condução desse processo de implantação.

Com a sua experimentação, a nova tecnologia poderá começar a ser consolidada na empresa, em função do seu sistema de produção. A cada nova experimentação, a documentação de suporte poderá ser avaliada e até mesmo modificada, evoluindo continuamente e estando sempre registrada na forma de procedimentos de produção da empresa. 
Essa posição é ratificada por BOGGIO [1995]. Segundo esse pesquisador, o desenvolvimento da documentação pode ser realizado de forma incremental, sem demandar grandes investimentos. Além disso, deve ter um caráter interno à empresa, ainda que possam ser desenvolvidos com base em modelos produzidos externamente.

A criação da "memória tecnológica" da empresa é a base para que ocorra a evolução de seu processo de produção. $E$ a elaboração dos procedimentos para produção possibilitam criá-la.

Essa posição é confirmada por MELHADO [1994], ao tratar da qualidade de projeto. Segundo esse pesquisador, o caminho para a evolução tecnológica deve passar pela estruturação de um banco de informação, o qual denomina "Banco de Tecnologia Construtiva".

Para que esse Banco de Tecnologia Construtiva seja uma ferramenta efetiva para a evolução tecnológica da empresa, ele deverá conter as informações que expressem o sistema produtivo a ser empregado para a produção de edifícios. Assim sendo, será possivel, através das informações desse Banco de Tecnologias, subsidiar tanto as atividades que se realizam na etapa de projeto, quanto as que se realizam no momento da produção propriamente dita.

Para que haja a melhoria contínua e a diminuição da variabilidade do processo, a empresa deve estabelecer o seu "sistema de produção" o qual deverá ser constantemente avaliado e renovado, acompanhando o desenvolvimento tecnológico da sociedade, assim como, o desenvolvimento tecnológico, organizacional e gerencial da empresa.

Cabe destacar, no entanto, que a formalização dos procedimentos de produção e do Banco de Tecnologia não implica na implantação da tecnologia na empresa e, nem mesmo, na sua evolução técnico-organizacional. As TCR's serão efetivamente implantadas, quando elas forem incorporadas à produção. Para isso, outras diretrizes, discutidas à frente, devem conduzir as ações estratégicas, visando o repasse da tecnologia aos demais envolvidos no processo de implantação. 
As ações de ordem estratégica para a elaboração dos procedimentos de produção que deverão fazer parte do Banco de Tecnologia Construtiva da empresa serão discutidas no âmbito do item 5.5.

\subsubsection{Desenvolvimento dos recursos humanos}

Em praticamente toda a bibliografia analisada no capítulo 4, que enfoca a inovação ou a racionalização dos processos de produção, um dos elementos destacados como imprescindiveis para o processo de inovação, para qualquer setor industrial, é a participação das pessoas que formam a empresa, como bem demonstram as seguintes afirmativas:

"a inovação de processos raramente pode ser realizada na ausência de uma combinação bem pensada dos recursos técnicos e humanos" [DAVENPORT, 1993];

"a tecnologia não existe independente das formas de relações sociais na produção e não é concebivel fora da divisão social do trabalho" [GARCIA; SEGRE; TAVARES, 1994];

"esta é a base de toda e qualquer estrutura que se deseja sólida: o fator humano, pois ele é quem detém os valores necessários para se alcançar qualquer tipo de melhoria (...) [DALCUL, 1994].

ZAWISLAK [1995], em particular, afirma que: "no bojo da questão da gestão de inovação para grande parte dos setores industriais brasileiros está, mais do que qualquer outra coisa, o problema da formação de recursos humanos". E, acrescenta: "enquanto não se puder educar o trabalhador e o empresário para a inovação (...) dificilmente o Brasil será um pais capacitado".

Essa última afirmação, ainda que dirigida a todo o setor industrial, parece estar voltada de modo particular à Construção de Edifícios, expressando com muita clareza que para haver a implantação de TCR's, o desenvolvimento dos recursos humanos não poderá ser deixado em segundo plano.

Sem o completo envolvimento das pessoas, sem uma educação voltada para o processo de racionalização e inovação, em todos os níveis, nenhuma nova 
tecnologia será implantada nos canteiros de obras e não haverá chances de se conseguir a evolução pretendida para o processo de produção de edifícios.

O desenvolvimento dos recursos humanos é um elemento que vem sendo encontrado na estratégia de diversos setores industriais e estudado por diversos pesquisadores.

CHIAVENATO [1992], enfocando os recursos humanos nas organizações, salienta que: "as pessoas não devem ser tratadas como meros recursos das empresas - como são administrados os demais recursos físicos, materiais e financeiros. Pessoas são pessoas e nunca deixarão de sê-lo. Está chegando a hora de melhor prepararmos nossas organizações para as pessoas, invertendo uma velha conduta que priorizava sempre os interesses organizacionais e privilegiava os objetos da organização".

FLEURY; FLEURY [1995], enfocando a indústria de transformação, afirmam que: "o sucesso alcançado pelas empresas japonesas levou os paises ocidentais a reverem suas concepçōes não apenas sobre a organização do trabalho, mas também sobre os modelos de gestão de pessoal. Surge o conceito de "gestão estratégica dos recursos humanos", preconizando que as políticas de gestão de pessoal não devem ser passivamente integradas às estratégias de negócio, mas devem ser parte integrante desta estratégia".

Segundo JURAN; GRYNA [1991], essa nova abordagem dos recursos humanos, integrados na empresa, está sendo desenvolvida principalmente nos Estados Unidos e "tem objetivos relacionados ao aperfeiçoamento da qualidade e produtividade, à satisfação profissional do trabalhador, à cooperação entre a administração e o sindicato, a redução de conflitos e ao desenvolvimento da confiança".

Observa-se, em diversos setores industriais, que, a partir da discussão de novos modelos gerenciais, está se distinguindo uma postura de valorização gradativa do trabalhador, atribuindo-lhe maior responsabilidade no processo de produção e no sucesso das organizaçōes.

Para que se tenha integração efetiva das pessoas à empresa, CHIAVENATO 
[1992] defende a adoção de uma "política" de gestão dos recursos humanos, entendida como sendo "as maneiras pelas quais a organização pretende lidar com os seus membros e por intermédio deles atingir os seus objetivos organizacionais, permitindo condições para o alcance de objetivos individuais".

Para esse autor, uma política de recursos humanos pode ser subdividida em diversos elementos interdependentes, assim definidos:

- políticas de suprimento de recursos humanos - que definem: as diretrizes para o recrutamento dos recursos humanos; os critérios de seleção; e a forma de integração dos novos participantes à organização;

- políticas de aplicação de recursos humanos - que definem: os requisitos básicos da força de trabalho para desempenhar determinadas atividades; os critérios de planejamento, alocação e movimentação interna dos recursos humanos; os critérios de avaliação da qualidade e da adequação dos recursos humanos através da avaliação de desempenho;

- políticas de manutenção de recursos humanos - que definem: os critérios de remuneração direta dos participantes, em função dos cargos e salários de mercado; os critérios de remuneração indireta, através dos programas de benefícios; como manter uma força de trabalho motivada, de moral elevado, participativa e produtiva dentro de um clima organizacional adequado; os critérios relativos às condições físicas ambientais de higiene e segurança; como manter um relacionamento de bom nivel com sindicatos e representações de pessoal;

- políticas de desenvolvimento de recursos humanos - que definem: os critérios de diagnóstico e programação de preparação e reciclagem constantes da força de trabalho; os critérios de desenvolvimento de médio e longo prazos; a criação e o desenvolvimento de condições capazes de garantir a saúde e excelência organizacional pela mudança do comportamento dos participantes;

- políticas de controle dos recursos humanos - que definem: como manter um banco de dados capaz de fornecer as informações para análise quanti- 
tativa e qualitativa da força de trabalho; os critérios para auditoria permanente da aplicação e adequaçăo das políticas e dos procedimentos relacionados com os recursos humanos.

CHIAVENATO [1992] salienta, ainda, que as políticas variam sensivelmente de uma organização para outra, sendo que cada uma das empresas deve adotar uma política adequada às suas características.

Ou seja, não existe uma política única. As empresas, seja qual for o setor industrial em que atuem, precisarão definir completamente e claramente as metas que pretendem conquistar, expressando-as sob a forma de uma estratégia de ação organizacional que contemple a gestão dos recursos humanos.

As características intrínsecas de uma empresa de construção de edifícios são muito distintas daquelas apresentadas pela maioria das indústrias de bens de consumo. A visão estratégica dos recursos humanos, integrados nas organizações e participando efetivamente delas, materializada por uma "política de gestão de recursos humanos", ainda não é um enfoque corrente na Indústria da Construção Civil.

No entanto, se a participação do elemento humano vem sendo crescentemente destacada e valorizada nos setores cujo processo de produção tem grande potencial de automatização e que utiliza, em geral, mão-de-obra qualificada, esse tema merece ser considerado com maior ênfase, no caso da Construção Civil. Nesse setor industrial, o processo de produção sofre grande interferência dos processos de trabalho e do elemento humano e, além disso, os investimentos na formação da mão-de-obra praticamente nunca existiram.

Dada a complexidade da gestão dos recursos humanos numa empresa de construção de edifícios, não é possivel o seu completo desenvolvimento no contexto desta tese, merecendo ser enfocado em outras pesquisas específicas. Entretanto, cabe discutir o papel das pessoas, enquanto indivíduos e enquanto grupos de trabalho, no processo de implantação de novas tecnologias nos canteiros de obras.

Essa discussão abordará inicialmente as características de contratação da 
força de trabalho, procurando deixar claro que o enfoque da empresa de construção para a gestão dos recursos humanos poderá ser distinto conforme a sua estratégia de ação seja a de contratação de mão-de-obra própria ou através de subempreiteiros.

Feita essa distinção, serão discutidas as principais dificuldades comumente encontradas para o desenvolvimento dos recursos humanos, apresentando-se, na seqüência, alguns caminhos que as empresas vêm percorrendo a fim de capacitar os recursos envolvidos no processo de produção, bem como algumas diretrizes que poderăo balizar as ações daquelas que pretendam iniciar o processo de implantação de TCR's.

\subsubsection{As estratégias de contratação e o desenvolvimento de recursos humanos}

As pressōes impostas ao setor da construção, no sentido de minimizar os custos de produção, desde o início dos anos 80 , levaram as empresas a buscarem a redução de seus gastos com a força de trabalho. Esse fato, segundo FARAH [1992], implicou em "políticas de mão-de-obra de caráter recessivo, envolvendo compressão salarial, ausência de vínculo empregatício e minimização de gastos com segurança e benefícios para o trabalhador".

FARAH [1992] destaca ainda que tais políticas foram viabilizadas, principalmente, através da subcontratação, tanto da mão-de-obra, quanto de algumas etapas da construção. E, com isso, as construtoras puderam minimizar o seu quadro de pessoal, substituindo um vínculo empregatício pela contratação de serviços. Dessa maneira, conseguiram diminuir seus encargos trabalhistas.

A utilização de empresas subcontratadas, como uma estratégia das construtoras para ter maior flexibilidade frente aos "altos e baixos" do mercado, foi claramente constatada através da pesquisa realizada junto às empresas construtoras, tendo-se identificado que:

- muitas das empresas não possuem mão-de-obra própria para a produção. Trabalham principalmente com subempreiteiras, sendo comum apenas a 
mão-de-obra denominada "administrativa" fazer parte do quadro funcional da empresa; e

- quando as empresas possuem mão-de-obra própria para a produção, de maneira geral, referem-se aos operários responsáveis pela execução da estrutura, e mais raramente, pela execução de alvenarias e de revestimentos argamassados e cerâmicos, subempreitando os demais serviços, tais como revestimentos de gesso, esquadrias, instalações e pintura.

A tendência de se ter a maioria das empresas de construção subempreitando os serviços é confirmada por VILLACRESES [1995], ao afirmar que: "o setor da Construção Civil provavelmente representa um dos exemplos contemporâneos mais significativos de uma indústria na qual a subcontratação permanece como uma característica focal da organização das atividades produtivas".

A pesquisa realizada junto a um grupo de 27 construtoras de pequeno porte no Rio Grande do Sul, na qual se avaliou a estratégia de subcontratação adotada pelas empresas, permitiu a VILLACRESES [1995] concluir que a maioria das tarefas são subcontratadas e que somente as atividades definidas como "básicas", representadas pelas fôrmas, armadura, concretagem, alvenarias e revestimentos argamassados e cerâmicos, são passiveis de se empregar mãode-obra própria em algumas empresas, sendo que as demais são, quase sempre, subcontratadas.

Ao se implantar as TCR's nas empresas construtoras pode-se encontrar duas realidades distintas: quando a realização dos serviços ocorre através da contratação de subempreiteiras e quando se dispõe de mão-de-obra própria para a condução do processo, as quais serão aqui discutidas.

\section{a) $O$ contexto da subempreitada de serviços}

Reverter o processo de contratação de serviços e de mão-de-obra através de subempreitadas é bastante difícil nos dias de hoje, sobretudo pelas constantes

\footnotetext{
1 A equipe considerada "administrativa", para a empresa de construção de edifícios, é comumente composta pelo pessoal do escritório, incluindo, na obra, o engenheiro, o mestre de obras, os encarregados e, ainda, almoxarifes e apontadores.
} 
oscilações que a economia nacional vem sofrendo e, em decorrência, as construtoras.

Essa forma de contratação teve origem há algumas décadas, quando eram contratadas equipes especializadas para a realização das tarefas mais complexas do edifício e hoje, vem se generalizando. Caracteriza, de certa maneira, uma política de mão-de-obra para o setor da construção cujo objetivo é adaptar-se às constantes crises [FARAH, 1992].

À primeira vista, essa política parece estar em sintonia com uma tendência mundial de se imprimir flexibilidade à produção, inclusive através da "terceirização" dos serviços. No entanto, o que se observa na indústria seriada é que apenas os serviços considerados como suporte à atividade produtiva vêm sendo gradativamente repassados às empresas especializadas.

O pessoal alocado na atividade produtiva principal da empresa pertence ao seu quadro funcional. Esses funcionários, muitas vezes, são alvo de uma politica de recursos humanos, que visa o desenvolvimento das pessoas enquanto indivíduos e enquanto grupos, e visam, ainda, a sua completa integração à empresa.

Essa postura contrasta fortemente com as ações que vêm sendo praticadas pelas empresas do setor de construção de edifícios, no que se refere à gestão dos recursos humanos, o que dificulta a adoção dos modelos de políticas desenvolvidos para a indústria seriada.

A denominada "terceirização", que ocorre na Indústria da Construção, na realidade é apenas um sinônimo que vem sendo utilizado para o termo "subcontratação" ou "subempreitada" e está muito distante do processo de "terceirização" que vem ocorrendo na indústria de bens de consumo.

A indústria da Construção de Edifícios entrega a terceiros o que deveria ser a sua atividade principal: a produção de edifícios e, teoricamente, conserva consigo o "gerenciamento do processo de produção", o qual não conhece e sobre o qual não tem domínio. 
Ao fragmentar o processo de produção do edificio em uma série de etapas e ao repassá-las aos subempreiteiros, as empresas de construção, principalmente por não terem uma estrutura organizacional adequada, vêm perdendo, gradativamente, o domínio do processo produtivo. Os subempreiteiros, por outro lado, não conhecem completamente o processo de produção.

Além disso, possivelmente por não conhecer e não ter o domínio sobre o processo de produção como um todo, ao contratar os subempreiteiros, a empresa construtora acaba não estabelecendo regras claras, que definam como a produção deve ocorrer e como o produto final de cada atividade será recebido.

A inexistência de regras previamente estabelecidas ficou bem caracterizada na pesquisa realizada por VILLACRESES [1995], a partir da qual o autor constata que muitas vezes não existe qualquer tipo de contrato formal entre o construtor e o subempreiteiro, sendo estabelecido apenas um acordo verbal.

O que se pode concluir é que a construção de edifícios vem ocorrendo, a partir de conhecimentos fragmentados, sem diretrizes previamente estabelecidas que organizem as atividades em torno de um objetivo comum. Tudo isso tem levado a desperdícios de materiais e recursos humanos, à baixa produtividade e por conseqüência, à baixa competitividade empresarial.

Mantendo-se a subempreitada como uma diretriz estratégica das empresas de construção e buscando-se em conjunto a evolução do processo de produção, torna-se imprescindivel uma evolução nas relações entre as empresas construtoras e as empresas prestadoras de serviços ou fornecedoras de mãode-obra. Essa evolução deverá estar refletida na forma como os contratos entre as mesmas vêm sendo estabelecidos.

A empresa construtora, ao contratar os serviços de terceiros, precisa passar a fazê-lo de maneira técnica, ou seja, deve conhecer claramente o serviço que está contratando e deixar expresso o que pretende obter como produto final. Além disso, deve conhecer o potencial técnico da subempreiteira e não apenas decidir pela contratação em função do preço estabelecido pelo serviço, como atualmente vem ocorrendo, em muitos casos. 
Por outro lado, a empresa prestadora de serviço precisa conhecer com exatidão as características do que deve ser produzido, inclusive o método de produção definido, deixando claro, em função disso, sob quais condições deverá trabalhar, para que possa fornecer o produto final desejado.

A subempreitada precisa ser reconhecida como um verdadeiro processo de "terceirização" em que se objetiva a flexibilidade da produção pela contratação de empresas especializadas em determinadas atividades e não, ser encarada apenas como um subterfúgio para se minimizar o pagamento de encargos sociais e transferir a terceiros o desenvolvimento dos recursos humanos.

Para isso, no relacionamento das duas empresas deverão estar claramente definidos os compromissos e as responsabilidades de cada uma. Ou seja, é preciso que a relação de contratação entre a empresa construtora e a subempreiteira evolua ao ponto de se poder praticar o conceito de "parceria", atualmente empregado por diversos segmentos da indústria seriada.

A "parceria" nas relações de negócio entre empresas, é um conceito que vem sendo defendido por muitos pesquisadores da Indústria da Construção Civil, dentre eles COOK; HANCHER [1990], ABUDAYYEH [1994] e HARBACK et al. [1994], como "uma nova estratégia para abaixar os custos e ganhar vantagem competitiva num ambiente de negócio em mudança".

Segundo COOK; HANCHER [1990], O Construction Industry Institute (CII) define "parceria" como sendo: "um compromisso de longo prazo estabelecido entre duas ou mais organizações, com o propósito de realizar um objetivo específico de negócio, através da maximização da eficiência dos recursos de cada participante".

Uma relação típica de parceria, estabelecida entre organizações, deve ser baseada na confiança, dedicação aos mesmos interesses e ao entendimento das expectativas e valores individuais de cada uma. E, portanto, deve envolver: comprometimento; confiança; vantagem mútua e oportunidade, numa intensidade muito maior do que a que é encontrada numa relação tradicional de negócio [COOK; HANCHER, 1990]. 
As atividades desenvolvidas através de "parcerias" e não de "subempreitadas" poderá levar a uma evolução das relações entre as empresas, proporcionando oportunidades de negócios para ambas.

A "parceria" é uma filosofia de trabalho que começa a ser praticada, ainda que timidamente, por algumas empresas que atuam no mercado de construção de edifícios. Essa forma de relacionamento deve evoluir num futuro próximo, acreditando-se que a implantação de TCR's pode contribuir significativamente para a evolução dessa prática, alterando as relações atualmente existentes entre as empresas construtoras e as prestadoras de serviços, em que predomina o desconhecimento dos processos de produção.

A metodologia de implantação proposta, ao definir que a introdução da nova tecnologia deve ser feita na fase de projeto, tendo-se o suporte de uma documentação relativa à nova tecnologia, pretende fornecer os instrumentos para reverter a situação atual de ausência do domínio tecnológico.

Com esses instrumentos, é possivel que as construtoras definam o seu processo construtivo e, a partir daí, contratem exatamente os serviços que desejam ver realizados.

Por outro lado, existindo os projetos e os procedimentos voltados à produção, é possivel que as subcontratadas conheçam previamente quais serviços deverão realizar e quais exigências estão sendo feitas por parte de quem as está contratando. Desta maneira, poderão dimensionar e comprometer os recursos para atender às exigências contratuais.

A evolução dessa nova forma de relacionamento entre as empresas construtoras $e$ as prestadoras de serviços poderá levar a que algumas subempreiteiras venham a se organizar e até mesmo venham a investir na motivação e capacitação de sua mão-de-obra, tornando-se, para o mercado, especialistas num determinado tipo de serviço. Com isso, diferentemente do que ocorre nos dias atuais, será possível estabelecer uma verdadeira relação de parceria com as empresas construtoras, na qual os compromissos e as responsabilidades de ambas as partes estarão completamente definidos. 
Haverá, no entanto, outras subempreiteiras que exigirão algum impulso das construtoras para poder evoluir. E, para isso, num primeiro momento poderá caber à construtora realizar os investimentos para o desenvolvimento dos recursos humanos, ainda que não pertençam ao seu quadro de funcionários.

Esse processo deverá ser acelerado à medida em que as exigências de mercado levarem os prestadores de serviço a deixarem de ser apenas "agenciadores de mão-de-obra" e passarem a ser especialistas na prestação de serviços, que assumem a responsabilidade conjunta pelas atividades executadas, numa verdadeira relação de parceria ${ }^{2}$.

\section{b) $O$ contexto da mão-de-obra própria}

Segundo BOBROFF [1989], "diferentes organizações e modos de recomposição dos processos de trabalho são aplicados aos canteiros. As estratégias definidas dependem da história das empresas, de suas características, de suas tradições e comportamento de mercado, o que origina as mais diversas combinações dos fatores produtivos".

Uma das possiveis estratégias a serem adotadas pelas empresas é a contratação de praticamente todos os recursos humanos envolvidos com o processo de produção como funcionários da empresa. Nessa situação, as empresas podem ter inclusive a equipe de projeto no seu quadro de funcionários, sobretudo quando se tratar de uma incorporadora e construtora; no entanto, essa não tem sido uma prática comumente encontrada.

Quando a empresa assume a contratação direta, tanto do pessoal administrativo, quanto da mão-de-obra envolvida com a produçăo, as ações para o desenvolvimento pessoal e profissional das pessoas estará totalmente sob a sua responsabilidade e sob o seu completo controle, dependendo, somente, de uma postura ativa da organização.

Nesta situação convém que a empresa defina a sua política de recursos humanos, que poderá envolver os elementos propostos por CHIAVENATO

${ }^{2}$ O estabelecimento de relações de parceria como uma "nova forma de racionalização da produção" é amplamente discutido por CARDOSO [1996]. 
[1992], anteriormente destacados, devidamente adaptados à organização da empresa.

O desenvolvimento de uma política de gerenciamento de recursos humanos, para as empresas que possuem mão-de-obra própria, não faz parte do escopo do presente trabalho de tese.

No entanto, a fim de contribuir para a definição do plano de ação das empresas para a implantação de TCR's, serão apresentados e discutidos os elementos que no entendimento da autora devem estar presentes na conduta das empresas para que ocorra o desenvolvimento dos recursos humanos, tanto para o caso de mão-de-obra própria, como para o caso de contratação de subempreiteiros.

\subsubsection{Elementos constituintes do processo de desenvolvimento dos recursos humanos}

Diversos autores consultados, no âmbito da pesquisa bibliográfica apresentada no capítulo 4, destacam a motivação pessoal, relacionada à qualidade de vida no trabalho e na organizaçăo, e a capacitação para a inovação, como elementos essenciais para o processo de implantação de inovações tecnológicas.

Entretanto, diversos autores alertam que existem certos entraves que dificultam as ações visando a motivação e a capacitação dos recursos humanos. BOBROFF [1989], em particular, analisando o setor da Construçāo de Edifícios na Europa, apresenta como principais entraves, os seguintes:

- uma organização de trabalho não adaptada às novas exigências;

- uma administração de canteiros mal treinada e que pouco se renova;

- uma mão-de-obra que envelhece, não qualificada, com baixo nível de escolaridade, formada na maioria das vezes nos grandes canteiros e não adaptada às novas exigências;

- jovens pouco atraídos por um setor que não tem bọ imagem e cujas condições de trabalho são difíceis. 
Esses elementos parecem estar presentes na realidade brasileira também, sendo que, no caso brasileiro, além desses dificultadores, deve-se destacar a elevada rotatividade sofrida pelo setor.

Segundo a FUNDAÇÃO JOÃO PINHEIRO [1992]: "Os niveis de rotatividade na indústria da Construção sempre permanecem muito superiores aos dos demais setores econômicos, peculiaridade inerente às singularidades de seu próprio processo produtivo parcelado e descontínuo (etapas e fases distintas que se sucedem), o que demanda trabalhadores com características diferenciadas a cada nova atividade que se inicia no canteiro de obras".

A rotatividade é acentuada pelas más condições de trabalho e pelos baixos salários que desestimulam a permanência dos trabalhadores nesse ramo de atividade [FARAH, 1992].

Tudo isso dificulta o processo de implantação de TCR's, pois, como bem destaca ROSSO [1980]: "a peculiaridade da mão-de-obra utilizada nos nossos canteiros faz com que se registrem condições adversas à aplicação dos princípios que estamos advogando ${ }^{3}$ : o elevado rodizio ou turn over do pessoal, que atinge a proporção de $40 \%$ para mais, e a resistência à transferência de uma obra para outra, impedem que se possa atingir com facilidade o grau de eficiência desejável."

Além disso, FARAH [1992] acrescenta que a rotatividade leva à interrupção da continuidade que o processo de formação no âmbito da estrutura de ofícios pressupōe, 'minando', de certa forma, o mecanismo de identificação do trabalhador com seu ofício".

A rotatividade não atinge somente os operários da produção, mas inclusive o pessoal de niveis superior e médio. A partir de uma pesquisa conduzida pelo SINDUSCON-SP [SINDUSCON, 1991] pôde-se identificar que o tempo médio de permanência desses profissionais na empresa é de cerca de 11 meses, o que representa, na maioria dos casos, um periodo inferior ao de produção de um edifício de múltiplos pavimentos.

\footnotetext{
${ }^{3} \mathrm{O}$ autor está-se referindo aos princípios da racionalização construtiva.
} 
Analisando-se as colocações anteriores, parece existir o que se poderia denominar de "círculo vicioso", ou seja, não se investe no desenvolvimento dos recursos humanos pela elevada rotatividade $e$ incertezas no processo de produção e, por outro lado, a presença desses elementos é atribuída à falta de investimentos que levem a uma maior motivação e capacitação da mão-deobra como um todo.

Essa situação de falta de motivação para o trabalho, ausência de formação profissional e de elevada rotatividade precisa ser alterada, quando se pretender fazer evoluir os processos de produção. Deve-se quebrar o "círculo vicioso" existente.

Segundo PICCHI [1992], as empresas que têm desenvolvido programas de racionalização e melhoria da qualidade estão tentando manter um maior vínculo e comprometimento com os operários, para diminuir a rotatividade gerada tanto pelas demissões por iniciativa da empresa, como as motivadas pelo próprio trabalhador.

As demissões por parte da empresa decorrem principalmente da falta de continuidade das atividades no canteiro de obras, acrescidas da dificuldade de se transferir o operário para outra obra.

Tentando modificar essa situação, as empresas construtoras vêm procurando adotar algumas estratégias de gestão dos recursos humanos, que imprimam maior flexibilidade ao processo de produção, mesmo nos casos em que a mãode-obra é contratada pela empresa. Uma dessas estratégias é a formação de "operários polivalentes", os quais podem realizar diferentes atividades no canteiro de obras, evitando-se, dessa maneira, a sua saída ao término de um determinado serviço [CAMPAGNAC, 1993]. Essa estratégia visa motivar o operário a não deixar a empresa por meio de uma perspectiva de carreira.

O combate às demissões geradas pelo próprio operário vem sendo feito sobretudo através da sua motivação ao trabalho.

O enfoque conceitual sobre a motivação dos recursos humanos é tema antigo na literatura, sendo desenvolvido em profundidade por diversos 
pesquisadores, cabendo destacar as publicações de BERGAMINI [1986] e CHIAVENATO [1992].

A motivação é considerada um fator interno à pessoa, que influencia fortemente o seu comportamento. Segundo CHIAVENATO [1992], "a motivação está relacionada com o sistema de cognição do individuo". Segundo esse autor, o sistema cognitivo de cada pessoa envolve os seus valores pessoais e é influenciado pelo seu ambiente físico e social, por sua estrutura e por seus processos fisiológicos, por seus anseios e por suas experiências anteriores.

Por isso, para se discutir a motivação do trabalhador da construção civil, devese passar por questões que envolvam a sua qualidade de vida no trabalho.

A discussão sobre a qualidade de vida do trabalhador da construção civil, apesar de ser tema recente, vem sendo cada dia mais ampliado. QUELHAS; MORGADO; DINIZ [1995] vêm desenvolvendo uma pesquisa na tentativa de criar indicadores para a qualidade de vida no trabalho. Segundo esses autores, a qualidade de vida no trabalho é definida pela presença de alguns elementos, dentre os quais destacam:

- a remuneração justa e adequada às suas responsabilidades;

- a segurança e direitos do trabalhador;

- a oportunidade de crescimento na empresa, de modo a sentir-se "parte da engrenagem" e não "material descartável";

- integração social;

- comprometimento com a empresa; e

- a valorização do trabalho.

LIMA; HEINECK [1995] também vêm realizando pesquisas junto a empresas de construção, nas quais estudam a qualidade de vida no trabalho. Esses pesquisadores abordam oito fatores intervenientes na qualidade de vida do trabalhador, assim definidos:

- condiçōes de trabalho;

- compensações e benefícios; 
- uso e desenvolvimento das capacidades;

- oportunidades de crescimento e segurança no emprego;

- integração social na firma;

- constitucionalismo (cumprimento das obrigaçōes, liberdade de manifestação e regras preestabelecidas);

- comunicação;

- programação dos serviços.

Segundo esses autores, "qualquer avanço pretendido em termos de qualidade, produtividade, redução de desperdícios e custos no setor dependerá da adoção de estratégias adequadas de desenvolvimento dos recursos humanos".

Portanto, investir em melhores condições de trabalho para as pessoas, em todos os niveis hierárquicos da empresa, deverá ser uma premissa para aqueles que pretendem percorrer o caminho da evolução dos processos de produção.

O outro elemento essencial no desenvolvimento dos recursos humanos trata da capacitação para a implantação, em que o treinamento para a realização das atividades em todos os níveis hierárquicos, assume um papel de destaque.

BOBROFF [1989] destaca a qualificação do trabalhador através do treinamento; porém, afirma que, na França, são poucas as empresas que "tentam reorganizar seu processo de trabalho a partir de uma valorizaçăo da qualificação"; sobretudo porque tal estratégia, baseada no recrutamento, treinamento e estabilidade da mão-de-obra, exige recursos elevados e uma motivação da direção e da administraçăo, por estar dirigida aos jovens.

Esses elementos, motivação e treinamento, deverão permear toda a empresa, pois sem que todos os agentes do processo de produção incorporem a nova tecnologia, poucos resultados poderão ser obtidos. Portanto, será imprescindível considerar-se todos os níveis hierárquicos.

Assim a reflexão sobre a participação das pessoas no processo de implantação de TCR's será focada na motivação e no treinamento para todos os niveis hierárquicos. 


\subsubsection{Motivação e treinamento dos recursos humanos}

Nāo há uma "fórmula" que possa ser seguida pelas empresas, de maneira a envolver todas as pessoas que participam do processo de produção.

Cada empresa deverá definir a sua estratégia de envolvimento, motivação e capacitaçăo dos recursos humanos segundo às suas características organizacionais e recursos disponiveis ${ }^{4}$. Entretanto, é certo que sem a participação das pessoas, inclusive da mão-de-obra de produção, seja ela subcontratada ou própria, dificilmente será possível a evolução desse processo.

O envolvimento das pessoas poderá ocorrer de maneira incremental e sempre evolutiva na empresa. Assim, num primeiro momento, pode-se envolver um grupo restrito de pessoas, ou seja, somente aquele envolvido diretamente com a implantação da TCR. Os resultados positivos de uma implantação acabarão por motivar outros membros da empresa, fazendo-os participar da próxima etapa do processo, às vezes até por disposição própria.

É interessante iniciar-se o treinamento pelas pessoas que irão participar ativamente da implantação da TCR. Isso, além de permitir um rápido retorno do esforço empreendido, possibilita que se realize uma avaliação do processo de treinamento, podendo-se, inclusive, reformulá-lo para uma aplicação futura.

Deve-se observar que as formas de envolvimento das pessoas variam conforme a sua posição na estrutura hierárquica; o que serve como motivação para o operário da produção, pode não servir para o gerente do empreendimento. Além disso, a capacitação profissional exigida é distinta. O conhecimento e envolvimento requeridos da área de engenharia são diferentes dos exigidos para a produção.

Por isso, a empresa precisará se organizar para poder proporcionar o desenvolvimento de cada grupo de indivíduos, procurando fazê-los participar da idéia de evolução através do processo de implantação de novas tecnologias.

\footnotetext{
${ }^{4}$ GOMES; SALDANHA [1995] discutem, por exemplo, a "administração participativa" em que a participação dos trabalhadores é incorporada à estratégia de atuação da empresa como uma forma de melhorar o desempenho organizacional, seja em termos de aumento da produtividade ou através de maior adaptação às mudanças.
} 
De modo geral, esse trabalho envolverá, no mínimo, dois níveis distintos na empresa: os diretores, gerentes e engenheiros da obra; e o pessoal ligado diretamente à produção: mestres de obras, encarregados e operários.

As atividades desenvolvidas com cada um desses grupos precisarão ser específicas. O material didático, a condução do treinamento e a maneira como as idéias são transmitidas, devem ser relevantes a cada grupo, sob pena de poderem comprometer o sucesso da implantação, caso não sejam.

Essa divisão justifica-se pelas fortes características hierárquicas atualmente encontradas nas empresas. É nítida a força exercida pelo mestre de obras e pelos encarregados sobre os demais operários, sejam eles funcionários da construtora ou não.

Na pesquisa realizada foi comum ouvir-se a seguinte afirmativa: "se você não convencer o engenheiro e o mestre de obras, de que a nova tecnologia dá certo, não adianta falar aos operários".

O "convencimento" do engenheiro muitas vezes esbarra no seu desconhecimento quanto à nova tecnologia, pois é flagrante o despreparo tecnológico observado nos profissionais da área.

NEVES [1995], a partir de um levantamento realizado junto a diversas empresas da região de Salvador, destaca que: "o engenheiro recém-formado não está habilitado, a contento, para desenvolver atividades de execução de obras, necessitando de um período de capacitação na empresa em torno de três anos".

Entretanto, continua a pesquisadora, "esse 'período de capacitação' implica em o engenheiro conhecer as práticas correntes na empresa, sobretudo referente aos aspectos administrativos, não havendo, necessariamente, investimentos em sua capacitação tecnológica, através de cursos visando o aprofundamento e a reciclagem de seus conhecimentos".

No que se refere à formação dos operários ligados à produção, segundo NEVES [1995], "a capacitação dos diversos operários, através do exercício da prática dos serviços, não está satisfazendo as necessidades das empresas no 
que diz respeito à qualidade da construção e à implantação de inovações e melhorias tecnológicas".

Reverter essa situação significa "desenvolver os recursos humanos". Portanto, além de um esforço voltado à melhoria das condições de vida no trabalho, deverá haver, ainda, uma valorização da capacitação profissional.

Essa capacitação dos recursos humanos poderá ser iniciada pelas empresas de maneira isolada, mas certamente, deverá evoluir, envolvendo mecanismos institucionais que incentivem os cursos profissionalizantes através de programas junto ao SENAI e mesmo junto aos sindicatos envolvidos com a categoria, como o SINDUSCON, por exemplo.

Falar em desenvolvimento de recursos humanos, mesmo frente às mudanças de paradigmas que estão sendo estabelecidas, é questão de grande dificuldade. No entanto, acredita-se que sem que esse investimento ocorra, não será possível capacitar as pessoas a produzirem segundo os princípios da racionalidade e, portanto, não será possível incentivar a evolução do setor.

\subsubsection{Desenvolvimento do setor de suprimentos}

A implantação de TCR's, além de exigir o desenvolvimento do projeto para produção e a existência de procedimentos, contendo o registro da tecnologia de forma acessivel a todos aqueles que participam do processo de implantação, além da motivação e o treinamento das pessoas envolvidas, exige, ainda, outras diretrizes gerenciais. Dentre elas, será enfocada, neste item, a "gestão do setor de suprimentos voltada à implantação das novas tecnologias".

ARAÚJO [1971], enfocando todo o setor industrial, destaca a relevância dessa diretriz balizadora afirmando que grande parte do capital de uma empresa muitas vezes é representada por aquisiçōes de matérias-primas, equipamentos, máquinas e ferramentas, acessórios, materiais de conservação, de manutenção, peças, veículos, motores, etc. Para esse autor, "nenhum mentor pode ignorar a importância da administração de materiais dentro de qualquer tipo de empresa". 
Passados cerca de vinte e cinco anos das colocações de ARAÚJO [1971], a administração de materiais vem sendo constantemente estudada e ganhando espaço na definição estratégica de diversos setores industriais.

SLACK [1993] salienta que se deve "administrar a rede de suprimentos", pois "nenhuma operação ou parte da operação existe isoladamente. Cada pedaço é parte de uma rede mais ampla e interconectada de operações. Materiais, partes, montagens, informações, idéias e dinheiro fluem através das ligações consumidor/fornecedor (...).

Nessa rede, segundo SLACK [1993], o setor de suprimentos deverá se integrar aos diversos setores da empresa e deverá manter uma forte relação com o mercado. Segundo esse autor, há uma tendência mundial de se estabelecer "parcerias" como uma forma de relacionamento estratégico entre cliente e fornecedor.

Da mesma maneira, a série de normas NBR ISO 9000 [ABNT, 1994a] destaca que um estreito relacionamento entre as empresas e os fornecedores é imprescindivel na busca da qualidade. Em particular, a NBR ISO 9004/1 [ABNT, 1994c] recomenda que: "convém que um relacionamento estreito de trabalho e um sistema de realimentação sejam estabelecidos com cada subcontratado. Desta forma a melhoria contínua da qualidade pode ser mantida e divergências evitadas ou resolvidas rapidamente. Este relacionamento estreito de trabalho e o sistema de realimentação beneficiarão ambas as partes".

O relacionamento estratégico entre o cliente e o fornecedor e, mais particularmente, o papel do setor de suprimentos no contexto estratégico da empresa são temas amplamente discutidos por MERLI [1994], que propõe algumas estratégias organizacionais diferentes para o setor de suprimentos de diversos segmentos da indústria seriada.

Entretanto, essa visão estratégica do setor de suprimentos, destacada como uma tendência nos dias atuais, ainda não é uma realidade completamente reconhecida na indústria da Construção Civil.

MARSH [1985], presidente do "AACE Materials Management Committee", sali- 
enta que o sistema de gerenciamento dos suprimentos na indústria da Construção Civil vem sendo negligenciado e pouco organizado. Para esse autor, o principal problema dos suprimentos nesse setor industrial decorre da falta de integração, tanto entre os diversos setores da empresa, como entre as próprias funções que o setor de suprimentos deve desempenhar.

Segundo MARSH [1985], em média, seis porcento do custo da mão-de-obra poderia ser economizado se os materiais e equipamentos fossem corretamente gerenciados e estivessem no local de trabalho, no momento da utilização.

Para PALÁCIOS [1995], "deve ser reconhecido que a indústria da Construção precisa investir em melhorias no gerenciamento de suprimentos (...) uma melhor utilização dos princípios de gerenciamento de suprimentos pode criar muitas oportunidades para aumentar a eficiência na construção e reduzir o custo total dos empreendimentos."

Essa visão estratégica do setor de suprimentos é destacada, igualmente, nas proposições feitas por PICCHI [1993] e pelo CTE [1994], os quais tratam da gestão estratégica do setor de suprimentos, voltada à implantação de programas de Gestão da Qualidade na indústria da Construção Civil.

A gestão estratégica do setor de suprimentos não é o enfoque a ser dado nesta tese, sobretudo porque, além das citações anteriores, há uma vasta bibliografia sobre esse assunto, ainda que não exclusivamente para a indústria da Construção.

O que se pretende aqui é discutir a interferência que o setor de suprimentos exerce no processo de implantação de novas tecnologias, uma vez que é o responsável por suprir os recursos físicos de materiais e equipamentos para que a produção ocorra segundo o planejamento realizado.

Como bem destaca MARSH [1985]: "a equipe técnica mais competente não realizará a produção se as necessidades de materiais e equipamentos não forem satisfeitas".

Para isso deve-se explicitar, primeiro, os objetivos que deverão nortear as atividades desenvolvidas pelo setor de suprimentos, bem como as suas funçōes. 
Segundo VIOLANI; CÂNDIA; MELHADO [1991], os principais objetivos da área de suprimentos devem ser:

- suprir a obra atendendo aos requisitos de qualidade e custos;

- evitar paralisações por falta de insumos ou serviços ou estoques elevados;

- coordenar o processo de compras de forma a minimizar os investimentos, deixando o capital da empresa livre para giro;

- comprar sempre nos melhores preços, obedecendo às especificações de projeto;

- negociar com os fornecedores à exaustão, assegurando para a empresa as melhores condições ou de preço ou de pagamento.

Com isso, e partir das proposições de ARAÚJo [1971], MARSH [1985] VIOLANI; CÂNDIA; MELHADO [1991] e PALÁCIOS [1995], destacam-se, na seqüência, as funções principais desse setor:

\section{a) Programação e escolha}

Essa função envolve o estudo de mercado e o planejamento da compra, ou seja: a verificação da disponibilidade de materiais; a análise de custos; o estabelecimento das fontes de fornecimento, com a qualificação e cadastro de fornecedores; a inspeção regular nas fábricas dos fornecedores; e o processamento e o controle das solicitações.

\section{b) Aquisição ou compra}

Essa função envolve atividades tais como: o levantamento e o estudo das propostas; a seleção dos fornecedores; a negociação de contratos; a decisão das compras de grandes lotes; a contratação dos pedidos; e o acompanhamento e a avaliação das atividades após o pedido.

\section{c) Recebimento e controle}

Esta função é desempenhada, geralmente, no próprio canteiro de obras, por pessoal ligado ao setor de suprimentos (almoxarife, por exemplo).

Consiste em: receber e controlar a qualidade dos insumos recebidos, verificando o cumprimento das especificações; fazer a notificação daquilo que foi 
recebido; estabelecer os locais para descarga e estoque dos materiais; cuidar da segurança e da conservação dos insumos; realizar a movimentação para o emprego dos insumos; realizar o controle de estoques; e definir a transferência e o destino das sobras, evitando excesso e obsolescência de estoques.

Considerando-se os objetivos e as funções do setor de suprimentos, fica clara a ligação existente entre o processo de implantação de TCR's e a organização desse setor.

As TCR's, na maioria das vezes, envolvem materiais e equipamentos distintos daqueles convencionalmente empregados, exigindo do setor de suprimentos:

- o atendimento preciso das especificações;

- $\mathrm{o}$ atendimento do planejamento;

- um suporte aos projetistas com relação aos novos produtos e equipamentos disponiveis no mercado.

Observa-se que as funções a serem desempenhadas pelo setor de suprimentos, para contribuir com o processo de implantação das TCR's, não diferem daquelas que tradicionalmente esse setor deve cumprir. O que muda com relação à sua forma de organização tradicional é a postura adotada frente às funções, as quais serão destacadas na seqüência.

\subsubsection{Atendimento às especificações}

As especificações quanto aos materiais, componentes e equipamentos a serem adquiridos deverão estar expressas no projeto e, em particular, no projeto para produção. Portanto, cabe ao projeto dar início ao processo de aquisição dos suprimentos, definindo claramente as características daquilo que deverá ser adquirido e fornecendo, além disso, os parâmetros e os referenciais de controle do recebimento desses insumos.

Sem as especificações de projeto, o departamento de suprimentos não terá parâmetros técnicos para efetuar suas atribuições, ou seja, realizar a seleção de fornecedores e efetuar a aquisição. Neste caso é comum que o "preço" dos suprimentos direcione as ações desse departamento. 
Para a realização de uma "compra técnica", não bastam as especificações vindas do projeto; além disso, o setor de suprimentos deverá estar devidamente organizado.

Deverá existir um responsável pelas "compras técnicas", o qual deverá ser um profissional com capacidade de supervisionar e orientar os compradores, classificar e analisar as solicitações de compras, estudar e analisar as especificações técnicas de cada produto ou serviço, montar as concorrências, analisar as propostas técnicas e comerciais e participar da seleção de fornecedores [VIOLANI; CÂNDIA; MELHADO, 1991].

Observa-se que a realização da compra de maneira técnica não finda a responsabilidade do setor de suprimentos. O material deve ser devidamente recebido na obra, verificando-se, através de procedimentos de controle previamente estabelecidos, se o material que foi entregue corresponde ao que foi definido e adquirido, a fim de que se possa dar um retorno, tanto ao setor que realizou a especificação, quanto aos responsáveis pela aquisição.

Aos poucos, o setor de suprimentos poderá ir se organizando de maneira a atender cada vez melhor as definiçōes de projeto. Isto implicará no estabelecimento de rotinas, procedimentos de trabalho e na definição das responsabilidades de cada pessoa envolvida com esse setor.

Com o controle adequado das atividades, em cada processo de aquisição, é possivel "rodar o ciclo PDCA", premissa da metodologia proposta, e melhorar as ações numa próxima intervenção.

\subsubsection{Atendimento ao planejamento}

O planejamento do empreendimento, de modo geral, apresenta poucas folgas entre atividades. E, inúmeras vezes, as justificativas para a não aplicaçăo das novas tecnologias são: "não foi possivel adquirir os equipamentos previstos no projeto; não foi possível encomendar a tempo os componentes e materiais a serem utilizados".

Essas situações poderão ser evitadas se o planejamento do empreendimento contemplar as exigências de prazo estabelecidas pela implantação das novas 
tecnologias (premissa aqui defendida) e, se esse planejamento for devidamente respeitado ao se realizar a programação das aquisições.

Para isso, o departamento de suprimentos poderá dar a sua contribuição, uma vez que, para a maioria dos insumos esse setor é capaz de prever o "tempo de aquisição", que segundo VIOLANI; CÂNDIA; MELHADO [1991], "é o tempo necessário para se processar uma tomada de preços, somado ao de decisão da compra e ao prazo de entrega do fornecedor".

\subsubsection{Suporte aos projetistas}

Essa é mais uma "função" que o setor de suprimentos pode desempenhar para aumentar o potencial de sucesso do processo de implantaçāo de novas tecnologias nos canteiros de obras.

Segundo um estudo realizado pelo IPT [1988], as principais alterações tecnológicas sofridas pelo setor da construção de edifícios nos últimos tempos têm tido origem na indústria de materiais e componentes que, de certa maneira, impõe seus novos produtos ao mercado das construtoras.

Esses novos produtos nem sempre entram no processo de produção através do projeto. O mais comum é que entrem através de sugestões do setor de suprimentos, o qual, na ausência de especificações completas, claras e seguras, torna-se o único responsável pela decisão quanto aos insumos a serem empregados. E nem sempre esse setor está devidamente orientado para fazer a melhor opção.

Ao se buscar a racionalização da produção, deseja-se eliminar as decisões não técnicas. Para isso, deve-se assegurar que os novos produtos possam ser devidamente avaliados pelos setores competentes; por isso, a exigência de um envolvimento estreito entre o departamento de suprimentos e os projetistas, para que se tenha uma melhor avaliação do comportamento desses novos produtos no processo de produção.

Além disso, o setor de suprimentos pode se constituir num elo de ligação entre os projetistas e os fornecedores de materiais e equipamentos, para o desenvolvimento de produtos que atendam às novas tecnologias. 
Isto é mostrado por PICCHI [1993] ao afirmar que a empresa de seu estudo de caso estabeleceu diversas parcerias para o desenvolvimento de produtos, em conjunto com fornecedores, e destaca como exemplos o desenvolvimento de equipamentos para a construção, de componentes do tipo painéis de gesso reforçados com fibras de vidro e de blocos cerâmicos.

MARSH [1985] destaca que: "um sistema de gerenciamento de suprimentos eficaz, integrado com os outros setores da empresa, permite evitar problemas que incluem: escassez, excesso, demora e erros no suprimento de materiais e equipamentos e problemas de fluxo de caixa".

Assim, ainda que a empresa não tenha enxergado o potencial estratégico do setor de suprimentos para alcançar a sua competitividade, o processo de implantação de TCR's permitirá que a eficiência desse departamento seja avaliada e que as necessidades de intervenção sejam identificadas, para que possa haver a melhoria continua.

\subsubsection{Desenvolvimento do controle do processo de produção}

As mudanças na gestão e organização do processo construtivo tradicional não se concretizam de uma hora para outra. Incrementar o seu grau de racionalização exige a adoção de uma postura que permita à organização ter o domínio do processo de produção.

A metodologia de implantação de TCR's no processo de produção de edifícios é um instrumento de grande valia para a consolidação das mudanças pretendidas, pois as diretrizes anteriormente discutidas fornecem os subsídios para que se tenha o domínio do processo de produção. Entretanto, ainda que essenciais, não são suficientes, pois esse domínio será completamente estabelecido apenas quando forem definidos mecanismos efetivos de CONTROLE do processo.

Somente através de uma adequada orientação para o controle do processo de produção será possivel garantir a consolidação das TCR's no sistema produtivo da empresa e, por conseqüência, a ausência de retrabalho, a produtividade esperada e o adequado desempenho do produto final. 
Pelas características intrínsecas do processo construtivo tradicional, discutidas nos capítulos precedentes, pode-se afirmar que sem a incorporação de mais essa diretriz balizadora, o controle do processo, dificilmente as açōes propostas por este trabalho irão se fixar na cultura da empresa.

Se não houver controle, não será possível avaliar as dificuldades de implantação das TCR's; não será possivel corrigir eventuais falhas e distorções, tanto na aplicação da tecnologia, como do próprio processo de implantação; não será possível retroalimentar a implantação; enfim, não será possível evoluir, no sentido de se ter a melhoria contínua.

Para que se possa entender mais claramente a proposta que aqui se faz, no item 5.4.5.1 discute-se como a atividade de controle vem sendo entendida na indústria da Construçāo Civil. Na seqüência, no item 5.4.5.2, apresentam-se as propostas encontradas na literatura e os resultados das experiências pelas quais a autora tem passado com a implantação da metodologia de controle de produção de contrapisos para edifícios. Finalmente, no item 5.4.5.3, são propostos os elementos que poderão fazer parte de uma metodologia de controle a ser estabelecida pelas empresas de construção, visando a implantação das TCR's.

\subsubsection{O controle na indústria da Construção Civil}

Para GARCIA MESEGUER [1980], o controle da qualidade na indústria da Construção Civil pode ser entendido como uma série de procedimentos de mensuração e avaliação, que aplicados ao longo da obra, funcionam como um instrumento para assegurar que a qualidade de um dado serviço (atividade) ou de um certo produto (edifício) atendam aos padrões e às tolerâncias prescritos em projetos.

Em uma publicação posterior, GARCIA MESEGUER [1989a] afirma: "tradicionalmente, o controle de qualidade na construção tem sido identificado com a vigilância em obra e a realização de alguns ensaios". Para o autor, "essa simplicidade contrasta com o conceito mais elaborado de controle da qualidade que se utiliza em outras indústrias, o qual envolve todas as 
atividades do processo (desde a concepção e projeto, até sua comercialização e atendimento pós-entrega) e faz uso de técnicas estatísticas mais ou menos sofisticadas; porém, de fácil aplicação".

VARGAS [1987] compara as questōes de controle para esses dois segmentos industriais, afirmando que: "na Construção Civil há poucos mecanismos que viabilizam a existência do controle, ao contrário do que ocorre na fábrica, onde "cada trabalhador recebe prescriçōes precisas sobre as suas atividades diárias e onde o ritmo da linha de montagem tende a se impor sobre cada operário individual."

Esse autor acrescenta: "na organização da produção assentada em bases manufatureiras sempre está presente uma dificuldade de controle do trabalho, dos custos, dos prazos de execução das atividades. De maneira geral, fica para o encarregado a função de supervisão e controle dos operários".

A dificuldade de controle, destacada por VARGAS [1987], não reside no fato de ser uma atividade atribuída ao encarregado, em particular, mas sim, por ser realizada de maneira aleatória, esporádica e sem os parâmetros adequados. Trata-se, na maioria das vezes, de uma atividade que fica à mercê do conhecimento e empenho pessoal dos mestres de obras e dos encarregados ou mesmo da direção da obra; não sendo formalizada.

A falta de formalização da atividade de controle é destacada por PICCHI [1993]. Esse autor afirma que: "no caso de materiais, existe, de uma maneira geral, nas obras de edifícios brasileiras, um controle de recebimento formalizado ao menos para alguns materiais, principalmente os relacionados com a segurança estrutural; já no caso de execução, são raríssimos os casos de controle formalizado. O que normalmente ocorre é um controle informal, realizado pelos mestres de obras e encarregados, extremamente variável de um profissional para outro".

Para ilustrar suas colocações, PICCHI [1993] apresenta uma comparação entre o que denominou de "controle informal" e "controle formalizado", apresentada na tabela 5.2 . 
TABELA 5.2: Comparação entre o controle informal e o controle formalizado [PICCHI, 1993]

\begin{tabular}{|c|c|c|}
\hline $\begin{array}{l}\text { ASPECTO } \\
\text { COMPARADO }\end{array}$ & $\begin{array}{l}\text { CONTROLE } \\
\text { INFORMAL }\end{array}$ & CONTROLE FORMALIZADO \\
\hline Forma de realização & $\begin{array}{l}\text { acompanhamento } \\
\text { informal do serviço }\end{array}$ & $\begin{array}{l}\text { controle sistematizado, realizado } \\
\text { segundo listas de verificação, } \\
\text { procedimentos e planos de controle } \\
\text { da qualidade }\end{array}$ \\
\hline $\begin{array}{l}\text { Pessoas envolvidas na } \\
\text { avaliação }\end{array}$ & $\begin{array}{l}\text { geralmente mestres } \\
\text { de obras e } \\
\text { encarregados }\end{array}$ & $\begin{array}{l}\text { definidas nos procedimentos, } \\
\text { podendo haver combinações em } \\
\text { diferentes graus, de: inspetores, } \\
\text { mestres de obras, encarregados e } \\
\text { os próprios oficiais (autocontrole) }\end{array}$ \\
\hline $\begin{array}{l}\text { Procedimentos de } \\
\text { avaliação }\end{array}$ & critérios pessoais & $\begin{array}{l}\text { padronizados e descritos em } \\
\text { procedimentos de controle da } \\
\text { qualidade }\end{array}$ \\
\hline $\begin{array}{l}\text { Padrōes para avaliação e } \\
\text { critérios de aceitação }\end{array}$ & $\begin{array}{l}\text { subjetivos, } \\
\text { personalizados }\end{array}$ & $\begin{array}{l}\text { objetivos, avaliando características } \\
\text { prioritárias, conforme padrões } \\
\text { estabelecidos em normas, com } \\
\text { critérios de aceitação e rejeição } \\
\text { claros, indicando tolerâncias } \\
\text { admitidas }\end{array}$ \\
\hline $\begin{array}{l}\text { Momento de realização e } \\
\text { serviços abrangidos }\end{array}$ & $\begin{array}{l}\text { assistemático, } \\
\text { ocorrendo em } \\
\text { intensidade maior } \\
\text { ou menor, } \\
\text { conforme } \\
\text { disponibilidade } \\
\end{array}$ & $\begin{array}{l}\text { sistemático, rotinizado, realizado em } \\
\text { momentos e sobre serviços } \\
\text { definidos no plano de controle da } \\
\text { qualidade }\end{array}$ \\
\hline $\begin{array}{l}\text { Reação inicial do pessoal } \\
\text { da obra (engenheiro, } \\
\text { mestre de obra, } \\
\text { encarregados, oficiais) }\end{array}$ & $\begin{array}{l}\text { aceito como parte } \\
\text { do processo }\end{array}$ & $\begin{array}{l}\text { rejeição - "conheço meu trabalho, } \\
\text { não preciso de burocracia ou } \\
\text { papelada para obter qualidade" }\end{array}$ \\
\hline Postura da gerência & $\begin{array}{l}\text { depende total e } \\
\text { exclusivamente da } \\
\text { competência } \\
\text { profissional e grau } \\
\text { de exigência da } \\
\text { equipe } \\
\text { administrativa }\end{array}$ & $\begin{array}{l}\text { adota controles que garantem a } \\
\text { homogeneidade e previsibilidade } \\
\text { dos resultados, dentro de metas e } \\
\text { parâmetros estabelecidos pela } \\
\text { empresa, reduzindo riscos e } \\
\text { desperdícios, e servindo como } \\
\text { instrumento de crescimento dos } \\
\text { profissionais envolvidos e melhoria } \\
\text { do processo }\end{array}$ \\
\hline
\end{tabular}


Superar a fase do "controle informal" e evoluir para o "controle formalizado" não é uma tarefa fácil na indústria da Construção. Uma ampla pesquisa realizada no CPqDCC-EPUSP, no período de 1988 a 1991, permitiu o desenvolvimento de diversas metodologias envolvendo o controle de materiais e serviços.

Quanto ao controle de materiais destacam-se as publicações de SABBATINI; SELMO [1989a,b] e SABBATINI; BARROS; SILVA, [1989]; e, quanto ao controle de serviços, dentre outros, destaca-se o trabalho de SABBATINI; BARROS [1989], no qual foi feita a proposição de uma metodologia para o controle de qualidade de execução de contrapisos para edifícios habitacionais e comerciais, dentro dos parâmetros definidos por PICCHI [1993], na tabela 5.2 , como sendo um "controle formalizado".

Ainda que relativamente simples, essas metodologias exigem, para a sua implantação, uma estrutura organizacional voltada ao controle do processo, o que nem sempre é visto com bons olhos pelos empresários do setor.

Como bem destaca PICCHI [1993], na indústria da Construção Civil, quando se estabelece algum tipo de controle, considera-se o informal suficiente, rejeitando-se a formalização de um controle da qualidade, segundo a alegação de que consiste em "burocracia", "papelada" e "comprometimento da produtividade".

O controle não será implementado se não houver uma intenção firme e verdadeira de se evoluir o processo construtivo tradicional. E, sem essa etapa, o processo de implantaçāo das TCR's acabará sendo completamente comprometido. Não será possível fixar a tecnologia na empresa, perdendo-se todo o esforço inicial.

Por isso, defende-se o controle do processo de produção como uma diretriz ' balizadora da metodologia de implantação de TCR's, sem a qual o plano de ação não se concretizará e não, possivelmente, não serão atingidos os resultados esperados. 


\subsubsection{As orientações para o controle de processos}

Ainda que o controle de qualidade seja um elemento intrinseco à atividade de produção, os modelos apresentados pela literatura referem-se, de modo geral, à indústria seriada, a qual utiliza os mais diversos mecanismos de controle para ter o domínio do seu processo de produção. Dentre esses modelos destaca-se o de JURAN [1992], que contém alguns elementos indispensáveis para que se possa pensar em "projetar o controle do processo de produção" na indústria da Construção.

No que se refere às publicações, com vistas ao controle, voltados à indústria da Construção Civil, identificaram-se algumas diretrizes estabelecidas pelos programas de Gestão da Qualidade e algumas diretrizes estabelecidas na metodologia proposta por BARROS; SABBATINI [1989] e por BARROS [1991b], acerca do controle de produção de contrapisos para edifícios habitacionais e comerciais, ambas discutidas no presente item.

Segundo JURAN [1992], o controle do processo consiste de várias atividades:

- avaliar o desempenho real do processo;

- comparar o desempenho real com as metas;

- tomar providências a respeito da diferença.

E acrescenta que essas atividades ocorrem em uma seqüência sistemática chamada de alça de feedback, ilustrada na figura 5.6.

Nesse modelo, para JURAN [1992], o fluxo de informações deve ocorrer da seguinte forma:

- o sensor (que está 'ligado ao processo') avalia o desempenho real;

- o sensor reporta esse desempenho a um árbitro (ou verificador, comparador);

- o árbitro recebe informações de qual é a meta;

- o árbitro compara o desempenho real à meta. Se a diferença justificar uma ação, ele aciona um atuador;

- o atuador modifica as condições do processo para colocar o desempenho em linha com as metas. 


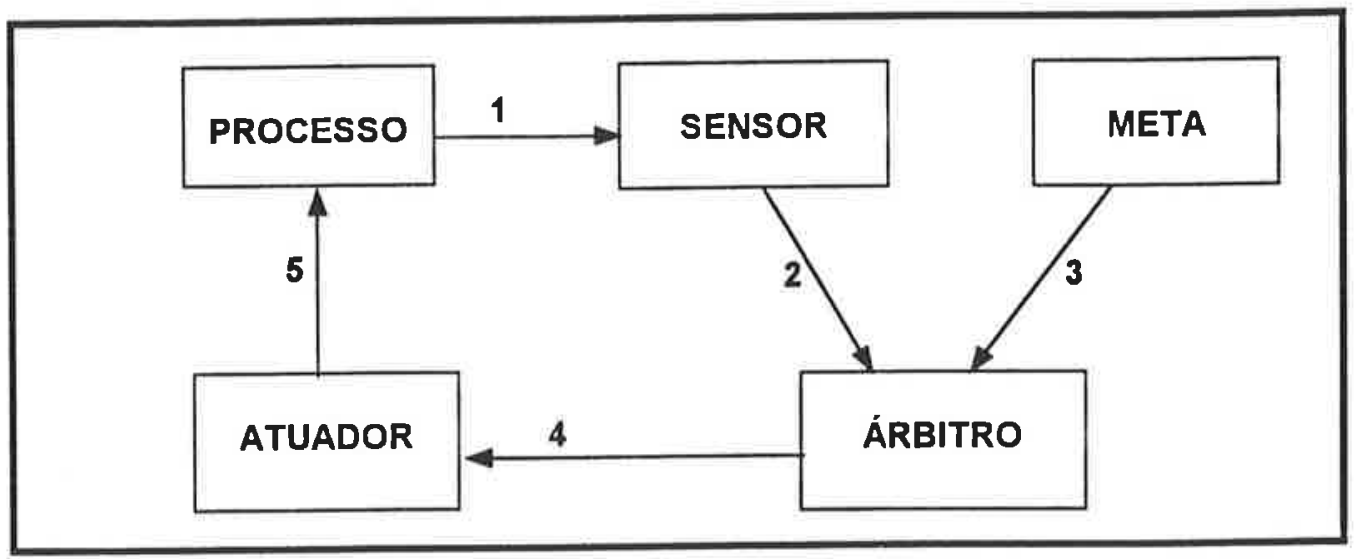

FIGURA 5.6: A alça de feedback para o controle do processo [JURAN, 1992] Nessa proposta, o controle do processo deve passar por três estágios:

- controle de partida - a partir do qual se identifica a possibilidade de se iniciar o processo;

- controle de operação - através do qual é possivel identificar se o processo deve ter continuidade ou deve ser interrompido. Nesse estágio, o desempenho do processo ou do produto é comparado com as metas e, se estiver em conformidade, a decisão será pela sua continuidade; caso contrário, isto é, se houver uma nāo conformidade, deverá haver uma ação corretiva;

- controle do produto - esse estágio ocorre depois que uma certa quantidade do produto tiver sido produzida. Sua finalidade é decidir se o produto está ou não em conformidade com as metas de qualidade do produto.

Para JURAN [1992], em todos os estágios do processo de controle, existe a tomada de decisões. A atribuição dessa responsabilidade, segundo o autor, varia de uma empresa para a outra e pode ser destinada, inclusive, aos trabaIhadores, apesar de não ser uma ação comum.

O autor salienta, ainda, que seja qual for o caso, "aqueles que devem tomar a decisão precisam estar munidos dos meios e do treinamento que thes permitirá: compreender as metas; avaliar a qualidade real; decidir se existe ou não conformidade". 
JURAN [1992] destaca, além disso, que todo o controle deve ser centrado em itens específicos a serem controlados, os quais denomina "objetos de controle", sendo cada um deles o ponto focal de uma alça de feedback.

Os objetos de controle podem ser uma mistura de características do produto, de características do processo e de efeitos secundários, que são as características que não têm relação direta com o produto, mas podem criar problemas secundários inoportunos, tais como irritação ao funcionário, ofensas a vizinhos, ameaça ao ambiente.

O autor acrescenta que os objetos de controle podem se apresentar em grande número. Em função disto, os projetistas do controle do processo devem ser capazes de identificar os "poucos objetos de controle que são vitais, para que estes recebam a prioridade adequada". JURAN [1992] recomenda, então, que se considere o conceito de "dominância", identificando-se as variáveis mais importantes dentre todas as demais combinadas entre si.

Segundo JURAN [1992], as variáveis dominantes mais usuais incluem:

- dominância da preparação: sobressai-se nos casos em que o processo tem alta estabilidade; neste caso, a preparação é imprescindivel. $O$ autor exemplifica com o processo de impressão;

- dominância de tempo: ocorre nas situações em que o processo varia com o tempo, como por exemplo, o desgaste de ferramentas. Neste caso, o controle deve prever meios de avaliação periódica do efeito da mudança progressiva e para os ajustes convenientes;

- dominância de componentes: nesse caso a principal variável é a qualidade dos insumos. Exemplifica com a montagem de equipamentos eletrônicos complexos. Destaca que a curto prazo, pode-se recorrer à inspeção no recebimento; a longo prazo, o projeto de controle pode se voltar às relaçōes com os fornecedores;

- dominância do trabalhador: nesses processos, a habilidade do trabalhador é básico para a qualidade. E assim, deve-se enfatizar os testes de aptidão dos trabalhadores, o treinamento e a certificação; 
- dominância da informação: neste caso os processos são de natureza intermitente e aleatória. Podem haver mudanças freqüentes nos produtos a serem feitos. Como resultado, as informações sobre os serviços mudam freqüentemente. Então, "o planejamento do controle deve concentrar-se na provisão de um sistema de informaçōes precisas e atualizadas a respeito de como o serviço em andamento difere daqueles que o antecederam".

Além de serem definidos os objetos de controle, segundo JURAN [1992], devem ser definidos, ainda, os "postos de controle". E salienta: "nos niveis mais baixos da organização, um posto de controle está normalmente confinado a uma só área física. Em niveis mais altos, um posto de controle pode estar amplamente disperso em termos geográficos, como por exemplo, o escopo da responsabilidade de um supervisor ou gerente".

No modelo de JURAN [1992], para cada posto de controle devem ser identificados os objetos de controle sobre os quais o controle deve ser exercido. E cada objeto exige uma alça de feedback, composta por múltiplas caracteristicas do processo.

Para acompanhar o processo de controle, os projetistas devem fazer uso de uma planilha de controle do processo. Nessa planilha, as linhas devem conter os vários objetos de controle do processo, enquanto nas colunas devem estar os elementos da alça de feedback, os quais podem incluir, a responsabilidade pela tomada de decisōes [JURAN, 1992].

No processo de controle proposto por esse autor, aparecem alguns elementos que merecem ser destacados para que possam ser aproveitados numa sistemática de controle que vise o processo de produçāo de edifícios, quais sejam:

- presença constante de um sensor em todo o processo: isto significa que todo o processo deve ser controlado ou por um individuo, ou por um equipamento. Esse "sensor" deverá estar devidamente capacitado a cumprir essa função; portanto, deverá conhecer os "objetos de controle";

- estabelecimento de metas: dizem respeito aos parâmetros com os quais serão comparados os resultados obtidos. Podem se tratar de tolerâncias, 
características do produto, indices de produtividade, indices de perdas, entre outras. Quando não se tem conhecimento do processo, num primeiro momento, pode ser difícil estabelecer as metas; no entanto, a própria realimentaçāo do controle permite que as metas sejam "lapidadas", num processo de melhoria contínua;

- avaliação e tomada de decisões: tem-se novamente a presença de um indivíduo que deve conhecer o processo e as metas a serem atingidas e ter poder de decisão sobre a condução desse processo, para que possa interferir rapidamente nos casos de não conformidade;

- revisão do processo para alinhá-lo às metas: envolve ações que permitam rever criticamente as variáveis do processo, para identificar os pontos falhos que estariam levando às variações não pretendidas;

- definição de um fluxo de informações e de atribuiçōes;

- definição das responsabilidades sobre as tomadas de decisão;

- estabelecimento dos estágios de controle: tanto de partida do processo, quanto de operação e do produto final, sendo que em qualquer um deles deverá existir a tomada de decisões;

- treinamento para o controle: os operadores deverão estar capacitados a compreenderem as metas; avaliar a qualidade real; decidir se existe ou não conformidade;

- direcionamento para o controle de itens específicos: os quais devem ser definidos segundo o conceito de dominância, ou seja, através da identificação das atividades de maior relevância no processo;

- definição das instâncias de controle, o que denomina "postos de controle", que podem abranger diferentes áreas e conseqüentemente objetivos distintos.

Além desse modelo, identificou-se que com o estabelecimento das normas da série NBR-ISO 9000 [ABNT, 1994a], voltadas à implantação de sistemas de Gestão da Qualidade, vêm se desenvolvendo algumas diretrizes para a implantação da atividade de controle para a indústria da Construção Civil. 
A NBR-ISO 9004/1 [ABNT, 1994C] contém um item destinado ao controle do processo, no qual é estabelecido que: "convém que os processos importantes para a qualidade do produto sejam planejados, aprovados, monitorados e controlados. Convém dar consideração particular às características do produto que não sejam fácil ou economicamente mensuráveis e aquelas que requeiram habilidades especiais (...) convém que a verificação tipicamente por inspeçōes ou ensaios, seja considerada nos pontos apropriados do processo para verificar conformidade. Os locais e a freqüência dependerão da importância das características e da facilidade de verificação durante o processamento".

A adaptação dessas diretrizes à realidade da construção de edifícios vem sendo proposta e experimentada por alguns autores, podendo-se citar como exemplos os trabalhos de: AZEREDO; PETRONI [1991]; PICOLI [1991]; PICCHI [1993]; CTE [1994] e FORMOSO [1995]

AZEREDO; PETRONI [1991], dentro de um amplo programa de implantação da qualidade na rotina de uma obra de edifício da Fundação Petrobrás, propuseram uma metodologia de controle da qualidade.

Segundo esses autores, o manual de controle da qualidade foi preparado visando estabelecer as diretrizes do sistema de controle da qualidade a ser aplicado pela construtora. Nesse manual foi indicada "a sistemática de todas as atividades que comprometem a qualidade dos serviços a serem executados e os seus responsáveis, de modo a garantir a 'rastreabilidade' de todos os recursos utilizados, a partir do controle da matéria-prima, desenhos, especificações, ensaios, inspeções, serviços, até a liberação final pelos envolvidos neste processo". Neste manual são registrados, ainda, "os resultados obtidos que, aglutinados, serão a 'memória' da construção, a qual certamente será de grande utilidade a consultas futuras".

Segundo PICOLI [1991], o modelo que propõe tem sido aplicado em muitas obras civis. No seu modelo, a cada procedimento de execução correspondem uma lista de verificação e um procedimento de inspeção.

Segundo esse autor, "as listas de verificação são formulários para consulta do 
inspetor da qualidade no campo. São preparadas pelo órgão da qualidade e discriminam ordenadamente as tarefas previstas no procedimento de execução, o critério de análise de cada uma, as tolerâncias e aspectos construtivos admitidos e as açōes necessárias do inspetor".

PICOLI [1991] afirma que a sua experiência em aplicar tal modelo de controle permitiu identificar uma série de obstáculos, dentre os quais destaca a dificuldade de se aplicar o programa em obras de pequeno vulto, devido ao custo envoivido e pelo fato dos resultados obtidos ficarem abaixo da expectativa.

O CTE [1994], por sua vez, afirma que: "(...) é necessário que os procedimentos referentes à técnica de execução e ao controle estejam formalmente documentados e disponiveis em formulários simples e de fácil manuseio (...) os registros da qualidade também devem ser anotados em formulários específicos, denotando que o controle da qualidade foi realizado. Isto permitirá a retroalimentação efetiva do sistema da Qualidade."

O CTE [1994] sugere o emprego de Procedimentos de Inspeção de Serviços (PIS) e Fichas de Verificação de Serviços (FVS), que se constituem de "checklists" que permitem "o registro da qualidade obtida em obra".

Segundo os autores, no "PIS" devem constar os itens a serem verificados, bem como, a metodologia e o critério de avaliação, e na "FVS" deve constar a aprovação ou não de cada item. Essa verificação deve ter um responsável, que empregará um "PIS" correspondente.

Nas pesquisas reunidas por FORMOSO [1995], é apresentado um modelo para a documentação da qualidade em empresas construtoras. $O$ autor desse modelo, BOGGIO [1995], afirma que: "através do registro dos resultados de inspeções, ensaios, testes e outras atividades do processo produtivo, são mostradas evidências claras de que o sistema da qualidade vem sendo empregado com eficiência".

No que se refere aos procedimentos que visam o controle da qualidade da execução, esse autor salienta que são indispensáveis os seguintes procedimentos: ensaio e recebimento de materiais; controle de qualidade da produção 
de materiais na obra e avaliação da execução de elementos construtivos. Destaca, ainda, que "em geral, os procedimentos de controle da qualidade estão associados às instruçōes correspondentes".

Na proposição de BOGGIO [1995], esses documentos são traduzidos em listas de verificação a fim de controlar e o monitorar os processos de produção; analisar as não conformidade; e realizar a inspeção. Salienta, ainda, que as listas de verificação podem ser acrescidas de outros itens, ou seja, uma mesma folha pode conter "instruçōes simplificadas para orientar a execução de uma tarefa e quadros de avaliação da qualidade de serviços, juntamente com o controle de produtividade".

Um exemplo de uma lista como essa, que contém diversos elementos de controle, é apresentada por PICCHI [1993]. Esse tipo de lista de verificação vem sendo utilizada na empresa do estudo de caso desse autor.

Segundo PICCHI [1993], a empresa possui um procedimento formalizado de controle, denominado "Controle da Qualidade de Execução - CQE", aplicado a todos os serviços de obra. E, para a sua realização, utiliza listas de verificação que estabelecem, para cada serviço, itens padronizados que devem ser avaliados, com as respectivas tolerâncias, quando aplicáveis.

Essa sistemática de controle, segundo o mesmo autor, foi implantada em todas as obras, em conjunto com a programaçāo de serviços (uma ficha que contém o procedimento de execuçăo), "através de amplo treinamento e elaboraçāo de material de apoio, tal como: fitas de vídeo para treinamento, procedimentos e caderno de referência".

A sistemática de controle montada pela empresa do estudo de caso de PICCHI [1993] é muito semelhante à proposta feita pela autora para o controle de execução dos contrapisos [SABBATINI; BARROS, 1989], a qual compreende três etapas:

- acompanhamento e avaliação do processo de execução do contrapiso;

- aceitação dos contrapisos executados, segundo parâmetros definidos em projeto; 
- implantação e a alimentação contínua de um banco de dados referente às características do contrapiso obtidas em obra, visando subsidiar projetos futuros.

Dentro dessa proposição, foram estabelecidos quatro niveis de controle:

- controle normal de execução (CNE): constitui um instrumento para a verificação das condições de execução do contrapiso, através da observação e análise critica das atividades que compōem o processo de execução. Envolve a verificaçāo das condiçōes para início dos serviços, dos níveis das taliscas e o acompanhamento das atividades de execução. A realização deste controle deve ocorrer para todos os contrapisos em execução e exige um responsável, devidamente treinado para a sua realização, denominado técnico do controle. Esse técnico è o responsável por realimentar a atividade de projeto e por orientar as equipes de trabalho nas situaçōes em que sejam identificadas falhas na atividade de execução.

- controle normal de aceitação (CNA): constitui a segunda fase da metodologia proposta. O técnico do controle dos contrapisos recebe todos os contrapisos executados, através de procedimentos visuais e ensaios expeditos, os quais envolvem as seguintes verificaçōes: adequação do contrapiso executado ao projeto (declividade de áreas molháveis, acabamentos sanitários, planeza de áreas secas, desniveis entre ambientes, acabamento superficial, soleiras, aderência do contrapiso à base); terminalidade; limpeza e quantificação dos serviços executados;

- controle especial de aceitação (CEA): constitui a terceira fase do controle e ocorre em dois niveis distintos, denominados CEA1 e CEA2. A primeira fase é de responsabilidade do técnico do controle e consiste num controle sistemático por amostragem do contrapiso pronto, em paralelo ao CNE. Compreende a verificação da uniformidade de produção do contrapiso e do seu desempenho quanto à compacidade e resistência mecânica superficial, através de ensaio expedito. Em função dos resultados obtidos, estabelecem-se duas condutas distintas: manter o processo de execução, caso aqueles estejam dentro do esperado ou, intervir nos pontos que podem 
estar causando a alteração dos resultados. O segundo nível dessa etapa de controle é de responsabilidade do engenheiro responsável pelo contrapiso (ERC). Essa etapa tem por objetivo verificar a uniformidade de produção entre diferentes obras e o desempenho dos contrapisos. É realizada através de ensaios de fácil realização, a partir de uma amostragem devidamente definida. A intervenção do ERC para a realização do CEA2 ocorre em função de um planejamento predefinido, mas pode se dar em função de uma solicitação feita pela própria obra, a partir dos resultados obtidos quando da realização do CEA1.

- controle do processo (CP): essa etapa do controle pretende realimentar o processo de produção do contrapiso, desde o projeto, até as etapas de controle em obra. É alimentada pelo CEA2 e serve como subsídios para a formação de um banco de dados que objetiva o aprimoramento dos critérios de avaliação da atividade de execução do contrapiso.

Para cada uma das etapas do processo de controle foram definidos, tanto os responsáveis, como: uma documentação correspondente; as atividades a serem realizadas; a frequêencia de realização; as tolerâncias admitidas e as possiveis formas de intervenção nos casos de não conformidades.

A sistemática de controle, nesses dois últimos modelos, da mesma maneira que na proposição de JURAN [1992], tem um caráter preventivo, pois permite avaliar os serviços durante a sua execução. Além da avaliação das etapas do processo, propõe-se açōes para corrigi-lo nos casos de nāo conformidade, minimizando os problemas com o produto final. As avaliações durante a execução têm uma freqüência e um responsável preestabelecidos e o controle final é feito por amostragem.

O controle servindo como realimentação do processo de produção, ou seja, permitindo que se "feche a alça de feedback", aparece em praticamente todas as propostas anteriormente analisadas.

Segundo PICCHI [1993], todos os resultados dos "CQE's" devem ser devidamente analisados pela equipe de produção, a fim de que se possa retroalimentar o processo, direcionando "ações para a melhoria da qualidade nos 
problemas mais freqüentes". Na proposta de SABBATINI; BARROS [1989] isto fica claro na quarta fase da metodologia, que trata do controle do processo.

PICCHI [1993] destaca, ainda, que o CQE é aplicado inclusive aos subempreiteiros que prestam serviços para as obras da empresa, sendo que a liberação dos pagamentos depende da aprovação desse controle.

Além disso, na sistemática descrita por esse autor, está previsto um prêmio de produtividade, atribuido segundo a qualidade obtida.

\subsubsection{Diretrizes para o controle do processo de execução na indústria da Construção de Edifícios}

A análise das diversas proposiçōes e das experiências apresentadas permite concluir que o controle do processo de produção é uma das etapas da metodologia que encerram uma grande dificuldade para a implantaçāo.

Foram diversas as oportunidades em que a autora buscou implantar a metodologia de controle de produção de contrapisos. Entretanto, na maioria delas nāo foi possivel obter o retorno esperado.

A partir dessas tentativas pôde-se concluir que o controle do processo de produção, exigido para a implantação de qualquer nova tecnologia, é de difícil efetivação, muitas vezes em decorrência da reação da própria gerência, que nem sempre admite 'onerar' o seu quadro de "funcionários administrativos", ou pela inclusão de um técnico de edificações, ou de um tecnólogo, ou mesmo, de um estagiário de engenharia, aos quais denomina-se, de maneira genérica, "técnico do controle".

Esse "técnico do controle", devidamente treinado, poderia fazer o papel do "sensor" e, em algumas situações predefinidas, até mesmo de "árbitro". De uma maneira geral o engenheiro da obra atuaria como "árbitro", a partir de uma capacitação adequada e do estabelecimento de um sistema de comunicação eficiente.

No processo de controle, é importante que as informaçōes atinjam o seu destino com rapidez e sem a introdução de ruídos, que desvirtuem seu teor inicial, e alimentem corretamente as instâncias de tomada de decisões. Assim, 
nos casos de não conformidade, o processo de produção poderá ser rapidamente corrigido.

No entanto, observa-se, em muitos casos, que a gerência das empresas não enxerga as suas obras como fábricas que possuem uma "linha de montagem" onde as atividades precisam ser devidamente planejadas e controladas, ainda que todos os participantes da produção estejam realmente motivados a "fazerem certo da primeira vez". E assim, a gerência não se preocupa em definir uma sistemática de controle formalizada.

O controle de todo o processo é imprescindivel, pois somente ele permitirá saber se os operários estão motivados a realizarem corretamente suas tarefas da primeira vez e, mais do que isso, somente ele permitirá identificar se esses operários estão devidamente orientados para fazê-lo.

Segundo JURAN [1992], "numerosos estudos conduzidos nos anos 50 e 60 mostraram que, para as operações ao nivel do trabalhador, a proporção entre as nāo conformidades controláveis pela gerência e aquelas controláveis pelo trabalhador era da ordem de 80 para 20 ". Esse autor acrescenta: "essa proporção ajuda a explicar o fracasso de tantos esforços para resolver os problemas de qualidade das empresas exclusivamente pela motivação da força de trabalho".

Cabe destacar, no entanto, que o controle do processo não deve ser uma atividade isolada na empresa. A análise das diversas proposta mostra que para se ter o controle do processo e do produto final, uma série de prérequisitos devem existir. Sem eles, essa atividade não se efetiva. Ou seja: para que a atividade de "controle do processo de produção" possa ser estabelecida e realizada é preciso que existam como premissas:

- projetos voltados ao produto e à produção, contendo especificaçōes claras quanto ao produto a e ao seu processo de produção (item 5.4.1);

- documentação do processo, na qual devem estar expressas as características intrínsecas do processo de produção, de forma clara e 
compativel com o grau de instrução de quem vai utilizar os documentos (item 5.4.2);

- desenvolvimento dos recursos humanos, em todos os niveis hierárquicos, no sentido de proporcionar a motivação e a capacitação de todos os trabalhadores, levando-os a "fazerem certo da primeira vez" e, além disso, capacitando-os a avaliarem sistematicamente o resultado de seu trabalho (item 5.4.3); e

- setor de suprimentos voltado à produção e devidamente instruído na aquisição de materiais e equipamentos, conforme as prescrições contidas em projeto (item 5.4.4).

Se as diretrizes anteriores não forem previamente observadas, não existirão os elementos essenciais para que a organização se volte ao controle do processo de produção e tenha efetivamente o seu domínio.

Os estudos realizados até aqui têm mostrado que as empresas, geralmente, não têm condições de montar, de uma única vez, um sistema de controle que envolva todas as atividades que compōem o processo de produção do edifício, quais sejam: projeto, execução, uso e manutenção. $E$, nem mesmo, que envolva todas as atividades que compõem a execução de um edifício.

Apesar de PICCHI [1993] salientar que a empresa de seu estudo de caso aplica o "CQE" para todas as atividades, sabe-se que esse processo deu-se gradualmente, a partir da racionalizaçăo de cada uma das atividades. Assim, as empresas de construção de pequeno e médio porte, a partir do momento que estiverem dispostas a mudar a sua forma de gerenciar e organizar 0 processo construtivo tradicional, poderão seguir, da mesma maneira, o caminho da melhoria gradual do processo.

E, para isso, essas empresas poderão utilizar a implantação de TCR's como um importante estímulo, projetando, desde o início do empreendimento, os controles que não poderăo deixar de existir para que as mesmas tenham efetivamente o DOMÍNIO DO PROCESSO DE PRODUÇÃO. 
A implantação de TCR's, evidentemente, interfere com todo o processo de produção. Os elementos de controle desse processo, porém, começam a ter maior relevância, para a empresa, nas etapas de projeto e de execução propriamente dita. Depois de entregue o edifício, na fase de uso e manutenção, deve-se, então, passar a monitorar os resultados, para, com isso, realimentar todo o processo de produção.

O controle do processo de projeto, de grande relevância para o sucesso da implantação de TCR's, indicado nas diretrizes propostas no item 5.4.1, foi amplamente discutido por MELHADO [1994] e por MELHADO; BARROS; SOUZA [1996], os quais deram expressivo destaque ao papel da coordenação de projetos para a obtenção da Qualidade de Projeto; portanto, esse controle não será objeto de discussão no contexto desta tese.

As diretrizes aqui estabelecidas concentram-se na etapa de execução propriamente dita e não irão se referir a uma atividade em particular. $O$ que se pretende é que a empresa possa aplicar tais diretrizes para o estabelecimento dos procedimentos de controle de qualquer atividade de construção do ediff́cio, como por exemplo: produção de fôrmas; montagem de armaduras; execução da estruturas de concreto; execuçāo das alvenarias, entre outras.

O conjunto dos controles de todos as atividades e serviços irá constituir o controle da fase de execução do edifício, que em conjunto com os controles estabelecidos para as fases iniciais do empreendimento e do acompanhamento pós-entrega, constituirão o controle de todo o processo de produção.

A implantação da etapa de controle permitirá tanto o domínio do processo de produção, quanto a sua evolução contínua, fechando-se continuamente "a alça de feedback", como proposto por JURAN [1992].

Assim, as principais diretrizes que deverăo nortear o estabelecimento do procedimento de controle de uma atividade de execução do edifício, em uma empresa construtora, são: definição das instâncias de controle; definição dos responsáveis; definição de um mecanismo de comunicação; determinação dos objetos de controle para cada estágio; estabelecimento da freqüência em cada 
uma das instâncias; definição das metas; determinação de diretrizes balizadoras; treinamento para o controle; e definição do procedimento de controle, destacadas a seguir.

Observa-se que cada empresa, a partir das diretrizes de controle, aqui propostas, deverá montar seus procedimentos, segundo as características de sua organização e gestão e de suas atividades de produção.

\section{a) definição das instâncias de controle}

As empresas deverão definir as instâncias nas quais o controle deverá ocorrer, sendo que deverāo ser, no mínimo duas, para o caso das empresas de pequeno e médio porte, podendo existir outras instâncias para as empresas de grande porte.

As duas instâncias fundamentais dizem respeito à realização do controle no contexto da obra e no contexto da empresa.

Os aspectos a serem focados em cada uma dessas instâncias diferem em função dos seus objetivos. Na obra, controlam-se aspectos localizados da produção, ou seja, deve-se verificar se os serviços estão sendo realizados segundo os parâmetros preestabelecidos. Com esse controle, espera-se manter o domínio do processo junto à gerência de obras.

No caso da empresa, procura-se conhecer resultados mais globais, originados pelo controle, para compará-los aos resultados de outros empreendimentos. Pode-se conseguir, com isso, diminuir a variabilidade do sistema de produção e motivar a melhoria dos resultados, pela comparação de diversos desempenhos.

\section{b) definição dos responsáveis}

Para cada instância, deverão ser definidos os responsáveis pelas diversas etapas do processo de controle, isto é: os "sensores", os "árbitros" e os "atuadores".

Cada pessoa participante do processo de controle deverá estar consciente de suas responsabilidades, de suas funções, de sua área de atuação e de seus 
limites. Por isso, a importância do treinamento para o controle, que será destacado no item "h".

\section{c) definição de um mecanismo de comunicação}

O processo de controle, na maioria dos casos, envolve mais de um participante. Por isso, deverão ser definidas as formas de comunicação entre eles, ou seja, como as informações e as decisões deverão ser passadas de um para outro, alimentando continuamente o processo de controle.

O sistema de comunicação deverá ser eficiente, ou seja, deverá permitir que as informações cheguem ao seu destino sem ruídos e sejam compreendidas, para que a análise da situação não seja equivocada, levando a uma decisão incompatível. Além disso, deverá permitir retorno rápido, minimizando desvios no processo produtivo.

A comunicação, de preferência, deverá ser formalizada, para que se tenha o registro do processo; entretanto, não se deve criar entraves a ponto do sistema não funcionar. Deve-se evitar burocracias, como por exemplo, um excessivo número de planilhas a serem preenchidas, sem uma função claramente definida.

\section{d) determinação dos objetos de controle para cada estágio}

Para cada atividade poderão ser estabelecidos, na maioria das vezes, três estágios de controle: controle das condições de início da atividade; controle de execução e controle de aceitação ou liberação do serviço (ou produto).

Em cada um desses estágios deverão ser definidos os objetos de controle, ou seja, os elementos que deverão ser controlados, considerando-se o conceito de dominância (discutido em 5.4.5.2).

É preciso ter em mente que não se deve transformar o canteiro de obras em um laboratório de ensaios e nem criar um sistema de controle que não seja praticável, em função do número de variáveis estabelecidas para a verificação.

Exemplificando-se para a atividade de execução da marcação da alvenaria, tem-se: 
- controle das condições de início: existência do projeto, prazos de carência atendidos, liberação da estrutura, transferência das cotas de nivel, execução do chapisco (no contato da estrutura com a alvenaria), blocos e argamassa no pavimento, limpeza do pavimento (remoção de gastalhos $e$ de pregos da estrutura, remoção de materiais soltos, retirada de material pulverulento na regiāo da marcação);

- controle de execução: marcação pelo eixo, marcação dos vãos de porta, compatibilização com o projeto (verificação do espaçamento de juntas e dos blocos para passagem de instalações), verificação de esquadro, verificação de alinhamento, verificação de nivelamento, embutimento de instalações elétricas, limpeza do ambiente, total de horas gastas, material gasto;

- controle de aceitação ou liberação do serviço: desvios com relação ao eixo e ao esquadro; nivelamento da fiada; espaçamento de juntas, dimensões dos vãos de portas.

É possivel que, em função das características de uma determinada empresa, não sejam essas as características dominantes do processo de produção, estabelecendo-se, então, outros objetos de controle para cada estágio.

\section{e) estabelecimento da freqüência em cada uma das instâncias}

Para cada instância e estágio de controle e para cada atividade, deverá ser estabelecida a freqüência de realização do controle, ou seja, deve-se definir quantas observações ou mediçōes deverão ser realizadas e qual a amostra representativa de um determinado lote.

Por exemplo, no controle que ocorre na obra, a atividade de marcação da alvenaria poderá ser controlada para todas as paredes; no caso da elevação, porém, pode-se estabelecer um determinado número de paredes por pavimento, por exemplo, ou mesmo, por equipe de trabalho.

No plano da empresa, é importante que os resultados desse controle cheguem na forma de resumos. Além de receber os resumos, a empresa deverá estabelecer um planejamento de controle, por amostragem, verificando-se, 
desta maneira, o desempenho de cada obra (como o "CEA2", discutido anteriormente na metodologia de controle dos contrapisos).

\section{f) definição das metas}

Para cada objeto de controle estabelecido, deverão ser definidas as metas a serem alcançadas, para que possam ser identificadas as não conformidades e para que possam balizar as tomadas de decisão.

Essas metas dizem respeito, por exemplo, a: aspectos visuais que devem apresentar (superfície lisa, sem ondulaçōes); tolerâncias dimensionais que serão aceitas para a realização dos serviços $(5 \mathrm{~mm}$ em $2 \mathrm{~m}$ no prumo das alvenarias); a produtividade $\left(25 \mathrm{~m}^{2}\right.$ de alvenaria por equipe/dia) ou, ainda, o consumo esperado (10 litros de argamassa por $\mathrm{m}^{2}$ de alvenaria).

\section{g) determinação de diretrizes balizadoras das decisões}

Nessas diretrizes, devem ser estabelecidos os parâmetros que iräo orientar as decisões dos "árbitros" quanto às não conformidades no processo de produção ou no produto ou serviço acabado. Deve-se considerar, por exemplo: o efeito da não conformidade em serviços futuros e no planejamento global da obra; os custos envolvidos na alteração do processo ou retrabalho; e características do contrato estabelecido com fornecedores, entre outros.

\section{h) treinamento para o controle}

Essa diretriz poderia ser discutida em conjunto com a de "treinamento dos recursos humanos para o processo de implantação" (item 5.4.3); entretanto, pela sua importância na condução do processo de controle, considerou-se melhor destacá-la aqui.

Deve ser realizado em todas as instâncias, para todos os envolvidos com o processo de controle, ou seja, "sensores", "árbitros" e "atuadores", tanto no nivel da obra, quanto no nivel da empresa.

Para esse treinamento, deve-se utilizar o projeto para produção e os procedimentos de execução, de modo que as pessoas sejam "capacitadas a 
compreenderem as metas; a avaliarem a qualidade real; a decidirem se existe ou não conformidade".

Deve-se esclarecer como cada item deve ser verificado; os mecanismos de recebimento de cada atividade; os parâmetros para correção das não conformidades.

\section{i) definição do procedimento de controle}

A partir do momento que os elementos anteriores estejam definidos, pode-se estabelecer um procedimento de controle para cada TCR a ser implantada, como parte intrinseca da documentação da empresa (discutida no item 5.4.2).

Nesse procedimento, poderão constar os elementos anteriormente definidos, além de outros que auxiliem no desenvolvimento dessa atividade, como por exemplo, os elementos gráficos e de registro, entre eles, as cópias reduzidas de projeto e as planilhas do controle de qualidade (fichas para inspeção, para liberação e para aceitação).

\section{j) definição da retroalimentação do processo}

O controle é um instrumento básico da metodologia porque ele permite a retroalimentação de todo o processo de produção $e$, particularmente no processo de implantação de TCR's, permite avaliar os resultados obtidos com a aplicação da própria metodologia.

Os resultados positivos e negativos obtidos em campo deverão retornar à equipe de projeto, à equipe de planejamento e à direção da empresa, possibilitando-Ihes incorporar tais informações a empreendimentos futuros.

Além disso, esses resultados permitirăo realimentar os procedimentos de execução e a própria metodologia de controle, para que se tenha a melhoria contínua. É uma constante aplicação do ciclo "PDCA", ou seja, após um primeiro projeto e seu devido planejamento ("P"), o mesmo é realizado, executado ("D"), passa-se por um controle de todo o processo ("C") e finalmente, corrige-se o processo, realimentando projetos futuros ("A"). 
Para que a realimentação possa ocorrer é preciso que existam a documentação e os registros mais importantes do processo anterior; sem isso, as informações perdem-se "na cabeça das pessoas", não conseguindo sedimentar a "experiência da empresa".

A efetivação das TCR's em uma obra, não finda o processo de implantação. Para que a empresa não pare de evoluir, o processo de implantação deve passar por uma constante avaliação, na qual devem ser verificados os possiveis problemas e as soluções que foram dadas.

É imprescindivel que se faça um CONTROLE da implantação, para que nesse aspecto também seja possivel a melhoria continua.

Devem ser objetos dessa avaliação:

- a verificação da interferência causada pela implantação das TCR's no processo produtivo e suas implicações;

- as possibilidades de aplicaçāo das TCR's em projetos futuros;

- a definição dos mecanismos de alimentação dos projetos futuros;

- os resultados advindos da implantação das TCR's pós-entrega do produto (edifício). Nesse aspecto, as açōes envolvendo as equipes de assistência técnica são de grande relevância para a melhoria continua;

- a consolidação das TCR's nos procedimentos de produção e de projeto da empresa.

\subsection{A Estratégia para a Implantação de TCR's na Produção de Edifícios}

Definir uma estratégia para a implantação de TCR's significa estabelecer um plano de ação para enfrentar o problema e conduzir, de modo otimizado, o processo de sua resolução.

O plano de ação, aqui apresentado, busca definir os passos principais que poderão ser empreendidos pelas empresas construtoras que pretendam implantar TCR's em seu sistema de produção. 
O objetivo do plano de ação é tornar a implantação de TCR's no processo de produção de edifícios pelo processo construtivo tradicional operacional, de maneira que se tenha elevada probabilidade de sucesso. Para isso, propõe-se uma seqüência de etapas estratégicas e as suas correspondentes relações de dependência.

A partir do plano de ação, as empresas deverão montar seu plano tático, ou seja, deverão definir seus meios particulares realizar a implantação, considerando-se os recursos disponíveis e as suas caracteristicas organizacionais.

O modelo do plano de ação, seu fluxo e também as etapas de trabalho serão detalhados na seqüência.

\subsubsection{O modelo do plano de ação}

A implantação de TCR's tem inicio a partir do momento que a empresa define a racionalização do seu sistema de produção como sendo uma estratégia empresarial e termina somente com a completa inserção das novas tecnologias na cultura da empresa. Isto é, quando for possível fechar o "ciclo da melhoria continua", iniciando-se a implantação das mesmas TCR's, a partir de um patamar mais elevado de racionalização do processo construtivo.

Do início ao final desse processo de implantação estão sendo propostas oito etapas fundamentais, assim denominadas:

1. criação de um ambiente favorável;

2. estudos iniciais;

3. investigação preliminar;

4. estudo em protótipos;

5. aplicação em escala piloto;

6. consolidação da documentação;

7. disseminação da tecnologia na empresa;

8. manutenção do processo de "inovação". 
As oito etapas do plano de ação estão reunidas em quatro fases, segundo suas características organizacionais e operacionais e subdivididas em passos de trabalho (subetapas). As quatro fases sāo definidas como:

a) organização da implantação;

b) estudo de viabilidade das TCR's;

c) aperfeiçoamento das TCR's;

d) disseminação e consolidação das TCR's na cultura da empresa.

O conjunto das oito etapas e das quatro fases e a ilustração do fluxo de ação estão apresentados na figura 5.7.

A simbologia empregada tanto na figura 5.7, como nas demais representações gráficas do plano de ação, apresentadas nas figuras 5.9 a 5.14, está ilustrada na figura 5.8 .

\subsubsection{Detalhamento do plano de ação}

Neste item serão apresentadas e caracterizadas cada uma das fases, etapas e subetapas (passos de trabalho) que compõem o plano de ação.

Ao se apresentar e detalhar o plano de ação, aqui proposto, busca-se dar condições para que, a partir dele, as empresas construtoras possam estabelecer o seu plano tático, em função de sua forma de organização. Por isso, não se é exaustiva na descrição das etapas e subetapas do plano.

Entretanto, algumas delas são discutidas com maior profundidade que outras, em função de suas caracteristicas particulares e até mesmo pela sua complexidade no processo de implantação. Outras, por serem de menor complexidade, ou ainda, por estarem fortemente ligadas às diretrizes fundamentais, anteriormente estabelecidas e discutidas, serão abordadas mais brevemente.

A apresentação do plano de ação é feita através da caracterização de cada fase, com a descrição e discussão de suas respectivas etapas e subetapas. 


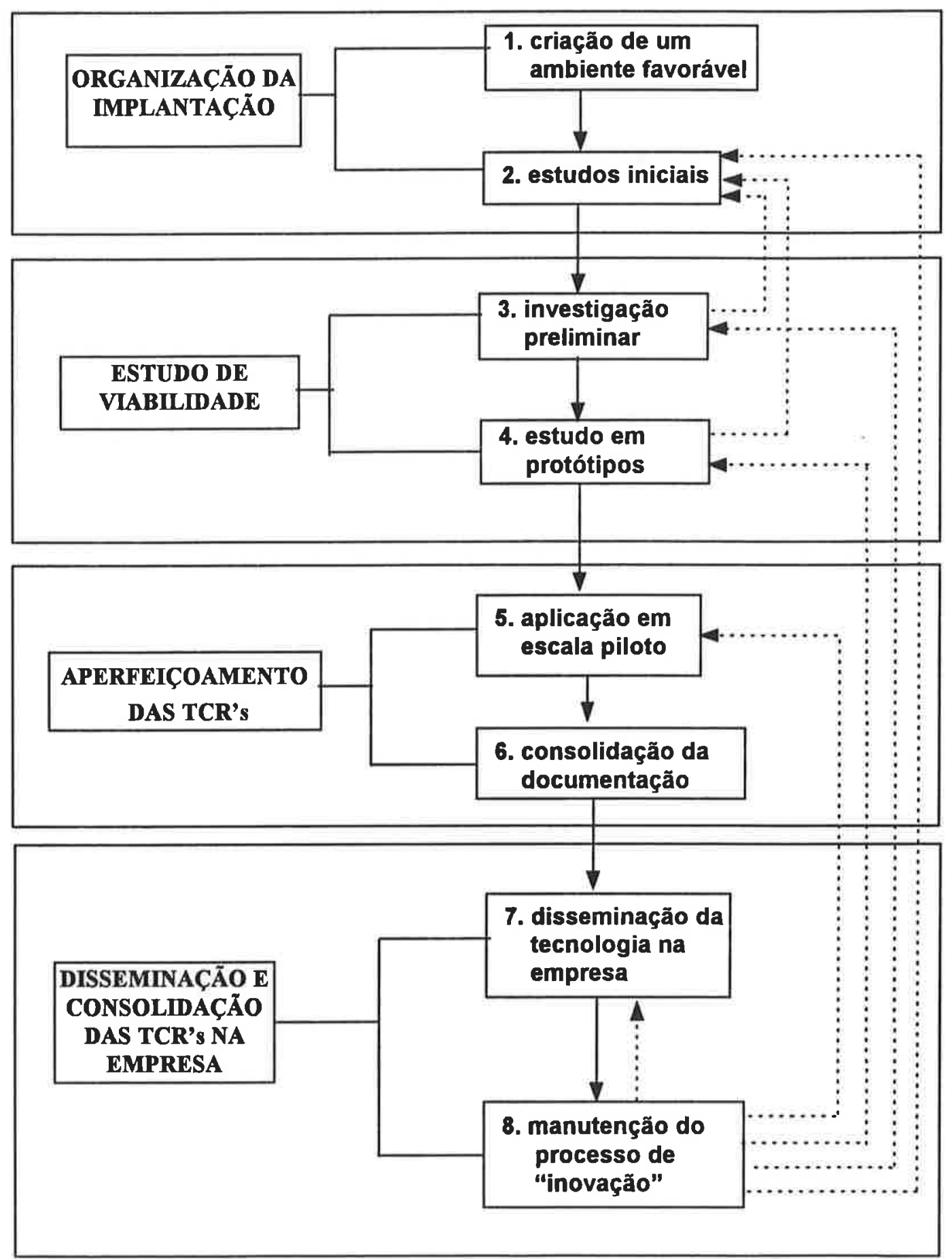

FIGURA 5.7: Ilustração das fases e etapas do processo de implantação de TCR's no processo de produção de edifícios 


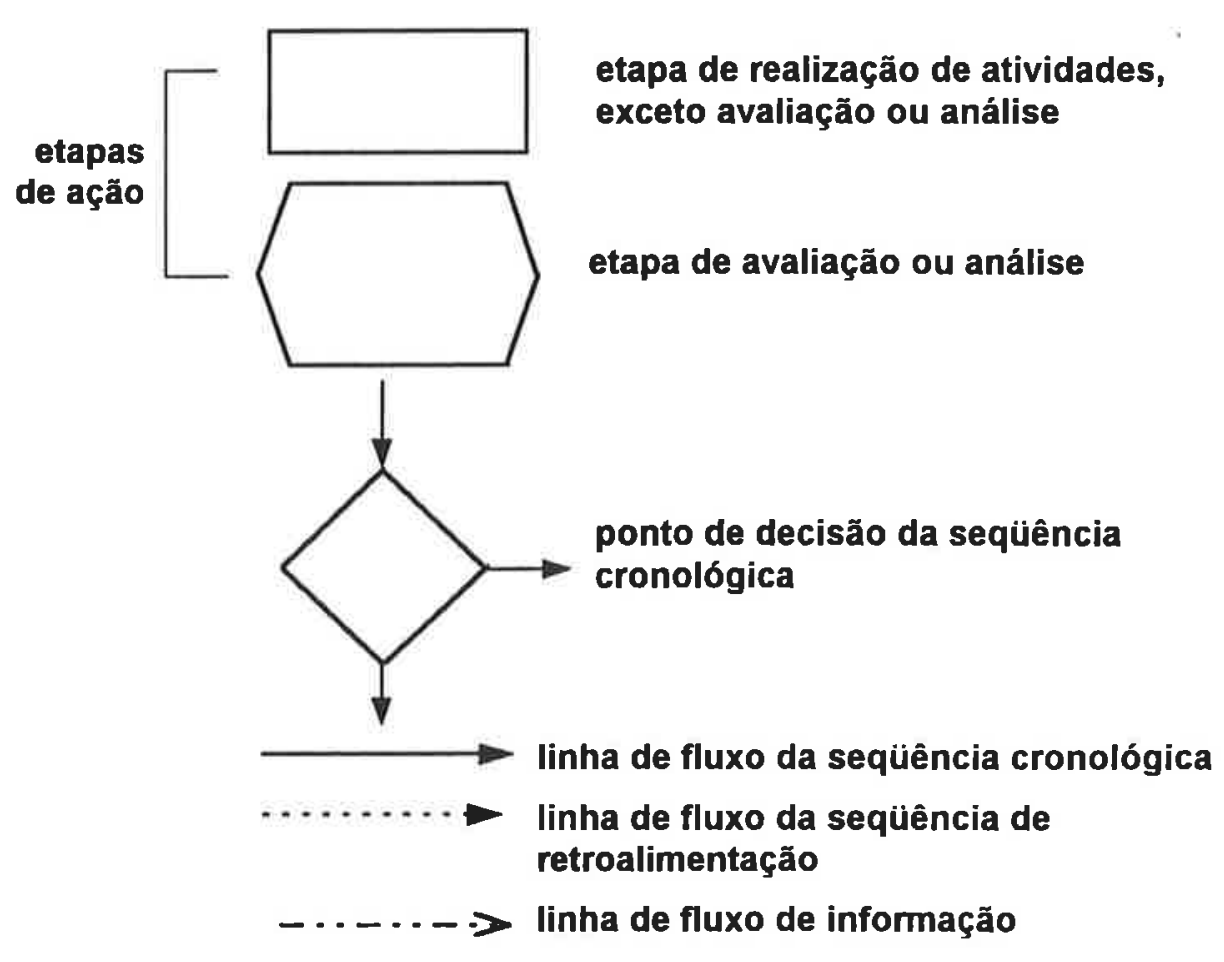

FIGURA 5.8: Simbologia adotada nas representações gráficas do plano de ação, adaptada de SABBATINI [1989]

Para cada uma das etapas foi montado um diagrama, contendo as suas subetapas, com o fluxo de ações e as suas inter-relaçōes.

As subetapas identificadas no interior de cada etapa, serão objeto de discussão, na medida em que isso seja essencial para a completa compreensāo de sua importância dentro do plano proposto.

\subsubsection{1a FASE - A organização da implantação}

Essa fase inicial do plano de ação tem por objetivo preparar o ambiente da empresa para o início do processo de implantação.

Quanto maior o nível de organização da empresa e quanto mais motivadas estiverem as pessoas que a constituem, maiores serão as chances de sucesso da implantação e, conseqüentemente, maior o potencial de racionalização do processo de produção. 
Essa fase envolve duas etapas fundamentais: a criaçāo de um ambiente favorável à implantação e os estudos iniciais, as quais serão apresentadas na seqüência, juntamente com suas respectivas subetapas.

\section{a) 1a ETAPA: criação de um ambiente favorável à implantação}

Nos itens precedentes, procurou-se mostrar que a implantação de TCR's não ocorre de um momento para outro. É um processo, às vezes de longa duração, que exige empenho e dedicação das pessoas e da organização como um todo.

O início das modificaçōes na empresa, não raras vezes, ocorre pela disposição e motivação de uma única pessoa; denominada na literatura, de líder do processo.

Em capitulos anteriores foi discutida a importância da posição que esse líder ocupa na hierarquia da empresa. Quanto mais elevada a sua posição e quanto maior o seu poder de decisão, tanto melhor para a efetivaçāo das TCR's no sistema de produção da empresa.

É consenso na bibliografia consultada, discutida no capítulo 4, que se não existir uma pessoa empenhada na conduçāo da modernização do processo de produção, dificilmente a implantação terá o sucesso esperado.

Assim, caberá ao líder, ao "condutor da modernização", criar o ambiente apropriado para que as mudanças possam ser estabelecidas. Uma só pessoa não conduz o processo de implantação de novas tecnologias por muito tempo. É preciso união. É preciso motivação de todos os envolvidos. Assim, o trabalho do líder deverá ser uma "célula" que dará início ao processo.

O ambiente propicio a mudanças é considerado uma premissa ao processo de implantação, por isso mesmo, no item 5.1, ao se iniciar a proposição da metodologia, foram definidos alguns elementos que devem estar presentes na organização, para que o processo de implantação tenha uma probabilidade maior de fornecer os resultados esperados.

Esses elementos foram definidos como premissas para o início do processo de implantação e referem-se: ao estabelecimento de um sistema de decisões 
e informações, à identificação da situação tecnológica da empresa; à disposição e motivação para o aprendizado; e à disponibilidade dos recursos iniciais (ver item 5.1).

Entretanto, observa-se que as empresas, mesmo estando dispostas a evoluir o seu processo de produção, nem sempre têm o seu ambiente organizacional completamente preparado para isso, desde o início. É comum que os elementos anteriormente apresentados não estejam completamente presentes nas organizaçōes. E, nem por isso, a implantação será fadada ao insucesso. Entretanto, quanto mais as premissas estabelecidas estiverem presentes, maior será o potencial de sucesso da implantação.

Se os elementos não existirem em intensidade nenhuma, precisarão ser criados. Se existirem em pequena intensidade, deverão ser desenvolvidos. É por isso que se estabelece essa etapa no processo de implantação, cuja representação diagramática é apresentada na figura 5.9.

A ordem em que as etapas 1B, 1C, 1D e 1E ocorrem não é rigidamente definida. No entanto, pelos estudos realizados pôde-se perceber que a empresa estará motivada a alterar seu processo de produção através da implantação de TCR's quando conhecer a sua situação tecnológica; daí a importância do diagnóstico inicial (subetapa 1B). A partir daí, deverá criar um ambiente empresarial que permita a busca de novas tecnologias, por isso a exigência de disposição para o aprendizado (subetapa $1 \mathrm{C}$ ). Esse aprendizado precisará ser facilmente repassado ao processo de produção, por isso, a importância de um eficiente sistema de comunicação (subetapa 1D). E, finalmente, tudo isso, de uma maneira ou de outra, exigirá recursos de diversas naturezas, como por exemplo, econômicos, tecnológicos e humanos, por isso, é preciso disposição para se realizar investimentos (subetapa $1 \mathrm{E}$ ).

Essas subetapas do plano de ação, foram amplamente discutidas no item 5.1, "premissas para a implantação de TCR's", por isso, não serão detalhadas nesse momento. Entretanto, é preciso que se façam algumas considerações importantes para a condução do processo. 


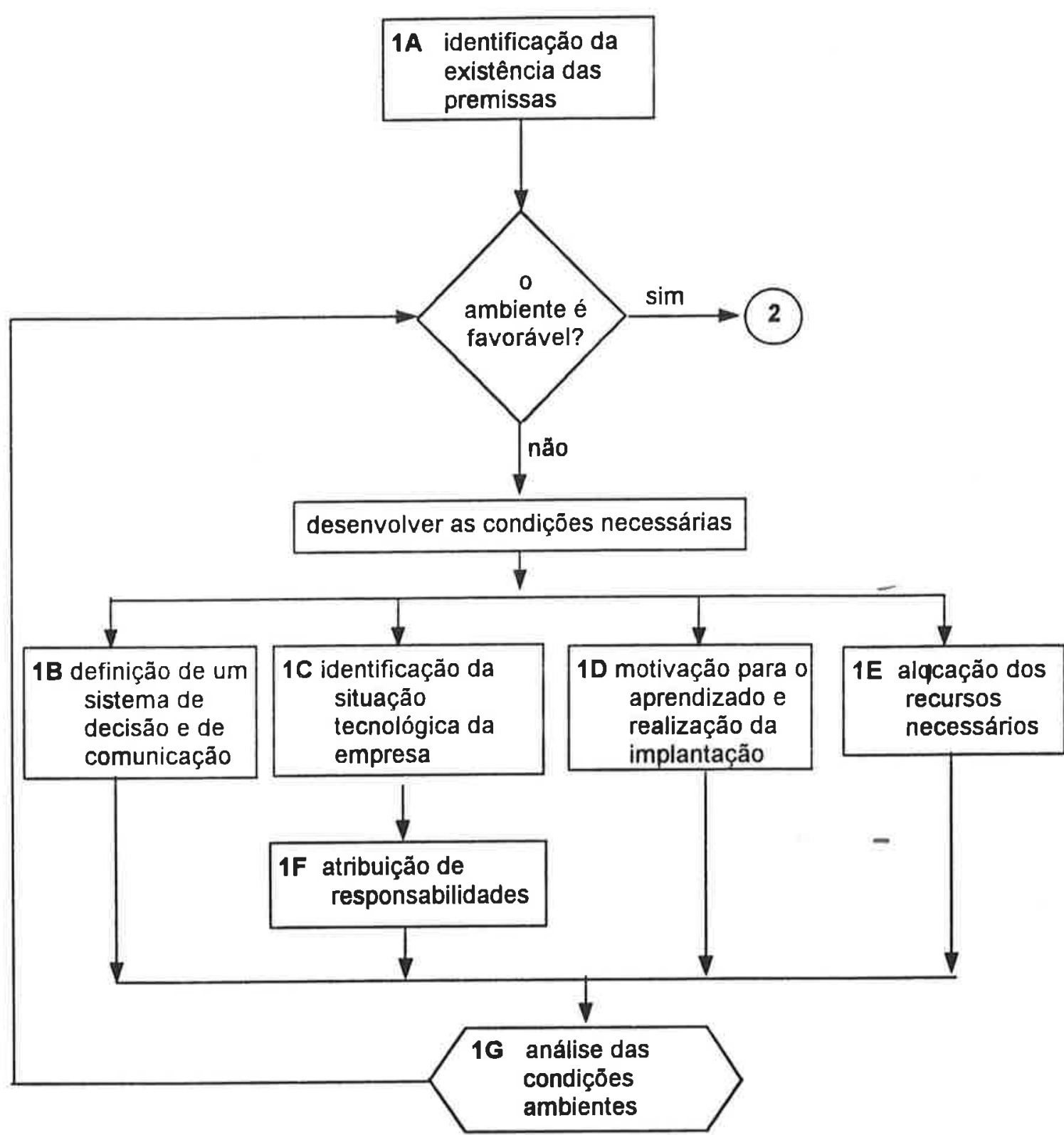

FIGURA 5.9: Fluxograma da etapa 1 - criação de um ambiente favorável

A condição ideal, de existência de todas as premissas em plenitude, dificilmente ocorre nas organizaçōes. Há aqueles que acreditam no processo de mudança e há os que preferem "deixar tudo como está". Frases do tipo: "para que mudar? sempre fizemos assim e deu certo!", sāo comuns nesse momento.

Se um comportamento desse tipo ocorrer na empresa, caberá ao líder encontrar um caminho através do qual possa mostrar que as mudanças são imprescindiveis e que as alterações tecnológicas podem trazer muitos outros 
benefícios para a empresa, além da própria racionalizaçāo do processo de produção.

A subetapa 1B: identificação da situação tecnológica da empresa pode ser um importante instrumento para o convencimento das pessoas. Um diagnóstico das características de produção, bem conduzido, pode explicitar as deficiências da empresa. Com essas deficiências à vista e conhecendo-se as TCR's, é possivel mostrar que através da implantação da racionalização do processo, pode-se diminuir ou mesmo eliminar as deficiências existentes.

Contudo, não se deve deixar para iniciar a implantação somente depois de todos estarem motivados e empenhados no processo. Pode ocorrer que esse dia não chegue tão cedo, se algo de concreto não for realizado.

Caberá ao líder encontrar os elementos mínimos para que se possa iniciar o processo de implantação, cujos resultados positivos, certamente motivarāo as pessoas incrédulas a esse processo.

Nas experiências pelas quais a autora tem passado, muitas vezes utilizou-se a "tecnologia racionalizada de produção de contrapisos" para iniciar o processo de mudança nas empresas.

Ao se realizar o diagnóstico do sistema de produção da empresa, com foco nessa atividade, ficam evidentes os desperdícios que ocorrem na obra, tanto pela ausência do conhecimento tecnológico, quanto pela falta de um projeto e de um sistema de controle eficientes.

Assim, ao se iniciar o processo de implantação por essa TCR, é possível, com algum empenho da empresa, ter um retorno significativo, em um tempo não excessivo. O retorno obtido sempre motiva as pessoas a acreditarem no processo de racionalização, levando-as a novas açōes.

Desta forma, com paciência e empenho para evoluir constantemente, aos poucos, os elementos colocados como premissa vão sendo consolidados na empresa e vão sendo cada vez mais favoráveis à evolução do processo.

Ainda nessa etapa, um elemento que merece ser melhor discutido é o que constitui a subetapa 1E: atribuição de responsabilidades. 
O líder do processo de implantação, no início, poderá realizar muitas coisas sozinho, entretanto, com a diversificação das atividades implantadas, precisará de apoio. Por isso, é importante que desde o início do processo envolva as pessoas dispostas a colaborar, passando-lhes responsabilidades específicas.

Há muitas atividades a serem realizadas, podendo-se destacar, entre outras:

- o planejamento da atividade frente às ações globais da empresa;

- a realização do projeto incorporando a nova tecnologia;

- a definição de fornecedores de materiais e equipamentos;

- a definição dos critérios para a contratação dos recursos humanos, seja pela própria empresa; seja através de subempreiteiras;

- o treinamento de todo o nível técnico da empresa;

- o treinamento e a orientação das pessoas em campo;

- o acompanhamento "de perto" de todo o processo de implantação.

É possivel que todas essas atividades sejam acumuladas por uma única pessoa, o líder; entretanto, para que a evolução do processo seja contínua, na empresa, deverá haver a formação de outros líderes do processo a fim de que as mudanças possam ser multiplicadas.

O líder deve ter consciência de que esse não é um trabalho exclusivamente seu, mas de toda a organização.

\section{b) 2 ETAPA: estudos iniciais}

A etapa de estudos iniciais, inserida na fase de organização da implantação, tem como objetivo principal conduzir a escolha das TCR's (ou das TCR) a serem empregadas pela empresa, em seu processo de produção de edificios.

Essa escolha deverá ser conduzida através de análise de dados concretos, provenientes tanto do mercado, quanto do processo de produção da empresa. Por isso, objetivando avaliar as melhorias obtidas ao longo da implantação, nessa etapa, deve ser feito, também, o registro do método construtivo que a empresa utiliza para a realização da atividade ou serviço que será objeto da implantação. 
A representação diagramática dessa etapa está apresentada na figura 5.10 e suas principais subetapas serão discutidas.
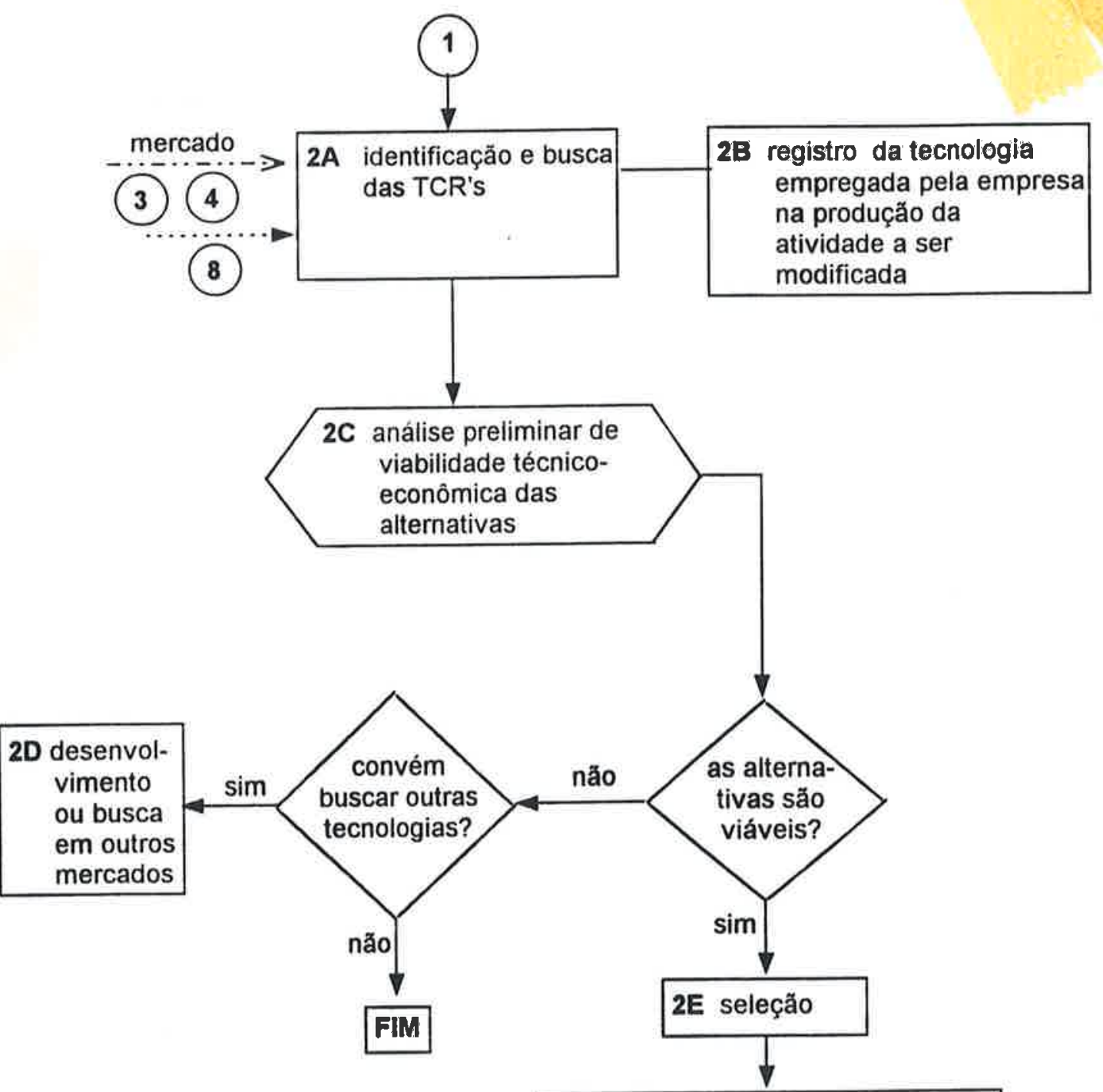

2F Registro das caracteristicas básicas da alternativa tecnológica definida para a implantação

FIGURA 5.10: Fluxograma da etapa 2 - estudos iniciais 


\section{Subetapa 2A: identificação e busca das TCR's}

Essa subetapa é de grande importância para o sucesso da implantação. A forma como as novas tecnologias chegam à empresa, bem como, a condução do processo de implantação são elementos essenciais para que as inovações sejam incorporadas ao sistema de produção da empresa. Por isso, será dada ênfase a esse passo do plano de ação, discutindo-o com mais profundidade.

Para que sejam implantadas, as TCR's precisam estar disponiveis e completamente definidas, devendo fazer parte do conhecimento tecnológico da empresa. Portanto, se a empresa nảo detém a nova tecnologia, precisará buscá-la de alguma maneira.

As empresas de Construção Civil têm investido pouco no desenvolvimento tecnológico. Segundo a FUNDAÇÃO JOÃO PINHEIRO [1992] essa ausência de investimentos decorre fundamentalmente das constantes oscilaçōes sofridas pelo setor, provocadas sobretudo pelas alterações na política econômica, o que faz com que as empresas, principalmente as de médio e pequeno porte, não tenham condições financeiras para realizarem esse tipo de investimento.

Enquanto na indústria de transformação é comum as empresas disporem de um departamento de desenvolvimento tecnológico, na indústria da Construção, poucas são as empresas cuja organização prevê profissionais voltados ao desenvolvimento de novas tecnologias. Com isso, a possibilidade de incorporar uma alteração tecnológica chega, comumente, por outras vias, que não a do desenvolvimento interno.

Uma maneira bastante comum de introdução de alterações tecnológicas na produção de edifícios, tem sido as alternativas trazidas pelos fabricantes de materiais e componentes e, também, pelos fabricantes de equipamentos, apesar destes o fazerem com uma menor freqüência.

No entanto, as "novidades" propostas pela indústria de materiais, componentes e equipamentos ao serem incorporadas na construção de edificios, muitas vezes, resultam em problemas, sendo freqüentes as falhas originadas pela introdução de novos produtos. 
Esses produtos, para serem adequadamente empregados, requerem uma integração com o processo de produção, o que de maneira geral não ocorre. Raramente são incorporados ao projeto; na maioria das vezes, aparecem "na porta" do canteiro de obras, sendo introduzidos diretamente na produção, sem que se faça uma avaliação prévia mais rigorosa de suas características e de como irão interferir no comportamento do edifício como um todo.

Há, de modo geral, uma expressiva falta de integração entre os fornecedores e as empresas de construção; ou seja, materiais e componentes novos são introduzidos no mercado, sem que se coloque à disposição dos "usuários" as informações técnicas para a sua correta utilização. Muitas vezes essas informações nem mesmo sāo de domínio daqueles que introduziram a "novidade".

Esses produtos, dissociados do processo de produção, não podem contribuir efetivamente para a evolução deste. Um caso que se tem observado com certa freqüência nos canteiros de obras é a introdução dos componentes modulares de alvenaria, sem a utilização de um projeto que contemple a sua relação com os subsistemas estruturas e instalaçōes, por exemplo. Esses componentes, se adequadamente incorporados à produção, podem proporcionar um elevado potencial de racionalizaçăo apesar de seu custo maior, se comparado aos tradicionais "tijolos baianos".

No entanto, muitas vezes esses componentes não são introduzidos ao processo de produção a partir do projeto e assim, no canteiro de obras, acabam sendo utilizados como os tradicionais "tijolos baianos", que são quebrados para fazer os ajustes no encontro da alvenaria com a estrutura e para receber as instalações, incorrendo, quase sempre, em grandes desperdícios.

Um outro exemplo bastante significativo que ilustra o emprego de novos materiais com a manutenção de métodos e processos construtivos tradicionais foi a substituição do bloco cerâmico, componente empregado largamente na produção de alvenarias de vedação de edifícios de múltiplos pavimentos, pelos blocos de concreto celular autoclavados, sem que se alterasse corretamente a tecnologia de produção de todo o edifício. O emprego desse "novo 
componente", muitas vezes, tem levado ao surgimento de inúmeros problemas tanto nas alvenarias quanto nos revestimentos.

Não apenas os materiais são introduzidos de maneira incorreta nos canteiros, mas também os equipamentos. Na ânsia de modernização do processo produtivo, muitas empresas acabam empregando equipamentos inadequados aos materiais neles processados.

Esse é o caso, por exemplo, do emprego de argamassadeiras de eixo contínuo, recentemente introduzidas no mercado, para a mistura de argamassas industrializadas com aditivos incorporadores de ar e retentores de água. Essas argamassas, para que tenham as características adequadas à sua utilização, exigem um tempo mínimo de batimento, um tempo mínimo de repouso após a mistura inicial e, finalmente, uma remistura mecânica antes da utilizaçăo, o que não é possivel de se obter através do misturador de eixo contínuo.

Em uma entrevista com o vendedor do equipamento, a autora obteve a seguinte explicação: "nossa função é colocar o equipamento no mercado, a culpa é do vendedor da argamassa que não instrui o seu cliente como deve misturá-la".

Dezenas de outros exemplos poderiam ser apresentados, pois essa é uma situação comum nos canteiros de obras. As empresas ficam à mercê dos interesses comerciais de inúmeros fornecedores de materiais e componentes que atuam no mercado.

Por isso, afirma-se que a introdução de novos materiais, componentes e equipamentos dissociada do processo de produção não pode ser considerada como uma melhoria tecnológica verdadeira. Para que se tenha um avanço tecnológico, em um determinado subsistema, deve-se considerar a sua interação e os seus reflexos em todas as demais partes do edificio. É por isso que a empresa precisa ter o domínio do processo de produção, sabendo onde e como interferir racionalmente, para que obtenha o ganho desejado, seja de material, seja de produtividade, ou no desempenho do produto final.

O aprendizado da empresa é algo que ainda precisa ser estabelecido. Pensando dessa forma, a empresa deve buscar fontes concretas para obtenção de 
novas tecnologias, o que não é uma tarefa fácil de se realizar. Primeiro porque muitas vezes as empresas nảo sabem o que querem realmente e segundo, porque não sabem onde buscar.

Não se pretende aqui dar uma "receita" de como a empresa poderá realizar essa tarefa, mas tão somente discutir algumas possibilidades disponiveis para a obtenção das novas tecnologias.

O diagnóstico da situaçăo tecnológica, colocado como premissa para o início do processo de implantação, pode auxiliar a empresa a conhecer mais precisamente o que pretende procurar, facilitando o trabalho de busca.

Algumas possibilidades "clássicas" de busca do conhecimento são as bibliografias disponiveis e também a normalização técnica, sobretudo a relativa a execução de serviços.

A pesquisa bibliográfica não é uma atividade comum aos engenheiros e gerentes de obras. $E$, ainda que o fosse, são raras as publicações nacionais envolvendo a tecnologia de produção de edifícios. Há muitas bibliografias internacionais, mas além da dificuldade do idioma, muitas vezes as situações de outros paises não podem ser diretamente aplicadas às do Brasil.

As normas, enquanto procedimentos de execução e controle de serviços, praticamente inexistem (no item 5.4.2 "diretrizes para a documentação" esse assunto foi melhor discutido).

O processo de elaboração de normas técnicas é exaustivo e dificilmente chega-se ao seu final. A proposição feita pela autora para a normalização da tecnologia racionalizada de produção de contrapisos, não passou de uma proposta. A comissão para a sua discussão foi instalada, mas quase nunca havia um número de pessoas suficientes para as discussões. Apesar disso, tratam-se de procedimentos que vêm sendo amplamente solicitados e utilizados pelas empresas.

Frente a essas dificuldades, uma opção largamente empregada pelas construtoras, sobretudo porque é de baixo custo, é "fazer o que outras empresas, com um maior grau de desenvolvimento tecnológico, vêm fazendo". 
A "imitação" da tecnologia empregada por outra empresa ocorre, na maioria das vezes, em função do constante movimento dos recursos humanos pelas diversas empresas. Entretanto, esse processo dificilmente permite à empresa "que imita", dominar completamente a tecnologia envolvida. É comum "fazer-se pela metade".

Quando a tecnologia de produção racionalizada de contrapisos começou a ser veiculada pelas pessoas que participaram das primeiras implantaçōes, falavase que a nova argamassa deveria ser feita na proporção de 1:6 (cimento:areia em volume), no entanto, não se veiculava que essa dosagem estava vinculada a uma adequada técnica de execuçāo e a um determinado nível de controle.

Algumas empresas que testaram a "nova argamassa" acabaram tendo sérios problemas de desempenho do contrapiso, por nāo terem aplicado a técnica de execução necessária e por não terem realizado o controle exigido.

Frente a essas dificuldades, um caminho que tem se mostrado como uma alternativa viável para a obtenção de resultados positivos é a realização de trabalhos conjuntos entre as empresas construtoras e as Universidades, através dos centros de pesquisa e desenvolvimento tecnológico dessas últimas.

Por ser uma modalidade bem conhecida pela autora e por se acreditar na sua eficiência, será enfocada com mais detalhe.

A parceria entre as Universidade e as empresas construtoras pode ser empreendida tanto por grandes como por pequenas e médias empresas.

Ao descrever as estratégias adotadas pela construtora de seu estudo de caso, PICCHI [1993] afirma que o seu crescimento foi apoiado por um programa de investimento em desenvolvimento tecnológico (...), através de convênios e projetos de pesquisa e desenvolvimento celebrados com Universidades, Institutos de Pesquisa e empresas de consultoria".

Esse investimento, pelos dados apresentados por PICCHI [1993], significou destinar uma quantidade de recursos financeiros que seria inviável para a majoria das empresas de porte pequeno e médio que atuam no setor. No entanto, para essas empresas que, isoladamente, não têm recursos para arcar 
com o investimento, tem-se proposto uma forma de atuação diferente, com resultados também satisfatórios.

Uma experiência envolvendo o repasse tecnológico para um grupo de cinco empresas de médio porte vem sendo desenvolvida no CPqDCC-EPUSP.

Essas cinco empresas, motivadas pela busca da melhoria do processo de produção de edifícios, procuraram os pesquisadores do CPqDCC para, em conjunto, encontrarem maneiras de alterar as condições de execução de obras, no sentido de torná-las mais racionais.

A implantação de TCR's, visando a alteração de alguns serviços identificados como prioritários pelas empresas, foi a resposta dada a esse anseio comum. Celebrou-se um convênio com tais empresas, dando-se inicio a um programa de capacitação tecnológica das empresas, através de cursos treinamento para alta e média gerência e trabalhos em campo, repassando as tecnologias aos operários.

Os resultados desse programa foram de grande importância tanto para as empresas como para os pesquisadores envolvidos.

Para as empresas significou o início do domínio tecnológico, o que pode ser confirmado pela declaração dos participantes do convênio, em uma entrevista a ALMEIDA [1995]: "a maior parte do que fazíamos como engenheiros era repetir procedimentos sacralizados pela prática dos nossos mestres, sem questionar se eram os mais corretos em termos de qualidade e tecnologia construtiva".

Além disso, a implantação de TCR's significou para os serviços objeto da implantação, em termos de resultados mensuráveis: menor custo de produção; menor tempo de execução; redução do retrabalho e de desperdícios; e ainda, uma maior precisão geométrica, melhorando as condiçōes de execução de atividades posteriores.

Essa racionalização refletiu, também, na própria organização da obra e da empresa. A obra, entre outros aspectos, teve suas instalações provisórias melhoradas, melhor definição do canteiro, com o emprego correto de novos equipamentos, o que levou, na maioria dos casos, ao aumento de produtivi- 
dade. As empresas, por sua vez, começaram a alterar seus procedimentos de projeto e de aquisição de suprimentos, passando a realizar um compra técnica.

Para os pesquisadores, essa experiência foi igualmente gratificante. Com ela, foi possivel uma maior divulgação das tecnologias desenvolvidas e, além disso, permitiu consolidar uma série de idéias que se tinha acerca da proposição de uma metodologia para a implantação de TCR's.

Essa experiência demonstrou que o trabalho conjunto entre centros de pesquisa e empresas construtoras, independente de deu porte, é um importante instrumento para que se modifique o processo construtivo tradicional. É possível imprimir a esse processo um caráter organizacional, gerencial e tecnológico que o faça evoluir no sentido de um maior grau de industrialização.

Mas é preciso destacar que, assim como um novo material ou mesmo um equipamento revolucionário precisam estar inseridos no processo de produção, a fim de que tenham o efeito desejado, também não adianta "adquirir" uma nova tecnologia, seja ela simples ou "avançada", se não for adequadamente inserida no processo de produção. Da mesma maneira que o emprego incorreto de novos materiais e equipamentos pode levar a significativos problemas, também a implantaçăo inadequada de uma mudança tecnológica no processo de produção poderá gerar inúmeros problemas para a empresa. Por isso, a importância da metodologia aqui proposta.

\section{Subetapa 2B: registro da tecnologia utilizada pela empresa}

Essa atividade pode ocorrer em paralelo com a busca das TCR's, ou num momento anterior (quando a situação tecnológica da empresa é identificada, na subetapa 1, por exemplo), ou ainda, depois de se ter conhecimento acerca das TCR's.

O importante é que ocorra antes do início do processo de aplicação da nova tecnologia, pois o seu objetivo é registrar as características de produção comumente utilizadas pela empresa, para as atividades que serão modificadas, a fim de que se possa avaliar a eficiência das TCR's implantadas. 
É uma atividade que não deve demandar muito tempo e nem mesmo muitas pessoas. Deve-se registrar de maneira clara e concisa, os principais os recursos envolvidos na atividade, tais como: consumo de materiais, equipamentos e mão-de-obra; além das características essenciais dos serviços realizados, ou seja, os cuidados prévios, a forma de execução propriamente dita e os cuidados posteriores.

Deve-se tomar cuidado com esse registro, a fim de que não existam dados distorcidos ou mesmo imprecisos, ou seja, aqueles "dados de orçamento", aqueles que o gerente "gostaria que ocorresse", que no entanto, não são os obtidos em obra. Deve-se registrar os dados reais de campo, para que a avaliação posterior seja feita segundo os mesmos parâmetros.

É interessante que esse levantamento seja realizado na mesma obra, na qual será feita a aplicação preliminar (etapa 3 do plano de ação); entretanto essa não é uma condição essencial, podendo-se, inclusive ter um levantamento amplo, tomando-se a empresa como um todo.

\section{Subetapa 2C: análise preliminar de viabilidade das alternativas}

Uma vez identificadas as alternativas tecnológicas que possam vir a atender aos objetivos da empresa, precisa ser feita uma análise prévia quanto ao seu potencial de aplicação. Deve-se avaliar, ainda que de maneira não aprofundada, o montante de recursos que estarão envolvidos, a disponibilidade dos materiais e dos equipamentos a serem empregados e as exigências quanto à mão-de-obra de produção.

Nessa análise deve-se trabalhar com estimativas sobre: os recursos financeiros e humanos que deverão ser inicialmente empregados; os prazos e os riscos envolvidos com a aplicação; as projeções de custo-benefício; e ainda, as mudanças organizacionais exigidas para aplicação da tecnologia. Tais mudanças dizem respeito, por exemplo, às interferências com o processo de projeto praticado pela empresa, à metodologia adotada pelo setor de suprimentos na aquisição de materiais e equipamentos. 
Ao final dessa análise, deve-se identificar se as alternativas previamente definidas são aplicáveis ou se outras tecnologias, a partir de fontes ainda não exploradas, deverão ser buscadas. Pode-se, nesse momento, optar, inclusive, pelo desenvolvimento de novas tecnologias, seja internamente à empresa ou em conjunto com centros de pesquisa. Essa decisão caracteriza a subetapa 2D do fluxograma (ilustrado na figura 5.10), a qual não será aqui pormenorizada por não fazer parte do escopo deste trabalho.

\section{Subetapas 2E e 2F: seleção e registro das características das TCR's}

O conjunto das alternativas viáveis deverá passar por uma seleção prévia, a fim de que seja investigada, em campo, aquela que tem maior potencial de responder aos objetivos inicialmente estabelecidos.

Há casos em que poderão ser selecionadas mais de uma alternativa objetivando a aplicação preliminar. Isto é perfeitamente possível para aquelas tecnologias de menor complexidade e que exercem menor interferência no processo de produção. Para as tecnologias de maior complexidade ou mesmo de grande interferência no processo de produção é mais difícil a aplicação simultânea de duas ou mais alternativas.

Por exemplo, o "chapisco rolado" pode ser produzido a partir de resina P.V.A. ou acrílica. Nesse caso, tanto um quanto o outro material poderão ser testados simultaneamente, avaliando-se os resultados. Entretanto, um novo sistema de fôrmas, dificilmente poderá ocorrer em duas versões distintas, numa mesma aplicação preliminar.

Sejam quantas forem as alternativas selecionadas para aplicação, suas características deverão estar devidamente registradas para que se tenha, pelo menos, recomendações básicas que orientem a sua aplicação em campo.

Nos casos em que essa tecnologia tenha sido obtida através de trabalho conjunto com centros de pesquisa e desenvolvimento, é comum existir material

1 o "chapisco rolado" é uma técnica relativamente recente de preparo de substratos, para aplicação de camada de revestimento de argamassa. É produzido a partir de uma mistura de areia, cimento e resina P.V.A. ou acrílica em quantidades adequadas e aplicado com rolo de pintura para textura. 
escrito acerca da sua produção, o qual poderá ser utilizado como diretriz para a aplicação. Quando a tecnologia for obtida a partir de trabalhos de consultoria de especialistas, deve-se solicitar do consultor, o registro da tecnologia como um todo, sobretudo os fatores condicionantes de projeto, a técnica de execução mais recomendada e, também, os equipamentos e materiais envolvidos.

\subsubsection{2 $2^{\mathrm{a}}$ FASE - Estudo de viabilidade}

Tendo-se definido as TCR's a serem implantadas, passa-se à segunda fase da metodologia de implantação, o estudo de viabilidade.

Essa fase tem por objetivo permitir a avaliação do emprego das TCR's quando inseridas no sistema de produção da empresa, em duas situaçōes distintas.

Inicialmente, busca-se confirmar a análise de viabilidade técnica-econômica feita durante os estudos iniciais, a partir da aplicação das TCR's em condições controladas, mas, sem a preocupação de que esteja inserida no sistema organizacional e gerencial da empresa. Essa confirmação ocorre durante a etapa 3 : investigação preliminar, do plano de ação proposto.

O segundo momento refere-se à etapa 4: estudos em protótipos. Aqui, procura-se viabilizar o emprego da tecnologia, a partir de sua inserção no sistema organizacional da empresa, ou seja, durante a aplicação realizada nessa etapa, são envolvidos todos os setores envolvidos com a implantação: projetos, suprimentos, recursos humanos e produção.

As características fundamentais e o fluxo de ações referentes a essas duas etapas serão apresentadas e discutidas nos itens a seguir.

\section{a) $3^{2}$ ETAPA: investigação preliminar}

É a etapa que tem por objetivo avaliar a exeqüibilidade e a viabilidade técnica e econômica das TCR's, a partir de sua aplicação em campo, bem como, preparar a aplicação piloto, a qual deverá concluir o estudo de viabilidade.

O estudo de viabilidade técnica e econômica, realizado na etapa 2, pode ter sido embasado em experiências anteriores ou mesmo em bibliografias que relatam o emprego da tecnologia. Entretanto, por uma série de razões, pode 
ocorrer que as TCR's sejam factiveis em outras empresas e não sejam nessa que está iniciando o processo de implantação. Por isso, deve passar por uma avaliação mais precisa, através da aplicação em campo.

A partir das recomendações para a aplicação, definidas ao final da etapa 2, a empresa deverá partir para a aplicação das TCR's em condições de obra, para que se possa avaliar, com mais propriedade, as variáveis e dificuldades envolvidas com sua utilização, como por exemplo: o aprendizado da mão-deobra; os prazos de execução; as características reais dos materiais e equipamentos e as dificuldades para sua obtenção; a interferência da atividade com outros subsistemas do edifício; a potencialidade do projeto.

Essa etapa da metodologia deverá ser conduzida totalmente pela "equipe" responsável pela implantação de TCR's na empresa.

Essa equipe poderá ser, em muitos casos, um único profissional: o líder. Outras vezes, pode ser constituída pelo líder, auxiliado por técnicos ou mesmo estagiários e, em algumas situações mais consolidadas, nos casos de empresas de maior porte, por exemplo, pode existir uma equipe ainda maior de profissionais voltados à implantação das TCR's na empresa.

O tamanho da equipe, apesar de poder interferir no plano tático da empresa para a condução do processo de implantação, não pode inviabilizá-lo; não deve ser empecilho. $O$ importante é que as pessoas realizem suas atividades com motivação e buscando sempre os melhores resultados.

Essa equipe deverá estar devidamente capacitada a conduzir o processo de implantação, ou seja, deverá conhecer a tecnologia e os passos do plano estratégico para a implantação. Caberá ao líder preparar previamente a sua equipe, e, para isso, poderá empregar diversos recursos, que farão parte do seu plano tático.

Durante essa etapa, a equipe de implantação terá a responsabilidade de:

- viabilizar os recursos envolvidos;

- realizar a orientação das pessoas que irão aplicar as TCR's; 
- acompanhar a realização, procurando identificar as variáveis e dificuldades anteriormente colocadas;

- avaliar os resultados obtidos; e

- preparar a próxima etapa, a partir dos dados coletados.

Para que possa desenvolver adequadamente a sua tarefa, a equipe deverá seguir uma série de passos que vão desde o planejamento para a aplicação preliminar até a elaboração da documentação que contenha todas as características da tecnologia, em função das particularidades da aplicação.

O fluxograma que representa o desenvolvimento da etapa 3 está ilustrado na figura 5.11, passando-se, a seguir, à discussão de seus elementos.

\section{Subetapa 3A: planejamento da aplicação preliminar}

Planejar a aplicação preliminar das TCR's significa preparar as condições para que elas sejam concretizada pela primeira vez na empresa. E, como anteriormente salientado, essa preparação estará sob a responsabilidade total da equipe de implantação.

As condiçōes a serem preparadas, discutidas na seqüência, dizem respeito a:

- definição da obra em que será feita a aplicação preliminar (subetapa 3B);

- inserção da aplicação preliminar no cronograma da obra (subetapa 3C);

- adaptação dos projetos, inserindo a nova tecnologia (subetapa 3D);

- definição da equipe responsável pela condução dos trabalhos (subetapa $3 \mathrm{E})$;

- orientação da equipe para a execução (subetapa 3F); e

- preparação dos equipamentos e materiais (subetapa 3G).

Subetapas 3B e 3C: definição da obra e inserção em seu cronograma

As características físicas, organizacionais e gerenciais da obra em que se pretende realizar a aplicação preliminar é importante para a obtenção dos resultados esperados. 


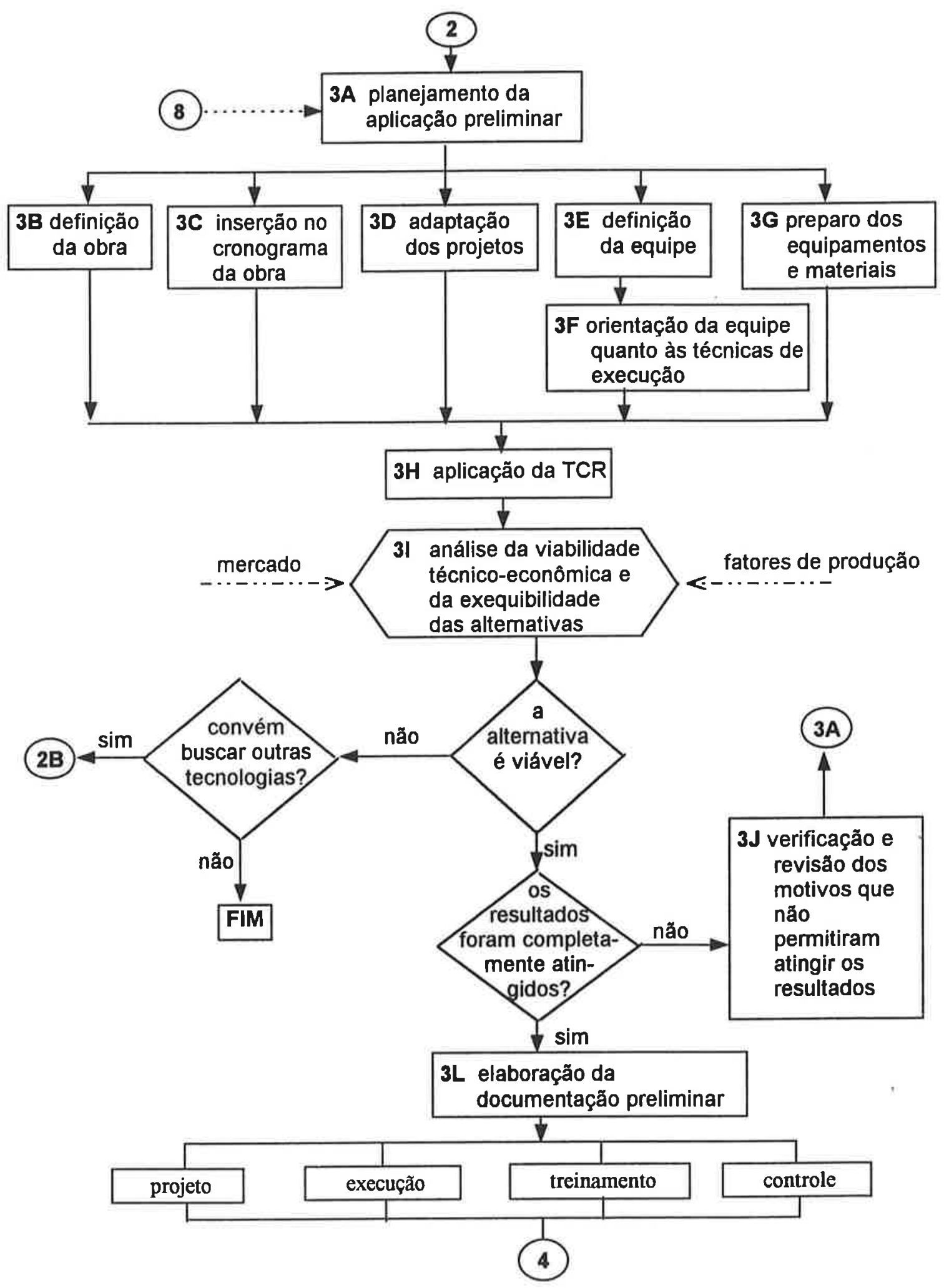

FIGURA 5.11: Fluxograma da etapa 3 - investigação preliminar 
Preferencialmente, deve-se escolher uma obra em que a atividade objeto da racionalização esteja em execução. A aplicação das TCR's em condições reais de produção, possibilita acelerar o processo de implantação, à medida em que proporciona um número maior de elementos para a avaliação.

Porém, nem sempre a obra em que a atividade esteja em execução é o local ideal para a realização dessa etapa, pois além da característica anteriormente destacada, é preciso verificar, ainda, a acessibilidade à administração da obra (engenheiros e mestres), bem como, a sua motivação em contribuir para a aplicação preliminar.

Os testes realizados em obras cuja gerência nāo acredita na nova tecnologia, dificilmente proporcionam resultados positivos. Se a gerência não acredita, não consegue convencer o mestre que, por sua vez, acaba agindo contra o processo, mesmo que de forma inconsciente, pois não se empenha para que o trabalho dê os resultados esperados.

Por isso, volta-se a salientar a importância da etapa 1, de motivação das pessoas para o aprendizado, que deve ocorrer em todos os niveis da hierarquia; e também, da diretriz fundamental de desenvolvimento dos recursos humanos, a qual deve nortear a realização desse plano de ação.

A aplicação preliminar não precisa ocorrer em um empreendimento todo. No caso de edifícios de múltiplos pavimentos, é possível que em determinadas situações, tenha-se um pavimento para realizar a aplicação preliminar, ou até mesmo um apto, sendo que o restante da produção poderá ocorrer segundo os procedimentos tradicionalmente empregados pela empresa.

Um outro cuidado que se deve ter, nessa etapa, é com o cronograma da obra. Deve-se evitar os casos em que se tenha cronograma "sem folgas", sobretudo quando as TCR's a serem aplicadas têm chances de interferir no caminho crítico da obra.

A não inserção das TCR's no cronograma global da obra pode levar ao fracasso da aplicação, uma vez que não foram previstos os prazos para a sua viabilização. 
A aplicação implica, muitas vezes, em alterações no projeto; na busca de novos materiais e equipamentos; no treinamento do pessoal; em várias tentativas, antes de se passar a uma próxima etapa; em um período de avaliação. Tudo isso exige prazos que devem ser observados para que os resultados não sofram com a introduçăo de mais uma variável: a falta de tempos adequados.

\section{Subetapa 3D: adaptação dos projetos}

A partir das recomendações propostas para a aplicação das TCR's, as quais devem estar conduzindo essa etapa do plano de ação, deve-se realizar as alterações em projeto, objetivando a viabilização das TCR's no canteiro de obras. Essas alterações poderão ser de maior ou menor intensidade, em função da complexidade das TCR's a serem aplicadas.

Podem existir tecnologias que nem mesmo foram previstas em projeto e que, ao serem aplicadas, não alteram os projetos de arquitetura, estruturas e instalações tradicionalmente elaborados. Esse é o caso típico do "chapisco rolado", anteriormente mencionado.

Atualmente não tem sido comum a realização de projeto de revestimentos; suas indicações são genéricas, inseridas no projeto de arquitetura. Portanto, dificilmente o tratamento a ser dado na base estará previamente definido.

Por outro lado, se a tecnologia referir-se, por exemplo, à produção da "laje acabada", ou seja, aquela com os desniveis e as características superficiais adequados ao recebimento direto de revestimentos, deverão ser feitas alterações no projeto estrutural e, algumas vezes, até mesmo no de arquitetura.

Mas, ainda que nos projetos tradicionais não existam definições da tecnologia a ser utilizada em canteiro, esse é o momento para que tenha início o projeto para produção, pois uma das diretrizes balizadoras da implantação, discuțida no item 5.4, é a incorporação das TCR's ao projeto, por mais simples que sejam, pois somente o projeto proporciona condições de se ter o registro claro da tecnologia a ser utilizada em cada parte do edifício que será construído. 


\section{Subetapa 3E e 3F: definição e orientação da equipe para a execução}

As questões relativas à mão-de-obra de produção, inclusive as referentes ao treinamento em todos os niveis hierárquicos, foram amplamente discutidas no item 5.4.3, relativo à diretriz fundamental de "desenvolvimento dos recursos humanos".

A mão-de-obra envolvida com a produção poderá ter, basicamente, duas origens distintas. Ser funcionário da empresa ou ser contratada por meio de terceiros. Em quaisquer dos dois casos, deverá haver uma "orientação" objetivando a capacitação das pessoas em realizarem corretamente a atividade que está sendo racionalizada.

No momento da primeira aplicação não é preciso haver um treinamento formalizado dos operários. Como se trata de uma aplicação totalmente monitorada pela equipe de implantação, uma orientação de como realizar a atividade, no próprio local, pode ser suficiente para a sua execução, dependendo, evidentemente, do grau de complexidade envolvido nas TCR's.

Seja quais forem as características das TCR's em implantação, considerandose que se trata de uma aplicação preliminar da tecnologia em que se pretende observar o seu potencial de aplicação numa situação real, mesmo sendo empregada mão-de-obra de terceiros, a orientação deverá ser feita pela própria empresa construtora, através da equipe de implantação. A participação e o envolvimento do empreiteiro podem ser de grande valia para a empresa, para os momentos subseqüentes.

Essa orientação ou treinamento da mão-de-obra deverá assumir características próprias em cada empresa, pois a condução do treinamento fará parte do seu plano tático, a ser definido para a implantação das TCR's. Esse plano poderá empregar os mais variados recursos, como por exemplo: realizar reuniões com os operários, utilizando recursos audiovisuais adequados; ou mesmo, envolver um técnico, que tenha liderança junto aos operários e que seja capaz de realizar as atividades que estão sendo implantadas, objetivando facilitar o repasse à mão-de-obra de produção; entre outros. 


\section{Subetapa 3G: preparo dos equipamentos e materiais}

Os equipamentos e os materiais para a implantação deverão estar disponíveis logo no início da aplicação. Dependendo da TCR a ser aplicada podem ser utilizados equipamentos ou mesmo materiais especiais, os quais deverão ser adquiridos no mercado ou até mesmo construídos, no caso dos equipamentos.

Nessa subetapa do plano de ação a equipe de suprimentos poderá começar a ser envolvida, ainda que deva realizar atividades fora de sua rotina. Como essa equipe tem um contato grande com o mercado, sua participação pode facilitar a aquisição dos recursos. Além disso, começa-se a "preparar o terreno" para que essa atividade seja repassada a essa equipe, como uma rotina de trabalho, nas etapas futuras do plano de ação.

\section{Subetapa 3H e 31: aplicação e análise da viabilidade das TCR's}

Somente depois que os recursos tenham sido providenciados, será possịvel passar à aplicação das TCR's (subetapa $3 \mathrm{H}$ ). A ausência de algum deles impede o início da aplicação, por impossibilitar uma análise adequada dos resultados, que poderão ser influenciados pela falta do recurso.

Essa aplicação preliminar das TCR's tem por objetivo permitir uma análise da sua viabilidade na empresa, tanto do ponto de vista econômico, quanto técnico. Para isso, deverão existir alguns parâmetros que permitam uma análise comparativa, os quais podem ser obtidos no mercado, como também, podem ser trazidos de uma análise dos fatores de produção da empresa.

Através da análise de mercado, por exemplo, pode-se saber se há outras empresas realizando essa mesma atividade, procurando-se identificar o resultado atingido por elas em termos de custos, tempo demandado e características finais do produto executado.

Os fatores de produção que irão proporcionar os parâmetros de comparação, dizem respeito àqueles definidos na subetapa 2B: "identificação e registro da tecnologia empregada pela empresa", os quais caracterizam a produção antes da interferência da equipe de implantação. 
Para que se possa ter dados para serem confrontados com os parâmetros estabelecidos, todos os recursos empregados para a aplicação das TCR's deverão ser devidamente apropriados, devendo-se distinguir aqueles que se esgotam nessa aplicação, daqueles que poderão ser utilizados outras vezes, como é o caso, por exemplo, dos equipamentos.

Além do custo envolvido com a aplicação da tecnologia, deve-se procurar avaliar outras variáveis, como por exemplo, o tempo demandado para a sua realização, pois, ainda que essa aplicação não esteja inserida no contexto da produção propriamente dita, pode-se estimar o tempo para as futuras aplicações, podendo-se melhorar os dados para o planejamento.

A aplicação deverá ser totalmente e cuidadosamente acompanhada pela equipe de implantação, a qual deverá:

- identificar a adequação das diretrizes estabelecidas no projeto, com a execução;

- observar o trabalho dos operários, identificando suas principais dificuldades e orientando-os;

- identificar os serviços que deverão ser objeto de controle de produção e de aceitação do produto final.

- reunir subsídios para a elaboração da documentação, identificando as alterações que foram realizadas com relação às diretrizes iniciais.

Essa observação permitirá reunir dados para que se prepare a documentação preliminar relativa a projeto, execução, treinamento e controle, que subsidiará a realização da etapa 4 - estudo em protótipo.

Os dados levantados da aplicação, comparados com os de mercado e de produção, permitirão à equipe de implantação definir se as TCR's aplicadas são ou não é viáveis no contexto da empresa.

Define-se, portanto, um ponto de decisão no fluxo de atividades do plano de ação. Se os resultados indicarem que a tecnologia não é viável, deve-se questionar, ainda, se é o caso de se buscar uma outra tecnologia para ser aplicada pela empresa ou não. 
Se a resposta a essa questão for negativa, ou seja, não se deve buscar outras alternativas tecnológicas, o processo de implantação termina nesse momento: é o "FIM" que aparece no fluxograma da etapa 3, na figura 5.11.

Caso seja definido que se deve tentar outras alternativas, deve-se voltar à etapa $2 \mathrm{~A}$, dos estudos iniciais, retomando-se, possivelmente, alguma das possibilidades que tenham sido abandonadas naquele momento.

Decorre daqui o fluxo iterativo entre as etapas 2 e 3 que aparece na figura 5.7.

A decisão pelo fim ou continuidade do processo vai depender de características muito particulares da condução da implantação como um todo e da própria empresa, não sendo possível fazer previsões neste trabalho.

Deve-se salientar, porém, que todos os resultados deverão ser cuidadosamente analisados, pois pode ocorrer que alguma variável particular tenha contribuido para um mau resultado, não sendo possível, com isso, atingir todos os objetivos previamente definidos. Isso não deve implicar, porém na desistência do processo de implantação.

Nos casos em que a análise tenha mostrado a viabilidade da alternativa, devese fazer um outro questionamento: os resultados foram plenamente atingidos?

Com isso, procura-se identificar se os objetivos estabelecidos no início da aplicação preliminar foram completamente atingidos ou não.

Esses objetivos podem não ter sido atingidos em decorrência de algum elemento presente no processo. Por exemplo, a obra que inicialmente parecia ser ideal, acabou por gerar problemas, pois a mão-de-obra abandonou o serviço no meio do caminho; ou ainda, o mestre que se declarou motivado com a nova tecnologia acabou por não participar do processo; as recomendações que pareciam claras e objetivas não foram suficientes para conduzir o processo. Enfim, podem ocorrer uma série de problemas no meio do caminho que não permitem a completa avaliação da tecnologia. Por isso, pode não ser possível o seu registro na forma de uma documentação preliminar para projeto, treinamento, execução e controle. 
Nesse caso, deve-se partir para a subetapa $3 \mathrm{~J}$ - verificação e revisão dos motivos que não permitiram atingir os resultados, retornando-se para a etapa $3 A$ e empreendendo-se uma nova aplicação preliminar a qual poderá ocorrer na mesma obra ou não, em função da avaliação feita pela equipe de implantação.

Os motivos que podem impedir o sucesso completo da aplicação preliminar podem ser de diversas naturezas e podem ter os mais diferentes encaminhamentos, em função da organização de cada empresa. Por isso, não serão objetos de discussão no presente trabalho. Caberá à equipe de implantação analisar os motivos e propor soluçōes, em função dos recursos disponíveis e da sua experiência na condução do processo.

Esse ciclo somente será concluído quando, ao final da aplicação preliminar, for possivel a elaboração da documentação que irá subsidiar a etapa seguinte.

\section{Subetapa 3L: elaboração da documentação preliminar}

Essa documentação deve conter as características fundamentais das TCR's considerando-se as particularidades da empresa. Pode ocorrer de serem poucas as modificações com relação às recomendações que deram início à etapa 3, mas pode ocorrer, também, de existirem diferenças expressivas.

Por isso, recomenda-se que a documentação acerca das TCR's seja elaborada somente depois que as mesmas tenham sido aplicadas com sucesso, na empresa, pelo menos uma vez.

A documentação a ser produzida, nesse momento, refere-se aos procedimentos preliminares para projeto, execução, treinamento e controle e deve traduzir - sistema de produção da empresa para uma determinada atividade ou serviço. Ou seja, ela deve conter toda a TCR de maneira que seja possivel a sua incorporação ao projeto e à produção em aplicações futuras.

A elaboração desses procedimentos poderá se dar das mais diferentes maneiras, em função da organização de cada empresa, e da tática empregada para a condução da implantação. 
Ainda que não se queira entrar nas questões de ordem tática das empresas, cabe observar que uma forma propícia à elaboração desses procedimentos é através do envolvimento da equipe que participou da aplicação preliminar.

A equipe de implantação deverá conduzir o processo de documentação, mas precisará ouvir e até mesmo questionar a equipe de produção, que certamente, após a aplicação preliminar, tem muito a contribuir para a padronização da atividade, em função do sistema de produção adotado pela empresa.

Essa conduta possibilita um maior nivel de motivação, envolvimento e comprometimento das pessoas, fazendo com que os procedimentos incorporem as características da empresa e venham a ser aplicados em projetos futuros.

Dessa atividade, poderão participar o engenheiro, o mestre de obras e, até mesmo, os encarregados e operários que realizaram os serviços.

Nessa etapa, os procedimentos são vistos como uma documentação preliminar, que deverá ser devidamente "testada" na etapa 4, de estudos em protótipo. Por isso, não deve ser uma atividade de longa duração, para que o processo de implantação não esmoreça enquanto os documentos estão sendo elaborados.

Nesses documentos deverão existir diretrizes para: incorporação das TCR's aos projetos; a execução dos serviços em obras; a realização do treinamento do pessoal de campo; o controle de execução e recebimento, sempre de forma clara e objetiva, de modo que possam ser facilmente utilizados nas aplicações.

\section{b) 4" ETAPA: estudos em protótipos}

Terminada a etapa de aplicação preliminar, tendo-se, portanto, os procedimentos preliminares para projeto, execução, treinamento e controle, é possível passar-se à etapa de estudo em protótipo, na qual, busca-se analisar a viabilidade de aplicação da tecnologia, frente às características organizacionais e de gestão da empresa, propondo-se para estas as alterações que forem necessárias à completa integração das TCR's na cultura da empresa.

Essa etapa consiste num ciclo iterativo de emprego da tecnologia em condições reais de uso, ainda num ambiente monitorado pela equipe de 
implantação, tendo-se, sempre, a avaliação dos resultados obtidos para permitir a evolução do processo.

É uma fase que pode ter longa ou curta duração em função das particularidades das TCR's e também das características organizacionais e de gestão da empresa.

O fluxograma que ilustra essa etapa estratégica está apresentado na figura 5.12 .

Uma análise superficial desse fluxograma pode levar a se pensar que seja idêntico ao proposto para a etapa 3. Mas, ainda que as subetapas sejam muito semelhantes, a característica da aplicação, nesse momento, difere da anterior.

Nessa etapa de protótipo, o objetivo de se aplicar as TCR's é distinto da aplicação preliminar. Quando se realizou a aplicação preliminar, o objetivo era a avaliação técnica e econômica das TCR's. Nesse momento, considera-se que isso já tenha sido verificado, senão, a etapa anterior não teria sido concluída com sucesso; entretanto, não se sabe, ainda, se é viável inserir as TCR's na estrutura organizacional da empresa. Portanto, o objetivo principal da etapa 4 é avaliar essa viabilidade.

\section{Subetapa 4A: planejamento do estudo em protótipo}

Planejar o estudo das TCR's em protótipos significa preparar as condiçōes para que a tecnologia seja viabilizada na organização da empresa. Essa preparação deverá estar sob a responsabilidade da equipe de implantação, a qual precisará envolver as demais equipes que, de alguma maneira, interferem na implantação, como por exemplo, as equipes de projeto, de suprimentos e de recursos humanos.

As condições a serem preparadas, discutidas a seguir, dizem respeito a:

- definição do empreendimento que será tido como protótipo (subetapa 4B);

- inserção das TCR's no cronograma do empreendimento (subetapa 4C);

- desenvolvimento dos projetos, considerando-se as TCR's (subetapa 4D); 


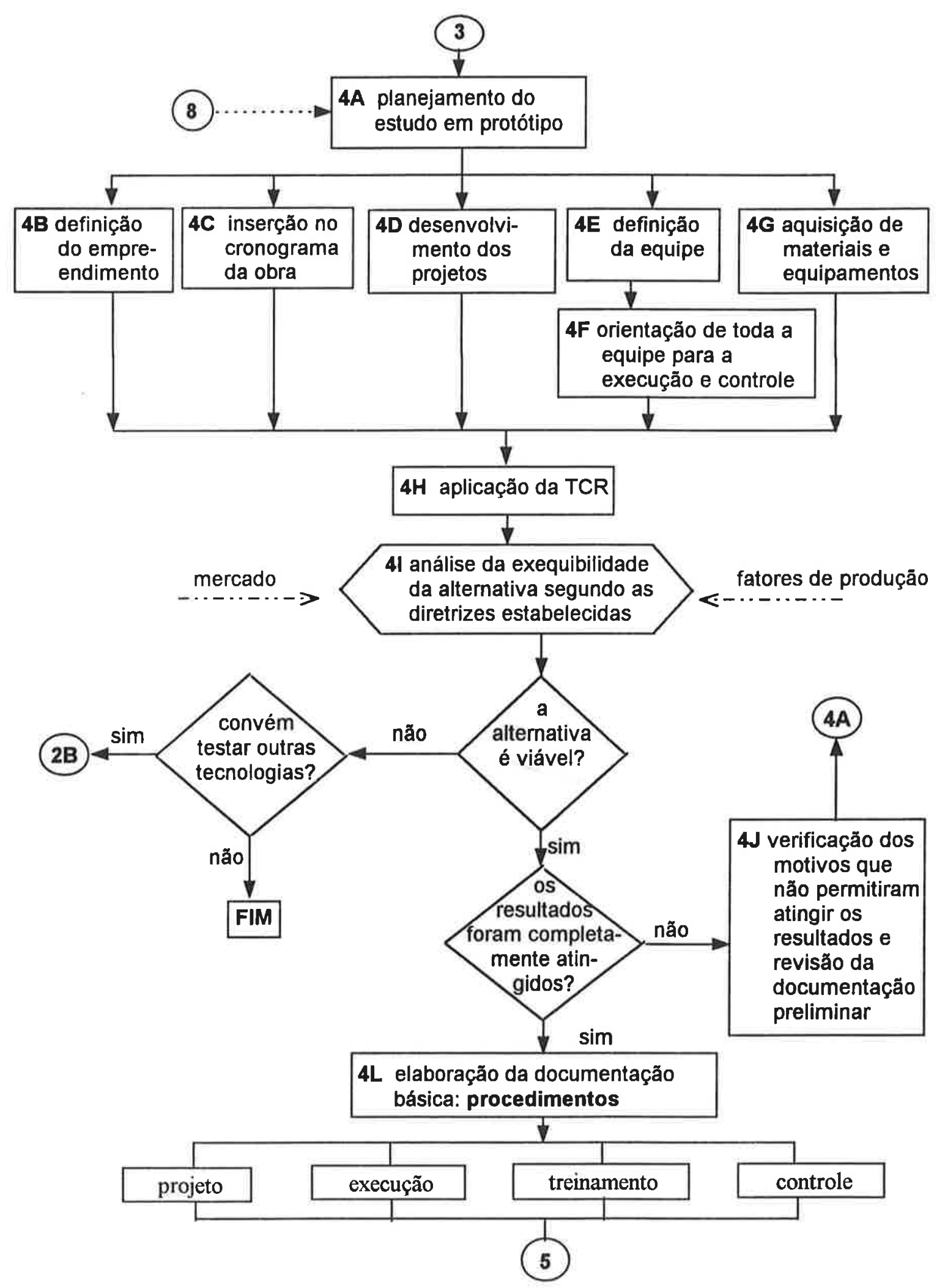

FIGURA 5.12: Fluxograma da etapa 4 - estudo em protótipos 
- definição da equipe responsável pela condução dos trabalhos em canteiro (subetapa 4E);

- treinamento do pessoal para a produção (subetapa 4F); e

- aquisição dos equipamentos e materiais (subetapa 4G).

Subetapas 4B e 4C: definição do empreendimento e inserção em seu cronograma

Os cuidados para a definição do empreendimento protótipo, no qual as TCR's serāo testadas, devem ser os mesmos estabelecidos na etapa 3; entretanto, para etapa 4, o ideal é que o empreendimento esteja no seu início, a fim de que as TCR's possam ser aplicadas desde a fase de projeto.

Para essa etapa, o cronograma do empreendimento é ainda mais significativo, pois se pretende ampliar a escala de aplicação das TCR's.

Na etapa de protótipo, as TCR's poderão vir a ser aplicadas no edifício como um todo, não ficando restrita a uma parte. Por isso, será importante que os prazos do empreendimento sejam compatíveis com as características de elaboração do projeto, treinamento, contratação de equipes especializadas, aquisição de materiais e equipamentos e realização da etapa de controle de produção e de recebimento dos serviços.

Deve-se evitar que o empreendimento protótipo tenha um cronograma muito apertado pois, na maioria das vezes, isso acaba interferindo de maneira acentuada na realizaçāo das atividades, não permitindo que se faça uma avaliação precisa dos resultados da implantação.

\section{Subetapa 4D: desenvolvimento dos projetos}

O desenvolvimento do projeto deverá ser conduzido pelos procedimentos preliminares, estabelecidos ao final da etapa 3.

Esses procedimentos deverão proporcionar condições para que o projetista, seja ele externo ou interno à empresa, possa expressar as TCR's no projeto, fornecendo à obra condições para a completa realização da atividade. 
Nessa subetapa deverá ser desenvolvido o projeto para a produção, podendo-se seguir as diretrizes balizadoras definidas no item 5.4.1.

A forma como as empresas irão viabilizar o desenvolvimento do seu projeto para a produção, deverá estar definida no seu plano tático. Entretanto, com o objetivo de auxiliar na elaboração desse plano, pode-se deixar registradas algumas idéias passiveis de serem adotadas.

Os mesmos projetistas que elaboram os projetos tradicionais de um edifícios, desde que orientados pela empresa construtora, poderão realizar os projetos voltados à produção, os quais deverão incorporar as TCR's definidas pela empresa.

Por exemplo, é possivel que o escritório de arquitetura elabore o projeto de alvenaria, segundo parâmetros predefinidos pela empresa, fundamentados na sua tecnologia de produção. O projetista de instalações, por sua vez, tem condições de desenvolver o projeto das passagens das instalações pela laje (denominado usualmente de "projeto de furação"), definindo as cotas acumuladas a partir de eixos preestabelecidos para todos os projetos. Esse projeto facilitará muito o trabalho em obra, além de evitar uma série de erros comuns durante a locação dessas passagens.

Há outras alternativas no mercado, como por exemplo as empresas que desenvolvem projetos específicos, tais como o de fôrmas, 0 de alvenarias e revestimentos e até mesmo o de canteiro.

Enfim, as alternativas existem e precisam ser utilizadas pelas empresas, a fim de que os projetos realmente passem a anteceder $e$ a considerar as exigências das obras.

\section{Subetapa 4E e 4F: definição e treinamento da equipe}

Apesar da ampla discussão sobre a importância do treinamento e da motivação de toda a equipe para o sucesso da implantação, realizada no item 5.4.3, cabem, ainda, alguns comentários, mesmo que se refiram às táticas que as empresas poderão utilizar para realizar o treinamento. 
O treinamento, objetivando a capacitação tecnológica da equipe, deverá ser realizado para todas as categorias profissionais, empregando-se técnica e linguagem adequadas a cada uma delas.

Essa atividade deverá estar sob a responsabilidade da equipe de implantação, a qual poderá organizar cursos treinamento, palestras técnicas, aulas práticas, com o objetivo de passar a tecnologia àqueles que deverão realizá-la nos canteiros de obras.

Um mecanismo que tem sido utilizado com sucesso é o emprego de procedimentos de execução ilustrados com figuras representativas das atividades mais importantes, como por exemplo, os propostos em BARROS [1991a], para a Tecnologia de Produção de Contrapisos.

As ilustrações poderão auxiliar em uma aula expositiva, passando-se, na seqüência, à execução no próprio canteiro. Essa atividade, em canteiro, poderá ser conduzida por um membro da equipe de implantação ou até mesmo por um oficial previamente treinado.

A expressão gráfica e a prática de obra, mais do que o texto, auxiliam na compreensão das atividades, para qualquer nível da hierarquia da empresa.

Além do procedimento ilustrado, o treinamento empregando-se recursos audiovisuais, como por exemplo as fitas de vídeo, tem sido um instrumento de grande valia para a completa compreensão das atividades e serviços a serem realizados.

PICCHI [1992] afirma que "a força de comunicação do vídeo, com animações, ilustrações, cenas reais de obras e depoimentos de pessoas que já estão utilizando os instrumentos, propicia uma receptividade e participação nos debates muito grande, auxiliando no objetivo de se ter treinamentos participativos e não expositivos (de menor eficácia)".

Além desse aspecto de motivação e participação, deve-se considerar ainda, que a existência de fitas de vídeo ou mesmo outros recursos visuais, auxiliando o treinamento, possibilita rápida difusão das idéias, proporciona uma homogeneidade do conteúdo de informações e permite que várias pessoas 
participem como multiplicadores do processo de treinamento, segundo um mesmo conteúdo básico.

Nesse momento, assim como no da investigação preliminar, todos os operários deverão ser treinados para a atividade, independente de serem da própria construtora ou de empresas subcontratadas.

É evidente que o esforço do treinamento não deve ser em vão, por isso, devese buscar empregar a mesma equipe utilizada na investigação preliminar, pois esse procedimento, além de permitir uma sedimentação do conhecimento da equipe, permitirá avaliar o efeito da sua aprendizagem, podendo-se analisar, inclusive, a eficiência do treinamento.

A formação de equipes especializadas em determinados grupos de atividades de produção, pode trazer muitos beneficios à empresa, permitindo a fixação dessa mão-de-obra nas atividades, um maior conhecimento das tecnologias envolvidas e, por conseqüência, o incremento da produtividade.

O treinamento a ser realizado deverá enfocar tanto os aspectos de execução quanto os de controle, enfatizando-se entre outros aspectos, os seguintes: como o controle deverá ser realizado, quais as responsabilidades de cada um no processo, quais serão os objetos de controle, quais as conseqüências de não se fazer certo logo da primeira vez.

As táticas empregadas pelas empresas na etapa de investigação preliminar poderão ser ampliadas nesse estudo em protótipo, procurando dar melhores condições para que a equipe de produção compreenda as suas tarefas, bem como, a maneira como as mesmas se relacionam com o restante do processo de produção do edifício.

\section{Subetapa 4G: aquisição dos materiais e equipamentos}

Nessa etapa do plano de ação, os materiais e equipamentos deverão ser providenciados através da equipe de suprimentos da empresa, a qual deverá passar também pelo processo de treinamento, objetivando a sua capacitação tecnológica. Se a equipe estiver bem orientada, com certeza, os suprimentos 
terão grandes chances de chegar como especificados e no momento correto para a implantação.

Caberá à equipe de implantação treinar a equipe de suprimentos e orientar suas primeiras ações, no sentido de subsidiá-la, sobretudo, quanto às especificações e aos prazos exigidos para a implantação das TCR's.

\section{Subetapa 4H e 4l: aplicação e análise da viabilidade das TCR's}

Essa etapa somente poderá ter início depois que todos os recursos estiverem viabilizados. A falta de algum dos recursos impede o início do estudo, uma vez que não será possível fazer uma análise correta dos resultados, pois estes poderão ser influenciados pelo recurso ausente.

É evidente que a equipe de implantação poderá assumir o risco de iniciar o processo, mesmo com algum dos recursos ausentes. $O$ risco poderá ser calculado, avaliando-se a relação custo-benefício de se iniciar o processo ou esperar até que todos os recursos estejam disponíveis. Essa decisão depende fundamentalmente das características de cada organização e não cabe discutir aqui as diversas possibilidades.

A aplicação das TCR's, nessa etapa, envolve tanto a execução da atividade, propriamente dita, como também, a aplicação da sistemática de controle. Dessa maneira, ao acompanhar a realização do serviço, a equipe de implantação deverá solicitar à equipe responsável pelo controle que realize em conjunto o controle da produção e, também, o de aceitação dos serviços.

Observa-se que neste trabalho a "função controle" está sendo considerada distinta da "função implantação", por isso, a menção de duas equipes. Pode ocorrer, no entanto, em função das particularidades de cada empresa, que uma única equipe cumpra as duas funçōes.

A distinção das duas funções permite que, ao final do processo de implantação das TCR's na empresa, a equipe responsável possa se afastar, ficando disponivel para empreender novas aplicações. Nessa situação, a verificação das atividades incorporadas à rotina da empresa deverá ser deixada sob a responsabilidade da equipe de controle. 
Tem-se, portanto, como objetivo principal dessa etapa, a aplicação dos procedimentos elaborados na fase anterior e a verificação de sua eficiência no processo de implantação, a qual poderá estar fundamentada na comparação dos resultados obtidos com parâmetros definidos previamente.

Para isso, a equipe de implantação deverá estar preocupada com o levantamento e a observação, entre outros, dos seguintes fatores de produção:

- consumos e a adequação dos materiais;

- equipe utilizada;

- quantificação dos serviços realizados;

- tempo total demandado para a realização da atividade;

- adequação dos equipamentos empregados;

- adequação das diretrizes estabelecidas no projeto, com a execução;

- adequação do sistema de suprimentos;

- resultados do treinamento realizado;

- resultados da sistemática de controle, identificando os possiveis problemas e dificuldades;

- reunião dos subsídios para a elaboração da documentação básica (os procedimentos de produção), identificando e registrando as alterações que foram realizadas com relação à documentação preliminar.

Com essas observaçōes busca-se verificar se os procedimentos contidos na documentação preliminar estão adequados às condições de produção; se eles subsidiam a produção, se eles funcionam realmente e, sobretudo, se as ações fluem naturalmente pela organização da empresa.

As observações realizadas permitirão à equipe de implantação definir se as TCR's são viáveis na organização da empresa ou não.

Define-se, portanto, um ponto de decisão no fluxo de atividades do plano de ação. Se os resultados indicarem que a tecnologia não é viável, deve-se questionar, ainda, se é o caso de se testar uma outra tecnologia para a evolução do processo de produção da empresa, ou não. 
Se a resposta a essa questão for que não se deve buscar outras alternativas tecnológicas, o processo de implantação termina nesse momento: é o "FIM" que aparece no fluxograma da etapa 4, na figura 5.12.

Caso seja definido que se deve tentar outras alternativas, deve-se voltar à etapa $2 A$, dos estudos iniciais, retomando-se, possivelmente, algumas das soluções que foram abandonadas naquele momento, reiniciando-se 0 processo de implantação, conforme os passos anteriormente apresentados e discutidos.

A decisão pelo término ou pela continuidade do processo, vai decorrer de características muito particulares da condução da implantação como um todo e da própria empresa, não sendo possível fazer previsões neste trabalho.

Nos casos em que a análise da alternativa aplicada tenha se mostrado viável, cabe, ainda, um questionamento: os resultados foram plenamente atingidos?

Ao se realizar esse questionamento procura-se identificar se os objetivos estabelecidos no início do estudo piloto foram completamente atingidos, ou seja, se foi possivel definir adequadamente o fluxo de açōes dentro da organização da empresa e se este ocorreu sem problemas, permitindo, desta forma, passar-se para a última subetapa deste fluxograma: a subetapa $4 \mathrm{~L}$ de elaboração da documentação básica.

Caso a resposta ao questionamento tenha sido negativa, não será possível concluir essa etapa, devendo a mesma ser reavaliada. Por isso, no fluxograma, há uma saída para a subetapa 4J, a qual possibilita a verificaçāo dos motivos que impediram que se atingisse os resultados esperados, bem como, a revisão da documentação preliminar.

A partir dessa revisão, incorporando o aprendizado do ciclo realizado, é possível voltar-se ao início do fluxograma e retomar a aplicação piloto, possivelmente em um outro empreendimento.

Os motivos que podem levar a ocorrência de problemas nessa etapa são diversos. Desde problemas com a documentação preliminar, inexperiência com o processo de treinamento, escolha inadequada do empreendimento, falta de 
entendimento entre as diversas equipes, não possibilidade de aplicação da sistemática de controle, entre tantos outros.

O objetivo da equipe de implantação não deve ser o de passar rapidamente por essa etapa, mas sim de possibilitar o início da consolidação da tecnologia na organização empresarial. Por isso, em algumas situações, esse estudo em protótipo pode ocorrer várias vezes, até que a empresa consiga ter formas de organização e gestão compativeis com a aplicação de novas tecnologias. Ou sejam: equipes trabalhando harmoniosamente; desenvolvimento de projetos adequados à produção; desenvolvimento dos recursos humanos; setor de suprimentos voltado à produção; e aplicação do controle de execuçāo e recebimento, para permitir a contínua realimentação do processo de produção.

\section{Subetapa 4L: elaboração dos procedimentos}

Essa etapa de "estudo em protótipos" somente será terminada quando for possível a elaboração da documentação que irá subsidiar a etapa seguinte.

Essa documentação deverá conter todas as características das TCR's inserida no contexto da empresa. Pode ocorrer de serem poucas as modificações com relação à documentação preliminar que deu início à etapa, mas pode ocorrer também, de existirem diferenças expressivas.

A documentação a ser produzida refere-se aos procedimentos básicos para projeto, execução, treinamento e controle e deve traduzir o sistema de produçăo da empresa para uma determinada atividade ou serviço. Ou seja, ela deve conter todas as TCR's, de maneira que seja possivel a sua incorporação ao projeto e à produção em aplicações futuras, sem que haja a interferência da equipe de implantação.

A partir dessa documentação a empresa deverá ser capaz de aplicar as TCR's em qualquer empreendimento, sem que seja considerada algo diferente de sua rotina.

Esses procedimentos constituem uma evolução da documentação preliminar, pois são decorrentes de uma revisão, na qual as dificuldades observadas e os problemas ocorridos são eliminados. Por isso, considera-se de grande valia 
que a mesma equipe que tenha participado da elaboração inicial, participe no momento da revisão; de modo que a equipe de produção tenha uma participação ativa, expressando sua opiniāo quanto às modificações realizadas.

Nessa etapa, os procedimentos são denominados "documentação básica", ou seja, são aqueles que contêm o sistema de produção da empresa e que poderá conduzir os trabalhos daí por diante, seja orientando a contratação de projetistas, a contratação de subempreiteiras ou mesmo de empresas prestadoras de serviços especializados.

Essa documentação não deve ser encarada como "definitiva". Ela precisa evoluir sempre, objetivando a melhoria contínua. Pensando assim, os procedimentos deverão continuar sendo revisados a cada nova aplicação das TCR's.

Como salientado na etapa 3 , a atividade de revisão da documentação, seja para dar início a um novo estudo em protótipo, seja para passar a uma nova etapa do processo de implantação, não deve ser uma atividade de longa duração, a fim de que esse processo não esmoreça na empresa, enquanto os documentos estão sendo elaborados.

\subsubsection{3 $3^{\mathrm{a}}$ FASE - Consolidação da tecnologia}

A terceira fase consiste no aperfeiçoamento da tecnologia, a qual pode ter início assim que a documentação básica estiver disponivel.

A diferença fundamental desta fase com relação à anterior refere-se à responsabilidade pela condução do processo de implantação. Nessa fase, a equipe de implantação começa a passar a responsabilidade da implantação à equipe de produção da empresa.

Essa $3^{\text {a }}$ fase consiste de duas etapas estratégicas, uma na qual as TCR's serão aplicadas pela própria equipe de produção, numa escala piloto (etapa 5) e outra, de consolidação da documentação (etapa 6), discutidas a seguir.

\section{a) 5" ETAPA: aplicação em escala piloto}

Esta é a etapa em que se inicia a consolidaçăo da tecnologia na empresa, através do repasse da responsabilidade da implantação à equipe de produção. 
Esse repasse, deve ser feito de forma controlada e não para toda a empresa de uma única vez. Deve-se envolver um número limitado de empreendimentos, nos quais as TCR's deverão ser implantadas, sob a responsabilidade da equipe administrativa da obra, a qual deverá ter o suporte dos setores de projeto, recursos humanos e suprimentos.

Nesta etapa, caberá à equipe de implantação monitorar as diversas aplicações que poderão estar ocorrendo ao mesmo tempo, identificando as dificuldades no processo, bem como, as possiveis melhorias que venham a ser estabelecidas em cada canteiro. Será sua responsabilidade, ainda, verificar se a aplicação da tecnologia está em sintonia com o processo de produção da empresa e se os procedimentos básicos são compativeis com as características do projeto, da produção e do controle.

Ao final da etapa 5, a equipe de implantação deverá fazer uma avaliação dos resultados obtidos, reunindo subsídios para a consolidação da documentação da empresa, na etapa 6.

A representação diagramática da etapa 5 está ilustrada na figura 5.13 e suas principais subetapas estão apresentadas e discutidas na seqüência.

\section{Subetapa 5A: planejamento da implantação piloto}

Assim como as etapas anteriores exigiram um planejamento prévio dos recursos, essa exige também. No entanto, os recursos aqui tratados são de outra natureza.

Para que as TCR's possam ser experimentadas numa escala piloto e gerenciadas pelos responsáveis pela produção, será imprescindivel:

- definir os empreendimentos onde as TCR's serão implantadas (subetapa $5 \mathrm{~B})$;

- proporcionar a capacitação tecnológica e gerencial àqueles que deverão se responsabilizar pela implantação (subetapa $5 \mathrm{C}$ ); e

- envolver e capacitar as equipes de projeto e suprimentos para participarem efetivamente do processo (subetapa 5D). 


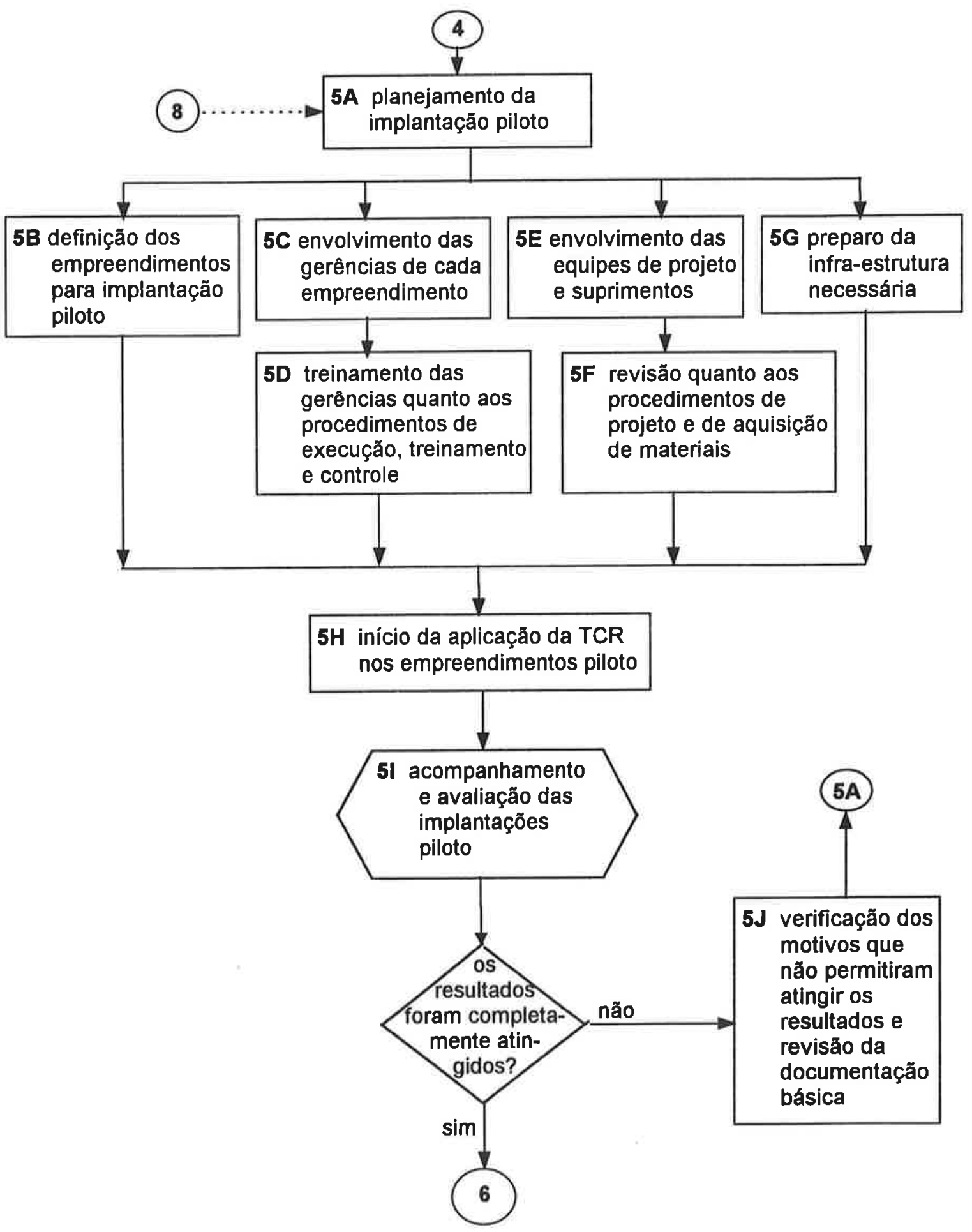

FIGURA 5.13: Fluxograma da etapa 5 - aplicação em escala piloto 


\section{Subetapa 5B: definição dos empreendimentos para implantação piloto}

A escolha dos empreendimentos para a aplicação piloto é tão importante quanto nas etapas anteriores.

E, novamente, o prazo de realização da obra é um fator que não se pode dei$x a r$ de lado. Ainda que, num determinado momento, todas as obras devam ser envolvidas, não é conveniente que, nas etapas de verificação e consolidação da tecnologia, participem aquelas que tenham um cronograma incompativel com a atividade de implantação.

Além disso, nessa etapa, deverão ser evitadas as gerências que não queiram se envolver com o processo de implantação. Mas, cabe lembrar que, para que as TCR's efetivem-se na cultura da empresa, todos os participantes deverão estar envolvidos e motivados com o passar do tempo, devendo-se sempre trabalhar no sentido de comprometer as pessoas e mostrar-lhes os benefícios que as novas tecnologias estão trazendo para a empresa.

O número de empreendimentos a serem tomados na implantação piloto é função da capacidade organizacional da empresa e de gestão da equipe de implantação, devendo-se lembrar que os projetos para produção deverão ser iniciados em conjunto com os demais projetos do empreendimento; a equipe de suprimentos deverá ser capaz de considerar todas as solicitações; a equipe de implantação deverá ser capaz de monitorar todas as implantaçōes.

\section{Subetapas 5C e 5D: envolvimento e treinamento da gerência de cada empreendimento}

Nessa subetapa caberá à equipe de implantação "formar" diversas outras equipes para implantação piloto. Ou seja, todos os gerentes de produção, cujas obras foram definidas como piloto deverão ser adequadamente treinados para realizarem a implantação das TCR's em seus canteiros de obras.

O treinamento deverá envolver duas partes distintas: uma que proporcione a capacitação tecnológica e outra a capacitação gerencial do processo de implantação. 
A gerência e a administração das obras deverão ter o domínio da tecnologia, ou seja, deverão saber como e porque realizar a atividade de determinada maneira e não de outra. Além disso, deverão estar capacitadas a transferir esse conhecimento às pessoas responsáveis pela produção; a solicitar os recursos adequados para a realização das atividades; realizar o controle da produção; e analisar os resultados obtidos.

Para isso, a equipe de implantação poderá preparar "cursos treinamento" objetivando tanto a capacitação tecnológica, quanto a capacitação gerencial.

A organização desses cursos está ligada ao plano tático de cada empresa, em função dos recursos que dispõe e, também, em função de sua complexidade organizacional.

Observa-se que, muitas vezes, a empresa pode adotar a tática de proporcionar a capacitação tecnológica de toda a sua equipe técnica: gerentes, supervisores, engenheiros de obras, de uma única vez. Essa ação, entretanto, não elimina a exigência da formação daqueles que irão participar do projeto piloto, antecedendo a subetapa de aplicação. Muitas dúvidas que tenham ficado de um curso mais geral podem ser solucionadas nesse momento.

Seja qual for a tática estabelecida, é importante que toda a equipe esteja devidamente capacitada para que se possa dar início à aplicação das TCR's na etapa piloto.

\section{Subetapa 5E e 5F: envolvimento e treinamento da equipe de projeto e suprimentos}

Ainda que na etapa de estudos em protótipo tenha havido o envolvimento das equipes de projeto e suprimentos, o mesmo deverá ser retomado para a aplicação piloto.

O processo de melhoria contínua exige sempre a reciclagem dos conhecimentos anteriores, para que um novo passo seja dado em direção a patamares mais elevados de racionalização.

Nessa etapa, a condução da implantação não estará mais sob a completa supervisão da equipe de implantação; por isso, é fundamental que as equipes 
responsáveis pelo desenvolvimento de projeto e pela aquisição de suprimentos e equipamentos colaborem decisivamente com a implantação.

Assim, é conveniente que antes de se iniciar a implantação piloto, essas equipes também passem por um treinamento, objetivando deixar claro a sua função no processo e, também para motivá-las a auxiliarem a equipe de produção na condução da implantação.

Com todas as equipes devidamente treinadas, deve-se passar à prática propriamente dita, aqui denominada: aplicação das TCR's nos empreendimentos piloto (subetapa $5 \mathrm{H}$ ).

\section{Subetapa 5G: preparo da infra-estrutura necessária}

Essa subetapa tem por objetivo viabilizar, com antecedência, os materiais e equipamentos que não são de uso comum da empresa, mas que serão utilizados na implantação.

Esses equipamentos e materiais, nessa etapa, ainda sāo de responsabilidade da equipe de implantação, em conjunto com a equipe de suprimentos e deverão estar disponiveis nas obras piloto antes da utilização.

A centralização do preparo dos equipamentos não usuais facilita a subetapa de aplicação em obra.

\section{Subetapa 5H: aplicação das TCR's nos empreendimentos piloto}

Cada gerente poderá considerar essa aplicação como se fosse um protótipo. Por isso, no âmbito da obra, o gerente poderá ser orientado a seguir os passos definidos para a etapa 4: estudo em protótipo.

Assim, deverá haver um planejamento da aplicação para cada empreendimento, a aplicação propriamente dita e uma avaliação por parte de quem está conduzindo a implantação.

Por se tratar de uma etapa longamente discutida, não será retomada. 


\section{Subetapa 5I: acompanhamento e avaliação das implantações piloto}

Essa é mais uma atividade de grande importância a ser realizada pela equipe de implantação. Caberá à ela, acompanhar o processo de implantação das obras piloto, observando e registrando os resultados que estão sendo obtidos.

São diversos os objetos de controle que esta equipe deverá estar observando, sendo destacados, na seqüência, alguns mais relevantes:

\section{- a eficiência da etapa de projeto}

$\rightarrow$ o processo de elaboração de projeto incorporou as recomendações contidas nos procedimentos?;

$\rightarrow$ houve algum tipo de alteração? por que?;

$\rightarrow$ houve dificuldades na elaboração do projeto?;

$\rightarrow$ os projetos foram elaborados em tempo de atender à produção?;

$\rightarrow$ a obra utilizou o projeto como fonte de informação para a realização da atividade?;

$\rightarrow$ houve alteração na obra, com relação ao que foi projetado?;

$\rightarrow$ há dificuldades na leitura dos projetos?

- a eficiência do repasse da tecnologia em campo

$\rightarrow$ a gerência conduziu adequadamente a implantação: realizou os treinamentos, fez a aquisição dos materiais, preparou a aplicação?;

$\rightarrow$ houve dificuldades de treinamento da mão-de-obra?;

$\rightarrow$ houve resistência dos operários com relação à nova tecnologia?;

$\rightarrow$ a mão-de-obra está utilizando os procedimentos recomendados?;

$\rightarrow$ houve problemas na aquisição dos materiais e equipamentos?

- a eficiência dos procedimentos de controle

$\rightarrow$ a obra está realizando o controle de produção e aceitação? Se não estiver, deve-se identificar as razões;

$\rightarrow$ existem deficiências nos procedimentos?;

$\rightarrow$ é de difícil condução?

Com os dados levantados de diversas aplicaçōes piloto, é possivel identificar se a implantação está ou não se efetivando na empresa. 
Caso os resultados obtidos não estejam dentro das expectativas inicialmente colocadas, deve-se fazer um diagnóstico da situação procurando identificar os gargalos, a fim de que os mesmos possam ser eliminados e a implantação possa 'fluir' sem problemas dentro da estrutura organizacional da empresa.

Em se tendo mais de um empreendimento, será possivel analisar se os problemas são localizados, caracterizando falhas na gestão da produção ou se os problemas tem sua origem na gestão da implantação.

É por isso que, nessa etapa, existe a subetapa $5 \mathrm{~J}$, na qual se procura identificar e eliminar os problemas, preparando a equipe para uma nova aplicação piloto.

Pode ocorrer que os procedimentos que deram origem à implantação piloto estejam com problemas. Se for isso, eles deverão ser revisados e uma nova implantação deverá ser feita, ainda numa escala piloto, antes de se disseminar por toda a empresa.

No entanto, pode ocorrer também que a organização da empresa não esteja completamente preparada para o processo de implantação. Podem ser exigidas mudanças no processo de projeto, no processo de suprimentos e até mesmo na contratação de pessoal.

Somente depois que se tenha atingido resultados satisfatórios dessa etapa é que se deve passar à consolidação dos procedimentos, na etapa 6 , discutida a seguir.

\section{b) $6^{2}$ ETAPA: documentação consolidada}

A documentação para a condução da implantação de TCR's deve ser sempre constituída de:

- procedimentos para projeto;

- procedimentos para a execução;

- procedimentos para o treinamento; e

- procedimentos para o controle. 
Todos esses procedimentos deverão refletir exatamente o sistema de produção da empresa. Por isso, o seu desenvolvimento vem passando por diversas aplicações, seguidas por uma consistente análise dos resultados e posterior revisão dos documentos, sempre numa contínua evolução dos conhecimentos e experiências registrados.

No item 5.4.2, em que se discutiu a diretriz fundamental de se desenvolver a documentação da empresa, procurou-se deixar claro que esses documentos devem ser sempre a referência para a produção. Devem constituir um Banco de Tecnologia Construtiva, efetivamente utilizado, e não se resumirem em "pilhas de papel" a preencher as prateleiras ou arquivos da empresa.

A documentação constitui o que se pode chamar de "memória" da empresa, a qual não é perdida quando alguém vai embora e a qual pode ser facilmente recuperada para proporcionar o aprendizado daqueles que irão chegar.

Por ser uma "memória" deve ser usada constantemente e deve ser dinâmica, ou seja, deve ser capaz de incorporar novos conhecimentos e evoluir sempre.

Portanto, o fato de ter sido chamada de "documentação consolidada", não significa que seja imutável, mas sim que seja de domínio do sistema produtivo da empresa.

A sua elaboração final deverá ficar sob a responsabilidade da equipe de implantação, a qual deverá incorporar as últimas revisões e sugestões, após a aplicação piloto.

Além disso, caberá à essa equipe a responsabilidade pela revisão constante dos procedimentos, a partir das informações que deverão chegar das diversas obras da empresa e, também, das nova tecnologias que poderão aparecer no mercado.

A partir da documentação consolidada, pode-se iniciar a última fase da implantação, que consiste na disseminação das TCR's em toda a empresa e na manutenção do processo de "inovação", discutida a seguir. 


\subsubsection{4 $4^{a}$ FASE - Disseminação e consolidação das TCR's}

A disseminação e consolidação das TCR's na cultura da empresa consistem na última fase da metodologia proposta. Nessa fase, através do emprego da tecnologia em todos os empreendimentos e sua constante avaliação, é possivel revisar a documentação relativa à tecnologia em questão, permitindo a sua melhoria contínua.

Essa fase é constituída de duas etapas estratégicas: a disseminação da tecnologia por toda a empresa (etapa 7) e a manutenção do processo de "inovação (etapa 8).

\section{a) $7^{a}$ ETAPA: disseminação da tecnologia por toda a empresa}

Essa etapa da metodologia tem por objetivo repassar as TCR's estudadas e testadas, para todas as obras da empresa construtora. Para isso, alguns passos são fundamentais para que o processo não seja atropelado. Esses passos, discutidos a seguir, estão ilustrados no fluxograma da figura 5.14.

\section{Subetapa 7A: planejamento da disseminação}

Para que as TCR's atinjam adequadamente todas as obras da empresa, sua disseminação precisa ser bem planejada e para isso deverão ocorrer os seguintes passos:

- divulgação da documentação consolidada a todas as obras da empresa (subetapa 7B);

- treinamento de toda a equipe técnica objetivando o repasse da tecnologia, bem como os procedimentos gerenciais (subetapa $7 \mathrm{C}$ );

- preparação da infra-estrutura (subetapa 7D).

\section{Subetapas 7B: divulgação da documentação}

O conjunto de procedimentos de projeto, execução, treinamento e controle deverão chegar ao conhecimento de todas as pessoas que formam a empresa, como uma maneira de consolidar o seu conhecimento tecnológico. 


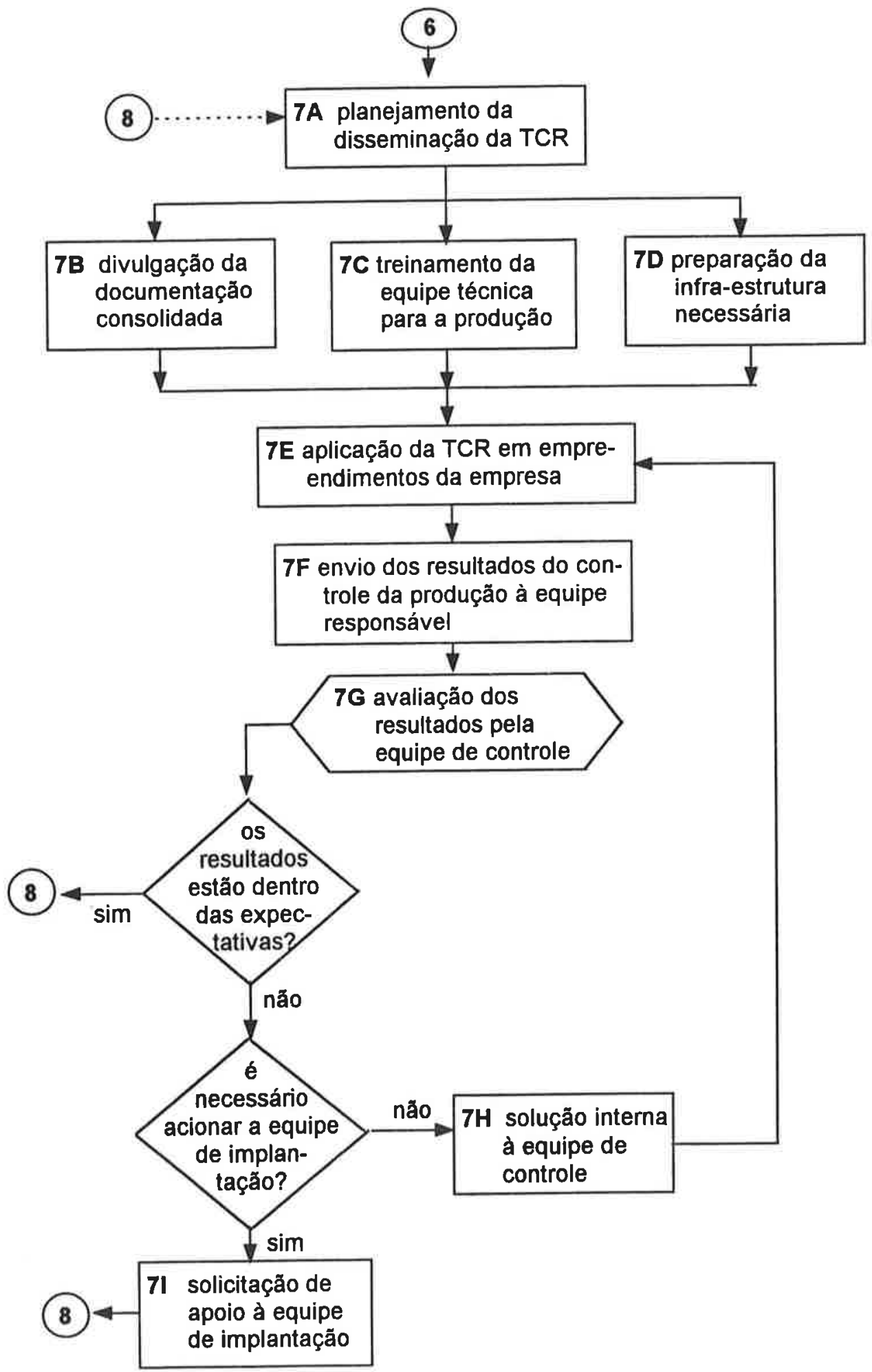

FIGURA 5.14: Fluxograma da etapa 7 - Disseminação da tecnologia na cultura da empresa 
É possivel que alguns documentos não circulem por toda a empresa, como por exemplo os relativo a projeto. Tais procedimentos poderão ser encaminhados somente àqueles que participam da elaboração dos projetos; entretanto, a idéia de que todos tenham acesso à documentação é interessante à medida em que muitos poderão analisar os documentos e inclusive contribuírem com opiniões importantes para a sua constante evolução.

As etapa de divulgação da documentação e a de treinamento da equipe técnica poderão ocorrer ao mesmo tempo, utilizando-se o mesmo evento.

\section{Subetapa 7C: treinamento da equipe técnica}

O plano tático para o treinamento, nessa etapa, poderá ser semelhante ao empregado na etapa de aplicação piloto, sendo que nesse momento a equipe deverá estar ampliada, envolvendo toda a equipe técnica que compōe a empresa.

Pode-se realizar o treinamento em duas fases distintas. Uma envolvendo as gerências e a equipe de produção e outra, envolvendo os mestres e encarregados, por exemplo. É importante que toda a equipe da empresa, inclusive a de produção, participe do treinamento, através do qual deve-se mostrar a importância das pessoas no processo de implantação e a importância desse processo para o crescimento tecnológico da empresa.

Nesse treinamento a equipe de controle deverá divulgar os critérios que serão utilizados para se proceder ao controle da implantação das TCR's em cada obra, ou seja, deverá deixar claro como será a atuação dessa equipe para verificar se os procedimentos estão sendo cumpridos e se estão levando aos resultados esperados.

Esses critérios fazem parte do plano tático da empresa e poderão envolver as mais variadas formas de motivação da equipe, podendo-se propor, inclusive, a participação da equipe nos resultados obtidos.

\section{Subetapa 7D: preparação da infra-estrutura}

Diz respeito, principalmente, à providência dos equipamentos especiais 
empregados na aplicação das TCR's. A centralização da aquisição desses equipamentos numa etapa de preparação da implantação evita que cada gerente de obras venha a dar soluções diferenciadas para os mesmos. Nesse momento, a preparação da infra-estrutura já deverá estar a cargo da equipe de suprimentos, devidamente orientada pela equipe de implantação.

\section{Subetapas 7E, 7F e 7G: aplicação das TCR's e envio e avaliação dos resultados}

Essas subetapas deverăo ser completamente conduzidas dentro da estrutura organizacional da empresa, com a participação de todas as equipes envolvidas: projeto, produçāo, suprimentos e controle.

A aplicação das TCR's, nesta etapa, deve ser feita implantando-se, inclusive, os mecanismos de controle previstos no procedimento. Realizando o controle do processo, a equipe de produção terá dados para encaminhar à equipe de controle.

Caberá à equipe de controle receber os dados das obras, referentes à implantação. Através desses dados, poderá avaliar o andamento do processo de implantação, ou seja, será possivel saber se a implantação das TCR's encontra-se dentro das expectativas da empresa ou não.

Além dos dados recebidos diretamente das obras, a equipe de controle poderá realizar verificações em campo, objetivando analisar o desempenho global de todas as obras da empresa, como discutido no item 5.4.5.

Com os dados recebidos da obra ou mesmo através da sua própria avaliação, a equipe de controle poderá tomar a decisão de acionar a equipe de implantação, seja para efetuar correções no processo, seja para comunicar-Ihe alterações que levaram à melhoria do processo.

Por isso, no fluxograma aparece um momento decisório, que poderá levar à subetapa $7 \mathrm{H}$ ou 71 .

\section{Subetapa 7H: solução interna à equipe de controle}

Quando os dados enviados pelas obras ou, se as avaliações que a equipe de 
controle vier a fazer, levarem a que os resultados não coincidam com as expectativas da empresa, caberá à equipe de controle avaliar se é um problema que ela mesma pode solucionar, através de alguma intervenção no processo, ou se é o caso de acionar a equipe responsável pela implantação. Essa última equipe poderá ser acionada também quando a equipe de controle detectar alguma alteração significativa no processo de produção que possa levar a alterações nos procedimentos, a cargo da equipe de implantação.

\section{Subetapa 7I: solicitação de apoio à equipe de implantação}

A ação da equipe de implantação nessa subetapa, coincide com a ação que deverá empreender na etapa 8 , comentada a seguir.

\section{b) $8^{2}$ ETAPA: manutenção do processo de inovação}

Consiste no fluxo contínuo de melhoria que a empresa deverá empreender para cada TCR implantada.

A equipe de implantação, através de constante pesquisa no mercado, ou mesmo através de desenvolvimentos incrementais internos, poderá detectar melhorias nas TCR's implantadas, podendo propor a sua alteração.

Essa alteraçāo poderá entrar na empresa em quaisquer fases do plano de ação, como ilustra a figura 5.5. Na realidade, a fase do plano de ação que a nova tecnologia deverá ser introduzida é função da complexidade tecnológica das TCR's e de sua amplitude dentro do processo de produção do edifício.

Por isso, a equipe poderá optar pelo início do processo de implantação na etapa de estudos iniciais, ou mesmo, em etapas posteriores, como por exemplo na etapa de investigação preliminar, estudo em protótipos ou até mesmo

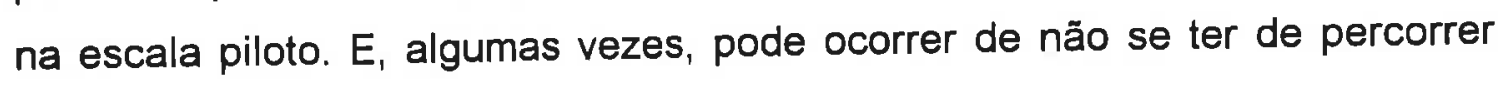
esse caminho, interferindo-se diretamente em toda a empresa.

Por isso, aparecem na figura 5.5, diversos fluxos que retornam da etapa 8 para as etapas $2,3,4,5$, e 7 . Cada retorno significa a evolução da tecnologia empregada pela empresa, em um determinado método construtivo, aumentando o seu patamar de racionalização. 


\section{CAPÍTULO 6}

\section{ANÁLISE DA METODOLOGIA DE IMPLANTAÇÃO DE TECNOLOGIAS CONSTRUTIVAS RACIONALIZADAS}

A metodologia proposta no capítulo 5 foi desenvolvida a partir de uma reflexão realizada com base em uma cuidadosa pesquisa bibliográfica sobre 0 assunto, e fundamentalmente, em diversos resultados positivos e também negativos obtidos a partir de algumas oportunidades que se teve de implantar TCR's em empresas construtoras.

Parte das proposições estabelecidas na metodologia foram aplicadas no processo de produção de edifícios de algumas empresas construtoras e muitas respostas positivas foram alcançadas; entretanto, o modelo como um todo não foi completamente testado. Mesmo assim, acredita-se que a metodologia proposta seja um instrumento de grande valia às empresas que pretendem caminhar em direção à evolução tecnológica e à melhoria contínua de seu processo de produção.

Com o objetivo de mostrar mais claramente a importância da metodologia na condução da implantação de TCR's, realizou-se uma pesquisa junto a diversas empresas construtoras, procurando-se registrar e analisar a sua conduta ao promoverem as alteraçōes tecnológicas e também as dificuldades encontradas e os principais resultados obtidos.

A pesquisa realizada envolveu um contato direto com mais de vinte empresas construtoras, referenciadas no início deste trabalho de tese, que prontamente aceitaram colaborar com o presente estudo.

Esse estudo abrangeu a identificação de características das empresas, bem como a sua atuação quanto a implantação de novas tecnologias.

Para isso, foram realizadas entrevistas com a alta gerência da empresa (diretores e gerentes técnicos e de desenvolvimento) e realizou-se também, uma série de visitas a obras dessas empresas, objetivando verificar a coerência dos dados obtidos nas entrevistas, com as aplicações nos canteiros. 
As visitas às obras, que subsidiaram a análise aqui realizada, estão registradas nos trabalhos de YOSHIDA; BARROS [1996] e NILES; BARROS [1996].

Ainda que todas as empresas tenham colaborado, de maneira fundamental, para as reflexões apresentadas no presente trabalho, não foi possivel obter de todas elas os elementos imprescindíveis à análise prevista. Assim, dentre todas as empresas pesquisadas, foram selecionadas dez, cuja caracterização foi obtida de maneira mais completa.

As características e a atuação dessas empresas, quanto à implantação de ações de racionalização serão aqui apresentadas e discutidas. Entretanto, antes de dar início à apresentação das empresas, deve-se observar que a pesquisa foi realizada ao longo do segundo semestre de 1995; portanto, retrata a situação das organizações em um momento particular.

É evidente que, num mercado "de altos e baixos", tal situação pode ter sido alterada por diversas ocorrências, como por exemplo, pelas oscilaçōes no mercado financeiro. Além disso, a própria evolução tecnológica, gerencial e organizacional que algumas das empresas vêm passando de lá para cá, podem ter contribuído para que tenham ocorrido mudanças no quadro aqui apresentado.

Não obstante a isso, essas possiveis alterações não invalidam a análise feita no presente capitulo, na medida em que, ao proceder tal análise procura-se compreender as tendências quanto ao desenvolvimento tecnológico das empresas de construção de edifícios e não apenas diagnosticar aspectos específicos.

A pesquisa realizada compreendeu uma ampla gama de informações, que envolveu as características de formação e organização das empresas e a sua forma de gerenciamento dos processos voltados: ao projeto; à documentação; aos suprimentos; aos recursos humanos; e ao controle.

Essas informações foram obtidas e registradas com o auxilio de um questionário, previamente preparado pela autora com a colaboração de pesquisadores de pós-graduação e de iniciação científica. 
Devida a extensão das informações coletadas, as mesmas não serão totalmente reproduzidas neste trabalho. Aqui, serāo apresentadas apenas aquelas que irão subsidiar a realização da análise da importância da metodologia proposta, procurando mostrar a sua validade para a condução do processo de implantação de TCR's.

Para isso, no presente capitulo, inicialmente será feita uma breve caracterização das empresas selecionadas, a fim de se identificar os fatores que as motivaram a procurar as novas tecnologias.

$\mathrm{Na}$ seqüência, serão destacadas as principais alterações tecnológicas que vêm sendo introduzidas no processo de produção dessas empresas. $E$, a partir dessas informaçōes, passa-se a apresentar e analisar a atuação das empresas pesquisadas quanto:

- à sua organização para a condução do processo de aplicação das novas tecnologias;

- ao processo de desenvolvimento dos projetos;

- ao processo de desenvolvimento da documentação;

- à organização do setor de suprimentos;

- à organização do setor recursos humanos; e

- às ações para o controle do processo de produção.

Ao se proceder essa análise, com enfoque para os principais resultados que as empresas obtiveram e para as principais dificuldades encontradas, tem-se por objetivo mostrar a importância e a validade da metodologia proposta, considerando-se as suas diretrizes balizadoras e o seu plano de ação.

\subsection{Caracterização das Empresas Participantes da Pesquisa}

As empresas estudadas foram escolhidas como objeto da pesquisa porque, de algum modo, manifestaram a preocupação e o empenho de alterar o seu processo de produção, a fim de alcançar a sua evolução tecnológica, organizacional e gerencial.

Com algumas delas o contato estabelecido foi mais estreito, porque se tratam de empresas que vêm trabalhando diretamente com os pesquisadores do 
CPqDCC-EPUSP, tanto através de consultorias técnicas, quanto por meio de projetos de pesquisa conveniados, objetivando a implantação das TCR's no seu sistema de produção. Outras foram contatadas pela pesquisadora, especialmente para a realização deste trabalho.

A razão social de cada uma das empresas que participaram da pesquisa não será identificada ao longo desta apresentação, para que se preserve a privacidade de cada uma delas. Este fato, no entanto, não invalida a análise.

As empresas serão identificadas por meio de letras, as quais não guardam relação com os seus nomes, nem mesmo com a ordem estabelecida no início do trabalho de tese quando as mesmas foram nominalmente citadas.

\subsubsection{Porte e a área de atuação das empresas}

Procurando-se dar uma idéia do porte e da área de atuação das empresas, apresenta-se na tabela 6.1 suas características principais.

Todas as empresas atuam no mercado paulista, sobretudo na capital e grande São Paulo, sendo que uma delas é do interior do Estado, com atuação também na capital.

A tabela 6.1 possibilita concluir que se tratam, na sua maioria, de empresas "jovens", ou seja, foram fundadas a partir de fins da década de 80 . Além disso, considerando-se a produção anual de cada uma, podem ser consideradas empresas de pequeno a médio porte ${ }^{1}$, que representa o perfil da maioria das empresas que atuam no segmento de produção de edifícios.

Apenas a empresa "D" foge a esse perfil, caracterizando-se por ser uma empresa de grande porte, com cerca de 30 anos de atuação no mercado. Sua introdução no conjunto das empresas pesquisadas deu-se em função dos intensos trabalhos que vêm sendo realizados pelos pesquisadores do CPqDCC, objetivando o repasse de TCR's ao sistema produtivo dessa empresa, o que proporcionou um valioso aprendizado.

\footnotetext{
1 A caracterização do porte da empresa não foi realizada em função do número de funcionários, como ocorre, de modo geral, nos diversos setores industriais, porque na amostra existem empresas que trabalham exclusivamente com mão-de-obra de subempreiteiras e outras que trabalham tanto com mão-de-obra subempreitada quanto com mão-de-obra própria, o que levaria a uma distorção nessa classificação.
} 
TABELA 6.1: Caracterização das empresas que participaram da pesquisa

\begin{tabular}{|c|c|c|c|c|}
\hline empresa & $\begin{array}{c}\text { ano da } \\
\text { fundação }\end{array}$ & $\begin{array}{l}\text { número de } \\
\text { funcionários }\end{array}$ & $\begin{array}{c}\text { área } \\
\text { construida } \\
\text { anualmente }\end{array}$ & áreas de atuação(2) \\
\hline "A" & 1983 & $85^{(3)}$ & 10.000 & $(1) ;(C) ;(H)$ \\
\hline "B" & 1986 & $200^{(4)}$ & 13.500 & $(\mathrm{I}) ;(\mathrm{C}) ;(\mathrm{H}) ;(\mathrm{Com})$ \\
\hline "C" & 1986 & $38^{(3)}$ & 11.500 & (I); (C); (H); (Com) \\
\hline "D" & 1966 & $2500^{(4)}$ & 126.000 & $(\mathrm{I}) ;(\mathrm{C}) ;(\mathrm{H}) ;(\mathrm{Com}) ;(\mathrm{Ind}) ;(\mathrm{P})$ \\
\hline "E" & 1986 & $350^{(4)}$ & 14.000 & (I); (C); (H); (Com); (Ind) \\
\hline "F" & $1986^{(5)}$ & $140^{(4)}$ & $5.500^{(6)}$ & $(\mathrm{I}) ;(\mathrm{C}) ;(\mathrm{H}) ;($ Com); (Ind) \\
\hline "G" & 1980 & $150^{(4)}$ & 10.000 & $(\mathrm{I}) ;(\mathrm{C}) ;(\mathrm{H}) ;(\mathrm{Com})$ \\
\hline "H" & 1977 & $190^{(4)}$ & 13.700 & $(\mathrm{I}) ;(\mathrm{C}) ;(\mathrm{H}) ;(\mathrm{Com})$ \\
\hline "I" & 1986 & $600^{(4)}$ & (7) & $(\mathrm{I}) ;(\mathrm{C}) ;(\mathrm{H}) ;(\mathrm{Com}) ;(\mathrm{P})$ \\
\hline "J" & 1994 & $14^{(3)}$ & 10.000 & $(\mathrm{I}) ;(\mathrm{C}) ;(\mathrm{H}) ;(\mathrm{Com})$ \\
\hline
\end{tabular}

(1) refere-se ao total de área construída desde a fundação da empresa até os dias atuais, dividido pelo tempo de permanência da empresa no mercado, considerando-se todas as suas áreas de atuação.

(2) legenda utilizada para este item: (1) incorporação; $(C)$ construção; $(H)$ habitação; (Com) comércio; (Ind) indústria; $(P)$ obras públicas.

(3) a empresa trabalha exclusivamente com mão-de-obra empreitada. Nesse total de mão-de-obra encontra-se apenas o pessoal de escritório e administrativo de obra (engenheiro, mestres e encarregados).

(4) a empresa trabalha com mão-de-obra própria nas atividades administrativas e em algumas atividades de produção e, também, com mão-de-obra de terceiros para serviços específicos, sendo que o número de funcionários apresentados não inclui a mão-de-obra de terceiros.

(5) a empresa foi fundada em 1977, tendo passado por uma reformulação em 1886, a partir de quando os dados foram considerados.

(6) no total de área construída foram considerados apenas os edifícios habitacionais que a empresa construiu.

(7) realizaram um total de 267 obras, as quais incluem diversos tipos de edificios. Por ocasião da entrevista estavam em construção 8 edifícios de escolas. Estava para ser iniciado um edifício habitacional, por incorporação. 
Todas as empresas atuam no mercado habitacional, tanto como construtoras que prestam serviços a terceiros, e também, como incorporadoras de seus empreendimentos.

Além disso, atuam na construção de edifícios comerciais tais como edifícios de escritórios e "shopping centers" e algumas atuam, inclusive, na construção de edifícios industriais. Apenas as empresas "D" e "l" atuam com obras públicas, incluindo-se infra-estrutura.

Considerando-se que o enfoque do trabalho é a racionalização da produção de edifícios de múltiplos pavimentos construídos pelo processo construtivo tradicional, o foco da pesquisa centrou-se na investigação das tecnologias construtivas empregadas na produção desses edifícios, tanto para o caso dos habitacionais, como dos comerciais.

\subsubsection{A motivação para a introdução de mudanças tecnológicas}

Com o objetivo de identificar os motivos que levaram as empresas a introduzirem novas tecnologias, uma das questōes feitas durante a pesquisa foi: Porque as alterações tecnológicas foram introduzidas?

As empresas foram unânimes em responder que um dos motivos principais tem sido a elevada competitividade atualmente existente no mercado, a qual vem exigindo a diminuição dos custos de produção, que tem sido buscada através de:

- eliminação dos desperdícios de materiais - $60 \%$ das empresas;

- eliminaçăo dos desperdícios de mão-de-obra - $60 \%$ das empresas;

- diminuição da incidência de problemas patológicos - 30\% das empresas;

Outros fatores também apresentados como motivadores da introdução de mudanças tecnológicas foram:

- aumento da qualidade dos serviços executados - $40 \%$ das empresas;

- maior competência tecnológica - $30 \%$ das empresas;

- aumento da produtividade - $30 \%$ das empresa.

Segundo depoimentos de algumas empresas, o preço de venda dos imóveis 
tem caído e o custo de produção tem aumentado. Além disso, a saturação de alguns segmentos de mercado, como por exemplo, a produção por preço de custo, tem levado as empresas a atuarem em um mercado mais competitivo, o de preço fixo, no qual, pelo depoimento do diretor técnico da empresa " $A$ ": "as incertezas não são repassadas para o custo do imóvel, mas devem ser absorvidas pela empresa".

Frente a essa realidade de mercado, as empresas passaram a analisar o seu sistema de produção e a maioria delas identificou que o emprego de novas tecnologias, que pudessem imprimir um menor custo ao processo de produção, seria uma das alternativas a serem consideradas. Apenas a empresa "G" optou pelo desenvolvimento dos recursos humanos como prioridade e, em segundo plano, a aplicação de novas tecnologias construtivas.

\subsection{Principais Alterações Tecnológicas Introduzidas pelas Empresas}

São diversas as mudanças tecnológicas encontradas nos canteiros de obras, as quais são introduzidas, sobretudo, pela indústria de materiais e componentes. Encontram-se, em menor intensidade, algumas alterações parciais na execução propriamente dita, muitas vezes, introduzidas em função de serviços prestados pelo mercado, como por exemplo, o acabamento de lajes executado por empresas especializadas.

Ao utilizarem um novo material ou componente ou mesmo ao contratarem uma empresa especialista na execução de algum tipo de serviço, muitas construtoras acreditam que estão promovendo uma inovação no canteiro, mesmo sem considerar a inserção desse novo produto no processo de produção como um todo.

Assim, a pesquisa, apesar de ter identificado todas as alterações que as empresas disseram ter promovido, não se ateve àquelas que foram introduzidas sem um vínculo com do processo de produção. Procurou-se concentrar a análise nas alteraçōes que de alguma maneira implicaram numa mudança, ainda que parcial, no processo de projeto, na aquisição dos suprimentos, na forma de execução e nos mecanismos de controle.

A tabela 6.2 mostra um quadro sumário com as principais atividades que 
compõem o processo de produção dos edifícios. As atividades demarcadas constituem aquelas que vêm sendo objeto de alguma forma de racionalização promovida pelas empresas.

TABELA 6.2: Atividades do processo de produção que vêm sendo alvo de ações de racionalização por parte das empresas construtoras

\begin{tabular}{|c|c|c|c|c|c|c|c|c|c|c|c|}
\hline \multirow[t]{2}{*}{ empresa } & \multicolumn{3}{|c|}{ estrutura } & \multirow[t]{2}{*}{ alvenaria } & \multicolumn{2}{|c|}{ instalações } & \multicolumn{2}{|c|}{ esquadrias } & \multicolumn{2}{|c|}{ revestimentos } & \multirow{2}{*}{$\begin{array}{l}\text { impermeabi- } \\
\text { lização }\end{array}$} \\
\hline & $F$ & $\mathrm{~A}$ & c & & Hid. & Elet. & Por. & Jan. & Ver. & Hor. & \\
\hline "A" & $x$ & $x$ & $x$ & $x$ & $x$ & $x$ & & $x$ & $x$ & $x$ & $x$ \\
\hline "B" & $x$ & $x$ & $x$ & $x$ & $x$ & $x$ & $x$ & & $x$ & $x$ & $x$ \\
\hline "C" & $x$ & $x$ & $x$ & $x$ & $x$ & $x$ & & $x$ & $x$ & $x$ & $x$ \\
\hline "D" & $x$ & $x$ & $x$ & $x$ & $x$ & & $x$ & & $x$ & $x$ & $x$ \\
\hline "E" & $x$ & $x$ & $x$ & $x$ & & & & & & $x$ & $x$ \\
\hline "F" & $x$ & $x$ & $x$ & $x$ & $x$ & & & $x$ & $x$ & $x$ & $x$ \\
\hline "G" & $x$ & $x$ & $x$ & $x$ & & & & & & $x$ & $x$ \\
\hline "H" & $x$ & $x$ & $x$ & $x$ & $x$ & $x$ & & & $x$ & $x$ & $x$ \\
\hline "I" & $x$ & & $x$ & $x$ & & & & & & $x$ & \\
\hline "J" & $x$ & $x$ & $x$ & $x$ & & & $x$ & & $x$ & $x$ & $x$ \\
\hline
\end{tabular}

LEGENDA:
$\mathrm{F} \quad=$ fôrmas
Por. $=$ portas
A $\quad=$ armação
Jan. $=$ janelas
C = concretagem
Vert. $=$ vertical
Hid. = hidráulicas
Hor. = horizontal
Elet. = elétricas

Deve-se observar que algumas atividades consideradas "novas" para determinadas empresas, não o são para outras. Além disso, há, ainda, significativas diferenças tecnológicas entre as empresas pesquisadas. Por isso, considerase essencial fazer alguns comentários acerca dessas novas tecnologias que vêm sendo aplicadas nos canteiros de obras das empresas.

\subsubsection{Alterações na produção da estrutura}

As alterações identificadas na produção da estrutura foram subdivididas em alterações nos sistemas de fôrmas, na armação e na concretagem.

As mudanças identificadas para os sistemas de fôrmas referem-se ou a aquisição de um sistema do tipo "fôrma pronta", fabricado por uma empresa 
especializada a partir do projeto estrutural, ou a produção do sistema de fôrmas em canteiro, mas segundo um projeto adequado para essa atividade, ou seja, um projeto para produção. Na maioria das vezes esse projeto é desenvolvido por um escritório de terceiros, especializado nessa atividade. Há casos também em que o projeto é desenvolvido pela própria empresa, como as empresas "D" e "I" que desenvolveram seu próprio sistema de fôrmas, através de pessoal interno à empresa.

O sistema do tipo "fôrma pronta", recentemente introduzido por algumas empresa, há muito vem sendo utilizado por aquelas que, agora, partiram para o desenvolvimento de um sistema de fôrmas, próprio para o seu sistema de produção.

O projeto para produção voltado ao sistema de fôrmas, dessas empresas, tem sido desenvolvido por um único escritório especializado.

O pessoal técnico desse escritório, além de desenvolver o projeto de corte e montagem das fôrmas, orienta a produção do sistema de fôrmas no canteiro e treina os operários na primeira montagem.

Além disso, o projeto de montagem, que é uma parte do projeto para produção, proporciona mecanismos eficientes para que se estabeleça, no canteiro, o controle da montagem do sistema de fôrmas, o que possibilita uma importante melhoria no processo de produção.

As empresas " $A$ "; " $F$ " e " $H$ " vêm utilizando esse sistema de fôrmas em suas obras; enquanto as empresas " $B$ ", "C", " $E$ ", " $G$ " e "J" estão empregando o sistema tipo "fôrma pronta".

As "inovações" aplicadas à produção da armadura são de duas naturezas: o emprego de telas metálicas para as lajes e o repasse das atividades de corte $e$ dobra das armaduras, a terceiros.

O uso das telas metálicas constitui uma alteração introduzida tipicamente pela indústria de materiais e componentes. Entretanto, por afetar o dimensionamento do sistema estrutural dos edifícios, é uma mudança que deve ser introduzida desde o início do processo de produção, ainda na fase de projeto. 
São muitos os benefícios trazidos por essa ação de racionalização, sobretudo no que se refere ao aumento de produtividade; entretanto, a tela metálica não pode ser empregada para qualquer tipo de estrutura, havendo limitaçōes que devem ser consideradas no projeto.

As empresas "B", "D", "E" e "G", sempre que possível, têm empregado telas metálicas em seus empreendimentos.

Observou-se que, apesar do potencial de racionalização oferecido pelo emprego de telas metálicas, principalmente porque essas telas são introduzidas na fase de projeto, a maioria das empresas não as utiliza.

No caso do repasse das atividades de corte e dobra a terceiros, não se promove alterações de projeto, mas somente, no processo de produção.

Essa mudança de processo, entretanto, é bastante pontual. Afeta uma atividade de suporte à produção, que é o preparo da armadura, e não a produção em si, que envolveria a montagem das armaduras na laje, a qual continua sem modificação alguma.

Trata-se de uma alteração introduzida pelo mercado, que vem disponibilizando um serviço de grande interesse às construtoras; pois, ao centralizar as atividades de corte e dobra fora do canteiro, esse tipo de prestaçāo de serviço permite a redução dos desperdícios e maior produtividade. Os resultados dessa racionalização, de certa maneira, refletem-se no menor custo do serviço prestado.

Praticamente todas as empresas entrevistadas estão utilizando essa forma de produção, exceto a empresa "I", por atuar principalmente no interior do Estado, onde esse tipo der prestação de serviço é menos comum.

Quanto ao serviço de concretagem, considerando-se que o concreto é produzido fora do canteiro de obras há muito tempo, segundo a pesquisa, essa atividade não vem sofrendo alterações significativas.

As principais alteraçōes relatadas pelas empresas são devidas às características mecânicas do concreto empregado e aos equipamentos de transporte.

As empresas vêm dando preferência ao emprego de concretos de elevada 
resistência mecânica, os quais apresentam, na sua maioria, resistência a compressão característica aos 28 dias $\left(f_{c 28}\right)$ acima de $20 \mathrm{MPa}$, sendo comum o uso de concretos com $\mathrm{f}_{\mathrm{c} 28}$ de $25 \mathrm{MPa}$.

Quanto ao sistema de transporte de concreto, as empresas têm optado mais intensamente pelo sistema de bombeamento ou pelo transporte por grua.

O primeiro sistema foi identificado em obras de todas as empresas. As gruas, equipamentos menos usuais num passado ainda recente, foram identificadas em canteiros de obras das empresas "B", "C", "D", "E" e "F".

A introdução desses equipamentos, ainda que levem a um maior custo direto dos serviços, tem sido justificada pela economia indireta que trazem à obra.

Segundo depoimento do diretor técnico da empresa "J": "o uso do concreto bombeado promove uma maior produtividade da mão-de-obra na realização dos serviços de concretagem, possibilitando o seu término sem a extensão da jornada de trabalho, o que permite aos operários estarem mais descansados ao retomarem as suas atividades no dia seguinte, melhorando sensivelmente o seu rendimento".

\subsubsection{Alterações na produção das alvenarias}

A tabela 6.2, anteriormente apresentada, mostra que a alteração no método construtivo de alvenarias vem ocorrendo para todas as empresas pesquisadas. Entretanto, constatou-se significativas diferenças entre os sistemas de produção adotados pelas diversas empresas.

Algumas empresas introduziram apenas modificações pontuais, como por exemplo a retirada da junta vertical de argamassa e a não realização da fixação rígida da alvenaria com a estrutura, como é o caso das empresas " $G$ " e "l". Outras estão realizando o projeto de alvenaria, incorporando as instalações e conseguindo, até mesmo iniciar um processo de controle da produção, como é o caso das empresas " $A$ " e " $H$ ". $E$, entre esses dois extremos foram identificados outros patamares de modificações.

Devido às diferenças identificadas e, também, por ser este um subsistema que vem sendo intensamente pesquisado no CPqDCC-EPUSP, a produção das alvenarias de vedação foi um dos métodos construtivos mais enfocados pela 
pesquisa, constituindo uma das principais mudanças tecnológicas que subsidiam a análise da importância da metodologia, frente às ações das empresas, realizada no item 6.3 .

\subsubsection{Alterações na produção das instalaçōes}

Essas alterações foram identificadas num menor número de empresas e referem-se basicamente à:

- realização de um projeto de instalaçōes compatibilizado com os demais projetos do edifício;

- introdução e uso de "shafts" para a passagem das prumadas;

- desenvolvimento de "kits", sobretudo hidráulicos; e

- substituição das caixas de madeira, comumente empregadas nas passagens de laje, por elementos mais adequados à realização dessa atividade.

De um modo geral, os principais avanços que foram identificados para o serviço de instalaçōes, tiveram sua origem na alteração da produção das alvenarias, nos casos em que as instalações são incorporadas, no momento da execução da alvenaria.

Para esses casos, tem sido desenvolvido o "projeto de furação", que contém o posicionamento de todas as instalações que passam pelas lajes, a partir de um único referencial de eixos cartesianos, definido para todos os projetos. Esses mesmos eixos deverão ser os materializado na obra, otimizando-se, com isso, a locação dos elementos.

Para a realização do "projeto de furação" é imprescindível a compatibilização dos demais projetos do edifício, o que possibilita a identificação prévia de interferências, minimizando os problemas comumente identificados na obra, no momento da execução.

Observou-se, entretanto, que a produção das instalações tanto elétricas como hidráulicas têm um grau de racionalização ainda insipiente, havendo muito que evoluir para que a produção possa ser atendida.

De um modo geral trata-se de uma atividade realizada por subempreiteiros especializados, para a qual o controle de produção ainda é precário. Há 
somente três empresas que utilizam mão-de-obra própria para a realização desse serviço, as empresas "D", "E" e "l".

\subsubsection{Alteraçōes na produção das esquadrias}

As novidades nesse subsistema são ainda difusas. As empresas que consideram ter "inovado" na produção das esquadrias de portas, referem-se ao emprego do batente de madeira aplicado com espuma de poliuretano. Algumas, apesar de estarem utilizando esse tipo de serviço, nem mesmo o classificaram como uma "inovação", como é o caso das empresas " $A$ " e " $C$ ", por exemplo.

O uso da espuma de poliuretano é uma inovação introduzida tipicamente pela indústria de materiais e componentes. Na maioria dos casos, a decisão pelo emprego do poliuretano é tomada no momento da colocação dos batentes, ou seja, não se realiza um projeto prévio, os vãos não são compatibilizados e analisados com antecedência; muitas vezes sobram "folgas" indesejáveis. Tudo isso caracteriza uma completa desvinculação dessa tecnologia com o processo de produção do edifício.

Ainda com relação aos batentes foi identificado também o emprego de batentes metálicos aplicados em conjunto com a alvenaria. Ao contrário do método construtivo anterior, o uso do batente metálico exige um projeto prévio da esquadria, no qual deve ser prevista a sua compatibilidade aos vãos da alvenaria e da estrutura, bem como aos revestimentos a serem aplicados.

Considerando-se o atual processo de produção do edifício, a incorporação do batente metálico traz uma série de benefícios. Exige a compatibilidade prévia de projetos, o que ajuda a minimizar os improvisos na obra, e ainda, funciona como um gabarito durante a execução da alvenaria, auxiliando na racionalização dessa atividade.

Não obstante às suas vantagens para a produção, segundo informações das empresas construtoras, o batente metálico tem pouca aceitação junto aos usuários do edifício; por isso, apresenta uma reduzida utilização. Seu emprego foi identificado apenas em uma das construtoras pesquisadas, que não consta das aqui apresentadas. 
No caso das esquadrias de janelas, as três empresas que manifestaram a alteraçăo, empresas " $A$ ", " $C$ ", e " $F$ ", estão contratando projetistas que, além de desenvolver o projeto da esquadria, acompanham a sua fabricação.

Entretanto, nestes casos, identificou-se que se trata mais de um desenvolvimento de produto do que de processo, pois o projeto da esquadria não contempla questões sobre a sua forma de fixação na obra. Além disso, o acompanhamento da aplicação da esquadria na obra, ainda não é sistematizado pelas empresas.

Ainda que não tenha sido registrado pelas empresas, identificou-se, também, alguns casos de aplicação de contramarcos pré-moldados de concreto, os quais vem sendo vagarosamente introduzidos nos sistemas produtivos das empresas. Esse componente pré-moldado, se bem integrado ao processo construtivo, pode trazer importantes benefícios ao ritmo de produção do edifício, assim como o batente metálico.

As empresas "B" e "C" estão realizando um trabalho conjunto, objetivando o desenvolvimento desse componente em parceria com uma empresa de prémoldados de concreto.

\subsubsection{Alterações na produção dos revestimentos}

No caso dos revestimentos verticais, as denominadas "inovações" referem-se ao emprego de argamassas industrializadas para os revestimentos de fachada e aplicação de revestimento de gesso interno, diretamente sobre a alvenaria, sem emboço. Há, ainda, algumas empresas que, para o caso dos revestimentos internos, iniciou a aplicação de revestimentos cerâmicos diretamente sobre a alvenaria, com o uso de argamassas colantes flexiveis.

O emprego da argamassa industrializada na fachada ou mesmo no interior dos edifícios tem se resumido à introdução de um novo material, em substituição às argamassas produzidas em canteiro.

Essa substituição, ainda que introduza um grande potencial de racionalização, sobretudo quanto à organização do canteiro, muitas vezes, é realizada sem que sejam consideradas as características próprias dos materiais antigo e novo, o que pode conduzir a sérios problemas patológicos nesse subsistema. 
Em alguns casos identificou-se o emprego de argamassas industrializadas somado à introdução de novos equipamentos, como é o caso da empresa "B", que vem empregando, em conjunto, um andaime fachadeiro e um equipamento de projeção de argamassa, os quais introduzem um grande potencial de alteração no processo de produção.

Quando do emprego do andaime fachadeiro, é mais fácil introduzir as etapas de mapeamento e taliscamento da fachada ${ }^{2}$. Essas etapas são mais difíceis de serem introduzidas no método tradicional de produção de revestimentos através de balancins, em particular, pela dificuldade de sua movimentação ao longo da fachada.

Além disso, o uso do andaime fachadeiro contribui, também, para o controle do processo de execução dos revestimentos, pois permite o acesso a toda a fachada, sem a necessidade de deslocamento do equipamento, o que não é possivel com os balancins tradicionais.

No caso da aplicação do revestimento cerâmico ou de gesso diretamente sobre a alvenaria, sem emboço, citado por algumas empresas como sendo uma "inovação", considera-se que seja uma decorrência direta da racionalizaçāo da alvenaria, sem o que, essas aplicações não seriam possíveis.

A regularidade geométrica do pano de alvenaria e a rugosidade superficial uniforme têm possibilitado o emprego de revestimentos de menor espessura, sendo possivel suprimir o emboço, comumente conhecido como camada de regularização. Entretanto, a regularização não é a única e nem mesmo a principal função do emboço e a supressão dessa camada não deve ser feita sem a adoção de critérios técnicos adequados, que levem em consideração as demais variáveis que interferem no comportamento dos revestimentos.

De modo geral, as empresas nem sempre consideram esses critérios e não raras vezes são identificados problemas nesses revestimentos, tais como fissuras e descolamentos.

\footnotetext{
${ }^{2}$ As etapas de mapeamento e taliscamento da fachada fazem parte da tecnologia construtiva racionalizada da produção de revestimentos argamassados exteriores e têm por objetivo a minimização e a garantia das espessuras do revestimento. Tais procedimentos são propostos por SABBATINI [1995].
} 
No que se refere às inovações citadas para os revestimentos horizontais, tratam-se sobretudo, da obtenção da laje nivelada, para o recebimento de contrapiso com espessuras mínimas ou da laje nivelada e acabada, para a aplicação direta da camada de acabamento (carpete, cerâmica, etc.).

A execução dessas lajes vem ocorrendo das mais diferentes maneiras, tendose posturas distintas das empresas quanto ao seu processo de produção.

Há empresas que vêm assumindo a sua produção, como é o caso, por exemplo, das empresas "B", "D" e "J"; enquanto as demais têm optado pela contratação de empresas especializadas nessa atividade.

Para a produção dessa laje, as empresas que estão produzindo com mão-deobra própria tiveram de realizar investimentos em equipamentos, tais como nivel a "laser", acabadoras de superfície e também em treinamento de sua mão-de-obra.

No que se refere à realização do projeto para produção, as açōes não têm sido homogêneas entre as empresas, tendo-se identificado diferentes níveis de desenvolvimento.

As diferenças acentuadas de postura entre as empresas motivou uma observação mais cuidadosa por parte da autora, constituindo também um importante objeto para a fundamentação da análise, realizada no item 6.3.

Além disso, a importância dessa atividade no conjunto das ações de racionalização empreendidas pelas empresas motivou também a elaboração de uma dissertação de mestrado, em fase final de conclusão [SOUZA, 1996].

\subsubsection{Alterações na produção das impermeabilizações}

As alterações identificadas referem-se, principalmente, aos sistemas de impermeabilização utilizados nas áreas molháveis internas dos edifícios, tais como, cozinhas, áreas de serviços, banheiros, boxes de banheiro e sacadas.

Em alguns desses locais, muitas empresas simplesmente suprimiram o sistema de impermeabilização, como por exemplo nas cozinhas, áreas de serviço e banheiros. Outras empregam, para esses locais, os sistemas poliméricos de membranas acrílicas, tradicionalmente disponiveis no mercado. 
A novidade mais significativa vem ocorrendo para os sistemas de impermeabilização utilizados para os boxes de banheiro e sacadas. Nesses casos, os sistemas de impermeabilização com mantas ou membranas asfálticas vêm sendo gradativamente substituidos por um sistema denominado "argamassa polimérica".

Através da pesquisa, pôde-se identificar que esse sistema consiste na produção de uma argamassa plástica, com teor de cimento da ordem de $450 \mathrm{~kg}$ por metro cúbico de argamassa, à qual é acrescentado um polímero, em geral acrílico, cujo teor tem variado de $5 \%$ a $20 \%$ do peso de cimento.

Identificou-se, também, que muitas empresas vêm realizando o projeto de impermeabilização, possibilitando a disseminação dessa nova tecnologia. Além disso, é comum que a execuçāo dos serviços seja realizada por empresas especializadas, o que tem facilitado a aplicação dessa nova tecnologia nos canteiros de obras.

Por ser uma tecnologia recentemente introduzida nas obras e devido aos poucos estudos disponíveis, a maioria das empresas consultadas, apesar de estarem empregando o sistema de argamassa polimérica, não conhecem exatamente o seu desempenho. Essas empresas têm manifestado dúvidas quanto à quantidade e tipo de polímero utilizado, bem como, com relação ao teor de cimento na argamassa. Trata-se, portanto, de uma tecnologia que merece ser melhor pesquisada e desenvolvida em trabalhos futuros.

\subsection{Análise das Ações das Empresas e a Importância da Metodologia para Implantação de TCR's}

As mudanças tecnológicas anteriormente destacadas estão sendo introduzidas nos sistemas produtivos das empresas a partir de uma série de ações que as mesmas vêm empreendendo sem, no entanto, seguirem uma metodologia adequada.

São ações definidas, muitas vezes, pelo "sentimento" e pela "percepção" das pessoas que dirigem a empresa que, pela sua experiência e vontade de melhorar, procuram os novos produtos e métodos construtivos disponíveis no mercado. 
Essas empresas, geralmente na base da "tentativa e erro", procuram aumentar o grau de racionalização de seu sistema de produção.

Através da pesquisa realizada é possivel mostrar que, apesar de não empregarem, na íntegra, a metodologia proposta, as empresas vêm adotando algumas das diretrizes estabelecidas neste trabalho $e$, com isso, têm obtido resultados positivos quanto à racionalização do processo de produção.

Entretanto, como essas empresas ainda nāo conseguiram definir uma metodologia de atuação, que considere a implantação de TCR's como uma ação sistêmica que deve envolver toda a empresa e não apenas pontos isolados, elas permanecem com resultados que oscilam de um empreendimento para outro e muitas vezes, aquém do esperado. Ou seja, o processo de modernização tecnológica, organizacional e gerencial não chegou a se fixar em nenhuma dessas empresas.

A metodologia proposta no capítulo 5 possibilita realizar a implantação de TCR's no canteiro de obras considerando-a no seu todo, ou seja, a partir de uma visão sistêmica do processo de produção do edifício e não, como uma atividade isolada no momento da execução dos serviços.

Por isso, a análise que procura mostrar a validade de se aplicar a metodologia proposta será feita considerando-se as ações das empresas e os resultados que vêm sendo obtidos, à luz das premissas e diretrizes estratégicas estabelecidas pela metodologia. Para isso, serão analisados os seguintes pontos:

- a organização da empresa voltada ao processo de implantação;

- a aplicação da nova tecnologia aos projetos do edifícios;

- a organização da documentação que dará suporte ao sistema de produção;

- o desenvolvimento de ações objetivando os recursos humanos;

- a organização do setor de suprimentos, voltada à nova tecnologia;

- a implantação de um sistema de controle.

\subsubsection{Organização da empresa voltada ao processo de implantação}

Nem todas as empresas pesquisadas estão num mesmo patamar de racionalização do processo de produção. 
Ainda que todas tenham manifestado a procura da racionalização como uma resposta às demandas do mercado, algumas saíram na frente priorizando essa alternativa; enquanto outras não concretizaram essa vontade através de ações efetivas.

O comprometimento da empresa, como discutido no capítulo 5 envolve, não apenas a vontade de evoluir, mas a destinação dos recursos para realizar essa intenção.

Dentre os recursos exigidos, a existência de um lider no comando do processo e a identificação de novas tecnologias, passíveis de serem aplicadas ao processo de produção, são elementos essenciais, os quais serão destacados nessa análise.

\subsubsection{Existência de um líder}

A organização de um setor, ou mesmo a destinação de um líder voltado exclusivamente às atividades relacionadas com a implantação de novas tecnologias, mostra claramente a prioridade da empresa no sentido de alcançar a sua evolução.

A busca do aumento da qualidade e da certificação da qualidade através das normas NBR-ISO 9000 [ABNT, 1994a], têm levado as empresas de grande porte a destinarem um setor exclusivo para o desenvolvimento tecnológico e qualidade. Esse é o caso da empresa "D".

Entretanto, é mais difícil existir esse setor quando se tratam de empresas de pequeno e médio porte.

No grupo das pequenas e médias empresas apenas a empresa "H" apresenta em seu organograma funcional um departamento voltado à implantação de novas tecnologias.

No caso da empresa "D", o departamento é constituido por três engenheiros, quatro técnicos e dois estagiários. Na empresa " $H$ ", o setor de desenvolvimento tecnológico tem apenas um engenheiro, auxiliado por três estagiários, o que tem sido totalmente compativel com o número de obras que constrói de uma só vez. 
A existência de um setor completamente voltado à implantação de novas tecnologias faz com que as ações dessas duas empresas ganhem velocidade, pois existe alguém cuja preocupação maior é fazer a tecnologia acontecer nos canteiros de obras.

As obras visitadas da empresa " $\mathrm{H}$ " mostraram claramente a importância de se ter um líder do processo, devidamente capacitado, sempre presente nos momentos principais das implantações.

A produção da alvenaria racionalizada, a partir de um projeto já é uma realidade nessa empresa. O projeto é desenvolvido pelo próprio gerente de desenvolvimento, auxiliado por um desenhista. $O$ treinamento tanto dos engenheiros de campo, quanto das equipes de trabalho, envolvendo a leitura do projeto e a execução da alvenaria é conduzido também por esse engenheiro. Um operário que executa a alvenaria, que inicialmente produzia cerca de $15 \mathrm{~m}^{2}$ por dia, após o treinamento passou a produzir de 25 a $30 \mathrm{~m}^{2}$ por dia.

Além disso, durante a última visita realizada a um dos canteiros dessa empresa, pôde-se observar o treinamento dos estagiários para iniciarem as atividades de controle da produção, a partir de procedimentos elaborados pelo gerente de desenvolvimento, auxiliado por um consultor externo à empresa.

A produção da alvenaria racionalizada não é a única tecnologia nova que vem sendo implantada por essa empresa. Açōes bem organizadas objetivando a produção racionalizada da estrutura e das impermeabilizações com argamassa polimérica também estão sendo empreendidas em conjunto, sempre lideradas pelo gerente de desenvolvimento.

No caso da empresa " $D$ ", a presença de uma equipe de desenvolvimento tem sido fundamental para a evolução tecnológica da empresa. No último ano a empresa estava construindo, ao mesmo tempo, cerca de 18 obras de edifícios.

Além do elevado número de empreendimentos, a descentralização das decisões é um elemento marcante nas caracteristicas administrativas dessa empresa. Até o início da atuação da equipe de desenvolvimento, cada gerente podia conduzir as suas obras segundo o seu conhecimento e experiência. Não existiam diretrizes para a condução das atividades de canteiro. 
Para reverter essa situação, além da vontade expressa da alta diretoria da empresa, é preciso realizar um trabalho extenso e intenso. Dessa forma, se não houvesse uma equipe trabalhando com o objetivo principal de implantar as TCR's, elas jamais poderiam vir a ser disseminadas por toda a empresa, como hoje estão sendo.

Atualmente, existem em andamento cerca de 15 obras de edifícios construídos pelo processo construtivo tradicional. Em todos eles está sendo produzida a laje nivelada e, em alguns deles tem havido o controle de produção.

Além disso, para alguns dos edifícios, a alvenaria está sendo produzida a partir de um projeto que prevê a modulação dos componentes ainda que parcialmente $^{3}$ e a incorporação das instalações.

As atividades objetivando a produção racionalizada da laje foram completamente desenvolvidas pela equipe de desenvolvimento, em compatibilidade com o sistema de fôrmas, o qual também foi desenvolvido pela própria empresa, com a participação fundamental dessa equipe.

A execução da laje racionalizada é realizada com mão-de-obra própria, a partir de um projeto para a produção, elaborado pela equipe de desenvolvimento. Um de seus técnicos tem sido o responsável pelo treinamento da mão-de-obra em canteiro e o acompanhamento de todo o processo de produção, desde a montagem da fôrma, até o controle de recebimento do produto final, após a desfôrma.

As empresas " $A$ ", " $B$ ", " $C$ " e "J", com características organizacionais muito semelhantes entre si e também com relação à empresa " $H$ ", não montaram nenhuma estrutura voltada à implantação de TCR's.

Nessas empresas, a conduçāo do processo de implantação de TCR's concentra-se nas mãos de seus diretores técnicos. Eles são os líderes do processo. No entanto, eles são também os responsáveis por uma série de outras atividades importantes na empresa, o que não lhes deixa tempo suficiente para

\footnotetext{
${ }^{3}$ A modulação é parcial porque os projetos de alvenaria têm sido realizados somente depois da completa definição dos projetos estruturais, por não se tratarem de empreendimentos incorporados pela construtora.
} 
atuarem como deveriam, de modo a acelerar o processo de implantação das tecnologias racionalizadas.

Não obstante às dificuldades que o seus cargos lhes impõem, esses diretores mostram total disposição em continuar realizando as ações para que asnovas tecnologias sejam fixadas em suas obras. Para isso procuram reunir subsídios que Ihes dêem suporte para a realização das atividades, como por exemplo, a contratação de escritórios de projetos, a negociação com subempreiteiros, o envolvimento de toda a equipe de produção através de reuniões técnicas, no sentido de motivá-la a participar do processo de implantação.

Por se tratarem de empresas que não têm um número elevado de obras ocorrendo ao mesmo tempo e havendo uma forte coordenação por parte de seus diretores, o processo de aplicação das novas tecnologias ocorre de modo contínuo nas empresas, apesar de não ter' a mesma velocidade da empresa "H" e, apesar, de muitas vezes, escapar ao controle dos diretores, retornando à etapa inicial.

Nessas empresas é possivel identificar que um certo patamar de racionalização já foi alcançado, sobretudo no que se refere à produção da laje nivelada e acabada e da alvenaria de vedação.

No caso das empresas "E", "F", "G" e "I", a condução do processo de inovação também está sob a responsabilidade dos diretores técnicos; entretanto, a aplicação de novas tecnologias não têm sido a prioridade dessas empresas, o que tem levado a ações mais pontuais e de menor impacto na produção.

No caso da empresa "G", a opção expressa da diretoria é pelo desenvolvimento das questões de segurança e de vivência no canteiro de obras. Para ela, a questão tecnológica é decorrência, sendo obtida diretamente no mercado, a partir do que este Ihe oferece. Seu diretor técnico afirma: "deixo os outros experimentarem primeiro, quando estiver bem consolidado no mercado, trago para a empresa".

Essa tem sido a sua postura, por exemplo, com relação à laje nivelada. Assim que encontrou no mercado uma empresa especializada neste tipo de serviço e depois que outras construtoras já tinham manifestado seus resultados, passou 
a executar a laje nivelada na obra. Entretanto, todo o processo de execução fica a cargo da empresa prestadora de serviço e nenhum tipo de controle tem sido realizado.

Através da pesquisa foi possível identificar que, nessas quatro empresas, por enquanto, as intenções dos seus diretores são maiores que ações praticadas e muito do que dizem estar fazendo não ocorre efetivamente nas obras.

Por não terem uma estrutura voltada à implantação de TCR's, e por não poderem estar pessoalmente conduzindo o processo de implantação, esses diretores acabam por estabelecer diretrizes genéricas que deverão ser adotadas pelas obras, o que nem sempre acontece. No entanto, como não foram estabelecidos mecanismos de comunicação e de controle eficientes, muitas vezes acreditam (ou querem acreditar) que as TCR's estão sendo praticadas, quando na verdade não estão.

Pelas colocações anteriores, fica claro que quando não se tem verdadeiros líderes envolvidos com o processo de implantação, dificilmente as novas tecnologias serão fixadas ao sistema de produção das empresas.

\subsubsection{Identificação de novas tecnologias}

Não são muitas as alternativas utilizadas pelas empresas para identificarem as novas tecnologias. Durante a pesquisa, foram encontradas duas posturas básicas: ou as empresas investem em sua capacitação tecnológica, através da contratação de consultores, ou de convênios objetivando o repasse tecnológico, ou elas utilizam as novas tecnologias apresentadas pelo mercado de materiais e componentes.

A empresa " $A$ " começou a procurar novas tecnologias e novas formas de organização, levando toda a sua equipe técnica a participar de um curso que envolvia conceitos ligados à qualidade e produtividade na construção civil, oferecido no segundo semestre de 1993 pelo Instituto Tecnológico e da Qualidade na Construção (ITQC) em conjunto com a Escola Politécnica da USP.

Nessa ocasião a empresa também levou a participar desse curso um de seus principais subempreiteiros, com o objetivo de acelerar o processo de terceirização da produção. 
Após o curso, a empresa identificou a premência de evoluir tecnologicamente o seu sistema de produção. Por isso, optou pela contratação de um consultor, . especialista em tecnologia de processos construtivos, que a tem auxiliado, desde aquela época, na condução do processo de implantação de TCR's nos canteiros de obras.

No caso das empresas " $B$ " e "C" houve uma ação conjunta para a identificação de novas tecnologias, incluindo um grupo de mais três outras empresas. Essas cinco empresas firmaram um convênio com o CPqDCC-EPUSP objetivando a sua capacitação tecnológica. O trabalho, inicialmente realizado, enfocou a produção racionalizada de alvenarias e revestimentos, incluindo-se a produção das lajes niveladas e acabadas.

O trabalho, que tem contado com a participação da autora, teve início através de cursos que objetivaram a capacitação tecnológica de sua diretoria e gerência técnica. Esses cursos não ficaram restritos à sala de aula, pois, além das aulas teóricas, incluíram a prática em canteiros, envolvendo os operários e também alguns subempreiteiros.

Depois desse trabalho inicial, de capacitação da diretoria e da gerência, vem sendo realizado um acompanhamento das ações dessas empresas, através de visitas periódicas a seus canteiros, procurando-se observar a evolução do processo de aprendizagem e de aplicação das novas tecnologias.

As visitas aos canteiros de obras dessas duas empresas mostraram claramente que, de um empreendimento para outro, há uma evolução no processo de aplicação das novas tecnologias.

As tecnologias aplicadas por essas empresas, inicialmente como experimentos, começam a fazer parte do seu "dia a dia", sendo gradativamente incorporadas aos novos empreendimentos e sendo alvo de negociação com os clientes, projetistas e subempreiteiros.

Para essas duas empresas, e também para as outras três que constituem o grupo que vem trabalhando em conjunto, está claro que $\circ$ aprendizado não terminou com os cursos de capacitação. Ele deve ser contínuo e sobretudo transferido às suas obras. 
Com isso, a troca de experiências entre as empresas e o CPqDCC permanece ativo. Uma das atividades previstas na continuidade dos trabalhos é a realização de encontros técnicos, nos quais se procura tratar de temas de interesse do grupo, procurando sempre a evolução e racionalização de seus processos de produção.

A empresa " $D$ ", pelo seu porte, tem investido de modo significativo em novas tecnologias. No início de 1994, com o seu departamento de desenvolvimento montado, contratou um grupo de consultores especialistas em tecnologia construtiva, com o objetivo de racionalizar e fazer evoluir o seu processo de produção.

A estratégia de repasse das novas tecnologias à empresa, foi a aplicação imediata em uma de suas obras, em andamento.

Essa obra foi utilizada para as aplicações preliminares e piloto das tecnologias de execução da laje nivelada e acabada; da alvenaria de vedação, a partir de um projeto para produção (ainda que não realizado sob condições ideais); e do contrapiso racionalizado.

Com os resultados que a equipe obteve dessa obra, a empresa pôde levar adiante a etapa de documentação das tecnologias, as quais foram elaboradas pelos que participaram das aplicações preliminares e piloto, auxiliados pela própria equipe de desenvolvimento.

Depois dessa primeira experiência e com a documentação elaborada na sua primeira versão, a equipe passou a atuar com cinco obras piloto, nas quais foram aplicadas as tecnologias construtivas da laje e alvenaria racionalizada.

Os resultados dessas aplicações iniciais iam, aos poucos, sendo passados para as demais obras da empresa, através de uma campanha interna de motivação e de capacitação do corpo técnico.

A equipe de desenvolvimento da empresa, aos poucos foi tendo o domínio das novas tecnologias e, com o tempo, a equipe de consultores pôde se afastar, deixando que a empresa caminhasse mais livremente no seu processo de evolução tecnológica. 
Dentre as empresas que têm escolhido a consultoria de especialistas em tecnologia de processos construtivos para promoverem a sua evolução tecnológica encontram-se, ainda, as empresas " $\mathrm{H}$ " e "J".

A empresa " $\mathrm{H}$ ", contratou um consultor, especialista em tecnologia construtiva, que está orientando e auxiliando a sua diretoria técnica a conduzir o processo de implantação de novas tecnologias na organização da empresa.

A empresa "J", por sua vez, participou de dois cursos de capacitação tecnológica, em conjunto com um grupo de outras cinco empresas, oferecido pela autora, em conjunto com mais um pesquisador do CPqDCC-EPUSP, com o objetivo fundamental de reunir elementos para este trabalho de tese.

A partir dos cursos, tanto a empresa "J", como as demais participantes, movidas pelo empenho particular de seus diretores técnicos, têm conseguido aplicar as tecnologias racionalizadas nos seus canteiros de obras.

No caso da empresa "J", em seus três edifícios em andamento, está sendo produzida a laje nivelada. Para um dos edifícios a empresa realizou o projeto para produção das alvenarias de vedação, através de um escritório de projeto e consultoria em tecnologia construtiva.

O acesso ao conhecimento tecnológico das empresas "E", "F", "G" e "I", tem uma origem distinta das anteriormente citadas. Essas quatro empresas fizeram parte de um grupo que participou de um programa desenvolvido pelo SINDUSCON-SP cujo objetivo foi a padronização dos métodos construtivos empregados pelas empresas.

Durante a realização desse programa, a autora foi convidada a auxiliar o grupo que estava padronizando os procedimentos de execução de revestimentos argamassados e cerâmicos, de maneira que fossem incorporadas, aos procedimentos, as tecnologias racionalizadas e as tradicionais, utilizadas no sistema de produção das empresas.

Portanto, o conhecimento tecnológico atual dessas empresas decorre desses procedimentos, elaborados em conjunto, sendo que, para a realização de alguns deles, houve a interferência de especialistas no assunto, como foi o 
caso dos procedimentos de revestimentos verticais e também de alvenaria e de contrapisos.

A partir desses procedimentos, em principio, as empresas estariam aptas a implantarem as novas tecnologias em seus canteiros de obras. Entretanto, considerando-se os resultados da pesquisa, o que se pôde constatar, foi que a existência de um procedimento escrito, ainda que contendo uma tecnologia construtiva racionalizada, não implicava, automaticamente, na produção racionalizada em canteiro.

A maioria dessas empresas, por ocasião da pesquisa, não estava organizada para implantar o processo de mudança tecnológica.

Alguns dos diretores acreditam que tendo o procedimento e contratando uma empresa especializada na produção da laje nivelada e acabada, por exemplo, é o suficiente para implantarem essa tecnologia na empresa e não mais se preocupam com essa atividade. Porém, no momento da execução dos revestimentos, esses diretores acabam percebendo que os defeitos resultantes na laje são muito superiores ao esperado, o que acarreta, na maioria das vezes, em uma regularização, inicialmente não prevista.

O trabalho realizado com esse conjunto de empresas mostrou claramente que o domínio da tecnologia, em todas as suas dimensões (projeto, execução e controle) é fundamental para que seja possível efetivar as mudanças.

Por isso, reafirma-se que, além da existência de um líder para a condução do processo, a empresa precisa conhecer a tecnologia a ser implantada e, também, disponibilizar uma série de recursos, a fim de que as diretrizes fundamentais do processo de implantação, discutidas na seqüência, sejam efetivadas. Por isso, a importância das premissas que integram a metodologia proposta.

\subsubsection{Aplicação da nova tecnologia aos projetos do edificios}

Uma diretriz fundamental estabelecida pela metodologia proposta no capítulo 5 refere-se à incorporação das TCR's aos projetos do edifício, de preferência, desde o inicio de seu desenvolvimento (ver item 5.4.1). 
Muitas empresas manifestam a dificuldade de atender a essa diretriz, argumentando que os projetos lhes chegam prontos, o que é comum nos casos em que são contratadas, por terceiros, apenas para a construção do edifício.

Entretanto, as dificuldades de realização do projeto, que incorpore as novas tecnologias, não se restringem às empresas que apenas constróem. As incorporadoras e construtoras também vêm desenvolvendo um processo de projeto que não é ideal à aplicação de novas tecnologias.

\subsubsection{O processo de desenvolvimento dos projetos}

$\mathrm{O}$ tratamento destinado ao projeto tem sido distinto conforme as empresas sejam incorporadoras e construtoras ou apenas construtoras.

A empresa "l", que trabalha mais intensamente no segmento de obras públicas e para terceiros, tem atuado de maneira a interferir no projeto recebido, para alcançar o máximo grau de racionalização, como ilustra o seu fluxo de projeto, apresentado na figura 6.1 .

O processo de análise de projeto adotado por essa empresa é muito favorável à incorporação de TCR's no processo de execução dos edifícios.

Observa-se pela figura 6.1 que existe uma atividade prevista no fluxo de desenvolvimento do empreendimento, verificação das interferências entre os projetos, a qual permite analisar os projetos executivos, para se identificar as possiveis interferências entre os mesmos.

Além dessa verificação, está prevista, ainda, uma etapa de análise do potencial de racionalização dos projetos, também favorável à incorporação das TCR's.

Entretanto, para que essa etapa seja efetiva, é preciso que a empresa tenha o domínio das TCR's potencialmente utilizáveis nos projetos de edifícios. Por isso, ainda que a empresa seja apenas construtora, deverá investir em novas tecnologias. Além disso, é favorável que a empresa organize um banco de tecnologia que lhe permita identificar, com facilidade, as melhorias que possam ser implantadas nesses projetos. 


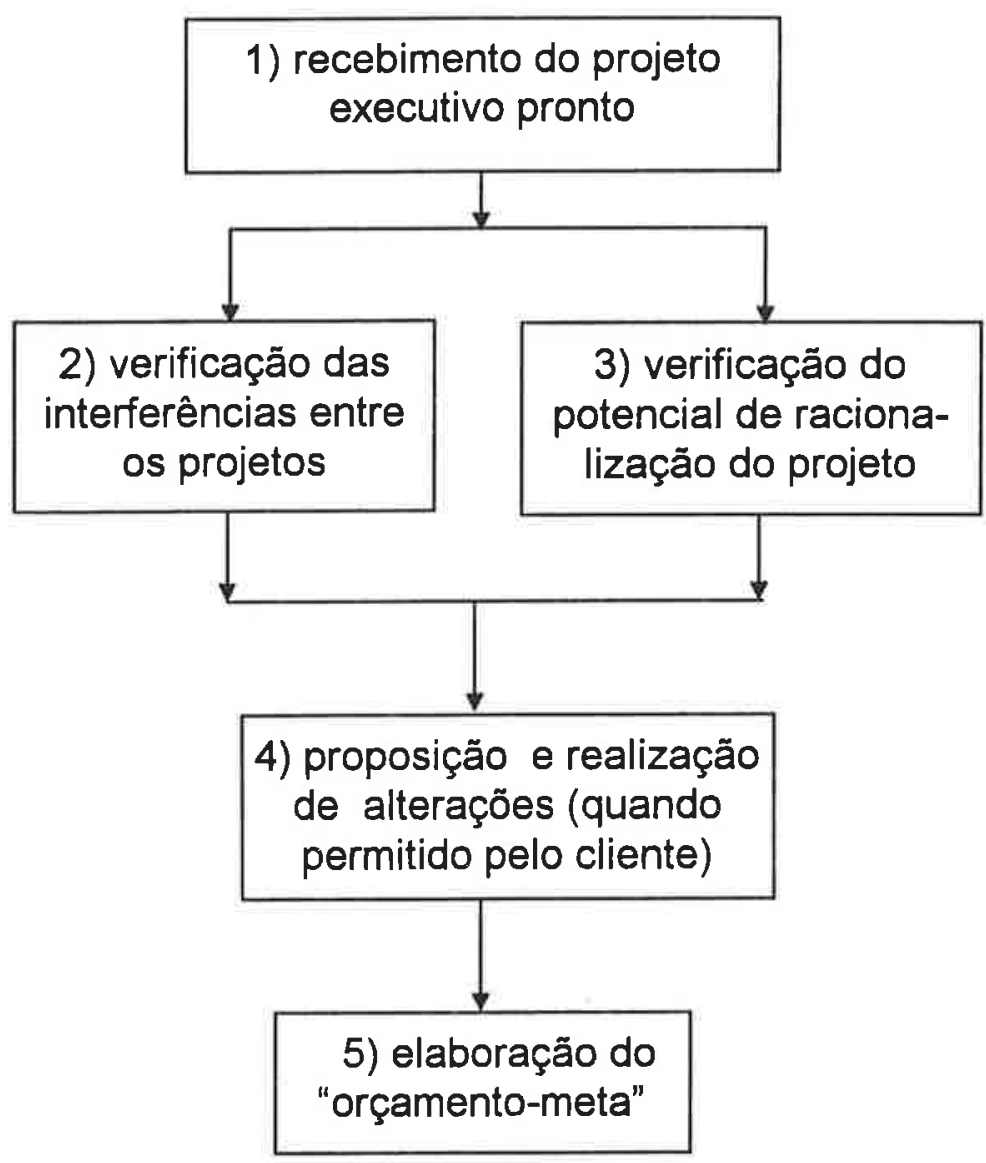

FIGURA 6.1: Processo de análise de projeto adotado pela empresa "I"

No caso de empreendimentos de terceiros, a simples identificação do potencial de racionalização não soluciona o problema. Essas melhorias deverão ser negociadas com os clientes, para a sua efetivação.

Apesar desse passo não estar explicitamente mostrado no fluxo da figura 6.1, acredita-se que ele exista, porque somente assim poderá ocorrer a etapa 4, a qual proporciona a oportunidade de desenvolver os projetos para produção, a fim de que se possa incorporar o conhecimento tecnológico da empresa.

O "orçamento-meta" realizado por essa empresa é o orçamento que se vai tentar atingir ao se desenvolver o empreendimento contido no projeto. É uma atividade de total responsabilidade do engenheiro que irá gerenciar a obra, o qual recebe suporte da equipe de orçamento da empresa.

A postura da empresa de responsabilizar o engenheiro da obra pelo orçamento, se bem conduzido, é particularmente interessante no que se refere à sua responsabilidade pelo processo de execução. 
Segundo o diretor técnico da empresa "I", esse procedimento tem evitado que se tenha "surpresas" no decorrer da obra, uma vez que todas as condições de produção são definidas previamente.

Ainda que o fluxo de análise de projeto proposto por essa empresa seja propício à incorporação de novas tecnologias, o que se pôde depreender da pesquisa realizada com o seu diretor técnico, é que essa oportunidade não está sendo totalmente explorada.

A análise dos projetos e a elaboração das alterações não são sistematizadas e nāo existem diretrizes que conduzam essa análise e a alteração de projetos.

Na maioria das vezes as modificações propostas estão fundamentadas apenas no conhecimento tecnológico da equipe técnica, cujo subsídio é o dia-a-dia na obra e o conhecimento repassado pelo diretor técnico.

Apesar de todas essas dificuldades, acredita-se que esse seja um caminho que deve continuar a ser percorrido pela empresa e por todas as que prestam serviços a terceiros, procurando, com isso, a melhoria contínua de seu processo de produção.

O processo de projeto das empresas construtoras e incorporadoras, ainda que tenha uma maior potencial de embutir as novas tecnologias, nem sempre tem aproveitado essa oportunidade.

$\mathrm{Na}$ figura 6.2, apresenta-se um modelo de desenvolvimento de projeto, comum a uma grande parte das empresas construtoras e incorporadoras pesquisadas.

Observa-se por essa figura que, na maioria dos casos, o departamento comercial é o responsável pela definição do produto e até mesmo do arquiteto. Apenas no caso da empresa " $G$ " identificou-se uma variação nessa conduta. Nessa empresa, o departamento comercial define o produto, mas, a contratação do projetista de arquitetura é realizada pelo departamento técnico.

No fluxo ilustrado na figura 6.2, o estudo preliminar de arquitetura dá início ao processo de elaboração do projeto do empreendimento. Após a elaboração desse estudo é que se faz uma reunião para a análise da proposta, com apoio dos demais projetistas. 


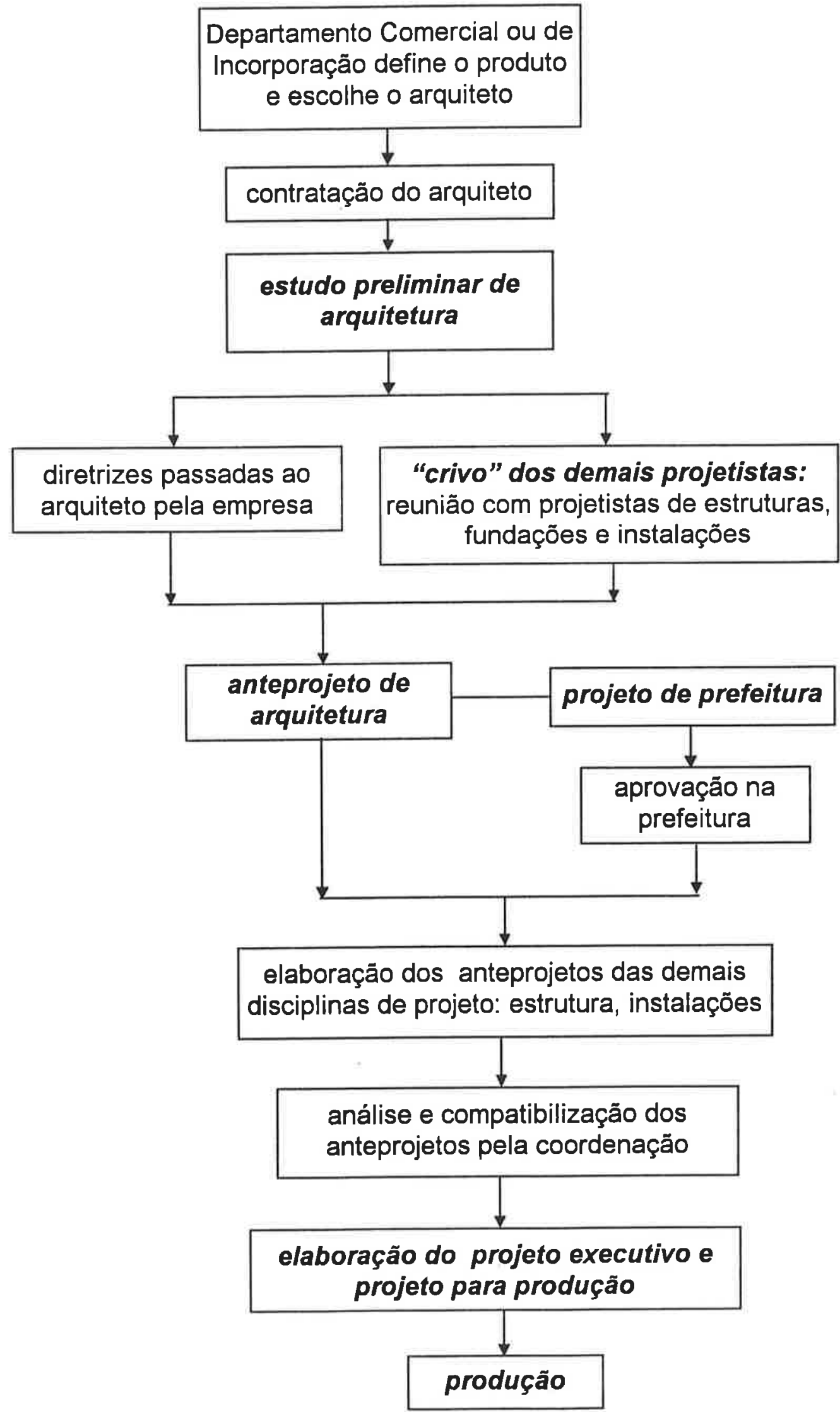

FIGURA 6.2: Processo de desenvolvimento de projeto mais comum entre as empresas construtoras e incorporadoras 
Entretanto, não se observou uma sistematização clara dessa etapa de projeto nas empresas. As diretrizes que as empresas repassam ao projetista, não são formalizadas, tratam-se, na maioria dos casos, de sugestões dadas pelo diretor técnico, no momento da reunião com o projetista.

O crivo dos demais projetistas também é feito em função da experiência de cada um destes, em função daquilo que percebem ao analisarem o estudo preliminar, durante a reunião. Se há uma sistematização dessa análise, ela ocorre por iniciativa dos próprios projetistas e não por iniciativa da empresa.

Além disso, nesse fluxo, fica claro também que o desenvolvimento dos anteprojetos para as disciplinas de estruturas e instalações ocorre somente após a aprovação do projeto na prefeitura. Portanto, muitas definições assumidas no anteprojeto de arquitetura não poderão ser modificadas, diminuindo-se, de certa forma, o potencial de racionalização.

Esse modelo de desenvolvimento de projeto mostra, ainda, que os denominados projetos para produção, os quais comumente referem-se aos projetos de alvenaria, da laje nivelada e acabada, de esquadrias e de impermeabilização, nos casos em que são elaborados, serão iniciados somente após a compatibilização dos anteprojetos, quando da realização dos projetos executivos.

O projeto incorporando as TCR's, desenvolvido em conjunto com o projeto executivo, na maioria dos casos, não tem o mesmo potencial de racionalização que teria se tivesse sido iniciado na fase de anteprojeto, sobretudo para aqueles subsistemas que têm grande interferência com os demais, como é o caso das alvenarias e revestimentos de piso, por exemplo.

Portanto, ainda que as incorporadoras e construtoras estejam numa situação um pouco mais favorável do que as empresas que recebem os projetos executivos prontos, as suas vantagens atuais não são muito maiores.

A pesquisa realizada mostra claramente que as empresas, de um modo geral, estão descontentes com o atual resultado do processo de projeto. Ainda que algumas declarem que a relação do projeto com a produção tenha evoluído, declaram também que essa relação ainda não atende à produção, sobretudo no que se refere aos projetos de arquitetura, estruturas e instalações, como 
mostra a tabela 6.3, que procura expressar a opinião das empresas no que se refere à relação do projeto com a produção.

A análise dos dados dessa tabela deixa claro que o atual processo de desenvolvimento de projeto está aquém das expectativas das empresas. Portanto, esse processo precisa ser alterado de modo a permitir a introdução das TCR's num momento mais propício à obtenção de um grau maior de racionalização.

TABELA 6.3: Opiniāo das empresas quanto à relação projeto-produção, expressa em porcentagem do total de empresas pesquisadas

\begin{tabular}{|l|c|c|c|c|}
\hline \multirow{2}{*}{ PROJETOS } & \multicolumn{2}{c|}{$\begin{array}{c}\text { projeto atende a } \\
\text { produção? }\end{array}$} & \multicolumn{2}{c|}{$\begin{array}{c}\text { a relação projeto/produção } \\
\text { evoluiu? }\end{array}$} \\
\cline { 2 - 5 } & $\operatorname{sim}$ & não & sim & não \\
\hline arquitetura & - & 100 & 60 & 40 \\
\hline estrutura & 80 & 20 & 80 & 20 \\
\hline fôrmas & 20 & 80 & 20 & 80 \\
\hline armação & 20 & 80 & - & 100 \\
\hline instalações & - & 100 & 100 & - \\
\hline montagem fôrmas & 100 & - & 100 & - \\
\hline alvenaria & 100 & - & 100 & - \\
\hline
\end{tabular}

A observação dessa tabela expressa, por outro lado, que os projetos que melhor atendem à produção são os de alvenaria e de montagem de fôrmas, os quais são tipicamente projetos para produção.

Em função dos retornos positivos dados por esses projetos, observa-se que os investimentos no seu desenvolvimento têm crescido entre as empresas.

Os dados a seguir, obtidos da pesquisa realizada, mostram um panorama quanto à tendência de realização do projeto para produção nas empresas construtoras:

- $100 \%$ das empresas vêm desenvolvendo o projeto de montagem de fôrmas;

- $80 \%$ das empresas vêm desenvolvendo o projeto de alvenaria;

- $70 \%$ das empresas vêm desenvolvendo o projeto de instalações hidráulicas contendo a "furação" nas lajes ou o desenvolvimento de "kits" hidráulicos;

- $90 \%$ das empresas vêm desenvolvendo o projeto objetivando a obtenção da laje nivelada ou nivelada e acabada; 
- $70 \%$ das empresas vêm desenvolvendo o projeto de impermeabilização das áreas molháveis internas aos edifícios.

Deve-se observar que o nível de detalhamento desses projetos é variável para cada empresa; portanto, atendem diferentemente às exigências das obras. $E$, além disso, o fato da empresa estar realizando o projeto para produção não significa que o faça para todos os seus empreendimentos. No entanto, enquanto tendência, acredita-se que a presença desses projetos nos canteiros deverá ser intensificada daqui para frente.

Mas, de maneira geral, observou-se que as empresas estão começando a enxergar a necessidade de alterar o seu atual processo de projeto; por isso, a importância da diretriz fundamental estabelecida no capítulo 5 , na qual se propõe um modelo para esse desenvolvimento, o qual poderá vir a ser adotado por qualquer empresa construtora e adaptado às suas características.

Para fazer com que os projetos atendam, realmente, à produção, a empresa " $A$ " vem modificando o seu processo de desenvolvimento de projeto. As modificações propostas merecem ser registradas, uma vez que estão muito próximas das diretrizes estabelecidas no item 5.4.1.

A empresa " $A$ " tem realizado esforços para implantar duas açōes que se complementam, objetivando a melhoria do processo de projeto: uma delas refere-se à criação de uma Banco de dados de Tecnologia; e a outra, à qualificação de projetistas.

A criação de um Banco de Tecnologia tem como objetivo subsidiar a orientação aos projetistas quanto ao sistema produtivo utilizado pela empresa e não ficar sempre na dependência da assessoria de um consultor.

A qualificação dos projetistas tem por objetivo encontrar parceiros que tenham interesses próximos aos da empresa, no sentido de fazer evoluir as atuais características do processo de projeto e por conseqüência da produção.

Nessa qualificação, a empresa está envolvendo projetistas de arquitetura, de estruturas e de instalações, os quais passarão a trabalhar nos próximos empreendimentos. Sua meta é definir escritórios de arquitetura e grupos de projetistas de fundações, estruturas e instalaçōes, que deverão trabalhar em 
conjunto e em compatibilidade com as diretrizes estabelecidas pela empresa. Por ocasião da pesquisa, diversos escritórios de arquitetura tinham sido visitados.

Além dos projetos tradicionalmente realizados para um empreendimento de edifícios, na proposta dessa empresa, haverá a sistematização da elaboração de outros projetos também importantes à execução, os quais a empresa denominou, genericamente, de "complementares".

Segundo a empresa, esses projetos referem-se aos de alvenaria, de impermeabilização e de esquadrias, os quais serão desenvolvidos por projetistas especializados em cada um dos assuntos, externos à empresa.

Pela a metodologia proposta pela empresa, esses projetos passarão a ser desenvolvidos em duas partes distintas.

A primeira parte, denominada de projeto complementar, refere-se à interface das disciplinas anteriormente citadas, com os projetos tradicionais do edifício. A empresa busca compatibilizar todos os projetos, o mais cedo possível, o que é finalizado com o detalhamento do projeto executivo.

A segunda parte, denominada na empresa de "projeto para produção", contém a preparação das atividades de execução propriamente dita, incluindo as características das ferramentas a serem empregadas, as frentes de trabalho, a seqüência de execução.

No modelo de desenvolvimento de projeto dessa empresa está prevista, ainda, a coordenação dos projetos por um profissional experiente, não necessariamente pertencente ao quadro funcional da empresa. Esse profissional, além da sua experiência, será orientado pelos procedimentos que a empresa deverá lhe passar.

Quanto à elaboração dos projetos para produção, será realizada e coordenada por uma equipe interna à empresa, para dar agilidade ao processo.

\footnotetext{
${ }^{4}$ Observa-se que neste trabalho o conceito atribuido ao projeto para produção envolve tanto 0 que a empresa " $A$ " denominou de projeto complementar, quanto ao que ela denominou de projeto para produção. Entretanto, independentemente da nomenclatura utilizada, o projeto objetivando as necessidade da produção está sendo contemplado na proposta feita pela empresa, assim como na metodologia proposta neste trabalho.
} 
A empresa acredita que o projeto deve ir para a obra suficientemente planejado, pensado e elaborado, mas não estanque. Isto é, deve passar por um contínuo desenvolvimento, a fim de atender à produção.

A empresa tem encarado o projeto como um serviço que acompanha toda a realização do edifício.

A figura 6.3 ilustra o processo de projeto idealizado por essa empresa e que deverá ser utilizado em seus próximos empreendimentos.

A empresa " $C$ " também vem procurando melhorar o seu processo de desenvolvimento do projeto. Uma de suas principais ações nesse sentido tem sido a contratação dos projetistas de arquitetura, estruturas, instalações, alvenaria, impermeabilização e esquadrias, todos ao mesmo tempo, logo no início do empreendimento.

Esses projetistas, trabalhando sob a coordenação do diretor técnico da empresa, vêm tentando aproximar os seus projetos das necessidades da equipe de produção.

Observa-se, porém, que nessa empresa a figura do diretor técnico é fundamental para o processo de implantação de novas tecnologias. Sem a sua presença e atuação, poucas ou mesmo nenhuma ação são realizadas. Há, portanto, uma sobrecarga que precisa ser distribuída, o que somente será possível à medida em que a empresa adotar uma adequada metodologia para a implantação das TCR's.

O desenvolvimento do projeto voltado à produção, não ocorre de um momento para outro. Deve ser encarado como um contínuo aprendizado dentro da empresa, a qual vai evoluindo à medida em que os projetos vão sendo elaborados e utilizados nos canteiros de obras.

O aprendizado contínuo pode ser ilustrado pelas açōes da empresa " $\mathrm{D}$ ". $\mathrm{Na}$ primeira obra dessa empresa em que o projeto de alvenaria foi elaborado por um de seus consultores, existiam: a disposição da primeira e segunda fiadas; os detalhes de fixação da alvenaria à estrutura; e as passagens de instalações elétricas pelos blocos. Nessa obra o referencial de locação ainda era a estrutura. 


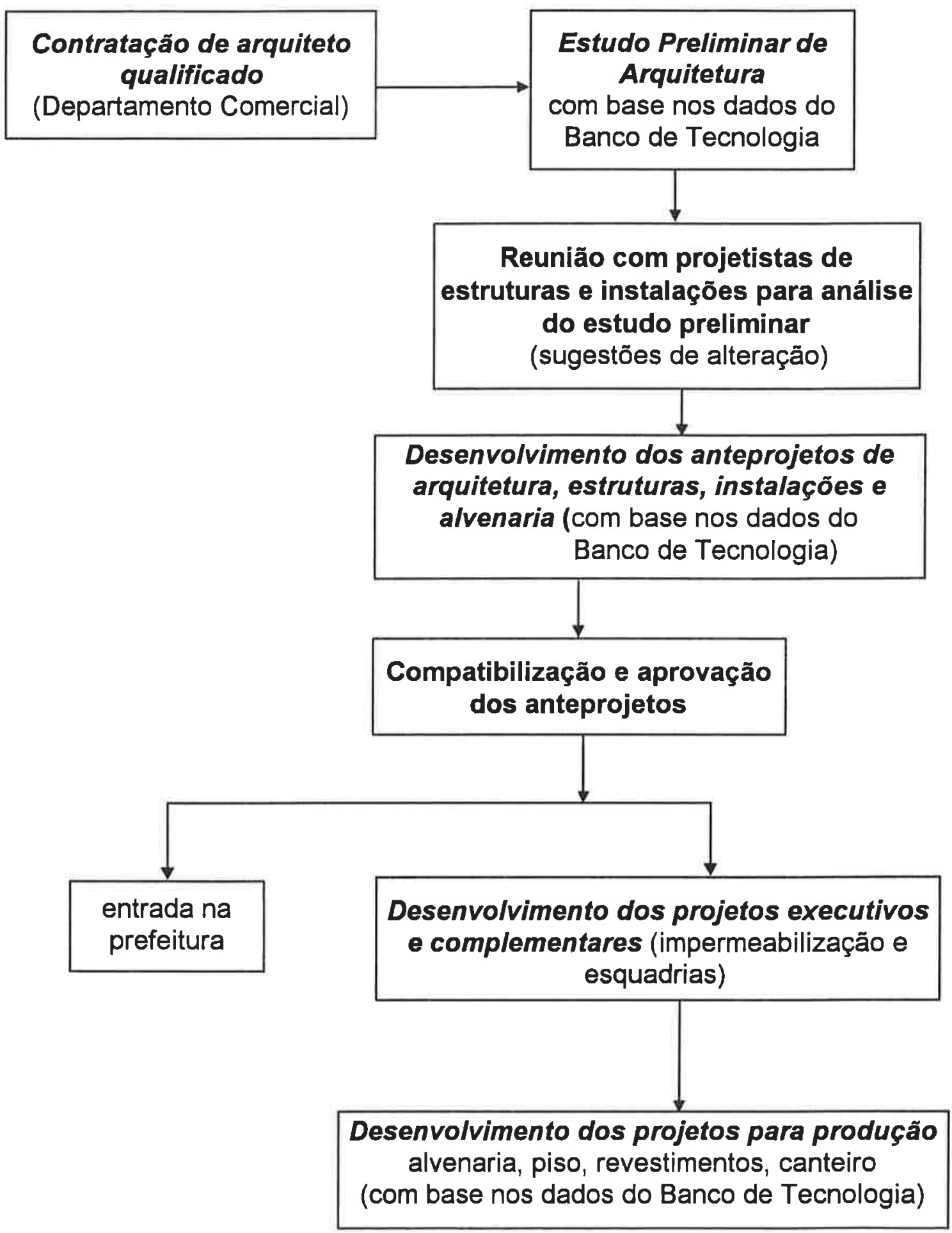

FIGURA 6.3: Processo de projeto desenvolvido pela empresa " $A$ " 
Uma série de problemas foram detectados com o emprego desse projeto, tais como: muitos erros na locação das alvenarias, em função do referencial adotado; dificuldades da mão-de-obra na leitura do projeto; rasgos indiscriminados da alvenaria para a passagem das instalações elétricas.

É evidente que todos esses problemas não poderiam ser atribuídos exclusivamente ao projeto. Outros elementos, tais como a organização e o treinamento da mão-de-obra acabavam interferindo nos resultados.

Entretanto, o processo de aprendizagem não parou com essa experiência. Em um novo empreendimento foi realizado, por um escritório de arquitetura externo à empresa, um outro projeto. No entanto, esse novo projeto continha, ainda, muitas incompatibilidades que dificultavam a sua utilização, mesmo com a presença constante de um técnico da área de desenvolvimento, no canteiro.

Frente a essa nova situação a empresa decidiu investir no seu processo de projeto, contratando um convênio com CPqDCC-EPUSP, através de sua equipe de pesquisadores, objetivando a "Qualidade do Projeto".

No escopo desse convênio foram desenvolvidos entre outros os procedimentos para a elaboração de projetos da laje acabada, alvenaria e revestimentos argamassados e cerâmicos, os quais seriam, a partir de então, repassados às equipes de projetistas.

Esses procedimentos, cuja elaboração foi coordenada pela autora, foram registrados em relatórios de pesquisa do referido convênio [MELHADO; BARROS; SOUZA, 1995a,b,c].

Esses procedimentos estão, ainda, em fase de implantação. Até o término da pesquisa, que subsidiou este trabalho, não foi possível realizar uma avaliação mais profunda da sua aplicabilidade e aceitabilidade junto aos projetistas.

A empresa " $D$ " já tem os seus procedimentos de projeto documentados. Além dela, a empresa " $A$ " está iniciando o processo de formalização desses procedimentos. A tendência é que outras empresas sigam esse mesmo caminho.

Entretanto, deve-se observar mais uma vez que a documentação dos procedimentos pouco vale se não for transformada em ações efetivas no canteiro de 
obras. Por isso, o processo de desenvolvimento de projeto não para com a formalização das orientações a serem passadas ao projetistas. Na realidade esse deve ser apenas o seu início, devendo ter continuidade com o uso do projeto no canteiro de obras.

\subsubsection{A aplicação do projeto nas obras das empresas}

O projeto para produção objetivando a incorporação das TCR's, realizado por um expressivo número de empresas, nem sempre tem atendido plenamente a produção, ainda que a maioria das empresas afirmem o contrário.

As visitas realizadas aos canteiros de obras de algumas dessas empresas permitiram verificar que a existência do projeto para produção, não implica, de maneira direta, em uma produção racionalizada.

Como na maioria das vezes os projetos tradicionalmente realizados não atendem à produção, permanece nos canteiros a cultura de que "o projeto não funciona". Por isso, encontra-se, ainda, muitas dificuldades para a utilização do projeto para produção nos canteiros de obras.

Às vezes as dificuldades têm origem no próprio projeto, como por exemplo a dificuldade de leitura, a ausência de informações importantes, mas outras vezes os problemas têm sua origem em outros setores da empresa como por exemplo recursos humanos e suprimentos.

O projeto para produção, incorporando uma determinada TCR, precisa retratar com fidelidade as condições de execução. Precisa, sobretudo, dar as soluçōes técnicas aos problemas que não são de domínio da māo de obra.

Por exemplo, um projeto de alvenaria, além de outros elementos importantes, deve definir o posicionamento da primeira e segunda fiadas a partir de um eixo preestabelecido na obra; deve prever as características, o posicionamento e 0 dimensionamento das vergas e contravergas; a passagem de instalações, as amarrações entre fiadas e da alvenaria com a estrutura; o tipo de preenchimento das juntas.

De nada vale um projeto de modulação de alvenaria que não incorpore as definições anteriormente destacadas. A distribuição dos blocos em um 
determinado vão, qualquer operário, com algum nível de treinamento é capaz de realizar, ainda que não exista um desenho.

Às vezes, as empresas acreditam que ao exigirem do escritório de arquitetura o projeto de modulação tenham solucionado o problema da alvenaria no canteiro, como ocorreu, por exemplo, em um dos empreendimentos citados da empresa " $D$ ".

No entanto, a simples modulação está longe de atender à produção e, com isso, os projetos são abandonados.

Ao se falar em projeto para produção da laje de concreto armado, a situação piora ainda mais. Às vezes, as empresas acreditam que, a partir da definição dos rebaixos da laje no projeto de estrutura, solucionaram todos os problemas da produção. Entretanto, eles apenas tiveram início, pois se não houver a definição dos gabaritos, das caixas de passagem, do planejamento da concretagem, entre outros itens, de nada adiantará a existência dos rebaixos no projeto e, às vezes, não adianta nem mesmo a contratação de empresa especializada na execução do acabamento.

Muitas vezes, o que as empresas denominam de projeto para produção nāo é utilizado no canteiro, justamente porque não atende à produção.

Em alguns casos a não utilização do projeto para produção na obra pode decorrer de problemas que fogem ao alcance do projeto.

Em algumas obras, como as das empresas " $F$ " e " $A$ ", por exemplo, ocorreu que as dimensões dos blocos recebidos não eram compatíveis com as de projeto. Em função disto, toda a modulação definida ficou prejudicada. Os operários acabavam utilizando apenas a planta de demarcação da primeira fiada, a fim de locar a parede, fazendo a distribuição dos blocos segundo seus próprios critérios.

Esse problema denota uma forte interferência da implantação das novas tecnologias com o setor de suprimentos da empresa, o qual também deverá estar devidamente preparado para o processo de implantação (a organização desse setor nas empresas será discutido no item 6.3.5). 
Dentre as empresas pesquisadas identificou-se casos em que o projeto de alvenaria chega nas obras somente depois da execução da alvenaria ter sido iniciada. Nessa situação, dificilmente o projeto poderá contribuir com a produção. Depois que a mão-de-obra inicia um determinado procedimento, dificilmente o abandona.

A aplicação do projeto para produção nas obras de edifício deve ser encarada como um contínuo aprendizado, assim como o seu desenvolvimento. Ainda que as empresas construtoras estejam no início desse aprendizado, muitos beneficios puderam ser observados ao se realizar as visitas às obras, citandose alguns, apenas para exemplificar:

- menor consumo de argamassas de assentamento;

- drástica redução de retrabalho, com menores desperdícios (foi possível evitar cortes na alvenaria para embutimento de instalações);

- maior precisão no posicionamento das instalações;

- redução das espessuras de revestimentos interiores $(5 \mathrm{~mm})$ e exteriores (25$30 \mathrm{~mm})$;

- aumento da produtividade e da qualidade dos serviços;

- maior limpeza na obra.

O processo de desenvolvimento e utilização do projeto incorporando as novas tecnologias é ainda uma grande novidade para a indústria da Construção, a qual deverá aprender a utilizá-lo como um importante instrumento de racionalização, em conjunto com as demais diretrizes estabelecidas pela metodologia proposta por este trabalho.

\subsubsection{A organização da documentação}

Uma parte expressiva das empresas pesquisadas está desenvolvendo os denominados procedimentos para produção, tanto os de execução, quanto os de controle, sendo que estes últimos são comumente denominados de procedimentos de inspeção.

Exceto a empresa "J", que está no início da padronização de seus procedimentos de produção, as demais empresas declararam que possuem procedi- 
mentos de produção para os principais serviços da obra. Em algumas dessas empresas a padronização dos procedimentos, em especial os de execução de serviços, decorre de aplicações experimentais realizadas na própria empresa. Esse é o caso das empresas "A", "B", "C" e "D" e "H".

As empresas "E", " $F$ ", "G", "I" constituem o grupo que participou do programa do SINDUSCON/SP cujo objetivo foi a padronização dos procedimentos de execução e controle, anteriormente comentado.

Assim, de uma maneira ou de outra, as empresas têm a documentação, que em princípio, deveria retratar o seu sistema de produção para cada atividade do processo de produção. Entretanto, o que se tem identificado é uma distância muito grande entre a existência e a prática do procedimento.

A existência dos procedimentos de produção somente é justificada pelo seu uso efetivo no canteiro. A produçāo de papéis a serem arquivados pelos gerentes das obras, não deveria ser uma prática corrente das empresas. Por isso, a documentação a ser produzida precisa ser de fácil leitura e compreensão para os que participam do canteiro de obras, a fim de que sejam utilizados realmente.

Analisando-se os procedimentos que têm sido desenvolvidos pelas empresas, percebe-se a procura por formas de comunicação mais adequadas. Algumas empresas, ao elaborarem seus procedimentos têm explorado mais os recursos visuais, tais como, as figuras que ilustram as etapas de execução.

Entretanto, grande parte dos procedimentos é ainda muito discursiva, não servindo à maioria da mão-de-obra que deveria ter acesso aos mesmos.

Uma alternativa encontrada pela empresa " $\mathrm{H}$ " foi a produção do procedimento de execução das alvenarias de vedação na forma de um "gibi". Desta maneira, ao mesmo tempo que conseguiu o acesso ao engenheiro da obra, atingiu também o operário. Trata-se, porém, de uma iniciativa isolada. Apenas um serviço encontra-se na forma de "gibi" e apenas uma das empresas o possui.

Algumas das empresas têm utilizado os procedimentos como uma importante fonte de informação tanto para os atuais funcionários, quanto para os novos. 
Servem como uma memória da empresa, sendo que os procedimentos são utilizados, quase sempre, como parte do material de treinamento.

Nas visitas realizadas em obras, uma das dificuldades colocadas pelos engenheiros das empresas "E", "F", "G", era a não disponibilidade dos procedimentos de execução como diretriz para a produção das alvenarias. No caso especifico da empresa " $F$ ", o engenheiro dispunha de um "fax", encaminhado pelo projetista, contendo as principais instruções de trabalho.

Quanto aos procedimentos de controle ou de inspeção, serão comentados especificamente no item 6.3.6, que se refere às diretrizes de controle.

\subsubsection{O desenvolvimento dos recursos humanos}

A diretriz fundamental de desenvolvimento dos recursos humanos, estabelecida pela metodologia proposta, de certa maneira, vem sendo observada pelas empresas construtoras da amostra pesquisada, às vezes com maior, outras vezes com menor intensidade.

A política de gestāo dos recursos humanos não é homogênea entre as empresas. Algumas delas encontram-se num patamar de desenvolvimento mais elevado do que outras. Observou-se que em certas empresas a organização dos recursos humanos, os programas de incentivos, a capacitação tecnológica encontram-se mais consolidados que em outras.

Năo obstante a essa heterogeneidade, todas elas têm reconhecido a importância de se realizar investimentos em recursos humanos, em todos os niveis hierárquicos, a fim de que possam realizar as mudanças tecnológicas, organizacionais e gerenciais, imprescindiveis ao incremento de sua competência empresarial.

A apresentação e discussão das ações que essas empresas vêm adotando no tratamento dos recursos humanos e do seu reflexo na produção procuram demonstrar a validade da diretriz fundamental estabelecida pela metodologia.

\subsubsection{A forma de contratação}

Os mecanismos de contratação dos recursos humanos observados, têm sido distintos em função das características organizacionais de cada empresa. 
Identificou-se que o denominado "funcionário administrativo" é contratado pela própria empresa construtora. Esses funcionários são os que trabalham no escritório, (responsáveis pela contratação e pagamento de pessoal, pelo orçamento, pelos suprimentos); e também o pessoal administrativo das obras (engenheiro, mestre de obras, almoxarife, apontador e às vezes, alguns encarregados).

No caso da mão-de-obra de produção, há diferentes mecanismos de contratação, sendo identificadas como principais formas:

- contratação de subempreiteiras para fornecimento de mão-de-obra;

- contratação de empresas especializadas em determinados serviços;

- contratação de mão-de-obra diretamente pela construtora;

- contratação através de empresas de mão-de-obra, ligadas exclusivamente às empresas construtoras.

Os dois primeiros mecanismos de contratação, ainda que muito semelhante, apresentam algumas diferenças, às vezes, significativas.

No primeiro caso, a empresa construtora contrata a subempreiteira para o fornecimento de mão-de-obra para serviços diversos. É o que costumam denominar "subempreiteiras de serviço civil", as quais comumente atuam nas atividades de produção da estrutura, da alvenaria e de revestimentos (argamassados e cerâmicos, tanto interiores como exteriores ao edifício).

O segundo caso, contratação de empresas especializadas, envolve o contrato com prestadoras de serviços específicos, como por exemplo: o de produção da laje nivelada e acabada; a produção de revestimentos de gesso, cuja contratação, na maioria das vezes, envolve até mesmo os materiais; entre outros.

Essas duas formas de contratação envolvem uma forte relação com o ambiente externo à empresa, ou seja, com os fornecedores. São diferentes das duas situações seguintes em que, de uma maneira ou de outra, a mão-de-obra é contratada pela própria construtora.

$\mathrm{Na}$ realidade, a contratação através de empresas de mão-de-obra ligada à construtora, trata-se apenas de uma adequação à legislação fiscal. A 
construtora cria uma empresa fornecedora de mão-de-obra distinta, a fim de separar as questões trabalhistas e fiscais.

A contratação de mão-de-obra através de subempreiteiras de serviço civil é um mecanismo que, apesar de ainda ser muito empregado, vem sendo, gradativamente, substituído pelas empresas.

Segundo alguns depoimentos obtidos dos empresários, a prática de contratar subempreiteiras de mão-de-obra não combina com a nova filosofia de trabalho, cujos objetivos são o desenvolvimento tecnológico e o ganho de qualidade e de produtividade.

Os diretores técnicos das empresas " $F$ " e " $\mathrm{H}$ " afirmam que o empreiteiro tem duas formas básicas de conseguir realizar um serviço por preço inferior ao que a própria construtora pode fazer: aumentar a produtividade de seus operários ou burlar a legislação. A segunda alternativa, segundo eles, compromete a construtora, o que não interessa. $E$, quanto à primeira, não acreditam que o empreiteiro o faça; pois ele não investe em treinamento e em novas tecnologias.

No conjunto das empresas pesquisadas, as empresas " $A$ ", " $C$ ", " $D$ ", " $E$ ", "G", e "J" ainda mantêm esse tipo de contratação, sendo que no caso da empresa "D", a mão de obra para a produção da estrutura é própria.

No caso da empresa "J", o objetivo é investir na capacitação técnica dos operários, atualmente contratados de subempreiteiros, fixando-os na empresa.

Como todas essas empresas estão empenhadas em procurarem melhores formas de produção, as maioria delas está desenvolvendo parcerias, junto aos seus subempreiteiros, sendo que essa postura é fortemente assumida pelas empresas " $A$ " e "C".

$\mathrm{Na}$ medida em que estão criando os seus procedimentos de produção, essas duas empresas têm realizado concorrências técnicas entre os subempreiteiros, definindo completamente o tipo de serviço que os mesmos deverão prestar e como esses serviços serão recebidos.

Segundo depoimento do diretor técnico da empresa "C", na primeira concor- 
rência que fez adotando esse novo padrão, não obteve resposta de nenhum de seus antigos subempreiteiros. Para que conseguisse a realização do serviço teve de convocá-los para uma reunião, a fim de lhes explicar os novos objetivos da empresa e de convencer pelo menos um deles a assumir o desafio de uma produção diferenciada.

Para o diretor técnico da empresa "A", a diretriz que tem norteado o trabalho dessas empresas que continuam com a contratação de subempreiteiros é: "trabalhar com poucas subempreiteiras dispostas a melhorar a sua forma de atuação, dando-se preferência àquelas que prestem serviços a outras empresas construtoras que também estejam procurando a melhoria dos processos de produção".

A segunda forma de contratação, anteriormente destacada, é praticada por todas as empresas construtoras, independentemente de terem mão-de-obra própria ou não.

Sempre que possivel, as construtoras dão preferência à contratação de empresas especializadas na prestaçāo de serviços. Esse tipo de contratação ocorre, por exemplo, ao contratarem empresas que fornecem: o sistema tipo "fôrma pronta", com a garantia de assistência na obra; a armadura cortada e dobrada; o preparo para execução da laje nivelada e acabada e o seu acabamento final; a aplicação do revestimento de gesso; a aplicação da impermeabilização, entre outros.

Apesar de serem empresas que prestam serviços específicos, o relacionamento empresa-construtora tem a mesma complexidade que a primeira forma de contratação, exigindo o preparo de ambas para que se possa estabelecer uma verdadeira relaçăo de parceria.

As empresas "B", "F", "H", "I" são as que trabalham com mão-de-obra própria para a realização da estrutura, alvenaria e revestimentos argamassados, sendo que as empresas " $B$ " e " $H$ " possuem uma empresa específica para a contratação dessa mão de obra.

A forma de contratação dos recursos humanos, sobretudo da mão-de-obra de produção, tem interferido nas ações das empresas quanto aos investimentos realizados em capacitação tecnológica e motivação das pessoas para o 
processo de implantação das TCR's. Esses dois temas serão enfocados e discutidos na seqüência.

\subsubsection{Capacitação tecnológica e organização das equipes de trabalho} A capacitação tecnológica proporcionada aos recursos humanos tem se dado de maneira diferenciada entre as empresas e também internamente na empresa, em função da posição ocupada pelo funcionário na escala hierárquica. Por isso, os resultados obtidos durante a pesquisa serão apresentados em função dessa posição, enfocando-se a capacitação voltada aos profissionais de nível superior e médio; aos mestres e encarregados; e aos operários da produção.

\section{a) profissionais de nivel superior e médio}

Praticamente todas as empresas pesquisadas estão investindo, de alguma forma, na capacitação tecnológica de seus profissionais de nivel superior (gerentes, arquitetos, engenheiros) e também de nível médio (técnicos de edificações).

No caso da empresa " $A$ ", essa formação ocorre através de cursos, de conteúdo tecnológico, ministrados periodicamente pelo consultor contratado pela empresa. Participam desses cursos o diretor técnico, os gerentes, os engenheiros e os arquitetos, tanto os que trabalham no escritório (projetos, orçamentos, suprimentos) como diretamente na produção.

A empresa " $\mathrm{B}$ " e "C" têm proporcionado a formaçăo dos diretores técnicos e gerentes através dos cursos de capacitação realizados em conjunto com 0 CPqDCC-EPUSP. Nesses cursos, não houve a presença intensa dos engenheiros de obras. A passagem do conteúdo tecnológico aos engenheiros de obra é de responsabilidade do diretor técnico e do gerente que participaram do referido curso.

A empresa "D", através do apoio de seus consultores, promoveu diversos cursos de capacitação tecnológica, dos quais participaram todos os seus funcionários de nivel superior e médio: gerentes, engenheiros, arquitetos, técnicos de edificações. Os temas desses cursos envolveram a maioria dos serviços relativos à produção do edifício. 
Os diretores técnicos das empresas "E", "F", "G" e "l", a partir do trabalho de padronização das atividades envolvidas na produção do edifício, realizado em conjunto com o SINDUSCON-SP, têm utilizado diferentes formas de repassar o conteúdo tecnológico aos seus engenheiros de obra, sendo que as reuniões de trabalho é a principal delas. Nenhuma dessas empresas, porém, estabeleceu uma atividade sistematizada para transmitir o conhecimento tecnológico adquirido.

A empresa "E", por exemplo, costuma oferecer a oportunidade para que os seus engenheiros participem de cursos rápidos oferecidos por entidades como a editora PINI, o Programa de Educação Continuada em Engenharia da EPUSP ou ainda por consultores especializados, levados à própria empresa.

Os cursos rápidos oferecidos pela editora PINI são também utilizados pela empresa "F", como uma maneira de "reciclar os conhecimentos" dos seus engenheiros.

No caso da empresa "l", os engenheiros, assim que são admitidos na empresa passam por um treinamento quanto à filosofia de trabalho da empresa, voltado à gerência do empreendimento. Esse treinamento é conduzido pelo próprio diretor técnico da empresa. Nessa empresa não há um programa especifico de capacitação tecnológica dos funcionários de nível superior.

A empresa " $\mathrm{H}$ ", através de seu diretor técnico e do gerente de desenvolvimento, apoiado pelo seu consultor em tecnologia, promove a capacitação de seu corpo técnico através da implantação das novas tecnologias diretamente nas obras.

Previamente à aplicação de uma nova tecnologia, o gerente de desenvolvimento repassa as informações relativas à tecnologia aos engenheiros da obra, assim como, os procedimentos de execução, quando os mesmos estão formalizados.

Segundo o gerente de desenvolvimento dessa empresa, não há um programa específico para o repasse das novas tecnologias aos profissionais de nível superior. 
A empresa "J", cujos trabalhos de construção de edifícios tiveram início recentemente, tem procurado desenvolver a capacitação tecnológica de toda a sua equipe técnica através de cursos oferecidos por consultores especializados em temas específicos. Segundo depoimentos do diretor técnico dessa empresa, os investimentos na capacitação dos recursos humanos, em toda a escala hierárquica deverão ser incrementados.

Muitas empresas detectaram, nesse patamar hierárquico, o maior nivel de rejeição às ações realizadas no sentido de evoluir o processo de produção de edifícios.

Segundo o diretor da empresa "A": "o treinamento em todos os niveis é a chave do processo de implantação de melhorias" e, além disso, acrescenta: "os cursos oferecidos pela empresa proporcionaram a oportunidade de ocorrer uma seleção natural dos engenheiros; sairam aqueles que não tinham competência para produzir com qualidade".

O diretor técnico da empresa " $B$ " também tem identificado dificuldades de aceitação da nova filosofia de trabalho por parte do corpo de engenheiros, segundo ele: "ao serem introduzidas alterações tecnológicas no canteiro, muitas vezes depara-se com a dificuldade que os engenheiros têm para entenderem $e$ assimilarem a nova filosofia de trabalho que deverá estar balizada sobretudo na terminalidade dos serviços quando da sua execução, evitando-se retrabalhos e desperdicios. A dificuldade no entendimento dessa filosofia, muitas vezes, leva à seleção natural desse profissional, que acaba desligando-se da empresa".

No caso da empresa "F", as dificuldades encontradas nesse patamar hierárquico têm sido muito expressivas. Seu diretor técnico afirma: "quanto maior o grau de instrução, maior é a rejeição pela novidade (...) tem-se tentado mudar o perfil do profissional disponivel no mercado: o 'engenheiro tocador de obra'. Busca-se formar o gerente da obra, capaz de fazer a gestão do empreendimento sob todos os aspectos: econômico-financeiro e técnico (...)".

Esse diretor afirma, ainda, que devido às dificuldades encontradas, no início de 1994, a diretoria decidiu investir em estagiários, de modo a poder formá-los com a filosofia da empresa. A partir de 1995, começou um programa mais 
organizado de contratação desses estagiários, sendo que o primeiro formou-se no meio desse mesmo ano, tendo sido contratado.

O diretor técnico da empresa "I", por sua vez, afirma: "é difícil o engenheiro entender que 'tocar a obra' é diferente de 'gerenciar a obra', como se fosse uma empresa sua, por isso a necessidade do treinamento inicial".

Pelo exposto fica claro que as empresas estão conscientes de que o caminho a ser percorrido é o da capacitação tecnológica de seus gerentes e profissionais de nível superior (engenheiros e arquitetos). Entretanto, os investimentos na formação desses técnicos ainda têm sido muito reduzido.

De modo geral, as ações das empresas, nesse campo, não têm sido balizadas por uma adequada metodologia, o que pode dispersar os investimentos.

$\mathrm{Na}$ medida em que os programas de capacitação fizerem parte do plano de ação das organizações, o retorno dos investimentos realizados poderão estar expressos nos resultados obtidos nas obras.

\section{b) mestres e encarregados}

A capacitação dos mestres de obras e dos encarregados, na maioria das empresas, tem sido deixada para um plano secundário.

O. contato dos mestres e encarregados com a nova tecnologia tem ocorrido somente no momento em que as atividades estão sendo realizadas nas obras, conduzidas pela equipe de engenharia. Dessa forma, os mestres e encarregados acabam sendo apenas espectadores do processo de implantação. E, muitas vezes, por não terem participado ativamente desse processo, rejeitam a nova tecnologia, dificultando a sua efetivação no canteiro.

A posição das empresas com relação ao papel dos mestres e encarregados no processo de implantação de novas tecnologias não tem sido homogênea.

Segundo o diretor da empresa "E": "o mestre é o elemento fundamental na organização da produção. Isso acontece porque o engenheiro não tem capacidade e conhecimento tecnologico suficientes. Os mestres da empresa vêm sendo formados há dez anos. A empresa possui mestres antigos que após o treinamento, começam a incorporar os procedimentos". 
No caso dessa empresa, a postura é clara. O mestre e os seus encarregados são quem conduz a produção. Portanto, eles são o elemento chave do processo. Por isso, os investimentos têm sido voltados para ambos.

Com essa filosofia a empresa tem proporcionado, a esses profissionais, algumas oportunidades de reciclarem o seu conhecimento, como por exemplo, os cursos oferecidos pelo SENAI.

Algumas outras empresas, apesar de não darem tanto destaque, avaliam que os mestres e encarregados estão abertos ao aprendizado, como demonstram os seguintes depoimentos:

- "os mestres têm disponibilidade plena e estão abertos, com vontade de aprender" (empresa "A");

- "quanto aos mestres, no inicio há uma desconfiança, mas no decorrer das atividades, as dificuldades vão sendo contornadas (...)" (empresa "B").

Entretanto, há empresas que apresentam dificuldades no relacionamento com os seus mestres, ao passarem as novas tecnologias ao canteiro de obras.

É o caso, por exemplo, da empresa "F" que afirma: "nesse processo de tentar passar a tecnologia diretamente para o operário, tem-se esbarrado na figura do mestre. Em função da velocidade crescente com que têm surgido as novas tecnologias, o mestre não consegue incorporar mecanismos compativeis de gestão, então, há uma rejeição pelo que é novo".

O diretor técnico da empresa "F" salienta que: "a figura do mestre "capataz" precisa ser modificada. A maior produtividade dos operários não se consegue com coação, mas com motivação e dando-lhes condições humanas de trabalho. Essas últimas poderiam estar a cargo do mestre. O mestre deve ser um provedor das equipes de trabalho". Para o diretor técnico da empresa "H": "o mestre de obras perdeu o poder de mandar fazer do jeito que quiser e, para que as novas tecnologias sejam implantadas nos canteiros de obras, a gerência de desenvolvimento está tendo de se impor com maior autoridade".

Nessa empresa, em uma das aplicações experimentais, o mestre de obras foi afastado de suas atividades no local específico da aplicação. 
Uma outra empresa que também fez parte da pesquisa, mas que não está inserida no conjunto das dez aqui apresentadas, está introduzindo diversas aplicações experimentais em um edifício em construção. Nesse edifício, além de testar algumas tecnologias racionalizadas, está testando, também, uma nova forma de gestão da mão-de-obra, afastando o mestre de obras do canteiro.

Segundo o gerente técnico dessa empresa, o mestre que inicialmente havia sido destinado a essa obra "começou a rejeitar as novas tecnologias e, por isso, foi afastado das suas atividades".

Nesse caso, a condução do processo de racionalização está a cargo do próprio gerente técnico, que realiza a aplicação com o apoio de diversas "células de trabalho", as quais são equipes constituidas por profissionais de um mesmo ofício, devidamente treinadas para a aplicação das novas tecnologias. Tem-se, por exemplo, "células de trabalho" de produção da estrutura, da alvenaria, das instalações, entre outras.

Deve-se observar, porém, que as açöes dessa empresa, ainda que apresentem alguns pontos positivos, quanto à organização da mão-de-obra, ainda não estão devidamente sistematizadas, como nas demais empresas. Tratam-se de ações isoladas no contexto de todo o processo de produção.

Tentando realizar um trabalho conjunto entre 0 engenheiro e o mestre de obras, a empresa " $D$ " tem procurado estender o trabalho de capacitação tecnológica também para os seus mestres, seguindo o mesmo modelo adotado para o treinamento dos seus engenheiros.

Esse trabalho tem envolvido a realização de cursos de conteúdo tecnológico, os quais procuraram levar aos mestres, numa linguagem acessivel, o porquê da realização de determinados serviços de uma maneira e não de outra.

Um programa mais específico, envolvendo os mestres de obras e os encarregados num trabalho de campo, está previsto pela empresa. Entretanto, essa idéia ainda não foi concretizada.

As colocaçōes anteriores levam a acreditar que para haver uma evolução no processo de produção do edifício, certamente, será preciso estabelecer novas formas de organização e de gestão da mão-de-obra no canteiro. O perfil atual 
dos mestres de obras deve ser mudado. E, também, a competência dos encarregados precisa ser ampliada.

Assim como nos demais setores industriais existe um responsável pela produção, devidamente formado e capacitado para atuar e gerenciar racionalmente os processos, também na indústria de construção de edifícios deverá existir essa pessoa.

Para isso, em sendo mantida a atual estrutura em que o mestre de obras ou os encarregados devem assumir esse papel, o treinamento e a reciclagem dos seus conhecimentos e a sua motivação para empreenderem novos desafios tornam-se fundamentais, como estabelecido nas diretrizes apresentadas no capítulo 5, quanto ao desenvolvimento dos recursos humanos, no item 5.4.3.

Uma outra alternativa seria a substituição gradativa desses profissionais por técnicos de nível médio ou mesmo engenheiros voltados à produção, os quais, também deverão ser devidamente formados para fazer o gerenciamento do canteiro de obras de maneira a otimizar todos os recursos envolvidos.

\section{c) mão-de-obra de produção}

Em todas as entrevistas realizadas com as empresas o treinamento da mãode-obra aparece como um importante elemento do processo de introdução de novas tecnologias.

Não obstante a essa constatação, nenhuma das empresas pesquisadas tem um programa de treinamento voltado aos seus operários.

Dadas as diferentes formas de contratação da mão-de-obra de produção pelas empresas, os investimentos na sua capacitação tecnológica tem ocorrido de distintas maneiras.

As empresas que costumam trabalhar com mão-de-obra de subempreiteiros ainda não conseguiram fazer com que esses realizassem os investimentos para o treinamento de seu pessoal e, na maioria dos casos, as próprias construtoras estão viabilizando meios para que os operários sejam treinados em suas obras.

No caso das empresas que trabalham com mão-de-obra própria, há algumas 
que estão organizando "equipes polivalentes", isto é, que tenham capacidade de atuarem na realização de diversas frentes de trabalho afins, como por exemplo, na execução de estruturas, alvenarias e revestimentos argamassados. Esse é o caso das empresas "H" e "l" e de duas outras que fizeram parte da pesquisa, mas não estão inclusas no conjunto das dez aqui apresentadas.

Na empresa "H" está sendo formada uma "equipe de elite", voltada à produção de alvenarias e revestimentos. Em período de escassez de obras esta equipe trabalha como única célula de produção. Quando o número de obras aumenta, essa equipe é subdividida, a fim de que os seus membros auxiliem no treinamento de novos operários.

No caso da empresa "I" existe uma equipe, formada por cerca de trinta pessoas, voltada à polivalência e que serve como "célula de disseminação" da tecnologia empregada pela empresa, na formação de mão-de-obra menos qualificada.

O diretor técnico da empresa " $A$ ", ainda que não trabalhe com mão-de-obra própria, acredita que o treinamento deve ser objeto de um programa muito bem planejado, afirmando: "como treinar e como transmitir a mensagem aos operários, é de grande importância para o processo de implantação".

O mecanismo mais usualmente empregado pelas empresas, para o treinamento da mão-de-obra, é a realização das atividades no próprio canteiro de obras, através de um técnico ou de um operário que conheça bem a atividade a ser executada. Para isso, as empresas fornecedoras de materiais e equipamentos têm contribuido muito, pois as empresas construtoras têm utilizado os próprios fornecedores de material, componentes e equipamentos para proporcionarem a maioria dos treinamentos realizados.

Ao introduzirem os novos materiais e até mesmo ferramentas e equipamentos, os fornecedores costumam fazer demonstrações em campo. Esse tem sido o caso, por exemplo, do uso da "bisnaga" para assentamento de componentes de alvenaria. A empresa fornecedora da argamassa industrializada utiliza o seu pessoal técnico para treinar alguns operários das obras no uso dessa ferramenta, objetivando a venda de sua argamassa. 
Esse tipo de treinamento, porém, nem sempre se mostra eficiente. Muitas vezes, assim que o fornecedor sai do canteiro, a mão-de-obra volta ao uso da colher, pois não houve um processo de fixação da nova ferramenta.

Nāo é fácil alterar uma técnica há muito tempo dominada pela mão-de-obra. Por isso, a empresa "I" tem optado pelo treinamento de serventes, os quais, segundo essa empresa: "são extremamente receptivos ao aprendizado".

De maneira geral, as empresas são unânimes em afirmar que não há rejeição expressiva por parte da mão-de-obra em aprender as novas técnicas trazidas aos canteiros. Mas, afirmam também que não há treinamento sem motivação das pessoas. Por isso, a maioria delas tem procurado a motivação de seus recursos humanos.

\subsubsection{Programas de motivação dos recursos humanos}

As formas de motivação usadas pelas empresas construtoras tem sido muito distintas de uma para outra, variando também com os níveis hierárquicos.

De modo geral foram identificados programas voltados ao que se poderia denominar "equipe administrativa" da empresa, envolvendo desde a gerência até os encarregados e programas voltados à mão-de-obra de produção.

Os programas de motivação destinados à "equipe administrativa" estão concentrados na distribuição de resultados, sob a forma de prêmios; enquanto os programas de motivação da mão-de-obra de produção concentram-se mais na melhoria das condições de trabalho nos canteiros de obras. Essas formas de incentivo serão abordadas a seguir.

\section{a) "equipe administrativa"}

Nem todas as empresas criaram programas específicos de motivação para seus técnicos de nível superior (gerentes, engenheiros e arquitetos) e nem mesmo para os mestres e encarregados.

Durante a realização das pesquisas identificou-se que algumas empresas, ao introduzirem o processo de mudança tecnológica, passaram a ter uma posição de cobrança de melhores resultados, sem entretanto, preocuparem-se com alguma forma de recompensa pelas mudanças empreendidas. 
As que declararam ter algum programa de motivação voltado à "equipe administrativa" foram as empresas: "A", " $E$ ", " $F$ " e "l". As demais não chegaram a formalizar um programa de motivação, até o término da pesquisa realizada.

Juntamente com a introdução de novas tecnologias e para fortalecer esse processo, a empresa "A" estabeleceu o Programa de Incentivo à Qualidade (PIQ), o qual envolve todos os funcionários da empresa, até os encarregados. Nesse programa são formados grupos de trabalho, os quais estabelecem metas a serem atingidas, passando-se por diversas etapas no período de um ano. A empresa definiu um prêmio em dinheiro para cada etapa cumprida, podendo totalizar, ao longo do ano, três salários do funcionário.

Para a empresa "A", "a motivação do nivel administrativo da obra é fundamental para o comprometimento com o processo de implantação. A postura do engenheiro é a peça fundamental, uma vez que ele motiva os demais niveis".

Na empresa "E" está em processo de implantação um programa de distribuição de resultados que envolve o coordenador, todos os engenheiros e mestres, e também os encarregados das obras. A avaliação é feita pelo diretor técnico, auxiliado pelo coordenador e ocorre a cada três meses. Em função dos resultados obtidos, segundo critérios preestabelecidos, cada funcionário pode vir a receber até três salários a mais por ano.

$\mathrm{Na}$ empresa " $\mathrm{F}$ " também existe um programa de avaliação dos resultados, muito semelhante ao da empresa " $E$ ". No entanto, no caso da empresa " $F$ ", os engenheiros recebem um prêmio em função dos resultados da empresa como um todo, enquanto os mestres e encarregados recebem um prêmio em função dos resultados de suas obras. Também neste caso a avaliação é realizada pelo diretor técnico, a partir de critérios previamente estabelecidos.

A empresa "I", por sua vez, possui um programa de incentivo que envolve tanto os recursos humanos alocados no escritório, como os alocados nas obras. Com relação ao "pessoal de escritório", a distribuição dos resultados ocorre desde a gerência até o "office-boy". Com relação ao "pessoal da obras", apenas os gerentes (engenheiros de obras) são contemplados.

O programa consiste na distribuição de $10 \%$ dos lucros da empresa, a cada 
três meses. A distribuição é feita proporcionalmente aos salários, cabendo $60 \%$ do prêmio aos gerentes de produção (obra) e $40 \%$ ao setor administrativo (escritório).

A distribuição da parte que cabe aos engenheiros de obra é feita da seguinte maneira: $60 \%$ proporcional ao salário e o restante segundo critérios estabelecidos pela diretoria técnica.

Atualmente a empresa está procurando um método que permita dividir a parte que cabe ao gerente de produção de acordo com o seu desempenho, ou seja, $70 \%$ do montante destinado à produção deverá ser relativo ao resultado obtido pela obra e $30 \%$ relativo ao resultado da empresa.

Os mestres e encarregados não são contemplados com esse prêmio. Sua avaliação ocorre no final da obra e os critérios são ainda subjetivos.

\section{b) mão-de-obra de produção}

A motivação da mão-de-obra de produção, quando inserida no programa de ação das empresas, objetiva sobretudo a diminuição da rotatividade e o aumento de produtividade na realização dos serviços.

Dessa forma, as empresas que trabalham com mão-de-obra de subempreiteiras pouco têm feito com relação à motivação, justificando que a contratação dos serviços ocorre por preço fechado.

Os maiores investimentos quanto à motivação da mão-de-obra de produção têm sido praticados pelas empresas " $E$ " e "G".

Ao tentar aplicar novas tecnologias, a empresa "E" verificou que os operários nāo se interessavam pelo treinamento. Sentiu uma completa desmotivação que, segundo o diretor técnico, não tinha correspondência com o ganho salarial, o qual se encontrava acima da média de mercado. Para reverter esse processo, a empresa vem investindo em outras formas de motivação.

Inicialmente criou, em cada obra, o "grupo de elite", constituído por vinte pessoas. Para integrar esse grupo, o operário deve ter mais de dois anos de trabalho na empresa; deve usar uniforme regularmente; estar constantemente com boa aparência (cabelos e barba aparados); ser produtivo e assíduo. 
Os funcionários desse grupo ganham $25 \%$ a mais no salário e a cada ano integrando o grupo, ganham um salário a mais como recompensa.

Segundo o diretor técnico da empresa, não é o maior salário que motiva os funcionários a quererem participar desse grupo, mas o "status" que advém dessa participação, a qual é amplamente divulgada pela empresa.

Além da formação do "grupo de elite", a empresa levou a Escola para dentro do canteiro e, apesar de todas as dificuldades enfrentadas, hoje conta com uma turma de vinte e cinco alunos no curso de alfabetização, para os quais paga horas extras para participarem das aulas. Além disso, conta com um programa de atendimento médico no canteiro a cada 15 dias.

Segundo a diretoria, esses programas de motivação têm contribuído, de modo expressivo, para a diminuição da rotatividade dos operários na empresa.

No caso da empresa "G", sua opção tem sido pela melhoria das condiçōes de trabalho e de segurança nos canteiros de obras, não importando se a mão-deobra é própria ou de terceiros. Esse trabalho tem envolvido o treinamento do pessoal quanto à segurança e estímulo ao uso de equipamentos de proteção. Envolve, também, investimentos na infra-estrutura do canteiro de obras, objetivando melhores condições de trabalho. Nesse sentido, foram melhoradas as condições de alojamento, alimentação, vestuário, lazer e educação.

Segundo o diretor técnico da empresa, os investimentos que têm sido realizados estão trazendo retornos positivos, podendo-se verificar uma queda expressiva na rotatividade dos operários, além de uma mudança de postura frente a diversas situações. Ele exemplifica com a situação da greve ocorrida no setor da Construção, por ocasião do dissídio de maio de 1995 , em que os operários da empresa não pararam.

A baixa rotatividade dos operários é uma condição desejável e significativa no processo de implantação das novas tecnologias, pois na medida em que são feitos investimentos na capacitação e no treinamento dos operários, é preciso que os mesmos não abandonem a empresa num momento seguinte.

Por isso, os programas de incentivo à mão-de-obra de produção que procuram resgatar a dignidade dos operários e fornecer-lhes melhores condições de 
trabalho nos canteiros de obras, tais como os que as empresas " $E$ " e "G" vêm adotando, constituem pontos fundamentais para o sucesso da implantação de TCR's, o que confirma a necessidade de uma diretriz fundamental de desenvolvimento dos recursos humanos defendida na metodologia proposta no capítulo 5, no item 5.4.3.

\subsubsection{A organização do setor de suprimentos}

Segundo os depoimentos das empresas, o setor de suprimentos sempre foi afetado pela introdução das novas tecnologias, na medida em que é o responsável pela aquisição de materiais, componentes e equipamentos, mesmo sendo diferentes dos tradicionalmente adquiridos.

Dessa forma, juntamente com a elaboração dos procedimentos de execução, muitas empresas vêm desenvolvendo procedimentos para solicitação e recebimento de materiais e componentes, os quais precisam ser acordados com o departamento de suprimentos.

De maneira geral as empresas são categóricas em afirmar que esse departamento deve adquirir os materiais e componentes especificados pelas obras, estando apto, portanto, a participar do processo de implantação de novas tecnologias, desde que as especificações sejam claras e os pedidos sejam solicitados dentro dos prazos comumente estabelecidos por esse departamento.

De fato, essa orientação foi observada na maioria das empresas pesquisadas. A organização interna do departamento de suprimentos de cada empresa parece não ser difícil de se realizar.

De modo geral tratam-se de pequenas equipes, que, se bem orientadas e formadas, têm condições de fazer as compras estabelecidas pelas obras, de maneira técnica.

O setor de suprimentos, na maioria das empresas, desenvolve suas atividades segundo as orientações expressas da alta diretoria. Se o objetivo é "comprar por preço", o setor trabalha segundo essa diretriz. Se o objetivo é realizar a compra técnica, desde que the sejam estabelecidos os parâmetros adequados, a compra técnica deverá ser realizada. 
Entretanto, mesmo com a declarada organização da equipe de suprimentos, diversos problemas foram detectados nas obras visitadas, decorrentes da inadequação dos materiais e componentes que chegavam ao canteiro.

Apenas para ilustrar algumas das principais situaçōes encontradas, apresentase o caso específico das alvenarias de vedação, cujos principais problemas identificados foram:

- atrasos na entrega de argamassas industrializadas para o assentamento;

- troca da argamassa de assentamento pela empresa fornecedora;

- atrasos na entrega dos componentes de alvenaria (blocos);

- elevada variação dimensional dos componentes de alvenaria entregues por um mesmo fornecedor;

- mudança de fornecedores de componentes (em uma das obras foram identificados três fornecedores distintos de blocos cerâmicos).

Os problemas anteriormente apresentados, num primeiro momento parecem não ser de responsabilidade da equipe de suprimentos, nem tampouco da construtora, pois foram os fornecedores que atrasaram a entrega, eles que trocaram o material entregue, eles entregaram um componente fora dos padrões dimensionais. No entanto, a empresa sujeitou-se a receber o material atrasado, o material trocado e o material fora dos padrões dimensionais.

Quanto à mudança de fornecedores, ela não se faz sem a consciência expressa da empresa. Se fornecedores distintos entregam componentes de alvenaria na obra é porque a empresa, representada pelo seu departamento de suprimentos, efetuou a compra.

Se todos esses "desencontros" ocorrem, é evidente que existe algum problema. E, esse problema, não está presente somente no mercado. Não é de responsabilidade exclusiva do fornecedor. Há, também, uma parcela de responsabilidade da empresa.

Por isso, para que o processo de produção de edifícios possa realmente evoluir, esses problemas precisam ser solucionados pela empresa em conjunto com seus fornecedores. 
O mercado de materiais e componentes para a construção, durante muito tempo, acostumou-se a "fazer o que bem entendia", "a entregar o que quisesse e quando quisesse". Esse processo precisa ser revertido. E, somente o será quando as empresas começarem a impor a sua diretriz de como comprar e como receber tecnicamente.

A definição de uma política de aquisição e recebimento de suprimentos para as obras de edifícios não é algo fácil de se estabelecer, sobretudo pelo número de variáveis que interferem nesse processo e principalmente porque interage fortemente com o mercado.

Muitas empresas, sobretudo as que estão participando de programas objetivando a gestão da qualidade, desenvolveram procedimentos rígidos de controle de recebimento de materiais. Houve casos em que as obras chegaram a devolver caminhões de blocos cerâmicos porque a amostragem não atendeu aos padrões estabelecidos.

Para o fornecedor de blocos a devolução do caminhão não significa praticamente nada. Ele o entregará a uma outra obra que não faz o controle. Para a obra que ficou sem o suprimento, pode significar um atraso expressivo no planejamento global do empreendimento.

Em função disso, as empresas precisam definir os procedimentos de aquisição e recebimento, de maneira que possibilitem evitar esses tipos de problemas. Lembrando que se deve trabalhar sempre em parceria com as empresas fornecedoras.

Alguns procedimentos de aquisição e compra de suprimentos com essa 'filosofia' estão sendo empregados pela empresa "D".

Segundo os procedimentos dessa empresa, inicialmente o fornecedor deve ser visitado pela equipe de suprimentos, a fim de se avaliar o seu potencial de fornecimento, bem como, as características de seu produto.

O contrato a ser estabelecido com os fornecedores prevê sanções gradativas, conforme o produto entregue não esteja em conformidade com os parâmetros estabelecidos. 
Ocorrendo uma primeira não conformidade, mas que esteja dentro de certas tolerâncias, também estabelecidas, o material ou componente pode ser "recebido com restriçōes". Nesse caso, a empresa fornecedora será comunicada que a nova remessa deverá estar dentro dos padrões definidos ou a empresa será eliminada do conjunto de fornecedores.

Essa postura não é fácil de ser mantida, sobretudo nos casos em que se tem um número reduzido de fornecedores e pouca flexibilidade no planejamento da obra. No entanto, pelo que foi anteriormente apresentado e analisado, fica clara a importância de se ter um setor de suprimentos voltado à produção.

Se as empresas não passarem a atuar de maneira técnica ao adquirirem e receberem os seus materiais e componentes, o departamento de suprimentos poderá estar com todaś as suas rotinas administrativas em dia, mas as obras poderão vir a continuar desprezando os projetos e a fazer adaptações, porque os materiais e componentes entregues e aceitos estão fora dos parâmetros de produção.

\subsubsection{A implantação de um sistema de controle}

De todas as diretrizes fundamentais estabelecidas pela metodologia de implantação proposta, pode-se dizer que esta é a de mais difícil concretização no interior das organizações.

A falta de uma cultura empresarial voltada ao controle dos processos de produção na indústria da Construção de Edifícios que ainda prevalece, ficou claramente demonstrada na pesquisa realizada, cujas constatações principais serão apresentadas e discutidas.

Identificou-se, através da pesquisa, que todas as empresas dizem possuir algum mecanismo de controle. Entretanto, esses mecanismos nem sempre estão formalizados e, além disso, há mecanismos formalizados que não são utilizados durante a execução das obras.

O mecanismo não formalizado refere-se ao controle costumeiro realizado nas obras, pelo mestre de obras ou mesmo pelos encarregados de serviço. 
Quando as empresas foram questionadas sobre os parâmetros empregados por esses profissionais para a realização do controle, responderam: "o bom senso e a sua experiência".

Esse tipo de controle, como discutido no capítulo 5, não oferece nenhum mecanismo de domínio do processo de produção à direção da empresa.

Entretanto, muitas empresas parecem acreditar que esse domínio do processo de produção deve existir. Por isso, algumas delas têm se empenhado na criação dos mecanismos de controle.

No decorrer da pesquisa foi possivel identificar três ações distintas voltadas ao controle de execução, ainda que não inseridas numa visão sistêmica do processo de produção do edifício.

Um dos modelos de controle identificados está inserido no conjunto de açōes previstas para a implantação de programas de gestão da qualidade nas empresas. O segundo modelo é específico para o controle da montagem de fôrmas da estrutura do edifício; enquanto o último vem sendo desenvolvido por duas empresas, em particular, fruto do programa de implantação da racionalização na produção de alvenarias.

O controle dos processos, previsto nos programas de Gestão da Qualidade, faz parte de um conjunto de medidas que visam a padronização e documentação dos processos de produção. Ou seja, os processos devem ser padronizados e deve haver um controle para verificar se o padrăo está sendo atendido.

Esse controle tem sido denominado de "inspeção de serviços", ao qual corresponde um procedimento de inspeção e uma ficha de verificação.

No procedimento de inspeção estão descritos os itens a serem verificados, a metodologia e o critério de avaliação; enquanto a ficha de verificação é utilizada para se efetuar o controle no momento da execução, existindo campos a serem preenchidos conforme o serviço tenha sido aprovado ou rejeitado.

As empresas "B", "C", "D", "E", " $F$ ", "G" e "I" possuem esse tipo de documentação para alguns serviços, com diferentes graus de desenvolvimento. 
Apenas para ilustrar cita-se o procedimento de inspeção de serviço padronizado pela empresa "B", para "alvenaria de vedação em blocos cerâmicos ou de concreto - fase marcação".

Nesse procedimento, um dos itens de verificação previstos é 0 alinhamento cuja metodologia e critério de avaliação são assim definidos: "verificar o alinhamento das paredes com régua técnica , admitindo uma tolerância de $2 \mathrm{~mm}^{5}$.

Para esse item a ficha de inspeção prevê campos a serem preenchidos conforme o mesmo seja "aprovado" ou "rejeitado", devendo-se o registro ser feito em porcentagem de aprovação ou rejeição.

É evidente que os "procedimentos de inspeção de serviços" significam um avanço para o processo informal de controle; entretanto, o que se verificou é que ao se propor tais procedimentos, criam-se apenas mais algumas planilhas a serem preenchidas na obra, cujo objetivo não fica claramente definido.

Na maioria dos casos, não se sabe o que fazer com os resultados do controle. Por exemplo, quando a tolerância estabelecida pelos procedimentos é ultrapassada (casos de não conformidade), o que deverá ocorrer? E ainda, quem realiza o controle? Qual a amostragem para cada atividade? Como as informaçōes do controle realimentarão a continuidade do processo de produção?

Os principais elementos que devem estar presentes num sistema de controle não estão claramente definidos nesse modelo. Dessa forma, ainda que os procedimentos existam, não têm sido utilizados pelos gerentes das obras, os quais, têm preferido manter o sistema informal, em que o mestre ou mesmo o encarregado, através de seu bom senso e de sua experiência, fazem o recebimento dos serviços.

O modelo que visa exclusivamente o controle da montagem das fôrmas foi desenvolvido por um projetista de fôrmas e inserido no próprio projeto de montagem. Nesse modelo, para cada um dos pavimentos, existe uma prancha do projeto de montagem na qual estão identificados os principais elementos do

\footnotetext{
5 A ferramenta denominada "régua técnica" consiste numa régua metálica, à qual são acoplados niveis de bolha, facilitando, com isso, a verificação das características geométricas de elementos do edifício.
} 
sistema de fôrmas e a sua respectiva medida de locação. Junto da medida de locação existe um espaço que deverá ser preenchido com as medições realizadas durante a montagem. O confronto da medida realizada com a que consta no projeto, bem como, com a tolerância estabelecida, permite identificar de imediato possíveis falhas de locação, as quais deverão ser corrigidas previamente à liberação da fôrma para a concretagem.

Esse modelo, ainda que de pequena complexidade, não tem sido facilmente incorporado pelas obras. O gerente de desenvolvimento da empresa " $\mathrm{H}$ ", que vem implantando com afinco esse tipo de controle da estrutura, fez o seguinte depoimento: "inicialmente houve muita reação dos carpinteiros em aceitar o sistema de controle, bem como as tolerâncias estabelecidas. Depois de muita insistência e conversas rotineiras, nas quais se explicavam os motivos da realização do controle, começou a haver uma mudança de postura. Hoje, os prazos de montagem da fôrma foram revistos, permitindo-se que o trabalho fosse feito com mais cuidado; além disso, diferenças de $3 \mathrm{~mm}$, hoje, são consideradas não conformidades e são corrigidas, enquanto no inicio, deixava-se passar".

Esse gerente enfatiza, ainda, que os ganhos com relação à precisão dimensional da estrutura foram significativos após a implantação do sistema de fôrmas em conjunto com o sistema de controle.

Deve-se salientar que essa empresa, além de ter o engenheiro de desenvolvimento acompanhando constantemente o processo de implantação do sistema de controle, destinou também um estagiário de engenharia devidamente treinado e exclusivamente responsável por essa atividade na obra.

Outras empresas como a " $A$ " e a "F" também estão trabalhando com esse sistema de fôrmas, utilizando, segundo os seus diretores técnicos, o mecanismo de controle estabelecido no projeto.

Além desses modelos de controle, pôde-se identificar também que as empresas " $A$ " e " $H$ " possuem, para o serviço de execução de alvenarias de vedação, um procedimento de controle que contém grande parte dos elementos propostos nas diretrizes estabelecidas na metodologia apresentada no capítulo 5. 
Os principais elementos que constituem os seus procedimentos de controle de alvenaria são:

- definição das instâncias de controle;

- definição dos responsáveis, em cada uma das instâncias;

- estabelecimento da freqüência de controle em cada uma das instâncias;

- determinação dos objetos de controle para cada estágio;

- definição das metas a serem atingidas;

- determinação de diretrizes balizadoras para as tomadas de decisão; e

- definição de um mecanismo de comunicação, através da elaboração de diversos tipos de relatórios contendo as principais informações advindas do controle.

Por ocasião da realização da pesquisa, tanto a empresa "A", como a " $\mathrm{H}$ ", encontravam-se na fase de experimentação desse modelo em uma de suas obras.

A empresa "J" não possui nenhum tipo de procedimento de controle formalizado. O controle do processo de produção na obra é completamente informal, sendo realizado pelos encarregados, mestres e engenheiros, sem a existência de parâmetros previamente definidos pela empresa.

Muito embora a maioria dos diretores técnicos reconheçam a importância de se ter mecanismos de controle aplicados ao processo de produção, a pesquisa realizada permitiu identificar que nenhuma das empresas conseguiu estabelecer uma sistemática de controle que possibilitasse à direção ter o domínio global do processo de produção dos edifícios.

Ou seja, as empresas que vêm procurando implantar novas tecnologias nos canteiros de obras, praticamente, não têm mecanismos formalizados que lhes permitam ter o retorno de suas ações.

Se não há controle, como saber se os projetos desenvolvidos estão sendo realmente utilizados durante a produção?; como identificar quais são os problemas causados por indefinições nos projetos; como saber qual foi a eficiência do treinamento?; como identificar os elementos que podem ser melhorados em empreendimentos futuros? 
Alguns dos diretores técnicos das empresas, para justificar a ausência de uma estrutura organizacional voltada ao controle dos processos afirmam: "minha empresa é pequena, estou sempre na obra verificando o que está ocorrendo. Faço reuniões periódicas com meus engenheiros e gerentes para ter o retorno dos principais acontecimentos da obra".

Entretanto, ao serem questionados: e se o número de obras aumentar, o que acontece? A resposta é única: "perco o dominio do processo; não daria tempo de acompanhar de perto".

Pelas colocações anteriores procurou-se deixar claro a importância dos mecanismos de controle na indústria da Construção Civil, assim como são importantes para qualquer outro setor industrial.

Não haverá evolução no processo de produção de edifícios se as empresas não souberem onde estão errando e onde precisam melhorar. E elas somente terăo esse retorno, a partir do momento em que conhecerem a sua produção, controlando-a, por mais simples que sejam os seus processos. Assim, a importância da diretriz estabelecida na metodologia proposta no capítulo 5.

\subsubsection{A retroalimentação das ações nos canteiros de obras}

Os resultados da pesquisa realizada junto às empresas, para o desenvolvimento deste trabalho, mostraram claramente que não existem mecanismos formais de retorno de informações da obra em execução, para um projeto futuro. Isto fica claro em alguns depoimentos, como por exemplo:

"O retorno não acontece. Estamos montando uma estrutura para isso" (empresa " $\mathrm{A}$ "). "O retorno acontece através da participação do Diretor de Engenharia e Produção e do Diretor de Planejamento, nas reuniões de coordenação de projeto" (empresa "B"). "O retorno das dificuldades existe informalmente. Acontece de forma verbal. $O$ engenheiro transmite ao coordenador dos projetos as dificuldades encontradas na execução dos serviços" (empresa "C").

"A realimentação é feita através de reuniões mensais do diretor técnico com os engenheiros e pelo controle das manutenções por serviços" (empresa " $\mathrm{H}$ ").

Observa-se que, na maioria das vezes, as trocas de informações ocorrem em 
reuniōes técnicas, quando existem, cuja maioria ocorre sem a participação de mestres e encarregados; portanto, nesses casos, as informaçōes passadas são apenas aquelas que originaram maiores problemas na obra e que, de alguma forma, chegaram até os engenheiros responsáveis.

Năo existe sistematização de dados, não existem registros formais, não existe análise das experiências vividas. O conhecimento adquirido fica registrado para algumas pessoas que participaram do processo de produção e, na maioria das vezes, não têm mecanismos formais para que possam transmitir e sedimentar esse aprendizado.

\subsection{Considerações Finais sobre a Importância da Metodologia}

Pelas colocações anteriores fica claro que não há uma estagnação do setor de Construção de Edifícios, como muitos autores insistem em afirmar.

As empresas são dinâmicas e estão procurando novas formas de produção que Ihes permitam alcançar maior competitividade no mercado presente.

A introdução de novas tecnologias nos canteiros apresenta-se como uma forte tendência para o setor. Muitas "novidades" tecnológicas foram identificadas ao longo da pesquisa. Já não se constrói mais como há dez ou vinte anos atrás. Entretanto, a introdução de melhorias nos canteiros não é sistêmica.

São poucas as empresas que estão conseguindo encarar o processo de produção como um todo. Mesmo assim, nenhuma delas conseguiu, ainda, atuar em todo esse processo de modo a alterar a sua organização tradicional, o que dificulta a mudança de postura e de cultura organizacional.

Com isso, muitas ações que visam a racionalização, mas que são pontuais, acabam por se perder no complexo processo de produção que envolve a construção de cada novo edifício.

A falta de um mecanismo que possibilitasse, às empresas, a sistematização do conhecimento adquirido e que favorecesse o seu processo de aprendizado, somada à análise anteriormente apresentada, certamente justificam a necessidade e a importância do estabelecimento de uma metodologia de ação, como a que foi proposta no capítulo 5 . 


\section{CAPÍTULO 7}

\section{CONCLUSÕES}

A indústria da Construção Civil, apesar dos baixos índices globais de desempenho registrados ao longo dos últimos anos, continua tendo um papel importante no crescimento da economia nacional, constituindo-se num elemento fundamental para a geração de empregos, bem como, para a integração de outros segmentos industriais, tais como os que produzem materiais, componentes e equipamentos e os que prestam serviços.

Hoje, esta indústria encontra-se em processo de transição, ficando evidente o aumento da competitividade no segmento de construção de edifícios. Há uma ampla abertura de mercado, com a iminente entrada de empresas estrangeiras disputando espaço com as nacionais. Por outro lado, grandes empresas construtoras, antes concentradas na produção de obras pesadas, devido à restrição de investimentos nesse segmento, estão se voltando também à produção de edifícios. Com isso, um grande número de empresas concorrem para ganhar uma parcela do limitado mercado existente.

As mudanças ocorrem também junto aos fornecedores de materiais, componentes e equipamentos. Principalmente em decorrência da abertura de mercado, diversas empresas têm trazido novos produtos, nem sempre conhecidos, que passam a disputar espaço nos projetos e também nos canteiros de obras de edifícios.

Para atuar nesse novo contexto de mercado, as empresas deverão estar preparadas para enfrentar o grande desafio de evoluir o seu processo de produção, a fim de reduzir os seus custos e de aumentar a qualidade de seus produtos.

A adoção de novas tecnologias, de novas formas de organização do processo de produção e de novas formas de gestão empresarial, que imprimam melho- 
res resultados aos produtos e processos do setor, é um dos caminhos que vêm sendo procurados por essas empresas.

Entretanto, alterar a estrutura técnico-organizacional de uma atividade tão antiga quanto o próprio homem não é uma tarefa fácil de ser realizada.

As poucas empresas que têm procurado adotar "ações inovadoras" através de alterações na sua forma de produção atual têm esbarrado em inúmeros obstáculos, tais como os apresentados e discutidos no contexto do terceiro capítulo, os quais, comumente, inibem o avanço do processo de produção.

Considerando-se essa realidade, a principal contribuição que se pretende dar com a realização deste trabalho é proporcionar os meios para que os obstáculos existentes venham a ser transpostos pelas empresas, possibilitando, assim, a evolução do processo construtivo tradicional.

O caminho aqui proposto procura envolver tanto a mudança tecnológica quanto a organizacional e a gerencial, através de uma visão sistêmica do processo de produção. Ou seja, evoluções tecnológica, organizacional e gerencial devem ocorrer em conjunto para que se tenha maior eficiência no processo de produção.

A Implantação de Tecnologias Construtivas Racionalizadas constitui um instrumento essencial para viabilizar essa mudança. Mas, para isso, a implantação deverá ser orientada por uma metodologia específica que possibilite às empresas conduzirem suas ações sempre de maneira sistêmica.

\subsection{A necessidade e a proposição da metodologia}

As experiências pelas quais a autora tem passado e os resultados das entrevistas realizadas com empresas construtoras mostraram claramente que há muitas empresas dispostas a evoluir o seu processo de produção, como uma resposta às solicitações de mercado. Entretanto, muitas delas não sabe nem mesmo por onde começar. Algumas iniciam por diversas frentes, perdendo-se logo depois num emaranhado de ações que não atendem aos objetivos iniciais. 
Por isso, buscou-se desenvolver uma metodologia de ação que pudesse conduzir racionalmente os passos dessas empresas dispostas a evoluir o seu sistema de produção, evitando-se desvios na condução da implantação. E, para isso, um longo caminho foi percorrido pela autora.

Inicialmente procurou-se montar um referencial teórico que fundamentasse a proposição. Para isso, foram desenvolvidos o segundo, terceiro e quarto capítulos.

No segundo capítulo buscou-se consolidar os conceitos empregados pelo meio técnico e os que dizem respeito à implantação de novas tecnologias nos canteiros de obras. Dentre os diversos conceitos apresentados e discutidos, definiu-se o que se entende por Tecnologia Construtiva Racionalizada e por Inovação Tecnológica, chegando-se à conclusão que:

"a Tecnologia Construtiva Racionalizada (TCR) configura-se numa Inovação Tecnológica, desde que se incorpore à cultura da empresa, sendo efetivamente aplicada ao processo de produção do edificio".

Com isso, buscou-se o desenvolvimento de uma metodologia que permitisse "transformar" as tecnologias construtivas racionalizadas disponiveis no mercado em inovações tecnológicas efetivas para a empresa construtora.

Entretanto, essa metodologia não poderia ser proposta sem que se considerasse o contexto no qual a indústria da Construção de Edifícios está inserida. Por isso, foi preciso desenvolver o terceiro capítulo, no qual se procurou entender como está organizada a indústria da Construção e, em particular, o seu subsetor Construção de Edifícios.

Além disso, procurou-se conhecer também quais estratégias as empresas vêm adotando para fazer frente às atuais exigências de mercado.

Dentre as diversas estratégias identificadas, destacaram-se a implantação de programas de gestão da qualidade e a aplicação de ações de racionalização. Essas duas formas de ação foram analisadas nesse terceiro capítulo, identificando-se, com isso, os principais pontos positivos e negativos dessas 
estratégias de ação, os quais vieram a contribuir para a proposição da metodologia.

Para completar o quadro de referência para o desenvolvimento da metodologia, elaborou-se o quarto capítulo, no qual são identificados os elementos fundamentais à formulação da metodologia especifica para a implantação de TCR's em empresas construtoras de edifícios pelo processo construtivo tradicional.

Esses elementos foram reunidos a partir da análise da bibliografia disponivel, voltada à implantação de inovações tecnológicas, tanto para a indústria seriada quanto para a indústria da Construção Civil e, também, por meio da análise de duas relevantes experiências vivenciadas pela autora, ao buscar implantar TCR's no processo de produção de edifícios.

A partir dos fundamentos proporcionados por esses três capitulos iniciais, no quinto capítulo, fez-se a proposição da metodologia propriamente dita, a qual inicia-se pelo estabelecimento de algumas premissas que a empresa deve observar, antes de se propor a alterar seu processo de produção.

Essas premissas envolvem fundamentalmente:

- empenho e disponibilidade de recursos para a realização das mudanças;

- existência de liderança na condução do processo de implantação.

Considera-se que sem a existência dessas premissas, mesmo com o emprego da metodologia proposta, as açōes de racionalização terão reduzidas chances de se efetivarem na cultura da empresa. E desta forma, será difícil que a "implantação de TCR's", defendida neste trabalho, como sendo a "consolidação da TCR no sistema produtivo da empresa e no processo de produção de edifícios, através de princípios que permitam a sua constante evolução, torne-se uma realidade para as organizações.

Com a observação das premissas estabelecidas e com a adoção da metodologia proposta, acredita-se que a empresa terá grandes chances de sucesso ao implantar as TCR's no seu sistema de produção. 
$\mathrm{Na}$ metodologia proposta procura-se considerar os principais aspectos envolvidos com a implantação de uma nova tecnologia numa empresa de construção de edifícios, visando conduzir efetivamente o processo de implantação.

Para isso, a metodologia está fundamentada numa doutrina que norteia todo o processo decisório. Essa doutrina é constituida por uma filosofia e por um conjunto de diretrizes balizadoras do processo de implantação.

A filosofia que sustenta todas as ações a serem empreendidas baseia-se na "melhoria contínua dos recursos tecnológicos, organizacionais e gerenciais empregados no processo construtivo tradicional de produção de edificios com vistas à sua máxima racionalização e conseqüente evolução".

Ou seja, ao se enfocar o processo construtivo tradicional, busca-se não romper drasticamente com a atual forma de organização e gestão da produção e, sim, poder otimizá-la aos poucos, aumentando, com isso, seu grau de racionalização e, por conseqüência, a competência produtiva das empresas.

As diretrizes que traduzem essa filosofia são cinco, assim definidas:

- desenvolvimento das atividades de projeto;

- desenvolvimento da documentação referente às TCR's;

- desenvolvimento dos recursos humanos;

- desenvolvimento do setor de suprimentos voltado à produção;

- desenvolvimento do controle do processo de produção.

Esse conjunto de diretrizes definem o encaminhamento das ações que deverão ser praticadas pela empresa, para que o processo de implantação de TCR's tenha maior probabilidade de sucesso.

Ao se estabelecer esse conjunto de diretrizes, propõe-se interferir fundamentalmente na mudança tecnológica, na organização e na gestão do processo de produção, buscando a sua completa integração. Ou seja, a introdução de uma nova tecnologia deixa de ser uma atividade localizada, que ocorre no momento da realização dos serviços e passa a ser uma atividade integrada ao processo 
de produção, imprimindo, assim, um maior potencial de racionalização construtiva.

Além desse conjunto de diretrizes, a metodologia é constituída, ainda, por uma estratégia de ação, que a empresa deverá adotar para a implantação das TCR's propriamente dita.

Essa estratégia é traduzida por um plano de ação que contém uma sugestão de como encaminhar o processo de implantação com todas as suas etapas e inter-relações, até que a tecnologia esteja inserida no sistema de produção da empresa.

Esse plano de ação prevê uma inserção gradual das TCR's. E à medida em que a empresa vai "experimentando" a nova tecnologia, vai tendo a oportunidade de modificar a sua forma de organizar e de gerir a produção, para melhor atender aos objetivos de contínua evolução desse processo.

Aos poucos, a empresa vai tendo o domínio das novas tecnologias, as quais vão sendo fixadas gradativamente ao sistema de produção da empresa, sendo incorporadas aos novos empreendimentos.

Ao serem fixadas no sistema de produção da empresa, as TCR's, além de terem modificado a sua organização, acabam modificando também o meio externo, uma vez que as relaçōes da empresa com os demais agentes do processo de produção acabam sofrendo alterações que, comumente, contribuem para a evolução do segmento de Construção de Edifícios.

\subsection{A Contribuição da Metodologia para a Evolução da Indústria da Construção de Edifícios}

A metodologia para a implantação de TCR's, ao mesmo tempo que proporciona uma evolução tecnológica, é também o elemento motivador das mudanças na organização e na gestão da empresa, essenciais para a evolução tanto do seu sistema de produção como também das relações existentes com os diversos agentes que interferem no processo de produção dos edifícios. 
A introdução de TCR's exige, por parte da empresa, uma nova visão quanto ao seu processo de aprendizado, quanto à organização e integração dos seus diversos departamentos e quanto ao processo de controle da produção que vem ocorrendo. Por outro lado, leva a que a empresa tenha uma postura diferenciada quanto aos seus clientes e fornecedores.

Por exemplo, uma das premissas da metodologia é a existência de um líder do processo de implantação. Portanto, a empresa deverá prever, na organização interna, a existência de um "setor" cujo objetivo seja o desenvolvimento tecnológico, organizacional e gerencial da empresa.

Esse "setor", evidentemente, deverá ser compativel com as características da empresa. Poderá ter uma única pessoa, um responsável pelo processo de implantação, como poderá ser constituído por um número maior de profissionais, devidamente capacitados a atuarem nesse tipo de atividade, sempre direcionados por um líder do processo.

Além disso, a empresa para efetivar a implantação das TCR's deverá organizar adequadamente todos os seus setores, em particular, os de projetos, recursos humanos e suprimentos.

0 processo de desenvolvimento de projetos é um dos primeiros a ser atingido com a implantação, pois é na etapa de projeto que se tem as maiores chances de se modificar racionalmente a produção. Os projetos realizados de maneira tradicional deverão dar lugar a um projeto voltado à produção, que seja capaz de atender às necessidades daqueles que executam o produto edifício.

A exigência de um projeto voltado à produção deverá implicar numa mudança de postura de diversos setores da empresa e também dos demais agentes que participam do processo de produção.

No caso de empresa construtora, a relação com seus clientes poderá ser afetada. Nesse caso, ela deverá passar a mostrar as vantagens que podem decorrer da modernização, "vendendo" as inovações como elementos importantes para o aumento da qualidade e da produtividade e para a diminuição de desperdícios, de problemas patológicos e, por conseqüência, de custos. 
No caso de empresas construtoras e incorporadoras, as relações entre os setores comercial e de produção deverão ocorrer de modo que as necessidades de um e de outro possam ser contempladas. E, nesse caso, o relacionamento com os projetistas também precisará ser alterado, buscando-se sempre o estabelecimento de parcerias de maneira que o produto e o processo de produção sejam contemplados pelo projeto.

No que se refere aos recursos humanos, há consenso entre os pesquisadores e até mesmo entre as empresas pesquisadas que os investimentos na capacitação profissional e na motivação são imprescindiveis para todos os niveis hierárquicos.

Apesar desse consenso, quase nada tem sido investido nesse recurso fundamental para o processo de produção.

Os investimentos para a reciclagem dos conhecimentos tecnológicos do pessoal de nivel superior praticamente inexistem; além disso, continua-se a trabalhar com mão-de-obra que não domina as técnicas construtivas racionalizadas, mal treinada, não motivada a alterar a sua condição no canteiro e, por conseqüência, com baixa produtividade.

Esse quadro referencial precisa ser alterado. E a introdução de TCR's facilita as mudanças imprescindíveis para a organização dos recursos humanos, uma vez que, de certa maneira, rompe com as técnicas tradicionais, de domínio quase que exclusivo da mão-de-obra.

Com isso, é possivel propor treinamento e reciclagem dos conhecimentos, além de outras formas de motivação sugeridas nas diretrizes para o desenvolvimento dos recursos humanos, apresentadas no capítulo 5 .

Ainda que se tenha projetos adequados à produção e recursos humanos devidamente capacitados e motivados, as novas tecnologias não se efetivam se toda a empresa não estiver motivada a trabalhar para que os recursos exigidos pela nova tecnologia estejam sempre disponíveis no momento correto. Nesse sentido, a equipe de suprimentos também tem uma participação fundamental no processo de implantação. 
A partir do momento que a empresa conhece a tecnologia a ser implantada $e$, também os insumos a serem empregados, caberá à equipe de suprimentos viabilizá-los. Aparece, mais uma vez, a relação empresa-mercado, a qual tem muito que evoluir.

Os fornecedores, acostumados a definirem as "regras do jogo", devem passar a considerar as exigências das empresas que constróem. Não há mais espaço para materiais e componentes inovadores dissociados do processo de produção. As empresas produtoras de materiais e componentes, dispostas a investir em pesquisas e a lançar novos produtos no mercado, deverão considerar esse produto devidamente inserido no processo de produção.

As empresas construtoras, por sua vez, deverão ser menos passivas com relação aos novos produtos. Elas deverão exigir dos fornecedores e dos projetistas a co-responsabilidade sobre o produto aplicado, quando os mesmos propuserem o emprego de um novo material ou componente no processo de produção de edifícios.

À medida em que as empresas construtoras passarem a especificar corretamente, a exigir dos fornecedores produtos dentro das especificaçōes, a recusar entregas de produtos fora das especificaçōes e a qualificar os seus fornecedores, o mercado terá de mudar a sua postura, passando a considerar a produção.

Ainda que no início do processo de implantação de TCR's as empresas não estejam completamente organizadas, a aplicação gradual e evolutiva das tecnologias disponiveis, balizada pela metodologia proposta, permitirá que as deficiências organizacionais e gerenciais do processo de produção sejam detectadas, possibilitando que as mesmas sejam corrigidas a fim de que esse processo evolua continuamente.

\subsection{A Continuidade dos Trabalhos e as Necessidades de Pesquisa para a Evolução da Indústria da Construção de Edificios}

Ainda que se tenha atingido o objetivo estabelecido para este trabalho, propondo-se uma metodologia para implantação de TCR's, passivel de ser 
aplicada às empresas construtoras, com grande potencial de thes proporcionar uma evolução no processo de produção, considera-se que o trabalho não tenha terminado. Pelo contrário, ele está apenas iniciando.

Como bem afirma FARAH [1992], "a incorporação de novas tecnologias e a inovação organizacional, como parte de estratégia empresarial, constitui, na verdade, uma tendência que se verifica num estreito segmento de construtoras".

Às colocações dessa pesquisadora, pode-se acrescentar que não apenas a introdução de inovações tecnológicas, organizacionais e gerenciais faz parte de um universo restrito de empresas, como também as inovações que vêm sendo realizadas por essas empresas são de escopo restrito.

Na pesquisa realizada junto às empresas, apresentada parcialmente no sexto capítulo, pôde-se perceber claramente que as inovações tecnológicas (que as empresas consideram ter feito) concentram-se, na maioria das vezes, em alteraçōes de componentes utilizados na produção do edifício ou mesmo na forma de obtenção dos insumos ou contratação de serviços e raras vezes no processo de produção, envolvendo as etapas de projeto, produção e controle.

Poucas são as empresas que estão enxergando a premência de uma visão sistêmica do processo, para serem competitivas no mercado. E, para que possa haver uma evolução significativa na indústria da Construção de Edifícios, acredita-se que seja essencial o envolvimento de um grande número de empresas com essa visão.

Por isso, um dos objetivos que se deve procurar atingir, na continuidade dos trabalhos, é o envolvimento de um grande número de empresas, tanto com o desenvolvimento, como com a implantação de TCR's, de maneira que a evolução possa ser mais homogênea e venha a refletir positivamente no sistema produtivo do país.

É preciso fazer com que as TCR's cheguem às empresas construtoras, assim como chegam os novos materiais, componentes e equipamentos. 
O trabalho envolvendo o repasse tecnológico a cinco empresas construtoras, que ainda vem sendo desenvolvido no CPqDCC-EPUSP, tem mostrado que a parceria entre a Universidade, através do seu centro de desenvolvimento tecnológico, e as construtoras é um dos possiveis caminhos para a evolução.

No entanto, essa experiência, enquanto abrangência do setor, é ainda muito tímida. O que significam cinco empresas no conjunto que forma a Indústria da Construção de Edifícios?

Acredita-se que os resultados já obtidos poderão ser potencializados à medida em que sejam realizados convênios, não apenas com grupos isolados de empresas, mas, sobretudo, através de associaçōes e entidades de classe, como por exemplo, através do SINDUSCON, que reúne um grande número de associadas, e também através do SEBRAE, que tem grande penetração junto às pequenas empresas do setor.

Esta deverá ser uma das frentes de trabalho que os pesquisadores da área precisarão dar continuidade. $E$, além dessa frente de ação, não se pode esquecer das pesquisas que originam as TCR's, sem as quais, não será possível fazer evoluir o processo construtivo tradicional.

As reflexōes realizadas ao longo deste trabalho permitiram identificar uma série de temas que precisam ser pesquisados a fim de subsidiar a continuidade dos trabalhos de implantação de TCR's nas empresas construtoras e a própria evolução do processo de produção de edifícios construídos pelo processo construtivo tradicional.

Dentre os diversos temas analisados, considera-se essencial o desenvolvimento de trabalhos envolvendo os temas voltados à organização e gestão do processo de produção e ao desenvolvimento tecnológico.

No que se refere aos trabalhos voltados à organização e gestão do processo de produção, acredita-se que se deva procurar investigar com maior profundidade, entre outros, os seguintes aspectos:

- a influência da documentação técnica na implantação de TCR's; 
- a influência da relação empresa-fornecedor na implantação de TCR's;

- a influência do processo de projeto na implantação de TCR's;

- as formas de parceria (empresa-fornecedor; empresa-projetista; empresasubempreiteiro) e sua interferência na implantação de TCR's;

- as formas de avaliação dos mecanismos de controle empregados no processo de produção;

- a implantação de TCR's como elemento facilitador da implantação de programas de gestão da qualidade;

- a implicação das formas de contratação da mão-de-obra na implantação de TCR's;

- a influência da formação de profissionais de nível superior na implantação de TCR's;

- a influência dos novos materiais e equipamentos disponíveis no mercado na implantação de TCR's.

No que se refere ao desenvolvimento tecnológico, acredita-se que esse grande tema deverá envolver o desenvolvimento de novos materiais, componentes, equipamentos e métodos construtivos para serem aplicados à racionalização do processo de produção de edifícios. Podendo-se destacar os estudos voltados à racionalização da produção da estrutura, das vedações, das instalações, das esquadrias, dos sistemas de impermeabilização e dos revestimentos para os edifícios construidos pelo processo construtivo tradicional.

Alguns trabalhos específicos, envolvidos com o tema desenvolvimento tecnológico, são apresentados a título exemplo:

- definição de diretrizes para produção de argamassas de assentamento e revestimento;

- definição de diretrizes para elaboração do projeto de alvenaria;

- definição de diretrizes para produção de alvenarias e instalações; 
- definição de sistemas de impermeabilização para áreas molháveis internas de edifícios;

- definição de diretrizes para a produção de revestimentos verticais e horizontais;

- definição de equipamentos e ensaios de campo para avaliação de desempenho de componentes e elementos construtivos;

- definição de equipamentos para a racionalização das atividades e serviços nos canteiros de obras.

\subsection{Conclusões Gerais}

, Acredita-se firmemente que o trabalho desenvolvido e apresentado constitui uma importante contribuição ao meio técnico e acadêmico, uma vez que nele resgata-se e propõe-se conceitos não completamente definidos nesses meios. Apresentam-se e discutem-se as principais estratégias de ação que as empresas de construção de edificios têm empregado objetivando, em particular, a redução dos custos de produção. E, ainda, ao discutir essas estratégias, evidenciam-se as dificuldades que as empresas têm encontrado para fazer chegar aos canteiros de obras a "evolução" desejada, traduzida, principalmente, pela redução de desperdícios e de problemas patológicos e pelo aumento da produtividade e da qualidade dos produtos.

E, nesse ponto central, "fazer a evolução atingir o canteiro de obras", é que reside a maior contribuição desse trabalho.

Ao se propor a implantação de TCR's no sistema de produção das empresas, abre-se a possibilidade de haver uma mudança tecnológica, organizacional e gerencial, fundamental para a evolução do processo de produção.

Entretanto, essa proposta não vem sozinha. Ela é acompanhada de uma metodologia que viabiliza a implantação, aumentando o potencial de sucesso dessa estratégia de ação.

A metodologia proposta, ainda que não tenha sido completamente testada em uma especifica empresa construtora, foi analisada, no sexto capitulo, à luz das 
ações que um conjunto de empresas vem adotando para alcançar a sua competência tecnológica e organizacional.

A partir dessa análise, pôde-se identificar tanto as dificuldades que as empresas vêm tendo ao buscarem a implantaçăo de novas tecnologias, sem empregarem uma metodologia adequada para a condução do processo, como também o potencial que o emprego da metodologia proposta tem de minimizar essas dificuldades e incertezas, comuns ao processo de implantação inadequadamente conduzido.

Considera-se, assim, que o objetivo inicialmente estabelecido para este trabaIho tenha sido plenamente atingido, pois a metodologia, necessária à condução do processo de implantação de TCR's foi desenvolvida e proposta ao meio técnico. E, além disso, pela análise realizada no sexto capítulo, acredita-se firmemente que essa metodologia é passivel de aplicação nas empresas construtoras de edifícios, com grandes possibilidades de sucesso.

A sua aplicação, certamente contribuirá para que as TCR's passem a integrar o sistema produtivo das empresas, constituindo-se em verdadeiras Inovações Tecnológicas.

Essas inovações poderão trazer o aumento da qualidade e da produtividade do processo de produção, incrementando, em conseqüência, a competitividade da empresa no mercado de construção de edifícios. 


\section{REFERÊNCIAS BIBLIOGRÁFICAS}

ABUDAYYEH, Osama. Partnering: a team building approach to quality construction management. Journal of Management in Engineering, v.10, n.6, p. 26-9, Nov./Dec. 1994.

ALMEIDA, Henrique S. de. Um estudo do vínculo tecnológico entre pesquisa, engenharia, fabricação e consumo. São Paulo, 1981. 163p. Tese (Doutorado) Escola Politécnica, Universidade de São Paulo.

ALMEIDA, Rubens de. Melhoria cooperativa. Construçāo. v.47, n.2450, p.12-4, jan. 1995.

ALTOS e baixos da construção. Dirigente Construtor, v.26, n.10, p.16-22, out. 1990.

AMORIM, Sérgio R. L. de. Tecnologia, organização e produtividade na construção. Rio de janeiro, 1995. 210p. Tese (Doutorado) - Universidade Federal do Rio de Janeiro.

ARAÚJO, Jorge S. de. Administração de materiais. 2.ed. São Paulo, Atlas, 1971. 311p.

ASSOCIAÇÃO BRASILEIRA DE NORMAS TÉCNICAS (a). Normas de gestão da qualidade e garantia da qualidade: diretrizes para seleção e uso - NBR ISO 9001. Rio de Janeiro, 1994.

ASSOCIAÇÃO BRASILEIRA DE NORMAS TÉCNICAS (b). Sistemas da qualidade: modelo para a garantia da qualidade em projeto, desenvolvimento, produção, instalação e serviços associados - NBR ISO 9001. Rio de Janeiro, 1994.

ASSOCIAÇÃO BRASILEIRA DE NORMAS TÉCNICAS (c). Gestāo da qualidade e elementos do sistema da qualidade: diretrizes - NBR ISO 9004-1. Rio de Janeiro, 1994.

AZEREDO, Francisco E. M. de; PETRONI, Alexandre. Implantando a qualidade na rotina da construção civil: estudo de caso em obra da Fundação Petrobrás. In.: CONGRESSO INTERNACIONAL DE NORMALIZAÇÃO E QUALIDADE, 2., São Paulo, 1991. Anais. São Paulo, ABNT, 1991. p.193-200.

BARATELLI JR., Fernando; et al. Administrando o processo de inovação tecnológica. In: SIMPÓSIO DE GESTÃO DA INOVAÇÃO TECNOLÓGICA, 18. São Paulo, 1994. Anais. São Paulo, PACTO/FIA-USP/NPGCT-USP, 1994. v.1, p.117-32.

BARNETT, H.G. Innovation: the basis of cultural change. New York, McGraw-Hill, 1953.

BARROS, Mercia M.S.B. (a) Tecnologia de produçāo de contrapisos para edificios habitacionais e comerciais. São Paulo, 1991. 316p. Dissertação (Mestrado) - Escola Politécnica, Universidade de São Paulo. 
BARROS, Mercia M.S. B. (b) Proposição de uma metodologia para o controle de qualidade de execução de contrapisos para edifícios habitacionais e comerciais. In: CONGRESSO INTERNACIONAL DE NORMALIZAÇÃO E QUALIDADE, 2. São Paulo, 1991. Anais. Sāo Paulo, ABNT, 1991. p. 222-29.

BARROS, Mercia M.S.B. Tecnologia de contrapisos melhora qualidade dos edificios. Ibracon, v.3, n.7, p.14-20, jan./fev./mar., 1993.

BARROS, Mercia M.S.B. Contrapisos para áreas internas de edifícios. Téchne, v.2, n.13, p.51-4, nov./dez., 1994.

BARROS, Mercia M.S.B. de; SABBATINI, Fernando H. Tecnologia de produção de contrapisos internos para edificios. São Paulo, EPUSP, 1995. (Texto Técnico. Departamento de Engenharia de Construção Civil, TT/PCC/13).

BARROS, Mercia M.S.B. de; MELHADO, Silvio B. Racionalização do projeto de edifícios construídos pelo processo tradicional. São Paulo, Departamento de Engenharia de Construção Civil/EPUSP, 1993. /Seminário apresentado no curso de pós-graduação da EPUSP - Datilografado/.

BARROS, Mercia M.S.B.; DORNELES, Valério P. Racionalização de métodos e processos construtivos: ação no plano da obra. São Paulo, Departamento de Engenharia de Construção Civil/EPUSP, 1991. /Seminário apresentado no curso de pós-graduação da EPUSP. Datilografado/.

BERGAMINI, Cecília W. Motivação. São Paulo, Atlas. 1986.

BOBROFF, Jacotte. A construção na França: novos modelos de organização e redefiniçāo das competências dos trabalhadores. In: ENCONTRO INTERNACIONAL DE ENGENHARIA DO SINDUSCON-SP, 1., São Paulo, 1989. Anais. São Paulo, SINDUSCON-SP, 1989. v.4, p.1-62.

BOGGIO, Aldo J. Um modelo de documentação da qualidade para a construção civil. In.: FORMOSO, Carlos Torres, ed. Gestāo da qualidade na construção civil: uma abordagem para empresas de pequeno porte. Porto Alegre, Programa de Qualidade e Produtividade da Construção Civil no Rio Grande do Sul, 1995. p.127-47.

BRASIL. Ministério da Ação Social. Programa Nacional de Tecnologia da Habitação. Brasilia, Secretaria Nacional de Habitação, 1991. 31p.

BURATI JR. James, L. et al. Quality management organization and techniques. Journal of Construction Engineering and Management, v.118, n.1, p.112-28, Mar. 1992.

CAMP, Robert, C. Benchmarking: identificando, analisando e adaptando as melhores práticas da administração que levam à maximização da performance empresarial: o caminho da qualidade total. Trad. De Nivaldo Montingelli Júnior. São Paulo, Pioneira, 1993. (Biblioteca Pioneira de administração e negócios) 
CAMPAGNAC, Elisabeth. Mutations des marchés et évolutions des systèmes de production et de travail dans le bâtiment en France et en Europe. In: ENCONTRO NACIONAL DE TECNOLOGIA DO AMBIENTE CONSTRUIDO, São Paulo, 1993. Avanços em tecnologia e gestão da produção de edificações:anais. São Paulo, EPUSPIANTAC,1993. v.1, p.27-39.

CARDOSO, Francisco F. Novos enfoques sobre a gestão da produção: como melhorar o desempenho das empresas de construção civil. In: ENCONTRO NACIONAL DE TECNOLOGIA DO AMBIENTE CONSTRUÍDO, São Paulo, 1993. Avanços em tecnologia e gestão da produção de edificaçōes:anais. São Paulo, EPUSPIANTAC, 1993. v.2, p.557-69.

CARDOSO, Francisco F. Stratégies d'entreprises et nouvelles formes de rationalisation de la production dans le bátiment au Brésil et en France. Paris, 1995. 478p. Tese (Doutorado) - École Nationale des Ponts et Chaussées.

CASTRO, Carolina M.P. de. Papel da tecnologia na produção de habitação popular - estudo de caso: C.H. José Bonifácio. São Paulo, $1986.473 p$. Dissertação (Mestrado) - Escola de Engenharia de São Carlos, Universidade de São Paulo.

CASTRO, Jorge A. de. Invento e inovaçāo tecnológica na construção. São Paulo, 1993. 258p. Tese (Doutorado) - Faculdade de Arquitetura e Urbanismo, Universidade de São Paulo.

CENTRO TECNOLÓGICO DE EDIFICAÇÕES (CTE). Sistema de gestão da qualidade para empresas construtoras. São Paulo, SEBRAE/ SINDUS-CON, 1994.

CHIAVENATO, Idalberto. Recursos Humanos. Ed. Compacta, 2.ed. São Paulo, Atlas, 1992.

CONSTRUCTION INDUSTRY INSTITUTE. Constructability: a primer. 2.ed. Austin, 1987. (Cll publication, n.83-1)

COOK, E. Lynn; HANCHER, Donn E. Partnering: contracting for the future. Journal of Construction Engineering and Management, v.6, n.4, p. 431-46, Oct. 1990.

COOMBS, Rod; SAVIOTTI, Paolo; WALSH, Vivien. Economics and technological change. Totawa, Rowman \& Littlefield, 1987

CRESSEY, Peter; MARTINO, Vttorio di. Agreement and innovation: the international dimension of technological change. New York, Prentice Hall, 1991.

DALCUL, Ane Lise P.C. Novas tecnologias e relações de trabalho na construção civil. In: SIMPÓSIO DE GESTÃO DA INOVAÇÃO TECNOLÓGICA, 18. São Paulo, 1994. Anais. São Paulo, PACTO/FIA-USP/NPGCT-USP, 1994, v.2, p.1045-61.

DALE, B.G.; PLUNKETT, J.J. Quality costing. London, Chapman \& Hall, 1995. p.114. 
DAVENPORT, Thomas $H$. Process innovation: reengineering work through information technology. Boston, Harvard Business School, 1993.

DAVIS, Donald D. Designing organizations for technological innovation, productivity and quality of work life: a human resource perspective. In.: TECHNOLOGICAL innovation: strategies for a new partnership. Amsterdam, Denis O. Gray, 1986. p. 145-70.

DE LA GARZA, Jesus M.; MITROPOULOS, Panagiotis. Flavors and mixins of expert systems technology transfer model for AEC industry. Journal of Construction Engineering and Management, v.118, n.3, p.435-53, Sep. 1992.

DEMING, W. Edwards. Out of the crisis: quality, productivity and competitive position. Cambridge, University Press, Massachusetts, 1986. 507p.

EDOSOMWAN, Johnson A. Integrating innovation and technology management. New York, Wiley, 1989. 294p.

EISINGER, André Bernardo; BARROS, Mercia M.S. Bottura de. (a). Desenvolvimento de uma metodologia para avaliação de desempenho de revestimentos de piso: metodologia de ensaio de desgaste por abrasão. São Paulo, Departamento de Engenharia de Construção Civil/EPUSP, 1993. (Relatório de iniciação científica apresentado ao CNPq).

EISINGER, André Bernardo; BARROS, Mercia M. S. Bottura de. (b). Desenvolvimento de uma metodologia para avaliação de desempenho de revestimentos de piso: equipamentos e metodologia de ensaio. São Paulo, Departamento de Engenharia de Construção Civil/EPUSP, 1993. (Relatório de iniciação científica apresentado ao CNPq).

ENCONTRO NACIONAL DE TECNOLOGIA DO AMBIENTE CONSTRUÍDO - ENTAC, Rio de Janeiro, 1995. Qualidade e Tecnologia na Habitação. Rio de janeiro, ANTAC, 1995. v.1.

FABRÍCIO, Márcio M.; MARTUCCI, Ricardo. Proposta de um programa de gestão da qualidade total para autoconstrução assistida. In: ENCONTRO NACIONAL DE TECNOLOGIA DO AMBIENTE CONSTRUÍDO, Rio de janeiro, 1995. Qualidade e tecnologia na habitação:anais Rio de Janeiro, UFRJ/ANTAC, 1995. v.1, p. 1738.

FARAH, Marta Ferreira Santos. Diagnóstico tecnológico da indústria da construção civil: caracterizaçāo geral do setor. Tecnologia de edificaçōes, v. 5, n.119, p.111-6, ago. 1988.

FARAH, Marta Ferreira Santos. Tecnologia, processo de trabalho e construção habitacional. São Paulo, 1992. 297p. Tese (Doutorado) - Faculdade de Filosofia, Letras e Ciências Humanas, Universidade de São Paulo.

FERREIRA, Aurélio Buarque de Holanda. Novo dicionário da lingua portuguesa. 2 ed. Rio de Janeiro, Nova Fronteira, 1986. 
FLEURY, Afonso C.; FLEURY, Maria Tereza L. Aprendizagem e inovação organizacional. Sāo Paulo, Atlas, 1995.

FORMOSO, Carlos T:; SJOHOLT, Odd. A experiência norueguesa na gestão da qualidade para a construção civil. In.: SEMINÁRIO INTERNACIONAL ESTRATÉGIAS PARA MODERNIZAÇÃO DA CONSTRUÇÃO CIVIL, São Paulo, 1994. Qualidade na cadeia produtiva. São Paulo, 1994. ed.? p.25-36.

FORMOSO, Carlos T.; LIMA, Irê S. Uma experiência de desenvolvimento cooperativo de um modelo para a gestão da qualidade. In.: FORMOSO, Cartos Torres, ed. Gestão da qualidade na construção civil: uma abordagem para empresas de pequeno porte. Porto Alegre, Programa de Qualidade e Produtividade da Construção Civil no Rio Grande do Sul, 1995. p. 11-35.

FRANCO, Luiz S. Aplicação de diretrizes de racionalização construtiva para a evolução tecnológica dos processos construtivos em alvenaria estrutural não armada. São Paulo, 1992. 319p. Tese (Doutorado) - Escola Politécnica, Universidade de Săo Paulo.

FREITAS, Edianez N. G. de O. O desperdício na construção civil: caminhos para a sua redução. In: ENCONTRO NACIONAL DE TECNOLOGIA DO AMBIENTE CONSTRUIDO, Rio de janeiro, 1995 . Qualidade e tecnologia na habitação:anais Rio de Janeiro, UFRJ/ANTAC, 1995. v.1, p. 167-72.

FUNDAÇÃO JOÃO PINHEIRO. Desenvolvimento da indústria da construção em Minas Gerais: impacto na evolução tecnológica e na qualificação da força de trabalho. Belo Horizonte, Centro de Estudos Econômicos, 1992. 375p.

GAMA, Ruy. Tecnologia e o trabalho na história. São Paulo, Nobel-EPUSP. 1986.

GARCIA, Liliana, N.H. de; SEGRE, Lídia M. ;TAVARES, Silvio R. S. O comportamento organizacional no contexto de inovação tecnológica: pessoas, ambiente e tecnologia. In: SIMPÓSIO DE GESTÃO DA INOVAÇÃO TECNOLÓGICA, 18. São Paulo, 1994. Anais. Săo Paulo, PACTO/FIAUSP/NPGCT-USP, 1994. v.2, p.1090-105.

GARCIA MESEGUER, Alvaro. Actuaciones para mejorar la seguridad y calidad de los edificios. Informes de la Construccion, n. 317, p. 25-39, 1980.

GARCIA MESEGUER, Alvaro. (a) Control de calidad en construcción. Madrid, Agrupacion Nacional de Constructores de Obras, 1989. 77 p.

GARCIA MESEGUER, Alvaro. (b) Garantía de calidad en construcción. Madrid, Agrupacion Nacional de Constructores de Obras, 1989. 101 p.

GARVIN, David A. Gerenciando a qualidade: a visão estratégica e competitiva. Trad. de João Ferreira Bezerra de Souza. Rio de Janeiro, Qualitymark, 1992. 
GHIO, Virgílio, A.; BASCUÑÁN, Roberto. Nuevas oportunidades para la innovación tecnológica en la indústria de la construcción en Chile. In: SEMINARIO INTERNACIONAL DE LA INDÚSTRIA DE LA CONSTRUCCIÓN, 6., Santiago, 1995. Innovación e transferencia tecnológica en la construcción: principios, aplicaciones y casos : anais. Santiago, Departamento de Ingenieria y Gestión de la Construcción/Pontifícia Universidad Católica de Chile, 1995. p.1-19.

GITLOW, Howard S. Planejando a qualidade, a produtividade e a competitividade. Trad. de Mauro Paganotti. Rio de janeiro, Qualitymark, 1993. p.1-80.

GOMES, Maria de Lourdes B.; SALDANHA, Maria Christine W. Administração participativa na construção civil: um estudo de caso. In: ENCONTRO NACIONAL DE TECNOLOGIA DO AMBIENTE CONSTRUÍDO, Rio de janeiro, 1995. Qualidade e tecnologia na habitação:anais Rio de Janeiro, UFRJ/ANTAC, 1995. v.2, p. 839-43.

GRAZIA, Silas. O problema da qualidade (TQC) na indústria da construção Civil. In.: SIMPÓSIO NACIONAL DE GERENCIAMENTO NA CONSTRUÇÃO CIVIL, 1. EPUSP, 1988. Anais. São Paulo, 1988, p.21-32.

HAGERSTRAND, Torsten. Innovation, difusion as a spatial process. Chicago, University of Chicago, 1953.

HARBACK, Herbert F.; BASHAM, Donald, L.; BUHTS, Robert E. Partnering paradigm. Journal of Management in Engineering, v.10, n.1 p. 23-7, Jan/Fev 1994.

HEINECK; Luiz Fernando M.; TRISTÃO, Ana Maria D.; NEVES, Renato M. Problemas em uma empresa de construção e em seus canteiros de obras. In: ENCONTRO NACIONAL DE TECNOLOGIA DO AMBIENTE CONSTRUIDO, Rio de janeiro, 1995. Qualidade e tecnologia na habitação:anais Rio de Janeiro, UFRJ/ANTAC, 1995. v.1, p. 155-66.

HILL, Christopher T. Technological innovation: agent of growth and change. In: HILL, Christopher T.; UTTERBACK, James M. Technological innovation for a dynamic economy. New York, Pergamon Press, 1983. p.1-39. (Pergamon Policy Studies on Science and Technology)

HOMEM de construção do ano. O Empreiteiro. v.32, n.317, p.30-45. nov. 1994.

INSTITUTO DE PESQUISAS TECNOLÓGICAS. Programa de atualização tecnológica industrial (PATI): construção habitacional. São Paulo, IPT/ Divisão de Economia e Engenharia de Sistemas/Secretaria da Ciência, Tecnologia e Desenvolvimento Econômico. 1988. 85p.

INTERNATIONAL ORGANIZATION FOR STANDARDIZATION. Quality: vocabulary ISO-8401. Berna, 1986.

IMAI, Masaaki. Kaizen: a estratégia para o sucesso competitivo. 4ed. São Paulo, IMAM, 1992. 235p. 
ISHIKAWA, Kaoru. Controle de qualidade total: à maneira japonesa. Trad. de lliana Torres. Rio de Janeiro,Campus, 1993. (Titulo original: What is total quality control?).

JURAN, J. M. A qualidade desde o projeto: novos passos para o planejamento da qualidade em produtos e serviços. Trad. de Nivaldo Montingelli Jr.,. 2 ed. São Paulo, Pioneira, 1992 (Coleção Novos Umbrais). p.221-303.

JURAN; J.M.; GRYNA, Frank M. Controle da qualidade: componentes básicos da função qualidade. Trad. de Maria Cláudia de Oliveira Santos. São Paulo, McGrawHill/Makron, 1991. v.2.

KOSKELA, Lauri. Apllication of the new production philosophy to construction. California, Center for Integrated Facility Engineering (CIFE), 1992. (Technical report 72)

KRUGLIANSKAS, Isak; SBRAGIA, Roberto. Função tecnológica em pequenas empresas: estudo de algumas dimensões críticas para sua implantaçäo. In: ENCONTRO NACIONAL DA ASSOCIAÇÄO NACIONAL DE PROGRAMAS DE PÓS-GRADUAÇÃO EM ADMINISTRAÇÃO, 19, João Pessoa, 1995. Anais. Anpad, 1995 vol. 1, p. 238-56.

LABORDE, Maria; SANVIDO, Victor. Introducing new process technologies into construction companies. Journal of Construction Engineering and Management, v.120, n.3, p.488-508, Sep. 1994.

LAUFER, A. On site performance improvement programs. Journal of Construction Engineering and Management, v. 111, n.1, p.82-97, Mar. 1985.

LEA, F.M. Preface. In.: CIB CONGRESS, 2., Cambridge, 1962. Innovation in Building. Amsterdam, Elsevier, 1962.

LIMA; Irê S.; HEINECK, Luiz Fernando M. Uma metodologia para a avaliação da qualidade de vida no trabalho operário da construção civil. In.: FORMOSO, Carlos Torres, ed. Gestão da qualidade na construção civil: uma abordagem para empresas de pequeno porte. Porto Alegre, Programa de Qualidade e Produtividade da Construçäo Civil no Rio Grande do Sul, 1995. p. 169-96.

MAIA, Maria A. M. Organização do trabalho a partir da padronização da produção de edificios. In: ENCONTRO NACIONAL DE TECNOLOGIA DO AMBIENTE CONSTRUIDO, Rio de janeiro, 1995. Qualidade e tecnologia na habitação:anais Rio de Janeiro, UFRJ/ANTAC, 1995. v.1, p.193-8.

MARSH, Jon W. Materials management: practical application in the construction industry. Cost Engineering, v.27, n.8, p.18-28, Aug. 1985.

MARTUCCI, Ricardo. Projeto tecnológico para edificação habitacionais: utopia ou desafio? São Paulo, 1990. Tese (Doutorado) - Faculdade de Arquitetura e Urbanismo, Universidade de São Paulo. 
MELHADO, Silvio B. Qualidade do projeto na construçāo de edifícios: aplicação ao caso das empresas de incorporação e construção. São Paulo, 1994. 294p. Tese (Doutorado) - Escola Politécnica, Universidade de São Paulo.

MELHADO, Silvio B. O que é qualidade de projeto?: uma discussão acerca das mudanças conceituais necessárias para a melhoria da qualidade na construção de edificaçōes. In: WORKSHOP QUALIDADE DE PROJETO/RS, Porto Alegre, 1995. Anais. Porto Alegre, Departamento de Engenharia Civil/Escola Politécnica/PUC-RS, 1995. n.p.

MELHADO, Silvio B.; BARROS, Mercia M.S.B.; SOUZA, Ana Lúcia R.(a) Diretrizes para elaboração do projeto de laje racionalizada. São Paulo, EPUSP-PCC, 1995. (Relatório CPqDCC n.20084 - EP/SC-1).

MELHADO, Silvio B.; BARROS, Mercia M.S.B.; SOUZA, Ana Lúcia R.(b) Diretrizes para elaboraçāo do projeto de alvenaria de vedaçāo. São Paulo, EPUSP-PCC, 1995. (Relatório CPqDCC n.20085 - EP/SC-1).

MELHADO, Silvio B.; BARROS, Mercia M.S.B.; SOUZA, Ana Lúcia R.(c) Diretrizes para elaboração do projeto de revestimentos verticais argamassados e cerâmicos. São Paulo, EPUSP-PCC, 1995. (Relatório CPqDCC n.20086 - EP/SC1).

MELHADO, Silvio B.; BARROS, Mercia M.S.B.; SOUZA, Ana Lúcia R. Padrões de conteúdo e etapas de elaboração de projetos para coordenaçāo de projetistas contratados. São Paulo, EPUSP-PCC, 1996. (Relatório CPqDCC n.20086 - EP/SC-1).

MERLI, Giorgio. Comakership: a nova estratégia para os suprimentos. trad. de Gregório Bouer. Rio de Janeiro, Qualitymark, 1994. 264p.

NAM, C.H.; TATUM, Clyde B. Toward understanding of product innovation process in construction. Journal of Construction Engineering and Management, v.115, n.4, p.517-34. Dec. 1989.

NAM, C.H.; TATUM, Clyde B. Stratégies for technology push: lessons from construction innovations. Journal of Construction engineering and Management, v.118, n.3 p. 507-24. Sept. 1992,

NEVES, Célia M.M. Alguns aspectos que interferem na implantação de melhorias e inovações tecnológicas na produção do edifício. In: ENCONTRO NACIONAL DE TECNOLOGIA DO AMBIENTE CONSTRUIDO, Rio de janeiro, 1995. Qualidade e tecnologia na habitação:anais Rio de Janeiro, UFRJ/ANTAC, 1995. Anais. v.1, p.79-84.

NILES, Felipe R. Amostra das técnicas de execução de alvenaria de vedação empregadas por construtoras civis em São Paulo. São Paulo, EPUSP-PCC, 1996. 43p. (Relatório de Iniciação Científica USP/CNPq).

NUNCA fomos tão modernos. Construção, v.47, n.2441, p.6-10, nov. 1994. 
PALÁCIOS, Vitor H. R. Gerenciamento do setor de suprimentos em empresas de construção de pequeno porte. In.: FORMOSO, Carlos Torres, ed. Gestão da qualidade na construção civil: uma abordagem para empresas de pequeno porte. Porto Alegre, Programa de Qualidade e Produtividade da Construção Civil no Rio Grande do Sul, 1995. p. 81-126

PARCERIA incentiva pesquisas técnicas. Obra, v.6, n.66, p.35-6, maio, 1995.

PARKER, Charles R. Going for growth: technological innovation in manufacturing industries. New York, John Wiley, 1985.

PICCHI, Flávio A. Utilização de videos em treinamentos sobre qualidade de construção civil. In: ENCONTRO NACIONAL INDÚSTRIA-UNIVERSIDADE SOBRE PEDAGOGIA DA QUALIDADE, Rio de Janeiro, 1992. Anais. Rio de Janeiro, Instituto Euvaldo Lodi, 1992.

PICCHI, Flávio A. Sistemas de qualidade: uso em empresas de construção de edificios. São Paulo, 1993. 462p. Tese (Doutorado) - Escola Politécnica, Universidade de São Paulo.

PICCINA, Antonio M. A absorção de tecnologia e o aprendizado tecnológico: um estudo da dinâmica do processo e de fatores intervenientes. São Paulo, 1991. 155p. Dissertação (Mestrado) - Faculdade de Economia, Administraçăo e Contabilidade, Universidade de São Paulo.

PICCOLI, Geraldo M. Controle da qualidade na construção. In: ENCONTRO NACIONAL DA CONSTRUÇÃO - ENCO, 9., São Paulo, 1988. Anais. São Paulo, Instituto de Engenharia, 1988. p.178-82.

PICCOLI, Geraldo M. Sistema da qualidade aplicado à construção civil. In.: CONGRESSO INTERNACIONAL DE NORMALIZAÇÃO E QUALIDADE, 2., São Paulo, 1991. Anais. São Paulo, ABNT, 1991. p.201-4.

PINTO, Tarcísio de P.; PINTO, César A. de P. Qualidade com pequenas soluções. Construção, v. 48, n. 2453, p.12-4, fev. 1995.

QUELHAS, Osvaldo L.G.; MORGADO, Cláudia R.V.; DINIZ, Luciana N. Qualidade de vida no trabalho na construção civil: estudo de caso para a construção de edificios na cidade do Rio de Janeiro. In: ENCONTRO NACIONAL DE TECNOLOGIA DO AMBIENTE CONSTRUÍDO, Rio de janeiro, 1995. Qualidade e tecnologia na habitação:anais Rio de Janeiro, UFRJIANTAC, 1995. v.1, 179-83.

QUINN, James B. Administrando a inovação: o caos controlado. Exame, n.363, p.6781 , out. 1986.

RATTNER, Henrique. O novo paradigma industrial e tecnológico. São Paulo, IPE/USP, 1989. 16p. (Texto de discussão 05/89).

RATTNER, Henrique. Tendencias: as incertezas nos rumos ao século 21 . São Paulo, IPE/USP, 1988. 13p. (Texto de discussão 05/88). 
$\mathrm{ROCH}$, Charles-Andre; COLAS, René. Remontée amont et nouvelles formes de cooperation: le process CBC. In: BOBROFF, Jacotte, coord. Journees d'etude sur la gestion de projet dans la construction. Paris, 1993. La gestion de projet dans la construction: enjeux, organisation, methodes et metiers: Actes. Paris, presses de l'ecole nationale des ponts et chaussees, 1993. 254p.

ROCHA LIMA JR., J. Qualidade na construçāo civil: conceitos e referenciais. São Paulo, EPUSP, 1993. (Boletim Técnico da Escola Politécnica da USP. Departamento de Engenharia de Construção Civil, BT/PCC/120)

ROCHA LIMA JR. João da. Sistemas de informaçāo para o planejamento na construção civil: gênese e Informatização. São Paulo, EPUSP, 1990. (Boletim Técnico da Escola Politécnica da USP. Departamento de Engenharia de Construção Civil, BT/PCC/26)

ROCHA LIMA JR. João da. Gerenciamento na construçāo civil: uma abordagem sistêmica. São Paulo, EPUSP, 1990. (Boletim Técnico da Escola Politécnica da USP. Departamento de Engenharia de Construção Civil, BT/PCC/27)

RODRIGUES, Indiana P. da F.; et al. Condições para inovação: estudo em quatro setores industriais. In: SIMPÓSIO DE GESTÃO DA INOVAÇÃO TECNOLÓGICA, 18., São Paulo, 1994. Anais. São Paulo, PACTO/FIA-USP/NPGCT-USP, 1994. v.1, p.208-18.

ROSSO, Teodoro. Racionalização da construção. São Paulo, FAU/USP, 1980. 300p.

SABBATINI, Fernando H. Desenvolvimento de métodos, processos e sistemas construtivos: formulação e aplicação de uma metodologia. São Paulo, 1989. 321p. Tese (Doutorado) - Escola Politécnica, Universidade de São Paulo.

SABBATINI, Fernando H. Tecnologia de produção de revestimentos. São Paulo, 1995. Notas de aula da disciplina PCC-816 - Escola Politécnica. Universidade de São Paulo. Não impresso.

SABBATINI, Fernando H.; BARROS, Mercia M. S. Bottura de. Recomendaçōes para definição, produção e execução de contrapisos para revestimentos de pisos convencionais. São Paulo, EPUSP-PCC, 1988. (Documento 1.G, Projeto EP/EN1).

SABBATINI, Fernando H.; BARROS, Mercia M. S. Bottura de. Metodologia para o controle de qualidade de execuçāo de contrapisos para revestimentos de piso convencionais. São Paulo, EPUSP-PCC, 1989. (Relatório Técnico R602/89, Projeto EP/EN-6).

SABBATINI, Fernando H.; SELMO, Silvia M. de Souza (a). Metodologia para controle de qualidade e procedimentos para caracterização dos materiais constituintes das argamassas. São Paulo, EPUSP-PCC, 1989. (Documento 1A, Projeto EP/EN-1). 
SABBATINI, Fernando H.; SELMO, Silvia M. de Souza (b). Diretrizes para a produçāo e controle de dosagem das argamassas de assentamento e revestimento. São Paulo, EPUSP-PCC, 1989. (Documento 1.C e 1.E, Projeto EP/EN-1).

SABBATINI Fernando H.; BARROS Mercia M.S.B.; SILVA, Margarete M.A. Recomendaçōes para construção de paredes de alvenaria. São Paulo, EPUSP-PCC, 1988. (Documento 1D, Projeto EP/EN-1).

SABBATINI Fernando H.; BARROS Mercia M.S.B.; SILVA, Margarete M. Metodologia para o controle de qualidade e procedimentos para caracterização dos componentes de alvenaria. São Paulo, EPUSP-PCC, 1989. (Documento 1B, Projeto EP/EN-1).

SALDANHA, Maria Christine Werba. Racionalização do trabalho na construção de edificaçōes: um estudo de caso. In: ENCONTRO NACIONAL DE TECNOLOGIA DO AMBIENTE CONSTRUÍDO, Rio de janeiro, 1995. Qualidade e tecnologia na habitação:anais Rio de Janeiro, UFRJ/ANTAC, 1995. Anais. v.1, p.261-6.

SANDERS, Steve R.; ESKRIDGE, W. Frank. Managing implementation of change. Journal of Management in Engineering, v.9, n.4, p.365-81. Oct. 1993.

SBRAGIA, Roberto; BARRA, Marcello Cavalcanti. O comportamento inovador de pequenas, médias e grandes empresas latino-americanas. In: SIMPÓSIO DE GESTĀO DA INOVAÇÃO TECNOLÓGICA, 18., São Paulo, 1994. Anais. São Paulo, PACTO/FIA-USP/NPGCT-USP, 1994. v.1, p.219-34.

SCARDOELLI, Lisiane S.; SILVA, Maria de Fátima; FORMOSO, Carlos T. Inventário de iniciativas de melhorias voltadas à produtividade e qualidade desenvolvidas por empresas de construção de edificaçōes. In: ENCONTRO NACIONAL DE ENGENHARIA DE PRODUÇÃO, 14, João Pessoa, 1994. Anais. p.821-6.

SCARDOELLI, Lisiane S. et al. Melhorias da qualidade e produtividade: iniciativas das empresas de construçāo civil. Porto Alegre, SEBRAE, 1994. 288p. Programa da Qualidade e Produtividade da Construçăo Civil no Rio Grande do Sul. (Série SEBRAE/Construção Civil)

SCARDOELLI, Lisiane S. Iniciativas de melhorias voltadas à qualidade e à produtividade desenvolvidas por empresas de construçăo de edificaçōes. Porto Alegre, 1995. 148 p. Dissertação (Mestrado) - Universidade Federal do rio Grande do Sul.

SLACK, Niegel. Administrando a rede de suprimentos. In.: VANTAGEM competitiva em manufatura: atingindo a competitividade nas operações industriais. São Paulo, Atlas, 1993. p.155-74.

SENAI. DN. Estudo setorial da construção civil: caracteristicas estruturais do setor. Rio de Janeiro, 1995. 131p. (projeto estratégico NA, 011. documento, 1) 
SERPEL, Alfredo. Innovación y desarrollo tecnológico: una estratégia de competitividad. In: SEMINARIO INTERNACIONAL DE LA INDÚSTRIA DE LA CONSTRUCCIÓN, 6., Santiago, 1995. Innovación e transferencia tecnológica en la construcción: principios, aplicaciones y casos:anais. Santiago, Departamento de Ingenieria y Gestión de la Construcción / Pontifícia Universidad Católica de Chile, 1995. p.1-17

SINDICATO DA INDÚSTRIA DA CONSTRUÇÃO DE GRANDES ESTRUTURAS DO ESTADO DE SÃO PAULO - SINDUSCON-SP. Perfil da construção civil: diagnósticos e perspectivas das empresas do SINDUSCON no Estado de São Paulo: principais aspectos e resultados. São Paulo, 1991.

SINDICATO DA INDÚSTRIA DA CONSTRUÇÃO DE GRANDES ESTRUTURAS DO ESTADO DE SÃO PAULO - SINDUSCON-SP. Seminário gestāo da qualidade em empresas construtoras. São Paulo, 1995. /xerocopiado/.

SIQUEIRA, Eliane M. F.; BEVERINOTTI, O. N.; SOUZA, Roberto de. Implantação se sistemas de garantia de qualidade. São Paulo, Departamento de Engenharia de Construção Civil/EPUSP, 1991. /Seminário apresentado no curso de pósgraduação da EPUSP. Datilografado/.

SOARES, Rosa Maria S. de M. Mudança tecnológica e dimensão organizacional: premissas para a qualidade e produtividade. In: SOARES, Rosa Maria S. de M., org. Gestão da qualidade: tecnologia e participação. Brasilia, CODEPLAN, 1992. P.9-22. (Série Cadernos CODEPLAN; 1).

SOUZA, Ana L. R; BARROS, Mercia M. S. B.; MELHADO, S. B. Projeto e inovaçāo tecnológica na construção de edificios: implantação no processo tradicional e em processos inovadores. São Paulo, EPUSP, 1995. (Boletim Técnico da Escola Politécnica da USP. Departamento de Engenharia de Construção Civil, BT/PCC/145).

SOUZA, Ana L. R. O projeto para produção aplicado à racionalização das lajes de concreto armado de edificios. São Paulo, 1996. Dissertação (Mestrado) Escola Politécnica, Universidade de São Paulo. Ino prelol

SOUZA, Roberto; MEKBEKIAN, Geraldo. Entraves comportamentais na implantação de sistemas da qualidade em empresas construtoras. In: ENCONTRO NACIONAL DE TECNOLOGIA DO AMBIENTE CONSTRUÍDO, Rio de janeiro, 1995. Qualidade e tecnologia na habitação:anais Rio de Janeiro, UFRJ/ANTAC, 1995. v.1, p. 237-42.

TATUM, Clyde B. Potential mechanisms for construction innovation. Journal of Construction Engineering and Management, v.112, n.2, p.178-91. June 1986.

TATUM, Clyde B. Organizing to increase innovation in construction firms. Journal of Construction Engineering and Management, v.115, n.4, p.602-17. Dec. 1989.

TATUM, Clyde B. What prompts construction innovation? . Journal of Construction Engineering and Management, v.110, n.3, p.311-23. Sep. 1984. 
TATUM, Clyde B. Process of innovation in construction firm. Journal of Construction Engineering and Management, vol.113, n.4, p.648-63, Dec. 1987.

TELLES, Pedro C. da Silva. História da engenharia no Brasil. Rio de Janeiro, Livros Técnicos e Científicos, 1984. v.1.

TRYLINSKI, Maria Helena C.V.; PRADO, Niobe. Inovação tecnológica e formação profissional na indústria de construção. São Paulo, SENAI, 1987. (Série Mercado de Trabalho).

TWISS, Brian C. The process of technological innovation. In: MANAGEING technological innovation. London, Longman, 1974. Cap.1. p.1-25.

UTTERBACK, James $M$. The dynamics of product and process innovation in industry. In: HILL, Christopher T.; UTTERBACK, James M. Technological innovation for a dynamic economy. New York, Pergamon Press, 1983. p.40-65. (Pergamon Policy Studies on Science and Technology).

VAI SER difícil esquecer 1991. Dirigente Construtor, v.28, n.9, p.14-21, set.1992.

VARGAS, Nilton. Racionalidade e não-racionalização: o caso da construção habitacional. In: FLEURY, Afonso C.; VARGAS, Nilton., coord. Organização do trabalho. São Paulo, ATLAS, 1987. p.195-219.

VARGAS, Nilton. Construção habitacional: um artesanato de luxo. Revista Brasileira de Tecnologia, v. 12, n.1, p.27-32, Jan./Mar. 1981.

VARGAS, Nilton. Tendências de mudança na indústria da construção. Obra, n.44, p.25-9, Fev. 1993.

VARGAS, Milton. Para uma filosofia da tecnologia. São Paulo, Alfa-Ômega. 1994. p.171-286.

VILLACRESES, Xavier E. R. Análise estratégica da subcontratação em empresas de construção de pequeno porte. In.: FORMOSO, Carlos Torres, ed. Gestão da qualidade na construção civil: uma abordagem para empresas de pequeno porte. Porto Alegre, Programa de Qualidade e Produtividade da Construção Civil no Rio Grande do Sul, 1995. p. 49-80.

VIOLANI, Marco A. F.; CÂNDIA, Mário C.; MELHADO, Sílvio B. Administraçāo de materiais na construção civil. São Paulo, EPUSP-PCC, 1991. 27p. /Seminário apresentado no curso de pós graduação da EPUSP. Datilografado/.

YOSHIDA, Adriana T.; BARROS, Mercia M. S. B. Amostra das técnicas de execução de alvenaria de vedação empregadas por construtoras civis em São Paulo. São Paulo, EPUSP-PCC, 1996. 95p. (Relatório de Iniciação Científica USP/CNPq).

ZAWISLAK, Paulo Antônio. Gestão da inovação tecnológica e competitividade industrial: uma proposta para o caso brasileiro. In: ENCONTRO NACIONAL DA ASSOCIAÇÄO NACIONAL DE PROGRAMAS DE PÓS-GRADUAÇÃO EM ADMINISTRAÇÃO, 19., João Pessoa, 1995. Anais. Anpad, 1995 vol. 1, p.157-74. 